\title{
CIUDADES DE PAPEL \\ ETNOGRAFIA MLLITANTE SOBRE \\ LA CULTURA DE PARTICIPACIÓN JUVENIL EN \\ LA CASA DE JOVENTUT LA MARANYA
}

Tesis Doctoral

Arecia Aguirre García-Carpintero

Dirección: Lidón Moliner Miravet y Joan A. Traver Martí

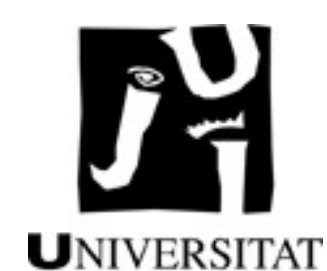

UNIVERSITAT
JAUME•I

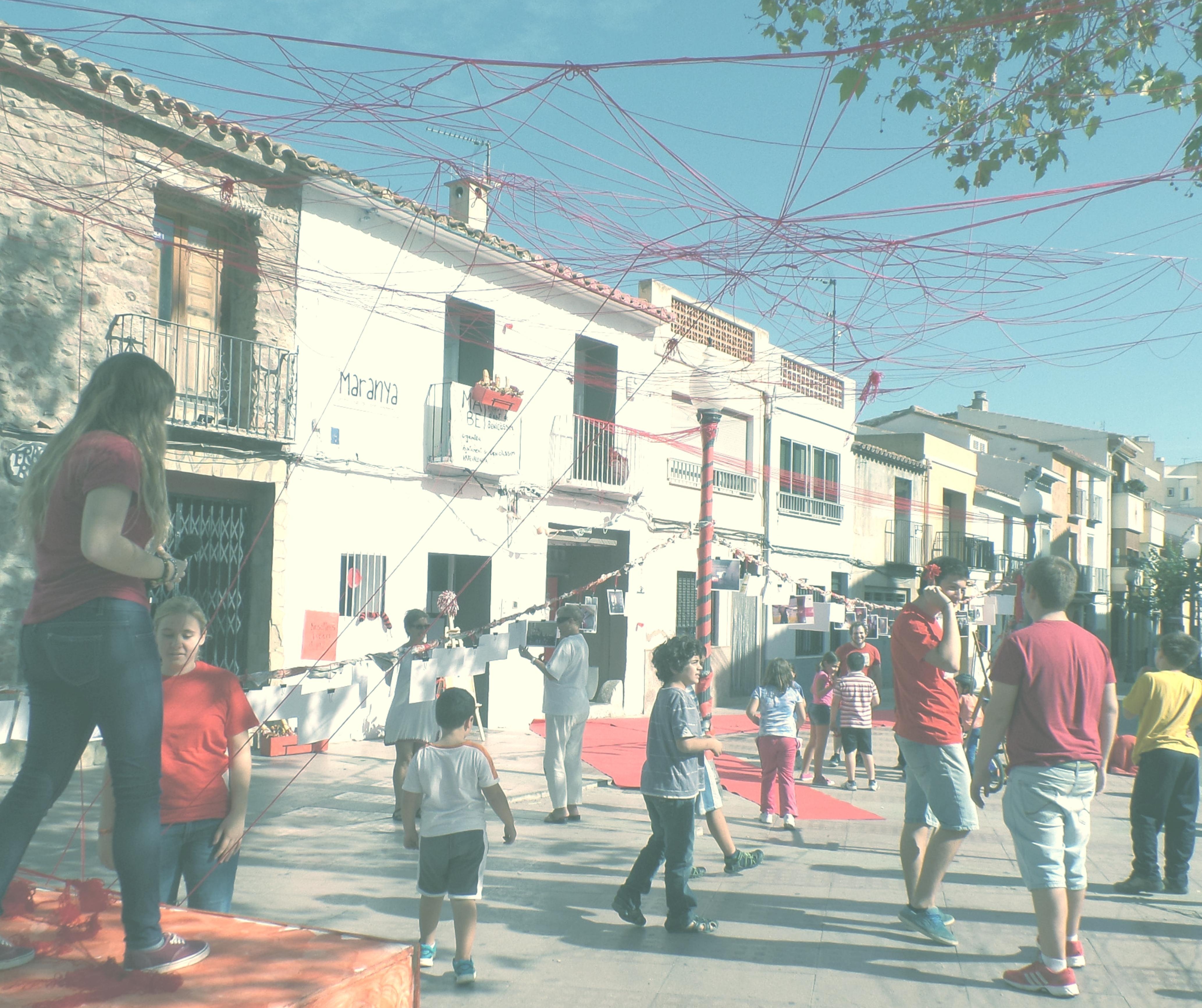

Facultad de Ciencias Humanas y Sociales Departamento de Educación Universitat Jaume I 
TESIS DOCTORAL

\title{
CIUDADES DE PAPEL
}

Etnografia Militante sobre la cultura de participación juvenil en la casa de Joventur La Maranya.

\author{
Arecia Aguirre García-Carpintero \\ Dirección: Lidón Moliner Miravet y Joan A. Traver Martí
}

Facultad de Ciencias Humanas y Sociales Departamento de Educación Universitat Jaume I Castellón

\section{gUUNIVERSITAT JAUME•I}

Programa de doctorado: Educación Secundaria

Código: 14034

Diciembre 2016 



\section{AGRADECIMIENTOS}

Durante todos estos años he recibido mucho de muchas personas. De compañeros y compañeras que han hecho que hoy este trabajo sea una realidad. Todas ellas han conseguido que esta tesis doctoral sea cabeza, corazón y manos. Cabeza por todas aquellas horas de aprendizajes, todos los conocimientos compartidos, todos esos momentos de reflexión y ebullición. Corazón por los sentimientos y las emociones que me han acompañado a lo largo de todo este proceso y que lo han convertido en vital en mi día a día. Manos por todas aquellas líneas escritas, por las lindas y críticas palabras pero también por los abrazos y los besos que me han fortalecido en cada momento. Por ser efecto de todos vuestros afectos os doy las gracias.

Per convertir-me en part de la lluita, per fer que açò no haja sigut només investigació sino transformació en la meua vida personal i acadèmica. Per compartir els vostres anhels, temors, aprenentatges i somnis. Per la vostra inestimable confiança. Per ser el nom que em tria i no puc llevar-me de damunt. Per ser la veu, el cor i el cap d'aquest viatge. Per ser passat, present i futur. Per ser la unió que fa la força. Per ser una entre tantes, però una molt especial en el meu camí. Gràcies Maranya. Gràcies a totes les persones que la conformen i molt especialment a aquelles que han aconseguit que el treball fora conversa i col·lectivitat. Gràcies Virginia, Víctor, Mireia, Noel, Iván Checa, Lydia, Ricky, Carlota, Aitana, Ana María, Iván Gómez, Tibi, Carla, Lluis, Pau, Josevi, Jose, Armand, Isabel, Joana, Guille, Julio, Enrique, Jesús, Miriam, Guiomar, Adriana, Miriam S, entre tantes altres. Gràcies a totes aquelles que han fet possible aquesta història maranyera i també a Laia i a Ona per ser futur i per a que d'ací uns anyets pugau saber el que aquesta història va representar en la nostra vida.

En especial a vosotros dos por todo vuestro trabajo. Por vuestras palabras siempre afectuosas y críticas, por la paciencia, por depositar vuestra confianza en mí, por contagiarme vuestra pasión por la educación, por ser directoras de una increíble experiencia. Gracias Lidón y Joan. 
Por formar parte del viaje, ser apoyo incondicional e inspiración continua.

Gracias Federació de Cases de Joventut, Escola de Cases, IES Violant de Casalduch, MLPV y MLPA.

Por vuestra disponibilidad. Gracias $\mathrm{M}^{\mathrm{a}}$ Carmen, Susana y vecinas de Benicàssim.

Por encender la llama, porque sin vosotras y vosotros quizá no hubiera empezado. Gracias Auxi, Odet, Andrea, María, Aida, Paula, Alicia, Miquel, Tomás, Aurora, Reina, Paola, Albert, Paco, Eugeni, Anabel y Anna.

Por compartir tiempos, espacios, palabras, miedos y sueños, por el camino lleno de recuerdos y el que nos queda por recorrer juntas. Gracias Ana.

Por hacer que todo fuera más amable, por nuestras tascas, risas y por esos grandes momentos. Gracias Gil, Diego, Alberto y Lidón Monferrer.

Por comprender las ausencias, por ayudar a encontrarme cada día, por compartir vuestras sonrisas. Gracias Tamara, Valli, Miriam, Cris y Marta.

Por ser referente y amiga, por hacer que dure, por ayudar a curar. Gracias Moni.

Por ser parte de mis inicios, por hacer que nada cambie aun estando separadas por un gran charco. Gracias Xus.

Por compartir este viaje, por tu gran amistad, por confiar infinitamente. Gracias Laura.

Por vuestras palabras siempre positivas, por vuestros abrazos. Gracias Toni, Cos, Laura, Javi, Gisela y Javi.

Por ser inspiración, alegría, sonrisas y vida. Gracias Adriana y Alejandro.

Por estar ahí siempre aunque la distancia cada día nos separe más. Por tu fortaleza, por tus ánimos y risas. Gracias Aaron.

Por hacer que todo fuera más fácil. Gracias Ana. 
Por los esfuerzos que durante toda la vida habéis hecho por mí. Por vuestra confianza y apoyo incondicional. Por no decirme nunca que era imposible. Por dármelo todo. Gracias papá y mamá.

Por creer en mí, por ser parte de este todo, por conseguir construir buenos momentos en los contratiempos, por ser el compañero más «espectáculoso» y «asombrocular» y hacer que el mejor lugar sea el compartido entre los dos. Gracias Raúl.

A todas, gracias.

Castellón, diciembre del 2016. 



\section{RESUMEN}

En este informe quiero compartir el proceso de investigación llevado a cabo en una tesis doctoral centrada en el valor educativo de la participación juvenil. Consideramos la investigación como un instrumento de reforma, de cambio y de transmisión cultural. El momento social que estamos viviendo nos pide investigaciones más cercanas a la realidad y coconstruidas con la ciudadanía. Reconocemos la necesidad de indagar en nuevos modelos de educación no formal con jóvenes. Debido a estas razones, se analizarán las claves que pueden hacer que el trabajo con jóvenes en una Casa de Juventud se convierta en una herramienta de transformación social como agente educativo de cambio en el territorio. Dicho estudio se diseña para facilitar los procesos de concientización, la construcción compartida de conocimiento y de significados elaborados por la sociedad. Además nos posibilita el análisis de nuevas formas de actuación social más igualitarias, que abren nuevas propuestas de carácter educativo e impulsa la construcción de una sociedad más participativa, crítica y libre. La investigación se lleva a cabo en la Casa de Joventut La Maranya de Benicàssim. Una asociación que se enfrenta a su invisibilidad por parte de diferentes agentes académicos y políticos. Un espacio que aun existiendo parece desaparecer como los cartógrafos hacen con sus ciudades de papel.

El objetivo de la investigación es conocer el papel que ocupa la Casa de Joventut La Maranya en la cultura de participación social de las jóvenes de Benicàssim y analizar cómo esta se convierte en un agente educativo de cambio en el territorio. Metodológicamente, la investigación se ha situado en los principios de la etnografía crítica. La investigación se ha realizado durante cuatro años, llevándose a cabo el trabajo de campo a lo largo de casi tres años. Se ha contado con múltiples agentes sociales que participan de la vida de la asociación, elemento que ha favorecido la pluralidad de voces en la investigación. Un aspecto a remarcar, ligado a la ética de investigación que encuadra esta tesis, es el rol que asume la investigadora dentro del campo, llegando a delimitar el tipo de investigación que se realiza. De esta forma realizamos un estudio de etnografía militante ubicado dentro de un enfoque de Etnografía Crítica. Para llevarlo a cabo se ha trabajado con un grupo asesor conformado por diferentes personas 
vinculadas a la Casa de Joventut La Maranya, al movimiento asociativo juvenil de la Comunidad Valenciana y al trabajo académico. Este grupo ha sido el encargado de evaluar la investigación a lo largo de todo el proceso. Además hemos realizado entrevistas a un total de 28 personas vinculadas a la asociación con la finalidad de realizar un relato de vida colectivo de $\mathrm{La}$ Maranya. Este se ha triangulado a partir de los datos procedentes de la observación, de los documentos de la Casa de Joventut, de la Federació a la que pertenece, de fotografías y videos elaborados por las jóvenes, de actas y del trabajo directo dentro del equipo de animadoras voluntarias, entre otras. El procedimiento empleado para realizar la investigación se divide en tres fases: la primera de aproximación al campo y demanda asociativa; la segunda de recogida de información y participación en el equipo de animadoras Voluntarias; la tercera de elaboración del relato y devolución y cierre colectivo.

En los resultados de la investigación se aprecia que las dinámicas de la asociación cumplen con dos partes fundamentales del centro: una más estructural y organizativa y otra más relacional y de vida. Ambas se cuidan a partir de la puesta en marcha de diferentes ingredientes que posibilitan que Maranya sea considerada agente educativa de cambio. El valor educativo de la Casa genera un modelo concreto de trabajo en espacios de ocio y tiempo libre permitiendo reelaborar nuevos modelos de asociacionismo juvenil con las jóvenes como principales protagonistas, así como reformular las políticas juveniles actuales.

Palabras clave: Etnografía Crítica, Participación, Democracia, Educación no formal, Jóvenes, Asociacionismo, Casas de juventud. 


\section{RESUM}

En aquest informe vull compartir el procés de recerca dut a terme en una tesi doctoral centrada en el valor educatiu de la participació juvenil. Considerem la recerca com un instrument de reforma, de canvi i de transmissió cultural. El moment social que estem vivint ens demana investigacions més properes a la realitat i co-construïdes amb la ciutadania. Reconeixem la necessitat d'indagar en nous models d'educació no formal amb joves. A causa d'aquestes raons, s'analitzaran les claus que poden fer que el treball amb joves en una Casa de Joventut es convertisca en una eina de transformació social com a agent educatiu de canvi en el territori. Aquest estudi es dissenya per facilitar els processos de conscienciació, la construcció compartida de coneixement i de significats elaborats per la societat. A més ens possibilita l'anàlisi de noves formes d'actuació social més igualitàries, que obren noves propostes de caràcter educatiu i impulsa la construcció d'una societat més participativa, crítica i lliure. La investigació es porta a terme a la Casa de Joventut La Maranya de Benicàssim. Una associació que s'enfronta a la seva invisibilitat per part de diferents agents acadèmics i polítics. Un espai que encara existint sembla desaparèixer com els cartògrafs fan amb les seves ciutats de paper.

L'objectiu de la investigació és conèixer el paper que ocupa la Casa de Joventut La Maranya a la cultura de participació social de les joves de Benicàssim i analitzar com aquesta es converteix en un agent educatiu de canvi en el territori. Metodològicament, la investigació s'ha situat en els principis de l'etnografia crítica. La investigació s'ha realitzat durant quatre anys, duent-se a terme el treball de camp al llarg de gairebé tres anys. S'ha comptat amb múltiples agents socials que participen de la vida de l'associació element que ha afavorit la pluralitat de veus en la investigació. Un aspecte a remarcar, lligat a l'ètica d'investigació que emmarca aquesta tesi, és el rol que assumeix la investigadora dins del camp, arribant a delimitar el tipus de recerca que es realitza. D'aquesta manera vam realitzar un estudi d'etnografia militant ubicat dins d'un enfocament d'Etnografia Crítica. Per fer-ho hem treballat amb un grup assessor conformat per diferents persones vinculades a la Casa de Joventut La Maranya, al moviment associatiu juvenil de la Comunitat Valenciana $i$ al treball 
acadèmic. Aquest grup ha estat l'encarregat d'avaluar la recerca al llarg de tot el procés. A més hem realitzat entrevistes a un total de 28 persones vinculades a l'associació amb la finalitat de realitzar un relat de vida col-lectiu de La Maranya. Aquest s'ha triangulat a partir de les dades procedents de l'observació, dels documents de la Casa, de la Federació a la qual pertany, de fotografies i vídeos elaborats per les joves, d'actes i del treball directe dins de l'Equip d'Animadors Voluntaris, entre d'altres. El procediment emprat per realitzar la investigació es divideix en tres fases: la primera d'aproximació al camp i demanda associativa; la segona de recollida d'informació i participació en l'Equip d'Animadors Voluntaris; la tercera d'elaboració del relat i devolució i tancament col-lectiu.

En els resultats de la investigació s'aprecia que les dinàmiques de l'associació compleixen amb dues parts fonamentals de la assocació: una més estructural i organitzativa i una altra més relacional i de vida. Totes dues es cuiden a partir de la posada en marxa de diferents ingredients que fan possible que Maranya siga considerada agent educativa de canvi. El valor educatiu de la Casa genera un model concret de treball educatiu en espais d'oci $i$ temps lliure permetent reelaborar nous models d'associacionisme juvenil amb els joves com a principals protagonistes, així com reformular les polítiques juvenils actuals.

Paraules clau: Etnografia Crítica, Participació, Democràcia, Educació no formal, Joves, Associacionisme, Cases de joventut. 


\section{ABSTRACT}

In this report I would like to share the process of investigation carried out in a doctoral thesis focused on the educational value of youth participation. We consider investigation as a tool of reform, change and cultural transmission. The social climate we currently have demands investigations that are closer to reality and jointly built with citizens. We see the need to investigate new models of non-formal education with young people. Because of these reasons, we will analyze the key factors that can make work with young people in a Youth Club turn into a social transformation tool as an educational agent of change in the territory. This study is designed to facilitate awareness processes, the joint construction of knowledge and meanings that are elaborated by society. Besides, it enables an analysis of new modes of social action that is more equal, that is open to new educational proposals and helps build a more participative, critical and free society. The investigation is carried out in the Casa de Joventut La Maranya in Benicàssim. It is an association that is invisible to different academic and political groups. A place that, despite its existence, seems to fade away like cartographers do with their paper towns.

The objective of the investigation is getting to know the role of the Casa de Joventut La Maranya in the culture of social participation of youngsters in Benicàssim and analyze how the Club becomes an educational agent of change in the territory. Methodologically, the investigation has been located in the principles of critical ethnography. The investigation has been carried out for four years, and the field research for almost three years. We received the collaboration of numerous agents that take an active part in the association, and this is an aspect that has favoured the plurality of voices in the investigation. An aspect that should be emphasized, linked to the investigation ethics that is part of the thesis, is the role the researcher takes on in the field, eventually defining the type of investigation that will be carried out. In this way we conduct a study of activist ethnography located in a Critical Ethnography approach. In order to conduct it we have created a consultative group constituted by different people associated to the Youth Club, to the youth association movement of the Valencian Community and to the academic work. This group has been in charge of 
evaluating the investigation all through the process. Apart from that we have interviewed a total of 28 people linked to the association with the aim of creating a collective life history of Maranya. It has been triangulated with data coming from observation, the Club's documents, from the Federation to which it belongs, from pictures and videos created by youngsters, from records and from the direct work in the volunteer animation team, among others. The procedure used to carry out the investigation is divided into three stages: the first one is the field approach and associative demand; the second is data gathering and participation in the Volunteer Animation Team; the third is elaboration of the life history and return and collective closure.

From the results of the investigation, one can see that the association dynamics meet two fundamental criteria of the association: one that is more structural and organizational and the other more relational and liferelated. Both are well-taken care of from the start of different ingredients that make Maranya an educational agent of change. The educational value of the Youth club generates a specific model of educational work in leisure and free time areas that have allowed the rework of new models of youth association with young people as major figures, apart from reworking current youth policies.

Keywords: Critical Ethnography, Participation, Democracy, Non-Formal Education, Youth, Association, Youth Club. 


\section{INDICE}

1.1 Pedagogía Social, Educación No Formal y ANimación Sociocultural en el TIEMPO LIBRE Y DE OCIO DE LA CIUDADANÍA................................................... 14

1.1.1 LA PEDAGOGÍA SOCIAL COMO DISCIPLINA MARCO. ........................................... 14

1.1.2 ¿QUÉ ES LA ANIMACIÓN SOCIOCULTURAL? ................................................ 20

1.1.3 ¿Y SI LA ANIMACIÓN SOCIOCULTURAL LA VIVIMOS DESDE LA EDUCACIÓN NO FORMAL?

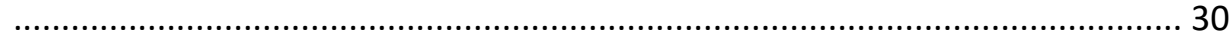

1.1.4 UN POCO DE AIRE LIBRE PARA DINAMIZAR EL OCIO DESDE LA EDUCACIÓN............... 36

1.2 JÓVENES, PARTICIPACIÓN SOCIAL Y DEMOCRACIA. ..................................... 39

1.2.1 ACTIVIDADES EN EL TIEMPO LIBRE CON JÓVENES.............................................. 40

1.3. EL APRENDIZAJE EN LA ACCIÓN: MOVIMIENTOS ASOCIATIVOS. ........................... 49

1.3.1. LA HISTORIA ASOCIATIVA ................................................................ 49

1.3.2. EL VALOR DEL ASOCIACIONISMO COMO ESPACIO DE APRENDIZAJE.......................69

1. 4. EL MODELO DE CASAS DE JUVENTUD. ...................................................... 79

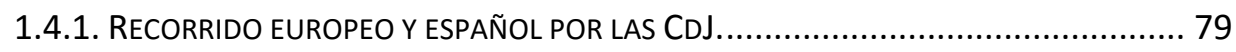

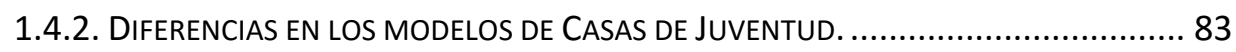

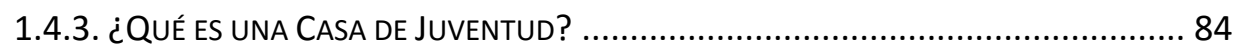

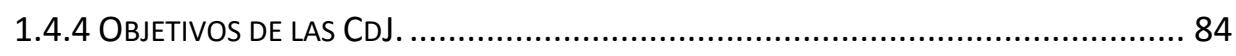

1.4.5 LA ORGANIZACIÓN EN UNA CDJ: LA QUÍNTUPLE ESTRUCTURA. ........................... 85

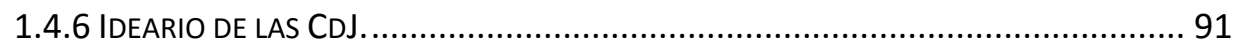

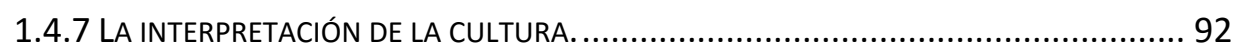

1.4.8 ESTUDIOS CONCRETOS SOBRE CASAS DE JUVENTUD EN EUROPA.......................... 94

1.5. ESTADO DE LA CUESTIÓN.............................................................. 96

CAPITULO 2. POSICIONAMIENTO METODOLÓGICO...........107

2.1. SIGNIFICADOS METODOLóGICOS Y ÉTICA DE INVESTIGACIÓN. .......................... 110

2.2. ¿QUÉ ES LA ETNOGRAFÍA? ............................................................. 116

2.3. EN LOS MÁRGENES DE LA ETNOGRAFÍA: ENFOQUES COLABORATIVOS, CRÍTICOS, ACTIVISTAS Y MILITANTES. ................................................................... 118

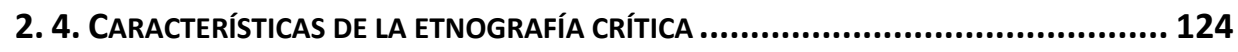

2. 5. DISEÑAR EL PROCESO ETNOGRÁFICO ................................................ 126

2.6. ARTESANÍA, BRICOLAJE O CÓMO HACER PATHCWORK EN LA ETNOGRAFÍA:

ESTRATEGIAS, TÉCNICAS Y HERRAMIENTAS DE INVESTIGACIÓN. 


\section{CAPITULO 3. CARTOGRAFÍA DE LA INVESTIGACIÓN...........131}

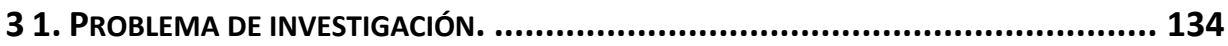

3. 2. LA HISTORIA INTERMINABLE: PREGUNTAS Y MÁS PREGUNTAS.......................... 139

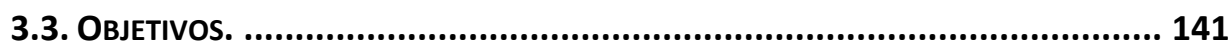

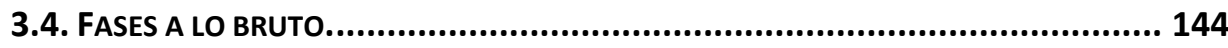

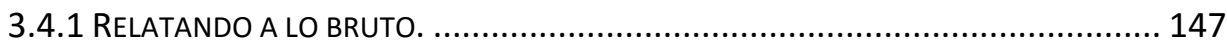

3.5. PROCEDIMIENTOS DE CONSTRUCCIÓN DE INFORMACIÓN: TÉCNICAS, DISPOSITIVOS

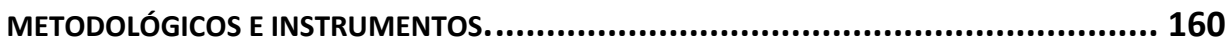

3.5.1 LA CONSTRUCCIÓN DE LA INFORMACIÓN DOCUMENTAL: LA OBSERVACIÓN Y EL

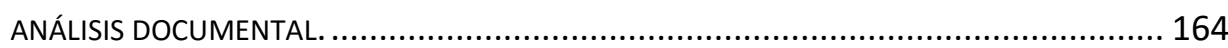

3.5.1.2 La observación dentro de la investigación militante............................ 164

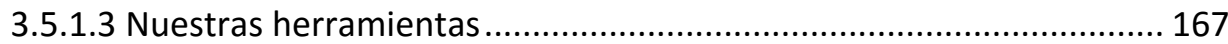

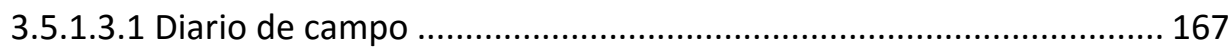

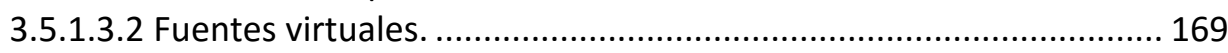

3.5.1.3.3 Fuentes documentales escritas ................................................. 170

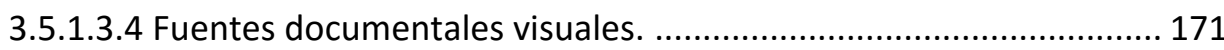

3.5.2 LA CONSTRUCCIÓN DE LA INFORMACIÓN COLABORATIVA: UN GRUPO ASESOR EN UN

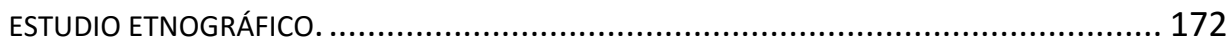

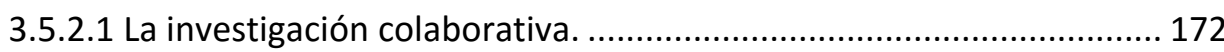

3.5.2.2 Objetivos y principios. ................................................................... 172

3.5.2.3 Nuestras herramientas................................................................. 172

3.5.2.3.1 Dinámica participativa: Mapeo relacional..................................... 173

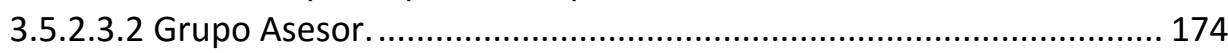

3.5.3 LA CONSTRUCCIÓN DE INFORMACIÓN NARRATIVA: TÉCNICA DEL RELATO BIOGRÁFICO

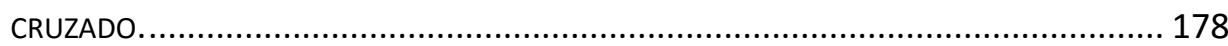

3.5.3.1 Investigación biográfico narrativa (IBN) .......................................... 178

3.5.3.2 Nuestra elección: relatos biográficos cruzados en la Historia de La

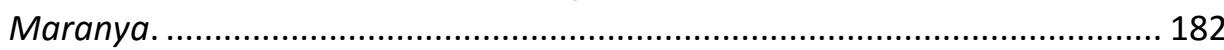

3.5.3.3 Proceso de construcción del relato de vida maranyero....................... 183

3.5.3.4 Propósito y principios en la construcción biográfico-narrativa........... 183

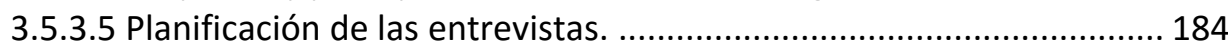

3.5.3.5.1 Análisis de la participación etnográfica realizada............................ 184

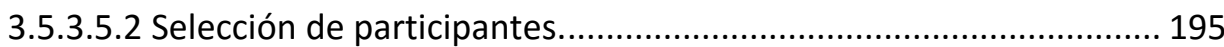

3.5.3.5.3 Elaboración del protocolo de entrevistas. ..................................... 198

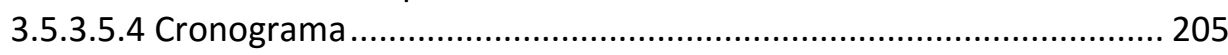

3.5.3.5.5 Rastreo de datos de unas entrevistas a otras. ¿Cómo se deriva de

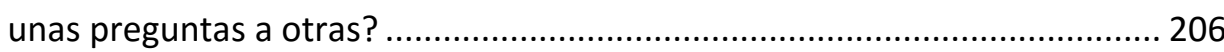

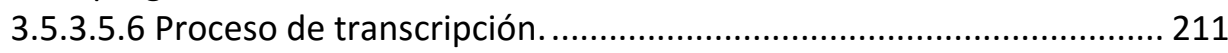

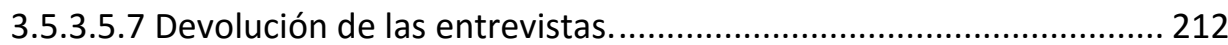

3.5.3.5.8 Ordenación de los datos de las entrevistas..................................... 213

3.6. PERSPECTIVAS Y PROCEDIMIENTOS DE ANÁLISIS DE LA INFORMACIÓN................... 215 
3.6.1 LOS TRES TIPOS DE ANÁLISIS................................................................... 217

3.6.1.1 Análisis estructural. .................................................................. 217

3.6.1.2 Análisis narrativo......................................................................... 240

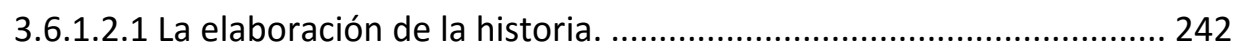

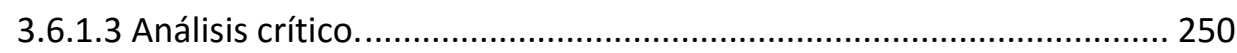

3.6.2 CRITERIOS DE RIGOR CIENTíFICO............................................................. 250

3.6.2.1 Herramientas y estrategias en la triangulación de la información. ... 252

CAPITULO 4. COMPONENTES CONTEXTUALES ....................263

4.1 Gente ENMARANYADA................................................................ 267

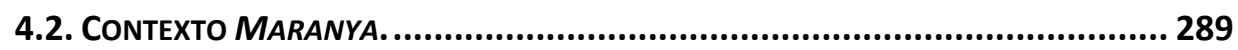

CAPITULO 5. RESULTADOS DE UNA HISTORIA _...................303

CAPITULO 6. DICUSIÓN Y CONCLUSIONES ..............................385

6.1. EL LADO FORMAL DE UNA ASOCIACIÓN: EL TRINOMIO ESTRUCTURAL. ................. 391

6.1.1 La estructura de la participación....................................................... 391

6.1.2. La construcción del discurso. ........................................................ 401

6.1.3. La organización delaprendizaje..................................................... 410

6.2 EL LADO INFORMAL DE UNA ASOCIACIÓN: EL TRINOMIO DE VIDA. ...................... 420

6.2.1. El cuidado relacional. ................................................................. 420

6.2.2. Las estrategias de afrontamiento................................................... 423

6.2.3. El empoderamiento colectivo. ................................................... 427

6.3. EL CAMBIO SOCIAL Y POLÍTICO TAMBIÉN DEPENDE DE LAS ASOCIACIONES JUVENILES.

CHAPTER 6. DISCUSSION \& CONCLUSIONS .......................437

CAPITULO 7. APORTACIONES, RETOS Y PROPUESTAS..... 481

7.1. APORTACIONES A LA INVESTIGACIÓN. ....................................................483

7. 2. RETOS DEL ESTUDIO. .................................................................. 487

7.3. PROSPECTIVA: POSIBLES LÍNEAS DE TRABAJO O INVESTIGACIÓN Y PROPUESTAS DE

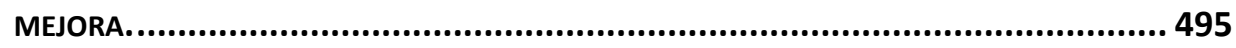

CIUDADES DE PAPEL ………....................................................... 499

BIBLIOGRAF|'A ................................................................................ 
ANEXOS

TABLA DE CONTENIDOS ....................................................................621 


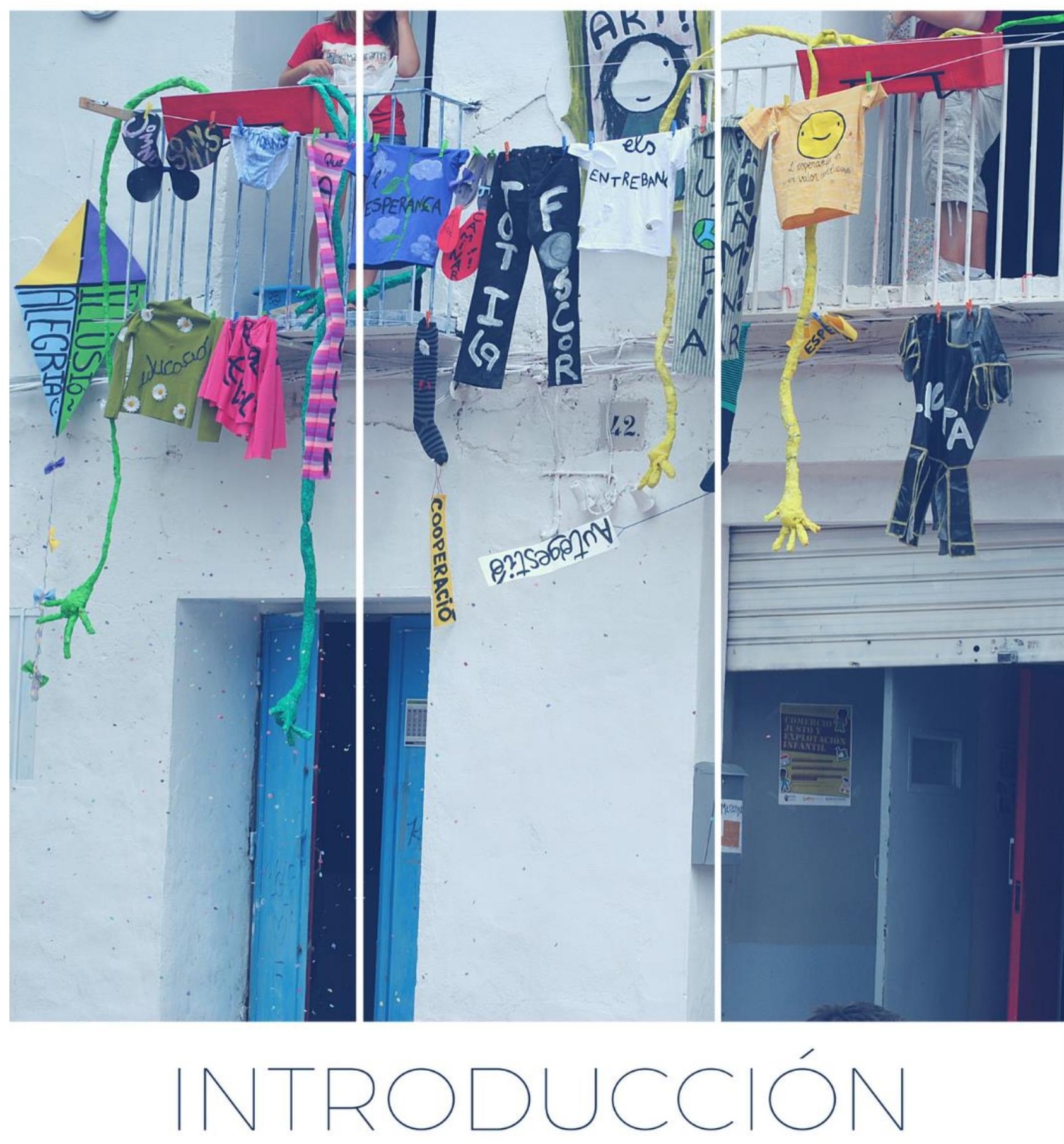



«El otro día oi un cuentecillo bonito - dice Morrie. Cierra los ojos durante un momento y yo espero.

Bueno. El cuento es de una olita que va saltando por el mar y lo pasa muy bien. Disfruta del viento y del aire libre, hasta que ve que las demás olas que tiene delante rompen contra la costa.

«Dios mío, esto es terrible - dice la ola-. jMira lo que me va a pasar!» Entonces llega otra ola. Ve a la primera ola, que parece afligida, y le dice: "¿Por qué estás tan triste?" La primera ola dice: " ¿Es que no lo entiendes? ¡Todas vamos a rompernos! ¡Todas las olas vamos a deshacernos! ¿No es terrible?»

La segunda ola dice: "No, eres tú la que no lo entiende. Tú no eres una ola; formas parte del man»

Sonrío. Morrie vuelve a cerrar los ojos.

- Parte del mar - dice-, parte del mar.

Lo veo respirar, inspirar y espirar, inspirar y espirar.» (Mitch Albom, 1998/2006. Martes con mi viejo profesor)

Observas la sociedad, te observas a ti dentro de una sociedad definida por el individualismo y la competencia. Te das cuenta que no eres una sola ola, sino que formas parte de todo ese mar. Formas parte de la sociedad y ves que el valor que tenemos como ciudadanas es precisamente eso, formar parte de una ciudadanía que deje de mirarse como ola y sea capaz de ver la inmensidad del mar del que formamos parte. Podemos sentir que lo que hacemos es simplemente una simple gota en todo ese mar pero cada gota cuenta en él y realmente ese mar sería menos si no existiese esa gota. Se trata de dar luz a todas esas gotas, de mirarlas desde su belleza individual a la vez que desde su fuerza colectiva. Cada ola está formada por millones de gotas, cada ola es distinta a la anterior y diferente a la que le sucederá cuando esta se convierta en espuma pero todas, absolutamente todas, forman un mar dispuesto a ocupar su espacio y enamorar con su fuerza e inmensidad. 
La Maranya

Arecia Aguirre García-Carpintero

Necesitamos

más aire libre

más diálogo

más pertenencia

más lucha

más cooperación

más compromiso

más participación

más democracia

más reflexión

más autonomía

más cultura

más relaciones

más aprendizajes

más voces

más horizontes

más crítica

más creatividad

más acción

más gotas,

más olas

y más mar. 
Esta investigación nace de mis inquietudes en la fuerza colectiva y en la necesidad de visibilizar procesos de aprendizaje fuera de la educación formal. Consideramos la investigación como un instrumento de trasformación, de cambio y de transmisión cultural. El momento social que estamos viviendo nos demanda investigaciones más cercanas a la realidad y co-construidas con la ciudadanía. Reconocemos la necesidad de indagar en nuevos modelos de educación no formal con jóvenes que nos hagan sentirnos mar. Debido a estas razones, se analizarán las claves que pueden hacer que la participación en espacios de educación no formal se convierta en esencial en la construcción de la cultura de participación juvenil. Dicho estudio se diseña para facilitar los procesos de concientización, la construcción compartida de conocimiento y de significados elaborados por la sociedad. Además nos posibilita el análisis de nuevas formas de actuación social más igualitarias, que abren nuevas propuestas de carácter educativo e impulsa la construcción de una sociedad más participativa, crítica y libre. La investigación se lleva a cabo en la Casa de Joventut La Maranya (a partir de ahora podrá verse como Maranya o como la Casa para facilitar la lectura). Una asociación que se enfrenta a su invisibilidad por parte de diferentes agentes académicos y políticos. Un espacio que aun existiendo parece desaparecer como los cartógrafos hacen con sus ciudades de papel.

El objetivo de la investigación es conocer el papel que ocupa la Casa de Joventut La Maranya en la cultura de participación social de las jóvenes' de Benicàssim y analizar cómo esta se convierte en un agente educativo de cambio en el territorio. Metodológicamente, la investigación, se ha situado en los principios de la etnografía militante. El trabajo de campo se ha realizado a lo largo de casi tres años y se ha contado con la participación de múltiples agentes sociales que participan de la vida de la asociación.

Un aspecto a remarcar, ligado a la ética de investigación que enmarca esta tesis, es el rol que asume la investigadora dentro del campo, llegando a delimitar el tipo de investigación que se realiza. De esta forma realizamos un estudio de etnografía militante ubicado dentro de un enfoque de

I En la redacción de la historia, al igual que en el resto de informe, utilizo la palabra persona para huir del genérico masculino gramatical. De esta forma hablamos de «las jóvenes», como «las personas jóvenes» evitando el uso de «las jóvenes». 
Etnografía Crítica. Para llevarlo a cabo hemos dado pie a diferentes perspectivas de construcción de la información desde la documental pasando por la narrativa hasta llegar a la colaborativa. En la documental se han recuperado diferentes documentos que han dado pie a entender el papel educativo y reivindicativo de la Casa. La narrativa se ha centrado en descubrir diferentes perspectivas para construir de manera plural y colectiva la historia de Maranya. Se han realizado entrevistas a un total de 28 personas vinculadas a la asociación de manera directa o indirecta, con la finalidad de realizar un relato de vida colectivo de Maranya. La colaborativa se ha centrado en reconstruir la investigación desde la comunidad a través de un grupo asesor conformado por diferentes personas vinculadas a la Casa, al movimiento asociativo juvenil valenciano y al trabajo académico. Este grupo ha sido el encargado de evaluar la investigación a lo largo de todo el proceso de forma colaborativa. Además toda la información construida a partir de estas tres aproximaciones ha posibilitado la triangulación a partir de los datos procedentes de la observación, del blog de la asociación, del trabajo directo dentro del equipo de animadoras voluntarias, de los documentos recogidos y de las reuniones del grupo asesor entre otras cosas.

El procedimiento empleado para realizar la investigación se divide en diez puntos que pueden resumirse en las siguientes cuatro fases: la primera de contacto y planificación; la segunda de trabajo de campo; la tercera de elaboración del informe y la cuarta de evaluación social de la tesis.

En los resultados de la investigación se aprecia que las dinámicas de la asociación cumplen con los principios del aprendizaje situado, además es la pedagogía crítica la que delimita la acción en este contexto. Esto permite reelaborar nuevos modelos de asociacionismo juvenil con las jóvenes como principales protagonistas, así como reformular las políticas juveniles actuales concretando el trabajo educativo en espacios de ocio y tiempo libre.

En este mundo tan dinámico ves que cada vez aparecen más espacios que pierden el valor de lo comunitario primando otras características que hacen que la construcción de la sociedad sea más individualista y competitiva. En esta investigación sumamos miradas y cruzamos relatos para conseguir una historia caracterizada por la diversidad de voces, que describe e interpreta la 
cultura de participación juvenil y visibiliza el silencio y la marginación que se produce sobre el colectivo.

La novedad de esta investigación radica en su método de investigación y en que se ha desarrollado en una Casa de Juventud autogestionada, poco estudiadas hasta el momento. Ahí reside la relevancia de nuestro estudio ya que introduce a un colectivo silenciado como el juvenil en un contexto académico en el que se abren nuevas líneas de investigación educativa próximas a la realidad.

Además, reside el interés por poner en marcha todo aquello que está en nuestras manos para conseguir el objetivo propuesto por la UE de animar a las jóvenes en la participación social y activa. Este objetivo otorga importancia al diseño de políticas y estrategias de intervención basadas en evidencias concretas, experiencia y conocimiento sobre la situación de las jóvenes, su bienestar, su calidad de vida y sus oportunidades para tomar parte activa en la sociedad. Por lo tanto, buscar alternativas reales al modelo de política de juventud existente hasta la actualidad es una de las finalidades de esta tesis.

A continuación describo de forma breve los capítulos que dan forma a esta tesis doctoral.

En el primer capítulo abordo el marco teórico y el estado de la cuestión en cuatro apartados distintos. El primero de ellos fundamenta la Pedagogía Social, la Educación no formal y la Animación sociocultural en el tiempo libre y de ocio de la ciudadanía. Paso al siguiente punto para indagar en el papel de las jóvenes en la participación social y la democracia para después, en el apartado tres, concretar este papel a través del asociacionismo como espacio de aprendizaje e indagar en el Modelo de Casas de Juventud. Finalmente se hace un recorrido por las diferentes investigaciones encontradas y más destacadas que han tenido lugar a lo largo de esta última década (2006-2016).

Seguidamente, en el segundo capítulo se describe el Posicionamiento metodológico que he asumido como investigadora en esta tesis doctoral. Hago un recorrido a través de la ética de la investigación concretando el significado de la etnografía y los diferentes enfoques etnográficos que han aparecido en las últimas décadas. También expongo las características de la 
etnografía, de su diseño y de las estrategias, técnicas y herramientas de investigación.

En el siguiente capítulo, Cartografía de la investigación, se describe el estudio realizado exponiendo todo el diseño de la investigación. En sus páginas se detalla el problema de investigación, las preguntas, los objetivos, las fases de la investigación, los procedimientos de construcción de la información y las perspectivas y procedimientos de análisis de la información.

El cuarto capítulo se divide en dos partes en las que conoceremos más de cerca los Componentes contextuales de la investigación. En la primera se presenta a cada una de las personas que han participado de manera directa en la construcción de la historia. En la segunda se hace una descripción del contexto de investigación, concretamente de la Casa de Joventut La Maranya y su entorno.

A continuación se plantea el capítulo cinco y en él los Resultados de la investigación. Estos resultados se narran en formato Historia de Vida de la Asociación relatándolos a partir de la cronología de vida del colectivo. En él se abordan todos los elementos estructurales que surgen a partir del análisis estructural y que después facilitan la redacción a partir del análisis narrativo. La investigadora se presenta como narradora al situarse desde el inicio del estudio como militante en el movimiento, además se considera que es una forma óptima para hacer surgir la pluralidad de voces existentes en el colectivo. El relato se divide en cuatro partes principales que ayudan a dar continuidad a la historia: Jo m'enmaranye...; Descobrint els nostres arrels; Propera estació Maranya: viatges compartits y Una tesi per a Maranya.

Para finalizar encontramos el capítulo seis en el que se desarrolla la Discusión y Conclusiones de la investigación. En primer lugar se realiza una aproximación conjunta entre conclusiones y teoría a partir de las preguntas de investigación. Se da respuesta a las dos principales preguntas sobre el papel que ocupa la Casa de Joventut La Maranya en la cultura de participación juvenil a la vez que se descubre como agente educativo de cambio. De forma consecutiva encontraremos la traducción en inglés de este apartado para continuar con el último capítulo. En él tendremos otros tres subapartados en los que se hacen aportaciones a la investigación, se 
describen los retos de la misma y se ponen en común diferentes líneas de trabajo e investigación futuras junto a algunas propuestas de mejora.

A continuación podremos leer el cierre de esta tesis: Ciudades de papel.

En la parte final se encontrará la Bibliografía que ha servido de apoyo a lo largo de todo este proceso. Los anexos y una tabla de contenidos que recoge un esquema de todas las imágenes, tablas, mapas, y códigos QR que aparecen a lo largo de esta tesis. 

«Tenim al cor una flama ben gran!

No tenim por a pensar, i més enllà, actuar!

Ens veiem al camí! »

(Cita textual del facebook de La Casa de Joventut La Maranya)

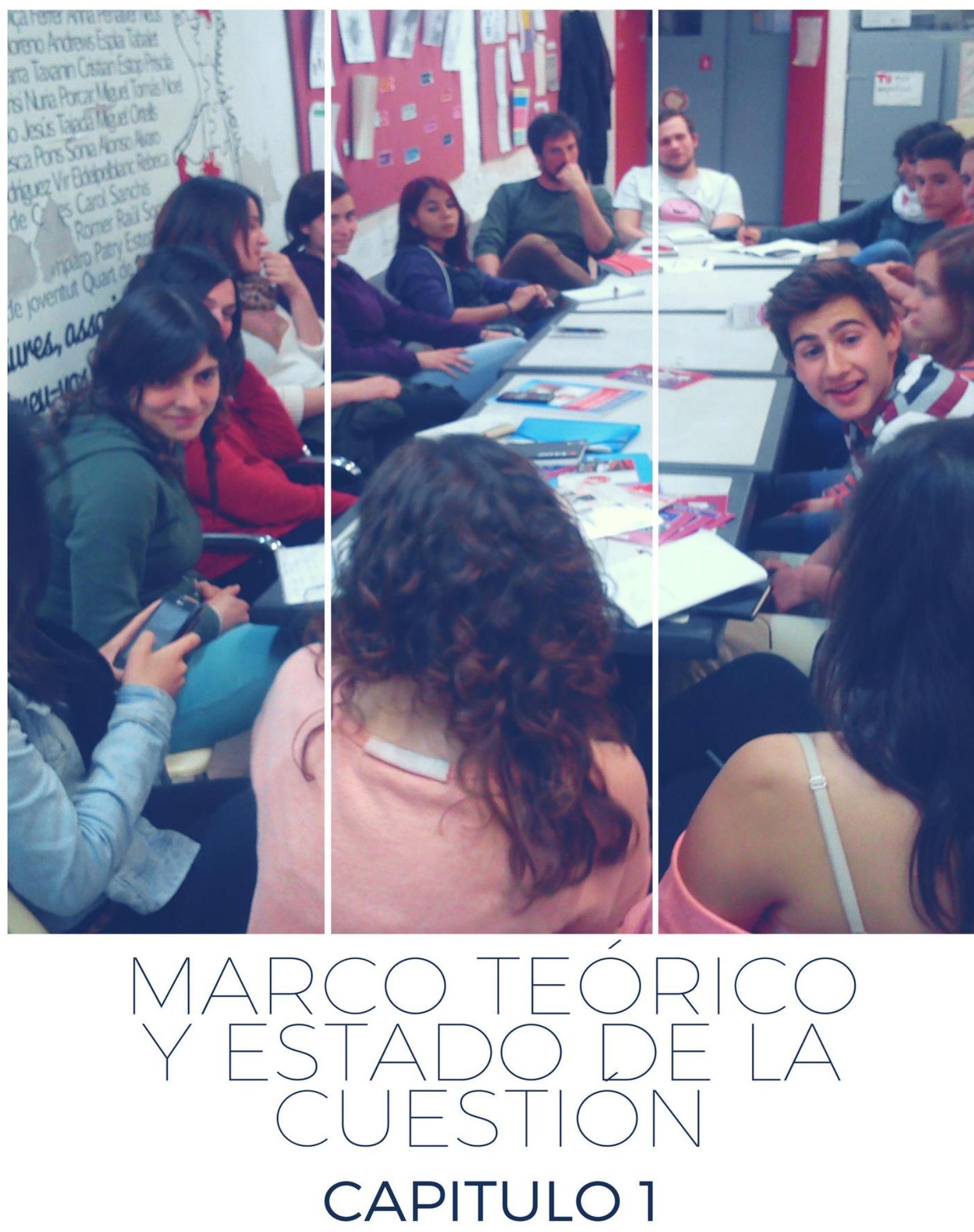



En el siguiente punto abordaremos el marco teórico que da forma a nuestra investigación. Reconocemos la importancia de analizar la literatura científica desde el contexto ya que sólo así conseguiremos definir los conceptos desde una posición mucho más entendible y próxima a nuestra realidad. Así se pensará el lugar desde el que trabajamos a partir de un contexto determinado, sumergiéndonos en la cultura de nuestro lugar de actuación. Por esta razón dotamos de una importancia singular a la literatura española que será la que nos permitirá entender el estado de la cuestión en nuestro país. Asimismo abordaremos el resto de literatura europea y americana principalmente, ya que esta nutre el contexto en el que empieza a surgir la Pedagogía Social y la Animación Sociocultural en España.

En primer lugar, haremos un recorrido por la Pedagogía Social como disciplina marco de este trabajo, entendiendo cual ha sido su papel en el proceso educativo de la comunidad. En este sentido focalizaré en la Animación sociocultural como ámbito particular de intervención para concretarla en la Educación No Formal y los espacios educativos en el Tiempo libre.

En un segundo punto, se aborda el papel de las jóvenesen la participación social y en la democracia concretando cual es el papel de las actividades en el tiempo libre con este colectivo. Además realizaré una aproximación al término democracia tal y como lo entiendo en el trabajo con la ciudadanía.

En un tercer apartado hablo sobre el asociacionismo como espacio de aprendizaje haciendo un recorrido histórico sobre el papel que han cubierto en España a lo largo de estas últimas décadas y el valor que se les da como lugar para un aprendizaje comunitario y situado.

En el cuarto punto, encontramos el punto que hace referencia al Modelo de Casas de Juventud (CdJ). En él hago un pequeño recorrido histórico que continuará con la descripción de las CdJ, sus objetivos, estructura, ideario y estado de la cuestión en referencia a la investigación concreta sobre CdJ.

Finalmente vemos cual es el estado de la cuestión, en los últimos 10 años, sobre participación juvenil en espacios de educación no formal como podrían ser las Casas de juventud. 


\subsection{Pedagogía Social, Educación No Formal y Animación Sociocultural en el tiempo libre y de ocio de la ciudadanía.}

\subsubsection{La Pedagogía Social como disciplina marco.}

Para conocer y reconocernos en la historia voy a transitar por la cronología de la Pedagogía Social. Esta nos ayuda a reconocer de dónde venimos y hacia dónde se dirige la nueva Pedagogía Social hoy.

Abordaremos esta primera parte ayudada por el trabajo de los profesores Schugurensky y Silver (2013). Estos dos autores nos ofrecen un interesante recorrido por la historia de la pedagogía, sus principales autorías y las ideas que dieron forma a lo que conocemos como Pedagogía Social. Son múltiples las autoras que combinan tres principios fundamentales que poco a poco irán conformando lo que conocemos bajo el nombre de Pedagogía Social. A través del Trabajo Social, el Desarrollo comunitario y la Educación, Johann Heinrich Pestalozzi, Robert Owen, Anton Makarenko, John Dewey, Jane Addams, Myles Horton, Moses Coady, Grace Abbott y Paulo Freire dan forma a esta historia.

El nacimiento de la Pedagogía Social data del siglo XIX, concretamente Karl Mager (1810-1858) es la persona que acuñó el término Social Pedagogy en 1844 aunque fue Friedrich Diestersweg (1790-1866), el que lo introdujo por primera vez. Ambos creían que la educación tiene una función social y que esta se conseguiría con la adquisición de conocimiento individual siempre que estuviera focalizado en la adquisición de la cultura por una sociedad que realice actividades orientadas a un beneficio comunitario. Si vamos un poquito más atrás, podemos conocer por quienes estuvieron influenciados Mager y Diesterweg. Pestalozzi (1746- 1827), fue la persona que introdujo, aún sin utilizar el concepto, lo que acabaría llamándose Pedagogía Social describiéndola como una balanza entre cabeza, corazón y manos. Además de reconciliar la tensión educativa existente entre los objetivos individuales y los sociales en la educación. Como vemos y como apunta Petrie (2013) es probable reconocer ideas de filósofos y visionarios (Voltaire, Kant, Fichter y Owen) del siglo XVIII en las ideas de los pedagogos sociales del siglo XIX. En este siglo, podemos destacar las ideas de otro pensador humanista como fue Nikolaj Grundtvig (1783-1872). 
Grundtvig trabajó para extender las ideas filosóficas de Owen y evidenciarlas en la práctica, a través de la fundación de las conocidas folk schools en Dinamarca siempre guiado por los conceptos de living word y school for life.

La intensidad de las ideas con base comunitaria evidencia como la realidad social siempre ha ido por delante de la Pedagogía Social. Primero surgió la práctica y después se configuró la teoría. «De hecho, el nacimiento de esta viene condicionado, en Alemania, donde surgió, por las situaciones de necesidad que en torno a la juventud en contextos extraescolares y extrafamiliares, se configuraron como resultado de la primera guerra mundial» (Sáez, 1997:47).

Durante el siglo XX aparecen diferentes figuras que ponen de manifiesto que la Pedagogía Social se conforma por los aspectos sociales de la educación y los aspectos educativos de la sociedad. «La pedagogía es siempre social, con vocación de práctica comunitaria» (Sáez, 1997:43). Es social o no es educación y así era como lo defendía el considerado padre de esta disciplina, Paul Natorp (Schugurensky y Silver, 2013). Este estuvo influenciado por las ideas de Kant (1724-1804) a la vez que por el sociólogo alemán Ferdinand Tönnies (1855-1936), el cual exponía que toda actividad educadora se realiza sobre la base de la comunidad ya que el individuo humano aislado es una mera abstracción de lo comunitario (Tönnies, 1979). En este sentido, Natorp extendía la idea de que la Pedagogía Social podía contribuir al proyecto de democracia ya que es un movimiento progresivo y emancipatorio. A la vez que Natorp redefinía sus ideas en Alemania, Anton Makarenko (1888-1939) desarrollaba una filosofía educativa centrada en la cooperación y la democracia. Este pedagogo realiza colonias con niños, niñas y jóvenes estableciendo su organización a partir de un sistema de trabajo basado en la autonomía (Mendia, 1991). Él creía fielmente en la idea de que la educación debe estar presente a lo largo de la vida y remarcó esta idea revistiendo de proceso educativo en todo lo que en ella se daba (Gadotti, 2003). Ambos recalcan la importancia de las necesidades comunes ante las individuales siempre buscando el bien común.

La Pedagogía Social es práctica, nace de ella y con ella ha de continuar, por eso no podemos olvidar la praxis para definirla, reconstruirla y constituirla científicamente, no podemos olvidarnos de hacerlo desde la realidad para 
continuar con una disciplina que siga teniendo el sentido social de sus inicios (Sáez, 1997).

Además de la divulgación europea de esta disciplina y sus ideas democráticas y humanitarias, fue durante los primeros años del siglo XX cuando educadores norteamericanos contactaron con estas ideas europeas progresistas y educativas a partir de filosofías y prácticas que daban nombre a la Pedagogía Social. Educadores como Joseph Hart, Edward Lindeman, Royce Pitkin, y Myles Horton no se nombraban como pedagogos sociales aunque se empezaron a interesar por las ideas de Grundtvig y su trabajo en las Folk. Schools queriendo actuar para conformar centros de aprendizaje comunitario promocionando herramientas comunitarias para el aprendizaje colectivo, la autogestión ciudadana y el uso de un método científico para afrontar los problemas sociales (Hart, 1926 citado en Schugurensky y Silver, 2013). Por ejemplo, Lindeman asumió ideas como el bien común y el cambio social y las promocionó a lo largo del país (Lindeman 1926 y Stubblefield 1988 citados en Schugurensky y Silver, 2013).

Desafortunadamente, y como ocurriría con otras disciplinas, aun teniendo un objetivo claro humanitario y democrático, entre 1930 y 1940 los Nazis se apropiaron de la Pedagogía Social. Impusieron una corriente en la que adaptaron su desarrollo comunitario y ciertos elementos educativos para la juventud Hitleriana rompiendo con la finalidad social de la pedagogía a partir de sus ideas exclusoras y dictatoriales.

Tuvimos que esperar hasta después de la Segunda Guerra Mundial para que una nueva generación progresista de pedagogos sociales revisara algunas ideas del pensador Noll. Fueron nuevos educadores alemanes como Klaus Mollenhauer (1928-1998) y Hans Thiersch (1935- ), influenciados por la Escuela de Frankfurt, quienes se aproximaron hacia ideas de la teoría crítica. Por su parte, en América del Norte, Horton emprendió el estudio de la cultura danesa y su lenguaje para entender mejor la potencialidad de las folk schools. De este modo hizo posible el proyecto educativo que convertiría a las participantes en agentes de cambio social (Adams y Horton, 1975).

Para entender como las ideas de Pedagogía Social se fueron extendiendo alrededor del mundo tenemos que echar la vista atrás. Concretamente al trabajo de John Dewey (1859-1952) ya que fue otro de los autores que, sin 
hablar de Pedagogía social, ya exponía muchos de los principios que dan forma a esta disciplina. Con sus ideas se cruzó Anisio Teixeira (1900-1971) quien hizo viajar las ideas de Dewey a través de Sudamérica. Fue esta conexión la que posibilitó que Paulo Freire (1921-1997) conociera las contribuciones de Dewey. Según Schugurensky (2011), Freire enfatizó todas las ideas que ya se sucedían hasta el momento incluyendo la importancia del trabajo en grupo, el diálogo, la acción reflexiva, la concientización, el conocimiento local y el desarrollo comunitario en el proyecto de humanización, emancipación y transformación social.

Según Sáez (1997), en España, con todas estas aportaciones se empieza a fraguar una definición de lo que significa Pedagogía Social. De forma general esta disciplina se centra en dos aspectos que se complementan entre sí. Uno de ellos es que los individuos tengan una correcta socialización. En segundo lugar es que en la sociedad existen múltiples necesidades humanas que la aquejan y la intervención pedagógica puede funcionar como remedio.

Las prácticas encaminadas hacia la socialización de las personas y la intervención en las necesidades sociales empiezan a darse en muchos países como Alemania, Reino Unido, Bélgica, Dinamarca, España, Estados Unidos, Brasil e incluso Canadá, en donde Moses Coady (1882-1959) y su equipo de Nova Scotia (Canadá) realiza un buen trabajo combinando educación para adultos y cooperativismo.

De toda la historia recogida hasta estas líneas Schugurensky y Silver (2013) remarcan tres aspectos importantes. Hasta la actualidad, se han continuado las prácticas y las teorías sin la necesidad imperante de denominarlas bajo el término de Pedagogía Social. Aunque la Pedagogía Social naciera en Alemania y se extendiera por toda Europa se pueden identificar ideas y prácticas sobre ella alrededor de todo el mundo. Por esta razón, la Pedagogía Social reconoce estas ideas y prácticas igualmente. Finalmente, remarcan que estas ideas han ido atrás y adelante en el tiempo de manera formal pero muchas de ellas también lo han hecho de manera informal con lo que es difícil capturar todo lo que ha supuesto la Pedagogía Social en algún momento de la historia.

Llega un nuevo siglo, el siglo XXI no abandona las ideas reconstruidas a lo largo de todos estos años. Hoy existe una disciplina que ha traspasado la 
práctica y la filosofía para implantarse como un espacio de educación superior. En España se establece la diplomatura de Educación Social que será la herramienta para seguir extendiendo la Pedagogía Social de un modo más profesionalizador. Además de ello, entran en juego nuevos contextos y los efectos de la política neoliberal provocan evidencias sobre la importancia de seguir trabajando bajo las líneas de la Pedagogía Social. Tal y como exponen Rodríguez (2013) y Counsell y Boody (2013) hay un interés en analizar el impacto de las políticas del gobierno en el bienestar de las personas y en la posibilidad de que estas cambien a partir de los esfuerzos de la Pedagogía Social. En definitiva, las intervenciones pedagógicas deben ir acompañadas de políticas orientadas hacia la justicia social (Schugurensky y Silver, 2013). Esta es una de las evidencias que establece conexiones entre la Pedagogía Social y los movimientos sociales y de esta forma se amplían los ámbitos de trabajo de la Pedagogía Social además de los espacios donde compartir experiencias, prácticas y teorías como por ejemplo, la Sociedad Iberoamericana de Pedagogía Social (SIPS) y la Nordic Educational Research Association (NERA).

En relación al término, España también ha ido evolucionando en cuanto a lo que entendemos por Pedagogía Social. Aun así es difícil encontrar una conceptualización estática de la misma ya que la Pedagogía Social, como disciplina social que es, permanece en constante movimiento tal y como ocurre con la propia realidad. Si recordamos, los inicios estaban ilustrados por indicadores de necesidades sociales y con el tiempo pasaron a basarse en elementos de libertad social (Trilla, 1992). Todo ello encaja con la complejidad de nuestras sociedades a la vez que lo hace con las dificultades para que exista una definición consensuada de lo que significa Pedagogía Social ya que esta emerge de cada encuentro que se produce (Úcar, 2013). Según este autor las relaciones humanas en las que se basa la Pedagogía Social en contextos socioculturales concretos son complejas y por ello, no sería suficiente enmarcar esta disciplina únicamente desde la técnica y la ciencia. Este encuentro educativo se singulariza también por la imprevisibilidad y lo singular del momento y esto posibilita que los agentes se conviertan en seres creativos además de abrir la búsqueda a nuevos caminos. Por ello Úcar (2013), retoma la idea de Morin cuando señala que en estos planteamientos se ve como el siguiente paso para la ciencia y la tecnología es el arte y por eso propone volver a la concepción clásica del 
arte de la educación para que la pedagogía se nutra tanto de la técnica y la ciencia como de lo humano, lo creativo y artesanal.

En 1996 Trilla plantea una propuesta teórica sobre la Pedagogía Social que actualizan Núñez y Úcar (2010) y que se basa principalmente en la idea de que la Pedagogía Social es un proceso educativo que:

1. Se dirige específicamente al desarrollo de la sociabilidad de los sujetos sea esta física o virtual. La Pedagogía Social se interesa por los procesos de socialización que se producen en ámbitos físicos y virtuales y por las maneras cómo unos y otros inciden sobre las personas. Se podría decir que, en general, la socialización y la sociabilidad constituyen el espacio propio de la educación y de la Pedagogía Social.

2. Busca la participación de personas, grupos o comunidades que están en situación de vulnerabilidad, riesgo o conflicto social.

3. Actúa en los diversos contextos, físicos y virtuales, en los que se desenvuelve la vida cotidiana de las personas, los grupos, y las comunidades.

En una línea similar la define Úcar (2013)

I understand social pedagogy, from an interdisciplinary and interprofessional view, to be a bybrid, complex, open, dynamic, changing, alive, and incredibly versatile subject. It may be considered both a science and a practice. When integrated, theory and practice explain social pedagogy, but they cannot do so independently. As a practical science or as a scientific practice, social pedagogy generates new knowledge from its actions and practices. This new knowledge can be applied to generate, once again, specific practices, knowledge and skills in an ever-growing spiral that is always in motion. ${ }^{2}$ (pp.11)

\footnotetext{
2 Entiendo la Pedagogía Social, desde una visión interdisciplinar e inter-profesional, como un híbrido, complejo, abierto, dinámico, cambiante, vivo y muy versátil. Se puede considerar una ciencia y una práctica. Cuando se integra, teoría y práctica explican la Pedagogía Social, pero no pueden hacerlo de forma independiente. Como una ciencia práctica o como una práctica científica, la Pedagogía Social genera nuevos conocimientos a partir de sus acciones y prácticas. Este nuevo conocimiento puede ser aplicado para generar, una vez más, las prácticas específicas, conocimientos y habilidades en una espiral creciente que está siempre en movimiento.
} 


\subsection{2 ¿Qué es la Animación Sociocultural?}

Definiendo la Pedagogía Social como una reflexión e intervención socioeducativa, la asumimos como el marco científico, normativo y racionalizador de la educación social (Caride, 1986). Dentro de este ámbito genérico contemplamos múltiples campos de actuación siendo uno de ellos la Animación Sociocultural (Úcar, 1996).

La Animación sociocultural (ASC) surge de la Educación Popular, algunos autores como Xavier Úcar (1992) piensan que ha existido siempre aunque no estuviera delimitada bajo un término concreto. Su origen se remonta a Francia y fue en 1945 cuando el término «animador» empieza a utilizarse (Simpson, 1989). Ya en 1955 se utilizaría también el concepto «animación» y en los años 60 «las expresiones de animation socioculturelle y animateur eran moneda corriente en los debates francófonos sobre asuntos culturales» (Simpson, 1989:282). Vemos como la Animación sociocultural aparece en Francia y se extiende por el continente europeo hacia Bélgica, Holanda, algunas regiones de Suiza y también el Reino Unido en donde, de forma paralela, se extiende bajo la vertiente de socio-cultural community development. Aun así, según Simpson (1989), esta expresión nunca acaba de asimilarse por el vocabulario educativo del país ni esta, ni la traducción sociocultural animation aunque ello no significará que en los países anglófonos no se practique la ASC. Lo que sucede según Calvo (2002:15) es que se utilizan otros términos como community development, capacity building, personal empowerment o community-based initiatives entre otros. Esta situación dificulta el consenso para generar un término común, complicando su desarrollo teórico (Simpson, 1989; Calvo, 2002). Aunque desde un análisis práctico realmente lo que consigue es ampliar la mirada desde el prisma de la acción.

Pronto se extendió a otros muchos países como España, en el cual nace como práctica social y cultural y no como una teoría (Úcar, 1992). Los antecedentes provienen del conjunto de acciones que se llevaron a cabo en el país con anterioridad a la Guerra Civil Española: Sociedades Económicas de Amigos del País, Ateneos burgueses, Asociacionismo obrero, Universidades Populares, Institución libre de Enseñanza, Misiones Pedagógicas, Escuela Nueva, Escuela Moderna y Colonias de vacaciones, entre otras iniciativas. 
En nuestro contexto, es en los años 50 cuando se intenta dar respuesta a diferentes problemáticas sociales que se han desatendido por completo por la administración (Núñez y Úcar, 2010). Recordamos que nos encontramos en plena dictadura franquista y es la ciudadanía la encargada de gestionar este movimiento que, desde finales de la guerra hasta esta época, estuvo atesorado por el gobierno franquista. A esta iniciativa ciudadana Úcar (2001:2) lo llama «intervenciones artesanas» ya que prescindían de conocimientos teóricos y metodologías de intervención socioeducativas y se ponían en práctica gracias a la militancia política y al deseo de cambio social. Esto genera un campo histórico en el que se empieza a trabajar la educación social en nuestro país.

Los años sesenta catalanes dieron pie a múltiples iniciativas que serían nombradas más tarde como prácticas de Animación Sociocultural. El acercamiento de las ideas de Freire al contexto español hacía que se conformara una base crítica que se empezaba a establecer en el país.

Durante los años setenta, se conforma un contexto socioeconómico desestructurado y repleto de múltiples necesidades; un contexto político que reivindica el «estado de bienestar». Se asume que el propio estado se hará cargo de que funcione este nuevo modelo. A su vez existe un contexto cultural que pretende acercar la cultura a todas las capas sociales y que pasa de la democratización de la cultura a la democracia cultural (Trilla, 1997). En ella será la propia ciudadanía la encargada de generar esa cultura (Simpson, 1979 citado en Úcar, 1992: 14). Tal y como Úcar (1992:14) cita a Ventosa (1989:72) «deja de ser un bien de consumo al convertirse en un ámbito de desarrollo personal y colectivo». En definitiva, el primer concepto asume que la cultura ya está creada y simplemente hay que acercarla a la ciudadanía. Sin embargo en la segunda conceptualización la potencialidad para crear la cultura es de la propia ciudadanía y en este sentido, «la animación sociocultural será el instrumento de la democracia cultural» (Trilla, 1996a:91).

A esto se le suma la fragmentación del contexto educativo formal que se ve sumido en una crítica sobre la institución escolar y la realidad social.

Para Úcar (1992), existen cuatro contextos que anteceden la aparición de la Animación sociocultural en España: socioeconómico, político, cultural y educativo. 
Estos cuatro contextos interactúan de una forma sistémica y globalizante para producir la aparición de la animación sociocultural como un movimiento de reacción y de respuesta frente a la crisis, que reconduzca, en una perspectiva innovadora y transformadora, el desarrollo sociocultural hacia un camino donde la persona sea protagonista autónoma y no dependiente de sus propias creaciones (pp.15).

Queremos destacar que aunque durante los años de transición se asume por parte de la administración pública el trabajar a partir de la ASC, esta no nace de ella ni tampoco del planteamiento teórico sino de la movilización civil, de la práctica directa y de la alta participación a partir del voluntariado.

De forma concreta, podemos leer a diferentes autoras, entre las que destacamos a Martínez (1999); Núñez (1999); Úcar (1996; 2001); Calvo (2002) y Centeno (2005) que se basan en los resultados de las Jornades sobre la formació d'educadors $i$ agents socioculturals que se realizaron en 1988 en Barcelona para presentar los tres ámbitos históricos de la educación social:

- La educación especializada

- La educación de adultos

- La animación sociocultural

Durante mucho tiempo la Animación sociocultural ha transcurrido de forma paralela a la Pedagogía Social pero desde que se implanta en España la diplomatura de Educación Social diferentes cuestiones conceptuales, epistemológicas, coyunturales y de oportunidad hacen que se asuman como propias de la Pedagogía Social, la Educación para adultos y la Animación sociocultural. Desde ese momento puede considerarse como integrada dentro del campo de la Pedagogía Social (Trilla, 1996).

Según Ventosa (citado por Úcar, 1992:30) la palabra «animación» se conforma en una doble raíz latina, anima y animus, «con un trasfondo griego que la fundamenta». Moulinier (1973, citado por Calvo, 2002) describe las dos formas de entender el término a partir de las raíces anteriores. Cada una de ellas se identifica con una idea de animación:

- Anima: con un sentido de alma, de vida, de aliento vital revitalizador, actuar sobre, dar vida. 
- Animus: con un sentido de movimiento, de dinamismo, de incitación a la acción, actuar en, poner en relación.

Tabla 1. Raíces latinas de la palabra animación. Elaborada por Calvo, 2002:17 a partir de Froufé y Sánchez, 1990:32.

\begin{tabular}{|l|l|}
\hline \multicolumn{1}{|c|}{ ANIMA } & \multicolumn{1}{|c|}{ ANIMUS } \\
\hline \multicolumn{1}{|c|}{ Dartuar sobre» } & \multicolumn{1}{|c|}{ «Actuar en» } \\
\hline $\begin{array}{l}\text { Animación estructurada y permanente a una } \\
\text { población por animadores profesionales o } \\
\text { semiprofesionales ayudados por voluntarios. }\end{array}$ & $\begin{array}{l}\text { Pnimación que pone por delante la } \\
\text { expresión del grupo y la gestión de este en } \\
\text { lespuestas a sus necesidades. El } \\
\text { animador no es más que una ayuda al grupo } \\
\text { en su gestión. }\end{array}$ \\
\hline $\begin{array}{l}\text { Animación programada en la que el discurso } \\
\text { procede de la acción. }\end{array}$ & $\begin{array}{l}\text { Animación sin programa, a no ser que el } \\
\text { grupo lo dé. La acción basada en el } \\
\text { intercambio y la relación. }\end{array}$ \\
\hline $\begin{array}{l}\text { Animación basada en equipos y espacios } \\
\text { concretos. }\end{array}$ & $\begin{array}{l}\text { Animación basada en el intercambio y la } \\
\text { relación. }\end{array}$ \\
\hline $\begin{array}{l}\text { Animación financiada y a veces preocupada } \\
\text { por la rentabilidad. }\end{array}$ & $\begin{array}{l}\text { La financiación por parte de las autoridades } \\
\text { locales es entendida como una limitación } \\
\text { operativa. No inquieta la rentabilidad } \\
\text { económica. }\end{array}$ \\
\hline $\begin{array}{l}\text { Animación destinada a favorecer una } \\
\text { progresión individual y colectiva en los } \\
\text { diversos dominios. }\end{array}$ & $\begin{array}{l}\text { Animación destinada a cambiar las } \\
\text { relaciones sociales. }\end{array}$ \\
\hline
\end{tabular}

Todo ello sumado a la dimensión social y cultural del término da vida al concepto de Animación sociocultural. En nuestro caso, situamos nuestra pretensión en sintonía con la de Calvo (2002:15) en «utilizar el término animación más allá de la simple actuación que pretende cambiar el estado de ánimo de la gente». Fuera de la delimitación de usarla únicamente como un simple mecanismo de consumo la acercamos a un proceso vital de aprendizaje. Por esta razón, a continuación abordamos diversas representaciones del término cercanas a lo que entendemos por Animación sociocultural.

Trilla (1997) define la Animación Sociocultural a partir de siete propuestas distintas que la describen en su amplitud. Como acción, intervención y actuación; como función social; como metodología, forma de hacer, 
técnica, medio o instrumento; como proceso; como factor; como programa o proyecto y como actividad o práctica social

En Calvo (2002:50-54) podemos leer las propuestas más representativas del término, aquellas que hacen Petrus (1989), Ander-Egg (1989b), Froufé y Sánchez (1990), De Miguel (1995) y Úcar (1996). Nosotras sumamos a estas propuestas la generada por esa misma autora (Calvo, 2002).

Observamos entre ellas (tabla 2) la potencialidad de la participación como proceso sine qua non de la Animación Sociocultural dentro de un trabajo en el que se promueve la cultura colaborativa con el protagonismo de la propia ciudadanía fomentando valores de convivencia, diversidad y comunidad a través de una metodología flexible, dinámica, reflexiva y activa que se adapta a la realidad en la que interviene. 
Tabla 2 Características de la Animación Sociocultural según diferentes autoras.

\begin{tabular}{|c|c|c|c|c|}
\hline 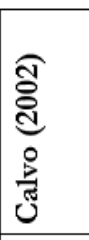 & 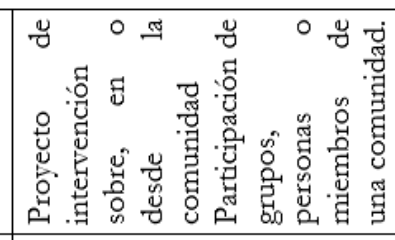 & 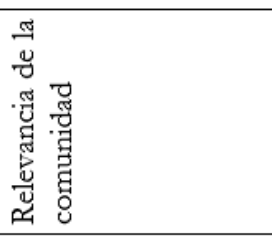 & 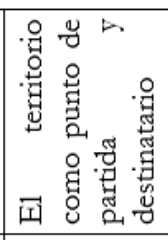 & 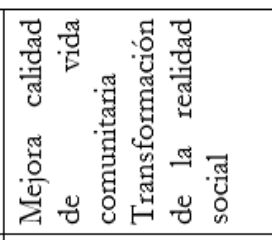 \\
\hline 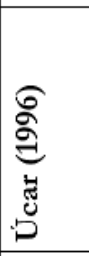 & 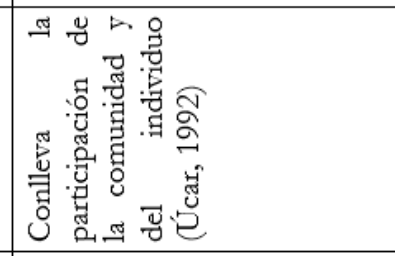 & 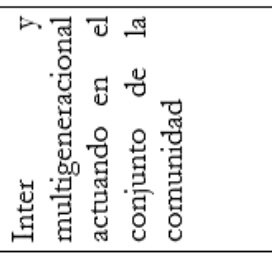 & 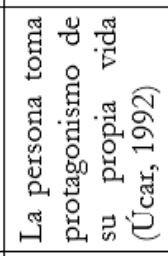 & 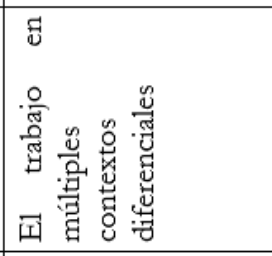 \\
\hline 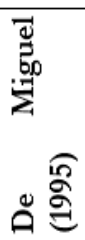 & 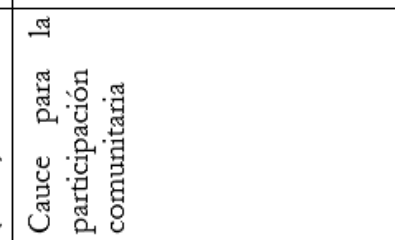 & 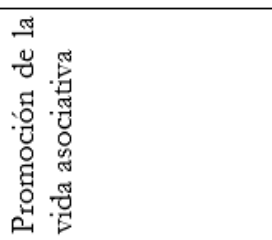 & 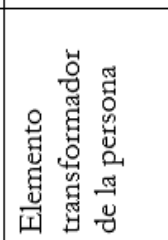 & 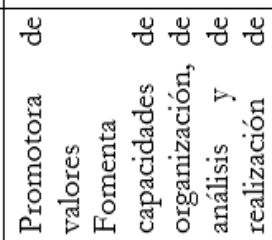 \\
\hline 产 & 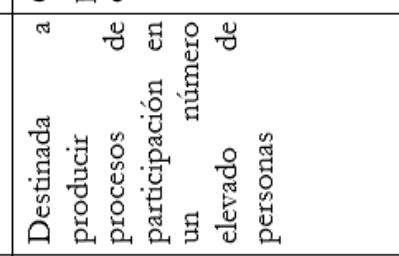 & 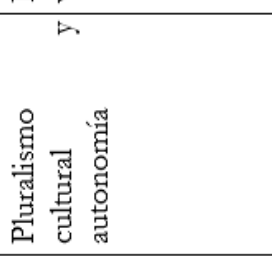 & 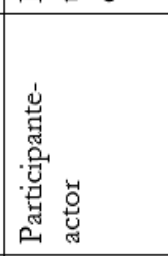 & 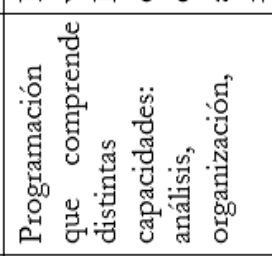 \\
\hline 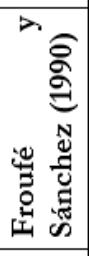 & 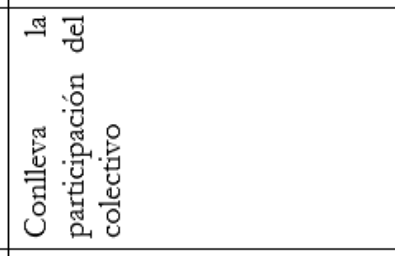 & 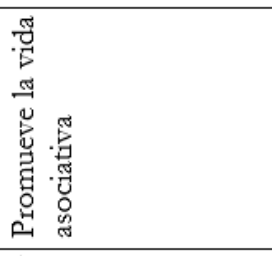 & 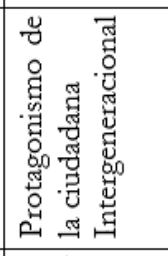 & \\
\hline 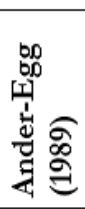 & ( & 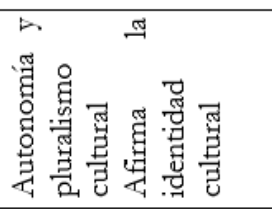 & 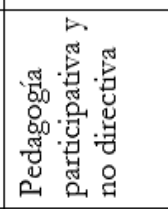 & \\
\hline 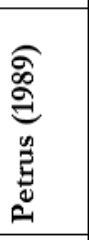 & 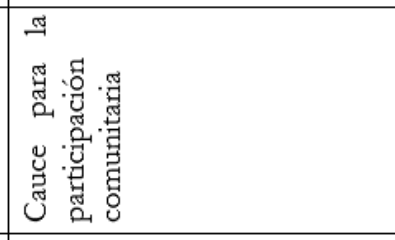 & 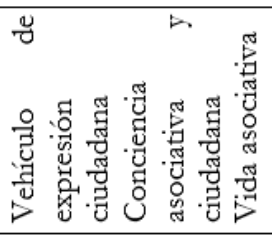 & 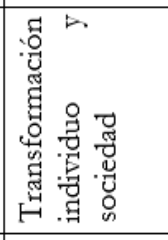 & 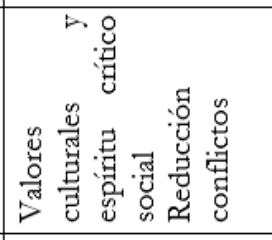 \\
\hline 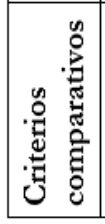 & 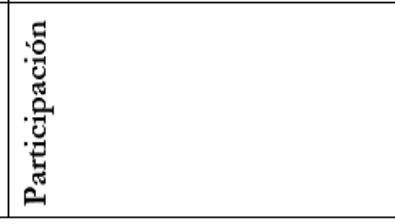 & 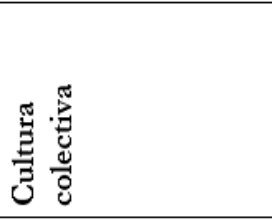 & 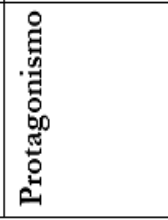 & 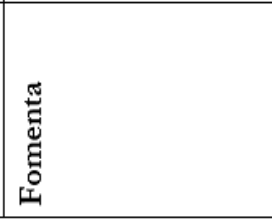 \\
\hline
\end{tabular}




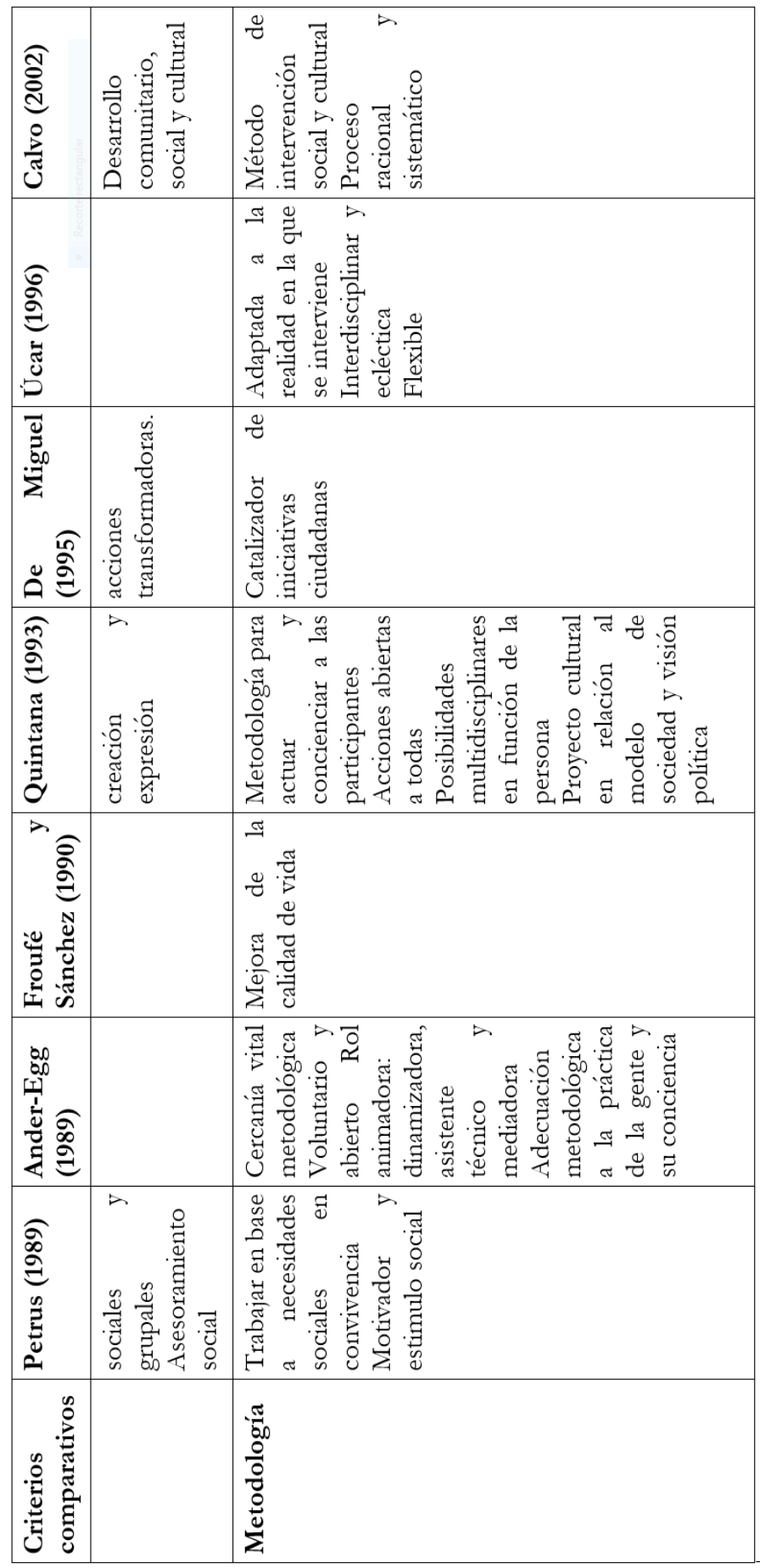


Existe una amplia diversidad de opiniones a la hora de definir la Pedagogía Social y no será menos la existente para definir la Animación sociocultural. Ya sabemos cómo todo lo relativo a lo social se encuentra en constante reconstrucción. Esta misma deficiencia conceptual del término Animación sociocultural es lo que la enriquece porque bebe de cada una de sus prácticas y se alimenta de ellas reconstruyéndose desde la propia realidad y no únicamente desde el estudio terminológico de la misma. «La animación se define por su manera particular de hacer» (Úcar, 1992:35) y eso es lo que la diferencia de otros ámbitos de intervención.

Este aspecto también lo destaca Morata en su tesis (2009) cuando habla de que la mayoría de autoras la definen como una tecnología social que pone en marcha diferentes técnicas, instrumentos, actividades y métodos pero que nunca se reduce a esta visión técnica. A la vez que técnica se aborda desde la praxis ideológica en diferentes procesos orientados al desarrollo, a la construcción de un modelo de desarrollo social y comunitario y, en última instancia, a procesos de transformación social.

Son Pérez Serrano y Pérez de Guzmán, (2006) los que nos aportan una síntesis de diversas definiciones, realizadas por autoras que desarrollaron los primeros textos sobre la teoría y la práctica de la Animación sociocultural. Entre ellas, Simpson (1980), UNESCO (1982), Simonot (1974), Imhof (1971), Del Valle (1971), Weisgerber (1980), Hicter (1980) describen la Animación sociocultural como: un estímulo, un elemento técnico, un conjunto de prácticas sociales, una tecnología social, una transformación social y un proceso de liberación, una acción o conjunto de acciones y un fenómeno social.

Otra interesante definición es la que propone Merino (1997) que define la Animación sociocultural como una metodología activa, dinamizadora, comprometida con el propio grupo y que puede coincidir igualmente con otras metodologías. Un aspecto relevante de este autor es su perspectiva sobre la ambigüedad que genera el hecho de hablar de Animación sociocultural en general y prefiere formular este concepto como «programas de animación sociocultural». Por ello su aportación, a partir de esta concreción, es que «la animación necesita de un proyecto real y concreto que responda a una concepción y que se fundamente en la realidad específica donde se va a desarrollar, con sus necesidades, sus 
posibilidades y alternativas». En este sentido Núñez y Úcar (2010) remarcan que la Animación sociocultural ha de proponer prácticas de dinamización social vinculadas a territorios y comunidades específicas. Es, por lo tanto, una intervención con una clara intencionalidad local. De este modo también lo escribe Trilla (1996) la Animación sociocultural es «el conjunto de acciones realizadas por individuos, grupos o instituciones sobre una comunidad o sector de la misma y en el marco de un territorio concreto, con la finalidad principal de favorecer la participación activa de sus integrantes en el proceso de su propio desarrollo social y cultural».

Siguiendo con Merino (1997), quien realizó un exhaustivo análisis de contenido de más de cien síntesis teóricas y descripciones prácticas, ofrece una serie de categorías que estructuran la base teórica de lo que significa la Animación sociocultural. Estas son:

- Acción social tendente a crear, potenciar, fortalecer el dinamismo y cambio social.

- Educación basada en una pedagogía activa y participativa, así como también sus metodologías.

- Democratización vs. Democracia cultural.

- Generar y fortalecer grupos sociales autónomos y procesos de grupo operativos.

- Prácticas sociales que estimulan la iniciativa, la participación y la «reflexión-acción».

- Tecnología de intervención social.

- Búsqueda y gestión de recursos, para potenciar la identidad y protagonismo de los individuos y grupos, en su desarrollo cultural y social, dentro del marco de su propio territorio y comunidad.

Además de las definiciones, las categorías y los rasgos que se han descrito sobre la Animación sociocultural, algo que puede orientar nuestra visión sobre el ámbito que estamos describiendo son los objetivos que persigue. Todos ellos muy relacionados con todo lo relatado hasta el momento. En este caso seguimos el listado de Úcar (1992) que es el siguiente «el desarrollo de la concientización y el sentido crítico, la participación, la 
integración social, la dinamización sociocultural, la innovación y la creación cultural, la utopía, el talante metodológico y la ideología y la tecnología» (pp. 63).

Para finalizar exponer otro de los aspectos más importantes que definen la Animación Sociocultural, el rol de animadora sociocultural como profesional y/o militante. Este ámbito de intervención se inicia a partir del voluntariado de muchas personas que se movilizan para generar el cambio social y multitud de militantes que dan base al movimiento. Hoy, la Animación sociocultural precisa de profesionales para continuar sustentándose como profesión acreditada aunque se sigan sucediendo potentes proyectos de Animación sociocultural promovidos por el voluntariado y la militancia. De ahí que el trabajo a partir de estas dos figuras siga siendo un aspecto relevante de la Animación sociocultural y un potente foco de análisis. La figura de la animadora sociocultural siempre ha estado cuestionada por su profesionalidad pero no debemos olvidar que esta «surge de las acciones voluntarias, o incluso militantes, que realizaban individuos durante su tiempo libre y de forma económicamente desinteresada»(Trilla, 1996a:93). Desde hace años existe una polémica entre profesionalización versus voluntariado que se instala en el significado de la Animación sociocultural. Tal y como Dapía (2002) contempla (tabla 3) existen coincidencias entre diferentes autoras (Quintana, 1993; Armengol, 1997; Froufé y Sánchez, 1990) que argumentan la ineficacia de la exclusividad hacia una esfera o la otra. Todas ellas abogan por la coexistencia de ambos perfiles y los argumentos que ofrecen para defender un papel u otro son:

Tabla 3. Diferencias entre animadoras profesionales o voluntarias.

\begin{tabular}{|l|l|}
\hline \multicolumn{1}{|c|}{ Animadoras profesionales } & \multicolumn{1}{c|}{ Animadoras Voluntarias } \\
\hline Competencia técnica & Alta dosis de implicación personal \\
$\begin{array}{l}\text { Mayor formación para la tarea } \\
\text { Servicio más regular, continuado e e } \\
\text { intensivo }\end{array}$ & $\begin{array}{l}\text { Motivación más militante que económica } \\
\text { Analizan los problemas de la sociedad en la } \\
\text { que viven }\end{array}$ \\
\hline
\end{tabular}

Vemos como los principales temas de debate dentro de esta diferenciación son los que cita Armengol (1997) entre vocación-profesionalidad; dedicación-retribución; encargo institucional y formación.

Este trabajo desinteresado es el que podría encabezar la relación que encuentran múltiples autoras entre la Animación sociocultural y el 
desarrollo comunitario. Muchas autoras lo que valoran es que la Animación sociocultural, como metodología, hace posible el desarrollo comunitario como objetivo (Bueno, 1991; Úcar, 1992; Froufé, 1998; Morata, 1997; Quintana, 2002, Úcar y Llena, 2006). La Animación sociocultural como elemento social y cultural permite que el desarrollo comunitario se emprenda desde la ciudadanía. Este es el valor que le damos a la animación sociocultural sea esta remunerada o no, voluntaria o profesional.

\subsection{3 ¿Y si la Animación Sociocultural la vivimos desde la Educación no formal?}

Conocemos experiencias de Animación Sociocultural en diferentes contextos, desde espacios no formales como podrían ser los centros de educación en el tiempo libre hasta contextos informales como las asociaciones de vecinos pero también formales como los Institutos de Educación Secundaria. Estructuralmente estas prácticas se ubican en múltiples actividades desde un curso de economía doméstica, la organización de una acción reivindicativa hasta la facilitación de programas de actividades formales.

Por eso para iniciar este punto quisiera definir los términos Educación Formal, Educación No Formal y Educación Informal para conocer de dónde partimos y dónde ubicamos a la Animación Sociocultural.

La formalización o institucionalización de la educación se produce cuando se asigna a la escuela la función educativa que le era propia, sometiéndola a objetivos y métodos (Traver, 2007). Tal y como afirma este autor se constituye la Educación Formal siendo la mayor expresión de la educación intencional.

Por otro lado, entendemos la educación no formal como aquella que tiene sus bases en necesidades educativas de la comunidad no satisfechas en el mundo de la escolaridad, o practicadas en ella de forma restrictiva, y en el aprovechamiento de la potencialidad pedagógica de las relaciones humanas no instituidas (Aguirre García-Carpintero, 2012). Además, esta se considera más democrática que la formal ya que, mayoritariamente, sus propuestas rompen la rigidez y las gradaciones establecidas en la escuela y propician mucho más la participación. La educación no formal se desvincula del sistema educativo para ejercerse de forma independiente o formar parte de 
una actividad más general. Sus objetivos sociales son mucho más amplios y no se reducen a currículums estandarizados y establecidos por jerarquía (Traver, 2009a).

En relación a la educación informal, tal y como apunta Coombs (1985), entendemos que es la modalidad de educación más omnipresente y, podría ser, a la larga, la más importante de todo el panorama educativo. Por este motivo, tampoco podemos dejarla al margen de nuestro proyecto. El nuevo modelo de sociedad intercultural requiere de la creación de una ciudadanía activa, responsable y crítica a través de la educación no formal desde las instituciones públicas, una ciudadanía que se sitúe en el espacio público desde posicionamientos críticos en claves de equidad, solidaridad y paridad de género (García de Mateos et al., 2011). Se promueve la necesidad de abrir el fenómeno educativo hacia otros espacios no formales (Trilla, 1992 y 1993) como el que abordamos en este trabajo.

En este sentido, diferentes autoras (Collado y Álvarez, 1986; Placer, 1989; Trilla, 1989) comprenden que la Animación Sociocultural se da en el ámbito de la Educación no formal, principalmente debido a que conlleva las siguientes características (Úcar, 1992:41):

- Es intencional, vivencial, crítica, creadora y contextualizadora.

- Se centra en las necesidades de los destinatarios.

- Utiliza metodologías activas y participativas.

- No se necesitan ni requerimientos académicos ni administrativos para la participación en sus actividades.

- Existe una falta generalizada de limitaciones en cuanto a tiempo y a espacios para su realización.

Siguiendo también a Trilla (1996a) recogemos el interés de analizar la Animación Sociocultural desde la Educación no formal sin la intención de reducir las acciones que se puedan llevar a cabo desde los parámetros descriptivos de la misma. Generar este marco pedagógico nos ayuda a describir la Animación Sociocultural sin ningún interés reduccionista. Al igual que este autor, no queremos situarnos en «retratar cánones metodológicos estancos ya que la potencialidad de la educación es su 
interrelación entre las tres educaciones (formal, no formal e informal) para impregnar la frontera entre ellas» (Trilla, 1988:41).

Retomamos un poco de historia para comprender de dónde viene la diferenciación de las tres educaciones. Cabello (2002) nos acerca la historia de la Educación no formal en nuestro país definiendo tres etapas diferenciadas que enmarcan las acciones que tuvieron lugar en cada una de ellas durante el siglo XX y que tienen relación directa con la Educación no formal. A su vez podremos observar las similitudes con las expuestas anteriormente de la Pedagogía Social y la Animación Sociocultural. A continuación hacemos un resumen de los tres períodos:

1) Etapa republicana: Período de desarrollo progresista y democrático. Se dan acciones como las Misiones Pedagógicas, Institución Libre de Enseñanza, la Residencia de Estudiantes y la «Escola Moderna» de Ferrer i Guàrdia entre muchas otras. Junto a ellas Palacios (2005) incluye la Animación Sociocultural desarrollada por la izquierda sindical y política.

2) Etapa dictatorial: Este período se caracteriza por el totalitarismo ideológico y una influencia doctrinaria nacional-católica. Se dan acciones como la Sección femenina, Movimiento Nacional y la Organización Juvenil Española (OJE) entre otras. Carbonell (2015) nos cuenta como durante estos años franquistas, fue la ciudadanía, en sus barrios populares y obreros quienes crearon centros para las personas adultas, eran centros educativos que se movían al margen de las iniciativas oficiales. Es en esos momentos cuando los movimientos vecinales, sociales y culturales resurgen y se tornan instrumentos de crítica hacia el sistema creando espacios que podríamos llamar freirianos de diálogo, imaginación, participación y utopía.

3) Etapa de Transición democrática: Se restaura la democracia y se suceden los diferentes programas en el ámbito nacional: Programas de Ecuación Compensatoria, Programas de Ecuación Permanente de Adultos y Programas de Formación Profesional. Los municipios implantan nuevas acciones sociales y culturales para las personas adultas mediante los Centros Cívicos y las Universidades Populares, las Escuelas Campesinas y las Escuelas Populares. Durante las dos últimas décadas se dan acciones dirigidas a la atención a la diversidad de género, cultural y étnica. Vemos como años después del movimiento ciudadano generado en la Dictadura, la administración se hace cargo de las escuelas que ha construido la sociedad 
civil, ampliándolas e institucionalizándolas. Este aspecto es interesante en dos sentidos: por un lado porque favorece la supresión del analfabetismo, aunque por otro rompe con un modelo pedagógico centrado en la realidad del alumnado que funcionaba a partir de objetivos transformadores. Desde la institucionalización de estas escuelas se deriva hacia el mero aprendizaje instrumental y la progresiva secundarización (Carbonell, 2015).

Esta última etapa coincide con acontecimientos mundiales que ponen en cuestión la misión de la educación. A finales de los años setenta se produjo la «crisis mundial de la educación» (Coombs, 1968). Aunque con anterioridad ya se dieran acciones que se podrían estructurar en los distintos espacios educativos (formal, no formal e informal), tal y como hemos visto en las tres etapas descritas, el origen del concepto data de 1967 cuando se realizó la Internacional Conference on World Crisis in Education celebrada en Williamsburg, Virginia (EEUU). Fue el documento encargado para el congreso el que dio lugar a la conocida obra de Coombs (1968) e instauró el concepto de Educación no formal.

Los años sesenta y setenta del siglo XX fueron tiempos social y políticamente agitados (luchas de liberación colonial y nacional, protestas estudiantiles y contra la Guerra de Vietnam...) que suponen el nacimiento de movimientos sociales y contraculturales y la cristalización de nuevas ideas que tratan de comprender mejor los envejecidos y renovados mecanismos de reproducción social e inculcación ideológica del sistema capitalista, a la vez que se alimentan sueños y utopías para transformarlo. (Carbonell, 2015:64).

Según Trilla (1996) lo que se derivó de aquella crisis es que únicamente con la ampliación de las instituciones formales de educación no se podría satisfacer las necesidades sociales que se acusaban en aquel momento. Esto se une a la aparición de relatos contra la institución escolar como los de Illich, Reimer, Goodman o Holt. Entre ellos sale a la luz la potencialidad de la Pedagogía Social y se desbanca a la escuela como único espacio de aprendizaje generando otros lugares donde poder crear un entorno educativo complementario a la escuela pero al margen de la misma. Estos autores exponían la existente desconexión con la realidad de la escuela y cómo influía esto en el aprendizaje. De ahí que surjan nuevas necesidades, entre ellas que la escuela y el territorio se unan, se hablen y compartan 
espacios. La cultura está en el territorio y es la única forma con la que se puede conseguir la transferencia en el aprendizaje (Carbonell, 2015).

Siguiendo con el recorrido histórico de la Educación no formal de la mano de Trilla (1996) vemos como en España fueron diferentes acontecimientos los que dieron pie a la expansión del concepto de Educación no formal:

- 1874: Jornadas de Estudio sobre la Educación Informal, Instituto Catalán de Cultura Hispánica y el Departamento de Pedagogía Sistemática de la Universidad de Barcelona. Documento de trabajo coordinado por Alejandro Sanvisens.

- 1981: Seminario Iberoamericano sobre Modalidades no formales en la educación de adultos, Universidad Autónoma de Barcelona y Organización de Estados Americanos (OEA). Recogida en la revista Educar (Núm. 1, 1982) bajo autorías de Sanvisens, Ferrández, Fernández de la Huerta, Sarramona, Marín, etc.

- 1983: Seminario Internuniversitario de Teoría de la Educación celebrado en Salamanca con una ponencia dedicada a las tres conceptualizaciones de la Educación con trabajos de Touriñán, Requejo y Trilla (referencias en Trilla, 1996).

- 1990: V semana monográfica sobre «La Educación no formal, una prioridad de futuro», Fundación Santillana, Madrid.

- 1991: X Seminario Interuniversitario de Teoría de la Educación celebrado en Llanes (Asturias) que planteaba un monográfico sobre la Educación no formal.

Todos estos acontecimientos conformaron la base histórica para la Educación no formal y dieron pie a la necesidad de abrir el fenómeno educativo hacia otros espacios no formales (Trilla, 1992, y 1993). En relación a estos tres tipos de educación enmarcamos la Animación sociocultural en el de la Educación no formal, como ya hemos adelantado, aunque la relación con la educación informal sea evidente en el contexto en el que nos movemos ya que, tal y como apunta Coombs (1985) entendemos que es la modalidad de educación más omnipresente.

Según Palacios (2005), la educación informal deviene de la interacción a la que estamos sometidos cada día, a esos procesos en los que se comparte 
información y conocimientos que dan forma a nuestra conducta y nuestros valores. Como tal estas interacciones no se consideran acción educativa ya que no tienen valor intencional aun así esa carga educativa deviene de la socialización permanente a las que nos sometemos como personas. Por su parte, la Educación no formal será aquella que sí que conlleva una carga educativa pero que se da en contextos fuera de la escuela. Las características que tiene esta son las siguientes:

- Promoción desde la sociedad civil. No es el estado ni una entidad concertada por él sino la pluralidad de colectivos sociales las que la promueven.

- Se produce al margen de las entidades educativas institucionalizadas.

- Las educadoras no son necesariamente profesoras tituladas, insertadas en una estructura jerárquica de enseñantes. Las agentes de la Educación no formal se confunden con los sujetos de esa educación, conformando una acción educativa que los convierte en agentes de su formación.

- Las educandas pueden estar conformadas por toda la población, independientemente de que se encuentren o no en periodo de formación escolar.

- No pretende la transmisión de conocimientos. Ni, por supuesto, la obtención de un reconocimiento oficial -titulación o gradación reglada-. Aunque a veces presente cierto reconocimiento oficial.

- Pretende la concientización del individuo. El desarrollo de una percepción de sí mismo, del entorno en el que habita; y, a partir de determinados postulados filosóficos, ideológicos o religiosos, la aceptación y/o modificación de esa realidad social.

- Presenta una intervención pedagógica sistematizada, intencional y consciente. Dentro de los parámetros filosóficos o ideológicos de la entidad.

Aun con las diferentes relaciones entre nuestro estudio y la educación formal e informal guiamos nuestro marco a partir de la Educación no formal siendo que sus objetivos sociales son más amplios.

Hoy, la Educación no formal sigue teniendo una gran influencia en la socialización de las personas y continúa cubriendo múltiples deficiencias 
que tiene la escuela y con ella la educación formal (Carbonell, 2015). Por este motivo podríamos decir que, en el año 2016, la mayor parte del aprendizaje se da fuera de la escuela. Por tanto la Educación no formal o informal ocupa una gran parte de nuestras horas de aprendizaje y no tanto la formal como estamos acostumbrados a asumir.

\subsubsection{Un poco de aire libre ${ }^{3}$ para dinamizar el ocio desde la educación.}

Nos remontamos a la revolución industrial para contextualizar la perspectiva sobre el tiempo libre. En ella al obrero se le permitía recuperarse durante la noche para poder continuar su trabajo durante todo el día, no existía un tiempo libre que pudiera utilizar para algo distinto a la recuperación. Poco a poco, a partir de la presión social ejercida por las clases trabajadoras y un incremento de la productividad, se genera la reducción de jornada que posibilita un aumento del tiempo disponible. Se va configurando el tiempo libre como la antítesis del trabajo y su antídoto (Trilla, 1996) y de ahí que se empiece a valorar de manera independiente el uno del otro. El tiempo libre empieza a hacer más fácil el tiempo de trabajo, dándole un valor especial al hecho de hacerse necesario el segundo para después poder disfrutar del primero. En esta historia habría que remarcar también el tiempo libre como tiempo de consumo ya que esto provoca su dependencia directa con la producción de trabajo.

Existen dos autores fundamentales en el estudio del tiempo libre: Dumazedier y Weber. Sus clásicas definiciones son las siguientes. Siguiendo con la definición clásica de Weber (1969), el tiempo libre es «el conjunto de periodos de tiempo de la vida de un individuo en los que la persona se siente libre de determinaciones extrínsecas, quedando con ello libre para emplear con un sentido de realización personal tales momentos, de forma que resulte posible llevar una vida verdaderamente humanas. Por otro lado, Dumazedier (1968) nos enmarca las actividades que se realizan en ese tiempo libre como ocio siendo este «un conjunto de ocupaciones a las que el individuo puede dedicarse voluntariamente, sea para descansar o para divertirse, o para desarrollar su formación o formación desinteresada, su voluntaria participación social o su libre capacidad creadora, cuando se ha

${ }^{3}$ En los años setenta al Tiempo libre se le conoce como Aire Libre. 
liberado de sus obligaciones profesionales o sociales». Observamos en la definición las famosas tres $\mathrm{D}$ de Dumazedier: descanso, diversión y desarrollo, que acabarán definiendo las funciones de las actividades de ocio. Debemos matizar que entendemos que el tiempo libre hace referencia a aquel espacio temporal que las personas tenemos fuera de todas aquellas obligaciones diarias, no únicamente aquel que existe en contraposición con el trabajo, tal y como Dumazedier expone en su definición. Por ello hablamos de tiempo liberado de responsabilidades en el que poder desarrollar la actividad por antonomasia del tiempo libre: el ocio.

Para perfilar nuestra visión sobre el ocio, el tiempo libre y la educación nos centramos en las dos variantes que expone López de Aguileta (1986): educar para el ocio y educación en el tiempo libre. Algunas autoras afirman que se ha errado en la finalidad de educar para el ocio y deberíamos de construir una pedagogía del tiempo libre que genere actitudes de ocio verdadero «que enseñe a utilizarlo de forma constructiva y creativa y que prepare a las nuevas generaciones para vivir sin riesgos esa futura civilización del ocio» (Mendia, 1991). Los tiempos libres pueden construir ciudadanas libres a partir de un ocio liberador (Palacios, 2005). Tal y como Palacios (2005) define, este puede estar ligado a la ingesta compulsiva de alcohol u otras sustancias tóxicas; o bien, relacionado con un ocio humanizante, activo, divertido, comunicante, placentero, que compromete al individuo frente a sus semejantes. En el primero tendría cabida educar para el ocio, para no desarrollar un ocio tóxico como el que se plantea. Por otro lado, la segunda opción tiene relación directa con la idea de educar en el tiempo libre, percibiendo en él un medio para la educación siendo secundarias las actividades y marcándose como primario el trabajo en valores humanos. En definitiva, «un ocio capaz de construir -a los constructores de ese ocio, agentes y sujetos de él- como ciudadanos activos, críticos y capaces de transformar la realidad. Capaces de cambiar un mundo que no nos gusta y no de no ser cambiados por ese mundo» (Palacios, 2005).

Estas realidades indistintas hacen que sea necesaria una intervención pedagógica que diferencie los tiempos. Es ahí cuando se empieza a diferenciar el concepto de ocio en su tridimensionalidad como un espacio de tiempo, de actividad y de actitud. Es en ese instante cuando surge la 
pedagogía del ocio que como afirma Trilla (1996) tiene como misión el «potenciar lo que de educativo tenga el ocio en sí mismo».

De ahí que Llull Peñalba (citado en Palacios, 2005) señale que el ocio es «el empleo positivo, cultural, activo y comprometido con aquello que pueda llegar a interpelar directamente al individuo durante su tiempo libre». El ocio hay que crearlo, construirlo y no consumirlo y la educación en el tiempo libre tiene que demostrar que se puede fomentar esa construcción y no suplir la capacidad de la ciudadanía para hacerlo. 


\subsection{Jóvenes, participación social y democracia.}

En esta tesis nos interesa la dimensión educativa del ocio por eso la valoramos desde ella y la encuadramos desde una Pedagogía Social centrada en el ámbito de la Animación sociocultural dentro de un marco de Educación no formal en el que construir espacios liberadores de educación. Además lo abordamos desde el trabajo con adolescentes y jóvenes ya que esta acción es distinta al resto de colectivos, pudiéndose diferenciar en los tres elementos que propone Palacios (2005):

- Características de la población sujeto de intervención.

- El mayor peligro de adoctrinamiento.

- La intergeneracionalidad entre las agentes y los sujetos educativos.

Hacer del tiempo libre de las jóvenes un espacio ocupado por un ocio liberador para que sean capaces de cambiar un mundo que no nos gusta y no de ser cambiadas por ese mundo (Palacios, 2016) es el objetivo principal de la Animación sociocultural en espacios no formales con adolescentes.

Tal y como nos cuenta Jaume Funes Artiaga (2010), la adolescencia no ha existido siempre, es más bien un período inventado que puede o no puede existir, todo ello dependerá de si este ciclo vital es posible en determinadas sociedades y en diferentes momentos históricos. Por esta misma razón, es interesante saber qué es lo que puede justificar la intervención en Educación no formal con adolescentes hoy. Para conocerlo seguimos a Palacios (2005) que debido a su formación, su experiencia, su reflexión y sus prácticas nos propone un abordaje sencillo de esta justificación.

Contamos con que las jóvenes son aquel segmento de la población que sociológicamente se sitúa entre una etapa de dependencia como es la infancia y una de autonomía como es la madurez. Esta etapa les hace tener unas características psicológicas distintas a las personas adultas. A su vez, estas jóvenes se enfrentan a un proceso de autoconstrucción en el que entra en juego su propio desarrollo físico, intelectual, afectivo y sexual. Todo este desequilibrio influirá en todo intento formativo que se dé. Por eso la formación estará determinada por la permeabilidad, la racionalidad, el entusiasmo y la ilusión además de tener unos intereses más fugaces. Si a esta serie de características le sumamos la situación contextual a la que se 
ven abocados vemos que, mayoritariamente, contamos con personas que han tenido una gran oportunidad al poder alcanzar unos niveles de enseñanza formal elevados. Además de tener la posibilidad de ser atendidas por una sanidad universalizada y de calidad. En sus barrios han podido disfrutar de centros culturales y deportivos y han tenido un acceso tecnológico que ninguna de las generaciones anteriores ha vivido. Por otro lado, no han sufrido de forma tan escandalosa el golpe de la droga que pudieron vivir sus hermanos mayores o sus tíos pero en cambio, no pueden dejar de ser jóvenes debido a las terribles dificultades que existen de acceder a un empleo y una vivienda, no pueden conseguir la autonomía plena para llegar a ser adultos.

De este modo, según Palacios (2005), la Educación no formal puede ayudarles a conseguir el dejar de ser jóvenes para acceder a una vida adulta en condiciones. Esto se conseguirá en función de las formas de organizar las prácticas participativas ya que estas representan diferentes formas de socialización (Funes Artiaga, 2010) y por tanto el modo en el que se diseñan los espacios de ocio y tiempo libre para adolescentes influirá en la consecución de dicho objetivo.

Así pues debemos conocer cómo promover esta participación juvenil tanto desde la administración como desde los distintos niveles técnicos y los liderazgos juveniles.

\subsubsection{Actividades en el tiempo libre con jóvenes.}

La adolescencia se alarga y surge una nueva dimensión, la juventud. Primero eres adolescente y la propia sociedad te exige que te definas. Después pasas a ser joven y debes mostrar tu rol activo en la misma sociedad. Como plantea Úcar (2008) la adolescencia y juventud pueden llegar a resultar momentos para la marginación, la infravaloración o el paternalismo. De ahí que las personas adultas debamos aprender, antes de ponernos a diseñar actividades para las jóvenes, «a pensar en las personas jóvenes como interlocutores de pleno derecho antes que como personas que aún no son adultos» (Úcar, 2008:6).

Como exponía en un trabajo anterior (Aguirre García-Carpintero, 2012), Jacques Rosseau decía que la infancia tiene sus propias maneras de ver, pensar y sentir, y que no hay nada más insensato que pretender sustituirlas 
por las nuestras. Si dentro de estos espacios de desarrollo anulamos a jóvenes, niños y niñas la posibilidad de participación, dejamos una voz por escuchar y nuevas miradas que descubrir. La infancia, la adolescencia y la juventud están preparadas para construir con sus propias manos. Para generar esta construcción, el tiempo libre puede ser una oportunidad extraordinaria que desarrolle entre adolescentes, hábitos de participación a la vez que transmite valores de convivencia y sociabilidad. Que todo esto sea posible, dependerá de si este trabajo se realiza como un tarea educativa o como una mera planificación de entretenimientos (Deltoro, 2006).

Por eso, debemos diferenciar entre animación y difusión cultural. Una se sitúa en el eje educativo y la otra en el del entretenimiento, son opciones distintas sin ser una alternativa de la otra. A continuación mostramos la tabla (tabla 4) en la cual, Grosjean e Ingberg (1980:98), muestran de un modo sencillo las diferencias entre una y la otra para facilitar el entendimiento de la planificación de las actividades en el tiempo libre con jóvenes hacia un extremo o hacia el otro.

Tabla 4 Diferencias entre animación y difusión. Fuente: Grosjean e Ingberg (1980).

\begin{tabular}{|l|l|}
\hline \multicolumn{1}{|c|}{ Animación } & \multicolumn{1}{c|}{ Difusión } \\
\hline Participación activa & Consumo cultural \\
La cultura en evolución & El patrimonio cultural \\
Contacto con toda la población & Público compuesto por una élite \\
Cultura confundida con política en el & Cultura en contraposición a la política \\
sentido profundo del término & \\
No directividad & Manipulación \\
Facultad de expresión para todos & Creación perteneciente a los especialistas \\
Progresismo & profesionales \\
Liberación & Conservadurismo \\
Libre expresión & Alineación \\
Comunicación abierta & Pasividad \\
Allí donde vive la gente & Discurso de arriba abajo \\
Abierta a todos & En los templos culturales \\
Valoración del grupo & Reservada a los iniciados \\
Creatividad & Triunfo del individualismo \\
\hline
\end{tabular}

Ander-Egg (1989:145 como se cita en Úcar, 1992) asume la animación cultural como aquella en la que cada cual viva y realice su cultura. En cambio, la difusión cultural es que la cultura esté al alcance de todos. De este modo, la primera producirá condiciones para la transformación 
cultural y la segunda lo que ya afirma con su nombre, la difusión de la cultura.

Tanto los trabajadores sociales, en general, como las animadoras juveniles en particular, mantienen una posición estratégica para poder promover esta participación juvenil y democracia cultural, pero tal y como exponen Checkoway y Gutiérrez (2008) muchos se han formado más para cuidar de las jóvenes que para empoderarlas. No es común encontrar «trabajadores sociales que fomenten el derecho juvenil a participar en la sociedad y su responsabilidad en el servicio comunitario». Por ello, debemos extender la necesidad de trabajar con las adolescentes y jóvenes como un modo de mejorar la sociedad en la que viviremos en las próximas décadas pero también con la importancia del presente de desarrollar una identidad crítica a partir del crecimiento personal y la adquisición de habilidades sociales (Deltoro, 2006).

En 2005, el informe mundial sobre la juventud ya afirmaba que había que «tomar medidas para fomentar las relaciones entre las distintas generaciones y poner a las jóvenes en condiciones de participar, en forma significativa, en los programas y las actividades que les afectan» (Úcar, 2008:7). De este modo, es necesario recuperar el espacio público para niñas y niños, adolescentes y jóvenes y enmarcarlo para conseguir un trabajo eficaz. Las transformaciones sociales y urbanas son los factores que hacen necesaria la existencia de estos espacios (colonias de verano, centros juveniles, ludotecas, etc.) y según Trilla (1996), desde una mirada pedagógica, estos lugares y las actividades en el tiempo libre que se puedan realizar con jóvenes tienen una serie de características que las definen como potencialmente educativas. Estas características son:

1) Promocionar la sociabilidad a partir de un trabajo de ocio grupal y colectivo.

2) Focalizar el trabajo en aspectos que la escuela ha abandonado como son la expresividad, la sensibilidad, la creatividad,...

3) Posibilitar que sean las propias niñas y jóvenes las que de forma autónoma generen proyectos de actividad.

4) Enfatizar el descubrimiento y la participación de las niñas y jóvenes en su propio entorno. 
La investigación ha demostrado que la riqueza de la socialización infantil crece en la medida en que lo hacen la cantidad, diversidad y cualidad de las interacciones de los niños y las niñas con las jóvenes, adultos y ancianos; de ahí la conveniencia de recuperar espacios comunes de encuentro y vivencias, experiencias y proyectos comunes de encuentro y vivencias, experiencias y proyectos compartidos (Carbonell, 2015:36).

En este sentido, Deltoro (2006) apuesta por un trabajo de formación ideológica que permita ofrecer posibilidades, abrir puertas y mostrar caminos a explorar juntas. Siguiendo principalmente estas cuatro bases de contenidos podremos diseñar los programas de actividades en el tiempo libre con adolescentes y jóvenes:

- Desarrollo personal: Autoestima, tolerancia al fracaso, toma de decisiones personales, desarrollo de la capacidad de análisis de la realidad y de la conciencia crítica,...

- Hábitos de comunicación y relación con las demás: Empatía, respeto, tolerancia a la diversidad, confianza, relaciones mutuas, ...

- Concepto de cooperación: Capacidad de realizar, individual y colectivamente, análisis de la realidad para marcarse objetivos en común, toma de decisiones en grupo, reparto de responsabilidades y adquisición de habilidades para desarrollarlas, entre otras cosas.

- Concienciar en valores: Posición activa ante los derechos humanos, por la justicia social global, la igualdad de derechos, la defensa de la libertad, el consumo crítico y responsable,...

La educación popular fue el impulso, la semilla que hizo que la educación en el tiempo libre germinara para ver brotar la Animación sociocultural. Esto fue porque, como nos dice Serrano (2008), la Animación sociocultural acaba convirtiéndose en nuestro país en un medio impuesto, profesionalizador y asumido por el poder político, en cambio la Educación Popular es la que nace del pueblo, de forma educativa y militante. Por ejemplo, en Francia las asociaciones son las que acaban politizando la Animación sociocultural pero aquí la Animación sociocultural aparece dirigida por ayuntamientos y desvinculada de las asociaciones. Aun así, tal y como plantea Palacios (2005), esta «acción educativa que se desarrolla en 
los colectivos juveniles de tiempo libre se enmarca en los parámetros de la educación no formal» y como no podemos obviar que hoy se nombra más como Animación sociocultural debemos tener presente que esta supone el fomento de la participación y la creación cultural entre otras cosas (Deltoro, 1995) sin olvidar que ha de partir de la ciudadanía y el asociacionismo.

\subsection{2. ¿La Democracia si no es participativa es Democracia?}

Es complicado hablar de democracia y participación con seguridad después de todo lo que se ha escrito y se sigue escribiendo sobre ello. Pero queremos abordar aquellos aspectos que enmarcan nuestro trabajo a partir de estos términos.

Partimos de las palabras de Dewey (1995:98) que difunde la idea de que la democracia es un estilo moral y modo de vida comunitario: «Una democracia es más que una forma de gobierno; es primariamente un modo de vivir asociado, de experiencia comunicada conjuntamente».

Viejo, Martí-Costa, Parés, Resende y Vilaregut (2009) dicen que si tomamos rigurosamente la definición democracia, esta «no es un estado de cosas definitivo que se pueda transcribir en una Constitución, sino más bien un método para adoptar decisiones políticas, fundado en unas garantías y procedimientos determinados». Cada régimen democrático encuentra sus afinidades con una u otra forma de democracia y de este modo, a la democracia, no dejan de salirle apellidos que intentan diferenciarla unas de otras: representativa, participativa, deliberativa, directa, radical,...

Pero, ¿¿se acaba la democracia en las instituciones? La política no se acaba entre esas cuatro paredes sino que va más allá porque constituye aquella capacidad para poder responder a los problemas colectivos sea en el espacio que sea. En esta línea, y de acuerdo con lo que Subirats (2005) expone, «necesitamos explorar y potenciar formas de organización social que favorezcan la reconstrucción de vínculos, la articulación de sentidos colectivos de pertenencia respetuosos con la autonomía individual. [...]Por tanto, parece importante avanzar en nuevas formas de participación colectiva y de innovación democrática que no se desvinculen del cambio concreto de las condiciones de vida de la gente». Porque, ¿puede la 
democracia no ser participativa como se pregunta Serrano (2008)? y la respuesta depende desde dónde se mire.

La democracia participativa es una ampliación del sistema democrático formal para muchas personas: técnicas, políticas, teóricas, ciudadanas,... En general, es posibilitar la participación ciudadana a partir de espacios generados desde las instituciones. Ahora bien, si la asumimos como tal puede que pierda el sentido de participación democrática que pretende, al convertirse en un espacio institucionalizado, burocrático y restrictivo. «No se trata tanto de retirar al Estado al banquillo de los suplentes, sino que acepte el hecho de que una nueva sociedad civil organizada debe ser incorporada al escenario de una gobernanza cooperativa y relacional» (Aranguren, 2010).

Por eso deja de tener sentido si únicamente lo hablamos desde la restricción que supone la institución, si únicamente intentamos buscar estrategias para mejorar los canales de relación entre las instituciones y la sociedad y abandonamos la capacidad democrática de la ciudadanía de reorganizarse y actuar. Podemos olvidar todo el trabajo que hay detrás de espacios de ciudadanía organizada o bien aprovecharlos como espacios de democracia participativa real. Como Wacquant (2005) propone hay que universalizar los medios reales que permitan que la ciudadanía ejerza la democracia. Subirats lo explica del siguiente modo:

No se trata simplemente de desafiar a la política convencional, sino de trabajar en los límites de lo convencional. Lo que se precisa es generar espacios de autonomía frente a la capacidad «recoge todo» de las instituciones y de las organizaciones políticas que trabajan exclusivamente en su seno. Por tanto, será «útil» lo que (también) refuerce la autonomía de los actores sociales y no sólo lo que sea «útil» a las instituciones. Será «útil» lo que sirva para aprender, lo que refuerce y consolide, lo que dé más poder a movimientos y organizaciones sociales, y no (sólo) lo que legitime más a las instituciones. Será «útil» lo que desde lo local conecte con preocupaciones, problemas, movimientos y debates que suceden más allá, y no lo que sea (estrictamente) útil a los efectos de resolver «el problema» local. Y será «útil» lo que supere la estricta visión utilitaria e instrumental de la política (2005:29). 
Para que la ciudadanía analice la democracia como pleno derecho debe sentirla y vivirla y para ello, necesitamos diferentes modos de convivencia que generen una construcción desde la autonomía y el sentido colectivo facilitando la pluralidad de voces desde el día a día. Han de ser procesos que refuercen el aprendizaje de la participación, porque a participar se aprende participando.

Podríamos estar más de acuerdo con otro tipo de aproximaciones democráticas como puede ser la Democracia Radical. Según Pateman (1970) la concepción de la democracia, dentro de una democracia radical, es como una forma de vivir, en la cual la horizontalidad de las relaciones participativas debe estar presente en diversos momentos de lo cotidiano y no sólo en las instituciones políticas (citado en Viejo, Martí-Costa, Parés, Resende y Vilaregut, 2009:50). Aunque la Democracia Radical haga referencia a la propia dinámica de construcción conjunta desde espacios para dialogar y cooperar y satisfacer las necesidades de las personas (Calle, 2007), tal vez la pregunta es cómo se va a llevar a cabo esta participación para conseguir democratizar el día a día de la ciudadanía y su vida social.

Sabemos que la participación es útil, genera vínculos comunitarios, refuerza y produce aprendizajes (Wenger, 2001; Serrano, 2008; Llena, Parcerisa y Úcar, 2009) pero resulta tal la diversidad y usos del término participación que tanto uso y abuso termina por desfigurar el fenómeno (Aranguren, 2010). Unas lo entienden como un medio, otras como un fin, unas como un derecho democrático y ciudadano; otras como un medio de aprendizaje pero con aquello que estamos de acuerdo es con que hay que reformularla como derecho ciudadano y «no únicamente como una invitación que puede amparar planteamientos paternalistas, intervencionistas o, simplemente, de manipulación» (Llena, Parcerisa y Úcar, 2009). Según Alberich (2004:24) la «participación ciudadana es el conjunto de actividades, procesos y técnicas por los que la población interviene en los asuntos públicos que le afectan» pero cómo se construye ese conjunto para que la sociedad civil participe es la cuestión que nos preocupa.

Como nos recuerda Ander-Egg en el prólogo que le escribe a Alberich (2004) no debemos confundir la participación ciudadana, con la participación popular y por ello nos planteamos si deberíamos abrir procesos de participación ciudadana en los ayuntamientos sin enseñar a 
participar, sin tener experiencias asociativas, sin ser parte de movimientos ciudadanos, debemos replantearnos si queremos participación ciudadana sin participación popular. En esta línea Alberich y Espadas (2011) quieren diferenciar participación social de participación ciudadana. La Social es cualquier acto, fenómeno o proceso colectivo de participación de la sociedad. La participación ciudadana sería una parte de la participación social, la que afecta directamente a la comunidad y se ejerce en relación con la Administración pública.

Según estas autoras, para mejorar el funcionamiento de la democracia local es conveniente que haya participación social y un tejido social activo e intenso.

El horizonte de la participación ha de ser el de la transformación social desde la conciencia de que esa transformación no es solo la resultante final de los procesos en marcha sino que la misma puesta en marcha de ese tipo de proceso, que apunta en esa dirección, ya es en sí mismo transformador en la forma de convocar, en el desarrollo de la acción, en los momentos que se pactan, en los sentimientos que suscita, en la identificación con determinados valores que se logra. La apropiación de posibilidades en sí misma no tiene sentido; lo adquiere cuando mira al horizonte de transformación social (Aranguren, 2010:53).

De ahí que necesitemos procesos de participación transformadores, prácticas y reflexiones desde la participación social que nos ayuden a afrontar y transformar la realidad social desde el espacio público favoreciendo la construcción colectiva de ciudadanía activa y justa.

Algo interesante es lo que remarca Aranguren (2010) cuando pide que no se confunda el espacio público con las administraciones públicas. La articulación de la sociedad civil es un costoso logro que no podemos perder de vista y de ahí que este autor incite a reflexionar sobre el modelo de espacios que estamos construyendo desde los modelos de participación imperantes. Aranguren, citando al antropólogo francés Marc Augé dice que los espacios urbanos se han convertido en no lugares, espacios de desencuentro más que de encuentro, de despersonalización más que de identidad y personalización perdiendo por completo el horizonte histórico que nos situaría en ellos. Innerarity (2016) nos acerca al término público 
para situarnos en esta diferencia. En griego, público quiere decir, de entrada, expuesto a la mirada de la comunidad, a su juicio y aprobación. El espacio público es el espacio cívico del bien común por contraposición al espacio privado de los intereses particulares. Un espacio público que conlleva una nueva ciudadanía identificada con él y con sus encuentros.

Por esta razón hay que dinamizar la cultura de la participación y reclamar con ella ciudadanas que sepan desarrollar lo personal tanto como lo colectivo para que esto se convierta en una forma de vivir demostrando que es posible convivir entre diferentes (Aranguren, 2010). Por eso la participación social tiene tres acepciones que hacen que esto sea posible: «ser parte» y desarrollar una actitud de pertenencia a la colectividad; ser capaz de «tomar parte» incorporándote activamente a la actividad para finalizar «partiendo con» el colectivo, desempeñando siempre la acción con otras personas desde lo común (García Roca, 2004; Aranguren, 2010).

Cuando las personas se instalan en su propia individualidad, tan propia de la modernidad, y no tratan de transcenderla integrándose activamente en un grupo, llámese asociación, plataforma, grupo de interés, etc. renuncian por añadidura a la construcción de una cultura colectiva, que parte de las peculiaridades individuales y las integra formando un todo diferente a la suma de sus partes (López y León, 2009). 


\subsection{El aprendizaje en la acción: movimientos asociativos.}

En el siguiente apartado hago un repaso sobre la historia asociativa en nuestro país comparándola en algunos momentos con hitos en la Europa asociativa. De este modo, veremos el sentido del asociacionismo hoy, las consecuencias de momentos clave en nuestra historia que provocan que el asociacionismo español sea lo que es en nuestros días. Continuaré enmarcando como espacio de aprendizaje acercándonos al concepto de aprendizaje situado en la acción colectiva.

\subsubsection{La historia asociativa.}

En el siglo XVIII y principios del XIX, tanto en Europa como en América, tal y como mostró en su día Alexis de Tocqueville y más tarde Maurice Agulhon, hubo una proliferación de formas de agrupación (sociedades de amigos del país, salones, círculos, academias, cafés, sociedades literarias, logias de francmasones...) que, consideradas en conjunto, desde la perspectiva de los largos procesos, conformaron un movimiento sociocultural en el que se alumbraban nuevos valores, se experimentaban espacios y formas nuevas de producir sociedad, sobre la base de la pertenencia voluntaria (Im Hof, 1995 citado en Ariño, 2004:86).

En España, podemos leer en Méndez y Mota (2006) como, la edad media de las asociaciones, veinticuatro años, nos demuestra por qué contamos con un asociacionismo joven en comparación con otros países occidentales. La razón principal de ello es la falta de libertades que trajo la dictadura franquista (Linz, 1970) y a esto se le sumó la falta de institucionalización política (McDonough, Barnes y López, 1984) ${ }^{4}$.

Por ello creemos relevante hacer un recorrido sobre la vida del asociacionismo en España puntualizando en aquellos datos que hablan sobre el movimiento asociativo juvenil. Es importante remarcar que el movimiento asociativo catalán marca las bases en España y por ello lo

${ }^{4}$ Para saber más sobre legislación y jurisprudencia en asociaciones puede verse Aznar (1993). 
trabajamos de una forma destacada en este capítulo. A esto se le suma el hecho de estipularse como referente en el territorio valenciano y de forma particular en el movimiento valenciano de Cases de Joventut. Así, a continuación, describiremos las siguientes etapas: república, franquismo y transición democrática, ayuntamientos democráticos, los años ochenta, los noventa y el desmantelamiento de las políticas de juventud acabando con datos de la actualidad.

\section{- Antes y durante la República:}

El asociacionismo surge como respuesta de la Sociedad Civil ante la complicada situación que produce el pauperismo en el tejido social (López, 2003). En esos momentos nacen diferentes tipos de espacios sociales que intentaban cubrir las necesidades ciudadanas, entre las que podíamos encontrar asociaciones, círculos de finalidades filantrópicas, sociedades de socorros mutuos, organizaciones reivindicativas, instituciones de caridad y congregaciones sin ánimo de lucro al amparo de la Iglesia.

Es un hito del asociacionismo en España la Real Orden del 28 de febrero de 1839 aunque solo recogiera un tipo de asociación: la de socorros mutuos. No es hasta tres décadas más tarde (1869) cuando se consigue el libre derecho de asociación y reunión en la legislación y la Constitución anunciada el 16 de junio de 1869 elevándose a categoría de derechos fundamentales (López, 2003). Aunque no es hasta 1887 cuando la ley daría cobertura al asociacionismo reivindicativo ya que centró el apoyo legal en las asociaciones con fines benéficos y círculos de recreo. La primera ley de asociaciones tarda unos años más, data exactamente del 20 de junio de 1887 así como la inclusión en el Código civil de 1889 de las asociaciones como personas jurídicas de interés público reconocidas por la ley. Entre 1904 y 1916 las asociaciones se tornan más reivindicativas y sindicalistas. De las 5.609 asociaciones existentes en 1904, y 18.986, en 1916, 1.147 eran sociedades de resistencia en 1904, y 4.764 eran sindicatos en 1916 (Soto Carmona, 1989 citado en López, 2003).

Como afirma López (2003) a principios del siglo XX, el Estado liberal intercede en la realidad social y económica mientras «la sociedad asumía, de forma solidaria y voluntaria, su propia asistencia, con el Estado como garante. La caridad se trocaba en derecho y el seguro social respondía a un contrato entre el Estado y ciudadanos». 
Ya en la II República surge la Ley de Asociaciones Profesionales de Obreros y Patronos de 1932. De manera particular en el ámbito juvenil, un punto de referencia en esta época es el movimiento juvenil catalán anterior al franquismo. Siguiendo a Serrano (2003) vemos que existen precedentes de grupos juveniles ya en el s.XVIII bajo el nombre de Partit Republicà Democràtic Federal como la Joventut Federalista del Poble Nou (1891), la Joventut Democràtica Lliurepensadora (1888), la Joventut Republicana Federal de Barcelona (1890), entre otros ${ }^{5}$. Además de estos datos Serrano (2003) nos acerca un listado de experiencias del movimiento asociativo relevantes en aquella época. Aunque no han sido muy estudiadas hacen un balance de los espacios que ocupaban esos 739.147 jóvenes de entre 15 y 24 años que vivían en Cataluña (en el año 2000 la cifra aumenta hasta el millón de jóvenes aproximadamente):

1915: Destaca el grupo juvenil Joventut Republicana de Lleida.

1920: El grupo Pomells de Joventut vuelve a retomar ideales cristianos y en 1923 cuenta con 849 grupos y entre 5.000 y 10.000 asociados. Durante estos años nace una alternativa no confesional y laica, la Jove Atlàntida y los Amics del Sol, dentro del Ateneu Enciclopèdic Popular (Solà, 1987).

1932: La Federació de Joves Cristians (FEJOC) integra a 5.315 jóvenes mientras que tres años después se eleva el número a 16.050.

Años 30: Joventuts d'Esquerra Republicana Estat Català (JEREC) consigue reunir entre 9.000 y 10.000 afiliados.

1936: Joventut Comunistes Ibèriques (JCI) tienen 7.000 militantes. Las Joventuts Llibertaries (JJLL) cuentan con 9.435 afiliados y un año después la cifra aumenta hasta los 46.000 .

1937: Las Joventuts Socialistes Unificades de Catalunya (JSUC) tienen 30.000 afiliados.

Durante la Guerra Civil, en Cataluña existen 299 grupos excursionistas.

Según este mismo autor en otro de sus trabajos (Serrano, 2008), uno de los casos más potentes de participación popular que ha existido en España fue

5 Podemos encontrar más información leyendo a Ángel Duarte, El Republicanisme català a la fi del segle XIX, Eumo, Vic, 1987:163 
la revolución del 19 de julio de 1936. La cual «estremeció las conciencias progresistas de todo el mundo y fue capaz de enfrentarse triunfalmente durante tres años al fascismo, prólogo de lo que acabó siendo la II Guerra Mundial». Todo ello conforma la historia de la participación en España y nos ayuda a entender la historia de lo que hoy ocurre.

\section{- Franquismo y transición democrática.}

Existe una causa que condicionará la historia del asociacionismo en España a diferencia de otros países europeos y es la Dictadura Franquista. En esta época el gobierno franquista hace desaparecer toda la red asociativa que se había generado alrededor de los años 30. Cuando las tropas nacionalistas entran, año 1939, toda la red de entidades, ateneos, centros republicanos y cooperativas entre otras serían confiscados (Serrano, 2008) quedando únicamente las pertenecientes a la Iglesia Católica. Por ejemplo, en 1953 hay 2.000 escoltas y guías en Cataluña y a principios de los años 60 es cuando surgen las asociaciones de escoltas laicas (marcado por el escultismo laico francés) los cuales se plantean la co-educación aunque no será hasta el año 74 que se funde Escoltes Catalans cuando se reunifique el escultismo laico (Serrano, 2003).

Tal y como explica Palacios (2005) los cientos de miles de afiliados jóvenes en las organizaciones sindicales y políticas -y en su extensa pléyade de círculos culturales y deportivos - casas del pueblo, ateneos,...- desmienten el mito de una pretendida disociabilidad de las jóvenes españoles. La dictadura franquista acaba con todo el movimiento juvenil a excepción de sus nuevas organizaciones adoctrinadoras (FET, JONS, OJE, SEU,...). Esto provoca que existan generaciones y generaciones de jóvenes que no han podido vivir un ocio cívico que les ayudara a formarse como ciudadanos libres.

Las organizaciones juveniles de los partidos de izquierdas intentan seguir con su actividad en la clandestinidad pero no es hasta llegados los años 70 que se articula un nuevo movimiento juvenil democrático que será relevante en la acción antifranquista y la instauración de la democracia debido a su dinamismo y su capacidad de movilización (Serrano, 2003; Merino, 2006). Mientras en España se daban estos canales, en las 
democracias occidentales se empezaban a consagrar vías institucionales de participación política (Merino, 2006).

En nuestro país, una de las comunidades autónomas en la cual esta movilización juvenil fue muy potente es el caso de Cataluña, donde se creó la Taula de Joves, siendo referente en el panorama español (Soler, Novella y Planas, 2014). De forma paralela se forma el movimiento del tiempo libre alrededor de los Clubs Juveniles de la Iglesia, de las asociaciones vecinales (Asociaciones de Cabezas de Familia) y de algunas estructuras del movimiento Scout. Exceptuando la realidad catalana que con una amplia realidad excursionista comparte la experiencia de los Esplais, espacios donde se forja una nueva generación de jóvenes democráticos (Palacios, 2005). La Escola de l'Esplai nace bajo la tutela de Cáritas y se convierte en la nueva fórmula para el asociacionismo del tiempo libre infantil (Serrano, 2003).

En 1964 se crea la Ley de Asociaciones que proporciona un marco legal mínimo que no se había dado en los 30 años de dictadura. Es interesante visibilizar el papel que tenían los ayuntamientos en los años de transición ya que su labor estaba limitada, en su mayor parte, a urbanismo, limpieza urbana y tráfico. Por esta razón, muchos servicios se atendieron directamente por la ciudadanía (cultura, deporte, servicios personales,...) en asociaciones vecinales, ayuda mutua comunal y redes familiares (Alberich y Espadas, 2011). En los años 70 del pasado siglo empezaron a surgir asociaciones con el fin de auto-organizarse para cubrir estas necesidades que tenía la ciudadanía. Estas asociaciones estaban formadas por distintos colectivos y en ellas se reunían jóvenes, mujeres, grupos culturales y artísticos entre otros. El asociacionismo era más homogéneo que lo que conocemos en la actualidad y generaba historia de barrio organizando múltiples actos y construyendo redes educativas y de solidaridad interna (Alberich, 2007).

Respecto al espacio en Tiempo Libre fueron tiempos en los que no se supieron legar recursos e infraestructuras y eso hizo mella en el nuevo Tiempo Libre Democrático (Palacios, 2005). 


\section{- Ayuntamientos democráticos}

En 1977 se produce un aumento en el registro de asociaciones debido a la transición y la recuperación de libertades (Méndez y Mota, 2006; Alberich, 1994). A partir de las primeras elecciones democráticas (1979) las asociaciones se debilitan al tener que prescindir de sus cuadros formales al pasar a las alcaldías, concejalías y liberados en partidos políticos (Villasante, 1988). Se da una fragmentación social y las administraciones empiezan a ofrecer nuevos servicios culturales y sociales. Alberich (2007) sitúa la crisis de estos años en diferentes acontecimientos y acciones tal y como podemos ver en la siguiente tabla (tabla 5).

Tabla 5. Acontecimientos y crisis. Fuente: Alberich (2007).

\begin{tabular}{|c|c|c|c|}
\hline Causas generales & $\begin{array}{l}\text { Factores de los } \\
\text { miembros de } \\
\text { asociaciones y de la } \\
\text { administración } \\
\text { pública }\end{array}$ & $\begin{array}{l}\text { Factores por parte } \\
\text { de los Movimientos } \\
\text { Sociales }\end{array}$ & $\begin{array}{l}\text { Otros factores } \\
\text { sociales y causas de } \\
\text { la crisis }\end{array}$ \\
\hline $\begin{array}{l}\text { Abandono de las } \\
\text { asociaciones }\end{array}$ & Sectarismo político & $\begin{array}{l}\text { Falta de nuevos } \\
\text { horizontes globales y } \\
\text { sociopolíticos }\end{array}$ & $\begin{array}{l}\text { Reducción de la } \\
\text { información sobre } \\
\text { los movimientos } \\
\text { sociales. }\end{array}$ \\
\hline \multirow[t]{4}{*}{$\begin{array}{l}\text { Cambios en el } \\
\text { sistema } \\
\text { socioeconómico y } \\
\text { estructura social }\end{array}$} & Competencia & $\begin{array}{l}\text { Desconfianza radical } \\
\text { hacia todo el poder } \\
\text { público }\end{array}$ & $\begin{array}{l}\text { Escaso } \\
\text { reconocimiento } \\
\text { social del trabajo } \\
\text { voluntario no } \\
\text { remunerado en } \\
\text { España y en la } \\
\text { cultura mediterránea. }\end{array}$ \\
\hline & Crisis en la izquierda & $\begin{array}{l}\text { Desencanto sobre la } \\
\text { democracia }\end{array}$ & \\
\hline & $\begin{array}{l}\text { Falta de } \\
\text { reconocimiento } \\
\text { público y de interés } \\
\text { hacia el } \\
\text { asociacionismo por } \\
\text { parte de las } \\
\text { administraciones }\end{array}$ & Debilidades & \\
\hline & $\begin{array}{l}\text { Temor de las } \\
\text { asociaciones a ser } \\
\text { controlados por la } \\
\text { administración }\end{array}$ & $\begin{array}{l}\text { Inadecuación de } \\
\text { formas y contenidos }\end{array}$ & \\
\hline
\end{tabular}


Todo ello provoca crisis internas en las asociaciones que acaban dividiéndose o extinguiéndose, además de la influencia de las políticas de subvenciones y el clientelismo con el que se relacionaba administración y asociación.

En el ámbito de la juventud, retomamos la Taula de Joves de Catalunya que emprende una campaña para recuperar el patrimonio del movimiento a sus legítimos propietarios pidiendo locales, instalaciones y presupuestos que están en manos de la Organización Juvenil Española, denunciando a su vez el destino de diez mil millones del erario público para mantener políticas de la dictadura. Es el antecedente del movimiento «okupa» ya que algunas organizaciones juveniles ocupan pacíficamente locales de la Organización Juvenil de Movimiento Nacional. Además se encarga de promover el I Congrés de la Joventut Catalana reivindicando Casals de Joves que se convierten en elemento central. El año 1979 la Taula reinvindica la creación de una Xarxa de Casals de Joventut (Serrano, 2003).

Posteriormente, tras la constitución de los nuevos ayuntamientos democráticos, se articulan las nuevas políticas de juventud y tiempo libre al recogerse ya en los programas electorales el modelo de asociacionismo promovido por la Taula. Según Palacios (2005) esta articulación tiene doble valor:

- Impulsó la estrategia de intervención en materia de juventud desde las administraciones.

- Sientan las bases para configurar a las jóvenes como agentes y no sólo sujetos de esta intervención.

En cambio su principal carencia es el tono «culturalista» que se le da, preocupándose exclusivamente en el ocio juvenil y no en los problemas globales de la juventud en aquella época (empleo, vivienda, educación,...).

En la mayor parte de las localidades españolas se da forma a los centros de información juvenil, de recursos, las casas de juventud, los programas de apoyo al asociacionismo o de dinamización sociocultural. Las administraciones autonómicas están en bancarrota y son incapaces de articular políticas democráticas de juventud, hasta mucho tiempo después. Además de que los ayuntamientos inician sus propios proyectos olvidándose del tejido social (Serrano, 2003). Un claro ejemplo nos lo 
explican Sanz y Luque (2006) y lo tenemos en el Ayuntamiento de Barcelona dónde se abren centros bajo el nombre de Casals de Joves (CdJ) pero lo cierto es que la relación tejido asociativo y CdJ no existió. Se crea la coordinadora de Casals de Joves de Barcelona de la mano de las animadores, que ya comenzaban a estar remunerados, y los grupos gestores de los CdJ. El Área de Juventud impulsa una Asociación de animadores que gestiona el pago de las animadoras. Los recursos provienen del convenio que hace cada grupo gestor con el Ayuntamiento. Una de las barreras que se dan es que este mismo área no quiere que los grupos gestores se constituyan como Asociación ya que según las técnicos es contrario a la idea del Ayuntamiento de querer ofrecer un servicio para las jóvenes, es decir, se quiere enfrentar a jóvenes asociados con las no asociadas en lugar de promover que las no asociadas se asocien. Todos estos problemas se acaban cuando se asume que los $\mathrm{CdJ}$ son equipamientos municipales gestionados por entidades contratadas por el Ayuntamiento.

No podemos olvidarnos de que en Europa, en el año 1976, se consagra el movimiento de Casas de Juventud conformándose la European Confederation of Youth Clubs (ECYC).

\section{- La década prodigiosa ${ }^{6}$ : los años ochenta.}

A nivel europeo, la Unión Europea y el Consejo de Europa han tenido un papel relevante en cuanto a las jóvenes, las políticas de juventud y el trabajo para jóvenes se refiere. En 1988 la Unión Europea inicia un programa de intercambio y movilidad Youth for Europe entre 1988 y 1991. Este programa junto con los tratados de Mastricht o el de Lisboa es lo que legitima la voluntad de trabajar por las jóvenes y su participación en Europa (Soler, 2015). El programa Youth for Europe los siguieron Youth for Europe II y III (1992-1995 y 1996-1999), Youth (2000-2006) y Youth in Action (2007-2013). Un dato relevante que puede ayudarnos a la reflexión es que en esta época, en la ciudad de Múnich (similar en tamaño a Barcelona) existen 90 clubes juveniles que están fundamentalmente financiados por las autoridades locales (Merino, 2006).

\footnotetext{
${ }^{6}$ Referencia a esta época de Palacios (2005).
} 
En España, se empiezan a extender los Consejos de la Juventud aunque los apoyos al asociacionismo juvenil aún son escasos y los organismos de representación juvenil no son suficientes por lo que con su aparición no se puede compensar la fragilidad del tejido asociativo existente (Merino, 2006). Los movimientos que se producen reúnen tres características son de aire libre, de infancia y laicos (Palacios, 2005). Las organizaciones de la izquierda se mantienen al margen porque no ven una necesidad en articular el Tiempo Libre, sólo es la Iglesia, con sus amplios recursos y múltiples estructuras la que continúa con su acción pastoral entre las jóvenes. Algunos ayuntamientos desarrollan Políticas Integrales de Juventud aunque los modelos pedagógicos que se extienden se concentran en aumentar el papel de las jóvenes como consumidoras de servicios (Merino, 2006).

No se habilitó un marco legal y administrativo que facilitara a las jóvenes tener un espacio social donde desarrollar su ciudadanía. Únicamente algunos gobiernos locales y autonómicos como Zaragoza y Murcia, emprendieron experiencias sociales que pronto verían su desaparición. En Valencia desde finales de los años 80 hasta la creación de las Casas de Juventud se desarrollan diferentes programas de trabajo con adolescentes relacionados principalmente con la prevención de drogas y la participación

Continuando con el ejemplo de Cataluña como espacio ampliamente estudiado. En 1982 se constituyen Esplais Catalans que reúne a los Esplais laicos y Barcelona cada vez cuenta con más CdJ (30 en 1985). El Ayuntamiento de la ciudad transfiere la responsabilidad de los CdJ a los distritos y aunque deficientemente dotados se consolidan como los equipamientos mejor dotados aunque debido a la falta de inversiones se teoriza en convertirlos en equipamientos intergeneracionales como instrumento de intervención municipal. Poco a poco se van convirtiendo en espacios deficientes por la escasez de recursos y por su poca complicidad con el tejido asociativo no cuentan con el apoyo de espacios como el Consell de la Joventut de Barcelona (Sanz y Luque, 2006).

El año 1985 parece suponer un refuerzo a las políticas juveniles porque se proclama como el Año Internacional de la Juventud. 


\section{- Los años noventa y el desmantelamiento de las políticas de juventud.}

Los noventa vienen cargados de problemas económicos en las administraciones y de contratos de servicios privados por ellas mismas, además de producirse un boom del voluntariado debido a las Olimpiadas del 92 en el que se extiende el fenómeno del voluntariado dentro y fuera del tejido asociativo. Según Alberich (2007) se da un asociacionismo mucho más pragmático y subvencionado acompañado del nacimiento de nuevas asociaciones autodenominadas como ONG.

La derecha llega a los gobiernos locales, autonómicos y estatales y se provoca una extensiva política de desmantelamiento asociativo. La izquierda española no ejerce oposición y únicamente algunas experiencias en Aragón, Valencia y otras localidades aisladas se resisten a ello. En Andalucía, Cataluña y Euskadi existe una diferencia significativa producida por la configuración del poder político que allí se da. Aunque en Cataluña el Ayuntamiento de Barcelona dedica sus presupuesto a equipamientos deportivos debido a las Olimpiadas del 92 y se resienten los presupuestos en políticas juveniles (Sanz y Luque, 2006).

Por otro lado, se genera de manera extensiva un discurso que echa por tierra las actitudes juveniles, menospreciando e infravalorando todo aquello que han vivido. Entorno al binomio joven-delincuencia, joven-drogadicto se instala el debate social y se oculta la génesis del problema y las responsabilidades que deben asumir las instituciones y la sociedad al respecto para poder facilitar el desarrollo de una cultura de ciudadanía. Por todo ello, las horas estaban contadas para las políticas de juventud propuestas hasta entonces.

Múltiples movilizaciones se suceden durante esta época, producidas por movimientos pro-derechos humanos, ambientalistas, por el 0\%7\%,.. El inicio de movilizaciones ciudadanas por problemas externos, principalmente por la solidaridad internacional. Nacen muchas ONG y asociaciones a partir de estos movimientos y las jóvenes juegan un gran papel, aunque no el único, ya que en todos estos espacios se mezclan distintas generaciones.

Esta nueva situación hace que existan oposiciones a las nuevas formas de vivir el voluntariado, existen diferentes discursos y algunos no quieren ser 
parte de la mano de obra barata que gestiona las asociaciones. Esto provoca que se configuren nuevas asociaciones que están mejor organizadas y que en su actuación diaria, se basan en procesos democráticos además de incorporar profesionales (voluntarias o no) que aportan nuevas formas de participación y gestión. Como vemos esto hace que las asociaciones sean más profesionalistas y gestionen los conflictos de forma mucho más eficaz (Alberich, 2007).

\section{- Actualidad.}

Recorremos algunos datos de la mano de Alberich (2007) en relación al asociacionismo en España durante los últimos años. Más de doce millones de personas están afiliadas en alguna asociación, esto representa un tercio de la población adulta española (Alberich, 2003). En relación a estos datos y a los publicados por El País (4-12-03) según el Registro Nacional de Asociaciones en el período comprendido entre 1978 y el año 2000 se pasan de 18.000 a 230.000 asociaciones registradas. Siete años más tarde aumenta este número en 20.000 asociaciones más. En todo este volumen de números tenemos que tener en cuenta que muchas asociaciones no se dan de baja en el registro y permanecen activas cuando ya no tienen actividad. Aun así podemos ver el aumento exponencial del asociacionismo en nuestro país desde la transición hasta la actualidad. Según Alberich (2007) medio millón de empleos remunerados dependen de Organizaciones No Lucrativas, principalmente asociaciones y fundaciones, el conjunto del denominado Tercer Sector. A su vez, alrededor de tres millones de personas en nuestro país se consideran voluntarias dentro de estas asociaciones y de entre todas ellas cerca del millón dedican alrededor de 20 horas semanales a esta acción. Dato muy relevante ya que equivaldría a algo más de 250 mil empleos de jornada completa.

En cuanto a la comparativa entre España y otros países europeos, según el estudio sobre el caso español de Ruiz Olabuénaga, este afirma que «los resultados dados a conocer recientemente sugieren, por el contrario, que el caso español, tanto en términos de número de entidades no lucrativas como de volumen de empleo generado y de volumen económico gestionado, es muy similar, en términos relativos, al de Francia, Italia, Alemania o Austria» (2001: 277). Por otro lado, Morales y Mota (2006) a partir de los datos de sus investigaciones afirman que existe mucha 
disparidad entre unos países y otros. Hablamos de un rango de participación asociativa entre el 90 y el 20\%. Los países escandinavos son aquellos en los que mayor afiliación asociativa existe, los países centrales y anglosajones se encuentran en la media y los del Sur y el Este rondan el 20$30 \%$ tal y como podemos ver en la tabla de datos que sigue (tabla 6). En estos datos podemos observar las diferencias entre países en gran parte justificadas en la historia del movimiento asociativo de cada país tal y como hemos visto con anterioridad.

Tabla 6. La participación en asociaciones en Europa, 1999-2002 (en porcentajes). Fuente: Morales y Mota (2006).

\begin{tabular}{|c|c|c|c|c|c|c|}
\hline País & $\begin{array}{l}\text { Cualquier } \\
\text { implicación }\end{array}$ & Pertenencia & Actividades & Donaciones & $\begin{array}{l}\text { Trabajo } \\
\text { voluntario }\end{array}$ & $\mathbf{N}$ \\
\hline Noruega & 96 & 88 & 58 & 66 & 45 & 2297 \\
\hline Suiza & 95 & 86 & 54 & 66 & 41 & 1647 \\
\hline Dinamarca & 93 & 92 & 70 & 43 & 44 & 1640 \\
\hline Suecia & 92 & 90 & 68 & 46 & 50 & 1271 \\
\hline Holanda & 87 & 84 & 54 & 41 & 31 & 1649 \\
\hline $\begin{array}{l}\text { Alemania } \\
\text { Occidental }\end{array}$ & 71 & 68 & 60 & 28 & 42 & 1991 \\
\hline Eslovenia & 63 & 53 & 33 & 39 & 21 & 1005 \\
\hline Portugal & 58 & 43 & 34 & 35 & 22 & 1010 \\
\hline $\begin{array}{l}\text { Alemania } \\
\text { Oriental }\end{array}$ & 55 & 51 & 42 & 20 & 26 & 1013 \\
\hline España & 49 & 42 & 32 & 23 & 16 & 4252 \\
\hline Rusia & 28 & 25 & 16 & 6 & 11 & 1733 \\
\hline Rumania & 20 & 20 & 15 & 9 & 9 & 1217 \\
\hline Moldavia & 20 & 20 & 14 & 8 & 12 & 1219 \\
\hline $\begin{array}{l}\text { Media de } 13 \\
\text { países }\end{array}$ & 64 & 59 & 42 & 33 & 28 & \\
\hline $\begin{array}{l}\text { Desviación } \\
\text { típica }\end{array}$ & 28 & 28 & 20 & 20 & 14 & \\
\hline $\begin{array}{l}\text { Razón } \\
\text { máx/mín }\end{array}$ & 4,8 & 4,6 & 4,9 & 11 & 5,6 & \\
\hline
\end{tabular}

* Encuestas realizadas entre 1999 y 2002 en el marco del proyecto sobre Citizenship, Involvement, and Democracy (CID); puede verse en Westholm, Montero y van Deth (2007). 
En otro estudio (Maloney y Rossteutscher, 2007) vemos como la densidad asociativa en España también es inferior al resto de países encuestados (Alemania, Dinamarca, Holanda, Reino Unido y Suiza). Incluso la Catalana, que es la más alta en todo el país, está por debajo de los porcentajes europeos. De este modo, observamos la diferencia significativa en el panorama español y la relevancia del movimiento asociativo en Cataluña respecto del resto de España. En el estudio al que hacemos referencia, Cataluña tiene una media de 7 asociaciones por cada mil habitantes, Madrid 3'8 y el País Vasco 6’4. La media Europea se sitúa en el 10’9 cada mil habitantes. Aun así vemos como en nuestro país la pertenencia de las personas adultas a asociaciones se ha incrementado entre 1980 y 2002 aunque sean menos de la mitad de las personas adultas las que participen en alguna asociación voluntaria. Estas autoras (Morales y Mota, 2006) también encuentran diferencias respecto a las implicaciones, observando un descenso cuanto más compromiso se precisa (tabla 7). Dividen el compromiso en cualquier implicación, pertenencia, actividades, donaciones y trabajo voluntario viéndose un descenso significativo desde el primero al último, de un $49 \%$ a un $16 \%$.

Tabla 7. Formas de implicación asociativa en España: porcentajes de ciudadanos que colaboran con alguna asociación, 2002 (en porcentajes). Fuente: Morales y Mota (2006).

\begin{tabular}{|l|l|l|l|l|l|l|}
\hline & $\begin{array}{l}\text { Cualquier } \\
\text { implicación }\end{array}$ & Pertenencia & Actividades & Donaciones & $\begin{array}{l}\text { Trabajo } \\
\text { voluntario }\end{array}$ & N \\
\hline España & 49 & 42 & 32 & 23 & 16 & 4252 \\
\hline Cataluña & 51 & 43 & 29 & 21 & 14 & 1135 \\
\hline Madrid & 60 & 48 & 38 & 34 & 19 & 479 \\
\hline $\begin{array}{l}\text { País } \\
\text { Vasco }\end{array}$ & 45 & 40 & 32 & 19 & 10 & 1000 \\
\hline
\end{tabular}

*Datos obtenidos de Encuesta del Centro de Investigaciones Sociológicas (CIS) Universidad Autónoma de Madrid (UAM), número 2450, realizada en 2002 en el marco del proyecto de investigación sobre Ciudadanía, Implicación y Democracia en España (CIDE).

Morales y Mota (2006) también hacen referencia a cuales son las asociaciones que atraen a un mayor número de personas en España pudiendo comparar el tipo de compromiso entre las mismas (tabla 8). Aunque los porcentajes no alcanzan en ningún caso el 15\% de implicación 


\section{La Maranya}

Arecia Aguirre García-Carpintero

sí que vemos como las que mejores puntuaciones obtienen son las categorías asociativas deportivas, de caridad/ayuda social y culturales.

Tabla 8. Implicación en diversas asociaciones en España, 2002 (en porcentajes). Fuente: Morales y Mota (2006).

\begin{tabular}{|c|c|c|c|c|c|}
\hline $\begin{array}{l}\text { Categorías } \\
\text { asociativas }\end{array}$ & $\begin{array}{l}\text { Cualquier } \\
\text { implicación }\end{array}$ & Pertenencia & $\begin{array}{l}\text { Participación } \\
\text { actividades }\end{array}$ & $\begin{array}{l}\text { Donación } \\
\text { de dinero }\end{array}$ & $\begin{array}{l}\text { Trabajo } \\
\text { voluntario }\end{array}$ \\
\hline Deportivas & 14 & 13 & 9 & 2 & 3 \\
\hline $\begin{array}{l}\text { Caridad/ayuda } \\
\text { social }\end{array}$ & 14 & 5 & 3 & 11 & 3 \\
\hline Culturales & 8 & 7 & 6 & 2 & 3 \\
\hline $\begin{array}{l}\text { Derechos } \\
\text { humanos/ } \\
\text { cooperación } \\
\text { humanitaria } \\
\end{array}$ & 7 & 3 & 2 & 5 & 1 \\
\hline \begin{tabular}{ll}
\multicolumn{2}{l}{ Asociaciones } \\
de madres y \\
padres & de \\
alumnos &
\end{tabular} & 6 & 6 & 4 & 1 & 2 \\
\hline $\begin{array}{l}\text { Jubilados- } \\
\text { pensionistas }\end{array}$ & 6 & 5 & 4 & 1 & 1 \\
\hline Sindicatos & 6 & 5 & 3 & 1 & 1 \\
\hline Religiosas & 5 & 4 & 3 & 3 & 2 \\
\hline Vecinos & 4 & 4 & 3 & 1 & 1 \\
\hline $\begin{array}{l}\text { Enfermos, } \\
\text { enfermedades, } \\
\text { adicciones }\end{array}$ & 4 & 1 & 1 & 3 & 1 \\
\hline Profesionales & 3 & 3 & 1 & 0 & 0 \\
\hline Juveniles & 3 & 2 & 2 & 1 & 1 \\
\hline $\begin{array}{l}\text { Partidos } \\
\text { políticos }\end{array}$ & 3 & 2 & 2 & 1 & 1 \\
\hline Mujeres & 3 & 2 & 2 & 1 & 1 \\
\hline Discapacitados & 3 & 1 & 1 & 2 & 1 \\
\hline $\begin{array}{l}\text { Otros clubes o } \\
\text { asociaciones }\end{array}$ & 2 & 2 & 1 & 1 & 0 \\
\hline $\begin{array}{l}\text { Automovilistas } \\
\text { o motoristas }\end{array}$ & 2 & 2 & 0 & 0 & 0 \\
\hline Ecologistas & 2 & 1 & 1 & 1 & 0 \\
\hline Protectoras de & 2 & 1 & 1 & 1 & 0 \\
\hline
\end{tabular}




\begin{tabular}{|c|c|c|c|c|c|}
\hline $\begin{array}{l}\text { Categorías } \\
\text { asociativas }\end{array}$ & $\begin{array}{l}\text { Cualquier } \\
\text { implicación }\end{array}$ & Pertenencia & $\begin{array}{l}\text { Participación } \\
\text { actividades }\end{array}$ & $\begin{array}{l}\text { Donación } \\
\text { de dinero }\end{array}$ & $\begin{array}{l}\text { Trabajo } \\
\text { voluntario }\end{array}$ \\
\hline \multicolumn{6}{|l|}{ animales } \\
\hline Agrarias & 2 & 1 & 1 & 0 & 0 \\
\hline $\begin{array}{l}\text { Empresariales, } \\
\text { negocios, } \\
\text { comerciantes }\end{array}$ & 1 & 1 & 1 & 0 & 0 \\
\hline $\begin{array}{ll}\text { Hobbies } & \mathrm{O} \\
\text { aficiones } & \\
\end{array}$ & 1 & 1 & 1 & 0 & 0 \\
\hline Consumidores & 1 & 1 & 0 & 0 & 0 \\
\hline Pacifistas & 1 & 0 & 1 & 0 & 0 \\
\hline $\begin{array}{ll}\text { Clubes } & \text { de } \\
\text { inversión } & \end{array}$ & 0 & 0 & 0 & 0 & 0 \\
\hline Inmigrantes & 0 & 0 & 0 & 0 & 0 \\
\hline $\begin{array}{l}\text { Ex militares o } \\
\text { ex } \\
\text { combatientes }\end{array}$ & 0 & 0 & 0 & 0 & 0 \\
\hline $\begin{array}{l}\text { Víctimas del } \\
\text { terrorismo }\end{array}$ & 0 & 0 & 0 & 0 & 0 \\
\hline
\end{tabular}

En esta misma tabla (tabla 8) también podemos ver la variedad de los sectores de actuación. Las asociaciones culturales, deportivas y educativas son las que más asociadas atraen. Algo significativo respecto a esto es la forma que se da del tipo de participación en función del tipo de asociación (tabla 9). Se diferencian del resto las dedicadas a la caridad/ayuda social, las que luchan por los derechos humanos y la cooperación humanitaria y las de enfermedades y adicciones como las promovidas a través de la donación de dinero. El resto son sustentadas, en su gran mayoría, por la participación de sus miembros. Otras como las religiosas, las culturales, las pacifistas y las de inmigrantes destacan sólo en algunas zonas del país por la participación a través de actividades.

Tabla 9. Forma de implicación que predomina para cada categoría asociativa en España y en las comunidades autónomas de Cataluña, Madrid y País Vasco, 2002. Fuente: Morales y Mota (2006).

\begin{tabular}{|c|c|c|c|c|c|}
\hline Asociaciones & & España & Cataluña & Madrid & $\begin{array}{l}\text { País } \\
\text { Vasco }\end{array}$ \\
\hline Deportivas & & $\mathrm{M}$ & $\mathrm{M}$ & $\mathrm{M}$ & $\mathrm{M}$ \\
\hline Caridad/ayuda social & & $\mathrm{D}$ & $\mathrm{D}$ & $\mathrm{D}$ & $\mathrm{D}$ \\
\hline Culturales & & $\mathrm{M}$ & $\mathrm{M}$ & $\mathrm{A}$ & $\mathrm{A}$ \\
\hline Derechos & cooperación & $\mathrm{D}$ & $\mathrm{D}$ & $\mathrm{D}$ & $\mathrm{D}$ \\
\hline
\end{tabular}


Arecia Aguirre García-Carpintero

\begin{tabular}{|c|c|c|c|c|}
\hline Asociaciones & España & Cataluña & Madrid & $\begin{array}{l}\text { País } \\
\text { Vasco }\end{array}$ \\
\hline \multicolumn{5}{|l|}{ humanitaria } \\
\hline $\begin{array}{l}\text { Asociaciones de madres y padres de } \\
\text { alumnos }\end{array}$ & $\mathrm{M}$ & $\mathrm{M}$ & $\mathrm{M}$ & $\mathrm{M}$ \\
\hline Jubilados- pensionistas & $\mathrm{M}$ & $\mathrm{M}$ & $\mathrm{M}$ & $\mathrm{M}$ \\
\hline Sindicatos & $\mathrm{M}$ & $\mathrm{M}$ & $\mathrm{M}$ & $\mathrm{M}$ \\
\hline Religiosas & $\mathrm{M}$ & $\mathrm{A}$ & $\mathrm{A}$ & $\mathrm{A}$ \\
\hline Vecinos & $\mathrm{M}$ & $\mathrm{M}$ & $\mathrm{M}$ & $\mathrm{M}$ \\
\hline Enfermos, enfermedades, adicciones & $\mathrm{D}$ & $\mathrm{D}$ & $\mathrm{D}$ & $\mathrm{M}$ \\
\hline Profesionales & $\mathrm{M}$ & $\mathrm{M}$ & $\mathrm{M}$ & $\mathrm{M}$ \\
\hline Juveniles & $\mathrm{M}$ & $\mathrm{M}$ & $\mathrm{M}$ & $\mathrm{M}$ \\
\hline Partidos políticos & $\mathrm{M}$ & $\mathrm{A}$ & $\mathrm{A}$ & $\mathrm{M}$ \\
\hline Mujeres & $\mathrm{M}$ & $\mathrm{M}$ & $\mathrm{A}$ & $\mathrm{M}$ \\
\hline Discapacitados & $\mathrm{D}$ & $\mathrm{M}$ & $\mathrm{M}$ & $\mathrm{M}$ \\
\hline Otros clubes o asociaciones & $\mathrm{M}$ & $\mathrm{M}$ & $\mathrm{M}$ & $\mathrm{M}$ \\
\hline Automovilistas o motoristas & $\mathrm{M}$ & M & M & $\mathrm{M}$ \\
\hline Ecologistas & $\mathrm{M}$ & $\mathrm{M}$ & $\mathrm{M}$ & $\mathrm{M}$ \\
\hline Protectoras de animales & $\mathrm{M}$ & $\mathrm{M}$ & $\mathrm{A}$ & $\mathrm{A}$ \\
\hline Agrarias & $\mathrm{M}$ & $\mathrm{M}$ & --- & $\mathrm{M}$ \\
\hline Empresariales, negocios, comerciantes & $\mathrm{M}$ & $\mathrm{M}$ & $\mathrm{M}$ & $\mathrm{M}$ \\
\hline Hobbies o aficiones & $\mathrm{M}$ & $\mathrm{M}$ & $\mathrm{M}$ & $\mathrm{M}$ \\
\hline Consumidores & $\mathrm{M}$ & $\mathrm{M}$ & $\mathrm{M}$ & $\mathrm{M}$ \\
\hline Pacifistas & $\mathrm{A}$ & $\mathrm{D}$ & $\mathrm{A}$ & $\mathrm{D}$ \\
\hline Clubes de inversión & --- & --- & $\mathrm{M}$ & --- \\
\hline Inmigrantes & --- & $\mathrm{A}$ & $\mathrm{A}$ & $\mathrm{M}$ \\
\hline Ex militares o ex combatientes & --- & --- & $\begin{array}{c}-- \\
--\end{array}$ & $\begin{array}{c}-- \\
--\end{array}$ \\
\hline Víctimas del terrorismo & $\overline{---}$ & --- & 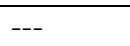 & 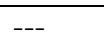 \\
\hline
\end{tabular}

M, miembro; A, participación en actividades; $\mathrm{D}$, donación de dinero; ---, sin casos.

Con todos los datos recogidos a través de esta investigación, Morales y Mota (2006) diseñan la siguiente escala del activismo asociativo (figura 1).

Figura 1. El activismo asociativo: Una escala. Fuente: Morales y Mota (2006).

Activista total (socio + actividades + voluntario + donaciones $)$

Activista (socio + actividades + voluntario)

Socio activo (socio + actividades)

Voluntario (sólo trabajo voluntario)

Cliente/usuario (sólo actividades)

Socio pasivo (sólo pertenece)

Donante (sólo donaciones)

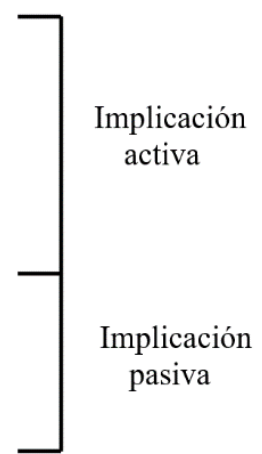


En ella dividen la implicación de las asociadas en implicación pasiva y activa. La primera se estructura a partir de las donantes y las socias pasivas. La segunda la forman usuarias de actividades, voluntarias, socias activas, activistas y activistas totales. En ella observamos también el nivel de compromiso aceptado por cada tipo de participación.

Encontramos un estudio más (Méndez y Mota, 2006) en el que se hace un balance de las asociaciones creadas en función de los períodos asociativos descritos más arriba. Los ciclos que mayor número de asociaciones tienen son el periodo de antes de 1975, con un $21 \%$ y el que se da entre 1990 y 2000 que aumenta hasta el 45\%. En este segundo período prácticamente la mitad de las asociaciones inscritas son juveniles (45\%). De los datos se deduce que aún hay un $20 \%$ de las asociaciones de la época predemocrática.

Como síntesis, en la tabla 10 podemos ver una pequeña aproximación de la evolución del asociacionismo y las políticas sociales en España propuesto por Alberich y Espadas (2011). 
Arecia Aguirre García-Carpintero

Tabla 10. Evolución del asociacionismo. Fuente: Alberich y Espadas (2011).

\begin{tabular}{|c|c|c|c|}
\hline 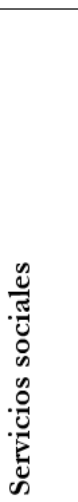 & 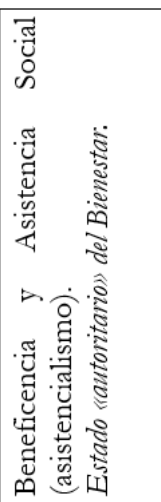 & & 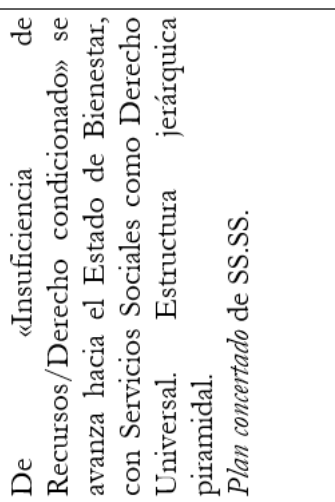 \\
\hline 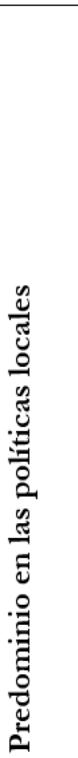 & 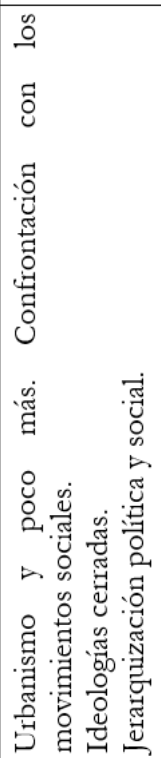 & 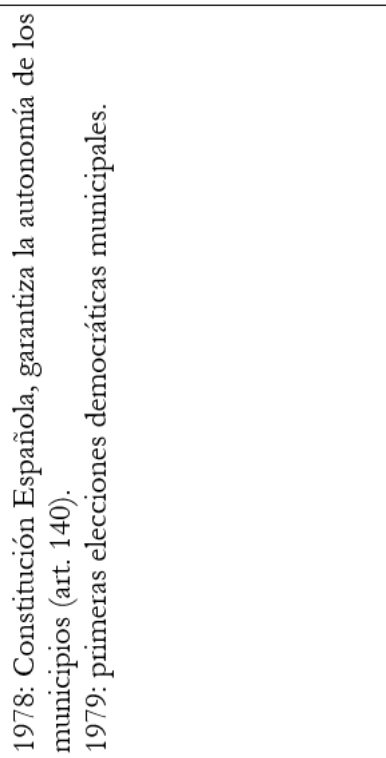 & 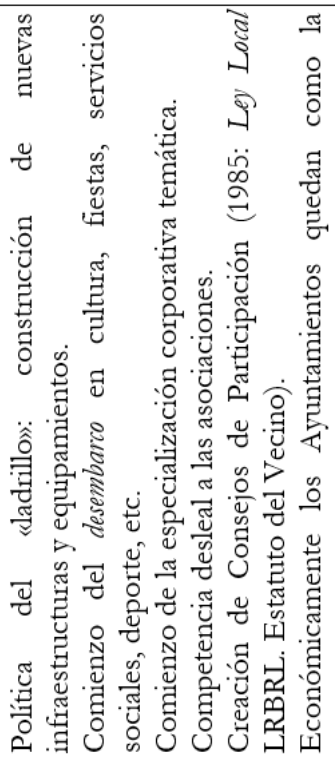 \\
\hline 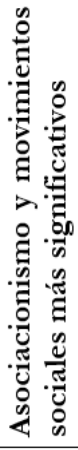 & 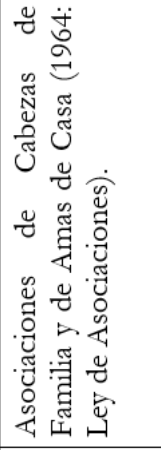 & 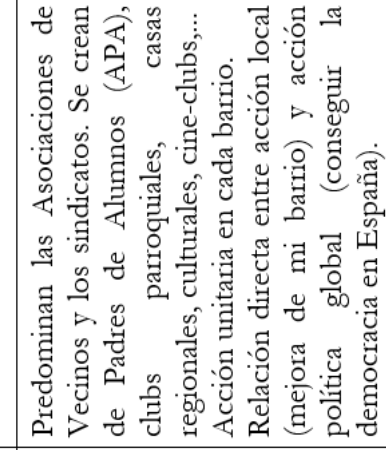 & 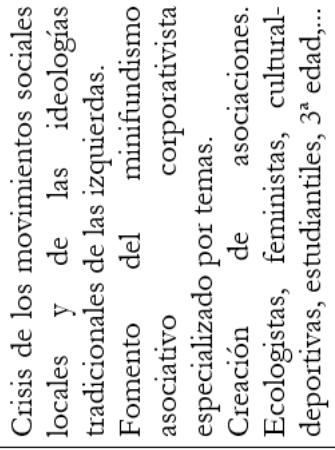 \\
\hline 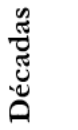 & $\begin{array}{l}\text { ఏ } \\
\text { (2) }\end{array}$ & 옹 & \begin{tabular}{l}
$\stackrel{0}{\sigma}$ \\
\multirow{2}{*}{}
\end{tabular} \\
\hline
\end{tabular}




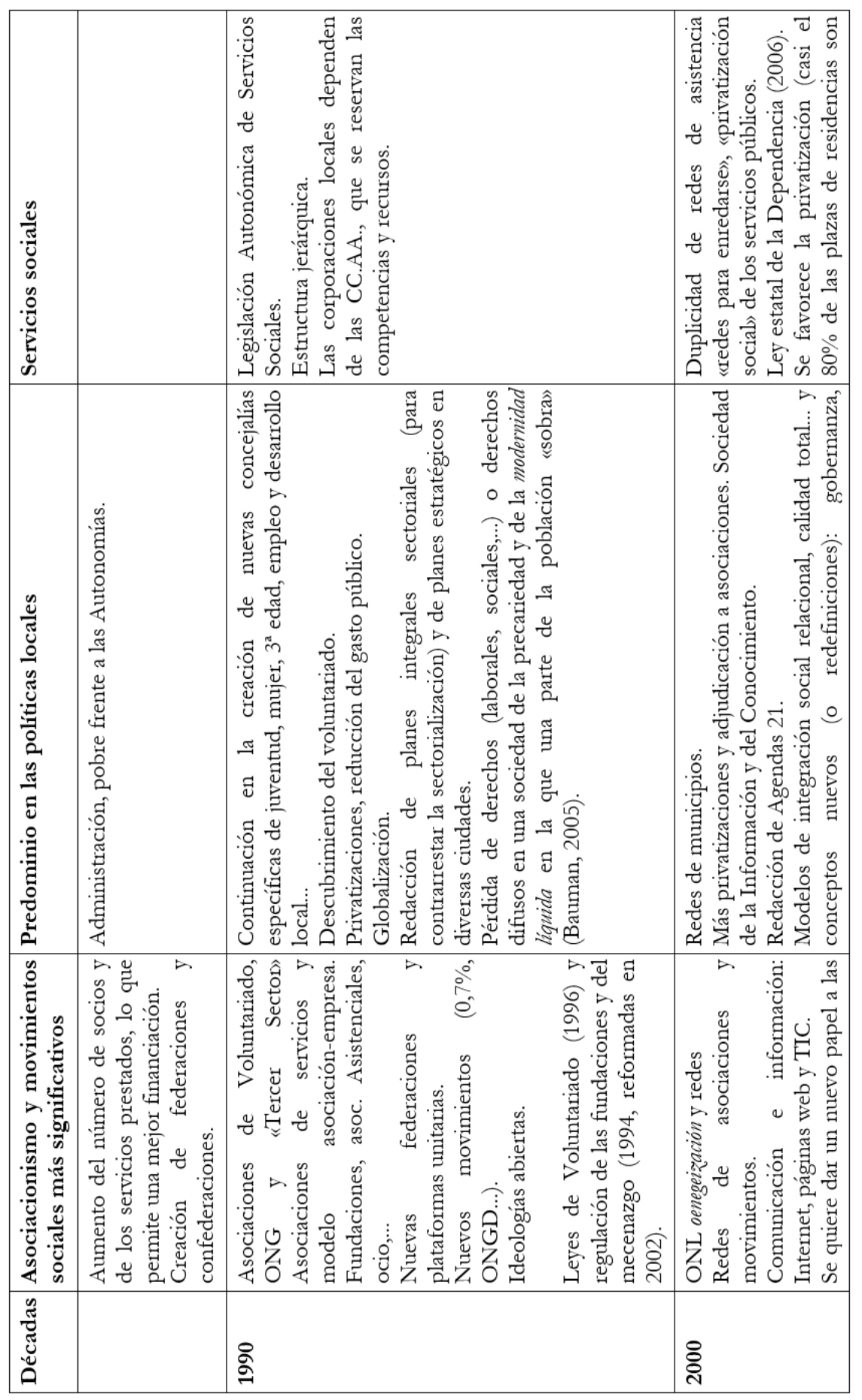




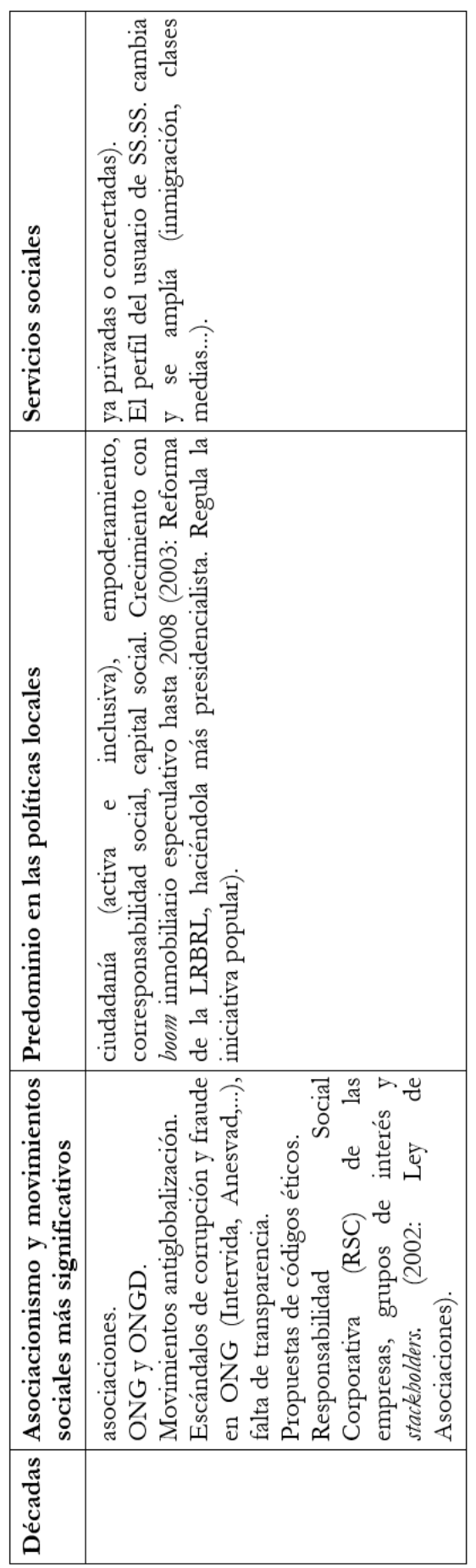


En conclusión, el análisis histórico del asociacionismo en España y Europa justifica en gran parte el estado actual en nuestro país. La dictadura franquista y las políticas llevadas a cabo durante la misma, así como las consecuencias que produjo en la etapa de transición, debilitan el movimiento y diferencia el asociacionismo español del mayoritario en el panorama europeo. Vemos que aún tenemos camino que recorrer para conseguir un tejido asociativo estructurado y potente que no base su acción en el consumo de servicios y que dote a la acción voluntaria de una relevancia acorde con la estipulada en los países vecinos.

\subsubsection{El valor del asociacionismo como espacio de aprendizaje.}

«Los sentimientos y las ideas no se renuevan, el corazón no se engrandece, ni el espíritu humano se desarrolla, sino [es] por la acción recíproca de unos seres humanos con otros. Esto sólo las asociaciones pueden lograrlo», así valoraba Tocqueville (1805-1859) (II, 1984: 98), la capacidad del asociacionismo para influir en el crecimiento personal de la ciudadanía tanto de forma individual como colectiva.

No podemos olvidar como la participación tanto infantil como juvenil se han convertido en grandes predictores para el ejercicio de una ciudadanía activa durante la edad adulta (Putman, 2002 y Collet y Sánchez, 2013). Por ello remarcamos el triple objetivo que cubre la Educación no formal desde el asociacionismo juvenil según Palacios (2005):

- Facilita el proceso de maduración de las jóvenes desde una amplia perspectiva personal y social previniendo patologías sociales que se presentan.

- Facilita el proceso de inserción social.

- Desarrolla una percepción del mundo desde cada acción asociativa concreta, acorde con los planteamientos religiosos, filosóficos o ideológicos del colectivo juvenil.

Así es interesante potenciar la participación y desarrollar una cultura participativa entre las jóvenes y toda la ciudadanía para así poder reforzar el componente democrático de nuestra sociedad. Así lo escribe Cornudella (2004:13) en la III Carta de la Joventut Catalana, 
la necessitat d'incidir, de participar, de col-laborar en els processos de construcció col-lectiva no és tan sols una necessitat per a moltes persones, sinó també és imprescindible per a construir la nostra societat democràtica. Però quan parlem de participació democràtica, podem dir que el moviment associatiu juvenil col-lectivament representa un sistema d'accions que porten a una evident millora democràtica del país.

De este modo, sería el asociacionismo infantil y juvenil el que provocaría el nacimiento de una ciudadanía política activa (Ariño, 2004) y favorecería una ética cívica. Según (Aranguren, 2010) la ética cívica surge del convencimiento de que no son las leyes las que consiguen una sociedad más justa y que en este sentido, no son los cambios de régimen los que garantizan que las personas cambien. Por ello,

conseguir un pueblo inteligentemente cohesionado que no se convierta en un pueblo de demonios, como advirtiera Kant, consiste en formar una comunidad de personas preocupadas no solo cada cual por sí misma sino también por lo que afecta a la comunidad, entendida no como núcleo de supervivencia sino como fuente de coexistencia (2011:48).

Collet y Sánchez (2013) también reafirman que el movimiento asociativo juvenil contribuye a ello ya que:

- Promueve ciudadanía al contribuir a la formación de personas autónomas y críticas.

- Son escuelas de democracia, tal y como las denominaría Alexis Tocqueville en la sociedad norteamericana del siglo XIX, al ser espacios de aprendizajes sociales y políticos.

- Como espacios políticos, contribuye a la construcción de un modelo de sociedad más justo, más solidario, más equitativo y más libre.

Aunque no todas las asociaciones persiguen los mismos objetivos y por ello, no deben contribuir de la misma forma a la construcción de una ciudadanía activa y ética. Morales y Mota (2006) construyen una tipología de asociaciones en función de sus objetivos (bienes constitutivos) y de las acciones para conseguirlos (acciones o medios consecutivos). Respecto a los bienes consecutivos se diferenciarán en asociaciones que bien busquen 
bienes privados o bienes públicos o colectivos. En cuanto a las acciones consecutivas existen las que quieren alcanzarlos por medio de acciones de carácter social o económico y las que realizan acciones político institucionales. Esta diferenciación da cuatro tipos de asociaciones:

1. Bienes privados + acciones sociales-económicas

2. Bienes privados + acciones político-institucionales

3. Bienes públicos + acciones sociales-económicas

4. Bienes públicos + acciones político institucionales

En esta misma línea, Boix y Posner (2000) y Warren (2001) también hacen esta diferenciación asociativa. Por su parte Putnam (2002) deduce tres tipologías que se construyen a partir de los grados de positividad social. Encontramos los siguientes:

- Asociación autocentrada, vinculantes, exclusiva o nicho (Bonding).

- Asociación que tiende puentes, inclusiva, relacional o nodo (Bridging).

- Asociación que construye red (Linking).

Llegados a este punto es necesario matizar que es una asociación para nosotras y tal y como Knoke (1986:2) expone de forma simple «es un grupo formalmente organizado y con un nombre, la mayoría de cuyos miembros no se ven recompensados económicamente por su participación». Dejamos de lado otras instituciones sociales, políticas y organizaciones que persiguen otros objetivos económicos (Morales y Mota, 2006). Por lo que entendemos por asociación aquella agrupación de personas físicas o jurídicas que se constituye bien para realizar una actividad colectiva o bien para conseguir un mismo fin de un modo estable a través de una organización democrática y sin ánimo de lucro contribuyendo en la creación de red ciudadana y trabajando por el bien común y público. En esta definición es evidente la alusión al voluntariado pero tal y como la define Ariño (2004) este término nace por una definición moral (obrar para las otras) y se compara con la militancia que surge de una definición política (hacer juntas). En las tradiciones anglosajona y francesa se utiliza de diferente forma. Las inglesas aluden al término para referirse a aquellas activistas dedicadas a los partidos políticos y sindicatos. En cambio las francesas llaman así a quienes participan activamente en todo tipo de 
asociaciones y grupos orientados hacia el ámbito político. Aun así hay cierta sintonía en aceptar que militancia queda reservada para aquellas personas que tienen un rol activo en el seno del grupo (Anduiza, Bonet y Morales, 2006:262). En España, se utiliza más el término militante para las personas que participan en partidos políticos y sindicatos y se ha extendido el uso de activista de forma más genérica para el resto de espacios de participación. Con lo que podríamos decir que las asociaciones son un grupo organizado de activistas y otros miembros que comparten un objetivo común, el cual persiguen a partir de una organización democrática y sin ningún ánimo de lucrarse con la misión de crear una red ciudadana que trabaje por el bien común y el servicio público.

Para conseguir construir esta red y para poder hablar de ciudadanía asociativa, Ariño (2004) precisa que se den dos condiciones:

- una interpenetración del Estado y de la sociedad en la que las asociaciones no aparezcan como exteriores frente a la sociedad política,

- y un reconocimiento por parte de las asociaciones de su responsabilidad en la definición de los valores de la esfera pública y en las carencias de las reglas democráticas.

Mark Warren ponía de relevancia en su libro Democracy and Association que tanto el Estado como el Asociacionismo tienen importancia en la construcción de la democracia. Concretamente Warren pone en relieve la dimensión cultural de la democracia de la siguiente forma:

La calidad de la democracia representativa depende de la calidad de la sociedad en la que está inserta, en especial en la procuración de las virtudes cívicas a través de los vínculos asociativos. La democracia debe tomar en cuenta, como se supone que ha sido siempre, el autogobierno que se expresa en la vida asociativa y en la cultura cívica que deriva de la experiencia asociativa (Warren, 2001: 30).

Otra reseña a la relación entre democracia y asociacionismo la hace Fung (2003) quien identifica seis contribuciones de las asociaciones para la dinamización de la vida democrática:

- Son el manifiesto de uno de los principios fundamentales de la democracia: la libertad de expresión. 
- Destacan como espacios de socialización cívica, política y cultural.

- Pueden asumir el papel de contrapoder en las manifestaciones ilegítimas de las autoridades del estado y en la concentración de sus intereses.

- Representan los intereses ante los políticos.

- Es uno de los componentes del espacio público en el que la deliberación colectiva puede darse y así contribuir a la democracia deliberativa.

- La participación directa de las asociaciones para superar las limitaciones que se dan en la participación ciudadana en las propuestas del gobierno.

Aun así, hay autoras como Ariño (2004) que ven que

la vida real interna de las asociaciones está lejos de mostrar que en ellas haya una alternativa de democracia participativa frente a los lastres supuestos de la democracia representativa: el déficit de democracia interna en las asociaciones es real; se da una débil renovación de los cargos, una notabilización de los responsables, una rutinización de las prácticas democráticas y un incremento de la distancia entre élite y base (2004:101).

Esto influye, según el autor, en que las asociaciones no sean, en la actualidad representativas de la democracia participativa.

Warren (2001) complementa el trabajo de Putman (1993) sobre capital social a partir de las relaciones que realiza Tocquiville entre asociacionismo y democracia. Mark Warren explica que hay distintos tipos de efectos que producen las asociaciones en la democracia. Las diferentes consecuencias del trabajo asociativo se dividen en tres espacios distintos. Uno el que conlleva a la persona que participa, otro al espacio público y otro a las instituciones.

1. Developmental Effects on Individuals: efficacy, information, political skills, civic virtues and critical skills.

2. Public Sphere Effects: public communication and deliberation, representations of difference, representations of commonality. 


\section{Institucional effects: representation, resistance, subsidiarity, coordination} and cooperation, democratic legitimation. ${ }^{7}$

Para conseguir estos efectos dentro del asociacionismo juvenil, tal vez podamos seguir los factores que hacen que una Asociación juvenil sea considerada de «excelencia social». Collet y Sánchez (2013) listan los siguientes:

- Si es un espacio de participación democrática, una escuela de participación y democracia a la par que de construcción ciudadana favoreciendo el desarrollo de personas autónomas y críticas.

- Si es un espacio de aprendizaje social donde se trabajen actitudes, valores, habilidades, conocimientos, relaciones,...

- Si fomenta el compromiso social y cívico, en la actualidad y para un futuro.

- Si es un espacio de politización, entendiendo esto como el interés y la actuación en temas, ámbitos, espacios y conflictos colectivos. Es decir, si construye una articulación colectiva de intereses y problemáticas individuales siempre que se busque la transformación social.

- Si fomenta el bienestar, la calidad de vida y la vertebración de las personas y el territorio donde sean insertadas.

- Si fomenta el encuentro y la interacción de personas de diferentes perfiles sociales.

- Si trabaja por la cohesión social y la inclusión de todas, respetando la diversidad y afrontando y aprovechando el conflicto.

De esta forma volvemos al concepto de Escuela de democracia tal y como se denominan muchas asociaciones siendo aquel espacio que «por su estructura y funcionamiento supone un ejercicio práctico de la democracia porque ya su mismo currículum implica oportunidades continuas de

7 Se han encontrado diferentes traducciones de estos elementos y por este motivo se ha decidido acudir a los originales. 
explorar las cuestiones que afectan a sus integrantes, de imaginar respuestas a los problemas y de guiarse por ellas» (Apple y Beane, 1999:120). Es así que las asociaciones por una parte educan para la democracia y por otro, promueven el ejercicio activo de la democracia favoreciendo el paso de una cultura individualista a una colaborativa y generando la participación auténtica (Cornejo, González y Caldichoury, 2007).

Vemos en todas estas palabras la relevancia de las asociaciones para promover un aprendizaje situado a través de la acción colectiva. Si echamos la vista atrás, tanto Vygotsky como Dewey nos han hablado de la importancia de situar el aprendizaje, ya que forma parte de la actividad, el contexto y la cultura. En la obra Experiencia y educación (1938/1997) de Dewey expone como «toda auténtica educación se efectúa mediante la experiencia» (p.22) y de él surge el aprendizaje experiencial. McKeachie (1999) es uno de los autores que apoyándose en el trabajo de Dewey nos habla de este tipo de aprendizaje en aquellas prácticas que se realizan en escenarios reales y que posibilitan a la persona una serie de aprendizajes como:

- Encarar diferentes fenómenos de la vida cotidiana

- Conseguir aplicar y transferir el conocimiento de manera significativa

- Aprender y desplegar habilidades que faciliten la construcción de un sentido de competencia profesional

- Saber cómo afrontar situaciones sociales y contribuir a la comunidad

- Relacionar el pensamiento con la acción

- Trabajar acerca de valores y cuestiones éticas y reflexionar sobre ellas

Asumimos que el aprendizaje situado es una de las teorías actuales más representativas de la teoría y la actividad sociocultural (Daniels, 2003), y marcamos como referentes los textos de Lev Vygotsky (1986; 1988) y otros como Leontiev (1978) y Luria (1987). Además de trabajos más recientes como los de Lave y Wenger (1991) con la participación periférica legítima, Rogoff (1993) con su aprendizaje cognitivo, Bereiter (1997) y también 
Engeström y Cole (1997) con sus aproximaciones a la cognición situada, Wenger (2001) con las comunidades de práctica y Daniels (2003) con su aprendizaje artesanal son, entre muchas autoras, algunas que enumeramos por la repercusión que han tenido en el ámbito educativo.

Según Paz (2009) estas perspectivas quieren refrendar la relación entre la persona y su cognición junto con el contexto en el que se mueve ya que el objetivo es que ella misma sea cognitivamente activa mientras participa en su entorno sociocultural cubriendo sus correspondientes necesidades. Es así como, desde una perspectiva situada, se apuesta por que el aprendizaje se centre en prácticas auténticas, «simplemente definidas como las prácticas ordinarias de la cultura» (Brown, Collins y Duguid, 1989:34).

Lave y Wenger (1991) defienden un enfoque en el que no es el aprendizaje el que está situado en la práctica sino que el aprendizaje es parte integral de la propia práctica social que se genera en la realidad ya que sostienen que «aprender es una parte integral de nuestra vida cotidiana» (p.26). Es decir, no es necesario que estructuremos el aprendizaje para que aparezca en la práctica ya que este es parte fundamental de la misma aunque no se organice de manera formalizada el aprendizaje y la práctica como partes inseparables. De este modo, ambas autoras focalizan la importancia del aprendizaje en el proceso y en la participación activa de actividades colectivas. Por ello el conocimiento se construye en interacción con las otras y con el medio ya que el hecho de aprender se enriquece de la experiencia compartida.

De esta forma que el aprendizaje situado resalte el valor del trabajo, en el contexto cultural, para conseguir una adquisición de habilidades auténtica. Según Lave y Wenger (1991) el hecho de adquirir conocimiento en sí no genera un aprendizaje situado, memorizar y conocer unas cosas y otras no no nos acerca a la participación activa si no somos capaces de entrecruzar el aprendizaje con la práctica. De este modo se ampliarán nuestros horizontes y se dará forma a nuestras trayectorias de aprendizaje. En ellas nos podemos identificar a partir de promover acciones, dinamizar discusiones y generar reflexiones que transformen nuestras comunidades. En este sentido, creemos que el aprendizaje más transformador es aquel que hace referencia a la afiliación a una comunidad, a ese sentimiento de pertenencia a un grupo, colectivo o espacio porque será el modo en el que 
podremos introducirnos en un verdadero aprendizaje situado. Así lo comprendemos desde un proceso multidimensional de empoderamiento cultural ya que según Barquero (2002) se trata de una experiencia que involucra el pensamiento, la afectividad y la acción.

Por todas estas razones, necesariamente la participación social y el proceso educativo van tendidos de la mano ya que «se trata de un proceso ineludiblemente lento, como el futuro que trae hasta el presente: lento, pero viene $^{8} »$ (Aranguren, 2010). Wenger (2001) se centra en el aprendizaje como participación social. Dicho autor, tanto si habla de la participación periférica legítima como de las comunidades de práctica, entiende que el aprendizaje es una construcción social (Moliner, Traver, Ruiz y Segarra 2016). Porque la participación se comprende como aquella interacción de compromiso en actividades y con personas, a la vez que hace referencia a la implicación en las prácticas de las comunidades sociales de un modo activo construyendo identidades en relación con estas comunidades. Así, «esta participación no sólo da forma a lo que hacemos, sino que también conforma quiénes somos y cómo interpretamos lo que hacemos» (Wenger, 2001:22).

De este modo, y siguiendo con este autor, los componentes que harán que la participación social sea un proceso de aprender y conocer son el significado (aprendizaje como experiencia), la práctica (el aprendizaje como hacer), la comunidad (el aprendizaje como afiliación) y la identidad (el aprendizaje como devenir).

Con todo ello no queremos decir que la práctica y la teoría estén reñidas, no son independientes la una de la otra, se autorregulan. Toda teoría debería ser práctica y toda práctica debería ser teoría. De hecho, las comunidades de práctica propuestas por Wenger (2001) son espacios en los que la práctica se lleva a cabo a partir de una reflexión de la acción tal y como Schön (1983) nos describía hace ya unos años tal que una característica esencial de la práctica es la reflexión de la acción. Todas las personas construimos nuestras propias teorías y maneras de comprender el mundo, y el lugar donde podemos desarrollarlas, negociarlas y compartirlas

\footnotetext{
${ }^{8}$ Palabras recordando a Mario Benedetti.
} 
es una comunidad de práctica ya que estas «se pueden concebir como historias compartidas de aprendizaje» (Wenger, 2001:115).

Para Wenger (2001) es muy importante diferenciar lo que significa la noción de práctica. Para él esta tiene que ver con el nivel de estructura social que refleja un aprendizaje compartido ya que se convierte en un proceso gracias al cual tenemos la oportunidad de experimentar el mundo y el compromiso que asumimos con él como algo significativo. En definitiva, la práctica hace referencia al sentido que tiene para nosotras como experiencia de la vida cotidiana. De este modo, si cumple estas tres dimensiones: compromiso mutuo, empresa conjunta y repertorio compartido se convertirá en una fuente de coherencia de la comunidad. Vamos viendo como las comunidades de práctica nos permiten integrar de una forma equilibrada la parte formal (estructura organizativa) e informal (la vida) de los espacios de aprendizaje (Moliner, Traver, Ruiz y Segarra, 2016).

Sagástegui (2004) hace hincapié en la necesidad de transitar en prácticas educativas auténticas para conseguir aprender a participar democráticamente y construir esa ciudadanía que añoramos.

sabemos que tenemos enfrente la tarea de fabricar y proyectar estrategias educativas de manera que se encuentren cada vez más situadas en nuestra cultura, para reivindicarlas bajo el signo de lo general y lo particular, de lo universal y lo local, de lo previsible y lo contingente. Esto no significa simplemente una moda sujeta a los vaivenes de la mercadotecnia académica sino el indicador de un nuevo régimen de racionalidad que nos acerca a una definición de educación como una continua reinvención de la realidad y de la cultura (2004:38). 


\section{4. El modelo de Casas de Juventud.}

En el siguiente apartado me gustaría describir el modelo de Casas de Juventud (CdJ) como referente en esta tesis. Es poca la bibliografía encontrada sobre las CdJ, prácticamente todo proviene de los escritos que la propia Federació Valenciana de Cases de Joventut (FVCJ) tiene sobre el tema, además de alguna que otra publicación procedente de la Fundació Ferrer $i$ Guàrdia, del Casal de Joves de Catalunya y de Jose Luis Palacios y las Casas de Juventud en Zaragoza.

Para ello haré un recorrido por el panorama europeo y español concretando en las CdJ de la zona valenciana. Después describiré lo que es una CdJ, cuáles son sus objetivos, cómo se organiza y estructura, cuáles son sus ideales y acabaré con las aportaciones de estudios concretos sobre Cdj en Europa.

\subsubsection{Recorrido europeo y español por las CdJ.}

Ya sabemos que la organización internacional de Casas de Juventud es la European Confederation of Youth Clubs (ECYC) situada en Bruselas y formada por más de 18 países miembros. En España las Casas de Juventud se llaman así por copia de los equipamientos franceses Maison de Jeunes et Culture. Estos están más volcados en ofrecer servicios que en el trabajo educativo con jóvenes por este cambio de estrategia no pertenecen a ECYC ya que esta reconoce el trabajo pedagógico con grupos de jóvenes frente a la mera oferta de servicios. El modelo español fue una evolución de equipamientos que ofrecían servicios a lo que hoy representan las Casas de Juventud, equipamientos que ofrecen servicios para captar a grupos de jóvenes con las que trabajar la educación en el tiempo libre. Aunque muchas Casas de Juventud en España han evolucionado en este sentido, aún existen muchas otras que siguen ofreciendo servicios sin ningún objetivo más. Después de este resumen paso a realizar un recorrido por Europa, España y la zona valenciana ${ }^{9}$.

9 Los datos de esta introducción han sido aportados por Julio Huerta y Enrique Deltoro como representantes del movimiento de Cases de Joventut en Valencia. 


\section{- Europa.}

Al finalizar la II Guerra Mundial surge en diferentes países europeos un movimiento de Casas de Juventud bajo nombres como Clubes Juveniles, Casas de Jóvenes y Cultura,..., entre otros. El panorama asociativo juvenil europeo fue completándose gracias a estos espacios ya que, hasta el momento, casi todas las asociaciones juveniles eran de carácter religioso o político.

Es así como se convierten en Centros de Convivencia donde se desarrollan iniciativas laicas y pluralistas desde una mirada política y en algunos países, con una vocación de trabajo social y comunitario. Cubren un espacio que hasta el cual no llegaban las asociaciones tradicionales contando siempre con un gran apoyo de las diferentes administraciones pero con una gestión independiente en manos de las jóvenes, algo que caracteriza al movimiento en Europa.

A día de hoy, las CdJ siguen federadas en L'ECYC (European Confederation of Youth Clubs), fundada en 1976. Actualmente, cuenta con 19 organizaciones en 18 países distintos de la $\mathrm{UE}^{10}{ }^{10}$ con alrededor de 1,2 millones de jóvenes con el objetivo de capacitar a las jóvenes mediante el trabajo juvenil abierto y el aprendizaje no formal con el fin de promover una sociedad democrática y civil, y animar a las jóvenes a participar activamente en sus comunidades.

\section{- España.}

En España ya hemos visto lo que ocurría con el asociacionismo a consecuencia de la Guerra Civil y los años de transición. A principios de los años 80 los ayuntamientos democráticos deciden poner en marcha Casas de Juventud y en pocos años son cientos de ellas las que se reparten por todo el Estado.

\section{可然地

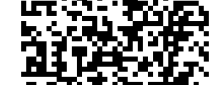

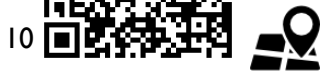


Diferentes planteamientos se dieron al hecho de que años después muchas de estas CdJ cerraran sus puertas. Por un lado había personas que decían que había sido por falta de un modelo claro de funcionamiento y otras que se posicionaban más a favor del desencanto del asociacionismo. La cuestión es que pocas quedaron en pie y las que quedaron quisieron hacer una aproximación a la ECYC con la idea de encontrar un lugar de referencia para poder avanzar. Desde FCVJ nos cuentan que nunca se produjo la integración efectiva ya que el modelo de gestión de las CdJ en España estaba en manos del Ayuntamiento y no de las jóvenes y esto no se admitía como válido para la Federación Europea 'I. Su fundamento era que las jóvenes no se sentirían parte de un proyecto si este no era gestionado por ellas mismas.

Todos estos acontecimientos hacen que algunas $\mathrm{CdJ}$ resistan: Alcobendas, Orense, Salamanca (que poco después también caería), Barcelona y Zaragoza. Entre estas dos últimas se retroalimentaban siendo, según Sastre (1992) Zaragoza para Barcelona un punto de referencia claro que demostró su capacidad de arraigo popular, consolidación y extensión.

En Cataluña, en el año 1994, se empiezan a diferenciar dos vías en el modelo, una es la que vio nacer a las CdJ, la otra procede de un grupo de jóvenes que deriva del movimiento de esplais laico y progresista. Ellas ven la necesidad de crear un proyecto común entre su movimiento y el modelo que existía de CdJ. Esto provoca que cuatro años después se cree la Federació de Casals de joves de Catalunya. Esta es, actualmente, la única que está vinculada como miembro en ECYC.

- Valencia ${ }^{12}$

Los orígenes de todo este movimiento en Valencia se sitúa en plena transición española en el CEMA francés, centros de educación bajo un

\footnotetext{
IIInformación recogida a partir de las entrevistes realizadas con algunos miembros de la Federació Valenciana de Cases de Joventut.
}

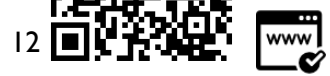


metodología activa. Esta metodología empieza a extenderse a través de cursos de formación en 1984 y llega a oídos de algunas personas de Valencia que a partir de algunas de sus profesoras empiezan a escuchar hablar de nuevas metodologías. Nunca hubo un contacto directo pero las ideas traspasaron fronteras. En 1985 la Dirección General de Juventud (actual IVAJ) realiza un curso de animadores juveniles en el que coinciden algunas personas como Enrique Deltoro y Jesús Marti ${ }^{13}$. Enrique empieza a trabajar en el Ayuntamiento y decide montar centros juveniles. En el año 1986 se monta el centro juvenil En Marcha del que forma parte un adolescente Julio Huerta que después acabará formando parte del mismo movimiento.

Durante los años 1986 y 1992 se suceden centros juveniles, políticas, espacios y van formando parte cada vez más personas del proyecto de adolescentes. Es en 1992 cuando futuras miembros de la FVCJ empiezan a viajar y conocen las iniciativas de Zaragoza y Cataluña. De forma concreta, se realiza un encuentro en Murcia en el que Enrique Deltoro, miembro del movimiento juvenil valenciano y Jose Luis Palacios, miembro de las Casas de Juventud zaragozanas y del Movimiento Laico y Progresista se conocen y por fin Enrique dice dar con una experiencia juvenil que funciona. A los de Cataluña se les copia la idea de Esplais, más que el espacio se les copia la idea de trabajar infancia desde los movimientos asociativos y por otro lado, a los de Zaragoza se les copia el modelo de funcionamiento de Casas de Juventud que se pone en marcha en Valencia en el año $1994^{14}$. Con todo este movimiento se decide montar la FVCJ y se presenta en el Ayuntamiento de Quart ese mismo año. A la puesta en marcha de distintas CdJ en: Manises, Xirivella, Mislata, Quart, Benetússer,... les siguieron más tarde: Alaquàs, Paterna, Torrefiel, Puçol, Polinyà, Torrent, Benicàssim, Aielo,... y en los últimos años: Betxí, Vila-real, Almassora, Maranya, Vilamarxant, Paiporta. Hoy la FVCJ está formada por 11 CdJ y más de 740 personas asociadas.

13 Miembros del movimiento valenciano integrado en la FVCJ. Puedes saber más de ellos en el capítulo 4. Componentes Contextuales.

${ }^{14}$ Información extraída de las entrevistes con FVCJ. 
Dos años más tarde se dará forma a la escuela de formación de la propia Federació, Escola de Cases. Esta escuela no surge de la nada, es hija de alguien, nace con el respaldo y la fuerza que puede transmitir una Asociación como Trajecte, pionera en la formación y la educación en el tiempo libre de este territorio. Juani, la actual directora de la Escuela, recuerda esa herencia de profesorado, materiales, publicaciones, experiencia, esencia de las personas que la formaron y también su energía y compromiso. La finalidad de la escuela es la de formar voluntarias, a las bases sociales y empoderar a la juventud. En los últimos años la Escuela se enreda con otros espacios que dicen dan sentido a su función: Fundación Movimiento Ciudadano, Impuls, Fundació L'hora y los Esplais. En 20 años de vida han pasado más de 5000 personas en su formación que han participado en 112 cursos: entre MTL, A.J y formadora de animadoras y 43 monográficos ${ }^{15}$.

\subsubsection{Diferencias en los modelos de Casas de Juventud.}

Son diversos los modelos de $\mathrm{CdJ}$ que se extienden alrededor de toda Europa. Principalmente en España encontramos modelos de intervención juvenil promovidos y gestionados por la administración, modelos que fomentan el asociacionismo tradicional y modelos de escuelas de participación y democracia.

La esencia de las CdJ es la creación de espacios con vocación de servicio público, de carácter laico e independiente con una gestión directa de las jóvenes. En España, se pretende ocupar espacios que en Europa ya se tienen desde hace años y para ello se toma como referencia este Modelo de Casas Juveniles (Youth Clubs). En muchas ocasiones se han definido erróneamente $\mathrm{CdJ}$ a espacios que sirven como centros de información y servicios para las jóvenes promovidos por la Administración produciendo en las jóvenes una mentalidad de consumidoras pasivas de servicios producidos, dirigidos, realizados y protagonizados por la Administración. Aun así desde FVCJ se reconoce como desde estos lugares también se ha dado pie a la creación de CdJ no municipales gestionadas por las jóvenes.

\footnotetext{
${ }^{15}$ Datos obtenidos de la presentación de la directora de Escola de Cases en la celebración del $\mathrm{XX}$ aniversario de la escuela de formación.
} 
Cuando la Administración ha optado por apoyar el asociacionismo tradicional se han creado modelos de intervención de apoyo asociativo tradicional a partir de Consejos Locales de Juventud y en otros lugares se han creado centros de recursos para asociaciones. Estos centros de recursos se han cedido en algunos municipios a la gestión asociativa al ver fracasar la gestión directa por el Ayuntamiento.

En nuestro caso, seguiremos el Modelo de Casas de Juventud extendido por la FVCJ que es en el que se encuentra la Casa de Joventut La Maranya.

\title{
1.4.3. ¿Qué es una Casa de Juventud?
}

La FVCJ define las Cases de Joventut como

\begin{abstract}
servei públic, instrument imprescinbible per a introduir en el joves hàbits de participació, generar en ells consciència d'actitud activa solidària, exercitar la capacitat d'emprenedors $i$ servir com una peça clau per a la prevenció de conductes $i$ comportaments antisocials, al mateix temps que és un instrument per a enfrontar-se al problema de les drogues (Federació, 2014:10).
\end{abstract}

Siempre estarán gestionadas por las jóvenes a partir de un modelo abierto, pluralista e independiente que garantice el protagonismo de las jóvenes. Las CdJ, según Federació, deberían potenciarse desde la administración, apoyando las iniciativas juveniles que vayan apareciendo. A su vez, cogiendo el modelo europeo, han de federarse ya que la Federació realizará las tareas de coordinación entre las entidades, fomentando la creación de nuevas sedes, la formación de sus voluntarias y dará apoyo fiscal y administrativo.

Sienten que el modelo de CdJ está en plena reconstrucción con el objetivo de conseguir uno nuevo que deje a un lado los errores de otros tiempos y tengan en cambio mayor similitud con el tejido europeo existente.

\subsubsection{Objetivos de las CdJ.}

Encontramos un listado de 10 objetivos que tienen todas las organizaciones juveniles que forman parte de la Federació Valenciana de Cases de Joventut.

1. Promover procesos de inserción activa de las jóvenes en la sociedad. 
2. Aumentar las prácticas participativas, culturales, asociativas y creativas de las jóvenes.

3. Favorecer el desarrollo y la autonomía social y personal de las jóvenes.

4. Dotar de recursos, servir de apoyo y promover la participación en iniciativas de dinamización sociocultural del entorno.

5. Hacer participar a las jóvenes en la resolución de los problemas sociales, medioambientales, económicos,...

6. Prevenir el abuso en el consumo de drogas y conductas adictivas.

7. Fomentar la integración de jóvenes desfavorecidas, grupos minoritarios y promover la convivencia y la diversidad en todas sus formas y expresiones.

8. Fomentar actitudes solidarias y comprometidas de carácter cotidiano y/o excepcional, denunciando injusticias sociales allá donde se produzcan.

9. Apoyar y promocionar las asociaciones juveniles existentes que podrán participar de los bienes materiales de la CdJ.

10. Participar en aquellas formas de coordinación con instituciones, asociaciones públicas y privadas, colectivos, redes y otras entidades de interés social.

En definitiva se pretende promover el cambio social a partir de educar en la participación (Giner, López, Maín y Murgui, 2013).

\subsubsection{La organización en una CdJ: La quíntuple estructura.}

Para favorecer la participación de las jóvenes debemos encontrar mecanismos de organización que nos faciliten el impulso de la autoorganización. Las estructuras han de construirse teniendo en cuenta los principios básicos de participación y democracia. Para conseguirlo seguimos la quíntuple estructura que propone Palacios (2005).

- Estructura de participación. Es la primera y esencial ya que a partir de ella se pueden diseñar todas las demás. Sabemos que todo el mundo no 
participa de la misma forma, que existen diferentes niveles de participación que hacen que una persona se implique más o menos en un sistema asociativo. Respetar las distintas potencialidades y realizar actividades que permitan la integración de jóvenes en las estructuras de participación (Alarcón, 1997). Teniendo en cuenta esto se diseña la siguiente pirámide de participación de cinco alturas. No es una jerarquía de mando,

I. El colectivo que se sitúa a la cabeza de la pirámide es el relacionado con el grupo de Animadoras. Serían aquellas que ejercen un liderazgo global.

II. Seguidos de las Activistas de Grupos Estables y de las miembros de la Junta Directiva de la Casa. Son aquellas que lideran actividades concretas en el centro y además algunas son miembros de la Junta directiva.

III. En el centro de la pirámide encontramos a todas aquellas personas que forman parte de los Grupos Estables, son sus Miembros. Son las jóvenes que forman grupos de actividad.

IV. Por debajo de este grupo vemos a las Usuarias de cursos y servicios que ofrece la Casa. Aquellas que usan con cierta regularidad una actividad del centro.

V. Finalizamos con las llamadas Consumidoras refiriéndose a aquellas personas que forman parte de las actividades masivas de la Casa. Las que consumen esporádicamente alguna actividad.

A participar se aprende participando es una de las máximas de las CdJ, por eso el protagonismo lo asume el proceso y no el resultado de participar. La actividad es un medio para conseguir la transformación social y la concientización de las jóvenes.

En las diferentes $\mathrm{CdJ}$ las jóvenes empiezan por asumir una responsabilidad que con el tiempo acabará desarrollando de manera autónoma. Entonces podrá pasar a formar parte de los plenarios de la Casa para contar su experiencia y organizar las responsabilidades junto con la persona coordinadora para acabar planificando ella misma actividades en la Casa y en el municipio. Este proceso de aprendizaje lo resumen del siguiente 
modo en los Casals de Joves de Catalunya (Giner, López, Maín y Murgui, 2013). Podrían darse hasta cuatro fases diferentes en el proceso:

$1^{\circ}$. El EAV planifica y organiza las actividades y las nuevas jóvenes las «consumen».

$2^{\circ}$. El EAV planifica y organiza actividades de forma conjunta con las nuevas incorporaciones de jóvenes.

$3^{\circ}$. Estas jóvenes planifican y organizan las actividades con el apoyo del EAV.

$4^{\circ}$. Existe una autonomía plena en la planificación y organización de las actividades por parte del grupo de jóvenes.

De este modo se conseguirá una evolución progresiva en cuanto a complejidad, duración, autonomía y asunción de responsabilidades.

- Estructura de actividad. Ofrece a cada nivel de participación una actividad formativa adecuada. De este modo una clasificación de estas actividades podría ser el siguiente:

A. Actividades comunes, que se deciden en asamblea y las concreta el EAV.

B. Actividades de grupos estables que surgen de las activistas y tienen funcionamiento autónomo entre jóvenes.

C. Talleres que se plantean por personas voluntarias con compromiso mínimo de un trimestre. Cualquier miembro puede proponer un taller y coordinarse con el EAV

D. Propuestas puntuales.

- Estructura funcional/acción. Organiza la acción en programas específicos de forma transversal. Las seis áreas de trabajo de una CdJ:

1. Animación de Órganos Internos $\longrightarrow$ Este área de trabajo se encarga de dinamizar las relaciones entre las socias de la CdJ, desarrollar los contenidos del manifiesto, formación y reciclaje de animadoras voluntarias y activistas. 
2. Gestión interna $\longrightarrow$ En ella se llevan a cabo diferentes acciones como son el control económico de la Casa, la secretaría, el mantenimiento y equipamiento del local, material, inventario, también coordinar las permanencias de las responsables, elaboración del Plan de Actuación de las CdJ y las memorias y la elaboración de fichas de planificación, evaluación y otros documentos.

3. Grupos Estables $\longrightarrow$ Se encarga del mantenimiento y creación de Grupos Estables.

4. Cursos y Servicios $\longrightarrow$ Las responsables de esta área se dedican a realizar la programación, ponerla en marcha y hacer el seguimiento de los cursos y servicios de la Casa.

5. Relaciones $\longrightarrow$ Este área ha de relacionarse con el tejido asociativo del barrio o del pueblo y con las instituciones del municipio como los institutos, partidos políticos,...

6. Difusión —> Aquí las responsables se encargan de realizar la publicidad, generar actividades de difusión y fomentar las relaciones con la prensa.

- Estructura orgánica para sustanciar los procesos educativos.

Esta estructura está dividida en cuatro fases. Arriba del todo podemos encontrar al Equipo de Animadoras Voluntarias (EAV) que es seleccionado por la Asamblea y es el encargado de dirigir las programaciones del centro, es decir, el Plan de Animación de la CdJ.

Después encontramos la Junta Directiva del centro, que es la responsable de la dirección de la CdJ y órgano representante de la CdJ. La Junta ha de estar formada por Presidenta, Secretaria y Tesorera además de por una representación de vocales elegidos de cada uno de los Grupos Estables de la Casa.

Los Grupos Estables se dividen en diferentes áreas y estas son la cultural, musical, deportiva, social y de 14 a 17 años.

Finalmente estos Grupos Estables están apoyados por las Coordinadoras de área. 
Figura 2. Estructura Casa de Juventud. Fuente: Federació Valenciana de Cases de Joventut.

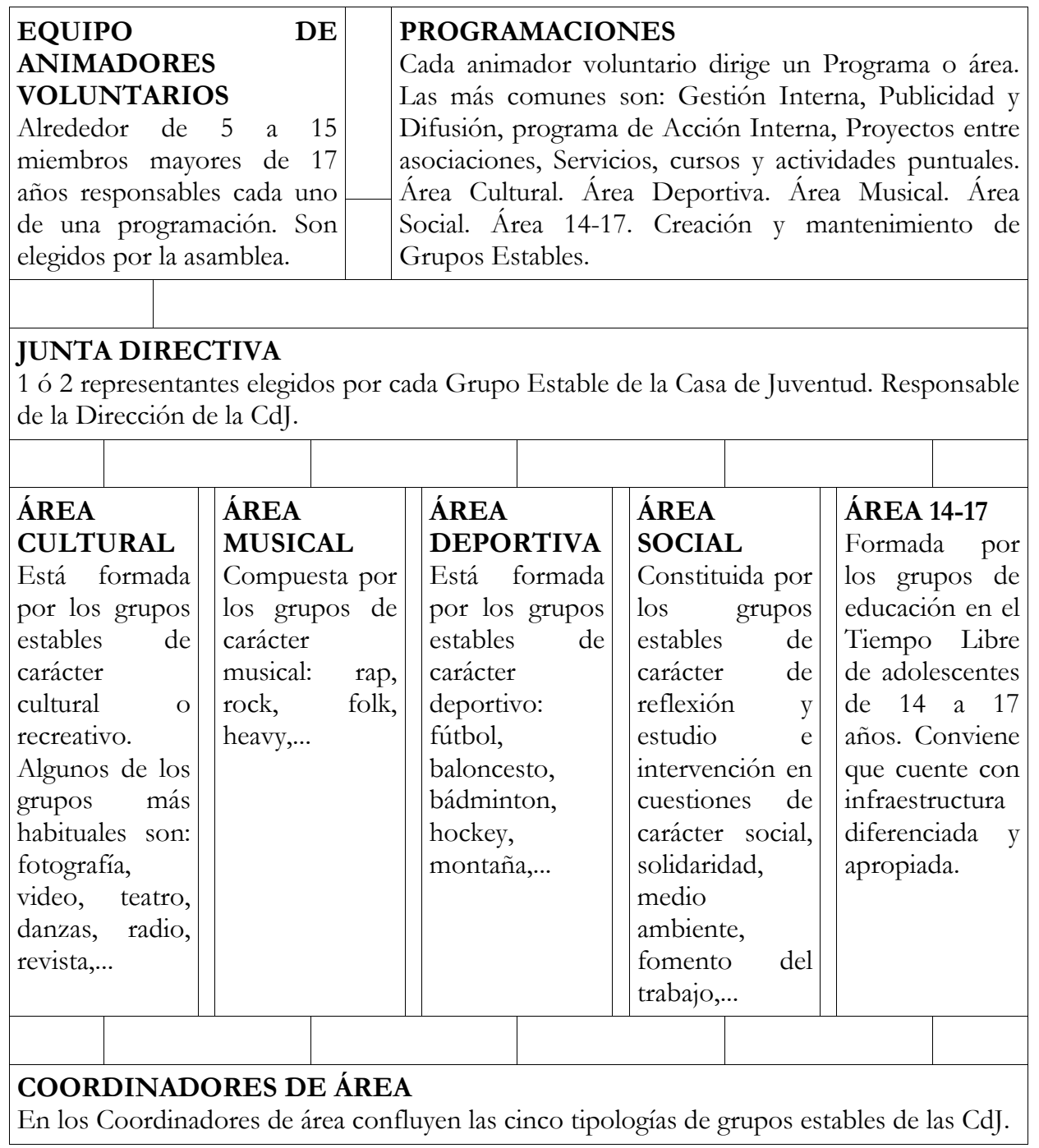

En esta estructura, tal y como ya explicábamos en Aguirre, Beltrán, Checa, Escoín, Morales y Tomás (2015), existen una serie de puntos de encuentro y decisión en las CdJ que dan forma a la estructura orgánica de la Asociación. Estos espacios son principalmente los cinco siguientes:

- El plenario mensual, donde representantes de los grupos estables y la persona representante de cada proyecto del centro se reúnen para hacer 
una puesta en común de las acciones y tomar decisiones de modo argumentado sobre las mismas.

- La asamblea general, se realiza dos veces al año, en octubre y en junio, y se define como el órgano soberano de la asociación. Está formada por todas las personas socias del centro y sus funciones principales son la elección de los órganos de dirección y la aprobación de la gestión y los planes de trabajo. Todas las personas participantes tienen derecho a realizar propuestas y acciones de forma argumentada en la asamblea, aunque actualmente el grupo con más responsabilidades sigue siendo el comprendido entre los 14 y 30 años, y son quienes únicamente tienen derecho a voto en las asambleas. Esta línea de trabajo se vincula directamente al objetivo de las casas de juventud de darles protagonismo directo en la gestión de sus propias iniciativas.

- Los grupos de tareas y la coordinadora apoyan a las activistas y las activistas que representan a cada grupo estable y a la persona animadora voluntaria como responsables en un ámbito concreto.

- La junta directiva, que es el órgano ejecutivo de las líneas generales, marcadas en la asamblea. Está formada por un o una representante de cada grupo estable o coordinadora de ámbito y por aquellos socios y socias que son escogidos por la asamblea general para llevar a cabo tareas de presidencia, secretaría y tesorería. Sus reuniones son mensuales.

- El equipo de animadores y animadoras voluntarios (EAV). En él cada participante es responsable de una programación de intervención. El equipo de animadores y animadoras está compuesto por entre tres y diez personas que selecciona la junta directiva. Se reúnen semanalmente para compartir la situación de cada acción, repartir tareas, repasar quiniela y organizar la semana.

- Sesión Federació. Una vez al trimestre hay una reunión con todas las CdJ que están federadas en FVCJ donde se comparte información y estado de cada CdJ.

- Estructura de recursos/presupuestaria para presentar su destino en función de la estructura de participación. El presupuesto de la CdJ no se 
puede gastar sin pensar en la estructura participativa que tenemos y un reparto razonable del presupuesto en función de esa pirámide participación sería: 10\%-EAV, 10\%-Activistas, 55\%-Grupos Estables, 10\%-Usuarios, 15\%-Consumidores.

\subsubsection{Ideario de las CdJ.}

Cada Casa da forma a un manifiesto diferente, cada Casa lo adapta a sus propias ideas pero estas siempre tienen nexos en común entre Casas. Estos nexos son transversales en su metodología y están descritos por los siguientes puntos:

- Denominación. Las Casas han de tener un nombre propio, una personalidad jurídica propia para ser sujetos de derecho.

- Igualdad de género. Las Casas hablan en femenino luchando para que hombres y mujeres tengan derecho a una igualdad total, al respeto y a las diferencias que les ocupan.

- Protección del medio ambiente. Las CdJ cuidan y defienden la naturaleza y asumen el compromiso de trabajar para no destrozar más el entorno.

- Democracia. Las Casas trabajarán para hacer Democracia Directa fomentando foros, encuentros de opinión y potenciando los caminos a la participación política libre como espacios independientes que son.

- Pluralidad. La defensa de la diversidad es la base de las Casas teniendo cabida todas las culturas, civilizaciones, ideas, formas de sentir y de expresarse y corrientes de aire nuevo.

- Violencia como contravalor. No se tolera la violencia, siempre estará la razón frente a la fuerza para conseguir cualquier objetivo que la persona se proponga.

- Rechazo a las drogas. Las Casas rechazan cualquier tipo de adicción. Las drogas limitan la libertad y son repudiadas como entretenimiento para pasar el tiempo.

- Solidaridad. Las CdJ manifiestan que solo el hermanamiento solidario puede garantizarnos la paz.

- Inclusión. No existen las barreras, son espacios inclusivos en 
contra de cualquier aspecto que pueda provocar la desigualdad. Se respetan las diversidades funcionales y las sociales.

- Contra el paro. Asumen el reto de convertirse en espacios activos comprometidos con la lucha contra el paro.

- Palabra. Las jóvenes siempre serán las últimas en tener la palabra quedando este manifiesto abierto a su propio desarrollo.

\subsubsection{La interpretación de la cultura.}

Tres aspectos relevantes que los Casals de Joves Catalanes (Giner, López, Maín y Murgui, 2013) tienen en cuenta en sus asociaciones con una relación directa con las Cases de Joventut es la forma de entender la cultura, la democracia y la autogestión. La democracia y la autogestión se entienden a partir de la quíntuple estructura. Para la interpretación que se hace de la cultura desde el Modelo de Casas de Juventud, expongo algunas ideas para que se entienda mejor cual es el tipo de metodología que persiguen las CdJ.

Tabla 11. Diferencias entre Extensión cultural e Intervención cultural. Fuente: Giner et al, 2013.

\begin{tabular}{|c|c|c|}
\hline & Extensión cultural & Intervención cultural \\
\hline Tipo de centro & Centro cívico & $\begin{array}{l}\text { Casal de Joves } \\
\text { associatiu }\end{array}$ \\
\hline $\begin{array}{l}\text { Producción y gestión } \\
\text { cultural }\end{array}$ & $\begin{array}{l}\text { Producción y gestión } \\
\text { cultural fiscalizada por el } \\
\text { Estado, el centro cívico es } \\
\text { un r equipamiento } \\
\text { municipal. }\end{array}$ & $\begin{array}{l}\text { Producción y gestión de la } \\
\text { cultura por parte de la } \\
\text { ciudadanía, el Casal de Joves } \\
\text { es una Asociación. }\end{array}$ \\
\hline Qué actividades se hacen & $\begin{array}{l}\text { Se hacen actividades } \\
\text { asistenciales. A partir de la } \\
\text { demanda, se ofrecen una } \\
\text { serie de actividades con el } \\
\text { objetivo de dar respuesta } \\
\text { a escala municipal a lo que } \\
\text { el consumidor quiere. } \\
\text { Trato « clientelar». }\end{array}$ & $\begin{array}{l}\text { Se hacen actividades de } \\
\text { dotación de capacidades. } \\
\text { A partir de la intuición de } \\
\text { lo que la gente quiere, se } \\
\text { ofrecen actividades que } \\
\text { puedan gustar, con el } \\
\text { objetivo de que actúen } \\
\text { «como gancho» para } \\
\text { intervenir en el cambio de } \\
\text { conciencia. }\end{array}$ \\
\hline El rol del ciudadano/a & $\begin{array}{l}\text { Actúa como consumidor } \\
\text { pasivo de actividades. }\end{array}$ & $\begin{array}{l}\text { Actúa como generador } \\
\text { activo de actividades. }\end{array}$ \\
\hline
\end{tabular}




\begin{tabular}{|c|c|c|}
\hline & Extensión cultural & Intervención cultural \\
\hline $\begin{array}{l}\text { Cómo se accede a la } \\
\text { actividad }\end{array}$ & $\begin{array}{l}\text { Como consumidor, el } \\
\text { acceso se hace de manera } \\
\text { individual, a través de una } \\
\text { inscripción y sin necesitar } \\
\text { a nadie más. }\end{array}$ & $\begin{array}{l}\text { Como generador, para } \\
\text { acceder a una actividad se } \\
\text { requiere la colectividad. }\end{array}$ \\
\hline $\begin{array}{lrr}\text { La actividad } & \text { y } & \text { el } \\
\text { conocimiento } & \text { que } & \text { se } \\
\text { deriva } & & \end{array}$ & $\begin{array}{l}\text { El conocimiento está } \\
\text { mercantilizado, sólo se } \\
\text { accede a través del pago. }\end{array}$ & $\begin{array}{l}\text { El conocimiento es } \\
\text { popular, se construye } \\
\text { entre todos y todas, a } \\
\text { partir de la propia } \\
\text { implicación } \\
\text { compromiso. }\end{array}$ \\
\hline $\begin{array}{l}\text { El conocimiento está en } \\
\text { manos de... }\end{array}$ & $\begin{array}{l}\text { El conocimiento está } \\
\text { centralizado, sólo de la } \\
\text { persona profesional que } \\
\text { es la propietaria. }\end{array}$ & $\begin{array}{l}\text { El conocimiento es } \\
\text { compartido por todas las } \\
\text { personas que participan } \\
\text { en la actividad. }\end{array}$ \\
\hline Objetivo de la actividad & $\begin{array}{l}\text { Entretenimiento. } \\
\text { Aprendizaje de unas } \\
\text { habilidades específicas. }\end{array}$ & $\begin{array}{l}\text { Aprendizaje participativo. } \\
\text { Educación en el } \\
\text { asociacionismo. } \\
\text { Conciencia } \\
\text { transformadora. }\end{array}$ \\
\hline
\end{tabular}

La cultura se asume como un medio educativo mediante el cual la ciudadanía ha de cambiar su rol a un modo activo en el que ella misma sea constructora de cultura, sólo de este modo llegaremos al verdadero significado de la Cultura como construcción colectiva.

Por ello se habla más de intervención cultural ya que se utiliza la cultura como excusa para intervenir con las jóvenes para aprender a participar a través de la organización de actividades culturales.

En la siguiente tabla (tabla 11) se muestra cuáles son las diferencias entre la extensión cultural que acerca la cultura a la ciudadanía y la intervención cultural que construye cultura con la ciudadanía que exponen Casals de Joves (Giner, López, Maín y Murgui, 2013). 


\subsubsection{Estudios concretos sobre Casas de Juventud en Europa.}

En España existen pocos estudios sobre Casas de Juventud. Los únicos se han realizado por la Fundació Ferrer i Guàrdia de Barcelona.

- (2012). Enquestes a la joventut de Catalunya donde se hace una radiografía de la situación de las jóvenes en los diversos aspectos que configuran su realidad (educación, emancipación, participación, salud, movilidad, etc.).

- (2006). Els locals de les entitats juvenils i els equipaments municipals per a joves a la ciutat de Barcelona. Informe de resultats. En el podemos encontrar un análisis de diferentes espacios juveniles que existen en la ciudad de Barcelona, entre ellos, las CdJ.

- (1992). Las casas de juventud, espacios de libertad. El Ayuntamiento de Barcelona les encarga un informe sobre las Casas de Juventud de Barcelona diez años después de su implantación para así valorar y realizar propuestas a partir de los resultados.

En ECYC podemos encontrar los siguientes realizados en Casas de Juventud:

- (2010). «Your Culture, My Culture.»: es un estudio sobre la juventud en Europa en el cual se recogen sus perspectivas sobre identidad étnica, la percepción personal, el individualismo, la colectividad y el prejuicio.

- (2009). ECYC Game Book: es una recopilación de diferentes juegos en grupo para gente joven.

- (2007). «Project Supplies»: manual para la organización de proyectos internacionales.

- (2007). "Getting it Right - Quality Assurance in Youth Work»: colección de las mejores prácticas de sus organizaciones miembro. 
Además hemos encontrado algunos manuales:

- (2014) Escoles de democràcia. La Federació Valenciana de Cases de Joventut hace una aproximación al significado del asociacionismo juvenil en nuestro entorno y explica que son las CdJ y cómo se organizan.

- (2013) Aixequem la persiana. Projecte educatiu de casals de joves de Catalunya. En él nos hacen un recorrido sobre la historia, el significado y la organización de las CdJ entre otras cosas.

Vemos como son escasos los estudios relacionados con las Casas de Juventud aun siendo un modelo de trabajo en la Educación en el tiempo libre extendido por toda Europa y relevante en cuanto a las experiencias pedagógicas que comporta. 


\subsection{Estado de la cuestión.}

En este apartado hacemos una revisión bibliográfica sobre las investigaciones más destacadas en el ámbito de la participación asociativa juvenil. Toda la información ha sido recogida a partir de una serie de bases de datos específicas del marco educativo como son Edu@ment y Eric: Educational Resource Information Center. En el ámbito multidisciplinar hemos navegado a través de Scopus, Annual Review, CSIC, Dialnet, JSTOR, Taylor \& Francis y Web of Science, sin olvidarnos de la plataforma TESEO. Para ello he utilizado la siguiente serie de palabras clave: Educación no formal, jóvenes, participación juvenil, cultura de participación, asociacionismo, casas de juventud, participación social, voluntariado, pedagogía social, adolescencia, activismo, participación ciudadana, ocio y tiempo libre.

Además de abordar en estudios propios del Consejo de la Juventud en España, el INJUVE, la Fundació Ferrer i Guàrdia y la European Comission.

Las investigaciones sobre el voluntariado y el empleo del tiempo libre se están haciendo recurrentes en múltiples países. Estados Unidos es uno de los que viene realizando encuestas con regularidad pero también lo hacen Canadá, Italia y Australia, entre otros. La Comunidad Europea ha dado pie a que se realicen estudios comparativos. De forma concreta en España, en su gran mayoría, los estudios se enmarcan dentro del Tercer Sector y son promovidos por el CIS (Montero, Font y Torcal, 2006, Ariño, 2007). Otros han sido promovidos por las comunidades autónomas en relación a la elaboración de los planes estratégicos del voluntariado. Como hemos analizado todos son encuestas que valoran las tendencias asociativas del momento.

A lo largo de toda la búsqueda bibliográfica, para enfocar el estado de la cuestión, hemos descubierto que los estudios sobre jóvenes y asociacionismo se centran en la participación electoral o virtual (Print, 2007 ; Glickman, 2009; Yang \& DeHart, 2012;Berson, Rodríquez-Campos, Walker-Egea, Owens \& Bellara, 2014; Aragon, 2015; Crossouard \& Dunne, 2015; Neely, 2015) y también en investigaciones sobre entidades públicas o promovidas por la administración ( Russel, Mielke \& Reisner, 2009; O’Donell \& Kirkner, 2016) pero escasas sobre espacios creados por la ciudadanía juvenil. Cuando hemos encontrado investigaciones concretas 
sobre asociacionismo juvenil estas se centraban en la integración de jóvenes en riesgo, en estudios sobre colectivos excluidos y en situación de precariedad (Kirschner, 2008; Serido, Borden \& Wiggs, 2014; De Jesús, Oviedo, Feliz, 2015). También hemos encontrado investigaciones que demuestran como influía su participación en la intención de voto en la edad adulta (Bhatti, Dahlgaard, Hansen \& Hansen, 2015).

Por otro lado, conectando el ámbito formal de la educación observamos como trabajos como los de Moliner, Traver, Ruiz y Segarra (2016), Fielding (2011), Susinos (2012) y Susinos y Ceballos (2012) muestran que es muy potente la vOz del alumnado para dinamizar el cambio y la mejora educativa. Si eso es así en un centro educativo formal también podría trasladarse a la Educación no formal de un centro asociativo.

En cuanto a estudios concretos sobre Casas de Juventud las publicaciones más relevantes pertenecen a compañeros del Movimiento Laico y Progresista (MLP) Catalán como es Jordi Serrano (Serrano, Martín, Sanz y Luque, 2006; Luque y Serrano, 2007), del movimiento Aragonés de la mano de Jose Luis Palacios (Palacios, 2005) y del movimiento Valenciano con los escritos de Enrique Deltoro (Deltoro, 1995, 2006) o bien, publicaciones de la Fundació Ferrer i Guàrdia que mantiene una estrecha relación con el MLP (Sanz y Luque, 2002). Todas estas publicaciones se han abordado en el punto anterior sobre Casas de juventud.

En definitiva, tras el análisis bibliográfico efectuado hemos observado como existen múltiples estudios sobre la juventud, su participación y la democracia pero no hemos encontrado investigaciones que nos muestren si las asociaciones autogestionadas por jóvenes se convierten en agentes de cambio educativo en el territorio.

A continuación hacemos un resumen de algunos de los estudios encontrados, que tienen alguna línea común con la investigación que aquí presentamos, exponiendo sus conclusiones más destacadas.

- Mcfarland, D. \& Thomas, R. J. (2006). Estos autores realizan un estudio sobre la influencia de la participación juvenil en la futura participación política adulta. En el estudio destacan como la participación en actividades extracurriculares es importante, pero de forma particular lo es la participación en asociaciones de jóvenes voluntarios en materia de servicio 
a la comunidad, la representación, el hablar en foros públicos, y generar una identidad común fomenta en mayor medida la participación política futura. Vemos la relación directa entre el trabajo de las asociaciones con la responsabilidad cívica de la ciudadanía.

- INJUVE (2007). El Instituto de la Juventud realiza uno de sus muchos sondeos sobre la opinión y situación de la gente joven en España indagando en el asociacionismo, la participación juvenil, las actitudes, valores y preocupaciones de las jóvenes. El estudio se realiza a través de una encuesta y en ella se observa lo siguiente. Uno de los valores que más destacan es la vinculación asociativa, un $46 \%$ de las jóvenes nunca han estado asociadas, un $28 \%$ declara estar asociada en el momento en que se realizó la encuesta (carácter deportivo (37\%), asociaciones culturales (14\%), recreativas $(10 \%)$, estudiantiles $(13 \%)$, religiosas $(11 \%)$ y excursionistas $(10 \%))$ y un $27 \%$ de jóvenes que perteneció en el pasado pero que no lo hace en la actualidad. Con este estudio podríamos remarcar la necesidad de encontrar modelos de asociacionismo más cercanos a las jóvenes que lleguen a ampliar los porcentajes aquí registrados.

- Durlak, J. A. \& Weissberg, R. P. (2007). The impact of after-school programs that promote personal and social skills. Los autores realizan un estudio sobre el impacto de las actividades extraescolares en el crecimiento personal y en la adquisición de habilidades sociales de las jóvenes. Concluyen diciendo que las jóvenes que participan en actividades extraescolares que tienen una línea de trabajo explícita de desarrollo personal y social mejoran en tres áreas generales: sentimientos y actitudes, comportamiento y rendimiento escolar. Con las actividades que no trabajan estos dos aspectos no se obtiene ninguna mejora en las jóvenes. Con ello podemos ver la importancia de diseñar un proyecto educativo que contenga como eje principal el desarrollo personal y social de las jóvenes.

- Moura Ferreira, P. (2008). Associações e democracia. Faz o associativismo alguma diferença na cultura cívica dos jovens portugueses? Este autor realiza un estudio basado en entrevistas mediante el cual se pregunta si el participar o no del asociacionismo marca la diferencia en la cultura cívica de las jóvenes. En la investigación se ve como existe una diferencia significativa entre las jóvenes asociadas y las que no lo están. La experiencia asociativa articula la participación política pero no olvida remarcar que no es sólo el 
asociacionismo lo que influirá sino que la pertenencia y la escolaridad también son dos factores fundamentales a tener en cuenta. Este estudio nos muestra, como en Portugal, existen diferencias en la construcción de una cultura cívica entre las jóvenes asociadas y no asociadas lo que remarca el interés sobre investigar sobre modelos de asociacionismo que generen espacios para construir una cultura cívica solidaria y crítica.

- Thomas \& McFarland. (2010). Joining young, voting young the effects of yourt voluntary associations on early adult voting. Estos autores llevan a cabo un estudio longitudinal en el que analizan como la participación en asociaciones de voluntariado adolescente influyen a lo largo de la vida. Principalmente observan cambios en el fomento al voto y promueven que las jóvenes se conviertan en ciudadanos de pleno derecho. Seguimos viendo investigaciones en las que se analiza como la participación asociativa influye en la madurez y responsabilidad cívica futura.

- Walker \& Saito (2011). Youth Are Here: Promoting Youth Spaces through Community Mapping. Este estudio retrospectivo nos muestra como la participación en programas juveniles (YAC) produce beneficios en las jóvenes a tres niveles: personal, social y académico. Un aspecto destacado es el aumento en las habilidades de liderazgo. Es interesante ver como la elaboración de programas diseñados de manera concreta para las jóvenes y basados en una mirada educativa aportan beneficios en estos tres niveles y sirve para promover habilidades de liderazgo en las jóvenes.

- Vázquez, C. (2011). La participación ciudadana juvenil como un recurso externo al Gobierno. Esta investigación analiza los programas y mecanismos de participación juvenil que promueve el gobierno de México. Después del análisis de documentos oficiales concluyen con la denuncia sobre la insuficiente participación juvenil y recursos económicos que deposita el gobierno. En este sentido se observa como escasea la dinamización juvenil y se promueve la necesidad de que la participación juvenil se aborde y se respalde desde los gobiernos estatales.

- Muñoz, J.M (2011). Adolescencia y tiempo libre. Análisis y propuestas educativas en Salamanca. El siguiente estudio es un estudio más por encuesta que indaga sobre el tiempo libre adolescente. Concluyen diciendo que muchas de las actividades desarrolladas en el Tiempo Libre no acaban siendo formativas aunque vengan definidas como tal. Tal vez sea un punto 
a abordar, indagar en los elementos que hacen que una actividad sea formativa para las adolescentes. Por otro lado, afirman que cualquier actividad en el tiempo libre ha de ir vinculada al territorio y ha de trabajar el sentido de pertenencia para conseguir que sea efectiva como propuesta educativa.

- Goig, J.M. y Nuñez, M.A. (2011). El fomento de la juventud participativa: tratamiento constitucional, desarrollo legislativo y políticas públicas. Una reflexión más que indaga sobre la participación juvenil en España. Las autoras afirman que para fomentar la participación juvenil es necesario generar una cultura participativa que solo será auténtica y comprometida en la medida en que se estimulen la creatividad, la libertad, la diferencia y la autonomía; formular e implementar programas dirigidos a las jóvenes que estén lejos de ser meramente asistencialistas, pues solo así promoverán su actuación comprometida, creativa y autónoma; diseñar y aplicar programas que partan de la realidad de las jóvenes y no de la cultura adulta hegemónica, para que respondan a sus necesidades, ya que únicamente así les generarán compromiso y un vínculo afectivo estrecho, sentido de pertenencia, y legitimar las culturas juveniles, entenderlas y comprenderlas como parte de un todo social y no como un apéndice problemático. Esta aportación basada en investigaciones anteriores de las autoras aborda una serie de cuestiones clave para generar una cultura participativa comprometida y auténtica.

- Academy for Educational Development. (2012). Young Adult Capacity Initiative Cross-Site Analysis. Los resultados de este análisis de casos cruzados nos muestran como la participación en el programa (YACI) en organizaciones comunitarias ha influido en cómo las jóvenes avanzan hacia sus objetivos de educación y empleo. Se considera la YACI como una estrategia de innovación en la movilización ciudadana. De este modo, encontramos un estudio internacional más que valora positivamente la participación en organizaciones comunitarias para conseguir un camino educativo y laboral más efectivo.

- Atkinson, K. N (2012). Education for Liberation: A Precursor to Youth Activism for Social Justice. La investigación llevada a cabo por Atkinson indica como los programas de educación y activismo juvenil liberadores tienen un enorme potencial como ejes de desarrollo de las jóvenes como ciudadanos 
comprometidos. Señalan formas innovadoras para fomentar la agencia de la juventud y la necesidad de reconstruir las condiciones, políticas y prácticas de las organizaciones de servicios. Un estudio, esta vez centrado en los EEUU, que nos indica la importancia de trabajar estos programas como constructores de ciudadanía crítica y comprometida.

- Ruiz-Olivares, R; Pino, M.J y Herruzo, J. (2013). Assessment of prosocial-altruistic behavior of members and non-members of the scout movement. Este diseño prospectivo de caso con encuestas muestra las diferencias entre jóvenes miembros de asociaciones scout y jóvenes que no pertenecen a ellas. La conclusión que ofrecen es que la participación en estas asociaciones influye en una mejor evaluación del comportamiento altruista prosocial. Podríamos deducir que la participación en centros en los que se promueve la solidaridad comporta cambios en el comportamiento altruista de las jóvenes.

- Izquieta J.L y Callejo, J.J. (2013). Asociacionismo y participación voluntaria de las jóvenes españoles. Cambios y tendencias actuales. La investigación por encuesta que llevan a cabo estos autores concluye con las siguientes afirmaciones. Las jóvenes se distancian de las asociaciones políticas y religiosas y sus preferencias van encaminadas a asociaciones de corte expresivo, lúdico y festivo. Además, las jóvenes españolas deciden hacerse voluntarias no por una determinación moral impersonal producto del sentido del deber, sino por una elección emotiva o utilitarista, porque les enriquece personalmente, porque les beneficia en un sentido práctico. Sólo un reducido grupo de jóvenes admiten que su opción surge por un sentimiento de indignación y por el deseo de transformar la realidad social. Finalmente se observa como su compromiso no es militante sino de colaboración en actividades a corto plazo. Tras estas conclusiones veo la necesidad de expresar la importancia del aprendizaje en la participación, cómo se enfoca este y cómo se plantean los espacios para conseguir lugares educativos que nos enseñen a comprometernos socialmente. Sin olvidarme de la importancia de obtener un beneficio personal del proceso que acabe convirtiéndose en colectivo.

- INJUVE (2014). Sondeo Jóvenes, Satisfacción Personal, Participación Asociativa y Voluntariado. Otro de los sondeos que realiza el INJUVE muestra la evolución asociativa juvenil. Esta vez vemos como el 36\% 
declara que nunca han estado asociadas, el 38\% de las encuestadas se encontraban asociadas en el momento en el que se realizó la encuesta (carácter deportivo (47\%), asociaciones culturales $(17 \%)$, recreativas $(13 \%)$, estudiantiles (14\%), religiosas $(14 \%)$ y benéficas $(11 \%))$, mientras que el $27 \%$ de jóvenes pertenecieron a alguna asociación en el pasado, pero no lo hacen en la actualidad. Las jóvenes que han participado como miembros activos en las actividades conforman el $69 \%$. Aquellas que participan esporádicamente se sitúan en el $22 \%$ y tan solo el $4 \%$ ha participado económicamente. Observamos cómo en 7 años desde la anterior encuesta el número de asociadas aumenta alrededor del 10\%, además la participación es mucho más activa que años anteriores. Ambos datos resultan relevantes como indicadores de que el movimiento asociativo está cambiando hacia mayores tasas de participación.

- González, A. (2014). Nuevas formas de ciudadanía: las entidades del tercer sector social. Esta investigación aborda un estudio de caso en el que muestran como las entidades del Tercer Sector Social constituyen una lealtad hacia la democracia pero un recelo ante la incapacidad del Estado para resolver sus dificultades. Transmiten actitudes y valores como la solidaridad, filantropía y tolerancia, comparten y afirman identidades colectivas y constituyen comunidades de aprendizaje. En conclusión, afirman cómo las entidades instaladas en el Tercer Sector social son relevantes en la transmisión de ciertos valores que promueven una ciudadanía crítica.

- Hart, P. (2015). Young people negotiating and maintaining boundaries in youth work relationships: findings from an ethnographic study of youth clubs. En este caso he encontrado un estudio etnográfico sobre jóvenes y casas de juventud (Youth clubs) en Inglaterra. En él realizan un análisis sobre las relaciones entre las animadoras juveniles y las jóvenes que participan en las Casas llegando a la conclusión de que las trabajadoras han de utilizar las habilidades y la voluntad de las jóvenes para provocar la construcción de un espacio de trabajo colectivo a través de esfuerzos comunes. Aquí vemos la importancia de que la animadora del centro asuma un rol u otro y cómo puede afectar la asunción de este rol en el proceso de aprendizaje de las jóvenes. 


\section{- European Comission. (2015). Focus on: Empowering young people to participate in} society. En la búsqueda bibliográfica hemos encontrado varias publicaciones en las que simplemente se muestran experiencias prácticas valoradas como empoderadoras, inclusivas, formativas y de movilidad sin un análisis investigador. Se observa cómo se están llevando a cabo múltiples prácticas con el foco en la juventud pero que no cuentan con un foco de interés en la construcción de conocimiento. Considero relevante que estas prácticas puedan analizarse desde la propia realidad y junto con las participantes para favorecer la construcción compartida de conocimiento desde la práctica.

- Cassels, A.; Post, L. \& Nestor, P. I. (2015).The 4-H club meeting: An essential youth development strategy. Estudio de caso realizado en el estado de Virginia (EEUU). En él vemos como el voluntariado en los Youth Clubs promueve ambientes en los cuales se trabajan principios de pertenencia, independencia, generosidad, dominio y liderazgo a partir de las reuniones del Club. Resaltan la importancia del rol de las líderes del centro para el trabajo de dichos principios y como la participación en los centros se asume como una oportunidad para el aprendizaje de diferentes habilidades. Se vuelve a remarcar la importancia del trabajo educativo en los Youth clubs y cómo este influye en el desarrollo de habilidades que favorecen el crecimiento persona y académico de las jóvenes.

- Kiilakoski, T \& Kivijärvi. (2015). A Youth clubs as spaces of non-formal learning: professional idealism meets the spatiality experienced by young people in Finland. En Finlandia se lleva a cabo esta Investigación acción en la que se consiguen resultados educativos cuando las jóvenes tienen posibilidad de tomar decisiones y gestionar su espacio. Además se observa que los Youth Clubs pueden ser espacios estancos que pueden influir en la inclusión de las jóvenes, aspecto que deben tener en cuenta las trabajadoras sociales del centro. En este estudio se remarca la importancia del rol educador de las trabajadoras sociales de los centros juveniles y cómo la participación en ellos influye en los resultados educativos de las jóvenes.

- Soler, P. (2015). Proyecto HEBE. El empoderamiento de las jóvenes: análisis de los momentos, espacios y procesos que contribuyen al empoderamiento juvenil. Pere Soler y su equipo llevan a cabo una evaluación participativa y grupos focales con jóvenes en Cataluña en la que concluyen exponiendo la necesidad de incorporar nuevas formas $y$ 
estructuras de participación juvenil que emerjan de las jóvenes mismas y que se configuren a partir de sus principios y necesidades, que tengan una organización interna, definida y sostenida por las mismas jóvenes y que puedan convivir con las creadas para ejercer la democracia representativa política. Exponen como las estructuras participativas como los consejos presentan una implantación débil y con dificultades y remarcan la idea de continuar creando espacios juveniles estructurados a partir de una participación democrática.

- Terriquez, V. (2015). Training Young Activists Grassroots Organizing and Youths' Civic and Political Trajectories. Este estudio de encuesta y entrevistas semiestructuradas llevado a cabo en Los Ángeles (EEUU) afirma como los grupos activistas adolescentes fomentan altos niveles de participación cívica y política en la adultez temprana. Estos grupos son útiles para entrenar la participación futura, la conciencia política y la participación en procesos políticos impulsando a las jóvenes hacia el compromiso permanente con los movimientos sociales. Volvemos a retomar la idea sobre la importancia de trabajar en espacios no formales para promover procesos educativos con el objetivo de dinamizar la construcción de una ciudadanía crítica.

- Kuhar, K. \& Sabljić, J. (2016). The Work and Role of Extracurricular Clubs in Fostering Student Creativity. Esta vez se aborda un análisis documental en el que se concluye exponiendo que la participación en «clubs» de actividades extraescolares influye en el desarrollo de la creatividad del estudiantado. Podemos ver esta vez en Croacia como las jóvenes que participan en clubs extracurriculares, como así nombran a lo que podría ser una Casa de Juventud, influye en el desarrollo de la creatividad de las estudiantes. Así vemos como los espacios de educación no formal complementan las deficiencias de la educación formal como es el abandono de la creatividad o la expresividad del alumnado.

- Mahmud, A. \&Manda, D. (2016). The Implementation of Character Education through Scout Activities. El siguiente estudio aborda las actividades scouts analizando como los elementos que se pueden trabajar en estas actividades son la minuciosidad, la paciencia, la cooperación, la responsabilidad, la asistencia social, coraje, confianza, perseverancia, creatividad, religión, patriotismo, conciencia ambiental, independencia, disciplina, curiosidad y trabajo duro. Vemos de nuevo un estudio más sobre la variante asociativa 
scout y de ella podemos recoger la importancia de trabajar habilidades esenciales que favorezcan el empoderamiento individual y la construcción colectiva como podría ser la confianza, la ayuda mutua, la conciencia ambiental, la curiosidad y creatividad entre otras cosas.

- Doistua, J., Pose, H. y Ahedo, R. (2016). Espacios, experiencia de ocio y participación de la juventud: contribución a los modelos de gestión e intervención a partir del análisis de buenas prácticas. Es en La Coruña donde se lleva a cabo este estudio en el cual se concluye que a una mayor implicación de la joven en el diseño y gestión de la oferta comunitaria de ocio, mejor es la experiencia de dicha actividad y el grado de compromiso y participación en el programa o servicio. Es aquí donde vemos la importancia de generar espacios de autonomía para las jóvenes ya que esto influye de manera exponencial en el compromiso que después adquirirán.

- Funes Rivas, M.J y Robles, J.M. (2016). Civic Participation as Means of Empowerment. Preventing Social Exclusion of Youth in Precarious Life Conditions in Spain. Esta investigación cualitativa se centra en colectivos excluidos y analizan como las asociaciones enseñan prácticas cívicas y valores que ayudan a las jóvenes a manejar su precariedad dotándoles de recursos para encontrar nuevas oportunidades. De este modo, vemos como el asociacionismo favorece el desarrollo del empoderamiento personal de las jóvenes.

Una vez abordadas todas estas investigaciones observamos cómo se han llevado a cabo diversos estudios a lo largo de todo el mundo en los cuales se focaliza en la importancia de generar espacios de aprendizaje, participación y democracia. Se indaga en cómo estos favorecen el desarrollo de diferentes habilidades que posibilitan el empoderamiento personal a la vez que se remarca, en alguna de ellas, el interés por el trabajo cooperativo/colectivo. Es ampliamente reconocido que el trabajo asociativo favorece de manera positiva los procesos de aprendizaje y se convierte en un espacio educativo importante en la trayectoria vital de las jóvenes. Ahí reside parte del interés de esta tesis, en profundizar en prácticas asociativas que puedan convertirse en agentes educativos de cambio en el territorio y que dicho análisis posibilite la construcción de modelos de trabajo que puedan favorecer todas estas características, ya 
abordadas en otros estudios, y que promueven una ciudadanía crítica capacitada para gestionar su propia realidad.

La participación juvenil y de forma concreta el asociacionismo juvenil se establece como una herramienta acorde al trabajo democrático y de ciudadanía crítica. Son múltiples las autoras, instituciones y prácticas que relevan el valor de participar en asociaciones para desarrollar habilidades que favorezcan el empoderamiento personal y colectivo. De este modo se sitúa como instrumento que favorece el trabajo en educación no formal dentro de espacios de tiempo libre y de ocio de la ciudadanía posibilitando el desarrollo de la Pedagogía Social. Así pues, la ciudadanía dispone de vías para la construcción y gestión cultural desde su propia voz, implicación y compromiso cívico. 
«Per a veure clar hi ha suficient amb canviar la direcció de la mirada» (cita campanya \#josócmaranya)
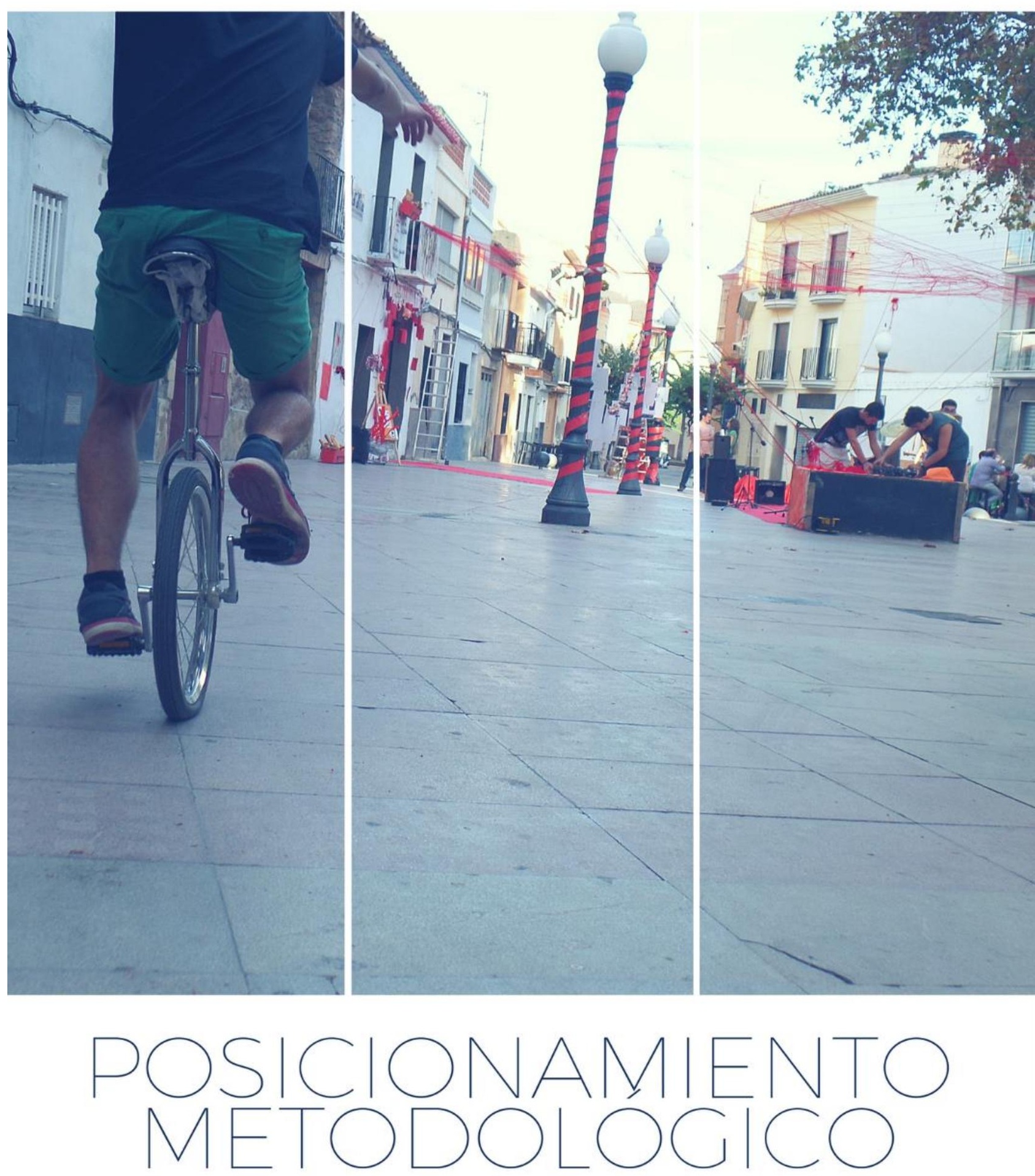

En este capítulo abordamos el paradigma metodológico del que partimos, los aspectos más relevantes que hacen que nos situemos en una corriente determinada y la metodología en la que nos hemos inspirado para realizar esta tesis. Para ello, conoceremos cuales son los significados y nuestra ética de investigación, abordaremos qué es la etnografía y en qué enfoque nos situamos dentro de la misma, conoceremos qué caracteriza a la etnografía seleccionada y cuál es el proceso etnográfico básico que debemos tener presente para funcionar. Por último, abordaremos la necesidad de utilizar diferentes estrategias, técnicas y herramientas para conseguir una investigación validada en términos cualitativos. 


\subsection{Significados metodológicos $\mathrm{y}$ ética de investigación.}

Desde nuestra perspectiva el conocimiento no se transmite, se construye (Francisco, 2013). La investigación no puede desvincularse de la práctica en nuestras realidades sociales. Al igual que no podemos focalizar la atención en los sujetos como objeto de investigación sino en ellas como personas que participan de la investigación y en su entorno.

No hay interés teórico que esté desvinculado de intereses prácticos. El desinterés es el ocultamiento de intereses que no quieren confesarse. No hay relación con el objeto, que no sea al mismo tiempo, consciente o inconscientemente, relación con un proyecto. No se trata aquí de intereses inmediatos, sino del proceso global por el que el hombre realiza su proyecto fundamental. El conocimiento no puede ser juez sin ser parte. Se sitúa necesariamente en relación con las fuerzas políticas y económicas; siempre es relativo a un proyecto de sociedad, activamente propugnado o pasivamente aceptado (Girardi, 1977:101).

Por ello, quisiera crear conocimiento basándome en el conocimiento local. La selección del paradigma, en el que me sitúo en esta investigación, ha de estar relacionado con ello $y$, por tanto, con la respuesta que dé a las preguntas ¿cómo se entiende el mundo?, ¿cómo debe investigarse? y ¿para qué sirve investigar? Guiada por estas preguntas, las premisas que forman el marco ontológico, epistemológico y metodológico, es lo que conformará el paradigma que orienta esta investigación (Denzin \& Lincoln, 2011). Que es, tal y como Guba (1990a:17) lo define «a basic set of beliefs that guides action» ${ }^{16}$. De forma concreta, será la posición ideológica que asuma en estas respuestas la que cuestionará la elección de un paradigma u otro (Denzin\& Lincoln, 2011; Cortés, 2010; Rojas, 1989).

La primera de las preguntas ya la he trabajado en el apartado del marco teórico. En cuanto al cómo y para qué sirve investigar lo abordo a continuación, centrándome en primer lugar en el para qué. Cortés (2013) justifica la respuesta al para qué concentrándose en el compromiso social y

${ }^{16}$ Conjunto básico de creencias que guían la acción. 
la compresión de la realidad. En mi lugar, complemento mi respuesta con sus afirmaciones, fundamentando las siguientes cuatro variables:

1. Comprometernos socialmente. La investigación es un acto de acción y activismo social de trabajar para la realidad. El compromiso para y con la sociedad busca conseguir una realidad movilizada por la justicia social. Por ello, debo asentarme en un paradigma que dé fuerza a la diversidad de voces, a la ciudadanía y posibilite mi posicionamiento como investigadora como una voluntaria más en el contexto.

2. Comprender la realidad. La realidad se construye, entre otras cosas, en función de las experiencias, de los acontecimientos, de las personas y de los tiempos. No es la misma realidad la que podemos analizar hoy que la perteneciente a otros espacios y tiempos, ya que tendrá detrás una historia concreta que la hace particular. La construcción de la realidad humana está contingentemente mediada por el contexto cultural, histórico y político en el que tiene lugar y este es el motivo que despierta mi interés. Desde el lugar desde el que me posiciono, la investigación trata de comprender esta realidad desde la proximidad y la particularidad que la hace especial.

3. Reconocer la dimensión pública de la ciencia. Contribuir a la transformación social que el saber científico debe propiciar, apoyando que la ciudadanía se apropie del conocimiento que hasta ahora se atribuía a la academia, reconociendo las prácticas sociales que se muestran al servicio del desarrollo y la transformación social. La academia está en crisis (Denzin\& Lincoln, 2011) y por ello los tradicionales vínculos entre ciencia y sociedad deben ser analizados críticamente. Levin \& Greenwood (1998) apuntan que la investigación acción puede ayudarnos en este sentido, ya que realiza un trabajo socialmente significativo y responsable. Según estos autores, la transformación se dará con el tipo de investigaciones que se comprometan con la praxis y el cambio social.

4. Reconstruir politicas educativas desde la realidad. La investigación ha de poder facilitar la construcción de políticas educativas y juveniles que no se alejen del proceso de cambio realizado por la comunidad. Tal y como expone Fullan (2002:4) «El proceso de cambio se ha caracterizado por seguir un patrón según el cual las innovaciones, se desarrollan fuera de los centros para ser transmitidas a ellos posteriormente, en función de bases universales». Frente a ello, la ciencia necesita de un paradigma que facilite la 
comprensión de la realidad desde la propia comunidad para que las políticas se construyan de forma justa para las personas. Las investigaciones cualitativas pueden influir en las políticas sociales de manera importante ya que son el medio para visibilizar la voz de la ciudadanía (Denzin\& Lincoln, 2011).

Vemos como uno de los mayores conflictos al que como investigadora tengo que enfrentarme es la elección de un paradigma que oriente la preferencia metodológica. Debo confrontar la ética y la política de la investigación y la búsqueda de un método que se adecue a estas prioridades. Es una de las primeras decisiones a asumir que se ve influenciada por el contexto, la experiencia, los valores, los compromisos y las motivaciones políticas. Como investigadora me sitúo como una persona intercultural con una historia personal y unas tradiciones de investigación, una conceptualización concreta de mi misma y de la otra y una ética y política de investigación definida (Bateson, 1972; Lincoln, Lynham, \& Guba, 2011).

Con este posicionamiento comparto que todas las verdades son parciales e incompletas:

We occupy a historical moment marked by multivocality, contested meanings, paradigmatic controversies, and new textual forms. This is an age of emancipation, freedom form the confines of a single regime of truth, emancipation form seeing the world in one color ${ }^{17}$. (Denzin \& Lincoln, 2011, p.95).

Diariamente, las personas expresamos respuestas hacia el contexto que varían en función del marco paradigmático en el que nos situemos. Este marco, da forma a las razones que nos harán tomar una decisión u otra (Alanís, 2000; Cruz, 1996). Desde mi perspectiva, la investigación que impulsa estas decisiones es la metodología cualitativa. Con ella tengo la posibilidad de describir, estudiar y analizar múltiples contextos desde la propia experiencia como investigadora, con la finalidad de generar información que nos ayude a comprender mejor las realidades estudiadas. Según Denzin \& Lincoln (2011), «qualitative research is a situated activity that

17 Ocupamos un momento histórico definido por la multivocalidad, los significados encontrados, la controversia paradigmática y las nuevas formas textuales. Es la época de la emancipación, de liberarnos del único régimen de la verdad, es la emancipación de ver el mundo de un solo color. 
localities the observer in the world. Consists of a set of interpretative material practices that make the world visiblè) ${ }^{8}$.

De esta forma, abandono paradigmas positivistas. Las ciencias sociales deben estar comprometidas con el mundo, deben responsabilizarse y situarse a favor de la justicia social, de la no violencia, de los derechos humanos, de la equidad y la paz, haciendo visible una investigación coherente con todo ello.

Linda Tuhiwai Smith (1999) nos habla de la vinculación entre la palabra investigación y el colonialismo europeo. En el vocabulario indígena es una de las palabras más desagradables que existe ya que se relaciona con la apropiación del conocimiento indígena por opresoras. Este era recogido, clasificado y representado en occidente sin ofrecer ningún tipo de titularidad u oportunidad en la construcción conjunta. De este mismo modo, hoy, puede sentirse parte de la ciudadanía, como simples objetos de estudio sin ningún beneficio más que el de deber sentirse orgullosas porque la academia quiere saber más sobre ellas. Definitivamente, esta situación debe reformularse a través de mecanismos más críticos, participativos, emancipadores y comprometidos. Por ello, a causa del posicionamiento en el que me sitúo, utilizaré esta investigación como dispositivo de acción de la propia asociación para dar visibilidad y fundamento al trabajo con jóvenes.

En la investigación cualitativa, la comprensión de la realidad se trabaja de manera holística. Pero además, en esta propuesta, ello se hace siempre bajo la consideración de las personas que integran el contexto y que pueden involucrarse en la investigación como participantes activas. Además mi papel como persona investigadora, se sitúa en una relación de horizontalidad con las participantes (Bisquerra, 2004; Massot, 2003; Sandín, 2003; Ruiz, 1999; Eisner, 1998; Del Rincón, 1997). Esto condiciona las funciones que llevo a cabo (interpretación, comprensión y transformación) en una praxis elaborada dialógicamente con el resto de protagonistas (Sandín, 2003).

\footnotetext{
${ }^{18}$ La investigación cualitativa es una actividad situada que localiza al observador en el mundo. Consiste en un conjunto de prácticas materiales e interpretativas que hacen el mundo visible.
} 
De esta forma, la investigación cualitativa refleja, describe e interpreta el contexto educativo con el fin de llegar a la comprensión o a la transformación de dicha realidad, a partir del significado atribuido por las personas que la integran y dándose en la persona investigadora una convivencia, aproximación y relación con las participantes (Bisquerra, 2004).

Diferentes autoras como Rodríguez, Gil y García (1996) defienden que la investigación cualitativa posee la característica de la amplitud a la hora de describir, interpretar o desarrollar la información. Hay que tener en cuenta multitud de factores que condicionan o determinan la realidad en la que nos involucramos. Esta amplitud se acota en el momento en el que como investigadora selecciono una corriente que me facilite esa descripción e interpretación de la realidad. Teniendo en cuenta que la investigación debe estar comprometida con la explicación de la realidad además de con la transformación de dicha realidad, todo ello desde una dinámica liberadora y emancipadora de las protagonistas (Escudero, 1987) abordo este trabajo desde un paradigma crítico desde el que me aproximo desde hace un tiempo a partir de otras investigaciones llevadas a cabo ${ }^{19}$ en las que se persigue la acción social. Me sitúo en una corriente crítica definida a partir de estas cuatro características fundamentales: democrática, transformadora, emancipadora y participativa ya que esta investigación se convierte en un estudio sobre la práctica social desde una organización considerada como democrática y participativa que genera cambios y transformaciones en la realidad social y en sus protagonistas. De forma concreta, esta investigación conlleva, en sí misma, la mejora educativa en el interés de analizar las Casas de Juventud como motor de cambio social.

\footnotetext{
${ }^{19}$ Algunos de los trabajos que abordamos desde un paradigma crítico son los siguientes:

Diagnóstico Social Participativo: Estudio de caso en el que se investiga a través de un DSP la participación juvenil de una comarca rural de Castellón.

Afrodita ha llenado mi corazón: A partir de una metodología biográfico-narrativa se trabaja las historias de vida de mujeres migrantes, lesbianas y bisexuales.

Reapropiant-nos de les nostres vides: Trabajamos mediante relatos de vida y teatro testimonio para abordar la LGTBfobia en los centros de secundaria.

Missions interculturals: Un proyecto de participación comunitaria que trabaja en los ámbitos de la educación, la cultura y el desarrollo local.

Escuela intercultural inclusive: Escuela incluída e investigación acción participativa que aborda la transformación de los centros de primaria.
} 
Bajo esta base formulo la tesis con la finalidad de superar planteamientos reduccionistas del positivismo y poder construir conocimiento más profundo e intersubjetivo de las realidades que se estudian (Rojas, 1989). Barham y Fals Borda (1992) transmiten que la investigación «ha de servir de base para la acción popular, para el cambio social y para un progreso genuino en el secular empeño de hacer efectivas la igualdad y la democracia». Justamente porque me muevo en una investigación que se construye desde el paradigma crítico no puedo dejar de sumergirme en la realidad junto con las protagonistas desde valores de justicia social.

En relación con este interés vemos cómo se va resituando la investigación cualitativa en la historia. Actualmente nos encontramos en el octavo estadio de la historia de la investigación cualitativa según Denzin \& Lincoln (2011) (tabla 12).

Tabla 12. Estadios de la historia de la investigación cualitativa según Denzin (2011).

\begin{tabular}{|l|c|}
\hline \multicolumn{1}{|c|}{ Estadio } & Época \\
\hline Tradicional & $1900-1950$ \\
\hline Modernista o edad de oro & $1950-1970$ \\
\hline Desdibujamiento de los géneros & $1970-1986$ \\
\hline Crisis de representación & $1986-1990$ \\
\hline Postmodernidad & $1990-1995$ \\
\hline Investigación experimental & $1995-2000$ \\
\hline Metodología comprometida & $2000-2004$ \\
\hline Futuro & $2005-$ \\
\hline
\end{tabular}

En él nos enfrentamos a la reacción metodológica asociada a los evidentes movimientos sociales. En este período, las ciencias humanas y sociales se convierten en espacios para las conversaciones críticas sobre la democracia, el género, las clases sociales, la globalización, la libertad y la comunidad. Es por ello por lo que necesitamos nuevos espacios compartidos que nos permitan resituarnos en la investigación desde una mirada crítica de la realidad. Así pues, abordamos esta investigación a partir del paradigma crítico el cual nos permite transitar entre estos espacios y continuar escribiendo la historia futura de la investigación cualitativa. 


\section{2. ¿Qué es la Etnografía?}

La etnografía es el método de investigación que orienta este estudio. Con una larga historia (Wax, 1971), el término etnografía proviene del griego «ethnos» ( $\varepsilon \theta \vee \circ \varsigma)$ que significa «tribu, pueblo» y de «grapho» ( $\gamma \varrho \alpha \varphi \omega)$ traducido como «yo escribo». Literalmente es la «descripción de los pueblos» y se utiliza para referirse al método mediante el cual se lleva a cabo la descripción del modo de vida, de la cultura de un grupo de individuos y/o comunidad (Woods, 1987; Aguirre Baztán, 1995). Este método surge a finales del siglo XIX y comienzos del siglo XX en la antropología cultural, y evolucionó a través de la antropología (Colonialismo Británico) y la sociología educativa (Escuela de Chicago) como una forma de aproximarnos a la investigación social en la cual la investigadora participa en la vida diaria de las personas (Hammersley y Atkinson, 1983).

En el ámbito educativo es considerada como un método de investigación, en la sociología se habla de ella como técnica y la antropología la concibe como aquel modo de proceder en la investigación de campo y también como el producto final de la investigación (Rockwell, 2009). Por las diferencias entre antropólogos (Goodenough, 1979; Spradley y McCurdy, 1972; Gumperz y Hymes, 1972; Bauman y Scherzer, 1977) sociólogos (MacCall y Simmnes, 1969; Bogdan y Taylor, 1975) y educadores (Agar, 1980; Spindler y Spindler, 1987; Hammersley y Atkinson, 1983; Goetz y Lecompte, 1988; Wolcott, 2000) para definir su particular significado de Etnografía, existen múltiples corrientes metodológicas y epistemológicas que la abordan. Por ello, se adopta la idea de que se la denomine enfoque o perspectiva etnográfica.

En la definición de Etnografía se dan múltiples aproximaciones que hacen que se le conceda este nombre a una modalidad de investigación. Por ejemplo, el análisis que realizan Hammersley y Atkinson (1994) sobre los elementos relevantes de la etnografía que caracterizan a esta forma de investigación social recoge las siguientes cuestiones. Destacan su énfasis en la descripción de la naturaleza de los fenómenos sociales frente a la elaboración de hipótesis, su tendencia a trabajar con datos no codificados en un sistema cerrado de categorías, su potencial para centrarse en un 
número reducido de casos que en muchas ocasiones será uno único y en detalle, y su modo de analizar datos alejado de la cuantificación.

Por otro lado, Elsie Rockwell (2009) nos matiza cuales son aquellas características imprescindibles por las que una etnografía se debe diferenciar del resto de investigaciones. En primer lugar, se debe documentar lo no documentado de la realidad social, lo familiar, cotidiano, oculto o inconsciente relacionado con el poder hegemónico y los movimientos alternativos a este. En relación al producto, remarca que ante todo es una descripción, aspecto que ha sido cuestionado por diferentes corrientes a lo largo de la historia. En tercer lugar, la etnógrafa se convierte en sujeto social con una experiencia prolongada en la comunidad de estudio. En cuarto lugar, expresa la atención que se le conceden a los significados locales como punto relevante en el trabajo etnográfico. Finalmente, Rockwell (2009) expone que toda etnografía ha de construir conocimiento a partir de las relaciones entre la teoría y la práctica como aspecto relevante del proceso.

En cuanto a la investigación etnográfica en el ámbito educativo, encontramos múltiples estudios que describen de forma detallada los ámbitos de vida social de la escuela (Woods, 1987) pero también los espacios de educación no formal (Requejo y Aznar, 1993). Sandin (2003) ofrece un estilo de investigación alternativo que facilita la comprensión e interpretación de los fenómenos educativos que tienen lugar en el contexto a partir de las diferentes perspectivas de las personas que lo componen. Serra (2004) expone que es la relación de confianza y el contacto cercano que puede existir entre la investigadora y las personas, que pertenecen al colectivo a estudiar, las que abrirán la única vía para el acceso a la información, muy difícil de contrastar y obtener por otras vías.

Desde la etnografía educativa en contextos no formales, observamos como el carácter de mejora y transformación de este estudio casa con la descripción que plantea Torres (1988:17): «Las etnografías no deben quedarse exclusivamente en su dimensión descriptiva, sino que, como modalidad de investigación educativa que son, deben coadyuvar también a sugerir alternativas, teóricas y prácticas, que conlleven una intervención pedagógica mejor». 
Así pues la etnografía se ajusta a nuestro ideal de ciencia. Por una parte, nos ofrece la oportunidad de comprometernos socialmente ya que con ella se trabaja a partir de la diversidad de voces y la investigadora asume un rol socialmente activo en el proceso; además nos permite comprender la realidad desde la proximidad del contexto, desde sus experiencias, vivencias y cambios; y nos posibilita reconocer la dimensión pública de la ciencia ya que la comunidad de la que parte la investigación es parte de la misma, no es la academia la que estudia y devuelve la información es la comunidad la que investiga los procesos y facilita la reconstrucción de políticas educativas desde el contexto, acercándonos al proceso de cambio desde dentro. En este sentido, y siguiendo a García (2014), debemos reflexionar no únicamente sobre las posibilidades que la ciencia social ofrece a la construcción del conocimiento teórico sino también sobre aquellos cuestionamientos que contribuyan a la acción de transformación del mundo.

En relación a esta contribución, son los enfoques críticos los que han ayudado a reconstruir la relación que existe entre la etnógrafa y las personas que componen el contexto de estudio. Concretamente la antropología feminista y la postmoderna ponen el foco en aspectos relacionados con la multiplicidad de voces, las relaciones de poder y la representación (Lassiter, 2005). Estas perspectivas exponen lo que Hammersley y Atkinson (2001) denominan como la política de la etnografía definida por las influencias que el marxismo, la teoría crítica y el feminismo han producido en la investigación social y que visibilizan la necesidad de la construcción de conocimiento junto con la acción hacia la transformación del mundo.

\subsection{En los márgenes de la etnografía: enfoques colaborativos, críticos, activistas y militantes.}

Tal y como he ido analizando a lo largo de este capítulo, la investigación debe ir más allá, debemos movernos en los márgenes de la etnografía y fortalecer nuevas formas de hacer etnografías. Quiero remarcar la necesidad de indagar en nuevos procesos etnográficos, saliendo de lo clásico para analizar modos más próximos al contexto actual. Por eso me sitúo dentro del paradigma crítico ya que me posibilita esta postura. 
La etnografía [...] puede prestar un servicio notable a los investigadores interesados en la acción y la transformación social. En realidad, el interés aplicado ha acompañado a la etnografía desde sus orígenes, a pesar de la aureola de erudición de que goza la antropología debido - entre otras cosas - a la difusión de la imagen del proverbial explorador en busca de lo exótico. Paradójicamente, el conocimiento antropológico basado en la etnografía constituyó una fuente notable de información en los procesos de colonización del Tercer Mundo, para convertirse luego, y en parte también simultáneamente, en la base de proyectos de «desarrollo», acción y transformación.

(Honorio Velasco y Ángel Díaz de Rada, 2009: 241-242).

Responsabilidad moral y ética con nuestros principios es la diferencia entre el antes y el ahora, un compromiso profesional con la investigación y con quienes participan en ella (Lassiter, 2005). No cabe duda que en estos márgenes se sitúan etnografías como la colaborativa, crítica, activista y militante, entre otras, las cuales ofrecen nuevas oportunidades a la investigación.

Dentro de la etnografía colaborativa son dos las autoras más representativas. Por un lado, Lassiter (2005) que expone que la característica que define a este tipo de etnografía es que las informantes pasan a ser consultoras y actuarían de forma paralela junto con la investigadora en leer, editar, coproducir, co-escribir. Por otro lado nos encontramos con Rappaport (2007), que va más allá hablando de co-teorización, proponiendo la creación de equipos mixtos (investigadora/agentes sociales) a lo largo de toda la investigación.

Es cierto que podemos considerar dicha etnografía como una de las que actualmente valora cambios realistas orientados hacia la acción. Aun así existen otras que se inclinan hacia «el compromiso explícito de trabajar en colaboración con los sujetos de estudio hacia objetivos políticos compartidos» (Speed, 2006: 80). Este tipo de etnografía se denomina etnografía crítica y fue promovida en los años setenta de mano de etnógrafos que a partir de teorías marxistas y neo-marxistas dieron lugar a movimientos críticos y sociales en defensa de las identidades oprimidas. Son diversas autoras (Thomas, 1993; Kincholoe, McLaren y Steinberg, 
2011; Soyini, 2012) las que consideran interesante el definir este tipo de etnografía como aquella que se convierte en el «hacer» de la teoría crítica, pensando en la Etnografía como la Teoría Crítica en acción.

El trabajo de Jim Thomas (1993) se basa en esta variante etnográfica delimitándola como:

a type of reflection that examines culture, knowledge, and action. It expands our horizons for choice and widens our experiential capacity to see, hear and feel. It deepens and sharpens ethical commitments by forcing us to develop and act upon value commitments in the context of political agendas ${ }^{20}$ (1993: 2).

Dentro de la etnografía crítica podemos encontrar diferentes propuestas que presentan gran influencia del trabajo de Freire (1970, 1974, 1978, 1985). García (2014) realiza un repaso bibliográfico por las diferentes denominaciones que se le han dado hasta el momento a este modo de entender la investigación social, y defiende un continuum reflexiónparticipación en el estudio de los movimientos sociales. Este autor diferencia las etnografías activistas (tabla 13) de la colaborativa (Lassiter, 2005; Rappaport, 2007) en el hecho de que las primeras ponen el foco en el compromiso de trabajar en colaboración con las sujetos de estudio, en nuestro caso, participantes. En esta línea traza un continuo entre antropologías teorizantes «sobre» los movimientos, antropologías militantes «desde» los movimientos sociales y antropologías aplicadas «para»los movimientos sociales.

Tabla 13. Denominaciones a un modo de entender la investigación social. Fuente: García (2013).

\begin{tabular}{|l|l|}
\hline \multicolumn{1}{|c|}{ Nombre } & \multicolumn{1}{|c|}{ Precursores } \\
\hline Engaged Anthropology/ antropología implicada & $\begin{array}{l}\text { Maria Isabel Casas Cortés (2008), Michael } \\
\text { Osterweil, Dana E. Powell, Jeffrey S. Juris, Alex } \\
\text { Khasnabish (2013) o David Graeber (2011) }\end{array}$ \\
\hline $\begin{array}{l}\text { Activist Ethnography / } \\
\text { etnografía activista }\end{array}$ & $\begin{array}{l}\text { Paul Routledge; Cristina Flesher Fominaya y } \\
\text { Laurence Cox (2013) }\end{array}$ \\
\hline
\end{tabular}

\footnotetext{
${ }^{20}$ Un tipo de reflexión que examina la cultura, el conocimiento y la acción. Expande nuestros horizontes para elegir y ampliar nuestra capacidad experiencial para ver, oír y sentir. Profundiza y agudiza compromisos éticos por los que nos obliga a desarrollar y actuar sobre los compromisos de valor en el contexto de las agendas políticas.
} 


\begin{tabular}{|l|l|}
\hline \multicolumn{1}{|c|}{ Nombre } & \multicolumn{1}{|c|}{ Precursores } \\
\hline $\begin{array}{l}\text { Investigación activista y comprometida } \\
\text { críticamente }\end{array}$ & Shannon Speed (2006) \\
\hline Investigación militante & $\begin{array}{l}\text { Marta Malo de Molina, Precarias a la Deriva o la } \\
\text { Fundación de los Comunes. }\end{array}$ \\
\hline $\begin{array}{l}\text { Etnografía militante y de educación popular } \\
\text { vinculada a los movimientos sociales }\end{array}$ & $\begin{array}{l}\text { Investigación- acción-participativa (IAP) y la } \\
\text { «pedagogía del oprimido»: Paulo Freire, } \\
\text { Rodrigues Ramalho, Orlando Fals Borda, } \\
\text { Davydd Greenwood, Stephen Kemmis y Robin } \\
\text { Mc Taggart, o Tomás Rodríguez Villasante. }\end{array}$ \\
\hline
\end{tabular}

La esencia básica de la etnografía, su principal objetivo, es aportar datos descriptivos de contextos, actividades y creencias de las participantes en sus correspondientes escenarios educativos (Goetz y LeCompte, 1988). Si en nuestro caso, únicamente hiciéramos etnografía con esta finalidad el significado que le hemos dado a la ciencia, al conocimiento y a la investigación se difuminaría. Para conseguir ampliar el discurso social desde lo social debemos ampliar la tradicional mirada etnográfica. Desde la perspectiva clásica se expone que hay que observar modificando lo menos posible el escenario de investigación. Es decir, bajo mi punto de vista, el efecto «mosca en la pared» tan extendido en la etnografía tradicional, en el que la investigadora se sitúa en un plano externo, sin interactuación con el contexto, sin participación en el espacio y simplemente como observadora para no interferir en el espacio, funcionaría de un modo contraproducente en realidades sociales concretas como en la que nos encontramos en esta investigación. Por ello, en este estudio se trabaja desde una orientación de Etnografía Crítica en la cual, como investigadora, formo parte activa del contexto en la búsqueda de una mayor conciencia crítica y emancipatoria de la propia realidad.

Se rompe con modelos de experta académica que se reproducen en las formas jerárquicas de hacer ciencia y se opta por procesos de construcción colectiva del conocimiento. Como afirma Botero (2012), somos parte de, participamos en las luchas ampliando las posibilidades de defender espacios y territorios para la vida. Por ello, hablar de un posicionamiento como investigadora dentro del concepto de «nativo marginal» (Freilich, 1970) rompería la finalidad ética y política de la etnografía crítica en la que nos orientamos. 
En este sentido, tal y como apuntan Sánchez y Estalella (2016) necesitamos transformar las prácticas etnográficas convencionales hacia formas más colaborativas de investigación. Prácticas que nos fuercen a reelaborar nuestras asunciones metodológicas, el tipo de relaciones que establecemos en el campo, los lugares de producción de conocimiento y la temporalidad de nuestra investigación, entre otras cuestiones.

En este caso particular, como investigadora no podría llevar a cabo el estudio en un grupo de voluntariado únicamente como observadora o incluso como observadora participante ya que rompería la dinámica interna de dicho grupo. Desde ese mismo momento se distorsionaría la realidad objeto de estudio. En el mundo del activismo social, desnaturaliza una persona ajena que únicamente se dedique a observar lo que allí ocurre. Por ello, busco conformar un espacio en el que encontrar mi enclave en la estructura asociativa de la que formo parte sin romper ni forzar la propia dinámica de trabajo. Esto es una cuestión crucial a la hora de planificar la investigación ya que debemos tener claro cuál es nuestro papel y en qué medida distorsionamos la realidad que queremos indagar (Cortés, 2010). Por tanto, como investigadora he tenido que analizar el contexto para concretar y seleccionar el método de investigación y mi papel dentro de la investigación para así conseguir la mejor adaptación a la realidad social de estudio. De la misma manera que en el trabajo de Sánchez y Estalella (2016), donde exponen cómo el método se va construyendo a lo largo de la investigación, la selección del método es procesual. En mi caso, para no alterar los sucesos reales lo más sincero es que forme parte del medio como voluntaria ya que lo que alteraría los procesos naturales que se dan en el contexto sería actuar como persona ajena al grupo con el único objetivo de observar y estudiar lo que sucede. Debemos matizar, que trabajar a partir de las voces de las participantes no obvia la perspectiva de la investigadora, de hecho es una de todas esas voces que no puede desligarse de la interacción con el medio (Ludhra y Chappel, 2011). Así mismo, asumo la importancia que tiene la implicación de la investigadora como aspecto fundamental de análisis.

Como exponíamos al inicio del capítulo, y desde la aportación más constructivista del conocimiento, la realidad social se construye socialmente y depende de los significados que se le atribuyen (Francisco, 2013). Estos 
significados han de emerger desde la interacción humana sobre una base argumentativa de validez y no de poder hegemónico (Habermas, 1987,1989). Por ello, tal y como plantea la investigación militante (Malo, 2004; Rojas, 1989) mi posicionamiento investigador exige que como investigadora me incorpore activamente a la realidad social que estudio, integrándome en las tareas que lleva la comunidad, conociendo a las participantes, problematizando junto a ellas, tomando decisiones de modo horizontal, sintiendo un compromiso con la comunidad y participando activamente en el proceso de transformación de la realidad. Todo esto nos lleva a utilizar la metodología como dispositivo social que nos ayuda a cuestionarnos políticamente. En relación a ello, Foley y Valenzuela (2013) nos avisan de que «las nuevas etnografías son más políticas y están orientadas a las políticas. Los antiguos rótulos de 'etnografía crítica' y 'críticas culturales' tal vez ya no capturen la nueva diversidad. Los últimos etnógrafos críticos son una minoría de activistas que están involucrados en movimientos sociales progresistas y en reformas basadas en la comunidad». Por eso proponemos la etnografía militante como el término adecuado a esta investigación.

En conclusión, perseguimos la descripción y el análisis cultural de un grupo concreto, la Casa de Joventut La Maranya, con el que queremos hacer una reflexión consciente sobre la cultura de participación juvenil que provoque la transformación de la propia realidad. El diálogo acoge un papel fundamental en todo el proceso, un diálogo igualitario que es posible cuando se tienen en cuenta la validez de los argumentos en lugar de la posición de poder o privilegio de las personas. Todos y todas somos igual de importantes, todos y todas tenemos que ofrecer nuestra voz en esta transformación. Es gracias a este enfoque por lo que mi discurso se convierte en uno más entre muchos, abandonando el rol del especulativo del sillón que Stocking (1993) nos remarca en más de una ocasión.

Observamos la relación directa de este enfoque con los valores que se exponen desde el inicio del capítulo, siendo conscientes de los objetivos políticos en la investigación, reconfigurándola desde la participación, originando procesos de empoderamiento ciudadano en la generación de conocimiento. Así, la etnografía estará comprometida con el cambio (Foley, 
2002; Anderson, 1989) y podrá partir de la acción comunitaria (Lassiter, 2005).

\section{4. Características de la etnografía crítica}

En estos modos de hacer y escribir etnografía crítica me gustaría recorrer de forma general cuáles son sus características esenciales. Del mismo modo que la teoría crítica no tiene una sola corriente, la etnografía crítica también se ve influenciada por muchas de ellas. Por ello es difícil listar una serie de características que sean comunes a toda etnografía crítica. Aun así voy a describir la que siento más cercano a mi quehacer investigador.

Partiendo de los rasgos más característicos de la Etnografía convencional y comparándolos con la Etnografía Crítica, según Jim Thomas (1993) observamos diferencias significativas (tabla 14) que hacen que me sitúe en esta investigación en un enfoque crítico y no convencional. Entre los elementos está el hecho de convertir el proceso en un espacio reflexivo mediante el cual entra en juego la voluntad de cambio político. Del mismo modo asumimos que el proceso se lleva a cabo de manera co-construida y de esta forma se analizan los significados de manera colectiva y desde la realidad que nos ocupa. Otro aspecto es aquel que responde más bien a un estado de apertura y dinamismo en la construcción del conocimiento sin dar nada por cerrado sino promoviendo que todo es cambiante en función del lugar, el espacio y el momento en el que nos situemos. A su vez, la etnografía crítica dota de autoridad a las participantes y no hace de ellas meros objetos de estudio. Así adopta un posicionamiento centrado en la conciencia de la realidad y el cambio. Finalmente se considera emancipatoria tanto para el colectivo con el que se trabaje como para la investigadora.

Tabla 14. Diferencias entre etnografía convencional y etnografía crítica (Jim Thomas, 1993).

\begin{tabular}{|l|l|}
\hline \multicolumn{1}{|c|}{ Etnografía crítica } & \multicolumn{1}{|c|}{ Etnografía convencional } \\
\hline $\begin{array}{l}\text { Proceso reflexivo con propósito político de } \\
\text { cambio }\end{array}$ & Descripción de la tradición cultural \\
\hline $\begin{array}{l}\text { Elección de alternativas conceptuales y } \\
\text { valoración y co-construcción de significados }\end{array}$ & Interpretación de significados \\
\hline Responde al ¿qué podría ser? & Responde al ¿qué es? \\
\hline Autoridad a las participantes & Sujetos de investigación \\
\hline
\end{tabular}




\begin{tabular}{|l|l|}
\hline $\begin{array}{l}\text { Su posición política apela a la conciencia y el } \\
\text { cambio social }\end{array}$ & Indeseabilidad ante los sesgos \\
\hline Hermenéutica y emancipatoria & Dependiente \\
\hline
\end{tabular}

Además de estas apreciaciones compartimos con Soyini Madison (2012) que la etnografía crítica se caracteriza porque «is always a meeting of multiple sides in an encounter with and among others, one in which there is negotiation and dialogue toward substantial and viable meanings that make a difference in others' worlds»" ${ }^{21}$.

Esta autora remarca la importancia del diálogo como aspecto fundamental que caracteriza a la etnografía crítica. Habla del valor de las conversaciones en la temporalidad formadas por otras voces, cuerpos, historias y anhelos.

Por otro lado Kincheloe, MacLaren \& Steinberg, (2011), destacan la importancia del papel de la persona crítica y la definen como una investigadora, una profesora o una teórica que utiliza su trabajo como una forma social o cultural de hacer crítica y que acepta una serie de asunciones que están en todo pensamiento. Estas suposiciones básicas, son entre otras, que todo pensamiento está mediado por las relaciones de poder; que en su construcción no podemos aislarnos del carácter ideológico que forma parte de nosotras; que los significados están influenciados por las relaciones sociales; que la opresión caracteriza a las nuevas sociedades y por ello debemos enfrentarnos a las injusticias de una sociedad en particular. De este modo anuncian su preferencia en contra de la objetividad en la lucha por un mundo mejor (Chapman, 2010; Grinberg, 2003; Horn, 2004; Kincheloe, 2001b, 2008b).

Foley y Valenzuela (2013) sitúan este enfoque como uno particular en el que se habla siempre desde un punto de vista histórico y políticamente situado remarcando que algo que caracteriza a la etnógrafa crítica es que, como productora de conocimiento, nunca es políticamente neutral. Es en este punto en el que Madison (2012) alerta de por qué es vital tener en cuenta la «posicionalidad» de la etnógrafa en el proceso de investigación. La autora expone que si cuestionamos nuestra «posicionalidad», nos obligamos

\footnotetext{
${ }^{2}$ Siempre es una reunión de múltiples caras en un encuentro con y entre otros, uno en el que existe negociación y diálogo hacia significados importantes y viables que marcan la diferencia en los mundos de los demás.
} 
a reconocer nuestro propio privilegio, el poder y los sesgos en los que nos situamos como investigadoras, al igual que denunciamos las estructuras de poder que rodean a las participantes en la investigación. Además todas estas autoras remarcan la necesidad de crear etnografías que lleguen a la ciudadanía.

Finalmente, observamos como este enfoque se caracteriza por sus propios objetivos tanto sociales como de investigación. Al fin y al cabo, la etnografía crítica nos sirve para articular e identificar las fuerzas ocultas y ambigüedades que operan bajo las apariencias; para guiar juicios y evaluaciones que emanan formando nuestro descontento; para dirigir nuestra atención a las expresiones críticas dentro de diferentes comunidades interpretativas en relación con su magnitud única de poder; para proporcionar una visión e inspirar actos de justicia; y para nombrar y analizar lo que se siente de forma intuitiva (Madison, 2012:).

\section{5. Diseñar el proceso etnográfico}

El proceso etnográfico no sigue la linealidad de otros métodos de investigación más estructurados. A veces incluso no sigue ninguna pauta cerrada ya que se construye desde dentro y se va modificando en función de la experiencia, las diferentes perspectivas, los cambios de estructura, los acontecimientos... (Sánchez y Estalella, 2016). En él se solapan las fases, los ciclos son iterativos ya que implican avances y retrocesos constantes y se reordenan en función del contexto. Del Rincón (1997a) sugiere que es un modelo cíclico en el que objetivos e instrumentos se pueden definir en diferentes momentos del proceso. Advierte que los informes son sucesivos para que las participantes puedan revisarlos y validarlos para así considerar nuevos interrogantes y centrar progresivamente los aspectos a analizar a través de una recogida y análisis de datos continuo y dialéctico. La figura de la investigadora ha de mantener una reflexión analítica continua y cíclica sobre los datos (Woods, 1987; Álvarez, 2011) que será fundamental para la organización de toda la información.

Aun así existen una serie de etapas básicas (Poveda, 2013; Blommaert y Jie, 2011; San Román, 2009; Heath y Street, 2008) por las que deberíamos pasar en todo proceso etnográfico. Podemos verlas en el gráfico inferior (Figura 3) donde se remarca la revisión bibliográfica, la formulación de objetivos, el 
diseño de la investigación, el trabajo de campo y el análisis que se convierten en un proceso cíclico constante, la redacción y la devolución.

Figura 3. Aproximación al proceso cíclico (Poveda, 2013).

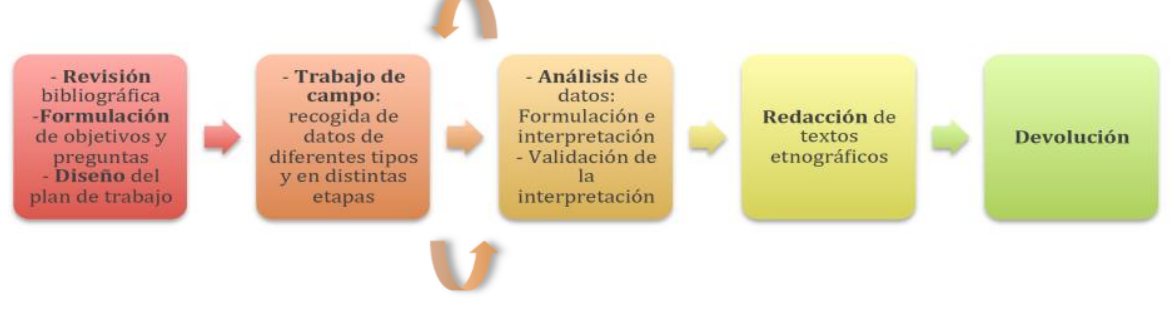

De forma resumida podemos explicar estas fases del siguiente modo:

1. Primera etapa: Es la etapa destinada a la elaboración del primer diseño del plan de trabajo y para ello, tenemos que realizar una completa revisión bibliográfica sobre el estado de la cuestión para poder formular los objetivos y preguntas que darán forma a nuestro trabajo.

2. Segunda etapa: Se centra en el trabajo de campo. La investigadora debe entrar en la comunidad a estudiar, ha de hacer las presentaciones oportunas, ha de negociar con las participantes y ha de comenzar a recoger datos con distintas herramientas y en diferentes fases.

3. Tercera etapa: Llega el momento de analizar los datos recogidos a través de las diferentes herramientas y fases anteriores. Estos datos han de interpretarse y validarse. Este proceso puede dar lugar a la vuelta al campo para continuar recogiendo información que necesite contrastarse o ampliarse. Aquí es dónde reside el sentido cíclico del proceso etnográfico.

4. Cuarta etapa: Ha llegado el tiempo de la redacción y elaboración del informe etnográfico a partir de toda la información recogida y analizada en las dos cíclicas etapas anteriores para así devolverlo al grupo. Esta etapa se diseña y amplía en función del paradigma en el que se sitúe la investigación dependiendo si sigue procesos críticos o positivistas. 
Como vemos uno de los aspectos que guiará el modo de actuar en la investigación es el diseño de la investigación. Julianne Cheek (2011) nos explica que en función de cómo nos planteemos el diseño nos situaremos como investigadoras en el «mundo de la experiencia». Aquí empezarán a cobrar sentido los significados metodológicos y la ética de investigación que he formulado a lo largo de todo este capítulo. Por ello, resulta interesante estructurar la elección del diseño en estas cinco preguntas que nos expone la anterior autora (Cheek, 2013) y que se resolverán en el siguiente capítulo:

- ¿Cómo se conectará el diseño con el paradigma o la perspectiva que se emplee? Es decir, ¿cómo los materiales empíricos serán moldeados por el paradigma en cuestión y cómo interactuarán con él?

- ¿De qué modo estos materiales le permitirán a la investigadora referirse a los problemas de la práctica y el cambio?

- ¿Quién o qué se estudiará?

- ¿Qué estrategias de investigación se emplearán?

- ¿Qué métodos o herramientas de investigación para recolectar y analizar materiales empíricos se usarán?

Para finalizar remarcar aquellos aspectos que según Lassiter (2005) son básicos en el diseño de la investigación y que para mí han resultado ser esenciales para diseñar y llevar a cabo una etnografía ética. Cada uno de ellos se ha tenido en cuenta de forma transversal en el siguiente capítulo de diseño. El primer aspecto es la necesidad de que haya un consentimiento informado, la prohibición de prácticas de investigación engañosas, la garantía de la privacidad y la confidencialidad y la responsabilidad de representar los resultados de la investigación minuciosamente.

\subsection{Artesanía, bricolaje o cómo hacer pathcwork en la etnografía: Estrategias, técnicas y herramientas de investigación.}

Tal y como citan Hammersley y Atkinson (2001) uno de los rasgos distintivos de la etnografía es la variedad de métodos y herramientas de investigación que tienen cabida en el proceso. Denzin \& Lincoln (2011) 
recogen en sus textos la definición de lo que muchas autoras (Harper, 1987; Certeau, 1984; Nelson, Treichler y Grossberg, 1992; Lévi-Strauss, 1966; Weinstein y Weinstein, 1961; Kilenchoe, 2001) llaman bricoleur u otros quilt maker. Las nuevas investigadoras se definen como tal por no utilizar un único método o herramienta sino que conectan diversos métodos y herramientas para dar vida a sus etnografías. Esto tiene una de sus razones en el interés por el caso particular y en la correspondiente adaptación metodológica en función de las características del colectivo o comunidad en la que nos encontramos. Así la iré incorporando técnicas y herramientas en función de las necesidades, dependiendo de los problemas que surjan y de los contextos (Nelson, Treichler y Grossberg, 1992). Son múltiples las analogías expuestas en los textos cualitativos, desde las metáforas del montaje cinematográfico, pasando por el artesano y el bricolaje, sin olvidarnos del tejido de colchas en patchwork y la improvisación jazzística. Todas estas definiciones tienen aspectos en común que remarcan que en esta clase de investigaciones se dan muchos elementos que se suceden en el tiempo y espacio desde diferentes voces, puntos de vista y perspectivas. Como exponen Denzin \& Lincoln, las investigadoras cualitativas «buscan estrategias de investigación empírica que les permitan establecer conexiones entre la experiencia vivida, las injusticias sociales, las estructuras sociales y culturales más amplias y el aquí y el ahora» (2013:33).

Ya lo expone Flick (2002) en algunos de sus textos, la investigación cualitativa emana de lo multimetodológico. Esta forma de estudiar los fenómenos a través de diferentes métodos, o de la propia triangulación, refleja a su vez, el interés por el rigor, la amplitud, la complejidad, la riqueza y la profundidad en la investigación. El pluralismo metodológico posibilita un nuevo marco de trabajo en la integración de las diversas metodologías. Desde este punto de vista, las orientaciones de autores como Shulman (1981, 1989) o Fenstermacher (1989) entre otros que apuestan por apoyar esta fórmula, sin confundirla con el politeísmo metodológico, en el que el subjetivismo reinante marcará la supremacía del «todo vale», fortalecen la base para utilizar estrategias que provienen de diferentes metodologías generando de este modo una comprensión más amplia y rica de la realidad educativa a estudiar. 
Teniendo en cuenta todo lo recogido en este capítulo considero esencial el reflexionar sobre los significados que tiene para cualquier investigadora su propio estudio ya que esto marcará la ética adecuada como base de la investigación. Reconociendo que la investigación ha de servir para comprometernos socialmente, comprender la realidad, reconocer la dimensión pública de la ciencia y reconstruir políticas educativas desde la realidad planteo esta investigación desde un paradigma crítico de investigación cualitativa que se materializa en el uso del método etnográfico. De este modo, propongo todo el diseño y correspondiente proceso de investigación desde un enfoque crítico y activista desde el cual asumo el compromiso de poner en marcha una etnografía cercana al contexto de estudio, diversa en relación a las herramientas utilizadas y comprometida socialmente con el cambio y la mejora educativa. 


\section{Caminem a muscles de gegants}

(Bernardo de Chartres. 1130, y siempre recordada en Maranya)

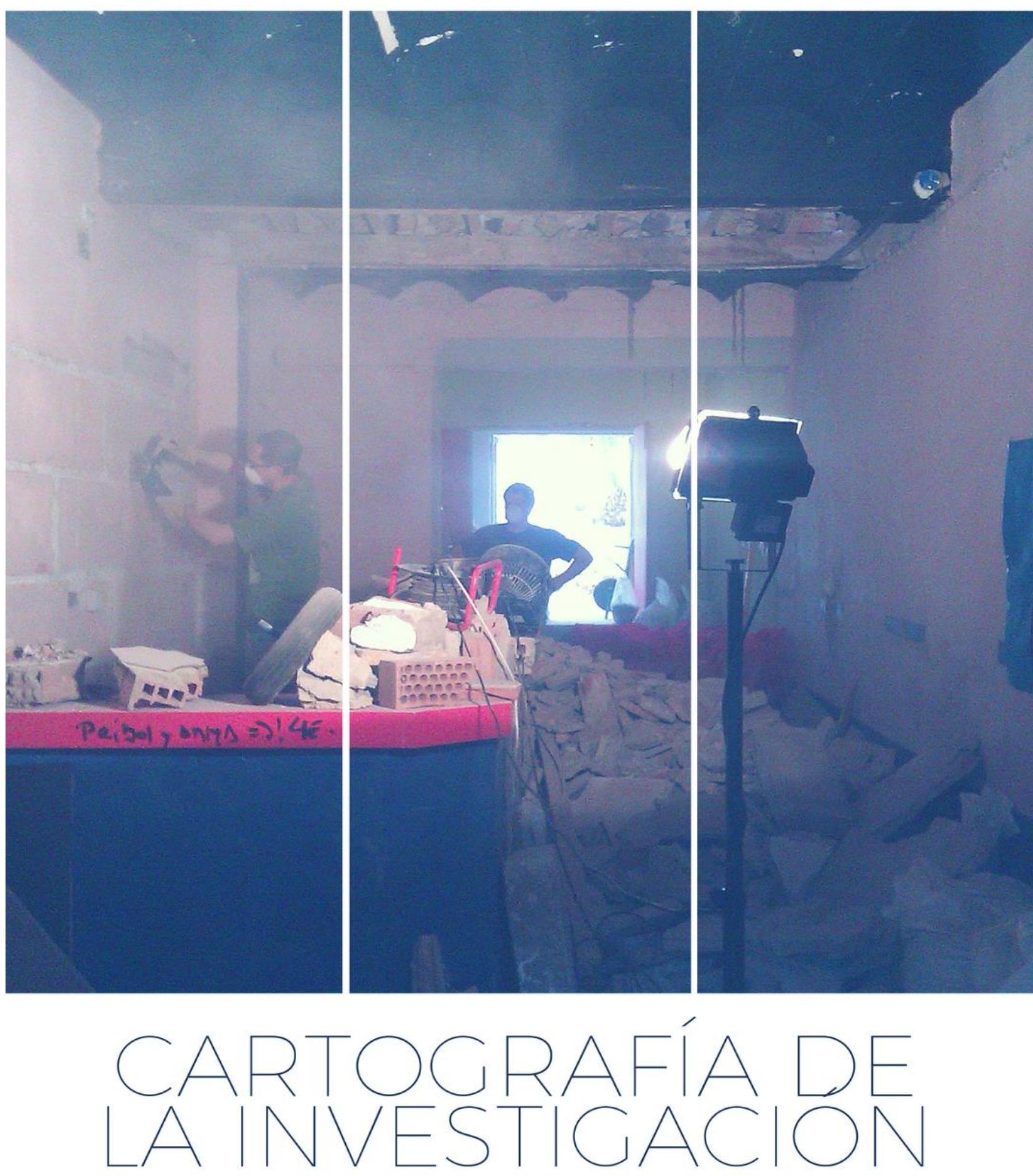



Una de las mayores críticas que se le hacen a la investigación cualitativa es la falta de transparencia en los procesos de construcción y análisis de información. Por eso, quiero contrastar este trabajo con dicha crítica dando garantías de cómo hemos llevado a cabo el estudio para así proporcionar esquemas de actuación para las nuevas etnógrafas.

Para ello haré un recorrido por las cuestiones más básicas que dan base a cualquier investigación como son: el problema de investigación, las preguntas y objetivos de la misma y las fases por las que se ha pasado a lo largo de todo el proceso de estudio. Además abordaré cómo se ha llevado a cabo la construcción de la información describiendo los instrumentos diseñados para este fin desde estrategias documentales, colaborativas y narrativas. Finalmente acabaré describiendo el procedimiento de análisis y los criterios de rigor científico en los que me he basado. Concluiré este capítulo hablando sobre el proceso de elaboración del informe etnográfico. 


\section{1 . Problema de investigación.}

Las diferentes estrategias europeas sobre la juventud exponen la necesidad de saber más sobre experiencias y prácticas que pongan en valor la participación activa de este colectivo en la sociedad. De forma concreta, uno de los objetivos de la UE para la juventud, es animar a las jóvenes hacia la participación social y activa. Para ello se plantean generar iniciativas específicas dirigidas a fomentar el aprendizaje no formal, la participación y las actividades de voluntariado. Además persiguen garantizar que estas iniciativas tengan en cuenta los problemas de la juventud a la hora de formular, aplicar y evaluar políticas y acciones en otros ámbitos con repercusiones significativas en sus vidas. Un aspecto relevante de dicho plan de actuación es que otorga importancia al diseño de políticas y estrategias de intervención basadas en evidencias concretas, experiencia y conocimiento sobre la situación de las jóvenes, su bienestar, su calidad de vida y sus oportunidades para tomar parte activa en la sociedad.

En los últimos años, el sistema económico y financiero ha situado en una posición muy difícil a la juventud, se trata de uno de los grupos sociales que más ha sufrido y aún sigue recibiendo las consecuencias de los retrocesos en políticas sociales. Debemos superar el modelo paternalista, asistencial e intervencionista que aún en la actualidad da forma al trabajo con jóvenes. Este reduce la libertad y la autonomía de la ciudadanía justificándose en una incapacidad e ineptitud no real de esta. Por ello, debemos buscar alternativas al modelo existente en políticas de dinamización juvenil. Este necesita redefinirse para conseguir cubrir las necesidades del colectivo y de esta forma conectarse de manera directa con las estrategias europeas que exigen un abordaje responsable de un problema social tan cercano y extendido como es el contexto actual de las jóvenes. Para conseguirlo es preciso trabajar desde la comunidad y la participación y de esta forma, repensar nuestra mirada desde estas dos variables, porque romper con el paternalismo es dar VOz al propio colectivo. Realizarlo desde la red comunitaria, y no desde lo particular, individual y autoritario debe ser uno de los objetivos para conseguir abordar un problema como este y convertirlo en una acción educativa y transformadora. 
Estos acontecimientos estimulan la investigación y proporcionan una oportunidad para explorar la situación desde una base educativa y comunitaria. En nuestra investigación sumaremos miradas y cruzaremos relatos para conseguir una historia caracterizada por la diversidad de voces, que describa e interprete la cultura de participación juvenil y visibilice el silencio y la marginación que se produce sobre el colectivo. De forma particular centraremos nuestra atención en aquellas experiencias que tienen como protagonistas o destinatarios preferentes a las jóvenes, experiencias asociativas que pretenden enmarcarse como estrategias de intervención educativa con jóvenes en su tiempo libre y de ocio.

En este sentido, las Casas de Juventud son, en Europa y desde la II Guerra Mundial, espacios donde las jóvenes se encuentran y ponen en común sus inquietudes, construyendo sus propias actividades de manera autónoma a través de una clara vocación de trabajo social y comunitario. Este servicio público, gestionado por las jóvenes de manera independiente, ha hecho que en Europa la tasa de asociacionismo juvenil aumente hasta valores de un $42 \%$ en el último año. Estos datos contrastan con los porcentajes en España que se sitúan alrededor del 25\% de asociacionismo juvenil (Federació Valenciana de Cases de Joventut). A partir del análisis de los datos anteriores surge la necesidad de investigar sobre componentes básicos de la sociedad y profundizar sobre qué entendemos por participación. Nos planteamos ahondar en nuestra realidad local y analizarla para contribuir a alcanzar la consonancia con Europa en temas de asociacionismo y construcción ciudadana.

En España, los centros autogestionados por jóvenes han sufrido la marginación y el silencio académico y político por parte de muchas instituciones. Las Casas de Juventud se han convertido en Ciudades de papel, asociaciones que se enfrentan a su invisibilidad por parte de las instituciones. Espacios que, aun existiendo, parecen desaparecer como los cartógrafos hacen con sus ciudades de papel. Las Casas existen pero las miran como si fueran puntos frágiles, irreales, invisibles para la ciudadanía que pueden borrarse del mapa con un abrir y cerrar de ojos. Ahí reside la relevancia de nuestro estudio ya que introduce a un colectivo silenciado como el juvenil en un contexto académico en el que se abren nuevas líneas de investigación educativa próximas a la realidad. 
Particularmente en la provincia de Castellón se están llevando a cabo procesos de dinamización juvenil, dentro de la animación sociocultural, que deben darse a conocer para facilitar su comprensión y ampliar nuestro conocimiento sobre el colectivo. No dejamos de escuchar diariamente que la juventud está perdida, que no tiene conciencia social, que es egoísta y no piensa en su futuro pero sabemos que esto no es así. La convicción ciudadana de que las personas jóvenes no participan lo que deberían hace saltar las alarmas. Observamos cómo desde diferentes partes del país se están llevando a cabo movimientos juveniles que luchan por su futuro y que se implican en su tiempo libre desde espacios juveniles. De ahí nuestro interés en analizar estos espacios, los cuales trabajan para las jóvenes y desde las jóvenes, en los cuales se educa en la participación, planteando y diseñando intervenciones desde una perspectiva democrática. Reflexionar en torno a estas acciones y cuestionarnos su papel las pone en valor, visibiliza al colectivo y ofrece nuevas líneas de investigación que nos permite contribuir en la elaboración de nuevas estrategias que provienen de una realidad activista, asociativa y juvenil.

A todo esto se le suma el interés académico de extender la reflexión teórica que ofrece la Pedagogía Social profundizando en contextos en los que las jóvenes sean protagonistas de la transformación social. Indagar sobre procesos reales para generar teoría aplicada, a partir de un grupo de personas, es lo que se pretende con esta investigación. Analizar, comprender y aprender sobre una comunidad, en este caso la juvenil, para que nos aporte información sobre su propia cultura de participación, sobre su saber cultural y cómo lo utilizan en su interacción social. Todo ello lo hacemos desde un contexto concreto, la Casa de Joventut La Maranya. De este modo, abordamos el estudio del tipo de asociacionismo que promueve la Casa y analizamos si influye en la participación juvenil local. Conoceremos más sobre la incidencia de las casas de juventud como instrumento de reforma, de cambio y de transmisión cultural, ahondando en la importancia de tejer redes para construir ciudadanía democrática.

Por estos motivos, conocer experiencias y prácticas que pongan en valor la participación activa del colectivo juvenil en la sociedad, ofrecer estrategias para no retroceder más en las políticas juveniles, redefinir la dinamización juvenil a partir del significado que se le da a la participación y al 
asociacionismo, visibilizar proyectos autogestionados por jóvenes y ampliar así la comprensión y el conocimiento sobre la cultura de participación juvenil acercando la teoría sobre pedagogía social a la realidad hace necesario investigar sobre la cultura de participación juvenil en espacios educativos de educación no formal.

En todas estas particularidades reside nuestro interés por conocer y comprender nuestra realidad y a las jóvenes en relación a los procesos de participación en los que están inmersas, para así analizar las diferentes características que hacen posible la construcción de su propia cultura participativa. Todo ello sin abandonar el análisis entre la estructura asociativa y la organización social, económica y política del contexto en el que se encuentra.

Para abordar este problema de investigación precisamos de una metodología que nos permite conocer a las jóvenes con las jóvenes, analizar el significado de la participación juvenil desde su propia mirada, comprender la cultura de participación juvenil, conocer los procesos en los que se conforma, las estructuras que genera, los espacios que provoca, y las posibilidades de transformación social en la cultura juvenil que favorece. Para conseguirlo abordamos el estudio a partir de la etnografía siguiendo una coherencia metodológica relacionada con nuestro compromiso científico, académico y social.

Consideramos la investigación como un instrumento de reforma, de cambio y de transmisión cultural. El momento social que estamos viviendo nos pide investigaciones más cercanas a la realidad y co-construidas con la ciudadanía. Nos pide espacios de reflexión colectiva e investigaciones que se conviertan en dispositivos de acción social y política. Por esto seleccionamos la etnografía crítica como metodología coherente con estas necesidades. Dicho estudio se diseña para facilitar procesos de concientización, construcción compartida de conocimiento y significados elaborados por la sociedad. Además nos posibilita el análisis de nuevas formas de actuación social más igualitarias que abren nuevas propuestas de carácter educativo e impulsan la construcción de una sociedad más participativa, crítica y libre.

Asumimos que nuestro problema de investigación viene dado por la necesidad de profundizar, entender y visibilizar procesos culturales de 
participación y de aprendizaje que se encuentran ocultos o pasan desapercibidos en nuestra sociedad y de forma concreta en relación directa con el asociacionismo juvenil autogestionado. Queremos analizar la cultura de participación dentro de un asociación concreta como es la Casa de Joventut La Maranya para poder dar razones por las que el asociacionismo juvenil debería de ser uno de los pilares fundamentales en la educación de las jóvenes. Por esto investigamos, para visibilizar el valor educativo del asociacionismo, para cubrir necesidades sociales e institucionales en referencia a la participación democrática juvenil, y porque como investigadora, profesora, estudiante, ciudadana, voluntaria y militante me encuentro con la necesidad de utilizar la investigación como un proceso de aprendizaje y un dispositivo de acción social y política, que contribuya a que nuestras Ciudades de Papel permanezcan en el mapa para siempre y puedan ser un referente de estrategias educativas sobre la juventud dando lugar a jóvenes comprometidas y activas con su propia realidad. 


\section{2. La Historia interminable: preguntas y más preguntas.}

Realizar un estudio etnográfico supone asumir el reto de preguntarse y repreguntarse a lo largo de todo el proceso, de construir los interrogantes conforme avanzamos en la investigación y ahondamos en la cultura de la comunidad. La naturaleza metodológica de la investigación influye en ello, ya que entendemos la investigación como un proceso abierto y dinámico dónde el interés se posa en indagar durante el mismo. De esta forma, la parte activista de esta investigación produce que el planteamiento de las preguntas sea el momento más complejo y rico si cabe. Surgen multitud de cuestiones a lo largo de todo el estudio, se formulan y reformulan por la investigadora y a su vez por el grupo asesor que forma parte de la investigación. Por ello, a continuación, vamos a plasmar los interrogantes principales que después derivan en otras cuestiones más directas a lo largo del proceso:

- ¿Qué papel juega la Casa de Joventut La Maranya en la cultura de participación social en las jóvenes de Benicàssim?

- ¿Por qué cubre este papel?

- ¿Es la Casa de Joventut La Maranya un agente educativo de cambio en el territorio?

- ¿Cómo se convierte la Casa de Joventut La Maranya en un agente educativo de cambio en el territorio?

Las investigaciones se transforman conforme avanzas en el proceso. Comienzas esta con unas preguntas muy concretas que poco a poco se van ampliando y van reuniendo las necesidades del propio contexto en el que te mueves. Es así por lo que nuestras preguntas están en constante movimiento y no es fácil cerrarlas. En ellas observamos cómo existen diferentes niveles de concreción que abordan temáticas distintas que complementan la historia de la Casa de Joventut La Maranya. Es así cómo 
Arecia Aguirre García-Carpintero

queremos resolver cuestiones relacionadas con la construcción de la Casa, averiguar el papel que juega esta en la cultura de participación juvenil, cómo se fragua como agente educativo pero también cómo se relaciona con el contexto social, político y económico. 


\subsection{Objetivos.}

Como hemos analizado con anterioridad existe una necesidad social, académica y personal de conocer realidades y analizar la cultura, la participación y la educación desde la calle junto con la ciudadanía. Necesitamos indagar en el papel de la educación en el tiempo libre y la animación sociocultural en el proceso de aprendizaje de la persona. Además con su vinculación a los problemas sociales nos permitirá conocerlos para mejorarlos.

La formulación concreta del objetivo general de la investigación es la siguiente:

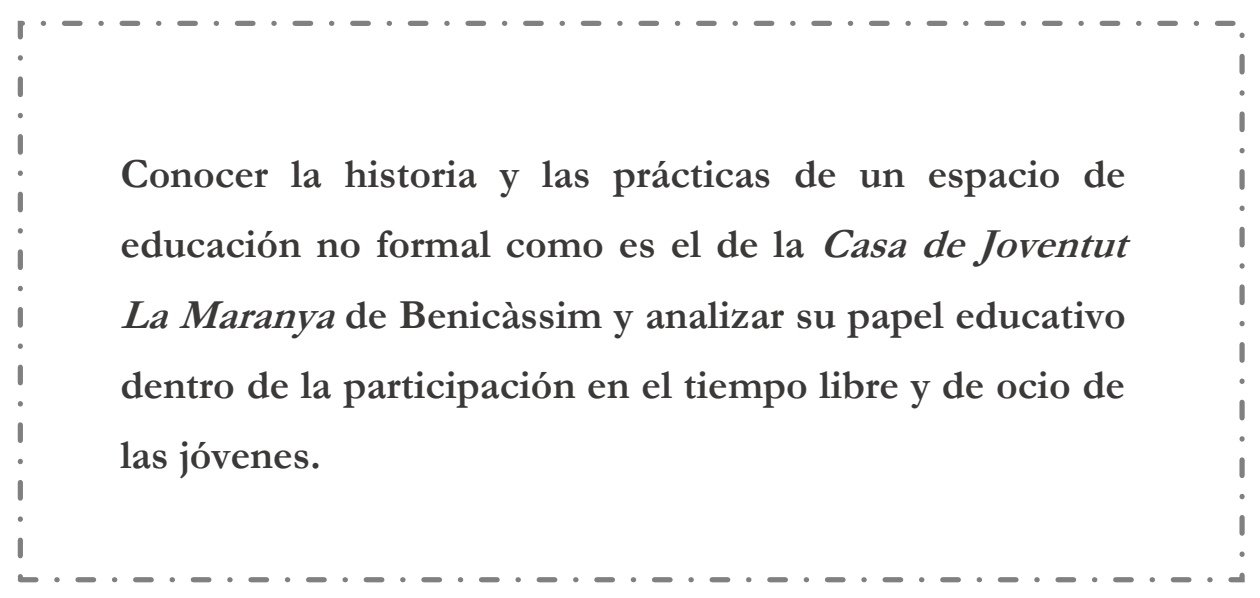

Este objetivo ha de especificarse en otros más concretos que guían diversos aspectos de análisis destacados de la investigación:

- Conocer cómo surge la Casa de Joventut La Maranya y analizar cuáles son sus particularidades a lo largo de su historia.

- Indagar en el significado de la participación dentro de la Casa, saber cómo se definen los roles y las estrategias de participación que aparecen.

- Analizar la existencia de espacios de aprendizaje, saber cuáles son los pilares educativos en los que se sustentan y cómo se trabajan y asumen.

- Explorar la línea ideológica de la Casa de Joventut La Maranya y reconocer cómo se genera el discurso del movimiento. 
- Analizar el significado de voluntariado, activismo y militancia que se tiene en el grupo de personas que forman parte de la Casa de Joventut La Maranya, o más concretamente en el Equipo de Animadoras Voluntarias.

- Ahondar en el modelo de asociacionismo juvenil promovido dentro de la Casa.

- Visibilizar la acción juvenil y la creación de espacios de educación no formal autogestionados.

En la tabla inferior (tabla 15) puede verse el cruce de preguntas generales y específicas de investigación con los objetivos correspondientes a los que pretende responder.

Tabla 15. Objetivos y preguntas cruzadas.

\begin{tabular}{|c|c|c|c|}
\hline OD & OBJETIVOS & OD & PREGUNTAS \\
\hline \multicolumn{4}{|c|}{ Nivel de concreción General } \\
\hline \multirow[t]{3}{*}{ OOG } & \multirow{3}{*}{$\begin{array}{l}\text { Conocer la historia y las prácticas de un } \\
\text { espacio de educación no formal como es el } \\
\text { de la Casa de Joventut La Maranya (CJM) de } \\
\text { Benicássim y analizar su papel educativo } \\
\text { dentro de la participación en el tiempo libre } \\
\text { y de ocio de las jóvenes. }\end{array}$} & PPG1 & $\begin{array}{l}\text { ¿Qué papel juega la Casa de } \\
\text { Joventut La Maranya en la } \\
\text { cultura de participación social } \\
\text { en las jóvenes de Benicàssim? }\end{array}$ \\
\hline & & PPG1 & ¿Por qué juega dicho papel? \\
\hline & & PPG2 & $\begin{array}{l}\text { ¿Es la Casa de Joventut La } \\
\text { Maranya un agente educativo } \\
\text { de cambio en el territorio? } \\
\text { ¿Cómo lo ha conseguido? }\end{array}$ \\
\hline \multicolumn{4}{|c|}{ Nivel de concreción específico } \\
\hline OOE1 & $\begin{array}{l}\text { Conocer cómo surge la Casa de Joventut La } \\
\text { Maranya y analizar cuáles son sus } \\
\text { particularidades a lo largo de su historia. }\end{array}$ & PPE1 & $\begin{array}{l}\text { ¿Cuáles son las características } \\
\text { de la Casa de Juventud La } \\
\text { Maranya? }\end{array}$ \\
\hline OOE2 & $\begin{array}{l}\text { Indagar en el significado de la participación } \\
\text { dentro de la Casa, saber cómo se definen los } \\
\text { roles y las estrategias que aparecen. }\end{array}$ & PPE2 & $\begin{array}{|lll|}\text { Cómo se } & \text { estructura } & \text { la } \\
\text { participación } & \text { juvenil en } & \text { la } \\
\text { CJM? } & & \end{array}$ \\
\hline
\end{tabular}




\begin{tabular}{|c|c|c|c|}
\hline OD & OBJETIVOS & OD & PREGUNTAS \\
\hline & & & $\begin{array}{l}\text { ¿Qué roles se dan? } \\
\text { ¿Qué estrategias se utilizan? }\end{array}$ \\
\hline OOE3 & $\begin{array}{l}\text { Analizar la existencia de espacios de } \\
\text { aprendizaje, saber cuáles son los pilares } \\
\text { educativos en los que se sustentan y cómo } \\
\text { se trabajan y asumen. }\end{array}$ & PPE3 & $\begin{array}{l}\text { ¿Qué valores trabaja: } \\
\text { educativos, } \\
\text { ideológicos,...? }\end{array}$ \\
\hline OOE4 & $\begin{array}{l}\text { Explorar la línea ideológica de La Maranya y } \\
\text { reconocer cómo se genera el discurso del } \\
\text { movimiento. }\end{array}$ & PPE4 & $\begin{array}{l}\text { ¿Qué ocurre si hay personas } \\
\text { que quieren trabajar desde } \\
\text { otros prismas? } \\
\text { ¿Cómo se generan estas } \\
\text { trayectorias diversas? } \\
\text { ¿Qué diferencias prácticas } \\
\text { existen respecto al modelo } \\
\text { educativo asentado de CJ? }\end{array}$ \\
\hline OOE5 & 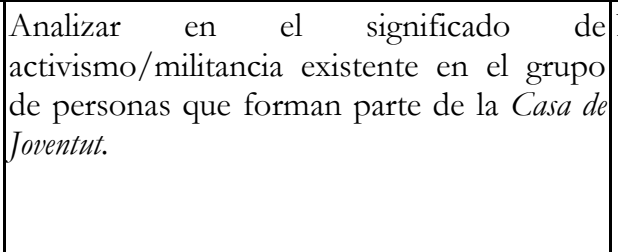 & PPE5 & $\begin{array}{l}\text { ¿Cómo se transmite esta } \\
\text { militancia?, } \\
\text { ¿Qué diferencias existen entre } \\
\text { voluntariado, militancia, u } \\
\text { otras conceptualizaciones? }\end{array}$ \\
\hline OOE6 & $\begin{array}{l}\text { Ahondar en el modelo de asociacionismo } \\
\text { juvenil promovido dentro de la Casa. }\end{array}$ & PPE6 & $\begin{array}{l}\text { ¿Qué tipo de asociacionismo } \\
\text { se trabaja en Maranya? }\end{array}$ \\
\hline OOE7 & $\begin{array}{l}\text { Visibilizar la acción juvenil y la creación de } \\
\text { espacios de educación no formal auto } \\
\text { gestionados. }\end{array}$ & PPE7 & \\
\hline
\end{tabular}




\subsection{Fases a lo bruto ${ }^{22}$.}

A lo largo de la investigación no existen fases cerradas, más bien son cíclicas, se solapan y reordenan, lo que implica avances y retrocesos en todo momento: revisión bibliográfica, preguntas, diseño, trabajo de campo, análisis, escritura, devolución. Aun así vamos a mostrar un primer acercamiento a la ruta que hemos realizado que ayuda a entender cómo se ha llevado a cabo el proceso de investigación.

Los tiempos reales de esta tesis doctoral abarcan desde 2011 hasta 2016. A grosso modo podemos hablar de tres fases diferenciadas aunque muy conectadas entre sí que marcan el acceso a esta investigación. A continuación podemos leer un resumen descriptivo de cada una de ellas.

Del 2011 al 2012

La primera fase comprende mi trabajo dentro de los proyectos de dinamización sociocultural del Proyecto de Extensión Universitaria (PEU) de la Universitat Jaume I. A partir de mi trabajo final de master en la Comarca Els Ports empiezo a vincularme con el movimiento asociativo juvenil y participo como miembro del equipo formado por el PEU para encabezar proyectos juveniles en diferentes municipios rurales de la provincia de Castellón. Debido a las personas que conforman el equipo y su vinculación con Federació Valenciana de Cases de Joventut y Escola de Cases, este es mi primer contacto con dichas plataformas.

Del 2012 al 2014

Esta segunda etapa se compone por el acercamiento a la Casa de Joventut La Maranya. A partir del trabajo anterior empiezo a formar parte activa en las formaciones promovidas por Escola de Cases y en las reuniones de su claustro. A su vez comienzo a asumir el vínculo con La Maranya a través de la colaboración en el Verkami que la Casa realiza para autofinanciarse un alquiler con su consiguiente obra de rehabilitación. Después del Verkami me comprometo a ser socia económica de La Maranya a partir de cuotas anuales y de donaciones procedentes de mi trabajo en las sesiones de Escola de Cases.

22 Quisiera hacer un guiño al seminario que desde hace dos años se está llevando a cabo en INTERMEDIAE en la ciudad de Madrid bajo la dirección de David Poveda y Fernanda Moscoso. El Seminario de «Etnografía a lo bruto» es un espacio de investigación etnográfica y educación que trabaja de manera colectiva materiales en bruto de diferentes investigaciones.

[http://www.mataderomadrid.org/ficha/4972/etnografia-a-lo-bruto.html ] 
Del 2014 al 2016

En esta tercera etapa se plantea la investigación en la Casa de Joventut La Maranya y asumo el papel de activista dentro del Equipo de Animadores Voluntarios de la Casa. Esta etapa se describe en mayor profundidad en el anexo 1 a través de una línea del tiempo que describe aquellos momentos clave junto con las actividades desarrolladas en cada uno de ellos.

A continuación podemos observar la figura (figura 4) en la que se plasman las fases y subfases más representativas de esta etnografía. Vemos cómo se dan tres momentos clave: los preparativos, la participación militante y el cierre. En el primero se trabaja el acercamiento al caso y se inicia la revisión bibliográfica y el diseño de la investigación, ambas son subfases cíclicas que se retroalimentan de forma mutua. En el segundo momento se dan tres subfases complementarias: la construcción de la información, el contraste de esta información y el análisis. Una no puede darse sin las otras y las otras no pueden darse sin la una. El último momento conlleva la elaboración del texto etnográfico, los momentos de compartir relatos entre las participantes, la propia defensa de tesis y la futura evaluación del Grupo Asesor. 
Figura 4. Ciclo de investigación etnográfico.

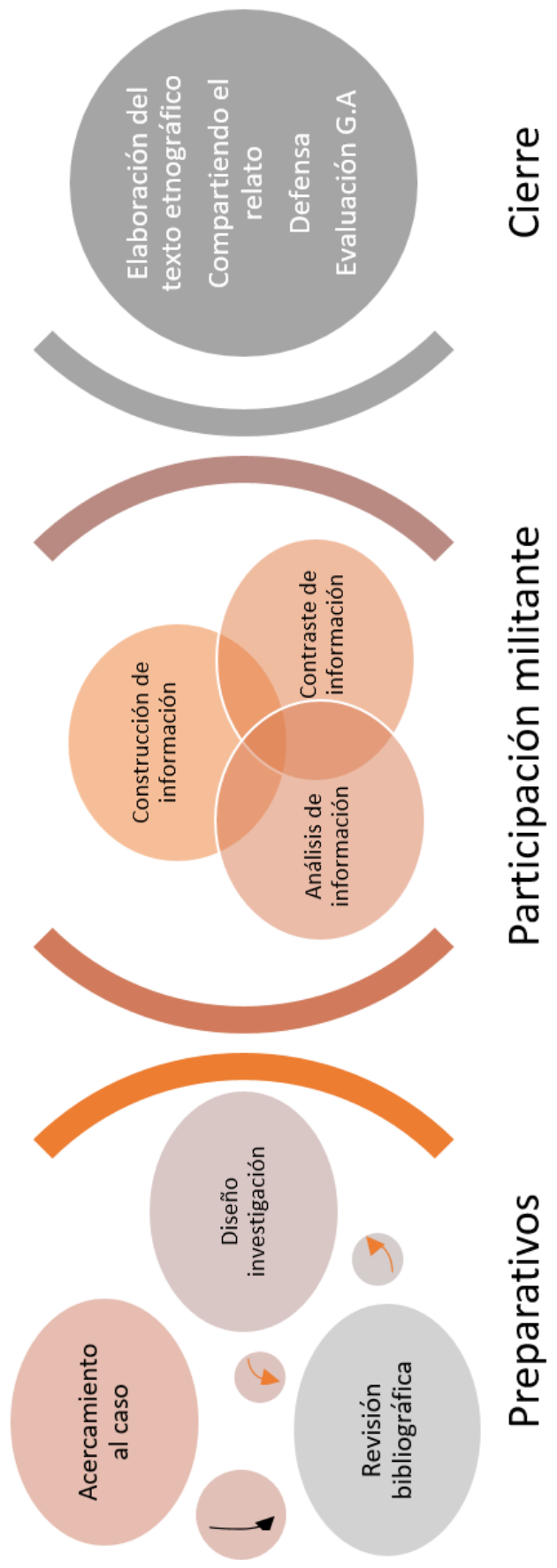


Seguidamente voy a iniciar un relato algo más cercano de lo que comporta cada una de estas fases y subfases para que así la lectora pueda hacerse una idea global de lo que ocurrió en cada uno de estos momentos ${ }^{23}$. Destacar que la primera parte, en la que hablo sobre los preparativos, es la más extensa ya que he realizado un relato más personal del momento de toma de decisión de la temática de tesis y del contacto con la asociación. El resto de las fases y subfases se cuentan de un modo más exhaustivo en la segunda parte de este capítulo donde se habla sobre los procedimientos, la construcción de información y las perspectivas de análisis de la información.

\subsubsection{Relatando a lo bruto.}

Llega el momento de iniciar una tesis con todo lo que ello comporta, dedicar unos años de tu vida a investigar, evaluar, conocer otros espacios, pensar junto con otras personas, indagar en tus propios puntos fuertes y puntos débiles, aprender a solas y acompañada y crecer personal y académicamente. Sumergirte en un proceso que no empieza y acaba con un trabajo de campo sino que se justifica en historias anteriores y se contextualiza en ellas y todas las que vengan después del trabajo de campo. Como la historia nos ayuda a focalizar de dónde venimos y nos enseña el camino hacia dónde vamos, esta tesis no quiero explicarla desde los únicos meses de trabajo en Maranya sino que me remontaré al momento en el que para mí empieza todo esto.

\subsubsection{Preparativos}

Prefases de investigación. Meses de contactos y acercamiento al caso.

Recuerdo que era 2011 y yo estaba de becaria en la universidad, concretamente acompañada de Joan y Lidón, mis actuales directores de tesis. Estaba acabando de cursar Psicopedagogía y Joan me insistía en que continuara estudiando y así acabar haciendo la tesis doctoral. Yo me sentía desorientada, muchas compañeras de carrera ya estaban trabajando y yo había apostado por combinar la segunda carrera con mis horas de trabajo

\footnotetext{
${ }^{23}$ Recuerde que para complementar toda esta información tenemos también el anexo I.
} 
en Decathlon. Pero me quedé enganchada, comencé a sentirme parte de algo, parte de un grupo de personas que me abrieron las puertas para conocer que se escondía detrás de los pasillos de la universidad.

Uno de esos días en los que nos reuníamos en el despacho de Joan me encontré que estaba hablando con Víctor ${ }^{24}$, me invitaron a pasar y los dos estaban emocionados hablando de todo lo que estaba ocurriendo en Benicàssim. Por lo que entendí en aquel momento el Ayuntamiento del pueblo había cambiado de equipo de gobierno y con ello, de grupo político. El nuevo se posicionaba en contra de muchas de las actividades que se realizaban en el Casal Jove del municipio. Las jóvenes que participaban, las familias y las animadoras cada vez estaban más molestas con sus actitudes y decisiones pero seguían insistiendo en la necesidad de conservar el espacio que llevaban años trabajando como lugar de iniciativas, cultura y autogestión juvenil. Pero ya había ido muy allá, estaban echándoles del Casal, el Casal se quedaba sin jóvenes porque el Ayuntamiento no estaba de acuerdo en sus formas.

La energía que sentí en ese momento me hizo emocionarme con el proyecto que este grupo de Benicàssim estaba llevando a cabo. Recuerdo leer y releer noticas, el blog, vi sus vídeos en más de una ocasión, empecé a pensar en la potencialidad de ese acontecimiento en la vida y aprendizaje de las jóvenes y de todas las demás personas que en ese momento estaban envueltas en esa espiral y pensé en la poca visibilidad que un movimiento de estas características podría tener a nivel académico e incluso social.

Fue pasando el tiempo y siempre que me cruzaba con Víctor me contaba historias nuevas de lo que ocurría. Desde unos días antes yo ya formaba parte del Seminario Garbell, un espacio en el que nos re-encontrábamos personal de la universidad, estudiantes y técnicos de los ayuntamientos, entre otros colectivos, para compartir lecturas, experiencias y proyectos comunes sobre participación comunitaria y cultura co-construida.

Acabé realizando un master y mi trabajo final estuvo dedicado a la participación juvenil en la Comarca Els Ports. Con el asesoramiento de Víctor y con dos compañeras del grupo Garbell nos decidimos por realizar

\footnotetext{
${ }^{24}$ Miembro del Equipo de Animadoras Voluntarias de Maranya.
} 
un Diagnóstico Social Participativo en los dos institutos de la Comarca. Eso hizo que me interesara cada vez más por la participación juvenil en espacios de ocio y tiempo libre y provocó que a partir de la insistencia de Albert, compañero y director del Servicio de Actividades Socioculturales (SASC), y junto a Víctor nos metiéramos en los proyectos de dinamización sociocultural para jóvenes dentro del Proyecto de Extensión Universitaria (PEU) de la Universitat Jaume I.

Lo que provocó toda esta historia es que empecé a vincularme cada vez más con el movimiento asociativo juvenil y empecé a conocer todo lo que se movía detrás de Federació Valenciana de Cases de Joventut (FVCJ) y Escola de Cases.

En el curso 2011/2012, fácilmente FCVJ estaba formada por alrededor de una decena de Casas de Juventud (CdJ) y Escola de Cases daba formación en muchos de los municipios en los que se habían construido CdJ. Una de ellas era Maranya y llega el día en el que por diferentes vías leo información sobre el Verkami que va a realizar Maranya para poder autofinanciarse la obra de rehabilitación que implicaba el alquiler de las dos casas que habían encontrado en el pueblo. Participo en la financiación como puedo y me alegro por todo lo que Maranya va consiguiendo. En mayo de 2012 se cierra el Verkami y en la Casa no dejan de hacer obra y obra para poder abrir y realizar actividades cuanto antes.

\section{Necesidad de leer y conocer: hacia la revisión bibliográfica.}

En octubre de 2012 defiendo mi trabajo final de master y empiezo a pensar en mi futuro objetivo, la tesis doctoral. Es en el año 2013 cuando empiezo a realizar la revisión bibliográfica para enfocar el diseño de la investigación. Busco textos, investigaciones, experiencias, visito a colegas en otras universidades y continúo el contacto con la participación juvenil en las zonas rurales de Castellón.

Las revisiones se hacen complicadas porque no existe mucha información al respecto de las Casas de Juventud pero sí que puedo encontrar artículos sobre investigaciones sobre el asociacionismo y el valor de la participación en espacios y países democráticos. Indago en ERIC, en Web of science, Google Schoolar y en Dialnet entre muchos otros lugares. Marcho a la biblioteca a buscar libros y revistas, contacto con compañeras de otras universidades 
para pedir consejos y bibliografía y me empapo de métodos de investigación próximos a la participación ciudadana.

Poco a poco voy conociendo a las personas que dan forma a todo el movimiento juvenil valenciano y Víctor me propone realizar alguna sesión en los cursos de Monitor de Tiempo Libre en Benicàssim. A partir de ahí se me invita a las sesiones del Claustro de profesores de Escola de Cases. Con el proyecto del PEU Joves empezamos a hacer sesiones de formación y algunas con adolescentes en los municipios, es en una de ellas en la que conozco a Virginia $^{25}$. A partir de ese día en Forcall, rodeada de juegos de mesa, sus historias sobre las jóvenes y todo lo que estaba produciéndose en Benicàssim hacen que se me contagie el entusiasmo y se me ilumina una bombilla sobre cómo sería el realizar la tesis doctoral en Maranya, sobre su historia y sus aprendizajes. Poco a poco voy desistiendo en la idea, que realmente hasta tiempo después no comparto con nadie. Desisto porque escucho en múltiples ocasiones la poca sintonía entre este movimiento juvenil y la academia. Muchas veces son las que escucho su desagrado sobre la investigación y sobre las personas que escriben teorías y técnicas sobre el movimiento juvenil sin haberse rodeado de acción y transformación directa con la ciudadanía. Esto hace que busque otras alternativas porque realmente creo que si les planteo la idea de hacer una tesis en la Casa me dirán que no. Entiendo cada vez que se habla del tema que son muchas personas en el movimiento las que piensan así, las que tienen sus reticencias hacia estas prácticas académicas y en alguna ocasión escucho a Víctor decir «es que ya estamos cansados de que siempre quiera venir la gente a pasar cuestionarios, a realizar proyectos personales desde la universidad sin pensar si nosotras los necesitamos». Esto hizo que me olvidara de la idea y empecé a leer sobre el asociacionismo juvenil, los proyectos con adolescentes con los libros de Enrique Deltoro y me empapé del contenido de las sesiones del curso de Escola de Cases. Continué con el contacto y empecé a conocer a más gente dentro de la Casa de Joventut La Maranya, cada vez me intrigaba más su historia y las personas que lo estaban haciendo posible.

\footnotetext{
${ }^{25}$ Miembro del Equipo de Animadoras Voluntarias de Maranya.
} 


\section{Diseño de una investigación y cambios a lo largo del proceso.}

Empecé a leer sobre metodologías interesantes, la investigación acción participativa ya la había trabajado con el grupo de investigación MEICRI y aun siendo una metodología muy potente quería aprender otras formas de hacer investigación. Fue cuando empecé a meterme en proyectos que hablaban del método biográfico narrativo y con el proyecto de «Afrodita ha llenado mi corazón: relatos de vida de mujeres migrantes lesbianas y bisexuales» descubrí un modo más sensible de hacer investigación. Sin olvidarme de proyectos colectivos como Missions interculturals que me trasladaron a la investigación desde espacios comunitarios y compartidos. No quiero decir con esto que la IAP no sea humana, comunitaria y compartida sino que en ese momento sentía que si tenía que hacer una tesis sobre Maranya debía contarla de un modo distinto.

A ello se le suma la visita a la UJI de la profesora de la Universidad de Sevilla Anabel Moriña. Asistí a una de sus sesiones de formación en la que nos habló de las Historias de Vida y de los proyectos de investigación que había llevado a cabo con ellas. Después también el profesor David Poveda de la UAM llegó para introducirnos en el mundo de la etnografía educativa. Con él tuve la oportunidad de escribir un primer borrador del proyecto de tesis para discutirlo y mejorarlo en la sesión. Tras estas formaciones y proyectos quise leer al respecto para conocer qué tipo de investigación podría hacer en un espacio de participación juvenil.

Después de todo esto me reuní con mis directores de tesis para compartir las diferentes alternativas que veía para realizar la tesis. Seguía vinculada a la participación comunitaria desde los pueblos rurales de Castellón y eso hizo que un par de opciones se centraran en el trabajo en los diferentes municipios. La tercera opción era realizar un estudio etnográfico en la Casa de Joventut La Maranya y hablamos de los pros y contras que podrían tener unas alternativas o las otras. Finalmente me animaron a que planteara la posibilidad en Maranya ya que era la opción que más me entusiasmaba en ese momento. Quedamos en que escribiría el proyecto de tesis y lo valoraríamos en otra sesión. Una vez cerrado el proyecto lo compartiría con las personas con las que tenía contacto de Maranya, Víctor y Virginia, para que así me comentaran que les parecía la idea de poder llevar a cabo la tesis con el colectivo. 
Recuerdo que fue un día de trabajo del proyecto Joves del PEU cuando quedé con Víctor y le conté todo lo que había pensado y cuál fue mi sorpresa cuando él me dijo que sería muy interesante que hiciera la tesis allí. Me comentó que podía ser una buena oportunidad para visibilizar el trabajo que se había hecho. Me propuso que lo habláramos un día en alguna sesión con las jóvenes y que así fueran ellas las que me dieran el visto bueno para empezar con el trabajo. Mi emoción fue máxima y me puse manos a la obra para poder concretar el proyecto de tesis. Lo que hice fue compartirlo con otros grupos de investigación y así lo hice con un grupo de profesoras de la Universidad de Valencia en donde había realizado una estancia de investigación dirigida por la profesora Piedad Sahuquillo, después me marché a Madrid. Allí me reuní varios días con el grupo de Infancia Contemporánea que dirige David Poveda y de esta forma pude abordar preguntas y obtener respuestas sobre todas las dudas y dificultades que le encontraba a la investigación que había planteado. Gracias a este viaje pude acabar de delimitar el proyecto de tesis con su contextualización, justificación, objetivos, preguntas, fases, materiales, herramientas y espacios que pensaba necesitar. Una vez finalizado recuerdo enseñárselo a Víctor y Virginia y de ahí salió la idea de presentarlo en alguna de las dinámicas que se hicieran con las jóvenes en los próximos días.

Ambos pensaron que podría estar bien hacerlo en la dinámica que se llevaría a cabo el domingo 13 de abril de 2014 sobre la historia de Maranya y yo vi ideal el poder enmarcar en ese día la investigación. Pasaron los días y llegó la jornada de la dinámica, me preparé una presentación con video ${ }^{26}$ para que fuera más sencillo de explicar, intenté escribir una exposición que estuviera en un lenguaje mucho más cercano pero al final de todo no fue el día para llevarlo a cabo. Sin embargo al acabar el día volvimos a retomar el asunto y se planteó la idea de poder asistir ese mismo lunes al plenario de jóvenes y que fuera allí donde poder hablarles sobre la propuesta.

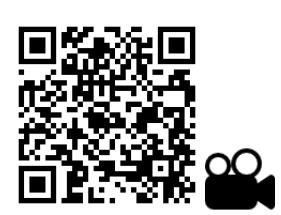


El lunes en el plenario lo presenté, sin video pero lo hice, hicimos una ronda de preguntas en las que alguna persona preguntó que cual iba a ser el beneficio de que Maranya tuviera una tesis, qué era lo que yo sacaba al respecto y qué era lo que ellas obtendrían. Yo les planteé mis intenciones y les exprese mi interés de conocer al grupo y realmente hacer una tesis que fuera interesante tanto para unas como para otras. Aunque se votara después y saliera mayoritariamente que sí mi sensación fue que no iba a ser todo tan fácil y me costaría conseguir una complicidad con ellas. Me iba a seguir encontrando barreras ante la opción de hacer una investigación en un espacio como en el que me encontraba pero ya sabía que era algo que existía y con lo que iba a tener que lidiar. Cuando acabó la sesión, Víctor y Virginia me comentaron que si quería que la tesis saliera adelante tenía que implicarme y acabar formando parte de la Casa como una activista más, sólo así, si me veían como una más podría conseguirlo. «En la Casa los proyectos que no se llevan desde dentro no funcionan» me dijeron, así que su recomendación es que empezara a inmiscuirme en la vida del grupo y que acabara siendo una activista maranyera más.

Esto dio un vuelco a la tesis, en un principio no cambió nada en mi forma de pautar los pasos a dar pero poco a poco me di cuenta que tenía que asumir una nueva perspectiva, más crítica y participativa que el simple hecho de estar como observadora participante en la Casa. Fue ahí cuando empecé a indagar en la investigación militante, estudios activistas e historias contadas desde la colectividad.

Tras la sesión del plenario decidí presentarme virtualmente para que todas las socias de la Casa supieran del acuerdo que habíamos tomado. Envié un email presentándome y compartiendo que íbamos a hacer a partir de ahora (anexo 2), además les adjunté el video ya que la idea de colgarlo en la web no pareció agradar cuando lo dije. Comentaron que en el blog no se suben noticias individuales sino que han de ser colectivas y si no viene de una acción común en los grupos estables no se puede colgar. Así que lo dejé pasar y por eso decidí enviarlo todo por email para que las personas pudieran disponer de él. Seguía con mi idea de que no me lo iban a poner fácil. 


\subsubsection{Participación militante}

\section{Trabajo de campo, elaboración de protocolos y espacios colaborativos de investigación.}

Desde abril del 2014 hasta la actualidad, empiezo a participar de forma activa en las reuniones de jóvenes y del Equipo de Animadoras Voluntarias (EAV) hasta que un día surge la oportunidad de acercarme mucho más a la dinámica de la Casa y participar dentro del grupo Perduts pel món que estaba formado principalmente por cinco jóvenes que se dedicaban a realizar videos sobre diferentes temáticas de interés social. Virginia y Víctor me remarcaron que podría ser una muy buena oportunidad y a la vez en mi cabeza sonaba la idea que me plantearon en Madrid de que me involucrara en uno de los proyectos que llevara la Casa para así poder analizar todo el trabajo desde dentro de un modo más eficaz. Se juntaron muchas cosas pero realmente lo que cambió en esas sesiones es que cada vez me sentía más cerca del colectivo y sentía que las relaciones se iban abriendo y, aunque con múltiples comentarios del equipo sobre mis funciones investigadoras en la Casa, reconocía que esos comentarios ya se hacían desde un lugar más próximo y con una mayor complicidad.

En estos momentos ya hacía meses que era socia económica de la Casa, cada mes destinaba una pequeña parte de mi dinero a mantener este espacio y además las horas de cursos de Escola de Cases iban a parar también a la Maranya. Era mi forma de militar, sobretodo al principio cuando no encuentras ese lugar desde el que participar y ofrecer algo al colectivo. Realmente me costó darme cuenta que mi militancia en la Casa no se centraba únicamente en aparecer por las reuniones, formar parte de Perduts pel món, organizar turnos de limpieza y asistir a obra. Mi militancia, sobretodo, se alimentaba de la tesis que estábamos realizando. Después de unas cuantas lecturas me di cuenta que aquello que yo podía aportar al grupo era el estudio que había emprendido meses antes en Maranya. Por eso el diseño de la investigación fue cambiando conforme me introducía en el campo. Con el tiempo fui analizando la necesidad de provocar un nuevo modelo de investigación que acomodara sus tiempos a lo que la Casa necesitaba generando una relación distinta con el saber popular. 
Tal y como leí un día en la web de Manos Invisibles ${ }^{27}$ lo que quisiera es encontrar el lugar entre la investigación y la militancia que me permita construir conocimiento desde lo colectivo y desde la acción. Quisiera tomar de ambas,

de la investigación tomamos el cuestionamiento del estado de cosas, pero también de las prácticas, las formas de vida, las instituciones, los grupos. Tomamos la confianza en lo que puede el pensamiento: enunciar, analizar, orientar, trastocar, crear. También cierta idea de rigor. De la militancia tomamos el compromiso: con lo que es de todos y para todos, con las gentes que desde situaciones particulares desafían la injusticia, resistiendo y creando otras maneras de vínculo social. Tomamos la implicación: una manera de estar en las situaciones que, de un modo u otro, se hace cargo. Y no porque cargue con un peso, sino porque acepta la pregunta de « ¿y a mí todo esto cómo me interpela?», "¿de qué manera puedo aportar? »... y lleva esta pregunta hasta sus últimas consecuencias. También una idea de lo común: de que ni el pensamiento ni las acciones son nunca una hazaña individual; siempre beben, forman parte, de un ecosistema que se cultiva entre muchas (Manos invisibles).

Así comencé a interesarme en la investigación militante y así le encontré el sentido a la tesis doctoral en La Maranya.

A partir de ahí, empecé a construir instrumentos que nos ayudaran a dirigir la tesis desde el propio colectivo y de este modo se creó un grupo asesor con personas que tenían relación directa con La Maranya y con el movimiento juvenil de Casas de Juventud. Durante el verano del 2014 me dediqué a crear protocolos que ayudaran a este grupo a entender los pasos que podíamos dar y de este modo y desde este espacio se reconstruiría la investigación junto a ellas. Los principales protocolos fueron uno particular del Grupo asesor y otro sobre el proceso de entrevistas, más tarde valoraríamos tiempos, productos y preguntas de investigación. Además realicé un protocolo de transcripción de entrevistas para cuando tuviera que comenzar con esta tarea de investigación. Por otro lado, escribí también el documento de consentimiento informado para las personas que

\section{Más información en http://manosinvisibles.net/}


participarían de las entrevistas y a su vez, adjunté a este una carta de bienvenida a la investigación agradeciendo la participación en el proceso.

En septiembre de 2014 hicimos la primera sesión y a partir de entonces empezaron los contactos con las 28 personas que acabaría entrevistando. Yo contactaba directamente con unas personas y algunas personas del grupo asesor me facilitaban el contacto con muchas otras. Así durante el mes de septiembre realicé las primeras entrevistas que iría transcribiendo y analizando ${ }^{28}$ durante los meses de octubre y noviembre que pasaría en mi estancia en Portugal. En las vacaciones de diciembre realicé un par de entrevistas más para así volver a transcribir y analizar durante el último mes de estancia en Coímbra. Desde octubre hasta enero fueron meses de contacto virtual y activismo a través de redacción de textos para revistas y convocatorias sobre buenas prácticas ciudadanas.

Todas las entrevistas transcritas y analizadas se enviaban a las entrevistadas para que las leyeran y realizaran los cambios que consideraran oportunos para así conseguir la versión definitiva para el análisis estructural que se realizaría al finalizar toda la tanda de entrevistas.

Durante estos meses estuve realizando revisiones bibliográficas para enfocar el capítulo del marco metodológico además de estar escribiendo sobre el capítulo del diseño de la investigación.

\section{Construcción de información.}

Desde febrero hasta mayo de 2015 estuve construyendo información a partir de diferentes documentos de la Casa y de Federació, además de continuar con las entrevistas y el activismo dentro de la Casa que me permitió vivir múltiples acciones que iría recogiendo en el diario de campo que había empezado años atrás. Toda esta información me dio la posibilidad de formular e interpretar algunos datos y rediseñar algunos puntos del proyecto de tesis como serían las herramientas con las que estaba construyendo la información.

\footnotetext{
${ }^{28}$ Este análisis era una primera aproximación, algo más natural de lectura y detección de temas importantes a valorar en las siguientes entrevistas
} 
Me di cuenta que es muy complicado realizar un proceso cerrado en una investigación de estas características ya que las etapas se van retroalimentando las unas a las otras y siempre pasa algo único que te hace repensar y rehacer el camino. Así es que la construcción de información no paró de darse en los casi tres años que ha durado el trabajo de campo. Durante los meses de mayo, junio y julio de 2015 estuve trabajando desde las idas y venidas de Madrid ya que me encontraba realizando una estancia de investigación en la UAM. Allí tuve la oportunidad de compartir el diseño de la investigación y todo mi posicionamiento metodológico lo que enriqueció el discurso de mi escrito al incorporar algunas de las discusiones que pudimos trabajar a lo largo de las sesiones.

Finalmente me dediqué a preparar todos los materiales que utilizaría para la siguiente reunión con el grupo Asesor en la cual contrastaríamos la información recogida, nos replantearíamos las preguntas de investigación y haríamos un balance de todos aquellos documentos que nos servirían para escribir la historia de la asociación.

\section{Contrastar información.}

Durante el segundo semestre de 2015 me dediqué al activismo en la Casa y a contrastar toda aquella información que tenía en mis manos. Era importante hacerlo para reconocer si la información estaba triangulándose o no y si no lo estaba encontrar los dispositivos para realizarlo. Además el poder contrastar la información entre fuentes y dispositivos era el primer paso para poder cruzar voces en el relato de vida.

Fueron meses de lecturas, visionados y estructuración de toda la información ya que necesitaba contrastar datos y detectar lagunas que pudieran existir en los datos que ya manejaba. Buscaba espacios donde poder preguntar a unas y a otras sobre documentos interesantes y sobre dudas que me iban surgiendo para complementar la información que ya tenía. Realmente todo era más sencillo porque compartía muchos momentos con las personas de Maranya y eso facilitaba que les pudiera preguntar de manera directa en función de mis dudas y de los encuentros que teníamos. Fueron momentos especiales y la gente en la Casa no dejaba de preguntar para cuándo podrían leer cosas, querían que la tesis estuviera ya, tenían ganas de saber, de leerse y reconocer a las otras. Tuve que parar 
para explicarles cuestiones de protección de datos, procesos de investigación y consecuencias que podría tener su incumplimiento. Me resultó sugerente todo este interés y me cuestioné pensando que debería de haber generado una investigación más participativa con la gente, no sabía si me estaban pidiendo más colaboración o simplemente más información pero fuera lo que fuese abría una puerta a nuevas líneas de investigación en el grupo.

\section{Análisis de la información.}

La siguiente fase se centró en la tarea de análisis de la información mientras seguía participando de la vida de Maranya. Estas tres últimas subfases descritas se retroalimentaban de manera continua, era más bien una espiral de construcción, contraste y análisis continuo. De este modo, conforme hacía el análisis de los datos, podría ir comprobando y contrastando información en la Casa.

Llegado el momento de analizar toda la información volqué todos los documentos al programa NVivo ${ }^{\circledR}$, organicé las codificaciones de cada uno de ellos y me dispuse a comenzar el análisis estructural. Debía tener muy en cuenta la triangulación de los datos y las diferentes categorías y codificaciones que saldrían de dicho análisis. Poco a poco me iba despegando de la Casa, sentía que cada vez podía participar menos ya que el análisis y la redacción me absorbían mucho más tiempo del que disponía. Llegó julio de 2016 y me ausenté por completo para meterme en la siguiente fase.

\subsubsection{Cierre}

\section{Redacción de textos etnográficos.}

Finalmente, una vez se tenía toda la información analizada de manera estructural y también de forma cronológica me dispuse a escribir el relato de vida de la asociación a través del propio análisis narrativo. Fueron días complicados. Miles de cuestionamientos: cómo empezar, cómo acabar, qué matizar, qué rol asumir en el relato, cómo descubrir las voces, de qué forma narrarlas, cuanto espacio necesitaría, si sería capaz de conectar con el relato de las personas, si esta forma de contar los resultados funcionaría o no... Preguntas y más preguntas que dieron pie al miedo de empezar a escribir 
pero que a la vez me provocaban emoción en cada cuestionamiento. Empecé el relato y cuestionarlo junto con las directoras me ayudó a coger distancia a la vez que relataba desde mi propio interés por esta historia.

Al finalizarlo sólo quedaba escribir conclusiones, esbozar líneas futuras de investigación y abrir la puerta a la discusión. Partes difíciles del final de una tesis.

\section{Compartir el relato.}

El penúltimo paso de esta investigación está dedicado a la colaboración con el grupo asesor. Una vez se tiene la historia escrita ha de enviarse para iniciar la devolución y el análisis de la misma. Este paso se tenía programado realizar durante el mes de septiembre pero por diversas razones ha tenido que postergarse al mes de octubre ya que hasta el momento no se han dado las condiciones deseables para poder hacerlo de un modo participativo. Existen múltiples causas derivadas de la vida de las miembros del Grupo Asesor. Desde asuntos personales como enfermedades familiares, embarazos,..., hasta laborales como aumento de responsabilidades en la gestión docente, cambios de trabajo, estancias de investigación y académicas como prácticas y formación universitaria, entre otras cosas. Todas ellas han impedido que se consiga el espacio idóneo y un mínimo de masa crítica para desarrollar este punto. Es importante para esta tesis y para la asociación el realizar este paso. Existe voluntad por todas las partes y por ello se ha decidido retrasar pero no anular del proceso. Este punto influye a la hora de presentar este informe de tesis en el hecho de que no se podrá cerrar este punto hasta después de la evaluación de expertas pero nos vemos obligadas a hacerlo de este modo debido, principalmente, al hecho de tener que depositar la tesis doctoral antes de que se extinga el programa de doctorado y antes de que me marche a realizar mi próxima estancia de investigación a la Universidad Estatal de Arizona (EEUU) en febrero de 2017.

Aun así, la programación de esta devolución está reservada para la última semana de octubre y se llevará a cabo siempre que exista una masa crítica de asistentes que puedan realizar un análisis crítico de la historia. Para ello, se enviará por email para que cada una de las personas que forman parte 
del grupo pueda leerla y así, en la sesión conjunta, poder hacer un análisis crítico de la misma.

\section{Defensa del trabajo.}

Toda tesis acaba con un acto de defensa del trabajo, es un paso que ninguna nos podemos saltar y que es importante para mostrar y visibilizar todo el trabajo que hemos estado haciendo a lo largo de estos años. Aun así, en nuestro caso, no será el último paso que daremos.

\section{Evaluación con el grupo asesor de todo el proceso de investigación.}

Para completar el estudio queremos llevar a cabo una evaluación con el grupo asesor sobre la investigación. Me gustaría conocer perspectivas, interrogantes, críticas, limitaciones y aprendizajes que ha conllevado la investigación etnográfica militante en el grupo e incluso analizar pros y contras con todas las participantes. Es el único modo que tendré de aprender sobre la experiencia y reconocer si esta investigación ha sido todo lo militante que se quería y lo suficientemente beneficiosa para el colectivo, el movimiento y el municipio como se pretende.

\subsection{Procedimientos de construcción de información: técnicas, dispositivos metodológicos e instrumentos.}

La construcción de información se ha dado desde diferentes enfoques que complementan lo que para nosotras significa la etnografía activista. Por una parte está la que podríamos llamar documentalista que consta de herramientas organizadas a partir de la observación militante. Entre otras se encuentra el diario de campo, fuentes virtuales y los documentos escritos y visuales. Por otro lado, nos encontramos con el proceso de construcción de información colaborativo que se pone en marcha a partir de las sesiones con el grupo asesor. Finalmente, está el proceso de construcción narrativo bajo el trabajo con entrevistas biográficas asociativas con las participantes.

La estrategia de utilizar diferentes técnicas de construcción de la información es una apuesta por una triangulación multifactorial propia de la investigación etnográfica que supone una garantía para evitar la baja fiabilidad que se puede derivar de la observación pura (Angrosino, 
2012:89). El conjunto de técnicas de construcción de la información se relaciona a continuación (tabla 16) con los dispositivos metodológicos y los instrumentos de registro utilizados para esta investigación.

Tabla 16. Conjunto de técnicas, dispositivos e instrumentos.

\begin{tabular}{|l|l|l|}
\hline \multicolumn{1}{|c|}{ Técnicas } & \multicolumn{1}{|c|}{ Dispositivos } & \multicolumn{1}{c|}{ Instrumentos } \\
\hline Observacional & $\begin{array}{l}\text { Diario de campo y fuentes } \\
\text { virtuales }\end{array}$ & Documento escrito \\
\hline Revisión documental & $\begin{array}{l}\text { Documentos escritos y } \\
\text { documentos visuales }\end{array}$ & $\begin{array}{l}\text { Archivos pdf y word, } \\
\text { videos y fotografías }\end{array}$ \\
\hline Biográfico-narrativa & $\begin{array}{l}\text { Entrevistas individuales y y } \\
\text { grupales }\end{array}$ & $\begin{array}{l}\text { Grabaciones de audio } \\
\text { (transcripciones) }\end{array}$ \\
\hline Participativa & $\begin{array}{l}\text { Grupo asesor y mapa de } \\
\text { relaciones }\end{array}$ & $\begin{array}{l}\text { Grabaciones de audio y } \\
\text { mural }\end{array}$ \\
\hline
\end{tabular}

Además se acompaña la leyenda (tabla 17) que identifica a los instrumentos utilizados con el código y su definición.

Tabla 17. Leyenda de codificaciones de dispositivos.

\begin{tabular}{|l|l|}
\hline Código & Definición \\
\hline DC & $\begin{array}{l}\text { Diario de campo del estudio de campo y de las tareas desempeñadas desde 2011 } \\
\text { en proyectos juveniles. }\end{array}$ \\
\hline FV & $\begin{array}{l}\text { Fuentes virtuales en donde se recogen todos los episodios relacionados con } \\
\text { plataformas virtuales como Facebook, twitter, blog, Instagram, whats app, } \\
\text { emails,... }\end{array}$ \\
\hline EI & $\begin{array}{l}\text { Entrevista individual con el objetivo de recoger información sobre el origen e } \\
\text { historia de Maranya. }\end{array}$ \\
\hline EG & $\begin{array}{l}\text { Entrevista grupal con el objetivo de recoger información sobre el origen e } \\
\text { historia de Maranya. }\end{array}$ \\
\hline PE & $\begin{array}{l}\text { Análisis documental de proyectos educativos de la Casa de Joventut La Maranya } \\
\text { que han sido redactados por el EAV para marcar la línea de trabajo en la } \\
\text { asociación. }\end{array}$ \\
\hline DM & Análisis documental de Documentos y actas generadas por Maranya. \\
\hline DF & $\begin{array}{l}\text { Análisis documental de Documentos de la FVCJ que contextualizan y enmarcan } \\
\text { el movimiento juvenil valenciano. }\end{array}$ \\
\hline NP & $\begin{array}{l}\text { Análisis documental de Noticias que salen en prensa en relación directa con la } \\
\text { Casa. }\end{array}$ \\
\hline Vd & Análisis de Videos elaborados por alguno de los grupos estables de Maranya. \\
\hline Ft & Fotografías elaboradas y seleccionadas por miembros de Maranya para completar \\
\hline
\end{tabular}




\begin{tabular}{|l|l|}
\hline Código & Definición \\
\hline MR & $\begin{array}{l}\text { Mapa de relaciones que muestra el tipo de relaciones que se dan dentro y fuera } \\
\text { de la asociación. }\end{array}$ \\
\hline GA & $\begin{array}{l}\text { Análisis de las Actas generadas en las reuniones del Grupo asesor de la } \\
\text { investigación que participa en el diseño y revisión del estudio. }\end{array}$ \\
\hline
\end{tabular}

La selección de los dispositivos ha variado en función del momento del estudio en el que nos encontrábamos. Primero se eligen todas aquellas que tienen que ver con el objetivo y la metodología etnográfica que vamos a utilizar en la investigación. Entre ellas se encuentra el diario de campo, las entrevistas, las fotografías y el mural de relaciones maranyeras. Con posterioridad, y gracias al trabajo llevado a cabo por el grupo asesor, se realiza una selección de los documentos imprescindibles para el estudio como podrían ser los proyectos de centro, subvenciones, documentos históricos de FVCJ, actas de asambleas y junta directiva, notas de prensa y vídeos y fotografías relacionadas con la línea del tiempo de la Casa y material virtual como el blog, Facebook, Twitter, Whats app e emails, entre otras. Un aspecto relevante de la investigación es que la propia marcha del proceso iba mostrando nuevas formas de recoger los datos que resultaban importantes debido a diferentes decisiones tomadas por el colectivo. Por ello, las técnicas e instrumentos se iban reconstruyendo sobre el proceso en función de las necesidades y las decisiones adoptadas por el grupo. En la siguiente tabla (tabla 18) vemos la temporalización de cada una de ellas.

Tabla 18. Tiempos de registro de los dispositivos utilizados.

\begin{tabular}{|l|c|c|c|c|c|c|c|}
\hline & Anterior & 2011 & 2012 & 2013 & 2014 & 2014 & 2016 \\
\hline Diario de campo & & $\mathrm{x}$ & $\mathrm{x}$ & $\mathrm{x}$ & $\mathrm{x}$ & $\mathrm{x}$ & $\mathrm{x}$ \\
\hline Entrevistas & & & & & $\mathrm{x}$ & $\mathrm{x}$ & $\mathrm{x}$ \\
\hline Proyectos educativos & & $\mathrm{x}$ & $\mathrm{x}$ & $\mathrm{x}$ & $\mathrm{x}$ & $\mathrm{x}$ & $\mathrm{x}$ \\
\hline Documentos Maranya & $\mathrm{x}$ & $\mathrm{x}$ & $\mathrm{x}$ & $\mathrm{x}$ & $\mathrm{x}$ & $\mathrm{x}$ & $\mathrm{x}$ \\
\hline Documentos FVCJ & $\mathrm{x}$ & $\mathrm{x}$ & $\mathrm{x}$ & $\mathrm{x}$ & $\mathrm{x}$ & $\mathrm{x}$ & $\mathrm{x}$ \\
\hline Noticias prensa & & $\mathrm{x}$ & $\mathrm{x}$ & $\mathrm{x}$ & $\mathrm{x}$ & $\mathrm{x}$ & $\mathrm{x}$ \\
\hline Videos & & $\mathrm{x}$ & $\mathrm{x}$ & $\mathrm{x}$ & $\mathrm{x}$ & $\mathrm{x}$ & $\mathrm{x}$ \\
\hline Fotografías & $\mathrm{x}$ & $\mathrm{x}$ & $\mathrm{x}$ & $\mathrm{x}$ & $\mathrm{x}$ & $\mathrm{x}$ & $\mathrm{x}$ \\
\hline Mapa de relaciones & & & & & $\mathrm{x}$ & $\mathrm{x}$ & $\mathrm{x}$ \\
\hline
\end{tabular}




\begin{tabular}{|l|c|c|c|c|c|c|c|}
\hline & Anterior & 2011 & 2012 & 2013 & 2014 & 2014 & 2016 \\
\hline Grupo asesor & & & & & $x$ & $x$ & $x$ \\
\hline
\end{tabular}

Con todas ellas recogemos una variedad de datos importantes para conformar el proceso de investigación. De este modo, disponemos de múltiples fuentes con las que tenemos una visión retrospectiva del estudio manteniendo la riqueza de situaciones, experiencias, momentos y contextos que hemos vivido. Además nos ofrece la oportunidad de analizarlo, ampliarlo y cruzarlo con otras experiencias que puedan extender el estudio sirviéndonos para mejorar una praxis social y educativa como la que se presenta. 


\subsubsection{La construcción de la información documental: la observación y el análisis documental.}

En este subapartado voy a describir que técnicas he utilizado para construir la información de base documental. Describiendo qué entiendo por análisis documental y posicionándome respecto a la técnica de observación y los instrumentos que hemos utilizado para llevarla a cabo de un modo etnográfico.

\subsubsection{El análisis documental.}

La otra técnica que hemos utilizado para la construcción documental es el análisis de documentos. Esta técnica se ha consolidado como fundamental en la investigación cualitativa y es una herramienta básica en las etnografías. Concretamente en etnografía es llamada también observación documental (Pujades, 2010) al derivarse de la selección de documentos escritos o visuales a partir de la observación del contexto a estudiar. Por ello su relación directa en este apartado con lo que viene siendo la técnica principal, la observación.

\subsubsection{La observación dentro de la investigación militante.}

Angrosino (2012) se cuestiona la objetividad en la observación y se pregunta si se puede describir las culturas estudiadas sin que la etnógrafa forme parte de la acción.

No existe fe más engañosa que una convicción personal
indiscutida de que el testimonio aparente proveniente de
nuestros ojos debe proporcionar un relato puramente objetivo
que casi no requiera de ningún tipo de validación más allá de la
afirmación en sí misma. La observación completamente objetiva
debe considerarse un mito primario y un tabú de la ciencia,
puesto que sólo podemos ver aquello que se adecua a nuestro
espacio mental y que toda descripción requiere de una
interpretación, así como de un informe sensorial (Gould,
1998:72 en Angrosino, 2012:229).

Actualmente, el rol de la investigadora se transforma y se convierte en la observación de un contexto en el que desarrollarse alejándose de la definición tradicional y posicionándose en un espacio activo y personal. Los presupuestos actuales dentro de la observación mantienen que las 
etnógrafas (investigadoras) forman parte como miembros de las comunidades que se estudian y ya se acepta que debido a las diferentes visiones y voces que se pueden dar en un estudio con estas características nunca se llegará a la «verdad etnográfica». De este modo, se reconoce un cambio en el posicionamiento observacional tradicional moviéndonos hacia observaciones más comprometidas y críticas.

Son conocidas las cuatro variantes de la observación (Junker, 1960 citado en Hammersley \& Atkinson, 2001) que dependen de la implicación de la investigadora, entre ellas: participante completo, participante como observador, observador como participante y observador completo. Consideramos que la etnografía crítica no se ha de quedar en una mera observación participante sino que ha de dar un paso más y situarse como participante completa. La investigadora forma parte del grupo a investigar, se vuelve miembro en pleno derecho y la observación se convierte en una herramienta que se utiliza de manera transversal al ritmo de la actividad asociativa. Utilizamos la observación dentro de la investigación militante como método en la construcción de información como ocurre en estudios con Investigación Acción Participativa. En ella la investigadora forma parte, pertenece al contexto en el que se investiga y no simplemente participa de dicho contexto. La investigadora permanece fiel al espacio, comprometiéndose con el movimiento asociativo y las acciones que desde él se llevan a cabo. Así se va definiendo la figura del investigador militante. Las condiciones en las que se trabaja son las que genera el propio colectivo y no las promovidas por la investigadora.

El resto de observaciones conllevan connotaciones expertas en las que la investigadora se sitúa, en el plano de la observación, sobre las participantes de su propio contexto de investigación y no al lado como promueve nuestra investigación. Asimismo, en el resto de observaciones se presupone una distancia de la investigadora con el contexto para favorecer la objetividad de la información. En cambio, nuestro rol activista nos permite formar parte del proceso como una persona más dentro del movimiento, asumiendo fórmulas más comprometidas y horizontales.

Ya avanzamos que en nuestro caso la participación completa y su consiguiente proceso de observación surge de la propia voluntad del colectivo. El grupo visibiliza la necesidad de que la investigadora forme 
parte activa del contexto. A este interés se le suma el posicionamiento ético de la investigadora lo que hace que desemboque en el ejercicio de un rol activista dentro de la asociación. De este modo la observación se convierte en militante y con ella se recoge la vida de la Casa desde una mirada interna y constructiva a partir del trabajo colectivo.

La observación permite obtener datos biográficos interesantes para el relato de vida del colectivo (Alberich, Bretones y Ros 2013). Por ello, el objetivo que nos marcamos para construir la información documental es reflejar, a partir de una serie de documentos, la vida interna de la asociación. Su finalidad de describir y explicar la forma de vida y los significados culturales que se le dan a la participación en la propia Casa de Joventut La Maranya. Para ello seguimos una serie de principios que dan forma a mi rol como investigadora militante:

- Sentirse parte del Equipo de Animadoras Voluntarias de la Casa de Joventut La Maranya.

- Participar en el desarrollo de las actividades.

- Asumir responsabilidades dentro del Equipo.

- Hacer sabedor al colectivo de la necesidad de documentar el día a día de la Casa.

- Presentarme como activista y no como investigadora.

- Preservar el anonimato en las notas de campo aún firmado el consentimiento informado.

- Comprender el contexto histórico, social, político y económico del municipio y del colectivo.

- Reivindicar un proceso de investigación transparente.

- Compartir perspectivas con el colectivo dotando a la investigación de espacios reflexivos.

- Favorecer un quehacer flexible en el proceso.

- Hacer visible el respeto hacia el colectivo y el trabajo de las compañeras. 


\subsubsection{Nuestras herramientas}

Para llevar a cabo este trabajo se decide utilizar una serie de instrumentos que faciliten la construcción de la información de una manera fiable, válida y contrastada. Para ello utilizamos instrumentos clásicos de la etnografía y la observación como puede ser el diario de campo. Además de otros que complementan y contrastan la información como pueden ser las fuentes virtuales y las fuentes documentales escritas y visuales. A continuación pasamos a describir en detalle cada una de ellas.

\subsection{Diario de campo}

Es el instrumento principal de cualquier etnografía. En él narramos los acontecimientos que hemos ido viviendo a lo largo de toda nuestra investigación y será el modo en el que, con el tiempo, podremos retornar sobre la memoria de lo que ocurrió. Según Adolfo Estalella (2015) «el etnógrafo no genera las condiciones específicas para la producción de datos sino que toma parte en la vida cotidiana de aquellas a quienes pretende comprender». Por esta razón precisa de una herramienta singular que permita recoger la información de dicha vida cotidiana. Con este fin utilizaremos el diario de campo.

Hablamos de que la técnica utilizada para generar el diario de campo es la observación como participante completa. Este diario recogerá mi propia experiencia como activista / militante dentro de la Casa de Joventut La Maranya. En él diferenciamos hasta tres niveles de registro: uno descriptivo, otro analítico y otro reflexivo. Así, detallo lo que veo, describiendo espacios, personas, cosas, diálogos y acciones, narrando acontecimientos y relacionando teorías y experiencias vinculantes. A todo esto le sumamos la descripción de cómo surge la investigación. El inicio de este diario de campo data del 2013 cuando comienzo a indagar en la idea de investigar sobre los procesos de participación juvenil. Esta herramienta se convierte en el espacio donde narro mis ideas, miedos, bloqueos, decisiones y relaciones con el contexto que deseo investigar. Todo ello, posibilita el dar cuenta del proceso de aprendizaje que produce el propio contexto social de investigación durante un período de tiempo concreto como es el de este estudio. 
En el procedimiento para escribir el diario de campo utilizamos los formatos de registro que describe Estalella (2015). Por un lado, notas al vuelo en papel que nos ayudan a no interferir excesivamente en el contexto, por otro lado notas de campo elaboradas que se registran informáticamente al finalizar el día y que son mucho más descriptivas y narrativas, y para finalizar registros de transcripciones de ciertos diálogos que se dan en el día a día (tabla 19). Tal y como ocurre en los textos de Diego Torrente (1997) las notas de campo se convierten en el material que da base al diario. Es un proceso que persigue la mayor naturalidad en el contexto y en la propia interacción de la investigadora con la comunidad a la que pertenece (García-Jorba, 2000) y en esta justificación reside el uso de las notas para configurar el diario de campo.

Tabla 19. Tipología de notas.

\begin{tabular}{|c|c|c|}
\hline Tipo de nota & Fecha & Fragmento \\
\hline $\begin{array}{l}\text { Notas } \\
\text { campo }\end{array}$ & $\begin{array}{ll}\text { Lunes, } 28 & \text { de } \\
\text { octubre } & \text { de } \\
2013 & \end{array}$ & $\begin{array}{l}\text { «Me pongo a escribir en el diario porque ya estoy } \\
\text { cansada de escuchar en los medios de } \\
\text { comunicación y en las conversaciones en la calle } \\
\text { que las jóvenes están perdidas. Es desesperante } \\
\text { que se piense que no tienen conciencia social, } \\
\text { que son egoístas y no piensan en los demás. Hay } \\
\text { muchos grupos de jóvenes que impulsan la } \\
\text { transformación social ¿qué es lo que hacen estas } \\
\text { jóvenes que se alejan de los prejuicios sociales?, } \\
\text { ¿ómo actúan y desde qué lugares? Parece que } \\
\text { desde esta necesidad puedo comenzar a hilar mi } \\
\text { problema de investigación...» }\end{array}$ \\
\hline Notas al vuelo & $\begin{array}{ll}\text { Domingo, } & 13 \\
\text { de Abril de } \\
2014\end{array}$ & $\begin{array}{l}\text { «Fil històric» división en mesas: } \\
\text { - Quelcom }(1996) \\
\text { - Esplai Cataflai (2006...) } \\
\text { - Casal }(2009 \ldots) \\
\text { - Maranya }(2011,2012,2013) \\
\text { Conversaciones con las jóvenes de Mislata. } \\
\text { Mañana tengo que realizar propuesta de tesis en el } \\
\text { plenario de jóvenes (hora 19h30). }\end{array}$ \\
\hline $\begin{array}{l}\text { Transcripción } \\
\text { de } \\
\text { conversaciones }\end{array}$ & $\begin{array}{l}\text { Lunes , } 5 \text { de } \\
\text { Mayo de } 2014\end{array}$ & $\begin{array}{l}\text { Momentos antes del plenario mensual: } \\
\text { A: «Si veus que la sessió es plena d'adults podries } \\
\text { portar-t’els a prendre una cervesseta» } \\
\text { B: «I quina és la raó? } \\
\text { A: «Doncs que pensem que és un moment per als } \\
\text { joves i si es plena d'adults sabem que els costa } \\
\text { participar. Si hi ha poquets parlen, però si són massa } \\
\text { monopolitzen els diàlegs i es tallen alhora de dir algo». }\end{array}$ \\
\hline
\end{tabular}




\subsection{Fuentes virtuales.}

El uso y la importancia de las tecnologías, internet y las redes sociales, entre otros aspectos, en el activismo social y más en colectivos juveniles, hacen que tengamos que elaborar nuevas herramientas para poder organizar la información derivada de estos dispositivos. Esto se plantea como un reto futuro pero no se encuentra dentro de los objetivos de este estudio.

A lo largo de esta investigación han sido muchas las fuentes de información procedentes de la plataforma virtual que se han utilizado en la Casa. Por ello, a continuación dejamos una muestra (Tabla 20) de cuales son tales dispositivos, sus direcciones y el año de su creación. Esto no implica que en el análisis de los datos utilicemos todas estas fuentes, es más de ellas únicamente trabajaremos sobre aquella información que puede ayudarnos a contrastar algunos aspectos recogidos por otras vías. Entendemos que con la cantidad de información virtual que existe bien podría hacerse una tesis doctoral paralela analizando el uso de las herramientas virtuales y el impacto que provoca en la participación juvenil de la Casa de Joventut La Maranya. Esto se convierte en un criterio fundamental a la hora de analizar la cultura de participación juvenil pero por cuestiones de espacio y tiempo no se llevará a cabo dicho análisis en esta tesis aunque admitimos que dejamos una vía abierta que bien puede estudiarse con posterioridad.

Tabla 20. Dispositivos virtuales.

\begin{tabular}{|l|l|l|}
\hline \multicolumn{1}{|c|}{ Dispositivo } & \multicolumn{1}{|c|}{ Dirección / url } & Desde \\
\hline Flickr & $\begin{array}{l}\text { https://www.flickr.com/photos/133462917@NN04/pag } \\
\text { el }\end{array}$ & 2015 \\
\hline Google + & $\begin{array}{l}\text { https://plus.google.com/104569609385365056664/pos } \\
\underline{\text { ts }}\end{array}$ & 2013 \\
\hline Instagram & $\underline{\text { https://instagram.com/lamaranya/ }}$ & 2013 \\
\hline Blog & $\underline{\text { http://blog.lamaranya.org }}$ & 2013 \\
\hline Facebook & $\underline{\text { https://www.facebook.com/cjlamaranya? rdr=p }}$ & 2011 \\
\hline Twitter & $\underline{\text { https://twitter.com/lamaranya }}$ & 2011 \\
\hline YouTube & $\underline{\text { https://www.youtube.com/user/LaMaranya/videos }}$ & 2011 \\
& $\underline{\underline{\text { https://www.youtube.com/channel/UCF36317aAsdolYhk4 }}}$ & 2013 \\
\hline$\underline{3 T \text { TwiA }}$ & & 2013 \\
\hline
\end{tabular}




\begin{tabular}{|l|l|l|}
\hline \multicolumn{1}{|c|}{ Dispositivo } & \multicolumn{1}{|c|}{ Dirección / url } & Desde \\
\hline $\begin{array}{l}\text { Correos } \\
\text { electrónicos }\end{array}$ & $\begin{array}{l}\text { eavmaranya@googlegroups.com } \\
\text { info@,lamaranya.org }\end{array}$ & \\
\hline Grupos de Jer(Cases de Castelló) & \\
WhatsApp & Les cracks de la neteja & 2015 \\
& Maranya 15 & 2015 \\
& Escola de Cases & 2014 \\
& Que fem? Animadors Adults & 2014 \\
& Sirenitas & 2014 \\
& Entrevista grup ex-activistas & 2014 \\
& Entrevista grup activistes & 2014 \\
& Entrevista grup animadors & 2014 \\
& EAV Centre La Maranya & 2014 \\
& Assemblea Virtual Maranya & 2013 \\
& Perduts pel món & 2013 \\
& 2013 \\
\hline
\end{tabular}

\subsection{Fuentes documentales escritas}

Para complementar el relato procedente de las entrevistas, los diarios y los medios visuales recuperamos todos aquellos documentos que nos supusieron una fuente de información bien por ser anterior al acceso al campo o bien por elaborarse durante el mismo (tabla 21). Toda esta información nos permite describir la situación de la Casa de Joventut La Maranya a través de todos aquellos documentos que han sido elaborados por las personas que forman parte de esta asociación y/o movimientos con relación directa con ella. Por ello, estos documentos se determinan como unidades de análisis que establecen una relación directa o causal con el estudio.

Entre los documentos objeto de análisis se encuentran:

Tabla 21. Documentos de interés.

\begin{tabular}{|c|c|c|c|c|}
\hline $\begin{array}{l}\text { Proyectos } \\
\text { educativos }\end{array}$ & $\begin{array}{c}\text { Actas } \\
\text { Asambleas }\end{array}$ & $\begin{array}{c}\text { Actas junta } \\
\text { directiva }\end{array}$ & $\begin{array}{c}\text { Documentos } \\
\text { FVCJ }\end{array}$ & $\begin{array}{l}\text { Noticias } \\
\text { prensa }\end{array}$ \\
\hline Centro & 2011 & 2011 & $\begin{array}{l}\text { Revista } \\
\text { antigua }\end{array}$ & $\begin{array}{l}\text { Casal Jove } \\
\text { sense joves }\end{array}$ \\
\hline Subvenciones & 2012 & 2012 & Revista actual & Nuevo local \\
\hline Esplai & 2013 & 2013 & $\begin{array}{l}\text { Instrucciones } \\
\text { CJ }\end{array}$ & $\begin{array}{l}\text { Esplai Cataflai } \\
\text { Setembre }\end{array}$ \\
\hline $\begin{array}{l}\text { Puc tocar la } \\
\text { lluna }\end{array}$ & 2014 & 2014 & $\begin{array}{l}\text { Propuestas } \\
\text { MLPV }\end{array}$ & $\begin{array}{ll}\text { Permisos } & y \\
\text { licencias } & \end{array}$ \\
\hline $\begin{array}{l}\text { Recrea la tena } \\
\text { ciutat }\end{array}$ & & & & $\begin{array}{l}\text { Ayuntamiento } \\
\text { demandas }\end{array}$ \\
\hline Teatre Europeu & & & Presupuestos & Colaboración \\
\hline
\end{tabular}




\begin{tabular}{|c|c|c|c|c|}
\hline $\begin{array}{l}\text { Proyectos } \\
\text { educativos }\end{array}$ & $\begin{array}{c}\text { Actas } \\
\text { Asambleas }\end{array}$ & $\begin{array}{c}\text { Actas junta } \\
\text { directiva }\end{array}$ & $\begin{array}{c}\text { Documentos } \\
\text { FVCJ }\end{array}$ & $\begin{array}{l}\text { Noticias } \\
\text { prensa }\end{array}$ \\
\hline & & & asociaciones & vecinal \\
\hline $\begin{array}{l}\text { Activisme al } \\
\text { L'IES }\end{array}$ & & & & $\begin{array}{l}\text { Aniversario } \\
\text { Maranya }\end{array}$ \\
\hline $\begin{array}{l}\text { Información } \\
\text { para la acción }\end{array}$ & & & $\begin{array}{l}\text { Retos } \\
\text { asociativos }\end{array}$ & $\begin{array}{l}\text { Encuentros, } \\
\text { coloquios, }\end{array}$ \\
\hline $\begin{array}{l}\text { Arrela Vila- } \\
\text { real }\end{array}$ & & & & Igualdad \\
\hline Art a l'abast & & & $\begin{array}{l}\text { Historia } \\
\text { Federació }\end{array}$ & $\begin{array}{l}\text { Ocio } \\
\text { nocturno }\end{array}$ \\
\hline Fem Xarxa & & & & $\begin{array}{l}\text { Creación } \\
\text { ACJCS }\end{array}$ \\
\hline La plaça roja & 2015 & 2015 & $\begin{array}{l}\text { Características } \\
\text { movimiento } \\
\text { asociativo de } \\
\text { la comarca }\end{array}$ & $\begin{array}{l}\text { Alternativa de } \\
\text { ocio }\end{array}$ \\
\hline $\begin{array}{l}\text { Tutoria entre } \\
\text { iguals }\end{array}$ & 2016 & 2016 & $\begin{array}{l}\text { Funciones } \\
\text { asociaciones }\end{array}$ & Formación \\
\hline
\end{tabular}

\subsection{Fuentes documentales visuales.}

Existen documentos visuales que complementan la línea vital de la Casa de Joventut La Maranya y que nos posibilitan el análisis de los acontecimientos clave en la vida de la asociación. Principalmente tenemos dos:

1. Els portadors de somnis. Video documental sobre la expulsión de las asociaciones juveniles del Casal Jove de Benicàssim por parte del ayuntamiento. Dentro de las acciones llevadas a cabo por la acción Casal Jove sense Joves dónde se reivindica el triunfo de la alegría por encima del abuso de poder y dónde las portadoras de sueños se van con la alegría a otro lado. Producido por La Maranya con la colaboración de Mel de Romer Col-lectiu Audiovisual con una duración aproximada de treinta minutos y presentado a finales del 2011.

2. Descobrint les nostres arrels. Actividad que dio paso a la elaboración del hilo histórico de la Casa de Joventut La Maranya a partir de documentos, fotografías y otros objetos simbólicos para las personas que forman parte de la asociación. Utilizamos estas fotografías para documentar la historia de Maranya integrando las actividades propuestas y encabezadas por el EAV en la Casa. 


\subsubsection{La construcción de la información colaborativa: un grupo asesor en un estudio etnográfico.}

A continuación abordamos las herramientas utilizadas desde un punto de vista colaborativo. De qué forma hemos construido esta información a través de la colaboración con el grupo asesor y las dinámicas de participación.

\subsubsection{La investigación colaborativa.}

De forma directa nuestra ética como investigadoras hace que el enfoque desde el cual partimos para realizar investigación hable de inclusión, participación ciudadana, construcción conjunta de conocimiento, pluralidad de voces y activismo entre muchas otras cosas. Por ello, debemos buscar dispositivos metodológicos que favorezcan dicho enfoque con la finalidad de enriquecer y construir discurso grupal. Estos se convertirán en estrategias clave de apropiación de la información que favorece el empoderamiento de las personas y atiende a valores de justicia social.

\subsubsection{Objetivos y principios.}

De acuerdo con los planteamientos de esta etnografía crítica queremos realizar la investigación enredando al mayor número de personas posibles bajo principios de colaboración y diálogo. Nos marcamos como meta el conseguir una investigación transparente y que adquiera sentido y cobre vida en el propio colectivo a estudiar. Nuestro pilar es el activismo y para conseguir que la investigación se convierta en un dispositivo social activista y político debemos favorecer espacios y encontrar necesidades en el grupo con el que vamos a investigar.

\subsubsection{Nuestras herramientas.}

Para conseguir este objetivo debemos comenzar a pensar en herramientas que nos ayuden a dinamizar una investigación mucho más participativa, transparente y vinculada a la realidad que nos ocupa. Para hacerlo emplearemos alguna dinámica de participación y también espacios sociales de colaboración. A continuación pasamos a describir en detalle cada una de ellas. 


\subsection{Dinámica participativa: Mapeo relacional.}

La introducción de técnicas de análisis dinámicas y visualmente atractivas en un contexto de animación sociocultural se convierte en un aspecto importante en la investigación. Es relevante analizar la redes que se producen hacia el interior y el exterior de la Casa y para conseguirlo realizamos un mapa de relaciones de todas las personas participantes en las entrevistas, las personas que configuran el grupo asesor y cualquier otra persona que estos dos colectivos considera interesante. De este modo podemos ver de manera gráfica qué relaciones existen en la Casa y cómo se configura el tejido grupal con el territorio.

Los pasos a seguir para realizar la actividad son los siguientes:

I. Al finalizar las entrevistas, se les lanza la siguiente pregunta: $¿$ Dónde ubicas a Maranya en el territorio? ¿ ¿Dónde te ubicas tú dentro de Maranya?

II. La persona, con una fotografía suya que se le ha pedido con anterioridad, se ha de acercar al mural y en él ha de coger un hilo de color y ha de unirse con él a las personas, espacios, colectivos, etc. que considere relevantes en su relación con el territorio y con Maranya.

III. Si la persona considera necesario, ha de introducir en el mural a través de un papel con el nombre, a todas aquellas personas, espacios, colectivos, etc. que aún no aparezcan en el mural y sean significativos en sus relaciones.

IV. En una sesión de grupo exponemos que tipo de relaciones son las que se representan diferenciándolas entre fuertes, débiles o en conflicto. Así se convierte en una herramienta útil para la reflexión del propio grupo.

Alrededor de 50 personas pasan por el mural para plasmar sus relaciones con Maranya y de esta con otros agentes externos. Toda la información recogida en esta red es útil para guiar las relaciones que aparecen a lo largo de la Historia de Maranya. Ayuda a que la persona se sitúe y coja conciencia del espacio que ocupa y además favorece la cercanía entre investigadora y entrevistada. 


\subsection{Grupo Asesor.}

El grupo asesor está formado por un equipo de personas relacionadas con la temática o el caso a abordar en una investigación. En nuestro estudio, debido al enfoque participativo de la misma, buscamos una representación de personas vinculadas con la participación juvenil, concretamente dentro de la Red de Casas de Juventud de la Comunidad Valenciana. Estas personas nos brindan la oportunidad de contrastar la información que allí se expone y trabaja para así acercarla a la muestra. Queremos saber, desde el punto de vista del movimiento juvenil, cómo se analiza todo lo que se aborda en la investigación y que en función de los propios intereses de las participantes dentro del movimiento juvenil se debatan las propuestas. Para ello, contamos con una red de personas que forman parte de Maranya de diferentes formas y que además, se han mostrado partidarias para seguir de cerca la investigación propuesta.

De forma concreta, la función que compartimos es la de analizar de forma colaborativa y crítica el proceso de investigación en las diferentes fases del estudio tomando decisiones en lo relacionado con el diseño y la aplicación de instrumentos, análisis de datos, interpretación de los mismos y formulación de conclusiones a lo largo del estudio (Pallisera, Fullana, Martín, Puyaltó y Vilà, 2013).

Debemos evitar que el grupo asesor se convierta en una réplica de los argumentos que la investigadora da, queremos debate, reflexión y nuevas propuestas procedentes de las propias participantes. En este mismo sentido valoramos la riqueza que puede aportar mi papel como investigadora en el grupo y por ello, ninguna de las personas que forman parte del grupo asesor abandona su rol dentro del movimiento ya sea este, activista, usuario o investigador, entre muchos otros. Mi papel está dentro de la estructura y la finalidad es conseguir dinamizar un espacio dónde la cercanía con el colectivo, la diversidad y pluralidad de voces se haga patente en el trabajo del grupo asesor.

La elección de personas que forman parte de este grupo la realizo junto con el Equipo de Animadoras Voluntarias de la Casa. A partir de todos aquellos datos que se han recabado hasta este momento y la perspectiva del EAV, se seleccionan personas que mantienen un papel estable dentro de la asociación y que tienen una visión a largo plazo de la acción que debe 
desempeñar Maranya. Todas tienen un papel destacable en la estructura organizativa del movimiento juvenil en Benicàssim.

La agrupación está compuesta por siete núcleos formados por las personas que pueden verse en la tabla 22. Todo el grupo asume que la persona que coordina el grupo es la doctoranda. Yo soy quien organiza la información a trabajar en cada una de las sesiones, elaboro el orden del día y lo envío al grupo por si quieren realizar aportaciones. Asumo este papel como investigadora y activista ya que la investigación se convierte en mi principal propuesta de acción dentro de la Casa.

Tabla 22. Participantes del grupo asesor.

\begin{tabular}{|l|l|}
\hline Núcleo & Participante \\
\hline $\begin{array}{l}\text { Externas a Maranya pero con vinculación a la FVCJ Escola de } \\
\text { Escola de Cases }\end{array}$ & Julio Huerta \\
\hline Promotores del EAV de la Casa de Joventut La Maranya & $\begin{array}{l}\text { Virginia Morales } \\
\text { Víctor Escoín }\end{array}$ \\
\hline Animadoras Voluntarias & Mireia Beltrán \\
\hline Miembro Junta Directiva & Noel Tomás \\
\hline Socio y Activista del grupo Adultos de la Casa de Joventut La Maranya & Armand Congost \\
\hline Directoras de tesis & $\begin{array}{l}\text { Lidón Moliner } \\
\text { Joan Traver }\end{array}$ \\
\hline Doctoranda & Arecia Aguirre \\
\hline
\end{tabular}

Una vez seleccionadas las personas participantes, se comparte con las directoras de tesis y empiezo a contactar con cada una de ellas de forma individual para describirles la intención de formar este grupo, exponerles la finalidad de la misma y preguntarles sobre su disponibilidad para participar en ella. Una vez conseguidos todos los vistos buenos de cada una, envío un email (anexo 3) para comenzar a trabajar. En él adjunto la carta de participación (anexo 4), el consentimiento informado (anexo 5) y el protocolo del grupo asesor (anexo 6). En este último hago un resumen remarcando el objetivo de la investigación, el tipo de metodología a utilizar, la finalidad de la G.A en la investigación, el por qué contamos con ella, qué significado tiene y cómo participa en la investigación. Además se hace un resumen de la planificación de sesiones del grupo a lo largo de toda la 
investigación. A todo esto le sumamos un link YouTube ${ }^{29}$ con el video que realicé para presentar el estudio en el plenario de jóvenes y otro link Doodle para ver la disponibilidad del grupo y poder convocar la primera reunión.

El cronograma del grupo ha variado a lo largo de la investigación ya que, al igual que esta, tenía que adaptarse a los tiempos, espacios y procesos de cada una de las personas que participan de algún modo en el estudio. Se han llevado a cabo las tres sesiones propuestas inicialmente. Cada una ha tenido alrededor de dos horas de duración, aproximadamente, se han realizado en horarios acordados con todas las componentes en función de la disponibilidad de cada una y ha sido esencial el haberse leído y trabajado la documentación enviada con anterioridad a la red vía correo electrónico. En todas las sesiones se trabaja de manera dialógica, asumiendo un rol activo por parte de todas las personas que allí nos encontramos. Es importante diseñar estas sesiones como un espacio de colaboración y construcción compartida dando valor a los argumentos por encima de las relaciones de poder.

A continuación podemos ver los objetivos y las actividades desarrolladas en cada una de las sesiones además de ver las dos futuras sesiones que hay propuestas y que se llevarán a cabo después del depósito de la tesis.

Tabla 23. Cronograma del grupo asesor.

\begin{tabular}{|c|c|c|}
\hline Sesión (fecha) & Objetivo & Actividades \\
\hline Uno (09/2014) & $\begin{array}{l}\text { Realizar una primera } \\
\text { aproximación al estudio y sus } \\
\text { particularidades. } \\
\text { Conocer a las personas que } \\
\text { componen el grupo. }\end{array}$ & $\begin{array}{l}\text { - Presentaciones } \\
\text { - Exposición del proyecto de } \\
\text { investigación. } \\
\text { - Firma de consentimiento informado } \\
\text { - Trabajar cronograma y tareas a } \\
\text { realizar } \\
\text { - Exponer protocolo de entrevistas } \\
\text { - Selección de las participantes a } \\
\text { entrevistar } \\
\text { - Aportaciones y toma de decisiones } \\
\text { sobre el proceso de construcción del }\end{array}$ \\
\hline
\end{tabular}

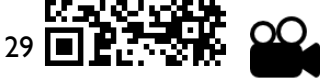




\begin{tabular}{|c|c|c|}
\hline Sesión (fecha) & Objetivo & Actividades \\
\hline & & $\begin{array}{l}\text { relato asociativo a partir de las } \\
\text { entrevistas }\end{array}$ \\
\hline Dos $(09 / 2015)$ & $\begin{array}{l}\text { Visibilizar la información } \\
\text { obtenida durante este tiempo. }\end{array}$ & $\begin{array}{l}\text {-Puesta en común de toda la } \\
\text { información recogida. } \\
\text {-Presentación de la carpeta drive. } \\
\text {-Puesta en común de la evolución de } \\
\text { las preguntas de investigación. } \\
\text {-Toma de decisiones sobre las } \\
\text { preguntas de investigación. } \\
\text { - Lluvia de ideas sobre producto final a } \\
\text { elaborar. } \\
\text {-Mostrar el cronograma de análisis. }\end{array}$ \\
\hline Tres (10/2016) & Compartir el relato & $\begin{array}{l}\text {.Lectura compartida del relato de vida } \\
\text {.Puesta en común del cierre académico } \\
\text { de la tesis } \\
\text {.Propuesta de presentación tesis de } \\
\text { manera pública. } \\
\text {.Puesta en común del protocolo de } \\
\text { defensa de tesis. } \\
\text { - Decisión sobre la difusión. } \\
\text {. Dudas y preguntas. } \\
\text {. Propuestas de futuro. }\end{array}$ \\
\hline Post depósito & Análisis colaborativo & $\begin{array}{l}\text { Lectura de tesis y análisis crítico entre } \\
\text { las participantes. } \\
\text {. Propuesta de modificaciones. } \\
\text {. Proponer grupos de discusión para } \\
\text { evaluar el proceso de tesis: } \\
\text { metodología y objetivos. }\end{array}$ \\
\hline Post depósito & $\begin{array}{l}\text { Planificación presentación tesis } \\
\text { en el centro }\end{array}$ & $\begin{array}{l}\text { Confeccionar el listado de asistentes. } \\
\text {. Reparto de tareas. } \\
\text {. Concreción de fecha. } \\
\text {. Comprar materiales. } \\
\text {. Otros. }\end{array}$ \\
\hline
\end{tabular}




\subsubsection{La construcción de información narrativa: técnica del relato biográfico cruzado.}

La investigación etnográfica intenta describir el estilo de vida de una sociedad o de un grupo de personas que viven en ella. Es necesario conocer su estructura, sus razonamientos, sus creencias,... y en definitiva, conocer su cultura, su forma de vida con la participación del grupo a investigar. Por ello, las entrevistas biográficas (Pujadas, 1992) son las herramientas más utilizadas, junto con la observación participante, en este tipo de investigación cualitativa. La entrevista ofrece al estudio la oportunidad de enriquecerse del diálogo y del intercambio de conocimiento gracias a la pluralidad de voces que participan en el proceso. El objetivo que abordamos con la realización de las entrevistas en profundidad, es conseguir el relato de vida de la asociación construido a partir de la diversidad de voces que participan en ella. De esta forma podremos contextualizar y analizar la Casa de Joventut La Maranya a partir de la información aportada por las participantes.

La finalidad de trabajar a partir del relato de vida viene motivado porque la persona nos ofrece el testimonio subjetivo de lo social desde su propia experiencia humana dentro del grupo y el análisis se realiza en primera persona. Además nos ayudará en la construcción de discurso grupal en la narración de la historia del grupo. En las entrevistas queremos conocer cómo y por qué nace Maranya, qué valores educativos tiene, cómo se participa en ella, cómo se enreda Maranya en el territorio, qué roles se dan, qué estrategias se utilizan, cómo se valora como espacio de aprendizaje, entre muchas otras cosas.

Por ello, a continuación vamos a describir nuestro posicionamiento dentro de la investigación biográfico narrativa, cual es nuestra elección dentro de las técnicas de construcción de una historia colectiva y finalizaremos con la descripción del proceso de construcción del relato de vida maranyero.

\subsubsection{Investigación biográfico narrativa (IBN).}

Para contextualizar la necesidad de utilizar técnicas específicas de la investigación biográfico narrativa en nuestro estudio queremos hacer un breve repaso a su historia, sus definiciones y usos. 
Hay quien marca los inicios de la IBN en la segunda mitad del s.XIX cuando etnógrafos estadounidenses se sumergen en las vidas indígenas más cercanas de su país. Aun así, existen autores (Bassi, 2014) que reclaman la inexactitud de esta afirmación ya que ni tan siquiera en el S.XIX las investigadoras «no coincidían en llamar método biográfico a ese conjunto de tradiciones». Es a partir de 1920, años dorados de la Escuela de Chicago cuando, de la mano de Thomas y Znaniecki con su obra The Polish Peasant, se fecha la aparición del método biográfico y se empieza a hablar de life history. Todo ello no sin haberse definido el método y el término como tal hasta unos años más tarde. Vemos como entre estas inexactitudes aparece el auge del positivismo, a la mayor parte de las investigaciones, y se abandona el trabajo biográfico. Es a partir de los años 70 y 80 cuando vuelve a irrumpir con fuerza en las ciencias sociales.

Actualmente, continua existiendo una gran controversia entre las diferentes formas de trabajar el método biográfico narrativo. Esto se debe al respaldo que ha tenido este método por parte de múltiples tradiciones académicas a nivel internacional, especialmente la francesa y la americana. Según Meneses y Cano (2008) ha provocado «cierta confusión terminológica y difícil delimitación conceptual». Por toda esta heterogeneidad metodológica y las múltiples tradiciones de origen se ha producido una «multiplicidad terminológica» (Bolívar y Domingo, 2006:5) entre historias, relatos, testimonios, biogramas e historia oral entre otras.

De forma popular, y a pesar de esta falta de consenso en las definiciones, es Denzin a quien se suele seguir para diferenciar los términos relato de vida (life story) e historia de vida (life history). El relato de vida se describe como la «narración biográfica de un sujeto» o «una historia de vida tal como la persona que la ha vivido la cuenta». En el caso de la historia de vida es «el estudio de caso referido a una persona que incluye su «relato biográfico» así como también «otro tipo de información» (Bassi Follari, 2014; Pujadas, (1992/2002:13).

Las diferentes definiciones relativas al relato de vida y a la historia de vida hacen que cada vez más se utilicen de manera particular en función de los objetivos concretos de la investigación. Meneses y Cano (2008) también coinciden con las definiciones anteriores delimitando el relato de vida y la historia de vida de la siguiente forma. Por ejemplo, si queremos que la 
historia tenga representatividad recogeremos un sustancial número de relatos que no perseguirán la lógica interna de una vida. A esta forma la llamamos relato de vida y se construye a partir de entrevistas biográficas que estarán focalizadas en recoger ciertos contenidos temáticos de la persona en cuestión. La información recogida podremos categorizarla para establecer las comparaciones oportunas.

Si en cambio queremos centrarnos en el relato de vida total de una persona llamaremos a esta forma Historia de Vida. Esta tipología narrativa se construye durante un período largo de tiempo en el que se emplean diferentes documentos y testimonios que contrasten la información recogida.

Por otro lado, podemos diferenciar historias de vida de caso único, paralelas o cruzadas:

- La historia de vida de caso único se compone por el relato de la trayectoria vital de una única persona.

- La historia de vida paralela analiza unidades sociales más amplias. Un ejemplo podría ser el estudio de una comunidad concreta mediante los relatos de sus miembros.

- La historia de vida cruzada estudia un tema común del que una serie de personas han sido protagonistas y observadoras. Para ello concurren los relatos de sus experiencias personales hacia dicho punto central de interés.

Por otro lado, Abel (1947) propone el término Biograma para referirse a «registros biográficos de carácter sucinto y que suponen la recopilación de una amplia muestra de biografías personales, a efectos comparativos» (Pujadas, 1992/2002: 14). Para acabar de centrar la terminología narrativa, no podemos olvidar la historia oral y el testimonio. Los historiadores usan el primer término para describir entrevistas en las cuales el foco no está puesto en los acontecimientos históricos en sí sino en el significado que esos acontecimientos tienen para quienes los han vivenciado (McMahan y Rogers, 1994; Thompson, 1978/2000; Chase, 2013). Por otro lado, el testimonio es un tipo de historia oral, historia de vida o relato de vida y de forma particular se define como una narrativa explícitamente política que describe y resiste la opresión. 
En definitiva, la narrativa es un modo de comprender las acciones propias y las de los demás, de organizar acontecimientos y objetos en un todo significativo y de relacionar y ver las consecuencias de las acciones y acontecimientos en el tiempo (Chase, 2013:69). En nuestro caso optamos por los relatos de vida pero asumiéndolos como proceso de análisis del colectivo, es decir, las narrativas biográficas son un medio de análisis del fenómeno social y no el objeto principal de la publicación.

Siguiendo con el debate en torno a las potencialidades y limitaciones del método vemos como diferentes autoras escriben sus propios listados sobre ellas. Siguiendo a Pujadas (1992/2002), resaltamos el breve repaso a las ventajas e inconvenientes que se dan cuando utilizamos los relatos de vida en la investigación. Utilizaremos las referencias de Pujadas ya que este recoge las que en 1958 exponían Thomas y Znaniecki, precursores de esta metodología en Sociología. En la siguiente tabla (tabla 24) se puede leer un resumen de las mismas junto a la respuesta que se le ha dado desde esta investigación a cada uno de los inconvenientes referidos.

Tabla 24. Ventajas e inconvenientes de las narrativas biográficas según Pujadas (1992) y propuesta en nuestro estudio.

\begin{tabular}{|l|l|l|}
\hline \multicolumn{1}{|c|}{ VENTAJAS } & INCONVENIENTES & \multicolumn{1}{|c|}{$\begin{array}{c}\text { Propuesta en nuestro } \\
\text { estudio }\end{array}$} \\
\hline $\begin{array}{l}\text { Facilita la formulación de } \\
\text { hipótesis iniciales }\end{array}$ & Obtener buenos informantes & $\begin{array}{l}\text { La selección de los } \\
\text { informantes a partir del } \\
\text { grupo asesor }\end{array}$ \\
\hline $\begin{array}{l}\text { Introduce en las relaciones } \\
\text { cercanas del grupo }\end{array}$ & $\begin{array}{l}\text { Completar los relatos } \\
\text { iniciados }\end{array}$ & $\begin{array}{l}\text { Disponer de tiempos y } \\
\text { espacios para hacerlo }\end{array}$ \\
\hline $\begin{array}{l}\text { Controla la información y } \\
\text { promueve } \\
\text { representatividad (Relatos de } \\
\text { vida cruzados) }\end{array}$ & $\begin{array}{l}\text { Controlar la información } \\
\text { obtenida }\end{array}$ & $\begin{array}{l}\text { Observación militante, } \\
\text { relatos biográficos cruzados }\end{array}$ \\
\hline $\begin{array}{l}\text { Da respuesta a preguntas } \\
\text { eventuales }\end{array}$ & $\begin{array}{l}\text { Pensar que el relato habla } \\
\text { por símismo }\end{array}$ & $\begin{array}{l}\text { Análisis en profundidad del } \\
\text { relato escrito }\end{array}$ \\
\hline $\begin{array}{l}\text { Produce un material valioso } \\
\text { para analizar el impacto de } \\
\text { las transformaciones en } \\
\text { estudios de cambio social }\end{array}$ & $\begin{array}{l}\text { Impaciencia del investigador } \\
\text { Envío con anterioridad a la } \\
\text { entrevista de la propuesta de } \\
\text { temas a tratar en la misma }\end{array}$ \\
\hline $\begin{array}{l}\text { Controla la visión etic y } \\
\text { macro, aportando una más } \\
\text { emic y micro }\end{array}$ & $\begin{array}{l}\text { Seducción del relato la } \\
\text { convierte en poco válida y y } \\
\text { fiable }\end{array}$ & $\begin{array}{l}\text { Criterios de validez y } \\
\text { criterios de representatividad }\end{array}$ \\
\hline Muestra la particularidad & Exceso de actitud crítica & \begin{tabular}{l} 
Observación y militancia en \\
\hline
\end{tabular}
\end{tabular}




\begin{tabular}{|l|l|l|}
\hline \multicolumn{1}{|c|}{ VENTAJAS } & \multicolumn{1}{|c|}{ INCONVENIENTES } & \multicolumn{1}{|c|}{$\begin{array}{c}\text { Propuesta en nuestro } \\
\text { estudio }\end{array}$} \\
\hline $\begin{array}{l}\text { Los relatos de vida paralelos } \\
\text { sustituyen a cualquier } \\
\text { encuesta }\end{array}$ & Fetichización del método & $\begin{array}{l}\text { Interacción con las } \\
\text { participantes, formar parte } \\
\text { de la vida del grupo }\end{array}$ \\
\hline $\begin{array}{l}\text { Eficacia en el control de los } \\
\text { resultados }\end{array}$ & $\begin{array}{l}\text { Gran cantidad de páginas } \\
\text { resultantes }\end{array}$ & $\begin{array}{l}\text { Transcurrir por un proceso } \\
\text { de duelo respecto a la } \\
\text { información }\end{array}$ \\
\hline $\begin{array}{l}\text { Ilustra de manera cercana la } \\
\text { publicación de los resultados }\end{array}$ & Forma de presentación poco \\
cuidada & $\begin{array}{l}\text { Relato de vida completo y } \\
\text { capítulo con el análisis y la } \\
\text { discusión generada por el } \\
\text { relato. }\end{array}$ \\
\hline
\end{tabular}

\subsubsection{Nuestra elección: relatos biográficos cruzados en la}

\section{Historia de La Maranya.}

Recuperamos una de las particularidades de este trabajo para encabezar este punto. La importancia de la diversidad de voces, la colectividad del grupo y la construcción conjunta de la historia hacen que la investigación se decante por elaborar la historia de vida del colectivo desde la polifonía de voces. Como remarcan Denzin y Lincoln (2013) «las historias colectivas pueden formar la base de un movimiento social». De este modo, los relatos colectivos se vuelven partes integrantes de los movimientos sociales (Davis, 2002) como el movimiento juvenil que nos ocupa. Son cada uno de los relatos recogidos los que conforman la historia global del grupo social, remarcando la importancia de la comunidad y la relación personal y social que se produce al elaborar de forma conjunta un relato de vida de la asociación (Alberich, Bretones y Ros, 2013). Necesitamos dar con una técnica que nos permita abordar el relato desde la diversidad de voces y con este propósito nos hemos basado en la Técnica de los relatos biográficos múltiples y en ella optamos por generar un relato biográfico cruzado de la Casa de Joventut La Maranya. Estos se caracterizan, según Zapata (2005) por ser «relatos de experiencias personales hacia un tema central», una situación concreta que haya vivenciado o fenómeno social en el que hayan participado. Algunas obras clásicas de este tipo de relatos son «Los hijos de Sánchez» de Oscar Lewis (1961), o en España «Cinquanta-quatre relats d'inmigració» de Jaume Botey (1981). 
La elección de esta tipología narrativa nos facilita la elaboración de memorias colectivas basadas en un contexto sociocultural específico. Alberich, Bretones y Ros (2013) nos remarcan como en ellas «prevalece la evidencia del testimonio personal». En esta investigación también prevalece esa mirada personal pero no desde la individualidad sino para configurar lo que es colectivo.

\subsubsection{Proceso de construcción del relato de vida maranyero.}

Bertaux (2005) define las funciones que tienen las historias de vida. A partir de ellas se construye el proceso de elaboración del relato ya que estructuran de un modo u otro las fases por las que el relato transita. Las funciones son las siguientes:

- Exploratoria, las historias de vida nos facilitan el sondeo de un tema en los inicios de una investigación, nos ayudan a entrar en el campo y a realizar el primer contacto con el colectivo.

- Analítica, con ellas teorizamos basándonos, además, en la observación que se realiza sobre la vida de las personas que participan en el estudio.

- Expresiva, para finalizar nos ofrece la oportunidad de ilustrar de una forma cercana y personal los resultados de una investigación.

A lo largo del siguiente punto abordaremos, cómo se ha utilizado esta técnica en la investigación que nos ocupa, hablaremos de cuál ha sido el propósito que la ha impulsado, qué temas se abordan, cómo se han seleccionado las participantes, cómo se han planificado y llevado a cabo las entrevistas, de qué forma se ha analizado la información y cuál ha sido el modo de devolver la información al colectivo, entre otras cosas. Entre líneas podremos descubrir cómo las funciones de Bertraux van apareciendo a lo largo de todo el proceso.

\section{narrativa. \\ 3.5.3.4 Propósito y principios en la construcción biográfico-}

Se puede decir que con el estudio del relato de vida cruzado de la asociación pretendemos indagar en el sentido que se le da a la aparición de 
una Casa de Joventut como La Maranya en el municipio de Benicàssim, abordando el papel que cubre como agente educativo de transformación social entre las jóvenes de dicha población. De esta forma, analizaremos el sentido que le dan las participantes a esta asociación y el interés que todo ello comporta en su cultura de participación juvenil. La novedad es la de generar un relato de vida de una asociación, y no relatos independientes, creando a partir de polifonía de voces un relato con entidad propia de la asociación.

Para poder llevarlo a cabo partimos de unos principios basados en el compromiso social y profesional con el activismo juvenil. Nuestro modo de entender la investigación provoca que el conocimiento se construya desde la polifonía de voces. De este modo contribuimos a que se produzca la liberación del conocimiento desde la propia voz de la ciudadanía favoreciendo un discurso que promueva la justicia social respecto a un colectivo marginado como el juvenil. En definitiva, creamos conocimiento basándonos en el conocimiento local tejido sobre el diálogo.

De esta forma, como tema principal a abordar en las diferentes entrevistas está el origen del movimiento juvenil que desemboca en el arranque de la Casa de Joventut La Maranya, su historia personal y el valor que se le da por las participantes a esta experiencia.

\subsubsection{Planificación de las entrevistas.}

Este subapartado consta del desglose de las diferentes acciones realizadas para aportar una visión específica del proceso.

\subsection{Análisis de la participación etnográfica realizada.}

Durante los primeros meses en el campo tuve la oportunidad de conocer y aprender cómo se estructura la organización de la Casa. Este dato fue muy relevante a la hora de planificar cómo se iba a recoger la información para el relato de la asociación. La necesidad del grupo de que yo como investigadora formara parte activa del equipo de Maranya derivó en que mi acceso a la información fuese más directo y las lógicas de funcionamiento del colectivo fueran más entendibles. Empecé a formar parte del colectivo hasta el punto de sentirme una más en las reuniones, en las actividades y en los problemas. 
Para comprender un poco más cómo las distintas fases afectan al trabajo narrativo podemos observar a continuación (tabla 25) los tiempos, las fases, las acciones y la información relevante que tienen relación directa con la planificación de las entrevistas.

Tabla 25. Proceso del trabajo narrativo.

\begin{tabular}{|c|c|c|c|}
\hline Tiempos & Fase & Acción & Información relevante \\
\hline $\begin{array}{l}\text { Enero a } \\
\text { Marzo, } \\
2014\end{array}$ & Planificación & $\begin{array}{l}\text { Revisión } \\
\text { bibliográfica, } \\
\text { Contacto con } \\
\text { fuentes personales } \\
\text { académicas (UAM) }\end{array}$ & Ausencia de relatos asociativos. \\
\hline $\begin{array}{l}\text { Abril a } \\
\text { Septiembre, } \\
2014\end{array}$ & Trabajo de campo & $\begin{array}{l}\text { Entrada, } \\
\text { participación } \\
\text { activa, elaboración } \\
\text { de protocolos,... }\end{array}$ & $\begin{array}{l}\text { Conocimiento de la estructura de } \\
\text { participación, informantes clave, } \\
\text { confianza, protocolos a discusión. }\end{array}$ \\
\hline $\begin{array}{l}\text { Septiembre } \\
\text { de } 2014 \text { a } \\
\text { Marzo de } \\
2016\end{array}$ & Trabajo de campo & $\begin{array}{l}\text { Activismo, } \\
\text { Reuniones GA, } \\
\text { Entrevistas, } \\
\text { Transcripciones, } \\
\text { Revisiones }\end{array}$ & $\begin{array}{l}\text { Elaboración de la historia a través } \\
\text { de las entrevistas, necesidad de } \\
\text { adaptar los protocolos a los niveles } \\
\text { de participación, los datos derivan } \\
\text { en nuevos informantes. }\end{array}$ \\
\hline \begin{tabular}{lr|} 
Marzo & de \\
2016 & a \\
Mayo & 2016
\end{tabular} & Análisis de datos & $\begin{array}{l}\text { Analizar, devolver, } \\
\text { reelaborar escritos }\end{array}$ & $\begin{array}{l}\text { Elaboración de los datos/resultados } \\
\text { para el estudio. }\end{array}$ \\
\hline
\end{tabular}

A lo largo de este punto haremos un pequeño recorrido por la información que se extrajo del trabajo de campo y que sirvió para elaborar los protocolos de entrevistas. Toda ella parte, en primer lugar, de la observación militante registrada en el diario de campo, después se contrasta con los documentos escritos por la propia asociación, y para finalizar se discute en un monográfico sobre las entrevistas con el Grupo Asesor.

Observamos cómo esta información se triangula (figura 5) para ofrecer datos fiables que apoyen la planificación de las entrevistas. 
Figura 5. Triangulación.

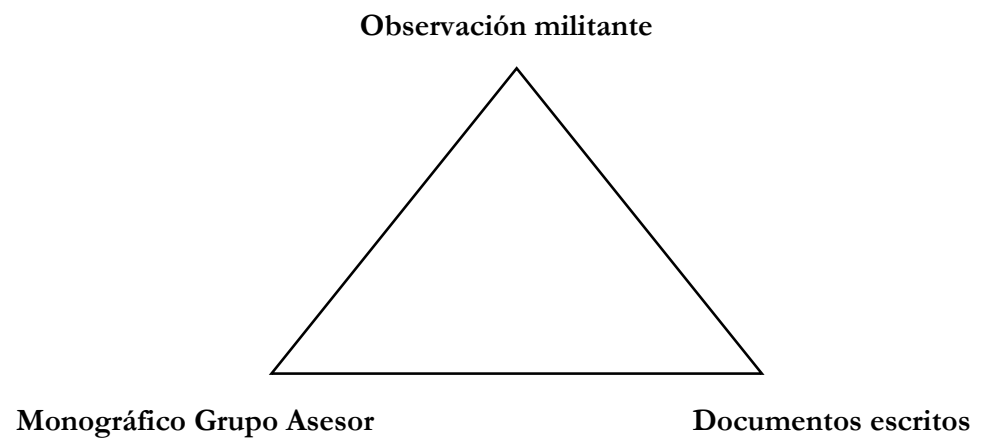

\section{* Observación Militante}

Fueron seis meses los dedicados a analizar, principalmente, cuál era la estructura que da forma a la Casa de Joventut La Maranya. Aun así, un tiempo antes, ya colaboraba con el movimiento y empecé a escuchar de dónde venían todas estas ideas estructurales: Zaragoza, un tal 'Palas' y algo llamado la 'Quíntuple estructura' parecían tener la culpa. En los Claustros con las miembros de la Escola de Cases y en las sesiones de los proyectos de Joves en el PEU de la UJI estos términos se sucedían como algo particular del movimiento. La sensación de que la estructura de participación era un aspecto muy relevante en la asociación cada vez se hizo más explícita. Esta se repite en múltiples ocasiones a lo largo de las sesiones en el centro: «Maranya funciona porque trabajan cinco personas», estas cinco personas son el 'Equipo de Animadoras Voluntarias' (EAV). Por otro lado, a las jóvenes se les organiza en función de los 'Grupos Estables' y todas ellas son las que se deben responsabilizar de las tareas básicas de la Casa. A todo esto se suman las sesiones concretas de la 'Junta directiva', que se reúnen para tomar decisiones sobre el curso de la asociación.

Siguiendo con la pirámide de participación, observamos como es punto de partida en algunas reuniones del EAV y en los plenarios de la Casa, sin olvidarnos de que es eje de trabajo en la evaluación anual del proyecto. Es decir, en los diferentes espacios se muestra la importancia de la pirámide, siendo esta un punto esencial de partida para discutir la organización de las tareas, responsabilidades y evaluaciones del proyecto de centro. 
Otro de los aspectos relevantes a la hora de elaborar el protocolo de entrevistas y seleccionar a las personas que participarían de ellas son los tres espacios de actividad que se diferencian en la Casa de Joventut. Estos vienen determinados por la historia particular del origen de Maranya y las personas que participan de la misma. Aun siendo una asociación de jóvenes, también forman parte un grupo de niños y niñas bajo el nombre del Esplai Cataflai, un grupo de jóvenes en lo que sería en sí la Casa de Juventut y un grupo de personas adultas, principalmente padres y madres que se reúnen bajo el Grupo de Consumo además de querer formar una asociación ecologista (Voltants). Podemos observar que los tres grupos pertenecen a las distintas franjas de edad que se reúnen en Maranya. Además vemos como la Casa de Joventut no es un único lugar de adolescentes sino que comparte espacios y tiempos con generaciones distintas a la suya haciendo que el nombre global de Casa de Juventud pase a convertirse en un Centro Cívico Intergeneracional.

Por otro lado, un criterio a valorar en la fase que nos ocupa es todo aquel contenido y todas aquellas personas que tienen relación con Maranya en lo que concierne a sus orígenes. En la Casa se realizan diversas actividades que ponen en valor la importancia de las raíces. Una de ellas es el Fil històric en la cual se contextualiza a Maranya como parte de un movimiento más global y no como una entidad ajena al contexto que le rodea. En la dinámica se disponen diferentes mesas compuestas por materiales y fotografías que componen una época. En este caso se habló de la Casa de Joventut Quelcom, del inicio del Esplai Cataflai y de la Casa de Joventut La Maranya durante los años 2012, 2013 y 2014. De ella podemos rescatar la importancia que tuvieron algunas personas y entidades en el origen de la Casa. Entre ellas las jóvenes que formaron parte de Quelcom, la primera Casa de Joventut del municipio de Benicàssim; los promotores del Esplai Cataflai; las técnicos que trabajaban en juventud durante los años que Maranya y Esplai se ubicaron en el Casal Jove del municipio; las relaciones con el instituto y las escuelas; los vínculos con Federació Valenciana de Cases de Joventut y Federación de Casas de Juventud de Aragón; el Movimiento Laico Progresista, la Escola de Cases; y sin olvidarnos del papel que cubrió el Ayuntamiento benicense en la aparición de Maranya. Todas estas personas han formado parte de la Historia de Maranya y deben formar parte de la selección de las participantes clave en la elaboración del relato de vida 
asociativo. El hilo histórico nos marca los pasos del lugar hacia el que tendremos que dirigirnos, las temáticas que deberíamos abordar y con quienes deberíamos contar. En este sentido habla también una de las fuentes personales (Poveda, 2013) a las que me dirigí, en el ámbito académico, para evaluar mi proyecto de tesis : «Cuando diseñas un plan de entrevistas debes captar a la gente que estaba y ya no está, a los que acaban de entrar, a los que llevan más tiempo,...Intentar que tu muestra de entrevistas refleje un poco toda la diversidad de lugares y roles que se pueden tener en el centro, se han tenido y se pueden llegar a tener». Por todo ello, una de las variables a tener en cuenta en la elaboración del protocolo es el contexto histórico al que pertenecemos.

De forma resumida, observamos la importancia de una serie de variables a contemplar a la hora de planificar las entrevistas y el consecuente relato de vida. Entre las principales variables recogidas a partir de la observación activista se encuentran:

- Pirámide de participación

- Roles establecidos

- Espacios generacionales

- Contexto histórico

\section{* Documentos escritos}

Se han seleccionado los documentos escritos procedentes de FVCJ ya que aportan una mirada externa y global a lo que significa el movimiento de Cases de Joventut. Entre ellos encontramos los siguientes:

- Revista antigua

- Revista actual

- Instrucciones CJ

- Propuestas MLPV

- Presupuestos asociaciones

- Retos asociativos 
- Historia Federació

- Características movimiento asociativo de la comarca

- Funciones asociaciones

Entre todos ellos el principal documento escrito que se utiliza para elaborar el protocolo de entrevistas que dará lugar a la información para generar el relato es la Revista de la Federació Valenciana de Cases de Joventut: Escoles de Democràicia ${ }^{30}$.Hemos seleccionado esta revista ya que da visibilidad a las Casas de Juventud, hace un pequeño recorrido por el asociacionismo juvenil en España y Europa y hace explícito la forma de estructurarse de las Casas de Juventud. Esto nos ayudará a la hora de elaborar el protocolo de entrevistas y seleccionar a las participantes ya que nos explica de manera global cómo se estructura una casa y nos facilita la comparación con la realidad en Maranya.

De forma concreta, el punto que más nos interesa es cuando aborda cómo la participación en una Casa de Juventud viene definida por diferentes tipos de implicación. A través de la llamada Pirámide de participación cada persona puede ubicarse en función de sus propios intereses y del «proceso de maduración de la organización». En definitiva, cada persona perteneciente a la Asociación debería relacionarse con uno de estos cinco escalones:

I. El colectivo que se sitúa a la cabeza de la pirámide es el relacionado con el grupo de 'Animadoras'.

II. Seguidos de los 'Activistas' de Grupos Estables y de los miembros de la Junta Directiva de la Casa.

III. En el centro de la pirámide encontramos a todas aquellas personas que forman parte de los Grupos Estables, son sus 'Miembros'.

IV. Por debajo de este grupo vemos a las 'Usuarias' de cursos y servicios que ofrece la Casa.

\footnotetext{
30 Puede consultarse en la web de Federació: http://lafederacio.org/wpcontent/uploads/2015/05/revistaweb.pdf
} 
V. Finalizamos con las llamadas 'Consumidoras' refiriéndose a aquellas personas que forman parte de las actividades masivas de la Casa.

Observamos cómo estos cinco perfiles vertebran el funcionamiento y la estructura orgánica de la Asociación Juvenil tal y como pudimos contrastar a través de la observación militante.

\section{* Monográfico Grupo Asesor}

Llegamos al tercer vértice del triángulo, es el momento de discutir y consensuar, con aquellas agentes sociales que forman parte del G.A., el protocolo elaborado por la investigadora a partir de la observación militante y el análisis de los documentos. Este es uno de los objetivos que se contemplan en la sesión. Para ello, se envía el protocolo de entrevistas (anexo 7) con anterioridad y se marca la siguiente pauta «Per a un treball més efectiu el dia de la reunió, és convenient que totes llegiu aquest document i vingau amb propostes, dubtes, crítiques,... treballades des de casa» ${ }^{31}$. De esta forma, la sesión pudo profundizar en la discusión sobre los temas que queríamos que aparecieran en la entrevista, la tipología de entrevistas que se llevaría a cabo, los criterios para la selección de las personas a entrevistar y las características que debían de reunir las mimas.

En la siguiente imagen (Figura 6) vemos como a partir de la observación activista los tres criterios de selección se componen por: los espacios generacionales que conforman la Casa, el contexto histórico y la pirámide de participación. El análisis documental fortalece la idea de estructurar las entrevistas a partir de la pirámide. Cuando llega el momento de discutir los criterios junto al G.A., ya había generado una propuesta de protocolo a partir de estos datos. Dicha propuesta se expone ante las agentes sociales y son estas las encargadas de evaluar y proponer nuevas ideas.

Figura 6. Mapa de criterios de selección de las entrevistadas

${ }^{31}$ «Para un trabajo más efectivo el día de la reunión es conveniente que todas os hayáis leído este documento y vengáis con propuestas, dudas o críticas trabajadas desde casa». 


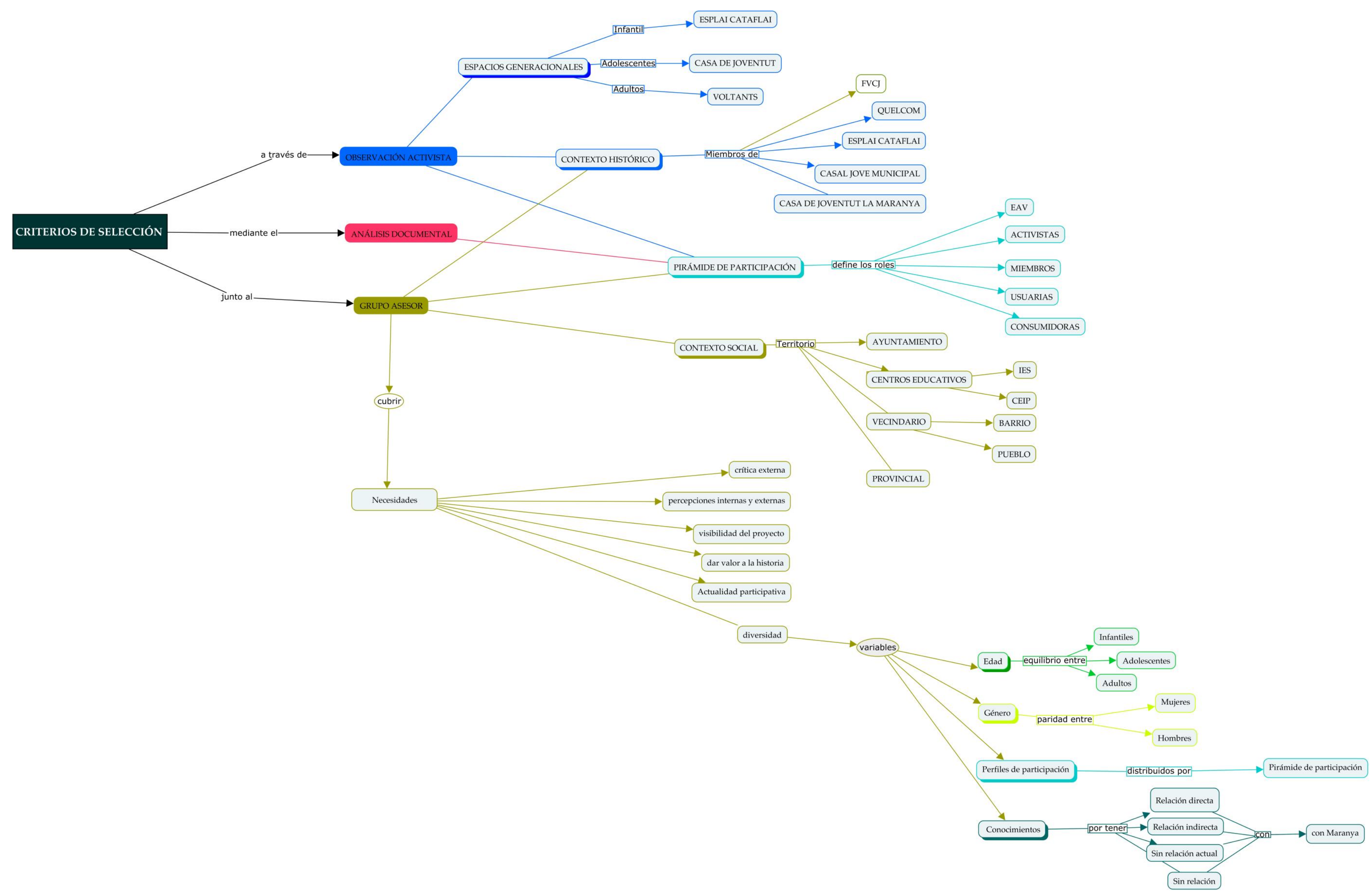


El hecho de estructurar las entrevistas a partir de la pirámide de participación se aceptó sin ninguna oposición entre las personas que allí nos encontrábamos. Este hecho dio de sí para poner sobre la mesa la importancia que le da la Casa a este tipo de estructura participativa siendo la principal vía para definir los roles de participación que se dan en Maranya (tabla 26).

Tabla 26. Perfiles de las entrevistadas.

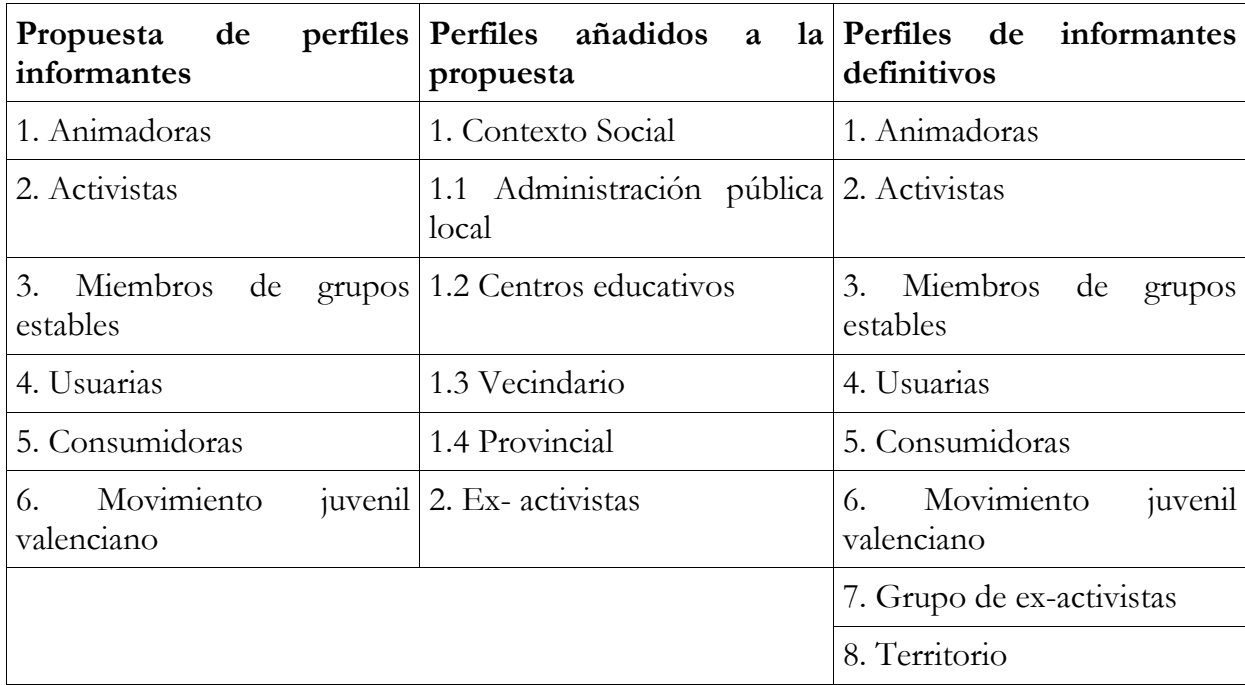

Del mismo modo, el G.A. expone sus necesidades respecto a la elaboración del relato de vida. Entre las que se hacen explícitas en la reunión obtenemos el siguiente listado que ayudará a confeccionar las preguntas de las entrevistas:

1. Favorecer la crítica interna y externa a la Casa de Joventut La Maranya.

2. Obtener percepciones internas y externas que puedan provocar procesos de discusión interna y mejora en la Casa.

3. Facilitar la visibilidad del proyecto juvenil.

4. Dar valor a la historia contextualizada del movimiento juvenil y no a la Casa como ente único, así se indaga en los orígenes ideológicos de Maranya.

5. Actualizar la participación en la investigación en función del proceso vital de la Casa. 
6. Favorecer la diversidad de voces en el relato a partir de variables como la edad, el género, el perfil de participación y el conocimiento sobre la Casa.

7. Comparar los procesos de participación en Maranya con respecto a otros que se dan en diferentes contextos.

Para entender mejor estas variables definimos a continuación las particularidades de cada una de ellas. En primer lugar, la variable edad, se define por los espacios generacionales que se dan en la Casa. Un dato relevante es la necesidad existente, por parte de las agentes del G.A., de escuchar la voz de las más jóvenes. Por ello, una de las necesidades es que exista un equilibrio entre el colectivo infantil y adulto con respecto a las jóvenes ya que estas se definen como el pilar fundamental de trabajo en la Casa. A su vez, está la paridad entre hombres y mujeres, esta relación de igualdad entre géneros se presenta como una variable esencial a la hora de configurar el listado de participantes en las entrevistas, haciendo que sean un total de 14 mujeres y 14 hombres las personas entrevistadas. Los perfiles de participación es un elemento definido a través de la pirámide de participación y serán los perfiles que la componen los encargados de guiar el discurso respecto al relato de vida de la asociación. Otro de los factores que parte del análisis del G.A. es el conocimiento que se tiene sobre Maranya influenciado por el tipo de relación que se tiene con la misma. En este sentido se deben tener en cuenta las siguientes cuatro posibilidades:

- Relación directa,

- Relación indirecta,

- Sin relación actual,

- Sin relación

Para finalizar con el análisis llevado a cabo junto al G.A debo incidir en la propuesta sobre la tipología de entrevista. En un inicio se plantea la idea de seleccionar a una o dos personas de cada una de los perfiles de participación. Una vez generada la discusión en el grupo se propone llevar a cabo, en la mayor parte de los perfiles, entrevistas en grupo para más tarde incidir en particularidades a partir de entrevistas individuales. Aunque estas 
no hacen falta ya que con el trabajo militante se producen múltiples espacios en los que se comparte información para que pueda incidir en esas particularidades. Por ello, se concreta con qué personas se realizarán entrevistas individuales y con quienes grupales. Esto dependerá del tipo de afinidad que tengan las participantes del grupo concreto y la riqueza de información que se pueda obtener de cada una de ellas a nivel individual o colectivo debido a sus características personales. Uno de los ejemplos que se mostraron fue el hecho de pertenecer al colectivo de adolescentes o al de adultos. En este caso, la opción de mezclar edades en una misma entrevista, se valoró de forma negativa ya que podía producir una menor participación por parte de las jóvenes al no encontrarse cómodos con un grupo de adultos.

\subsection{Selección de participantes.}

Es a partir del análisis de la observación, los documentos y la sesión con el G.A. desde donde seleccionamos los criterios más significativos para escoger a las participantes. Un aspecto relevante que expone el G.A y que se reafirma con las ideas de Pujadas, Comas y Roca (2010) es el hecho de que la muestra se actualice. En una investigación etnográfica, la selección de las participantes es un proceso abierto y se somete a cambios constantes en función de la información recogida y el propio proceso de vida de la comunidad. En nuestro caso la construcción de la muestra para las entrevistas es abierta aunque se preestablecen una serie de participantes que marcan la representatividad de la misma. Observamos cómo los datos analizados nos llevan a la selección de personas que reúnen «todos los matices, las diferentes posiciones, circunstancias y puntos de vista» (Pujadas, Comas y Roca, 2010:296) que proporcionan la mayor riqueza de información posible para elaborar el relato de vida de la asociación (Patton, 2002; Martínez, 2012).

En la investigación cualitativa una de las variables para garantizar rigor en la aproximación es situar a las participantes dentro del contexto (Marshall, 1996; Crouch \& Mckenzie, 2006). En nuestro estudio, el hecho de seleccionarles a partir del papel que juegan en su realidad fue un punto destacado en el análisis anterior. El G.A. muestra la importancia de seleccionar a las participantes a partir del contexto social, cultural e histórico en el que se desenvuelve cada una. Por ello la selección ha sido 
totalmente dependiente del contexto singular de la investigación y se han buscado a las personas que son más significativas para participar en el relato colectivo. La búsqueda de personas características del fenómeno social que queremos estudiar, a través del análisis documental, observacional y colectivo, ha supuesto un aspecto clave de la investigación. De este modo se ha elaborado un diseño rigurosamente definido y se han expuesto los criterios de selección de las participantes, lo cual ha favorecido la representatividad de la muestra (Mejía Navarrete, 2002).

Para obtener los relatos de vida sobre Maranya tenemos que realizar una serie de entrevistas individuales o grupales a informantes que de forma interna o externa tienen una vinculación con la Casa de Joventut La Maranya. Tras el análisis realizado durante los primeros meses de observación activista en las actividades de Maranya, y tal y como propone la Federació Valenciana de Cases de Joventut, la estructura seleccionada es la pirámide de participación de la figura 7.

Figura 7. Pirámide de participación.

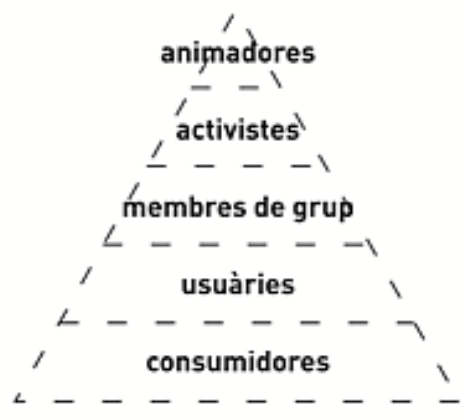

La Casa de Joventut La Maranya se estructura de este modo y por ello debemos de basar nuestro estudio y la construcción de los relatos de vida en distintas personas que formen parte de cada una de estos niveles. Justificándonos en ella se seleccionan los cinco grupos que conforman la estructura. Además añadiremos cuatro estamentos más que nos ofrecerán una visión más amplia y externa. En total serán 8 los grupos entrevistados, formados por un total de 28 personas (anexo 10). En cada uno de estos grupos hay entre dos y cinco personas a entrevistar. A continuación podemos ver una tabla (tabla 27) resumen con la información sobre cuáles serán los grupos, una descripción sobre el mismo y qué tipo de entrevista se realizará. 
Tabla 27. Niveles de participación.

\begin{tabular}{|l|l|l|}
\hline Niveles de participación & Descripción & Tipo de entrevista \\
\hline ANIMADORAS & $\begin{array}{l}\text { Implicados en la dirección y } \\
\text { en el proyecto de manera } \\
\text { global. }\end{array}$ & $\begin{array}{l}\text { Entrevista semiestructurada } \\
\text { grupal }\end{array}$ \\
\hline $\begin{array}{l}\text { ACTIVISTAS / JUNTA } \\
\text { DIRECTIVA }\end{array}$ & $\begin{array}{l}\text { Comprometidos a dinamizar } \\
\text { su grupo y participar como } \\
\text { miembros de la junta } \\
\text { directiva. }\end{array}$ & $\begin{array}{l}\text { Entrevista semiestructurada } \\
\text { grupal }\end{array}$ \\
\hline $\begin{array}{l}\text { MIEMBROS DE GRUPOS } \\
\text { ESTABLES }\end{array}$ & $\begin{array}{l}\text { Jóvenes ydultos } \\
\text { participantes de actividad } \\
\text { cotidiana de su colectivo. }\end{array}$ & $\begin{array}{l}\text { Entrevistas } \\
\text { semiestructuradas } \\
\text { individuales }\end{array}$ \\
\hline USUARIAS & $\begin{array}{l}\text { Asistentes a servicios y y } \\
\text { cursos que ofrece la Casa }\end{array}$ & $\begin{array}{l}\text { Entrevistas } \\
\text { semiestructuradas } \\
\text { individuales }\end{array}$ \\
\hline CONSUMIDORAS & $\begin{array}{l}\text { Participantes de actividades } \\
\text { masivas organizadas por la } \\
\text { casa. }\end{array}$ & $\begin{array}{l}\text { Entrevistas } \\
\text { semiestructuradas } \\
\text { individuales }\end{array}$ \\
\hline TERRITORIO & $\begin{array}{l}\text { Participan de la vida del } \\
\text { municipio. }\end{array}$ & $\begin{array}{l}\text { Entrevistas } \\
\text { semiestructuradas } \\
\text { individuales }\end{array}$ \\
\hline $\begin{array}{l}\text { MOVIMIENTO JUVENIL } \\
\text { VALENCIANO }\end{array}$ & $\begin{array}{l}\text { Involucrados en los orígenes } \\
\text { del movimiento y en la FVCJ }\end{array}$ & $\begin{array}{l}\text { Entrevista semiestructurada } \\
\text { grupal }\end{array}$ \\
\hline EX-ACTIVISTAS & $\begin{array}{l}\text { gesvinculados del proyecto } \\
\text { Enasa. }\end{array}$ & $\begin{array}{l}\text { Entrevista semiestructurada } \\
\text { grupal } \\
\text { Entrevista semiestructurada } \\
\text { individual }\end{array}$ \\
\hline
\end{tabular}

Toda esta estructura justifica el contexto de participación de Maranya y sólo de este modo podremos obtener la imagen de lo que es la Casa para analizar Maranya desde diferentes miradas. La pirámide de participación en las entrevistas queda del siguiente modo (tabla 8): 
Figura 8. Pirámide de los niveles de participación en las entrevistas.

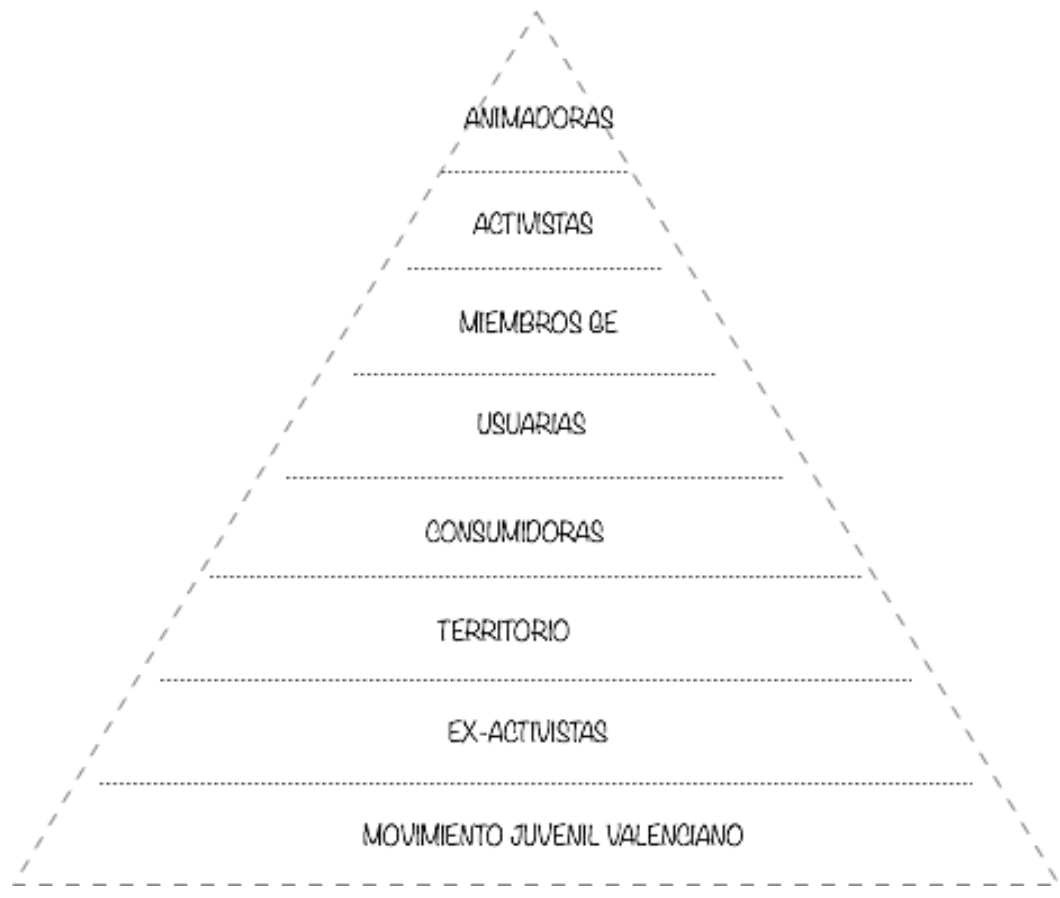

3.5.3.5.3 Elaboración del protocolo de entrevistas.

El proceso de entrevistas se lleva a cabo de septiembre del 2014 a marzo de 2016. Para comenzar con esta fase de entrevistas se procede a la realización de una guía de entrevistas (anexo 7) que es revisada por el grupo asesor. Después de la reunión se modifica y se envía a todas las personas que van a participar en el proceso.

En la elaboración del protocolo también influyen cuestiones técnicas como el tipo de entrevistas que vamos a utilizar. En nuestro caso, realizamos entrevistas semiestructuradas ya que queremos incidir en las preguntas confeccionadas por el grupo asesor y también abrirnos a otras posibilidades que surjan a lo largo de las mismas. De esta forma el análisis de los elementos más significativos para el relato han generado que se apueste por este tipo de entrevista de carácter abierto en el que las propias respuestas generan nuevas preguntas para el relato (Pujadas, Comas y Roca, 2010). Sobre este análisis previo se construye el protocolo de entrevista. Por ello, 
tenemos una pequeña estructura basada en preguntas abiertas que son de interés para el grupo y que variarán y se complementarán con otras a lo largo de las entrevistas.

Recordamos que las entrevistas nos posibilitan triangular toda la información procedente de otras herramientas para así poder relatar la historia de Maranya. De esta forma posibilitamos la construcción de esa historia colectiva desde las distintas voces que intervienen y desde las diferentes fuentes de información seleccionadas.

Para conseguirlo se realizarán entrevistas grupales e individuales. La decisión sobre esta cuestión se valoró en la primera reunión del grupo asesor. Se decide que la elección entre individual o grupal se basará en si el grupo de personas a entrevistar puede definirse como grupo social o no. Si es así se haría grupal, sino sería individual. Las entrevistas individuales nos permitirían profundizar en el relato de personas que tienen un nivel de participación en la Casa que encontramos en la base de la pirámide como son las miembros de los diferentes grupos estables, las consumidoras y las usuarias así como a las personas del territorio. Los cuatro colectivos no se definen como grupo social con anterioridad a las entrevistas ya que son participantes que no se conocen entre sí y/o no han compartido espacios comunes en la Casa. Por otro lado, las grupales se realizarían a las animadoras, a las activistas y ex activistas de la Casa y a las personas del Movimiento Juvenil de Cases de Joventut que tienen una implicación de mayor militancia en el contexto y sí que se pueden definir como grupo social.

Todos estos acuerdos siguen la línea que expone Pujadas, Comas y Roca (2010) sobre el gran potencial que tienen las entrevistas grupales como fuente de información. Estos autores insisten en que, si se opta por este tipo de entrevista, debemos tener en cuenta que el grupo ya exista como grupo social en el contexto. Podemos definir a un grupo social por ser un conjunto de personas que se reúne en diferentes ocasiones para trabajar sobre un objetivo común y compartido. Además el grupo tiene sentimiento de pertenencia al mismo lo que les dota de una identidad común. Otro de los aspectos relevantes que remarca Pujadas es la posibilidad de favorecer el recuerdo y la memoria colectiva, lo que contribuirá a la riqueza de la información. 
Analizamos como fundamental el generar un ambiente relajado y flexible en el cual se facilite la comunicación entre entrevistadora y entrevistada y para ello debemos tener en cuenta que los espacios y los tiempos se adapten a las personas que forman parte del relato. El espacio que se utilizará para las entrevistas será la Casa de Joventut La Maranya o si la entrevistada prefiriera otro espacio, se modificaría por otro lugar cercano del entorno social de la persona entrevistada. La duración de las entrevistas varía entre media hora y dos horas aproximadamente y la cita se consensua con la investigadora. Se propone en el protocolo que las entrevistas no duren más de una hora pero esto varía en función de las participantes teniendo en cuenta el agotamiento y la dispersión de la entrevistada.

Figura 9.Proceso lineal de entrevistas.

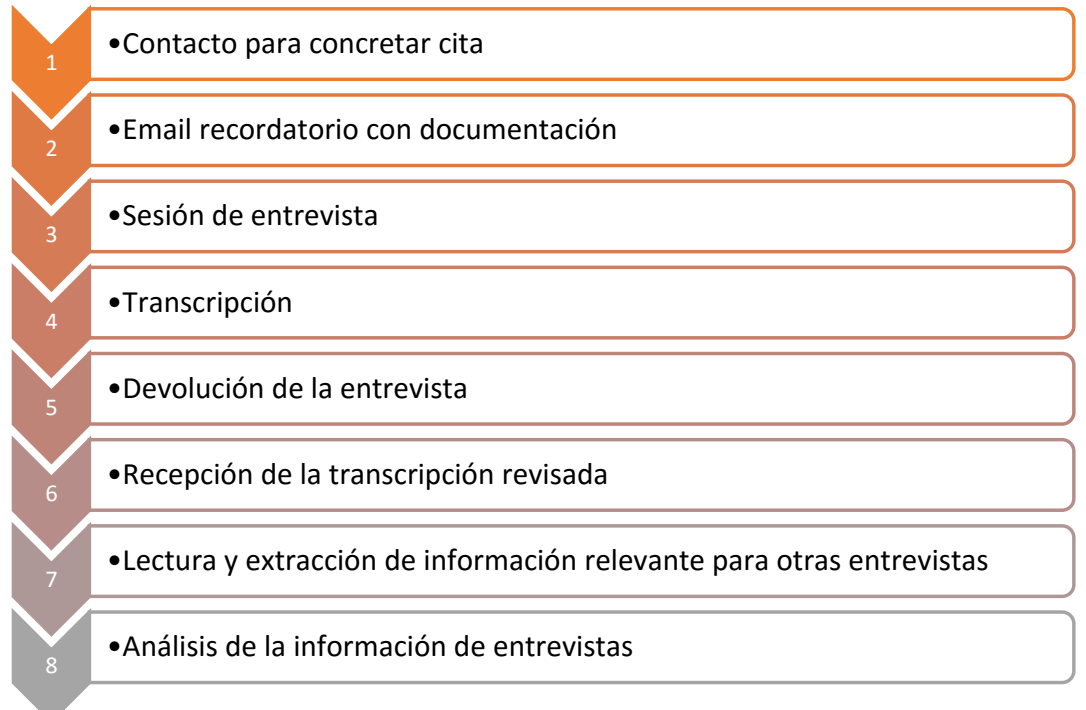

La primera acción que se lleva a cabo es el contacto con las participantes (Figura 9). Este se da a partir de tres vías (tabla 28) en función de si, yo como investigadora, tengo contacto directo, indirecto o no lo tengo en absoluto con la persona en cuestión. Para las personas con relación directa concretamos día y hora por teléfono o en persona en la Casa. En cambio, con las personas con las que no existe relación directa son las agentes del G.A quienes se responsabilizan en hacer de puente. En algunos casos ocurre que las personas activistas son las responsables de hacer de puente entre los contactos y yo. Esto se genera porque entre ellas tiene una 
relación más igualitaria al tratarse, en su gran mayoría, de jóvenes. En algunos casos en los que la relación era indirecta, hacían de enlace personas cercanas al contexto del participante pero todas ellas pertenecientes al grupo asesor.

Tabla 28. Relaciones entre entrevistadas e investigadora.

\begin{tabular}{|l|c|c|c|l|}
\hline \multicolumn{1}{|c|}{ Entrevistadas } & $\begin{array}{c}\text { Relación } \\
\text { directa }\end{array}$ & $\begin{array}{c}\text { Relación } \\
\text { indirecta }\end{array}$ & $\begin{array}{c}\text { Sin } \\
\text { relación }\end{array}$ & ¿Quién hace de puente? \\
\hline Animadoras & $\mathrm{X}$ & & & Investigadora \\
\hline Activistas & $\mathrm{X}$ & & & Investigadora \\
\hline $\begin{array}{l}\text { Miembros de grupos } \\
\text { estables }\end{array}$ & $\mathrm{X}$ & & & Investigadora \\
\hline $\begin{array}{l}\text { Miembro de grupo } \\
\text { estable - Guiomar e hija }\end{array}$ & & & $\mathrm{X}$ & Animadora (GA)-Virginia \\
\hline Usuarias- Tibi & & $\mathrm{X}$ & & Animadora (GA)-Mireia \\
\hline Usuarias- Miriam T. & & & $\mathrm{X}$ & Animadora (GA)-Virginia \\
\hline Usuarias- Iván & & $\mathrm{X}$ & & Animadora (GA)-Noel \\
\hline $\begin{array}{l}\text { Consumidoras-Miriam } \\
\text { S. }\end{array}$ & & & $\mathrm{X}$ & Activista-Lydia \\
\hline Territorio- Profesor & $\mathrm{X}$ & & & Investigadora \\
\hline Territorio- Vecina 2 & & & $\mathrm{X}$ & Miembro GA-Joan \\
\hline Territorio- MCarmen & & & $\mathrm{X}$ & Investigadora \\
\hline Territorio- Alcaldesa & & & $\mathrm{X}$ & Investigadora \\
\hline Territorio- Merche & & & $\mathrm{X}$ & Activista-Iván \\
\hline Ex-activista - Isabel & & $\mathrm{X}$ & & Animador(GA)- Víctor \\
\hline Ex-activista - Joana & & $\mathrm{X}$ & & Animador(GA)-Víctor \\
\hline Ex-activista- Guille & & $\mathrm{X}$ & & Animador(GA)- Víctor \\
\hline Ex-activista - Ricky & & $\mathrm{X}$ & & Animador(GA)- Víctor \\
\hline $\begin{array}{l}\text { Movimiento juvenil } \\
\text { valenciano }\end{array}$ & $\mathrm{X}$ & & $\begin{array}{l}\text { Investigadora + MJV } \\
\text { (GA)-Julio }\end{array}$ \\
\hline
\end{tabular}

En cualquiera de los casos, ellas les informan sobre la investigación que estamos realizando, les explican nuestra intención de entrevistarles y les preguntan sobre su disponibilidad y voluntad en participar en el relato. Que dichas personas acepten a participar es un elemento que se convierte en 
imprescindible y éticamente intrínseco a nuestra investigación (Martínez, 2012).

Una vez hecho el contacto, les envío un email (modelo de email 1) a cada una de las participantes recordando nuestra cita y adjuntándoles el documento referente al Consentimiento informado (anexo 5), una carta de bienvenida a la participación en la entrevista (anexo 4) y el protocolo de entrevista (anexo 7).

Modelo de email 1:

Asunto: Información sobre entrevista viernes 19 de septiembre, a las 16:00hrs.

\section{Buenas tardes 'nombre participante',}

Este email es para recordarte que el viernes tenemos entrevista en La Maranya a las 16:00hrs. En este correo encontrarás tres documentos distintos: el primero es el protocolo de la entrevista que voy a realizarte, en él puedes ver qué proceso vamos a llevar a cabo y la estructura que tiene la entrevista. El segundo es el consentimiento informado, un documento que utilizamos en investigación para que nos des tú visto bueno sobre el uso de la información que recoja durante la entrevista. En tu caso, al ser menor de edad, tendrá que leerlo tu madre/padre o tutor legal también y deberá firmarlo al igual que tú. El tercer documento es una invitación formal a la investigación, concretamente a la fase de entrevistas.

En el protocolo de entrevistas verás que voy a necesitar que traigas una fotografía, objeto, canción o lectura que relaciones con Maranya. Por favor, no lo olvides.

Quiero agradecerte tu participación en el proceso. Gracias 'nombre participante' por tu importante aportación.

Nos vemos el viernes.

Saludos,

Arecia

Respecto al Consentimiento informado (anexo 5), encontramos esencial que exista un documento que recoja una serie de elementos básicos para que la participante pueda entender la investigación y de su consentimiento 
oficial hacia la misma. Este documento está formado por una contextualización de la investigación, la presentación de la investigadora, se expone la finalidad de la investigación, el uso que se hará de la información, se habla del derecho al anonimato, de cómo se registrará la información, se exponen las posibilidades de publicación y su papel en la misma, entre otras cosas. Un aspecto relevante respecto a este documento es que todas aquellas participantes que sean menores de edad deberán de traer el consentimiento firmado por su madre, padre o tutora legal. Esta petición está regulada bajo la normativa capítulo II del Real Decreto 1720/2007, de 21 de diciembre, por la cual se aprueba el Reglamento de desarrollo de la Ley Orgánica 15/1999, del 13 de diciembre, de protección de datos de carácter personal.

Es el momento de realizar la entrevista. Para hacerla sigo una serie de pasos que están descritos a continuación:

1. Presentación de la investigadora y de las personas a entrevistar.

2. Breve explicación de la investigación y contextualización de la entrevista dentro del proceso de investigación.

3. Aclarar el uso de las herramientas utilizadas para digitalizar la información: grabadora de voz, de video o cámara de fotos. Solicitud de permiso para utilizarlas.

4. Explicación, lectura y firma del consentimiento informado con sus correspondientes aclaraciones y resolución de dudas.

5. Descripción del proceso de entrevista.

6. Iniciamos la entrevista con la descripción de un objeto que han traído seleccionado y que es simbólico en su paso por Maranya. Esta estrategia se utiliza para romper el hielo y empezar la entrevista indagando en los acontecimientos y circunstancias que rodean al objeto elegido. Es muy utilizada en la investigación biográfico narrativa ya que facilita y complementa el relato. En la mayoría de los casos se utilizan únicamente fotografías, por ello que adquiera el nombre de la Técnica de la foto. Tal y como explica Aldridge (2007) y Moriña (2010) esta técnica nos permite evocar el recuerdo y aporta gran detalle 
sobre la escena narrada. En nuestro caso decidimos ampliar el campo de una fotografía a un objeto en general, para posibilitar la libertad de expresión de las participantes en la elección de aquello más significativo y relevante para iniciar el relato.

7. Continuamos con la entrevista y al finalizar las preguntas realizamos la actividad del mural de relaciones. (ver punto 6.6)

8. Agradecemos su participación.

9. Informamos que se realizará la devolución escrita de la entrevista para que puedan modificar, eliminar o añadir la información que consideren oportuna.

Según Pujadas, todas las entrevistas, sean del tipo que sean, como cualquier interacción social, son estructuradas tanto por parte de la entrevistadora como por parte de la participante. La diferencia es que estas son entrevistas reflexivas y las otras son entrevistas estandarizadas. A lo largo de la entrevista se pasará de preguntas más generales a concretas, de impersonales a personales y de informativas a interpretativas. Entre ellas los temas a tratar son los siguientes:

01. Relación con la fotografía, lectura, canción u objeto que la persona trae.

02. Definición y significado de Maranya.

03. Experiencia personal.

04. Participación.

05. Aprendizajes.

06. Espacio físico.

07. Comunicación externa e interna y relaciones.

08. Otras cuestiones.

Estos temas variarán en relación a las entrevistadas y al propio proceso de la investigación. Para saber cómo se suceden los temas puedes leer el punto 5.3.5.5 que encontrarás en este mismo capítulo. En él hablamos sobre cómo se deriva de unas preguntas a otras en la investigación. 


\subsection{Cronograma}

Los primeros grupos en ser entrevistados fueron Animadoras, Activistas y Miembros de Grupos Estables ${ }^{32}$. Esto se debe a la facilidad de contacto entre la investigadora y las participantes. Además se realizó una entrevista a una usuaria y otra a una agente territorial, concretamente al representante del IES. En total se entrevistan a catorce personas durante el mes de septiembre de 2014. Desde octubre a febrero, me encuentro de estancia de investigación en Portugal y se paran las entrevistas. Este tiempo me sirve para transcribir las entrevistas y hacer la devolución a las distintas personas. Además hago un análisis superficial sobre las entrevistas lo que me ayuda a concretar preguntas para el resto de grupos que quedan por entrevistar. Aun así, en diciembre, aprovecho la visita por vacaciones para entrevistar al grupo de Ex-activistas. Se realiza una entrevista grupal con tres personas. Uno de los ex-activistas no puede asistir a la sesión y decidimos hacer una entrevista individual con él más adelante.

Es durante los meses de marzo y abril de 2015 cuando continúo con las entrevistas a consumidoras, usuarias y participantes del movimiento valenciano juvenil. En total realizo entrevistas a seis personas, algunas de ellas de forma grupal y otras individuales. De mayo a julio vuelvo a irme de estancia de investigación, esta vez a Madrid con lo que retomo las entrevistas a partir de mi vuelta y utilizo este tiempo para la transcripción y devolución, entre otras cosas. En julio realizo la entrevista a la técnico del Ayuntamiento. Por otro lado, completo el grupo de ex-activistas en septiembre cuando realizo la entrevista a la última participante que quedaba por entrevistar.

Es en octubre de 2015 cuando consigo realizar la entrevista a la alcaldesa del municipio después de esperar nueve meses desde que realizo la primera petición formal por registro (anexo 9).

En estos momentos sólo queda entrevistar a un par de vecinas del pueblo lo cual se convierte en una misión casi imposible. La mayor parte de personas a las que se les pregunta no aceptan participar y comenzamos a contactar con otras hasta que damos con dos personas que aceptan nuestra

\footnotetext{
${ }^{32}$ Pueden verse las fechas de entrevistas en el anexo 10.
} 
solicitud. Estas dos entrevistas se realizan una en febrero y otra en marzo de 2016 completándose de este modo el ciclo de entrevistas.

\subsection{Rastreo de datos de unas entrevistas a otras. ¿Cómo} se deriva de unas preguntas a otras?

A continuación vamos a hacer un análisis de las preguntas que se derivan de cada una de las entrevistas. No entramos en el contenido de las mismas ya que eso se realizará en el apartado de los resultados pero sí que utilizamos lo recogido en una entrevista para generar nuevas preguntas en entrevistas posteriores. La tabla general de preguntas que surge de la sesión con el G.A. y de la que partimos podemos verla en el cuadro que hay más abajo.

01. ¿Qué objeto, fotografía, canción, lectura,... has traído?, ¿por qué lo relacionas con Maranya? y ¿por qué lo relacionas contigo?

02. ¿Qué imagen quieres mostrarme de Maranya?

03. ¿Qué es Maranya?, ¿qué significado tiene para ti?, ¿qué te une a Maranya?

04. ¿Cómo empezaste a formar parte de la CJ?, ¿Cual es tú papel en Maranya?, ¿Para qué vienes a M?

05. ¿A qué grupo de participación perteneces dentro de Maranya?, ¿identificas a tu grupo dentro de Maranya?, ¿qué haces en M.?, ¿qué responsabilidades tienes?

06. ¿Qué aprendes en Maranya?, ¿Cómo lo has aprendido? Formas concretas

07. ¿Cómo esos aprendizajes los trasladas a la vida?

08. Cuéntame tu historia en Maranya. ¿Cómo nace Maranya y cuál es tu experiencia en esa historia?

09. Si tuvieras que mantener a Maranya en tu memoria, ¿con qué recuerdo la mantendrías? ¿Qué recordarás de Maranya dentro de cinco/diez años?, ¿cómo ves a Maranya dentro de cinco/diez años?

10. ¿Qué opinas del espacio dónde está ubicado? (privado con ganas de hacerlo público, plaza, interior). Provocar qué pensamos sobre el espacio físico (propio y autogestionado). 
11. ¿Qué tipo de comunicación tiene Maranya con el exterior? A nivel virtual, presencial,...

12. ¿Qué relación tiene con el Casal Jove, el Ayuntamiento, los IES, los colegios,...?

13. ¿Dónde ubicas a Maranya en el territorio? y ¿Dónde te ubicas tú dentro de Maranya? Actividad: Mural de relaciones.

14. ¿Qué te gustaría contar que no te he preguntado?

Observamos las conexiones que existen entre los temas que se preguntan a lo largo de todo el proceso de entrevistas a través del mapa relacional que vemos a continuación (figura 10). Con él vemos que la mayor parte de los temas se contrastan entre las personas entrevistadas. Podemos observar a partir de sus líneas los niveles de saturación de cada una de las temáticas tratadas. A su vez vemos como existe una ampliación temática que se concreta en función del grupo entrevistado a partir de contenidos que aparecen en entrevistas anteriores.

En el gráfico siguiente (figura 10) vemos representados cada uno de los temas que surgen en las diferentes entrevistas realizadas. Están organizadas de arriba abajo primero la parte izquierda (pirámide de participación) y después la derecha (participantes sin participación directa en la Casa). En él podemos ver cómo se van complementando los temas y cómo aparecen nuevos que acaban formando parte de las siguientes entrevistas. A su vez, el gráfico, me ayuda a ver cuáles son las lagunas existentes en un nivel concreto de participación y de este modo me facilita la tarea de contrastar con otros documentos o herramientas de investigación.

Figura 10. Temáticas que aparecen en las entrevistas. 



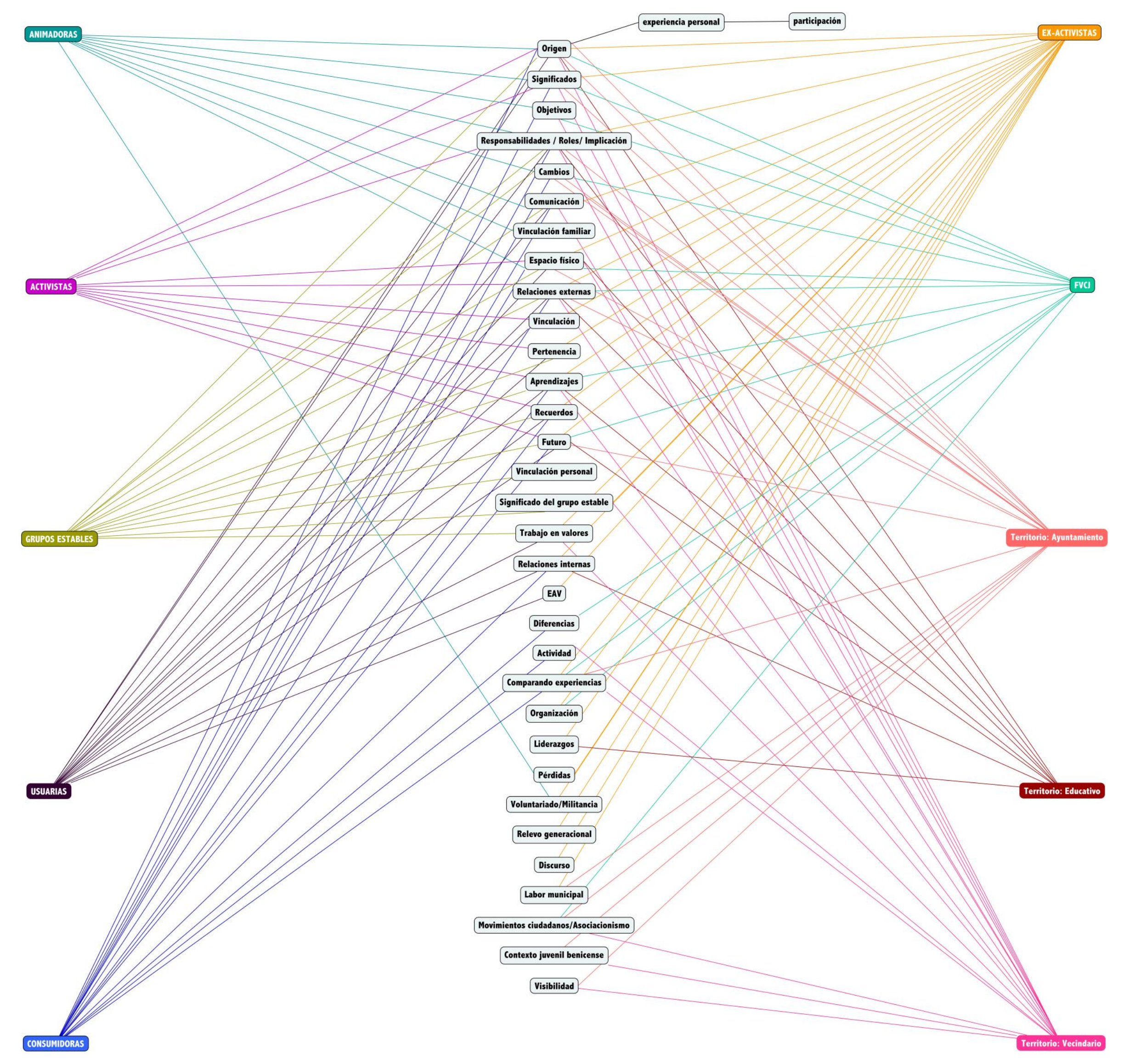




\subsection{Proceso de transcripción.}

A la hora de realizar la transcripción de las entrevistas elaboré un protocolo de transcripción que sigue las siguientes indicaciones. Para sistematizar el proceso describí cuales eran los pasos que tenía que seguir a la hora de escribir todo aquello que se había hablado en una entrevista. En primer lugar hay que abrir una carpeta de transcripciones y otra de audios. Una vez se sube el audio, se hace un documento para la transcripción. En él aparecerán las dos tablas que podéis ver a continuación y que han de adjuntarse a todos los documentos que se creen para escribir transcripciones. Estas tablas (tabla 29- tabla 30) han de completarse antes de iniciar la transcripción.

Tabla 29. Datos de la entrevista.

\begin{tabular}{|l|l|}
\hline Entrevistadora & \\
\hline Entrevistada & \\
\hline Objetivo de la entrevista & \\
\hline Fecha & \\
\hline Duración & \\
\hline Tipo de grabación & \\
\hline Persona que transcribe & \\
\hline $\begin{array}{l}\text { Documentos adjuntos a la entrevista (si se } \\
\text { precisa) }\end{array}$ & \\
\hline $\begin{array}{l}\text { Contexto de grabación (antes de comenzar a } \\
\text { grabar, clima, etc.) }\end{array}$ & \\
\hline Incidencias (si se precisa) & \\
\hline
\end{tabular}

Tabla 30. Leyenda entrevista.

\begin{tabular}{|l|l|}
\hline Entrevistadora & Arecia (A) \\
\hline Entrevistada & Nombre (Inicial) \\
\hline $\begin{array}{l}\text { Frases inconclusas, silencios en medio de } \\
\text { una frase }\end{array}$ & $\ldots$ \\
\hline $\begin{array}{l}\text { Reproducción literal de lo que ha dicho otra } \\
\text { personas o reproducción de pensamiento }\end{array}$ & 'aaaaa' \\
\hline Intervenciones entrevistadora & $\mathrm{kkkkk}$ \\
\hline Aclaraciones a la entrevista & {$[\ldots]$} \\
\hline Risas & $(\mathrm{R})$ \\
\hline
\end{tabular}


Palabras que no se entienden (se marca el $<>$

tiempo en la grabación)

Un apartado relevante, que nos facilitará la recuperación del momento de entrevista, es el espacio para describir que es lo que ha ocurrido antes de empezar la entrevista: de qué se habla, dónde se hace la entrevista y cuál es el ambiente, entre otras cosas. Además en el apartado incidencias he de describir si he tenido problemas para llevar a cabo la entrevista como por ejemplo que se hayan dado fallos en la grabadora o se pierda la grabación. Si esto ocurre, la persona que transcribe ha de describir todo aquello que recuerda de la entrevista antes de que pase más tiempo. Así podrá recuperar gran parte de la información recogida y si fuera necesario se repetiría la entrevista de nuevo.

Una vez completadas las tablas pasamos a escribir literalmente, con todos los matices, el contenido de la entrevista. La transcripción se ha facilitado a través del sistema técnico Express Scribe ${ }^{\circledR}$ lo cual ha reducido el tiempo de transcripción que se ha situado alrededor de las 4-5 horas para una hora de entrevista.

Respecto a la corrección gramatical, esta ha sido mínima ya que el objetivo de la transcripción no es hacer un análisis lingüístico de la entrevista. Aun así remarcamos que todas aquellas entrevistas que se han realizado en valenciano no han sido corregidas gramaticalmente siempre que el «error» haya sido localizado como una variante dialectal de la lengua en la que se habla.

Es importante seguir los códigos de la segunda tabla (tabla 30) para que todas las transcripciones tengan un mismo formato. Esto facilitará el trabajo a la hora de realizar el análisis ya que todo mantendrá una misma forma y significado. Una vez transcrita la entrevista se hace un repaso de la transcripción.

\subsection{Devolución de las entrevistas.}

La devolución de las entrevistas a las participantes ha sido fundamental en nuestra investigación. Establecer un diálogo entre la entrevistadora, lo escrito y la entrevistada nos ha ayudado a analizar nuevas temáticas a parte de validar, consensuar y valorar (Rivas y Leite, 2010). 
Seguimos a estas dos autoras para remarcar el sentido de la devolución. Ese momento en el que a la participante le llega de nuevo su información aportada y la lectura le hace de espejo de aquello vivido. Por ello la devolución implica un proceso de horizontalidad entre las partes. Además y muy unido a esta cualidad de la devolución está la posibilidad de generar un espacio de aprendizaje a partir de la propia devolución que genera un intercambio de conocimiento respecto a la propia historia, a su contexto y también a la investigación. Es una oportunidad para construir ese conocimiento de manera colaborativa y democrática generando una situación de cambio para contextualizar, ampliar y dotar de significado a todas las partes de la entrevista en particular y de la historia del colectivo en general.

En nuestro caso el proceso que llevamos a cabo es el siguiente. Al finalizar la correspondiente transcripción de toda la entrevista la envío por correo electrónico (anexo 11) a la persona entrevistada remarcándole la importancia de su revisión y el derecho por parte de esta a modificar, añadir o eliminar toda aquella información que le resulte adecuada. La investigadora se ofrece para aclarar cualquier duda respecto al proceso además de estar disponible para realizar el intercambio de manera presencial. Una vez se incorporan los cambios oportunos realizados por las entrevistadas, las transcripciones se codifican y se archivan en sus correspondientes carpetas. De esta forma estarán listas para subirlas al software que se vaya a utilizar para el análisis. De este modo, el audio ya no es imprescindible para el análisis pero sí que nos puede seguir siendo útil para aclarar dudas que surjan respecto al documento transcrito.

\subsection{Ordenación de los datos de las entrevistas.}

Las entrevistas son uno de los pilares fundamentales de esta investigación. Por esta razón el cómo procesemos toda la información construida a partir de esta herramienta es imprescindible para entender el análisis del relato de vida. Una vez transcritas todas las entrevistas es momento de hacer un registro de contenido (Pujadas, Comas y Roca, 2010:300). Para ello, paralelamente al registro en formato de transcripción, debemos llevar a cabo tres formas más para organizar la información: 
I. Registro temático. Los fragmentos de las diferentes entrevistas han de agruparse en función de los temas que interesan en la investigación y que se encuentran relacionados con las preguntas de investigación.

Imagen 1. Registro temático final.

Nombre
Aspectos educativos
Comunicación
Incidentes críticos
Organización
Participación
Percepciones
Prospectiva

II. Registro de personas. Organizar la información en función de cada una de las personas que ha participado nos permite facilitar criterios de rigor de calidad científica y a su vez disponer de datos concretos de cada caso, definiendo caso como la persona entrevistada.

Imagen 2. Registro de entrevistadas: autocodificación de casos.

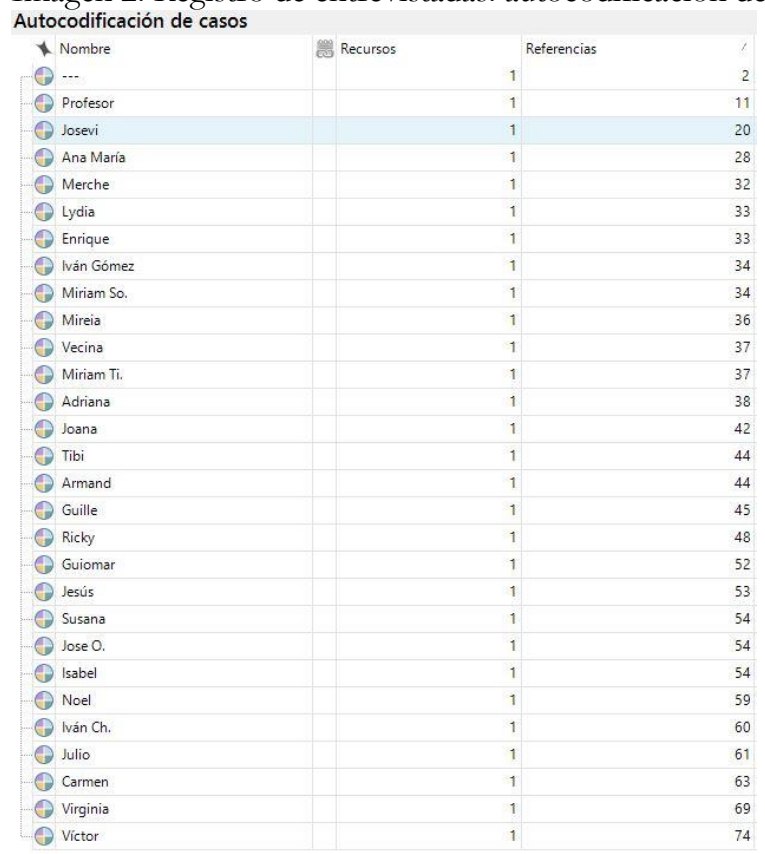


III. Registro cronológico. La pauta de ordenar los datos a través de un hilo cronológico facilita la comprensión del proceso de vida de la asociación y además posibilita una narración biográfica sencilla, entendible y organizada.

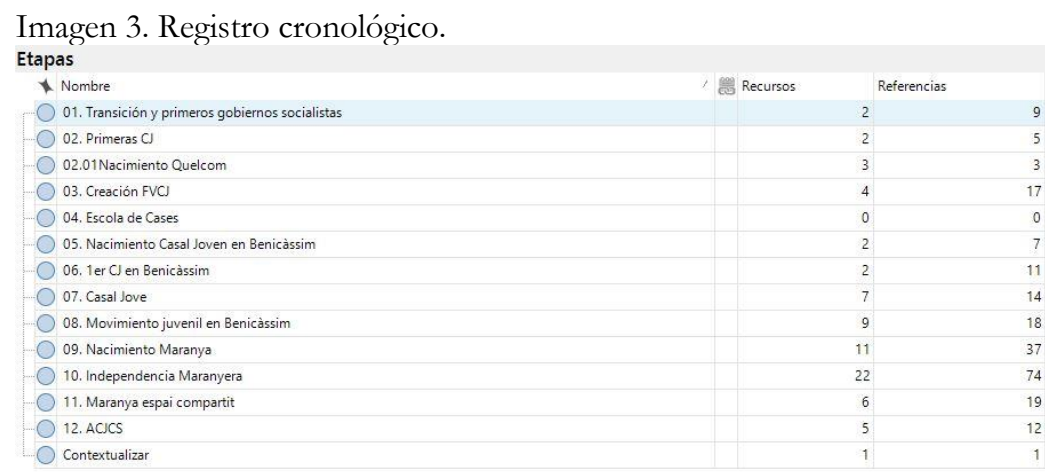

Toda esta información se organiza a través del software NVivo ${ }^{\circledR}$ lo cual nos ayudará a tenerla ordenada para después cruzarla, en fases posteriores, con la del resto de herramientas.

\subsection{Perspectivas y procedimientos de análisis de la información.}

Una de las finalidades de esta tesis es generar una interpretación teórica de aquellos procesos de participación que se dan en la Casa a partir del relato narrativo de la propia asociación que convierta los datos en significativos. En este sentido, nos interesa abordar los datos desde un razonamiento narrativo y no simplemente categorial. Como Bolívar (2002) expone: «Lo que importa son los mundos vividos por los entrevistados, los sentidos singulares que expresan y las lógicas particulares de argumentación que despliegan». Desde el análisis paradigmático únicamente haríamos cuenta de patrones generales o comunes entre las entrevistadas y en nuestro estudio también queremos abordar las particularidades de las distintas voces (tabla 31). Por eso, siguiendo a Atkinson (1997) y a Moriña (en prensa), entre otras autoras, hemos decidido optar por utilizar varios tipos de análisis que nos ayudarán a comprender los relatos, estructurar la historia y comprenderla en su complejidad. 
Tabla 31. Diferencias entre análisis paradigmático y narrativo según Bolívar (2002).

\begin{tabular}{|l|l|l|}
\hline & Análisis paradigmático & Análisis narrativo \\
\hline $\begin{array}{l}\text { Modos de } \\
\text { análisis }\end{array}$ & $\begin{array}{l}\text { Tipologías, categorías, normalmente } \\
\text { establecidas de modo inductivo. }\end{array}$ & $\begin{array}{l}\text { Conjuntar datos y voces en una historia } \\
\text { o trama, configurando un nuevo relato } \\
\text { narrativo }\end{array}$ \\
\hline Interés & $\begin{array}{l}\text { Temas comunes, agrupaciones } \\
\text { conceptuales, que facilitan la } \\
\text { comparación entre casos. } \\
\text { Generalización }\end{array}$ & $\begin{array}{l}\text { Elementos distintivos y específicos. } \\
\text { Revelar el carácter único y propio de } \\
\text { cada caso. Singularidad. }\end{array}$ \\
\hline Criterios & $\begin{array}{l}\text { Comunidad científica establecida: } \\
\text { tratamiento formal y categorial. }\end{array}$ & $\begin{array}{l}\text { Autenticidad, conerencia, } \\
\text { comprensible, carácter único. }\end{array}$ \\
\hline Resultados & $\begin{array}{l}\text { Informe «objetivo»: análisis } \\
\text { comparativo. } \\
\text { Las voces como ilustración. }\end{array}$ & $\begin{array}{l}\text { Generar una nueva historia narrativa } \\
\text { conjuntada - a partir de las distintas } \\
\text { voces- por el investigador. }\end{array}$ \\
\hline Ejemplos & $\begin{array}{l}\text { Análisis de contenido convencional, } \\
\text { «teoría fundamentada». }\end{array}$ & $\begin{array}{l}\text { Informes antropológicos, buenos } \\
\text { reportajes periodísticos o televisivos. }\end{array}$ \\
\hline
\end{tabular}

Como producto final en esta fase, queremos escribir el relato de la Historia de Maranya. Un documento público que aunará la información de todas las herramientas utilizadas y todas las perspectivas que en ellas se recogen.

El análisis estructural nos será útil para organizar la narrativa a través de la pluralidad de voces y el narrativo nos dará esa narración particular de la asociación. En definitiva y de forma resumida, abordaremos el análisis de la siguiente forma:

(a) Realizaré el registro estructural de la información construida a lo largo de toda la investigación que nos ayudará a organizar el relato de vida. Para ello se genera un análisis estructural en el que surgen los elementos distintivos y específicos de toda la investigación.

(b) Continuaremos con un análisis narrativo que dará forma al relato de vida y que facilitará

(c) la devolución y el análisis crítico que se llevará a cabo junto al Grupo Asesor en la tercera fase.

En la mayor parte de los estudios cualitativos las tareas analíticas no suelen visibilizarse. En esta evidencia es en la que, históricamente, se han basado las críticas sobre opacidad y subjetividad de la investigación cualitativa. En la literatura metodológica, la falta de descripción de los procedimientos seguidos en el análisis de los datos es conocido como el problema de la 
«caja negra» (Potter, 1996). Este problema hace alusión a conocer el tipo de datos que las investigadoras han construido en sus estudios y cuál ha sido su resultado final pero desconocemos que ha pasado entre esos dos momentos clave. Además esta conceptualización también es asumida por Gimeno Sacristán (1982) para realizar una crítica a la investigación experimental y positivista que durante años ha ocupado el panorama educativo. Con ella lo que se pretende es construir procesos y darles luz denunciando aquellos modelos que sólo se centran en los resultados.

Por ello durante toda la tesis hemos diseñado la investigación desde la visibilidad del proceso y así en este apartado partimos de la idea de hacer más transparentes los procedimientos llevados a cabo durante el Análisis de Datos Cualitativos. Queremos que salgan de la «caja negra» y se hagan públicos y transparentes (Anfara, Brown \& Mangione, 2002; Constas, 1999).

De este modo, a continuación describiré tanto el análisis estructural, el análisis narrativo y el análisis crítico que sustentan el análisis global de todos los resultados de esta tesis.

\subsubsection{Los tres tipos de análisis.}

\subsubsection{Análisis estructural.}

Para llevar a cabo un análisis estructural necesitamos extraer el conjunto de los elementos e interrelaciones que caracterizan el fenómeno social que estamos estudiando. Por ello, nuestra investigación se fundamenta en el Análisis de Datos Cualitativos (ADC) en el que se establece la búsqueda de patrones en los datos que hemos ido construyendo a lo largo del estudio, además de la propuesta de ideas que explican la existencia de esos patrones (Bernard y Ryan, 2010; Paré, 2015). Esta búsqueda de patrones nos interesa para encontrar las asociaciones, relaciones, conexiones, oposiciones, distinciones, divergencias o aislamientos entre datos (Bernard, 2000).

Para llevarlo a cabo, el ADC atraviesa cuatro fases (Paré, 2015):

- Reducir los datos en forma de categorías durante la codificación.

- Identificar las relaciones existentes entre los datos en la organización de patrones. 
- Utilizar herramientas para verificar los resultados durante la corroboración de las afirmaciones derivadas del análisis.

- Presentar los resultados mediante la disposición de los datos.

A continuación podemos ver el siguiente gráfico (Figura 11) que nos muestra el ciclo del análisis cualitativo, desde la reducción de datos hasta la exposición de los resultados. Este gráfico ha sido adaptado de Miles \& Huberman (1994) por Paré (2015) y nos muestra cuales son las particularidades de cada una de las fases.

Figura 11. Ciclo y fases del Análisis de Datos Cualitativos de Miles \& Huberman (1994) adaptado por Paré (2015).

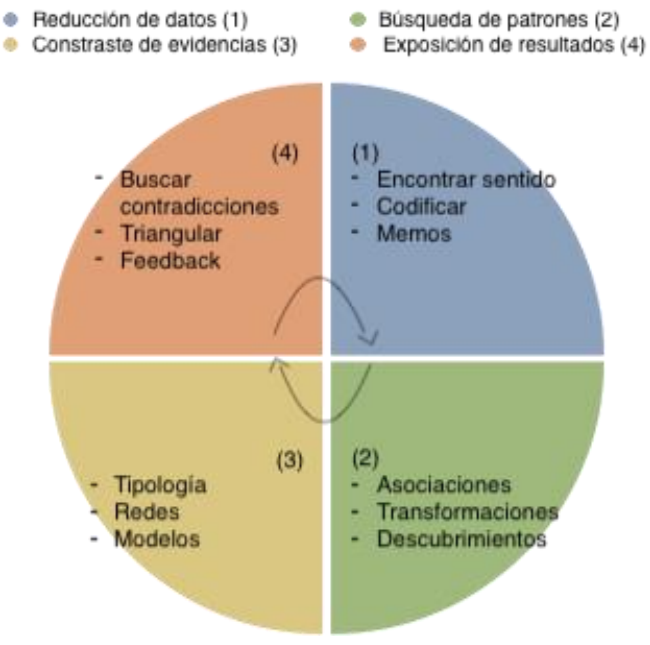

Para llevar a cabo un buen ADC, es fundamental, que exista coherencia entre las preguntas de investigación, los datos recogidos y la finalidad del estudio (Paré, 2015). Por ello nos centramos en descubrir, a través de diferentes autoras, cuales son los fundamentos a seguir para dotar de coherencia el ADC.

En relación a la pregunta de investigación, Blaikie (2010) nos expone que fundamentalmente existen tres tipos de preguntas: preguntas del «qué», preguntas del «por qué» y preguntas del «cómo». Estas hacen referencia a diferentes tipos de concreción (tabla 32) basados en la descripción, la explicación y el cambio respectivamente. En nuestro estudio contamos con 
los tres niveles de concreción ya que nos hacemos preguntas que cuestionan el qué, el por qué y el cómo.

Tabla 32. Los tres niveles de concreción de nuestro estudio.

\begin{tabular}{|l|l|l|}
\hline Tipo de pregunta & $\begin{array}{l}\text { Formulación de la } \\
\text { pregunta }\end{array}$ & Categorías de pregunta \\
\hline Pregunta Qué & $\begin{array}{l}\text { ¿Qué papel juega la Casa de } \\
\text { Joventut La Maranya en la } \\
\text { cultura de participación } \\
\text { social en las jóvenes de } \\
\text { Benicàssim? }\end{array}$ & $\begin{array}{l}\text { Descriptiva: Representa las } \\
\text { características del fenómeno } \\
\text { componentes de } \\
\text { social. }\end{array}$ \\
\hline Pregunta Por qué & $\begin{array}{l}\text { ¿Por qué? } \\
\text { Pregunta Cómo }\end{array}$ & $\begin{array}{l}\text { Explicativa: Establece las } \\
\text { relaciones entre los } \\
\text { diferentes atributos. }\end{array}$ \\
\hline $\begin{array}{l}\text { ¿Cómo se convierte la Casa } \\
\text { de Joventut en un agente } \\
\text { educativo de cambio en el } \\
\text { territorio? }\end{array}$ & $\begin{array}{l}\text { Transformativa: Explica la } \\
\text { forma tal y como se sucede } \\
\text { el fenómeno social. }\end{array}$ \\
\hline
\end{tabular}

En la primera pregunta abordamos la parte descriptiva de la Casa representando características y componentes del fenómeno social que estamos estudiando. En segundo lugar abordamos la parte explicativa reconociendo las relaciones que existen entre dichas características y componentes. Por último, hablamos de la parte transformativa en la que se indaga en la forma del proceso de acción de la propia Casa.

En cuanto al propósito de la investigación seguimos a autoras como Creswell (2003), Blaikie (2010), Marshall \& Rossman (2006/1999) y Paré (2015) que sugieren que en un estudio se pueden perseguir diferentes finalidades, entre ellas: exploratoria, descriptiva, explicativa, predictiva, evaluativa y valorativa. El propósito de nuestro estudio etnográfico es describir la Casa de Joventut La Maranya y explorar el papel que juega dentro de la Cultura de participación juvenil de las jóvenes de Benicàssim explicando a su vez cómo se construye como agente educativo para poder crear nuevas oportunidades de acción social.

Otro de los aspectos que debe tener coherencia dentro del ADC es la construcción de datos. Recordamos que queremos encontrar el equilibrio entre la construcción, la pregunta de investigación y el propio diseño de investigación (Guest et al., 2012). Así podemos preguntarnos qué tipo de 
datos estamos construyendo (tabla 33) y si estos datos son apropiados para el tipo de análisis que queremos realizar.

Tabla 33. Tipo de datos utilizados en el análisis.

\begin{tabular}{|l|}
\hline \multicolumn{1}{|c|}{ Tipo de datos } \\
\hline Transcripciones de entrevistas \\
\hline Notas de observación \\
\hline Documentos \\
\hline Videos y audios \\
\hline Fotografías \\
\hline Datos de Medios de Comunicación Social \\
\hline Artículos de prensa \\
\hline Objetos \\
\hline
\end{tabular}

Todos estos datos nos facilitan el análisis para contestar tanto las preguntas descriptivas como las explicativas y transformativas a partir de un análisis estructural. Según Boyatzis (1998) el ADC nos ayuda a ver, reconocer la información y su significado a través de la codificación e interpretación de los patrones en los datos. Con este tipo de análisis se reducen los datos a categorías sabiendo qué significado tiene cada una y la relación entre ellas. Así estas te llevan a diferentes dimensiones, pudiendo mostrar aquello por lo que se componen y las relaciones entre las mismas. Sus dos principales fortalezas son que se puede utilizar con todo tipo de datos cualitativos y que se pueden realizar aproximaciones tanto deductivas como inductivas. LeCompte (2000) afirma que la estructura se debe exponer por partes ya que serán la base del relato, y que la propia relación entre ellas nos dará la respuesta a las preguntas de investigación.

Reconocemos que el análisis cualitativo no puede tener una guía exacta y replicable en todos los estudios. Este tipo de investigación ha de seguir unos pasos básicos que nos doten de flexibilidad para poder ajustarlo a las preguntas de investigación concretas y al singular contexto en el que se investiga (Patton, 1990).

En nuestro caso seguimos una serie de pasos que a partir de la literatura metodológica de diferentes autoras como Paré (2015), LeCompte (2000), Miles y Huberman (1994) y Braun \& Clarke (2006) concretamos en la siguiente secuencia. 
Tabla 34. Fases del análisis según Braun \& Clarke (2006) y LeCompte (2000).

\begin{tabular}{|c|c|c|}
\hline \multicolumn{3}{|c|}{ Realizando el análisis } \\
\hline Fases & Braune Clarke (2006) & LeCompte (2000) \\
\hline Uno & Familiarizarte con tus datos & Poner en orden la información \\
\hline Dos & Generar códigos iniciales & Buscar elementos \\
\hline Tres & Buscar temas & Crear grupos estables de elementos \\
\hline Cuatro & Revisar temas & Crear patrones \\
\hline Fases & BraunéClarke (2006) & LeCompte (2000) \\
\hline Cinco & Definir y nombrar temas & Recopilar estructuras \\
\hline Seis & Elaborar el informe & \\
\hline
\end{tabular}

De forma inmediata pasamos a describir nuestro propio proceso de análisis que principalmente consta de ocho fases:

Figura 12. Fases proceso de análisis estructural.

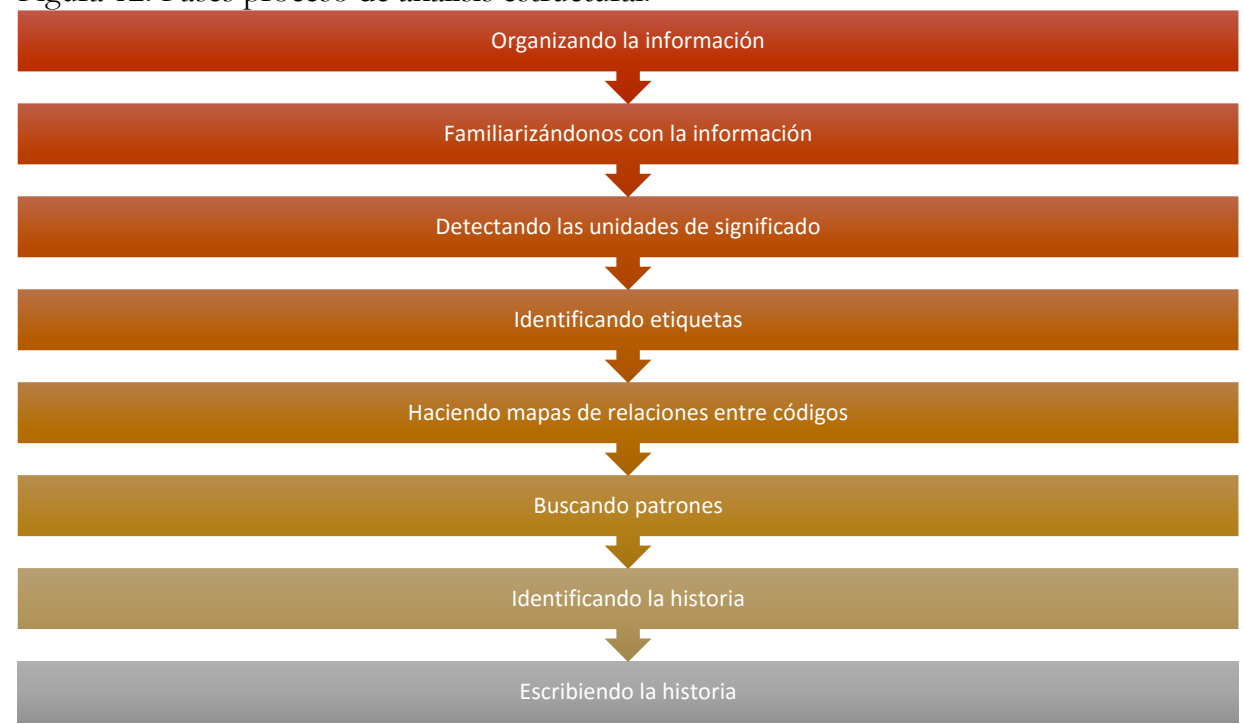

\section{Fase 1: Organizando la información}

Uno de los pasos más importantes en la investigación en general y en el análisis de datos en particular es poner en orden la información (Romagnano, 1991; LeCompte, 2000). Es necesario no olvidarse de esta fase ya que nos facilita el trabajo posterior y nos ayuda a orientar el análisis. 
Entre las diferentes acciones que he llevado a cabo para organizar la información nos encontramos con:

1. Crear carpetas diferenciadas por capítulos desde el inicio de la tesis para poder complementarlas durante todo el proceso.

2. Realizar copias de toda la información en diferentes memorias y ordenadores.

3. Trabajar desde una plataforma como Dropbox para tener actualizados los datos en los diferentes espacios de trabajo.

4. Generar una carpeta dedicada a todos los instrumentos de construcción de información y organizarla por subcarpetas de instrumentos y fechas de puesta en marcha.

Imagen 4. Herramientas de recogida de información.

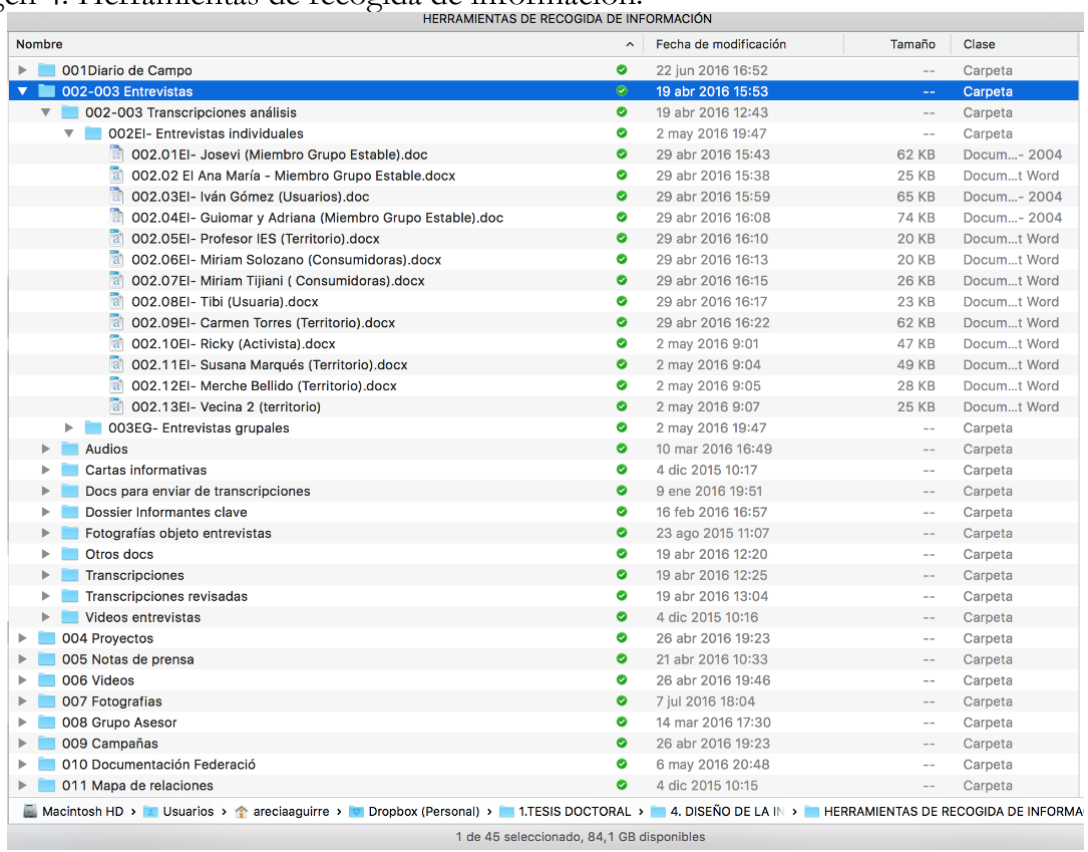

5. Estructurar cada una de estas subcarpetas dividiéndola en participantes, fechas de recogida y/o temas vinculados a las preguntas de investigación.

6. Introducir los distintos archivos en sus carpetas correspondientes.

7. Dotar de códigos numéricos y acrónimos que faciliten el orden y la búsqueda del material. 
8. Crear un libro Excel con todos los contenidos organizamos por nombre, código/acrónimo, fecha de recogida, breve descripción, participantes.

Imagen 5. Códigos entrevistas grupales.

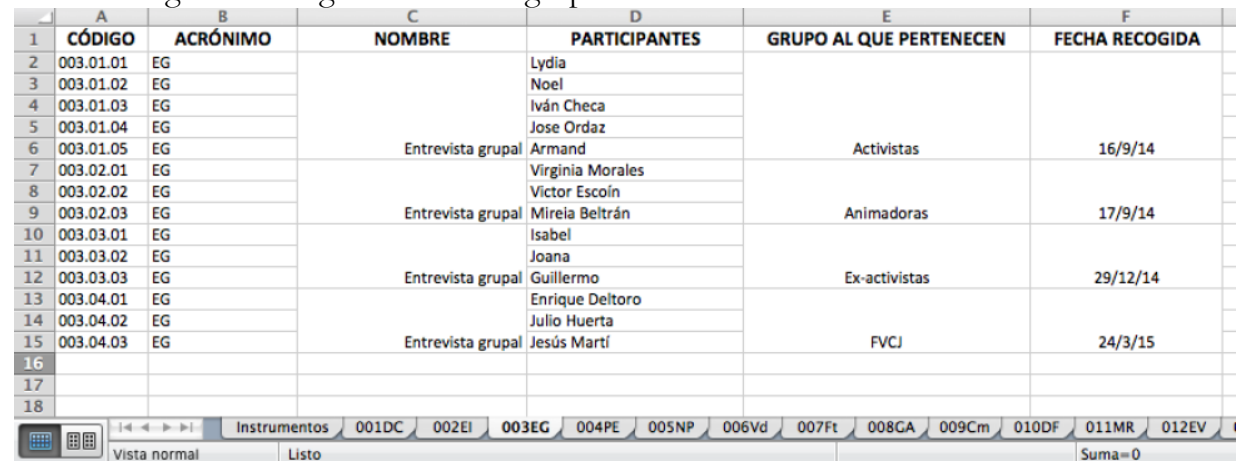

9. Identificar si se tienen todos los documentos y recuperar aquellos que se han perdido o extraviado.

\section{Fase 2: Familiarizándonos con la información}

Llegamos al siguiente punto con el objetivo de conocer la información con la que vamos a trabajar. Este paso nos ofrece la oportunidad de detectar las primeras ideas para un análisis inicial (Braun \& Clark, 2006) al igual que nos permite observar si existen lagunas de información relevante. En este caso, los pasos que he realizado se podrían resumir en los siguientes:

1. Dotar de un mismo formato, texto en nuestro caso, a toda la información posible. Para ello he transcrito todos aquellos audios de entrevistas y he extraído notas de todos aquellos videos que hemos grabado para la investigación.

2. Leer o visualizar detenidamente todos los documentos con la información que hemos construido.

3. Identificar las principales ideas y generar memos de ellas. 
Imagen 6. Memos registradas.

\begin{tabular}{|c|c|c|}
\hline \multicolumn{3}{|c|}{ Memos } \\
\hline 4 & Nombre & Nodos \\
\hline mag & Dudas & \\
\hline 的 & Democracia interna & \\
\hline neg & Relación sociedad & \\
\hline mag & Perfiles & \\
\hline 然 & Es la participación obligatoria & \\
\hline 筍 & Ayudan al cambio & \\
\hline ang & Análisis & \\
\hline 垉 & Trayectoria & \\
\hline 照 & Vinculación y Compromiso & \\
\hline 器 & Dependencia & \\
\hline aga & Relación con entornos de apre & \\
\hline
\end{tabular}

4. Detectar las posibles lagunas de información y volver a recoger toda la información para eliminar dichos vacíos.

\section{Fase 3: Detectando unidades de significado.}

Es el momento de generar toda la estructura de análisis y comenzar la codificación. Entendemos por codificación el proceso mediante el cual se segmenta la información en unidades de codificación (categorías), se etiquetan las unidades como códigos y se categorizan estos en un listado (Tesch, 1990).

Para conseguirlo el primer paso es encontrar aquellos extractos de información que marcarán nuestras propias unidades de significado (Glaser, 1992; Miles \& Huberman, 1994).

Después, a través del programa NVivo ${ }^{\circledR}$, seleccionamos extractos en la unidad de significado, buscamos aquellas frases que son comprensibles por si solas y significativas en los datos 
Imagen 7. Ejemplo de extracto en la unidad de significado.

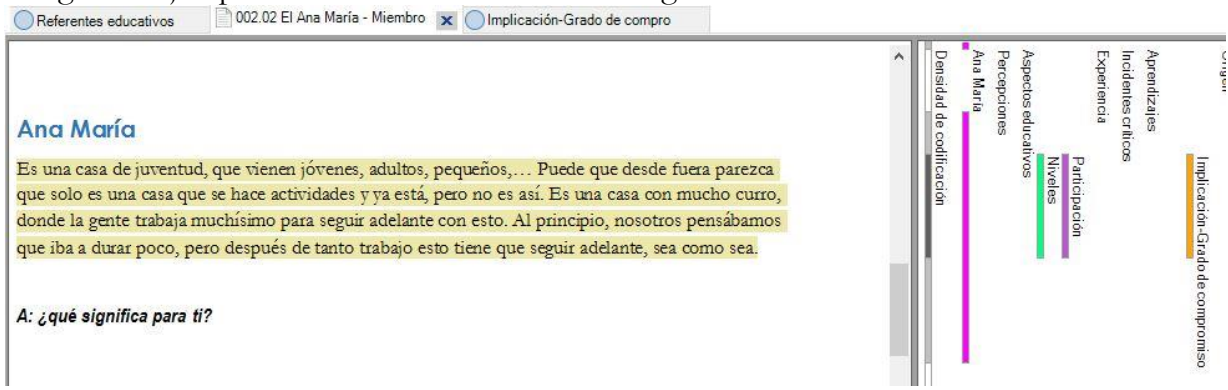

Para ello establecemos una serie de criterios que nos facilitarán la elección de estas unidades de codificación como son las repeticiones numerosas, o mínimas, las que son determinantes para la entrevistada, saturación, fortaleza argumentativa y la ejemplaridad entre otras.

Dependiendo del diferente método de análisis cualitativo se darán un tipo de unidades de codificación u otras (Tesch, 1990; Weaver\&Atkinson, 1994). En nuestro caso hemos trabajado a partir de una codificación múltiple tal y como proponen Marcelo (1994) y Parrilla (2000). Esta se ha basado en diferenciar por un lado la codificación temática y por otro lado la codificación cronológica. La codificación se ha dado de manera sucesiva a lo largo de todo el análisis simplemente diferenciando en NVivo ${ }^{\circledR}$ dos agrupaciones, una para las categorías de tipo temático y otra para las categorías de tipo cronológico.

En las siguientes tablas podemos diferenciar estas dos agrupaciones. En la primera (tabla 35) podremos leer cuales son las categorías que han formado parte de este análisis estructural y qué códigos forman parte de cada una de estas categorías. A su vez podemos ir al anexo 12 para ver categorías y códigos con una definición de cada código y un ejemplo del mismo. La segunda tabla (tabla 36) marca la categoría etapa y todos sus códigos y descripciones. 
Arecia Aguirre García-Carpintero

Tabla 35. Listado de categorías y códigos.

\begin{tabular}{|c|c|c|c|}
\hline Categorías & \multicolumn{3}{|c|}{ Códigos } \\
\hline \multirow[t]{10}{*}{ 1. Participación } & \multicolumn{3}{|c|}{ 1.1 Cauces participativos municipales } \\
\hline & \multirow[t]{7}{*}{ 1.2 Niveles } & \multicolumn{2}{|c|}{ 1.2.1 Autonomía } \\
\hline & & \multicolumn{2}{|c|}{ 1.2.2 Disponibilidad-tiempo } \\
\hline & & \multicolumn{2}{|c|}{ 1.2.3 Implicación-Grado de compromiso } \\
\hline & & \multicolumn{2}{|c|}{ 1.2.4 Liderazgo } \\
\hline & & \multirow{3}{*}{$\begin{array}{l}1.2 \\
\text { Escala }\end{array}$} & 1.2.6 Obligación \\
\hline & & & 1.2.7 Responsabilidades \\
\hline & & & 1.2.8 Roles \\
\hline & \multicolumn{3}{|c|}{ 1.3 Trayectoria participativa } \\
\hline & \multicolumn{3}{|l|}{ 1.4 Valoración } \\
\hline \multirow{11}{*}{$\begin{array}{l}2 . \\
\text { educativos }\end{array}$} & \multicolumn{3}{|c|}{ 2.1 Actitud activa de aprendizajes } \\
\hline & \multirow[t]{3}{*}{ 2.2 Aprendizajes } & \multicolumn{2}{|c|}{ 2.2.1 Formativos } \\
\hline & & \multicolumn{2}{|c|}{ 2.2.2 Personales } \\
\hline & & \multicolumn{2}{|c|}{ 2.2.3 Sociales } \\
\hline & \multicolumn{3}{|c|}{ 2.3 Día a día-transferencia } \\
\hline & \multirow[t]{3}{*}{ 2.4 Métodos } & \multicolumn{2}{|c|}{ 2.4.1 Evaluación } \\
\hline & & \multicolumn{2}{|c|}{ 2.4.2 Herramientas } \\
\hline & & \multicolumn{2}{|c|}{ 2.4.3 Proyectos } \\
\hline & \multicolumn{3}{|c|}{ 2.5 Objetivos/Resultados } \\
\hline & \multicolumn{3}{|c|}{ 2.6 Referentes educativos } \\
\hline & \multicolumn{3}{|c|}{ 2.7 Trabajo en valores } \\
\hline \multirow[t]{9}{*}{ 3. Organización } & \multicolumn{3}{|l|}{ 3.1 Actividad } \\
\hline & \multicolumn{3}{|c|}{ 3.1.1 Ritmo } \\
\hline & \multicolumn{3}{|l|}{ 3.2 Espacio físico } \\
\hline & \multicolumn{3}{|l|}{ 3.3 Estructura } \\
\hline & \multicolumn{3}{|c|}{ 3.3.1 GE Consumo } \\
\hline & \multicolumn{3}{|c|}{ 3.3.2 GE Humanos y Casas } \\
\hline & 3.3.3 EA & & \\
\hline & 3.4 Grado & & \\
\hline & 3.4.1 Au & estión & \\
\hline
\end{tabular}




\begin{tabular}{|c|c|c|}
\hline \multirow[t]{2}{*}{ Categorías } & \multicolumn{2}{|r|}{ Códigos } \\
\hline & \multicolumn{2}{|c|}{ 3.5 Relevo generacional } \\
\hline \multirow[t]{15}{*}{ 4. Significados } & \multicolumn{2}{|c|}{ 4.1 Asociacionismo } \\
\hline & \multicolumn{2}{|c|}{ 4.2 Cases de Joventut } \\
\hline & \multicolumn{2}{|c|}{ 4.3 Ciudadanía organizada } \\
\hline & \multicolumn{2}{|l|}{ 4.4 Educación } \\
\hline & \multicolumn{2}{|l|}{ 4.5 Federació } \\
\hline & \multicolumn{2}{|c|}{ 4.6 Grupo estable } \\
\hline & \multicolumn{2}{|c|}{ 4.7 Investigación } \\
\hline & \multicolumn{2}{|l|}{ 4.8 Maranya } \\
\hline & \multicolumn{2}{|l|}{ 4.9 Militancia } \\
\hline & \multicolumn{2}{|c|}{ 4.10 Ocio-Tiempo libre-Animación Sociocultural } \\
\hline & \multicolumn{2}{|c|}{ 4.11 Participación juvenil } \\
\hline & \multicolumn{2}{|c|}{ 4.12 Política socializadora } \\
\hline & \multicolumn{2}{|c|}{ 4.13 Referente } \\
\hline & \multicolumn{2}{|c|}{ 4.14 Técnico de juventud } \\
\hline & \multicolumn{2}{|c|}{ 4.15 Voluntariado } \\
\hline \multirow[t]{7}{*}{ 5. Prospectiva } & \multicolumn{2}{|c|}{5.1 Asociacionismo } \\
\hline & \multicolumn{2}{|c|}{ 5.2 Cases de Joventut-Maranya } \\
\hline & \multicolumn{2}{|l|}{ 5.3 Deseos } \\
\hline & \multicolumn{2}{|c|}{ 5.4 Expectativas } \\
\hline & \multicolumn{2}{|c|}{ 5.5 Participantes-Jóvenes } \\
\hline & \multicolumn{2}{|l|}{ 5.6 Política } \\
\hline & \multicolumn{2}{|l|}{ 5.7 Recuerdos } \\
\hline \multirow[t]{6}{*}{ 6. Comunicación } & \multirow[t]{3}{*}{ 6.1 Discurso } & 6.1.1 Asunción \\
\hline & & 6.1.2 Relevancia \\
\hline & & 6.1.3 Tipo \\
\hline & \multicolumn{2}{|c|}{ 6.2 Hacia Dentro } \\
\hline & \multicolumn{2}{|c|}{6.3 Hacia Fuera } \\
\hline & \multicolumn{2}{|l|}{ 6.4 Visibilidad } \\
\hline
\end{tabular}


Arecia Aguirre García-Carpintero

\begin{tabular}{|c|c|c|c|}
\hline Categorías & \multicolumn{3}{|c|}{ Códigos } \\
\hline \multirow[t]{14}{*}{ 7. Territorio } & \multirow[t]{13}{*}{$\begin{array}{l}7.1 \quad \text { Contexto } \\
\text { benicense }\end{array}$} & \multirow[t]{4}{*}{ 7.1.1 Ayuntamiento } & $\begin{array}{l}\text { 7.1.1.1 Acción } \\
\text { ciudadano-alcaldía }\end{array}$ \\
\hline & & & 7.1.1.2 Demanda \\
\hline & & & $\begin{array}{ll}\text { 7.1.1.3 } & \text { Posibilita } \\
\text { recursos } & \end{array}$ \\
\hline & & & 7.1.1.4 Preocupación \\
\hline & & \multicolumn{2}{|l|}{ 7.1.2 Construyen IES } \\
\hline & & \multicolumn{2}{|c|}{ 7.1.3 Contexto político en Benicàssim } \\
\hline & & \multicolumn{2}{|c|}{ 7.1.4 Datos sociodemográficos } \\
\hline & & \multicolumn{2}{|c|}{ 7.1.5 Estructura municipal } \\
\hline & & \multirow[t]{2}{*}{$\begin{array}{l}\text { 7.1.6 Labor } \\
\text { municipal-territorial }\end{array}$} & $\begin{array}{l}\text { 7.1.6.1 Misión pública } \\
\text { Administración }\end{array}$ \\
\hline & & & $\begin{array}{l}\text { 7.1.6.2 Misión pública } \\
\text { Maranya }\end{array}$ \\
\hline & & \multicolumn{2}{|c|}{$\begin{array}{l}\text { 7.1.7 Mov. Ciudadanos-Asociaciones } \\
\text { municipales }\end{array}$} \\
\hline & & \multicolumn{2}{|l|}{ 7.1.8 Oferta cultural } \\
\hline & & \multicolumn{2}{|l|}{ 7.1.9 Perfil jóvenes } \\
\hline & \multicolumn{3}{|c|}{ 7.2 Contexto social Global } \\
\hline \multirow[t]{3}{*}{ 8. Percepciones } & \multirow[t]{3}{*}{ 8.1 Comparativas } & \multicolumn{2}{|l|}{ 8.1.1 Diferencias } \\
\hline & & \multicolumn{2}{|l|}{ 8.1.2 Mejoras } \\
\hline & & \multicolumn{2}{|l|}{ 8.1.3 Nombres } \\
\hline
\end{tabular}




\begin{tabular}{|c|c|c|}
\hline \multirow[t]{2}{*}{ Categorías } & \multicolumn{2}{|r|}{ Códigos } \\
\hline & & 8.1.4 Semejanzas \\
\hline & \multicolumn{2}{|c|}{ 8.2 De dentro a fuera } \\
\hline & \multicolumn{2}{|c|}{ 8.3 De fuera a dentro } \\
\hline & \multicolumn{2}{|l|}{ 8.4 Experiencia } \\
\hline & \multicolumn{2}{|l|}{ 8.5 Origen } \\
\hline \multirow[t]{8}{*}{ 9. Incidentes críticos } & \multirow[t]{2}{*}{9.1 Barreras } & 9.1.1 Externas \\
\hline & & 9.1.2 Internas \\
\hline & \multicolumn{2}{|l|}{9.2 Cambios } \\
\hline & \multicolumn{2}{|l|}{ 9.3 Conflictos } \\
\hline & \multicolumn{2}{|c|}{ 9.4 Estrategias de afrontamiento } \\
\hline & \multicolumn{2}{|l|}{ 9.5 Miedos } \\
\hline & \multicolumn{2}{|l|}{ 9.6 Pérdidas } \\
\hline & \multicolumn{2}{|c|}{ 9.7 Transformaciones } \\
\hline \multirow[t]{10}{*}{ 10. Pertenencia } & \multicolumn{2}{|l|}{ 10.1 Acciones } \\
\hline & \multicolumn{2}{|l|}{ 10.2 Afecto } \\
\hline & \multicolumn{2}{|c|}{ 10.3 Convivencia } \\
\hline & \multicolumn{2}{|c|}{ 10.4 Espacio de vida } \\
\hline & \multirow[t]{2}{*}{10.5 Intereses } & 10.5.1 Grupales \\
\hline & & 10.5.2 Personales \\
\hline & \multicolumn{2}{|c|}{ 10.6 Reconocimiento } \\
\hline & \multirow[t]{2}{*}{ 10.7 Relaciones } & 10.7.1 Externas \\
\hline & & 10.7.2 Internas \\
\hline & \multicolumn{2}{|c|}{10.8 Valores compartidos } \\
\hline
\end{tabular}


Arecia Aguirre García-Carpintero

Tabla 36. Tabla de categorías cronológicas.

\begin{tabular}{|c|c|c|}
\hline Categoría & Código & Descripción \\
\hline \multirow[t]{8}{*}{ Etapas } & $\begin{array}{l}\text { 1.1. Transición y } \\
\text { primeros } \\
\text { gobiernos } \\
\text { socialistas }\end{array}$ & $\begin{array}{l}\text { Historia asociativa: desmantelamiento } \\
\text { asociacionismo. De ser asociado a ser político. }\end{array}$ \\
\hline & $\begin{array}{lr}\text { 1.2. } & \text { Primeras } \\
\text { Cases } & \text { de Joventut }\end{array}$ & $\begin{array}{l}\text { Cuando surgen las primeras casas de juventud y bajo que } \\
\text { paraguas legal, social y político. }\end{array}$ \\
\hline & $\begin{array}{ll}1.3 . & \text { Creación } \\
\text { FVCJ } & \end{array}$ & Nacimiento de la Federació. \\
\hline & $\begin{array}{l}\text { 1.4. Escola de } \\
\text { Cases de Joventut }\end{array}$ & Nacimiento y homologación de la escuela. \\
\hline & $\begin{array}{lr}1.5 . & \\
\text { juvenil } & \\
\text { Benicàssim } & \text { en } \\
\end{array}$ & $\begin{array}{l}\text { Surge un movimiento juvenil en Benicàssim: primeros } \\
\text { grupos, Quelcom, esplais,... }\end{array}$ \\
\hline & $\begin{array}{l}\text { 1.6. } 1 \text { er } \mathrm{CJ} \quad \mathrm{a} \\
\text { Benicàssim }\end{array}$ & Origen de la primera $\mathrm{CJ}$ en el municipio de Benicàssim. \\
\hline & $\begin{array}{l}\text { 1.7. Nacimiento } \\
\text { de Maranya }\end{array}$ & Historia de la creación de Maranya \\
\hline & $\begin{array}{l}\text { 1.8. } 4 / 5 \text { años de } \\
\text { independencia } \\
\text { maranyera }\end{array}$ & $\begin{array}{l}\text { Tiempo de independencia respecto al ayuntamiento, } \\
\text { autogestión y nuevo local. Cinco años desde se creó } \\
\text { Maranya en el papel y } 4 \text { desde que se independiza de las } \\
\text { instalaciones municipales. }\end{array}$ \\
\hline
\end{tabular}




\section{Fase 4: Identificando etiquetas.}

Continuando con el proceso llega el momento de codificar, es decir, debemos dotar de etiquetas a dichas unidades de codificación. Estas deben ser cercanas al concepto que representa ya que nos permitirá la recuperación posterior (Paré, 2015).

Según Paré (2015), Boyatzis (1998) y Tesch (1990) la información que se debe tener en cuenta a la hora de construir un buen código es la que sigue:

- etiqueta: clara, concisa, cercana a los datos, descriptiva y no interpretativa.

- definición: qué significa.

- criterios: indicadores de cuando aparece el código.

- ejemplos: ocurrencias del código en los datos.

Tabla 37. Elementos de un código.

\begin{tabular}{|l|l|}
\hline \multicolumn{1}{|c|}{ etiqueta } & \multicolumn{1}{c|}{ Roles } \\
\hline definición & $\begin{array}{l}\text { Situaciones en la que se observan comportamientos, funciones y normas } \\
\text { distintas en función del estatus social de una persona. }\end{array}$ \\
\hline criterios & $\begin{array}{l}\text { Personas actúan de un modo estipulado y se le da un estatus diferente al } \\
\text { resto. }\end{array}$ \\
\hline ejemplo & $\begin{array}{l}\text { " No he estado nunca porque si tuviera que llamarles la atención me } \\
\text { costaría, hacer de juez y parte es complicado. Por eso me mantengo más al } \\
\text { margen de lo que me gustaría hacerlo« }\end{array}$ \\
\hline
\end{tabular}

Los códigos pueden ser de diferentes tipos: descriptivos, interpretativos e inferenciales / de patrones (Miles\&Huberman, 1994). Estos van de la inducción a la deducción en el mismo orden en el que se han nombrado. El código descriptivo es aquel que nombra a una parte de la unidad de significado sin realizar interpretaciones. Por su parte, el interpretativo, refleja aquello que la investigadora entiende de una unidad de significado. Finalmente el código inferencial o de patrón hace explícito los datos que referencian teorías. Un ejemplo de nuestro estudio lo podemos ver a continuación (tabla 38): 
Tabla 38. Ejemplo de tipos de código.

\begin{tabular}{|c|c|c|}
\hline Descriptivo & Interpretativo & Inferenciales \\
\hline Responsabilidades & Liderazgo & Niveles de participación \\
\hline $\begin{array}{l}\text { Yo he asumido bastante } \\
\text { tema eléctrico, estructurales } \\
\text { y fontanería pero no sólo soy } \\
\text { yo, comparto el tema de } \\
\text { responsabilidades con otros } \\
\text { compañeros, con otros } \\
\text { padres que también tienen } \\
\text { conocimientos en ello y } \\
\text { otros monitores. (002.01 EI- } \\
\text { Josevi) }\end{array}$ & 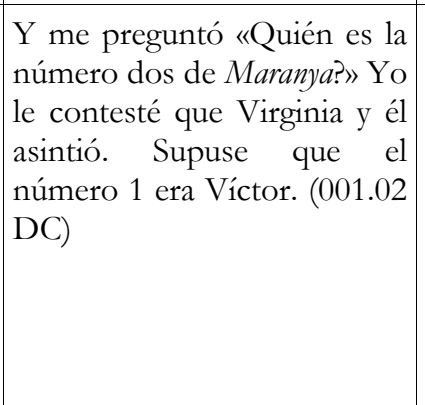 & $\begin{array}{l}\text { Me explican que llevan desde } \\
\text { marzo parados con el nuevo } \\
\text { video y que los otros tres los } \\
\text { tenían preparados Virginia y } \\
\text { Víctor: estructura, contenido, } \\
\text { todo y por eso fue más fácil } \\
\text { ya que ellas dirigían. Ahora } \\
\text { nos han dado el presupuesto } \\
\text { y tenemos que montarlo } \\
\text { nosotras todo. (001.01 DC) }\end{array}$ \\
\hline
\end{tabular}

\section{Fase 5: Haciendo mapas de relaciones entre códigos.}

Llegados a este punto tenemos que organizar todo ese listado de códigos que hemos producido. Es aquí cuando comienzan a surgir categorías y subcategorías que muestran la relación entre el fenómeno estudiado y los códigos que se han construido (Gibbs, 2007; Dey, 1993; Miles\&Huberman, 1994). Este listado de códigos se modifica a lo largo de toda la investigación, no es un proceso cerrado sino que el código se define, cambia, se sustituye, se subdivide o se incluye en otros durante todo el proceso.

La finalidad es revisar todos los códigos que se han elaborado y encontrar el modo en el que se configura un patrón coherente (LeCompte, 2000). Al dar este paso lo que estamos realizando es segmentar la información, reduciéndola a las categorías analíticas creadas. Para ello tendremos que:

1. Revisar los códigos.

2. Buscar las relaciones entre los grupos de códigos. 
Capítulo 3

Cartografía de la investigación

Imagen 8. Mapa NVivo ${ }^{\circledR}$ de relaciones entre códigos de la categoría aspectos educativos.

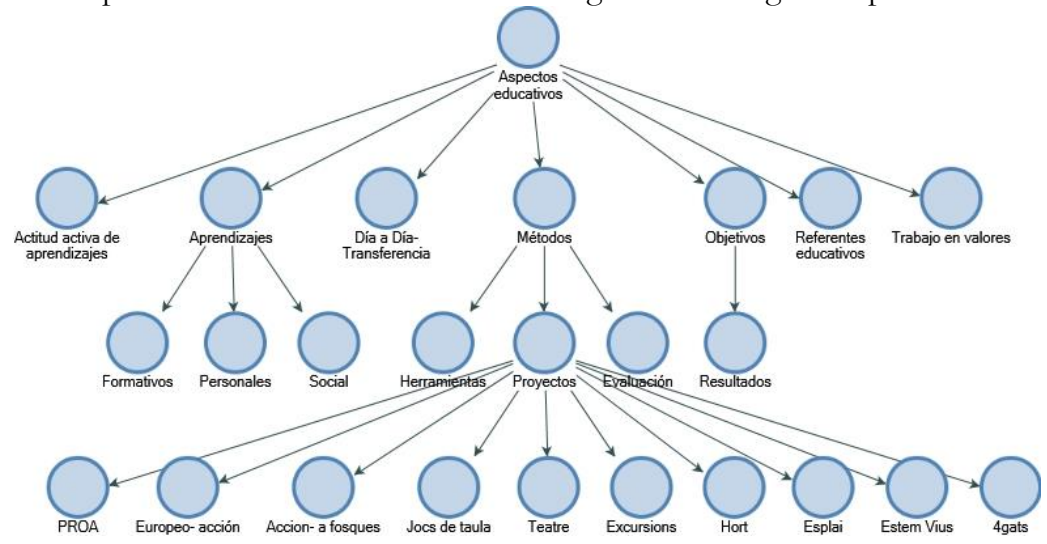

3. Descubrir las relaciones entre ellos con grupos temáticos más amplios.

Imagen 9. Ampliación de grupos temáticos.

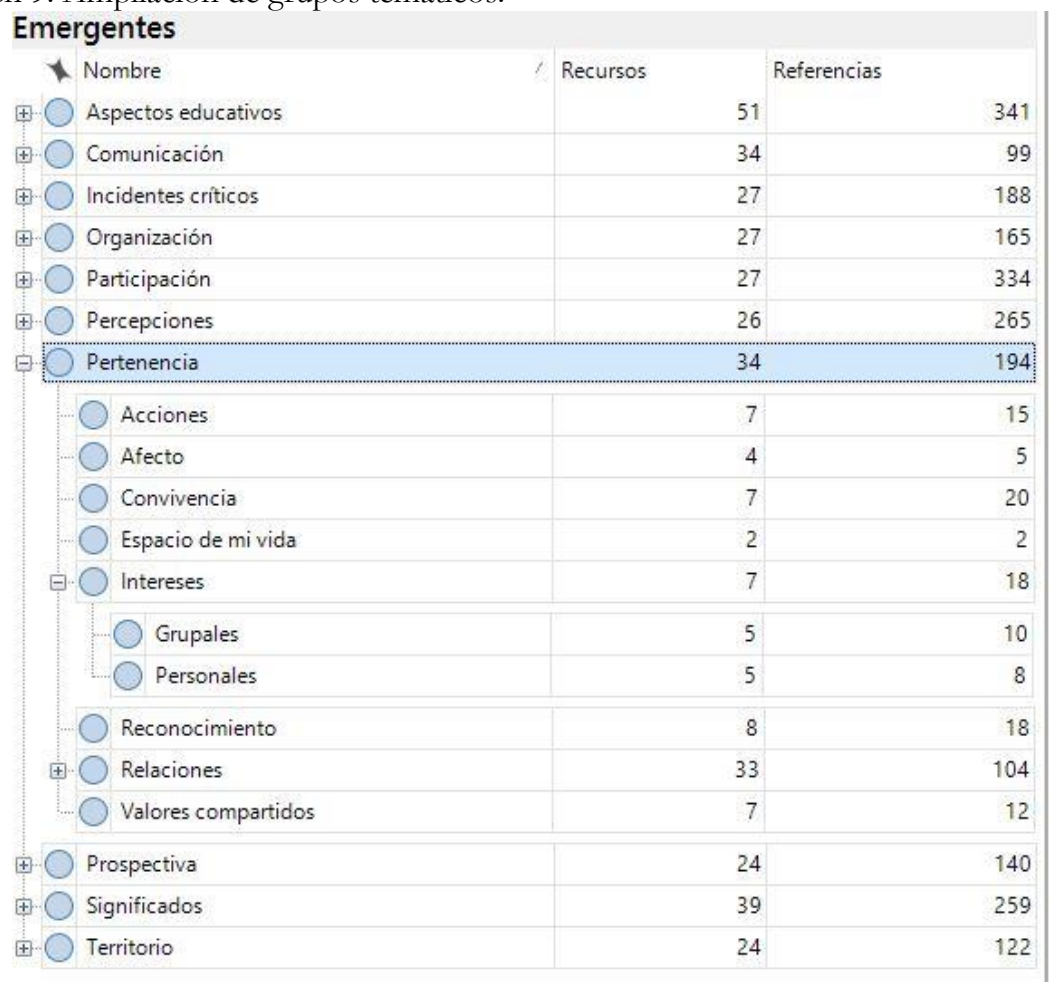


4. Ponerle a los datos el nombre de la categoría analítica que le corresponde.

5. Configurar las categorías y subcategorías en familias temáticas a partir del agrupamiento de los códigos.

6. Reconfigurar los códigos que no formen parte del grupo preguntándonos si son válidos o no para así redefinirlos o descartarlos.

Bien sabemos que los datos no nos dicen nada por sí solos hasta que no los clasificamos a partir de categorías analíticas. De esta forma podremos hablar del fenómeno a partir del cruce de categorías desde una perspectiva teórica. Las categorías analíticas:

a) expresan intenciones teóricas del investigador.

b) reordenan y recodifican la información observada.

c) permite comparar «observables».

Todas estas categorías surgirán de nuestra perspectiva teórica, nuestra experiencia anterior y también de todo aquello observado y recogido a lo largo de la investigación.

\section{Fase 6: Buscando patrones.}

Este ejercicio requiere la búsqueda de repeticiones en los datos cuando entre ellos se asocian, relacionan, conectan, oponen, distinguen, divergen y aíslan de otros (Bernard, 2000). Para desarrollarlo seguimos la estrategia de codificación de Paré (2015):

1. Mostrar el esquema de códigos.

2. Observar si emergen patrones de los códigos a partir de la coocurrencia.

3. Identificar clusters a partir de la codificación anterior. Los patrones se convierten en agrupaciones (clusters) en los cuales se incluyen aquellas relaciones que pueden llegar a convertirse en teoría o que explican el fenómeno concreto.

4. Al utilizar NVivo ${ }^{\circledR}$ debemos establecer un nivel (set level) en el programa por cada patrón observado. 
5. Elegir el nombre más adecuado para el nivel en función de los datos y la teoría.

6. Visibilizar el proceso para no quedarnos en lo abstracto de la codificación. Ayudarnos de las tablas que se elaboran a partir del trabajo en NVivo ${ }^{\circledR}$.

7. Analizamos si los niveles (sets) son empíricamente sólidos, a través de la saturación y teóricamente válidos, a partir de la revisión de la literatura (Paré, 2015:21-22)

El trabajo en esta fase se centra en la asociación de patrones, por ello es muy importante generar mapas conceptuales que nos ayuden a analizar las relaciones entre códigos, agrupamientos y niveles (Figura 13).

Figura 13. Mapa conceptual: Maranya estructurada en categorías y códigos. 



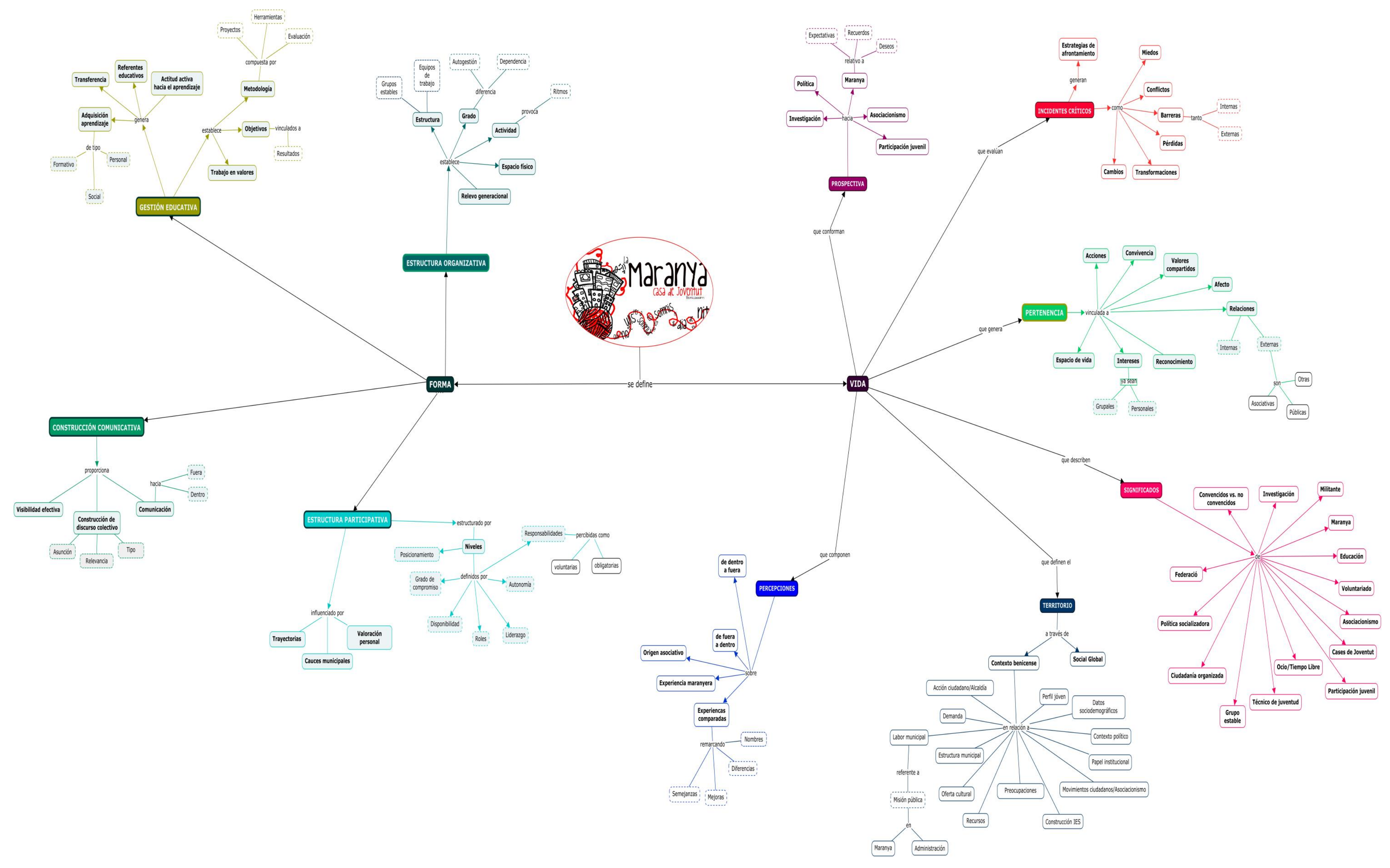




\section{Fase 7: identificando la historia.}

Una vez identificados los niveles debemos organizarlos con el objetivo de configurar estructuras que nos cuenten una historia. En nuestro caso queremos saber de qué forma contestan a las preguntas de investigación del estudio y para ello debemos contrastar todas las evidencias que surjan de los datos. Todo ello nos dará la oportunidad de entender los datos de un modo analítico para ofrecer perspectivas del fenómeno y así comparar con otros similares.

En este momento debemos realizar la triangulación de los patrones correspondientes y visibilizarla para que pueda evaluarse con posterioridad. En este ejercicio nos ayudarán las tablas que obtenemos del NVivo ${ }^{\circledR}$ y los mapas conceptuales que hemos elaborado.

\section{Fase 8: escribiendo la historia.}

Según Bolívar (2002) la tarea de la investigadora:

es configurar los elementos de los datos en una historia que unifica y da significado a los datos, con el fin de expresar de modo auténtico la vida individual, sin manipular la voz de los participantes. El análisis requiere que el investigador desarrolle una trama o argumento que le permita unir temporal o temáticamente los elementos, dando una respuesta comprensiva de por qué sucedió algo. Los datos pueden proceder de muy diversas fuentes, pero el asunto es que sean integrados e interpretados en una intriga narrativa (2002:13-14).

En esta fase nos apoyaremos en los listados de códigos, los patrones, las tablas NVivo ${ }^{\circledR}$ y los mapas conceptuales para generar el argumento relacionado con nuestras preguntas de investigación. Para contestarlas debemos estructurar el texto en función de los datos que han ido apareciendo ofreciendo una narración ordenada, clara y precisa del análisis. Esta descripción no puede estar excesivamente fragmentada sino que debemos localizar las relaciones entre los datos para narrar los resultados. Tal y como Bazeley (2009) expone " the data must be challenged, extended, 
supported, and linked in order to reveal their full value» ${ }^{33}$ para que la presentación de los resultados no se convierta en una presentación temática que no lleve a ningún sitio (Paré, 2015). Para ello realizamos un análisis narrativo que nos ayudará a generar el producto final, el relato.

\subsubsection{Análisis narrativo.}

Bolívar, Domingo y Fernández (2001) nos habla de la necesidad de alejarse del informe clásico que propone APA para acercarnos más a la nueva etnografía con textos narrativos de estilo periodístico ya que tiene muchas más opciones. Entre ellas podemos construir escena por escena contando la historia por episodios o bien, desarrollar al personaje a través de un registro completo de diálogos. Por otro lado podríamos ubicarnos a partir de un punto de vista subjetivo en tercera persona, experimentando un acontecimiento a través de la perspectiva de una de las participantes y también cuidar los detalles en cuanto a las participantes en escena: sus gestos habituales, hábitos, modales, costumbres, estilos de mobiliario, vestimenta, decoración, modos de comportarse y otros detalles que podrían aparecer a lo largo de la historia.

Tal y como Gibbs (2012) nos propone las narraciones constituyen una forma muy natural de transmitir los resultados al centrarse en multitud de aspectos que componen la información en una investigación. Este autor organiza el proceso de análisis narrativo del siguiente modo:

1. Buscar:

a. Acontecimientos: qué sucedió. Secuencia causal unos llevan a otros.

b. Experiencias: imágenes, sentimientos, reacciones, significados.

c. Explicaciones: justificaciones, excusas.

d. Narraciones: modos de interacción con el investigador, secuencia temporal, personajes, construcción de la trama, imágenes.

2. Identificar rasgos clave como principio, mitad y final de la historia.

3. Buscar ideas temáticas y puntos estructurales.

33 «Los datos deben ser desafiados, extendidos, apoyados, y vinculados con el objetivo de revelar todo su valor». 
4. Coger memos para orientar las explicaciones y la estructura general de la historia.

5. Observar contradicciones.

6. Vínculos entre elementos.

7. Sentimientos y emociones.

8. Codificar las ideas temáticas y desarrollar un marco de codificación.

9. Conectar las ideas con publicaciones teóricas sobre el tema

10. Comparaciones caso por caso.

A su vez, Moriña (en prensa) también basa su investigación en la realización de un primer análisis estructural y un posterior análisis narrativo. Generando los siguientes pasos para el narrativo:

1. Lee, de cada una de las protagonistas de las historias de vida, toda la información que tiene.

2. Organiza la información a partir de la cronología de la historia, desde el pasado al presente.

3. Identifica momentos clave narrados por las participantes en la investigación.

4. Se sitúa en un rol de neutralidad ya que respeta la historia tal y como la narra la protagonista.

En nuestro caso, es también el análisis estructural temático y cronológico los que dan soporte al narrativo ya que la narración se escribe bajo las estructuras generadas (Moriña, en prensa). De ahí que los pasos que finalmente hemos dado para realizar este tipo de análisis hayan sido los siguientes:

1. Lectura de toda la información a partir de la estructura cronológica y la estructura temática.

2. Detección de acontecimientos, experiencias e incidentes críticos que sean simbólicos para generar «enganche» en la lectora.

3. Seleccionar un momento clave para iniciar el relato.

4. Identificar rasgos esenciales de ese momento para realizar una descripción profunda del momento elegido. 
5. Estructurar la historia a partir de episodios cronológicos relacionados con dicho momento clave.

6. Indagar en las temáticas del primer análisis a partir de la estructura anterior profundizando en ellas en función de los episodios cronológicos narrados.

7. Contraponer y contrastar ideas a través de las diferentes voces participantes.

8. Compartir el producto final con el grupo asesor de la investigación para realizar el análisis crítico del mismo.

\subsection{La elaboración de la historia.}

Como De la Rosa (2010) o Moriña (en prensa) afirman, con los mismos datos, con la misma información construida se pueden contar múltiples historias en función de la persona que la narre. La nuestra simplemente es una de las posibles formas que podrían haberse escrito. A continuación me gustaría mostrar cómo he llegado a escribirla a partir de los pasos anteriormente definidos que dan forma al análisis narrativo.

Nos encontramos en el momento de narrar la historia de una unidad social como tantas otras veces se han realizado en otros estudios etnográficos. La diferencia es contar esa historia desde la pluralidad de voces existente sin dividir a las participantes en apartados sino darles entidad a lo largo de esta historia colectiva, intentando hacerlas fluir las unas con las otras para contar una misma historia. La historia de una Asociación Juvenil llamada Casa de Joventut La Maranya, en la que no siempre esas voces se comparten, unas veces se diferencian y otras se asemejan tanto que esta será nuestra mayor dificultad. Saber encontrar el equilibrio entre unas y otras para conseguir narrar en cada momento lo que ocurrió y lo que ha dado forma a lo que Maranya representa.

Para escribir esta historia hemos decidido optar por una en la que no aparecen interpretaciones de la investigadora, ni de otras autoras pero sî que se narra a partir de las palabras de las personas que han participado en la investigación ya bien sea desde sus entrevistas, desde los documentos de trabajo o desde las observaciones etnográficas entre muchas otras. Así, los comentarios e interpretaciones quedarán desplazados al siguiente punto de 
conclusiones y discusión, tal y como Moriña (en prensa) nos recomienda. Por lo tanto mi voz como investigadora en la historia simplemente sirve para narrar la historia sin emitir juicios ni valoraciones. Únicamente se observa algún posicionamiento como miembro de la asociación que soy.

Ya he explicado con anterioridad cual es la información construida y qué herramientas se utilizaron para conseguirlo. Ahora me gustaría remarcar cómo el análisis estructural y el cronológico me han ayudado a escribir esta historia. Sabemos que el resultado del análisis estructural es una serie de categorías y códigos los cuales nos asisten para conocer cuáles han sido aquellos aspectos que llegarán a contestar las preguntas de investigación a través del relato de esta historia. El análisis estructural me ha ayudado a cruzar voces y herramientas consiguiendo una triangulación que facilitará y sustentará la narración.

En el anterior mapa conceptual (Figura 13) vemos cuales son aquellos elementos que han de aparecer a lo largo de la historia. Estos son aspectos fundamentales que han emergido de toda la información construida y van contestando las preguntas de investigación.

A su vez está el análisis cronológico que me facilita la detección de las etapas fundamentales en la vida de la asociación y gracias al cruce de categorías estructurales y cronológicas he podido descubrir los elementos que van apareciendo en cada una de esas etapas para así detectar aquello simbólico que pueda «enganchan» a la lectora.

Del mismo modo tenemos que tener en cuenta a la hora de escribir el uso que le damos a la voz en el relato. Moriña (en prensa: 99) divide en cuatro los tipos de narraciones en función de este factor:

- Transcripciones literales de los textos.

- Escritos en los que la investigadora es la encargada de narrar.

- Textos en tercera persona porque la participante es la que narra de forma indirecta.

- Narraciones en primera persona en las que la participante escribe su propia historia.

En la Historia de Maranya ha sido complicado seleccionar una voz para que todas las personas se pudieran ver representadas. Por eso después de 
mucha reflexión se decide que la persona que narre la historia sea yo misma como investigadora militante pero siempre introduciendo las voces de las participantes y sin asumir ningún juicio como investigadora, simplemente como responsable de cruzar las voces de las personas.

Otro de los aspectos relevantes a lo hora de escribir la historia es saber cómo estructurarla. Para ello hemos identificado aquellas etapas críticas en la vida de Maranya, todas aquellas que dan forma a su historia intentando plasmar las diferentes realidades de la asociación: la interna y la externa (Taylor y Bogdan, 1987; Bruner, 1986; Moriña, en prensa) pero sin olvidar que como Germeten (2013) y Moriña (en prensa) dicen, las buenas historias no se escriben de manera estanca sino que las diferentes vidas fluyen en el escrito de la vida.

Por todo esto, en primer lugar he detectado elementos, etapas y aspectos simbólicos que hacen la narración atractiva y coherente con el objetivo. Más tarde he seleccionado un momento clave para iniciar el relato. La elección no fue fácil, en función del momento temporal en el que me ubicara la historia podía cambiar por completo pero decidí arriesgarme por empezar a escribir desde lo emocional y simbólico, desde mi primera aparición en la Casa de Joventut La Maranya. El primer día que me rodeé de las personas que han dado forma a esta historia y aquellas que me abrirían las puertas para realizar la etnografía de una parte de sus vidas. En definitiva, la historia comienza el mismo día que me invitan a participar de una de las dinámicas de la Casa en la que estarán familias, adolescentes, monitoras y vecinas y lo más interesante si cabe, es que ese mismo día la dinámica trataba de recorrer las diferentes etapas de vida de la Casa, compartir aquellos momentos que habían posibilitado que Maranya hoy sea como es. Una oportunidad estupenda para comenzar a indagar en aquello que se convertiría en esta tesis doctoral.

De este modo, el relato se estructura alrededor de ese día comenzando por narrar y describir lo que allí ocurrió. Para que sea más fácil entender la lectura posterior de la historia me gustaría adelantar en qué consistía la dinámica. Podíamos dividirla en dos partes distintas. En la primera realizábamos un recorrido por diferentes mesas. En cada una de ellas encontrábamos fotografías, artículos, revistas, documentos y otros objetos simbólicos de aquel momento temporal y con todo ello una o varias 
personas de la Casa contaban cuales habían sido los acontecimientos más significativos de esa época. Así fuimos recorriendo una primera mesa en la que nos trasladamos en el tiempo hasta 1996 cuando se formó la Casa de Joventut Quelcom (1996). La segunda mesa hablaba de cómo aparece el espacio infantil Esplai Cataflai (2006...) y más tarde, en una tercera mesa llega el turno de compartir todo aquello que trajo el Casal Jove de Benicàssim (2009...). El final de este recorrido dejaba lugar a las mesas en las que se recordaría cómo fue Maranya en 2011, que es lo que le pasó a Maranya durante el 2012 y por último, que hizo Maranya en 2013.

Una vez finalizada esta dinámica se dio paso a la segunda actividad con el objetivo de trabajar la parte más emocional y relacional de la casa a través de la Estació de tren.

Tras analizar lo simbólico de este día para mí, tanto como investigadora como miembro de la Casa, decido estructurar la historia a partir de ese acontecimiento. Así al inicio de la historia comienzo a relatar cómo se va sucediendo el día y aprovecho el recorrido por las diferentes etapas, a partir de las mesas, para desgranar todo aquello en lo que he ido indagando durante estos casi tres años de trabajo de campo. Será así hasta que en el relato llegue al final de ese día, domingo 13 de abril de 2014, en el que se hacen las anteriores dos dinámicas descritas (mesas y estación).

A partir de ese momento comienza una segunda parte de la historia en la que relato lo que ocurre durante los años en los que formo parte de la asociación. Dos cursos académicos enteros que dan forma a los acontecimientos vividos que acabarán de componer esa historia que comienza en 1996 y se cierra, para esta tesis, 20 años después.

Así la estructura de nuestra historia es la siguiente: 

'Domingo 13 de abril de 2014.

-- Descobrint les nostres arrels $\rightarrow$ Introduce la dinámica de las seis mesas I ¡con la que compartiremos las siguientes seis etapas de la vida maranyera:

I. Explican's Quelcom que ens faci reviure (1996)

II. En un tren va nàixer Cataflai (2006) I III. El Casal torna a ser jove (2007)

IIV. Una Maranya de joves, una Maranya de versos sense adulterar (2011)

'V. Qui no té ulls per a somniar no veu els somnis ni de dia ni de nit (2012)

:VI. Maranya espai compartit, Maranya té ulls per a

isomniar col·lectivament $(2013 / 2014)$

!-- Propera estació Maranya: viatges compartits $\rightarrow$

-Descripción de la segunda dinámica del domingo y cierre del día.

parte Segunda

!-- Una tesi per a Maranya $\rightarrow$ Relato desde el día en el que presento la tesis a las jóvenes y me dan su visto bueno para comenzar. Se suceden los dos cursos en los que formo parte como miembro e investigadora de la realidad maranyera y que suceden a las seis etapas anteriores.

VII. Maranya avui és moltes coses, encara que d'avui en endavant será imoltes altres (2014/2015)

IVII. Fem camí (2015/2016) 
Es interesante remarcar que toda la información construida a partir de mi trabajo de campo en la Casa se intercala en las diferentes etapas. Tanto en las primeras en las que no formo parte de la asociación como en las dos últimas en las que formo parte activa del colectivo. La información compartida el día de la dinámica de las mesas no es exactamente la misma que se relata en esta historia ya que durante los años de trabajo de campo se ha podido indagar con mayor profundidad en cada una de dichas etapas para así poder ofrecer hoy una visión más detallada de lo que ocurrió en ellas. Por esta razón me ha resultado interesante el mantener una dinámica tan simbólica en la Casa y que enmarca a la perfección en esta investigación. De esta forma, el producto final, la historia relatada en los siguientes capítulos acaba correspondiéndose con uno de los intereses de la Casa: «conocer nuestra historia nos permite saber quiénes somos y hacia dónde vamos».

Para finalizar quisiera describir aquellos elementos técnicos que también influyen a la hora de utilizar la información. Uno de los aspectos fundamentales para esta investigación es la confidencialidad y el anonimato de aquellas personas que no han participado de forma directa en la investigación además de aquellas otras que han participado pero no han querido que apareciera su nombre en el informe. Para todas ellas se ha decidido optar por pseudónimos para mantener su anonimato en el relato. El resto de nombres que aparecen en el relato, todos y cada uno de ellos, aparecen porque las personas concretas han dado su consentimiento para que su nombre apareciera como tal en el texto.

Por otro lado, un elemento significativo del relato es el uso de dos lenguas relevantes para quien escribe. La utilización del castellano y el valenciano no se hace de manera indistinta en la historia. Asumo la escritura en castellano por ser mi lengua materna y aquella en la que más cómoda académica y sentimentalmente me encuentro para narrar. Aun así utilizó fragmentos en valenciano por ser la lengua referente de la Casa de Joventut La Maranya y aquella con la que muchas de las personas que forman parte de la misma se sienten unidas. Por esta razón, algunas partes del texto aparecen en valenciano con la intención de buscar esa cercanía con la persona que expone la idea. Aun así he de decir que me siento en deuda 
con la Casa y sé que les debo esta historia escrita en la lengua materna de Maranya.

Otro de los aspectos que quisiera remarcar en esta parte es mi posicionamiento en cuanto al género se refiere. En la redacción de la historia, al igual que en el resto de informe, utilizo la palabra persona para huir del genérico masculino gramatical. De esta forma hablamos de «las jóvenes», como «las personas jóvenes» evitando el uso de «los jóvenes».

Antes de abordar el uso de los verbatims me gustaría comentar que a lo largo de toda la historia, la lectora podrá encontrar diferentes códigos QR. Estos códigos se adjuntan con la intención de evidenciar bien sea aspectos del contenido de la historia o también ornar el relato con música o poesía que en algún momento dado de la historia maranyera ha sido relevante para el colectivo. De este modo, utilizo diferentes iconos que situados al lado del código QR indicarán el tipo de contenido que la lectora podrá encontrar en él. A continuación se acompaña la leyenda (figura 14) con los iconos utilizados ${ }^{34}$ :

Figura 14. Leyenda iconos códigos QR.

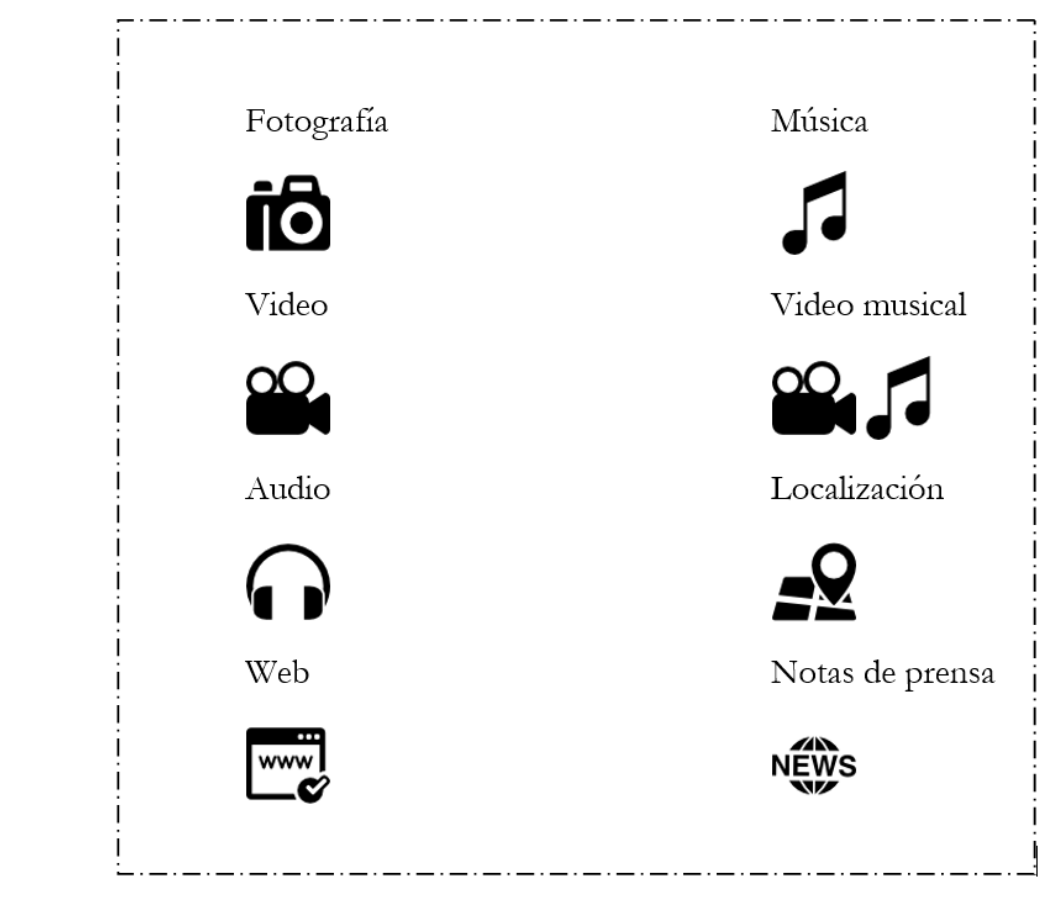

${ }^{34}$ Iconos diseñados por Freepik de www.flaticon.com 
Para que la lectora pueda disfrutar de la lectura le pediría que abriera dichos códigos ${ }^{35}$ en el momento en el que se los encuentre en el texto y disfrute de su lectura o reproducción.

Para acabar hablaré de uno de los elementos más importantes a la hora de utilizar la información que se ha ido construyendo a lo largo de todo el trabajo de campo, el uso de los verbatims en el relato. Los verbatims se utilizan para evidenciar o justificar aquello que se está tratando en el texto en el momento en el que aparece. Además en nuestro caso se han utilizado para ayudar a describir aspectos del relato desde la cercanía de las participantes. Siguiendo las consideraciones de Moriña (en prensa) procederé a describir aquellos aspectos relevantes del uso en nuestro caso.

Siempre que aparecen tienen un formato distinto al resto del texto, en cursiva, con letra más pequeña y con sangrado a derecha e izquierda si son muy largos. Además al final del verbatim aparecerá la referencia que indicará la persona y el instrumento del cual procede la información. De este modo se ayuda a la lectora a clarificar y desentrañar la historia que está leyendo ${ }^{36}$.

A lo largo de toda la historia se pretende conseguir una proximidad a la narración más etnográfica o periodística. Esto da lugar a que quiera encontrar una coherencia entre los diferentes discursos y las distintas personas que participan, los parafraseos que aparecen al cruzar información de diferentes fuentes y los verbatims utilizados. Recordamos que el análisis como investigadora se llevará a cabo en el capítulo de conclusiones y discusión. Por ello se ha cuidado que el relato acabe siendo un escrito en el que fluyan las voces y en el cual podamos escucharlas en un relato compartido y co-construido con muchas personas. Esta es la razón por la que en algunos casos los verbatims son más extensos que en otros. Ello dependerá de lo adecuado que sea para ilustrar el relato y de la potencialidad de las palabras de la participante para describirlo. Por último,

\footnotetext{
${ }^{35}$ Podrás abrir cada uno de los códigos QR con cualquier aplicación gratuita para móviles. Un índice de los códigos QR utilizados puede verse en la tabla de contenidos final.

${ }^{36}$ Las referencias aparecen desglosadas en el anexo 14 .
} 
el verbatim se contextualiza en el propio relato y eso ayuda a comprender el significado del mismo sin tener que utilizar las preguntas u otros aspectos que aparecen cuando se está construyendo dicha información a través de entrevistas u otros documentos.

\subsubsection{Análisis crítico.}

Para finalizar llega el momento de realizar el análisis crítico de la narración. Este se lleva a cabo a partir del trabajo con el grupo asesor de la investigación. Con él se pretende abordar el análisis para validar la historia desde la colaboración del grupo y así conseguir un producto definido desde la militancia.

Como hemos justificado, en el punto de devolución de la historia, no hemos podido llevar a cabo este análisis, antes de enviar el trabajo a la evaluación de expertas, debido a la falta de masa crítica que hubiera propiciado el análisis que demandamos como investigación militante que hacemos. Es una laguna pendiente de realizar durante los próximos meses y que gracias a la voluntad de las diferentes partes se realizará a partir de una reunión con el grupo asesor de la investigación. Para ello se enviará la historia y se citará para una reunión futura durante el mes de octubre.

\subsubsection{Criterios de rigor científico.}

Son múltiples las autoras que han escrito sobre la rigurosidad de la ciencia, la calidad de las investigaciones y el devenir de los criterios de rigor científico cuando hablamos de investigación cualitativa. Por ello, para evitar dificultades en la interpretación, de comparación, inestabilidad y prejuicios optamos por una serie de estrategias a lo largo de toda la investigación que posibilitan cumplir con los criterios de rigor y calidad que precisan las investigaciones cualitativas para evitar peligros en la credibilidad, transferibilidad, dependencia y confirmabilidad. Para Lincoln \&Guba (1985), los aspectos a tener en cuenta son los siguientes:

- Valor de verdad que le otorga el significado de que la investigadora contraste la credibilidad de sus creencias e interpretaciones comparándolas con las diferentes fuentes de las que se han obtenido los datos haciendo comprobaciones entre las participantes. 
- Aplicabilidad que va directamente relacionada con la generalizabilidad. Guba recuerda como Cronbach (1975) afirma que toda generalización es más historia que ciencia con el paso del tiempo. Los fenómenos están directamente vinculados a los momentos y a los contextos en los que se producen aunque sí que existe la posibilidad de realizar transferencias entre contextos. Para ello se precisa de una descripción exhaustiva del contexto para que así se pueda comprobar el grado de similitud entre contextos.

- Consistencia: se interpreta como dependencia y persigue los elementos que den estabilidad a los datos y su rastreabilidad. En este proceso vuelve a destacar la importancia del componente descriptivo de las condiciones, la complementariedad entre las fuentes de información y la verificación de las participantes para conseguir una adecuada interpretación (Erazo, 2011).

- Neutralidad por la que hay que dejar de lado todo aquello que pueda ejercer influencia en los datos. Esto es complicado en investigación y en la investigación cualitativa se acepta que hay que nutrirse de los valores de la investigadora. Por ello se opta por la reflexividad (Guba, 1983; Hammerley y Atkinson, 1994) mediante la cual se pretende que la investigadora sea consciente de la influencia de su posicionamiento, pensamientos, planteamientos o la perspectiva desde la que aborda la investigación (Noreña, Alcaráz-Moreno, Rojas y Rebolledo-Malpica 2012). Así se favorece la autocrítica para comprender mejor lo estudiado. En la siguiente tabla (tabla 39) se descifran cuáles son estas estrategias empleadas para asegurar los criterios de calidad.

Tabla 39. Tabla criterios de rigor.

\begin{tabular}{|c|c|c|c|}
\hline $\begin{array}{l}\text { Criterios de } \\
\text { rigor }\end{array}$ & $\begin{array}{c}\text { Investigación } \\
\text { cualitativa } \\
\text { (Lincoln \& Guba, } \\
\text { 1985; Guba\& } \\
\text { Lincoln,1982,1981) }\end{array}$ & $\begin{array}{l}\text { Investigación } \\
\text { cuantitativa }\end{array}$ & $\begin{array}{l}\text { Estrategias empleadas para } \\
\text { asegurar los criterios de calidad }\end{array}$ \\
\hline $\begin{array}{l}\text { Valor } \\
\text { verdad }\end{array}$ & Credibilidad & Validez interna & $\begin{array}{l}\text { - Estancia prolongada en el campo } \\
\text { - Triangulación en técnicas y } \\
\text { personas } \\
\text { - Devolución y revisión de la } \\
\text { información por las participantes } \\
\text { - Recogida de información y } \\
\text { transcripción por una única } \\
\text { investigadora de la investigadora } \\
\text {-Activismo de }\end{array}$ \\
\hline
\end{tabular}




\begin{tabular}{|c|c|c|c|}
\hline $\begin{array}{l}\text { Criterios de } \\
\text { rigor }\end{array}$ & $\begin{array}{c}\text { Investigación } \\
\text { cualitativa } \\
\text { (Lincoln \& Guba, } \\
\text { 1985; Guba\& } \\
\text { Lincoln,1982,1981) }\end{array}$ & $\begin{array}{l}\text { Investigación } \\
\text { cuantitativa }\end{array}$ & $\begin{array}{l}\text { Estrategias empleadas para } \\
\text { asegurar los criterios de calidad }\end{array}$ \\
\hline & & & dentro del grupo \\
\hline Aplicabilidad & Transferabilidad & Validez externa & $\begin{array}{l}\text { - Descripciones detalladas } \\
\text { - Uso de múltiples y diversas fuentes } \\
\text { de información que facilitan la } \\
\text { contextualización detallada del caso } \\
\text { - Muestreo teórico } \\
\text { - Recogida de abundantes datos } \\
\text { descriptivos }\end{array}$ \\
\hline Consistencia & Dependencia & Fiabilidad & $\begin{array}{l}\text { - Trabajo de revisión del grupo } \\
\text { asesor } \\
\text {-'Triangulación } \\
\text { - Revisión por pares (directores) } \\
\text { - Estrategias colaborativas de análisis } \\
\text { y codificación } \\
\text { - Descripción detallada de los } \\
\text { instrumentos de recogida y } \\
\text { reconstrucción conjunta con el } \\
\text { grupo asesor }\end{array}$ \\
\hline Neutralidad & Confirmabilidad & Objetividad & $\begin{array}{l}\cdot \text { 'Triangulación } \\
\cdot \text { Construcción de los instrumentos } \\
\text { de recogida para facilitar la } \\
\text { recuperación de la información } \\
\cdot \text { - Reflexión constante } \\
\cdot \text { Revisión por expertos }\end{array}$ \\
\hline
\end{tabular}

\subsubsection{Herramientas y estrategias en la triangulación de la información.}

Es interesante que facilitemos el acto de fe que tienen que hacer las lectoras para creer que la triangulación se ha dado. Una de las mayores críticas en la investigación cualitativa es la ausencia de transparencia a la hora de exponer la triangulación llevada a cabo en las investigaciones.

Creswell (2002) define la triangulación como

the process of corroborating evidence from different individuals, types of data, or methods of data collection... This ensures that the study will be accurate because the information is not drawn from a single source, individual, or 
process of data collection. In this way, it encourages the researcher to develop

a report that is both accurate and credible 37 .

En nuestro caso, realizaremos una triangulación múltiple (Denzin, 1970) en la que contrastaremos los datos a partir de diferentes fuentes de información como son las técnicas utilizadas, las herramientas construidas y las voces de las participantes involucradas. Además se lleva a cabo una triangulación de investigadores regulada por el grupo asesor.

Veamos cómo se da esta triangulación a partir de los datos. Por un lado, para observar cómo cada una de las fuentes de datos utilizada proporciona evidencia corroborativa para verificar la información obtenida por otras fuentes, hemos generado una tabla compuesta por las diferentes categorías y subcategorías en relación con la fuente de datos de la que surge. Cada hallazgo enumerados en la tabla (tabla 40) es corroborada por al menos otra fuente de datos.

${ }^{37}$ «El proceso de corroboración de las pruebas de diferentes individuos, tipos de datos, o los métodos de recolección de datos... Esto asegura que el estudio sea preciso porque la información no se extrae de una fuente única, individual, o el proceso de recolección de datos. De esta manera, se anima al investigador para desarrollar un informe que es a la vez preciso y creíble». 
Arecia Aguirre García-Carpintero

Tabla 40. Cruce de categorías con fuentes de datos.

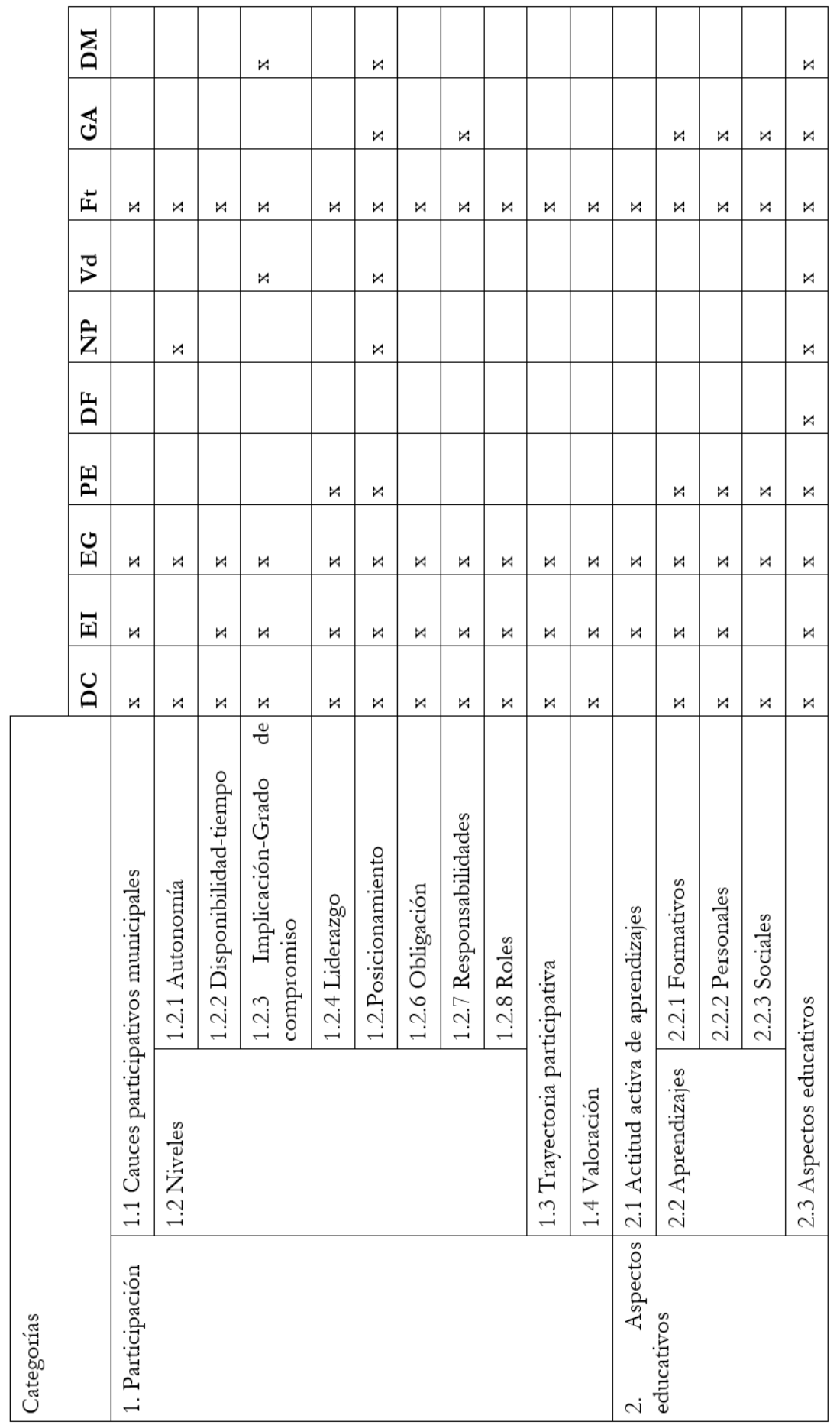


Capítulo 3

Cartografía de la investigación

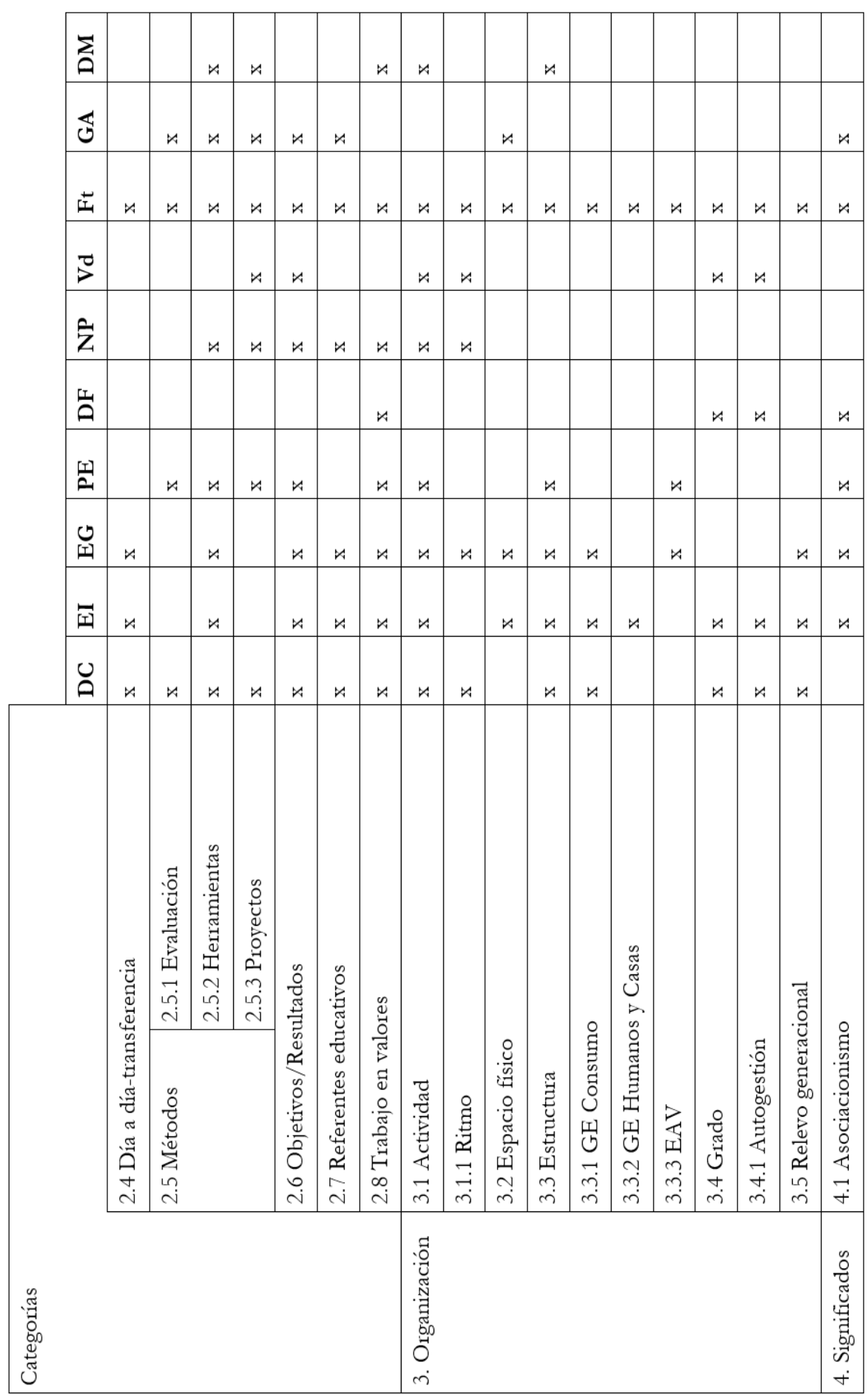


Arecia Aguirre García-Carpintero

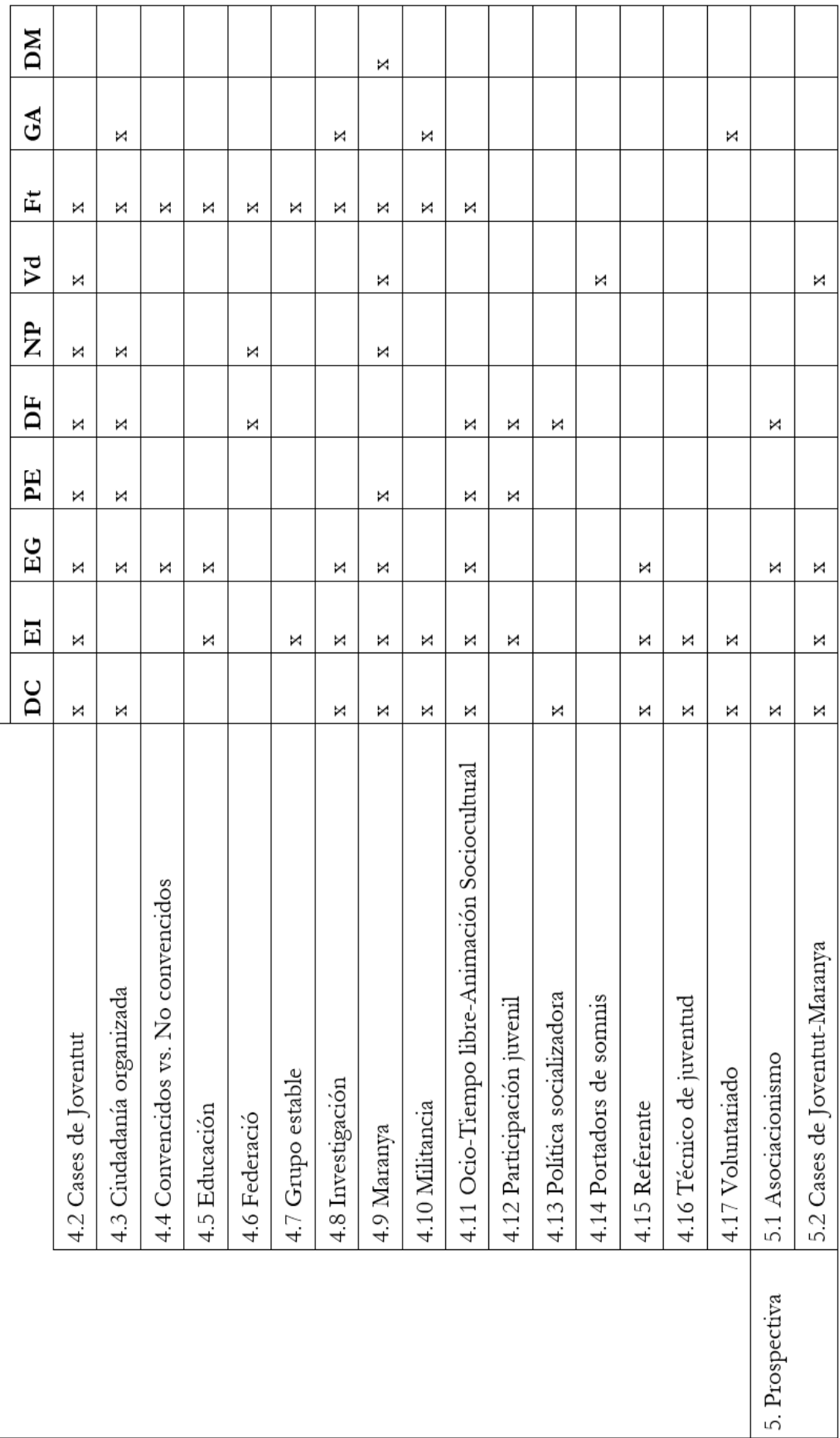


Capítulo 3

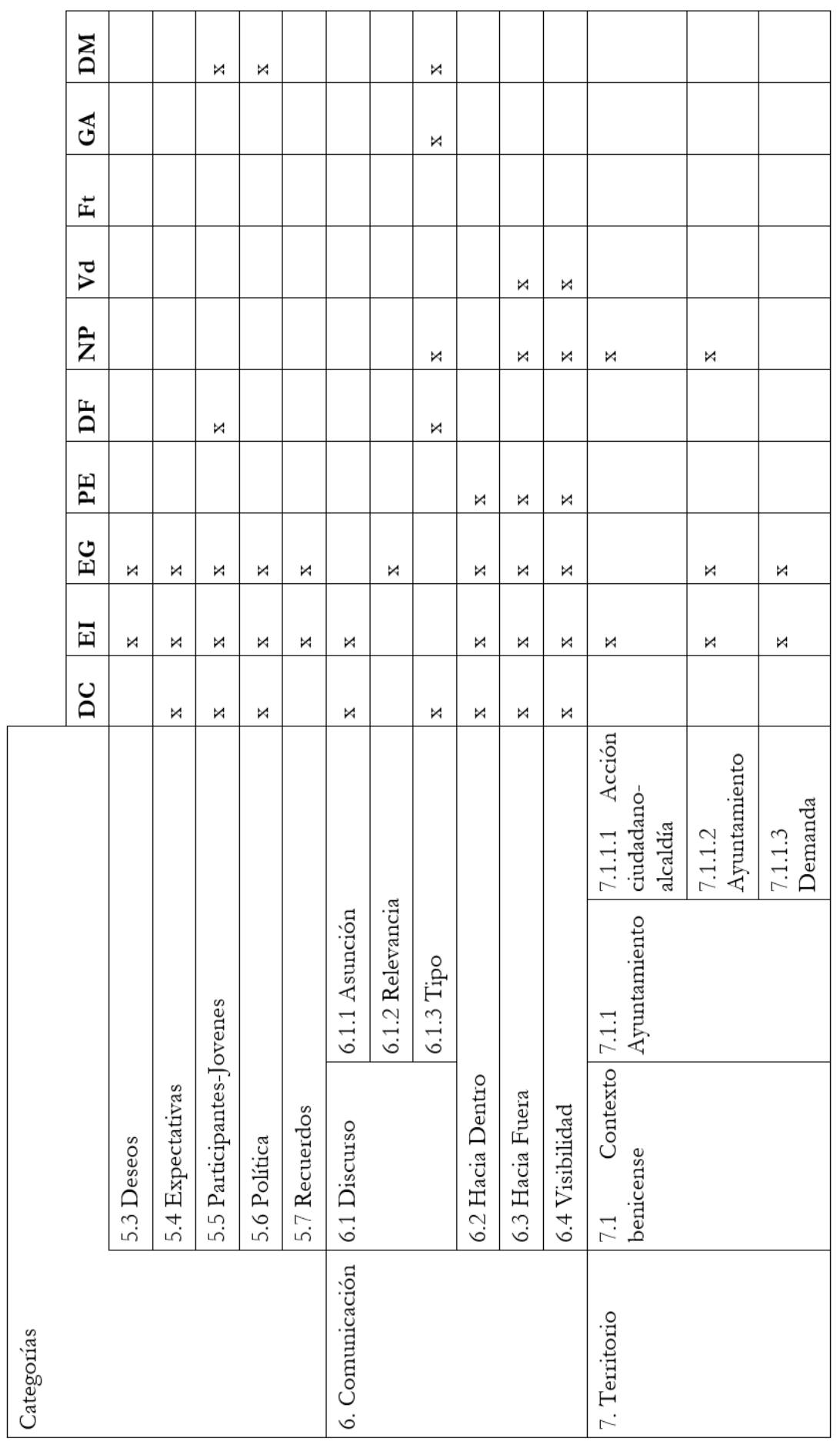




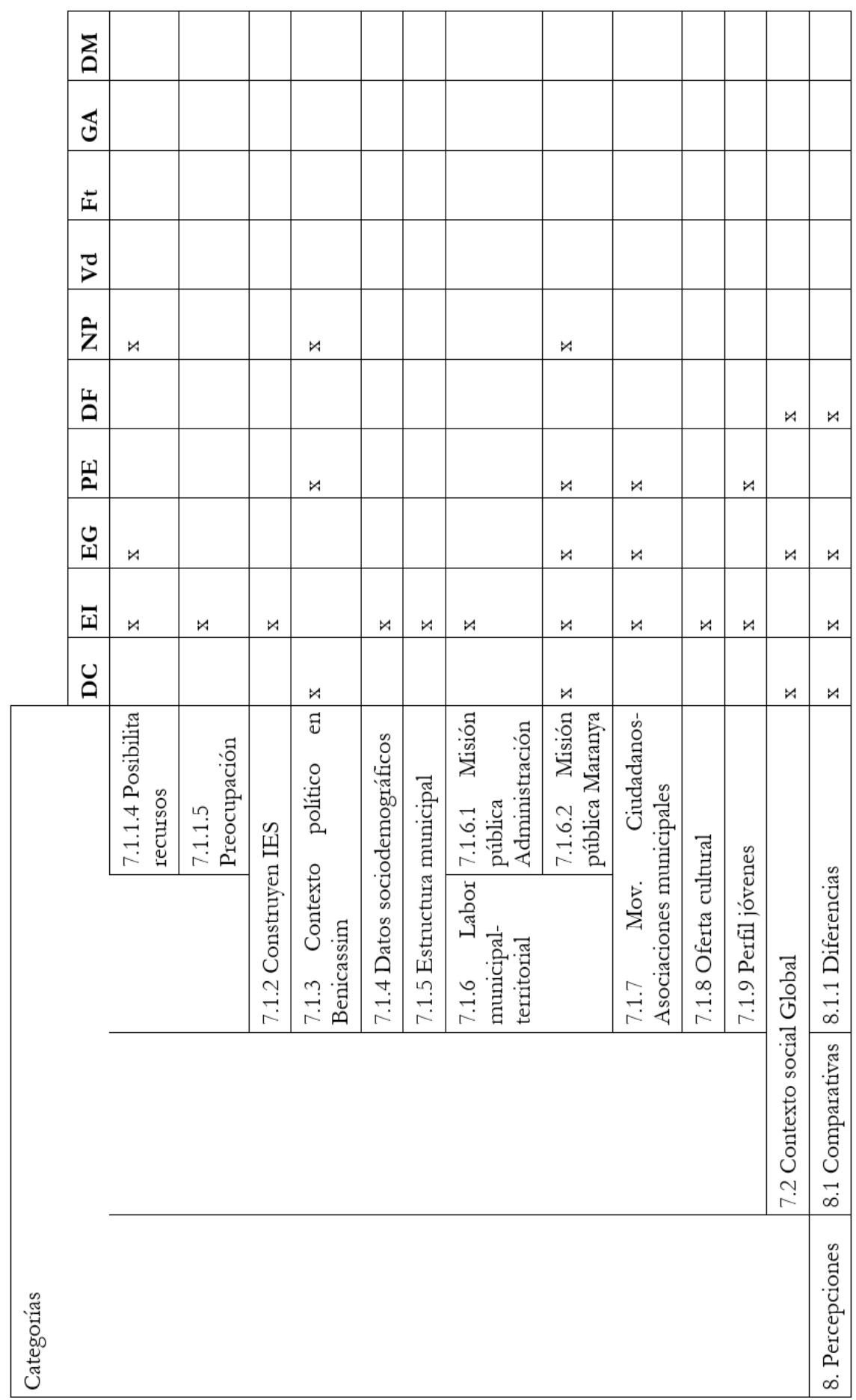


Capítulo 3

Cartografía de la investigación

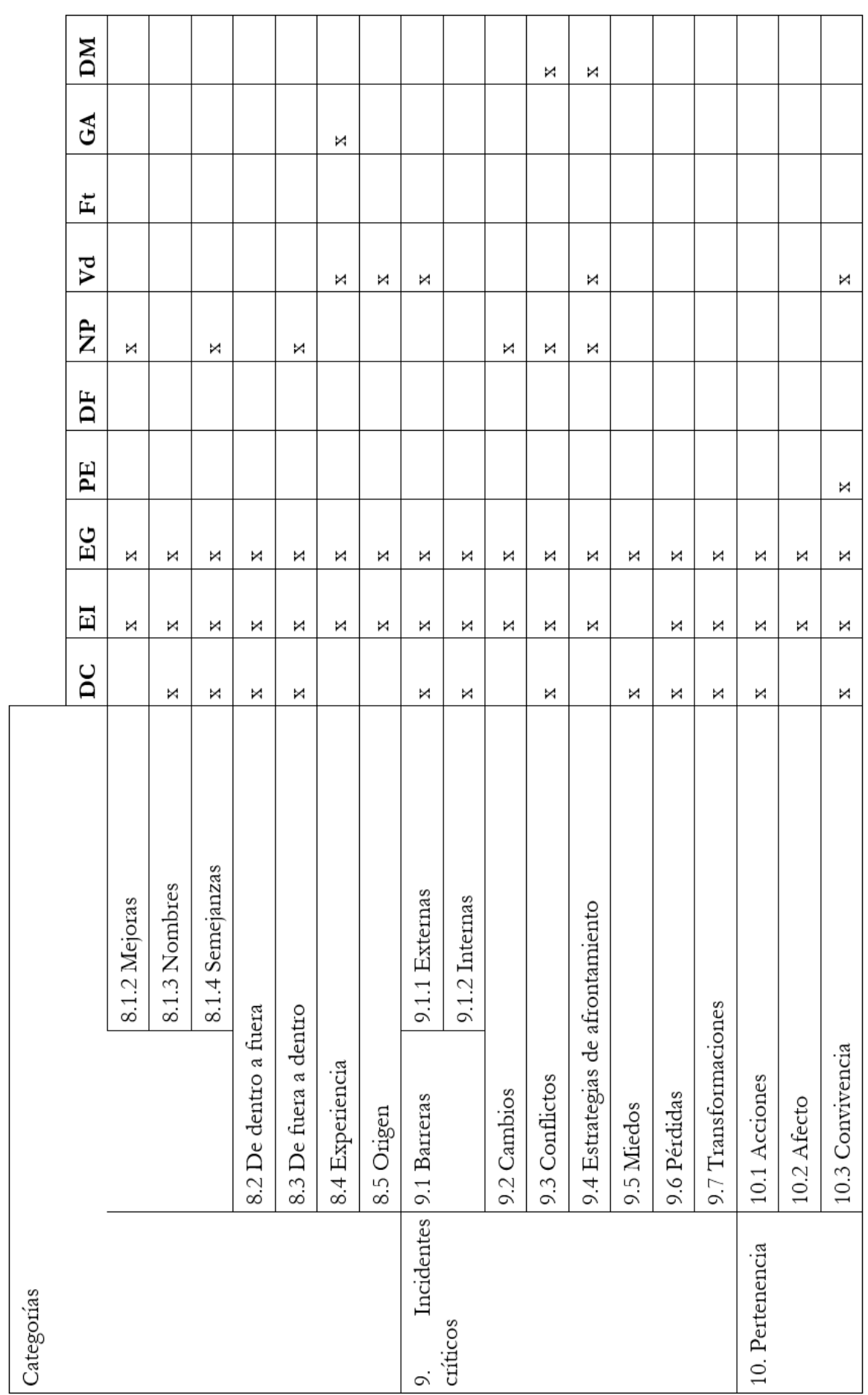




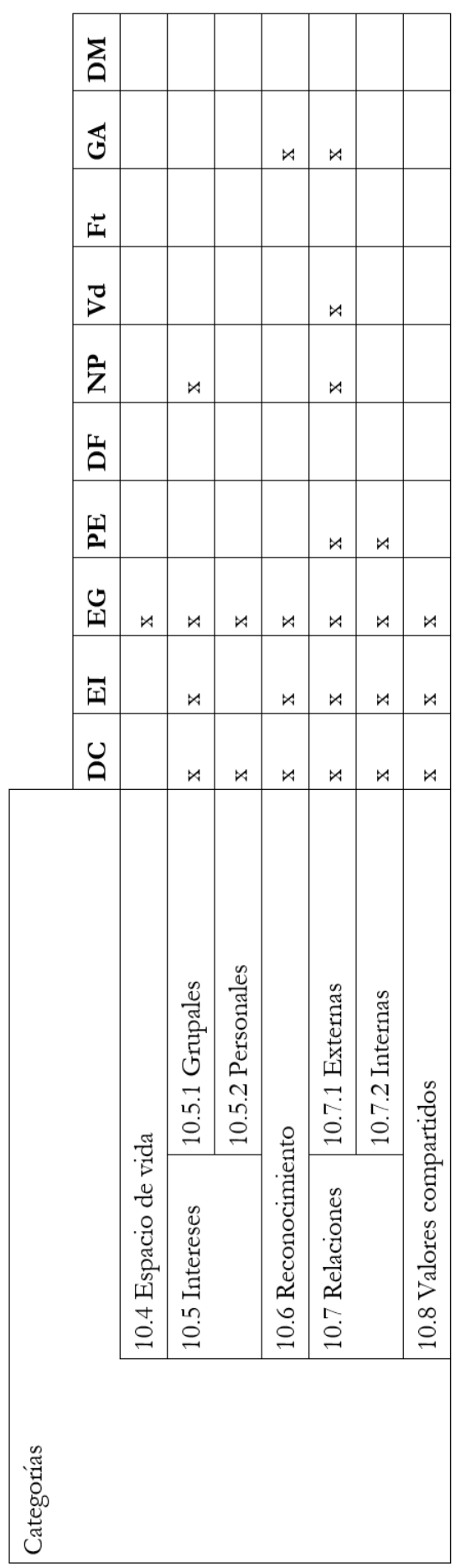


Además las entrevistas se han abordado desde la pluralidad de voces a través de la participación de una muestra representativa de la estructura del contexto, lo cual otorga neutralidad, consistencia y credibilidad a los datos.

Por otro lado, Ratcliffe (1983) decía que los datos no hablan por sí solos, sino que siempre hay una persona que los interpreta, un traductor de datos en relación al contexto que ocupa la investigación. En nuestro caso hay un grupo de intérpretes de datos, con una relación directa con el movimiento juvenil que hará que los datos sean traducidos desde la fiabilidad y la credibilidad. El grupo asesor juega un papel importante en la triangulación de los datos dando coherencia a la información recogida.

De este modo, se le otorga la coherencia necesaria al estudio para conseguir afianzar los criterios de rigor en investigación cualitativa. 

Tendiendo puentes con hilos rojos (proverbio asiático)
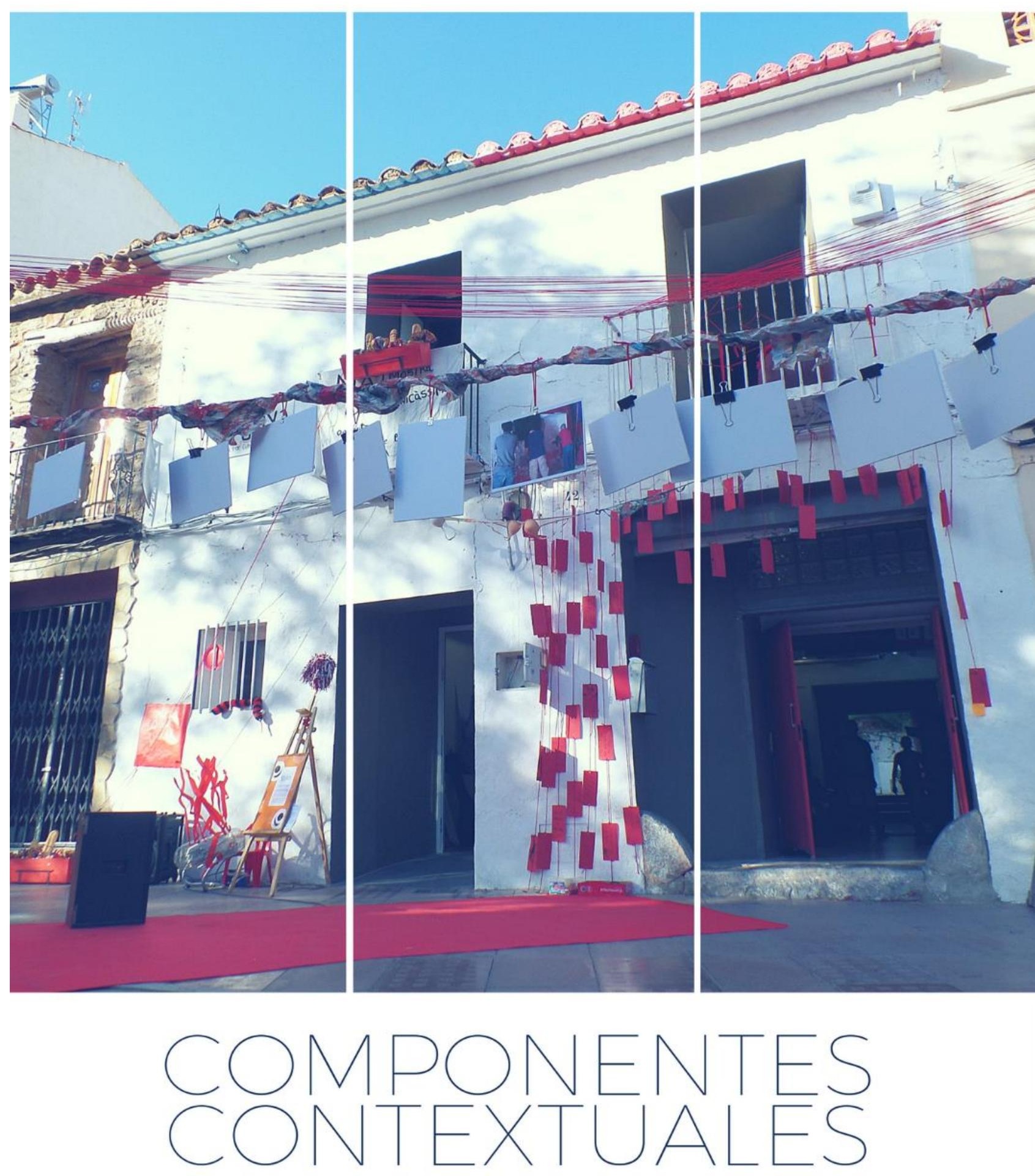

\section{CAPITULO 4}



La leyenda del hilo rojo del destino es una creencia de Asia Oriental que aparece en la mitología japonesa y china. Esta dice que los dioses atan un cordón rojo alrededor del dedo meñique de los que han de conocerse o ayudarse en un momento concreto y de una manera determinada.

«Un hilo rojo invisible conecta a aquellos que están destinados a encontrarse, sin importar tiempo, lugar o circunstancias. El hilo se puede estirar o contraer, pero nunca romper».

Una de las leyendas sobre este hilo rojo cuenta que un anciano que vive en la luna, sale cada noche y busca entre las almas aquellas que están predestinadas a unirse en la tierra, y cuando las encuentra las ata con un hilo rojo para que no se pierdan. Pero la leyenda más popular y la que se recita en casi todos los hogares japoneses a los niños y jóvenes es esta

Hace mucho tiempo, un emperador se enteró de que en una de las provincias de su reino vivía una bruja muy poderosa, quien tenía la capacidad de poder ver el hilo rojo del destino y la mandó traer ante su presencia. Cuando la bruja llegó, el emperador le ordenó que buscara el otro extremo del hilo que llevaba atado al meñique y lo llevara ante la que sería su esposa. La bruja accedió a esta petición y comenzó a seguir y seguir el hilo. Esta búsqueda los llevó hasta un mercado, en donde una pobre campesina con una bebé en los brazos ofrecía sus productos. Al llegar hasta donde estaba esta campesina, se detuvo frente a ella y la invitó a ponerse de pie. Hizo que el joven emperador se acercara y le dijo: «Aquí termina tu hilo», pero al escuchar esto el emperador enfureció, creyendo que era una burla de la bruja, empujó a la campesina que aún llevaba a su pequeña bebé en brazos y la hizo caer, haciendo que la bebé se hiciera una gran herida en la frente, ordenó a sus guardias que detuvieran a la bruja y le cortaran la cabeza. Muchos años después, llegó el momento en que este emperador debía casarse y su corte le recomendó que lo mejor era que desposara a la hija de un general muy poderoso. Aceptó y llegó el día de la boda. Y en el momento de ver por primera vez la cara de su esposa, la cual entró al templo con un hermoso vestido y un velo que la cubría totalmente... Al levantárselo, vio que ese hermoso rostro tenía una cicatriz muy peculiar en la frente. 
Arecia Aguirre García-Carpintero

En este apartado aparecen algunas de las personas que están atadas con hilos rojos a Maranya, ellas mismas se describen para esta tesis. En segundo lugar contextualizaré la Casa de Joventut La Maranya y su entorno. ${ }^{38}$

${ }^{38}$ En el siguiente apartado se ha respetado el anonimato de aquellas participantes que han decidido no aparecer en este capítulo. Por eso no están todas las que son ni son todas las que están. 
Capítulo 4

Componentes contextuales

4.1 Gente enmaranyada.

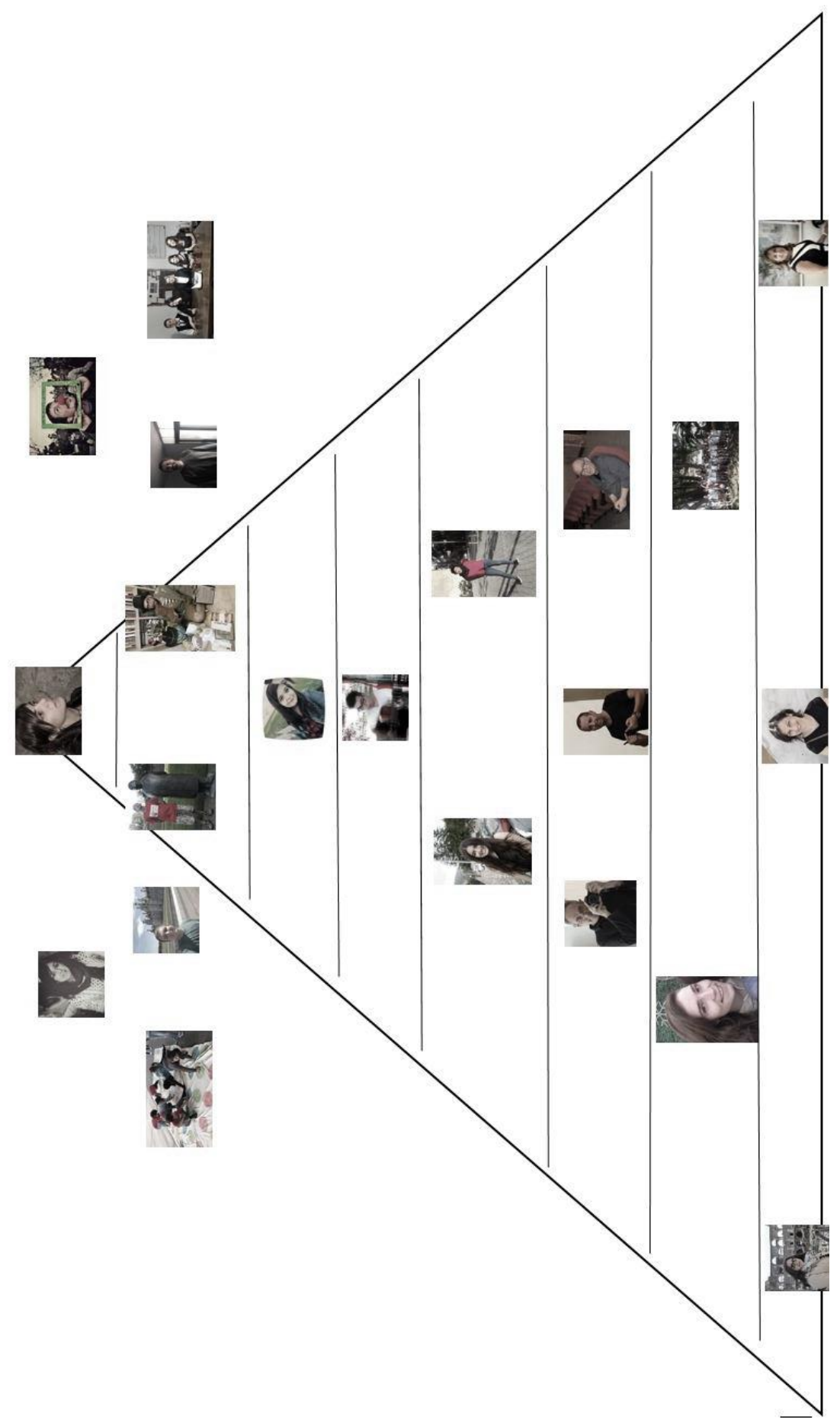




\section{TERRITORIO}

\section{VECINAS}

Me llamo Mercè Bellido y soy de Benicàssim. Mi relación con Maranya, la casa de jóvenes de aquí del pueblo, es bastante escasa. Yo, tengo a mi mejor amigo que forma parte del grupo de Maranya, y siempre estoy dispuesta a ayudar. En estos últimos tres años, si no recuerdo mal, sobre todo he participado en la Casa del Terror que organiza Maranya en Halloween, pero si me llaman intento estar ahí siempre.

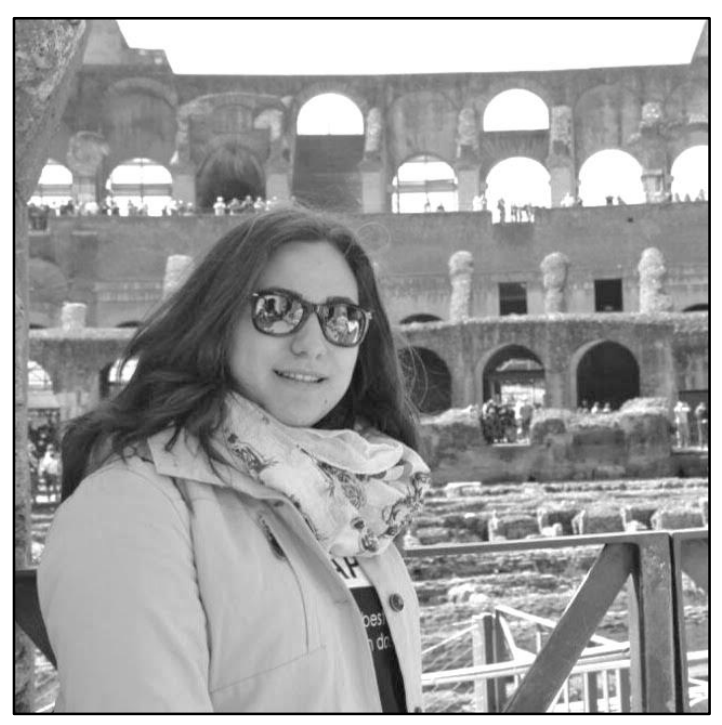




\section{ADMNISTRACIÓN}

Sóc Mari Carmen Torres i tot i que actualment -des de fa una mica més de tres

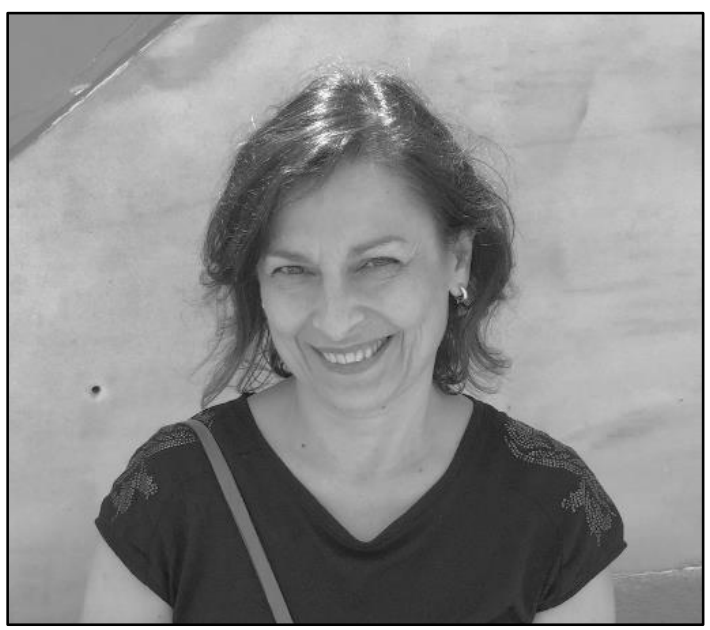
anys- treballe com a Tècnica d'Educació a l'Ajuntament de Benicàssim, fins llavors he estat treballant al Casal Jove d'informadora juvenil, monitora, animadora, dinamitzadora, facilitadora, tècnica... durant 22 anys. Això em va permetre treballar directament i principalment amb la joventut local, implementant i facilitant

programes i projectes que, atenent les seues demandes i en bona mesura promoguts pels mateixos joves, van anar evolucionant i donant forma a diferents accions de mirada transformadora i amb la intenció de generar inquietuds.

Mirant enrere, i passejant pel record del pas d'aquests anys, el treballar amb el collectiu juvenil ha estat una mica més que una feina; jo no sé ben bé si s'han cobert totes les expectatives plantejades al llarg d'aquests anys, però a mi m'ha suposat una experiència de vida molt gratificant i personalment un aprenentatge molt enriquidor.

D'alguna manera, i sense cap intenció de poder resultar pretensiosa, del treball i de la implicació social d'aquests anys naix la Maranya; i una conseqüència personal d'aquest procés és la satisfacció de la feina ben feta.

Des de l'admiració i el respecte per la tasca que estan duent a terme, m'agradaria pensar que la Maranya resumeix molt bé tota aquesta trajectòria, i, fins i tot podem celebrar que ha esdevingut un model de participació a copiar i seguir. 
Me llamo Susana Marqués, estoy al frente del equipo de gobierno desde el año

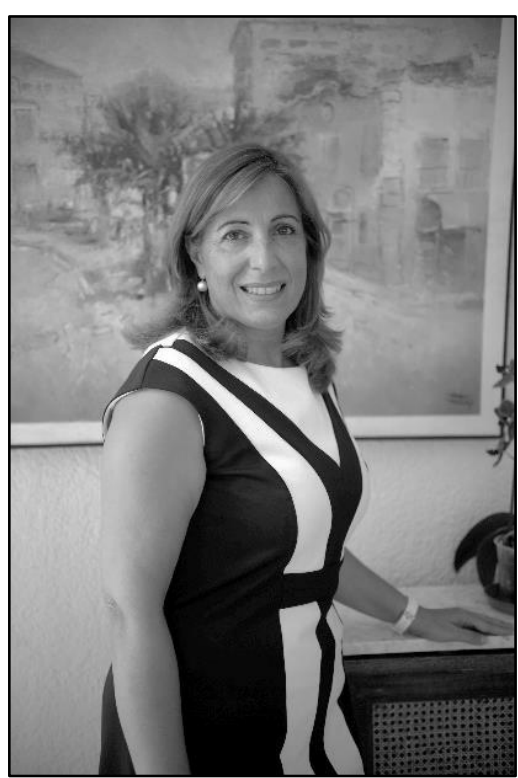
2011, como alcaldesa, aunque entré en política en el año 2003. Me presenté por primera vez en lista electoral del Partido Popular como número tres de la lista en la candidatura. Desde el 2004 al 2007 estaba de primer teniente de alcalde, concejal de hacienda, recursos humanos y fiestas y después, en el 2007, encabecé por primera vez la lista electoral. Conseguimos el mayor número de votos, el mayor número de concejales pero al final se unió un tripartito que consiguieron, dentro de lo que las normas democráticas permiten, coaligarse entre ellos, formar un tripartito y conseguir mantener la alcaldía desde 2007 a 2011.

En el 2011, volví a encabezar por segunda vez la candidatura del Partido Popular y ya ganamos con mayoría absoluta con un total de 9 concejales. Nos faltó muy poquito para el número 10.

Después, en el 2015, vuelvo a encabezar la lista, volvemos a ser la lista más votada y con la legitimidad de ser la lista más votada, al no haberse podido coaligar entre el resto de fuerzas políticas, pues me encuentro otra vez en la alcaldía.

Estudié la rama administrativa, he estado trabajando siempre en empresas privadas desde el año 86 hasta el año 2000. En ese mismo año cambio de empresa hasta el 2004, y en el 2003/2004 estuve compatibilizando los dos trabajos pero después ya me di muy pronto cuenta de que la política, si quieres estar al cien por cien trabajando, por el compromiso que tienes con tus ciudadanos, con tus vecinos esto exige un grado de compromiso, este trabajo exige un grado de compromiso muy, muy grande. La administración es una maquinaria que te va absorbiendo y cuando te das cuenta te han pasado las horas del día, de las semanas, de los meses, de los años y la verdad es que cuando uno lo vive de forma intensa y apasionada como lo vivo yo, el tiempo te pasa volando y necesitas muchísima dedicación. De ahí que ya decidiera dejar la empresa privada y dedicarme al cien por cien. Después también he estado 
Capítulo 4 Componentes contextuales

desde la legislatura 2007-2011 y 2011-2015 como diputada provincial, de la excelentísima Diputación de Castellón y bueno, la verdad, que compaginar los dos cargos también me ha servido de muchísima experiencia. 


\section{EX-ACTIVISTAS}

Sóc Isabel Bernat Mateu, actualment estic estudiant Treball Social. M'agrada participar en projectes socials, ja que mai he pogut comprendre ben bé el funcionament de la societat, la misèria que creem les persones o com permetem les injustícies que presenciem cada dia. Per això he participat en diverses iniciatives com la Maranya, ja que he sentit que entre totes podem millorar allò que no ens agrada per crear un món millor.

La meua relació amb la Maranya ha variat molt des que vaig entrar en contacte amb el projecte. Va ser a través del curs de monitora de temps lliure quan vaig conèixer la Casa de Joventut i vaig començar a

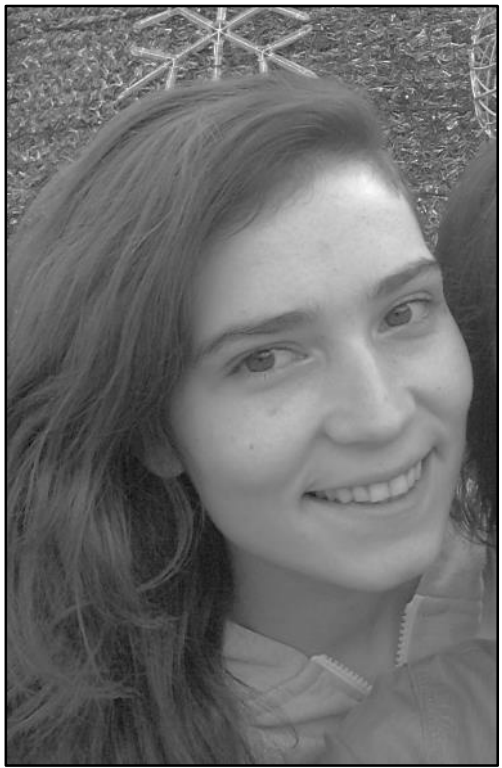
participar, a l'inici realitzant les pràctiques del curs i després com a voluntària. Encara que en l'actualitat ja no forme part de la Maranya, sempre hem sentiré connectada al projecte i al poble de Benicàssim, ja que va ser una experiència que em va fer madurar i entendre de manera pràctica com construir alternatives.

Al marxar a estudiar fora vaig tindre l'oportunitat de conèixer altres projectes i maneres de militància. Actualment forme part del moviment estudiantil, a través d'un sindicat d'estudiants, reivindicant una educació publica, popular, de qualitat, antipatriarcal i en català, tant als carrers com a les estructures de la universitat. També he conegut alguns barris de València amb problemàtiques socials molt arrelades i les diverses associacions que hi treballen. Actualment comencem a participar en algunes d'aquestes iniciatives veïnals un grup d'estudiants, que hem creat una assemblea d'alumnes de Treball Social a València. 
Soy Joana González, mi paso por Maranya empezó a partir del año 2012,

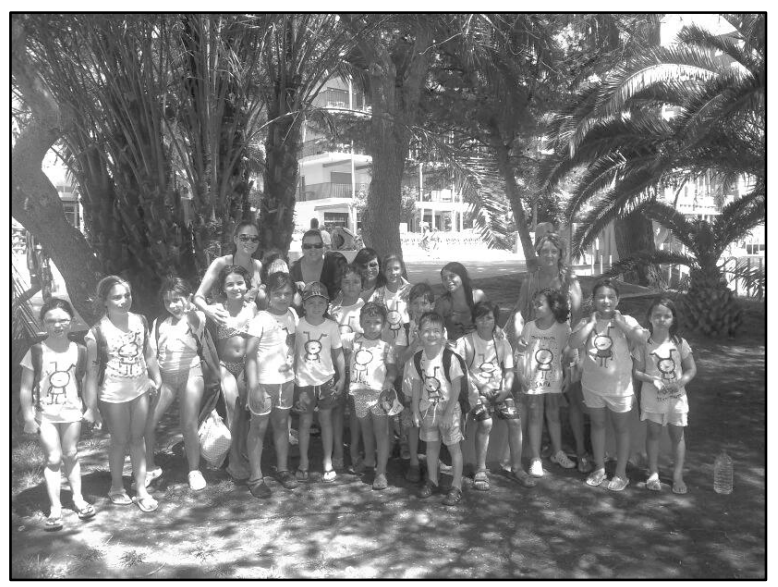
haciendo prácticas del MTL en el Esplai Cataflai, con el tiempo mi implicación fue aumentando y llegamos a realizar en Maranya una Escuela de Verano con una compañera. Han pasado cuatro años, y miro aquel momento de forma muy significativa, creo que ha sido determinante en la construcción de la persona que soy ahora, y sin duda, creo que pocas experiencias llegarán a tener el componente emocional que lleva implícito para mí recordar el tiempo dedicado al proyecto. Creo que el asociacionismo genera una reciprocidad, que a la vez que la acompaña la tensión, sus más y sus menos de la confluencia entre personas, te devuelve el doble de aquello que das. El hecho de sentirte parte activa de un colectivo que persigue ideales en los que crees, que busca la implicación ciudadana y que te requiere para este fin, sinceramente, marca. Ahora mismo, estoy alejada de todo esto, puedo ver con la distancia y me impresiona, a la vez que me alegra que todo marche, y deseo que siga siendo una parada importante para muchas otras personas, que como yo, tengan inquietudes y necesiten ver para creer. 


\section{FEDERACIÓ DE CASES}

Hola! Sóc Julio Huerta, coordinador del Centre de Recursos Associatius de I'Horta Sud, Educador Social, expert Universitari en Gestió Directiva de Organitzacions no lucratives, tècnic Superior en Animació Sociocultural i professor a l'Escola de Formació de la Federació de Cases de Joventut.

El meu contacte amb La Maranya ve a partir dels cursos de formació de l'Escola d'Animadors de Cases de Joventut i la promoció de projectes que fomenten l'autonomia i la capacitat crítica dels joves mitjançant la seua organització en grups on ells són els protagonistes i responsables dels seus projectes i no mers

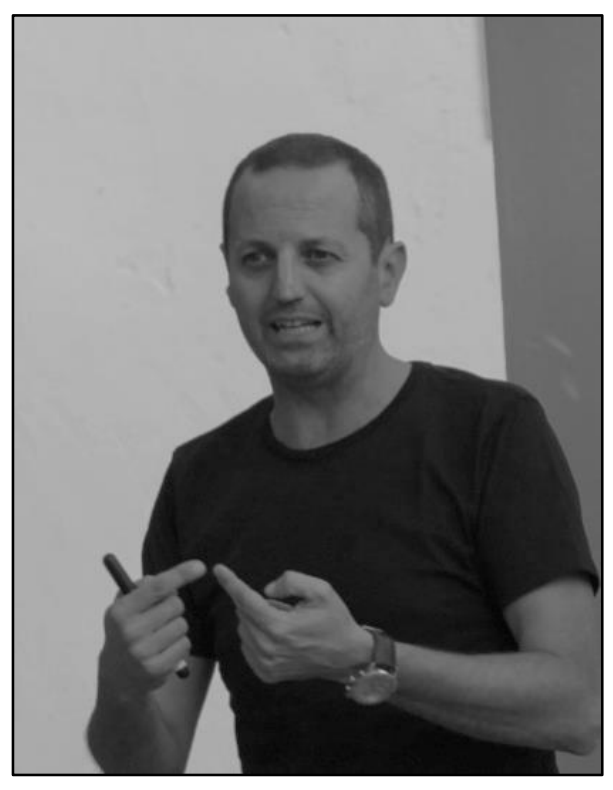
consumidors. La Maranya ha fet realitat les il-lusions de molts Joves, ha fet possible fer efectiva la participació, la democràcia, l'autogestió, el pensament crític, la coresponsabilitat,...

Jo no tenia ni setze anys encara quan Enrique Deltoro apareix en el meu barri i a un grup de jóvens ens enganxa per a que nosaltres formem una associació, un grup juvenil i que realment siguem protagonistes del nostre temps lliure i de la nostra forma d'organitzar-nos. Ací jo comence en este món, des de l'any 86 han passat ja quasi trenta anys i sempre he estat més o menys vinculat a moviments associatius d'oci i temps lliure. 
Enrique Deltoro Rodrigo. Formador de monitors i de animadors, enamorat del

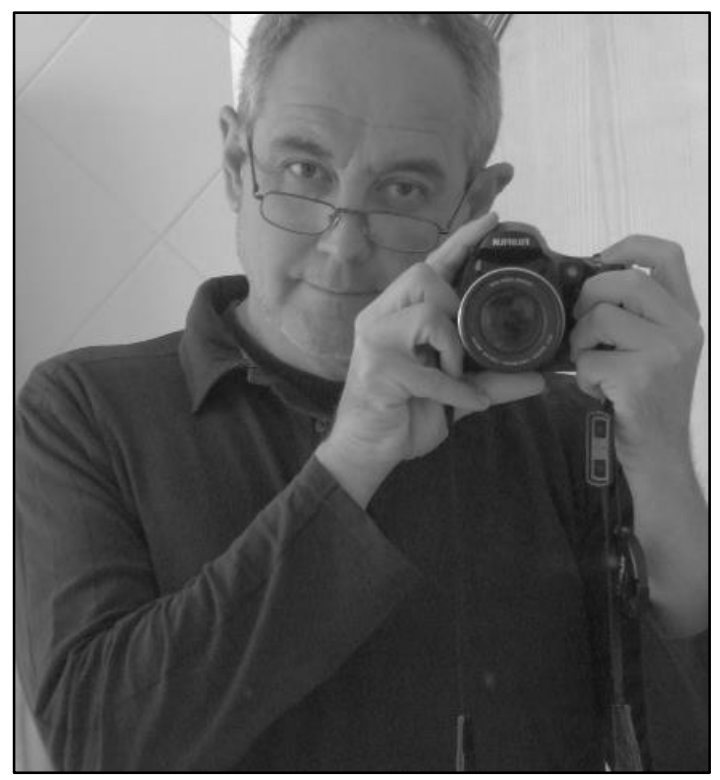

projecte Maranya i de la gent que I'ha dut endavant. Jo vaig començar treballant amb deficients mentals, vaig estar huit anys treballant oci i temps Iliure amb deficients mentals. Pensant en que la integració dels discapacitats a través del temps lliure era una realitat que es podia millorar. A partir d'ací ja et poses a treballar amb població normalitzada infantil en campaments, i hi ha un curs d'animadors de I'IVAJ, en aquell temps Direcció

General de Joventut, en què confluïm molta gent i d'ací ja vaig passar a treballar en un ajuntament en el departament de joventut. Treballar en un ajuntament en el departament de joventut quan has tingut una experiència prèvia de voluntariat en el temps lliure amb persones discapacitades, intentant treballar la integració, t'enfocava cap a una forma d'entendre açò d'una manera molt concreta, comptant amb gent, d'una forma oberta i no elitista i tenint en compte totes les possibilitats que pugues veure.

Sóc Jesús Martí Nadal, tècnic de joventut de l'ajuntament de Quart de Poblet des de 1987. Tinc ara 55 anys i no recorde quan vaig començar a dedicar-me a l'animació juvenil, però va ser molt prompte.

Des de molt jove vaig participar activament en la parròquia del meu poble, en l'inici del moviment Junior i, ja un poc més major, en altres

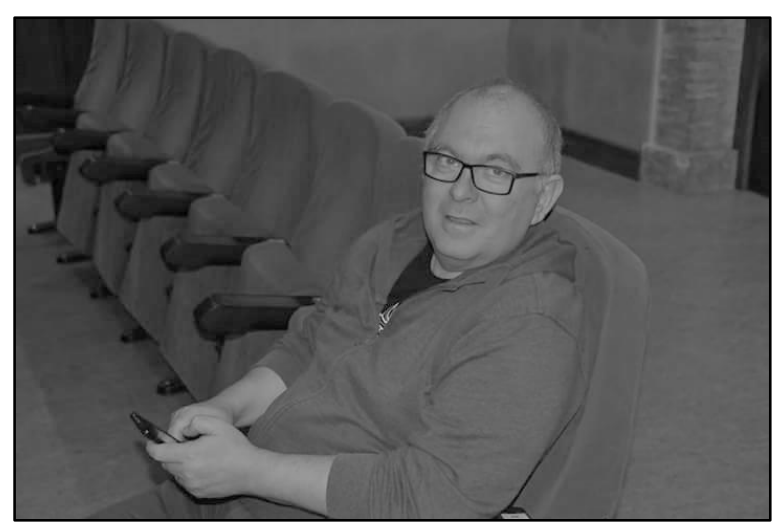


moviments, com el d'objecció de consciència al servei militar o de renovació pedagògica. En un curs d'Animació Juvenil que va fer el primer I'IVAJ, vaig conèixer/connectar amb una gent que enteníem l'animació sociocultural des d'una perspectiva més participativa i de canvi social: Enrique Deltoro, Neus, Amparo... i ens organitzarem en Trajecte Associats. En un curs a Murcia coneguérem a la gent de la Federació de Cases d'Aragó i començà una relació intensa i molt productiva.

He estat en el naixement de les Cases de Joventut a la Comunitat Valenciana, i he estat en els moments àlgids i en els moments de debilitat, en cadascuna de les crisis i renaixements, encara que he deixat el paper protagonista ja fa uns anys, a sang més jove. Quart ha estat sempre un ajuntament que ha donat suport oficial al projecte de Cases i a la Federació, i on s'ha articulat el model esplais-centres juvenils-Casa de Joventut com a eix vertebrador de la política d'educació en la participació.

Inclús he participat en la creació de la Casa de Joventut NFR de Polinyà de Xúquer. També he estat de Director i professor de I'Escola d'Animació de la Federació durant uns anys. Actualment estic com a Secretari General de I'Institut Valencià de la Joventut, organisme responsable de les polítiques de joventut de la Comunitat Valenciana.

I aparegué Benicàssim... 


\section{CONSUMIDORAS}

Em dic Míriam Solozano, visc a Benicàssim i sóc estudiant d'infermeria. Durant

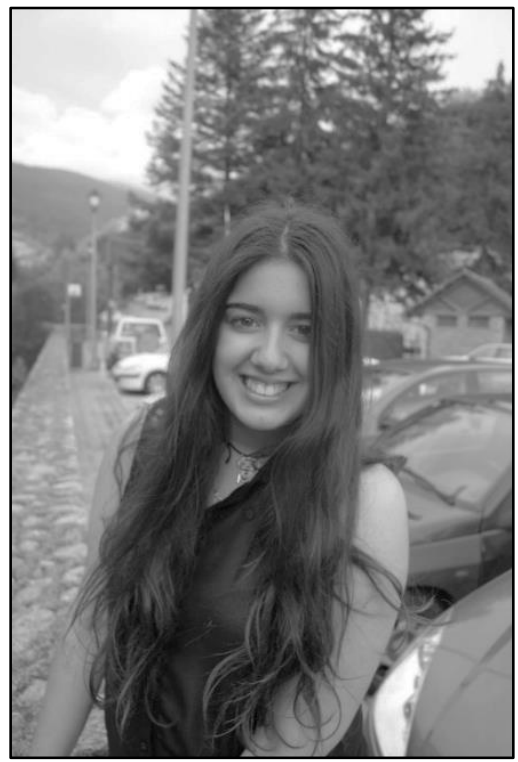
alguns anys he participat en diverses activitats organitzades per la Maranya gràcies a les meues amigues que m'han animat a fer-ho. Crec que és important que el nostre poble tinga una associació on els jóvens puguen reunir-se, realitzar activitats i relacionar-se.

Em dic Miriam. M'agrada fer preguntes, perquè sóc dispersa.

M'agrada entendre el món, i que el món m'entenga, perquè sóc intèrpret.

M'agraden les coses grans i les xicotetes, perquè sóc dispersa i observadora.

M'agrada compartir-me i que es compartisquen amb mi, perquè sóc contacontes.

M'agrada Maranya, perquè som diferents, perquè som paregudes, perquè fem preguntes, perquè ens compartim, perquè podem ser xicotets, i perquè som grans.

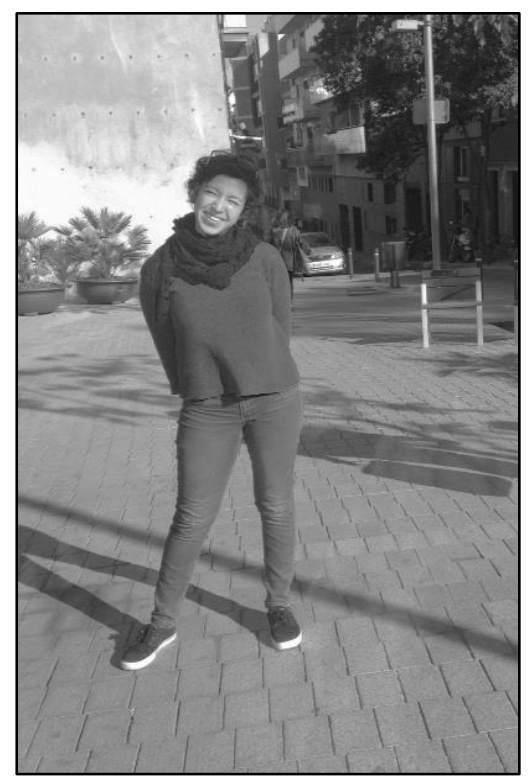


Arecia Aguirre García-Carpintero

\section{USUARIAS}

Hola! Soy Iván, estudiante del IES de Beni y mi relación con Maranya es a través

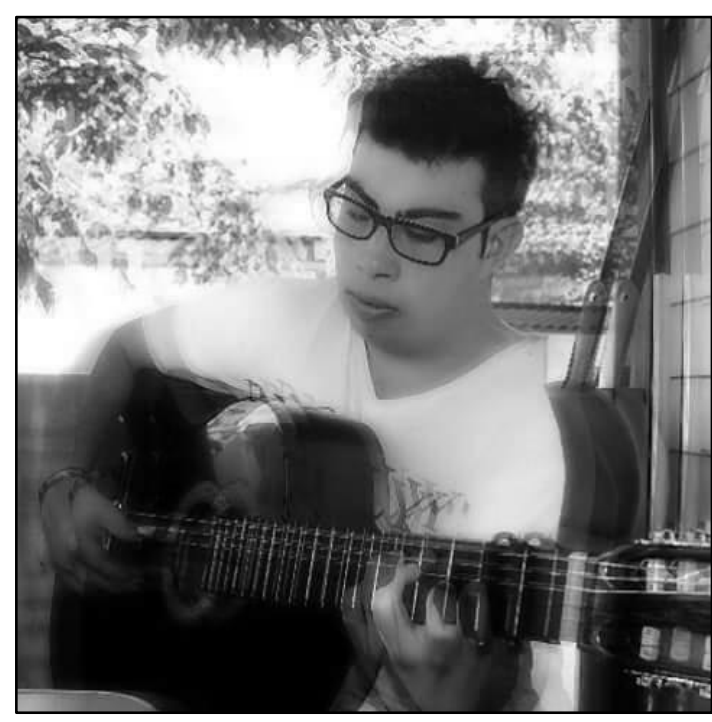
de conciertos y musica que allí se celebra, el último los conciertos del Pren. Yo soy Maranya porque me encanta todo lo que se hace por ahí, y su filosofía de Casa de Juventud me ha enriquecido mucho como persona y la última, por la gente, excepcional y me han tratado muy bien. 


\section{MIEMBROS DE GRUPOS \\ ESTABLES}

Soy Ana María y yo soy Maranya porque considero que gracias a Maranya se pueden conocer nuevas personas, también se aprende nuevos juegos y se realiza acampadas maravillosas, talleres de teatro, de cocina... e incluso ayuda a la gente vergonzosa como yo a poder soltarse más y no tener tanta vergüenza.

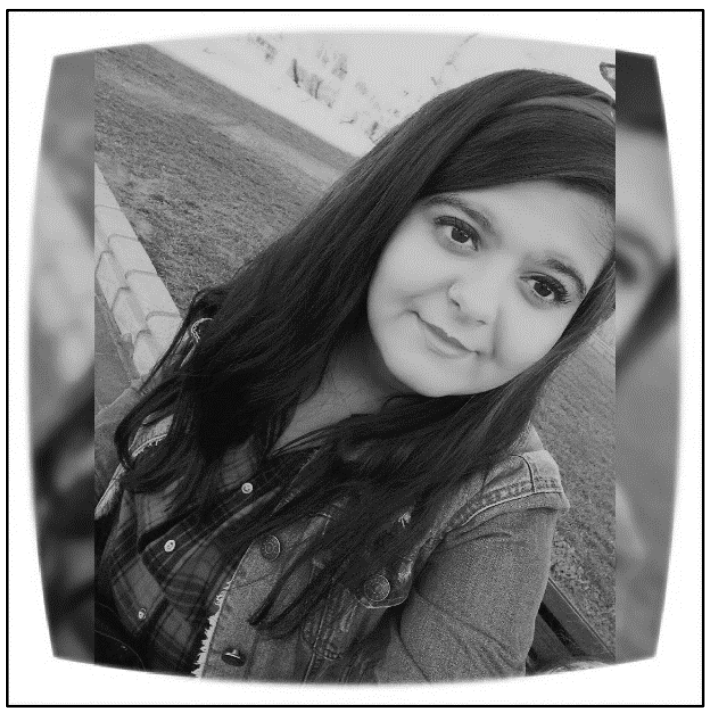

Hola, me llamo Jose Vicente Coderch. Me dedico a intentar ser elemento

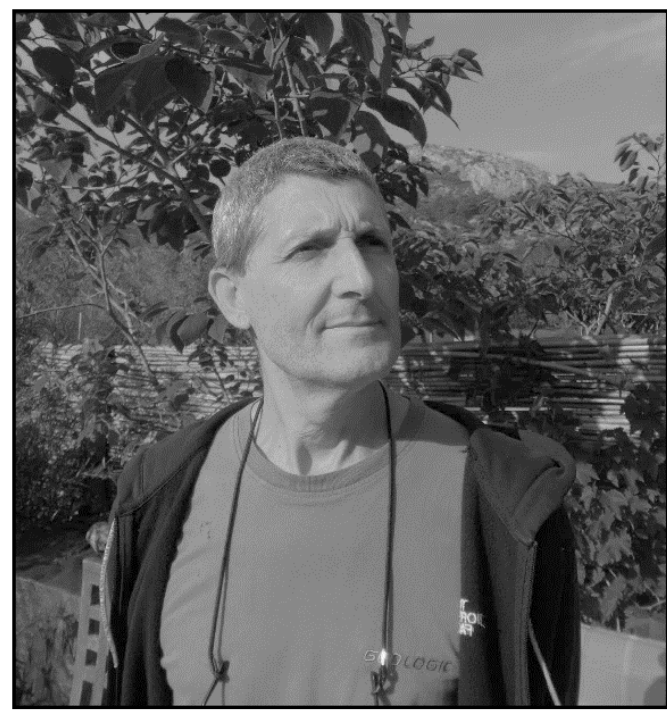
cohesionador en todas aquellos espacios que nos ayudan a dinamizar la cultura, la humanidad, la educación, la solidaridad, la conciencia; a través de los roles de padre, amigo, compañero, socio...

Por eso la Maranya es el tipo de proyecto donde confluyen todas estas sinergias.

Poder estar vinculado a un proyecto como este resulta gratificante desde lo que recibimos tanto como lo que ofrecemos. 


\section{ACTIVISTAS}

Sóc Armand Congost i Maestre, «sajeño» de naixement i benicassut d'adopció,

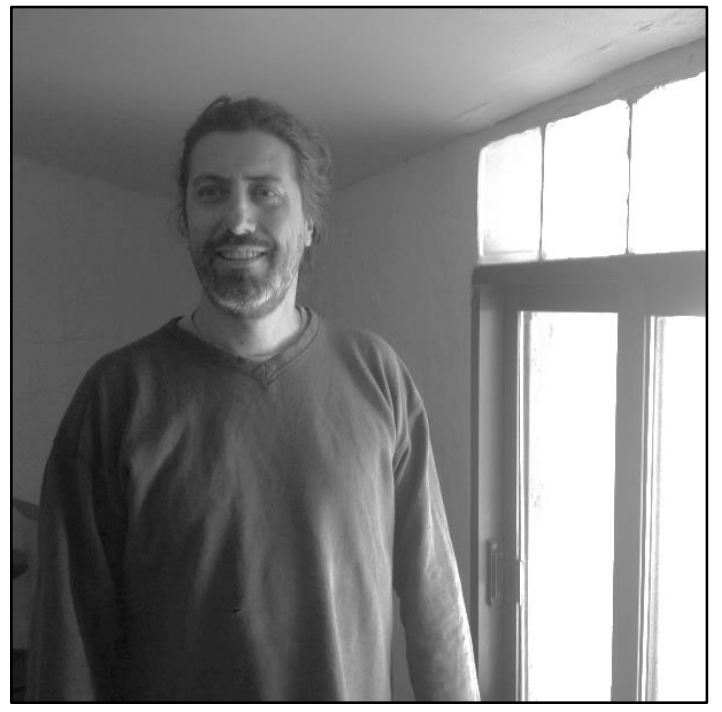
encara que passe moltes hores a València i Burjassot, ja que treballe a la Universitat de València com a Tècnic de Laboratori al Departament de Biologia Cel·lular.

Des de ben jove vaig participar al poble amb diverses associacions de caire esportiu i cultural, com el Grupo de Montaña Sax o Axtro (astronomia) dels que vaig ser membre fundador. A l'Institut vaig formar part del cor i vaig ser representant dels estudiants, activitat que vaig continuar a la universitat, on vaig formar part del Ciències Rugby Club i de I'Orfeó Universitari. Amb la incorporació al món laboral em sindique i participe activament amb la CGT, sindicat amb una gran component d'acció sociopolítica. Actualment sóc membre del Club Integral de Muntanya, del Cor L'Acadèmia d'Orfeu, de l'associació Voltants, d'Amnistia Internacional, de la cooperativa de consum d'energia verda Som Energia, de la CGT i òbviament del Centre de Cultura i Joventut la Maranya, al qual m'incorpore l'any 2012, a l'inici de la seua andadura, convençut de la necessitat al poble d'un espai obert i participatiu com aquest. En un primer moment la meua participació se basa en aportació econòmica, però després, a medida que vaig interaccionant amb les persones que habitan Maranya, vaig implicant- me amb el manteniment del local, amb la creació del grup estable d'adults, que es consolida a partir de l'activitat de consum agroecològic i acabe per formar part de l'equip d'animadors voluntaris. 
Jo sóc Iván Checa i la meua relació amb el Centre de Cultura i Joventut La Maranya va començar des de ben xicotet, quan encara el centre no existia com a tal. Als 8 anys vaig entrar a l'Esplai Cataflai, el grup d'oci educatiu per a xiquets i actualment continue en aquest grup com a monitor de temps lliure 10 anys després. També forme part de la junta directiva de l'Associació d'Esplais Valencians, la qual agrupa tots els grups d'esplai del País Valencià.

Jo sóc Maranya perquè sempre

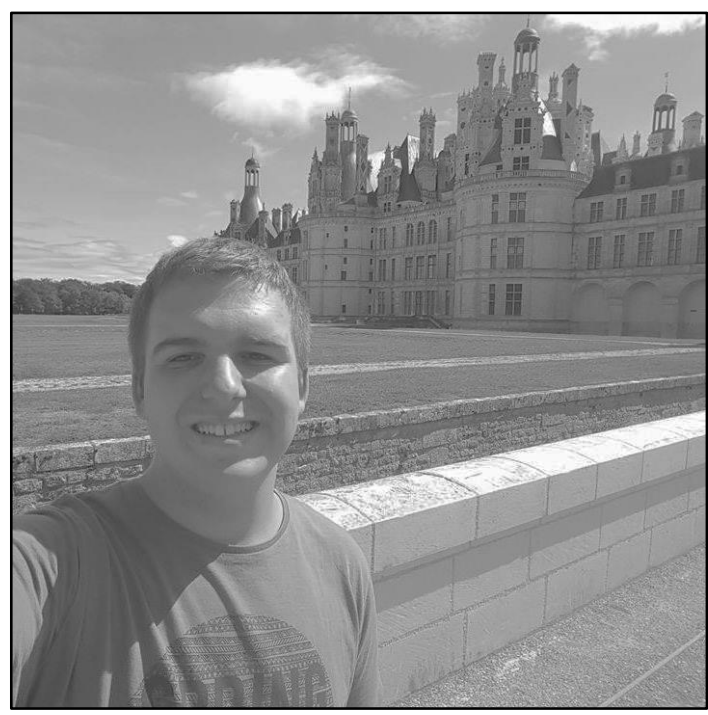
he cregut que l'associacionisme és una part molt important de la societat i una eina transformadora per canviar aquelles coses que no t'agraden.

Em considere una persona activista, dintre de La Maranya forme part de l'equip d'Animadors Voluntaris i de l'equip de responsables encarregant-me de la comunicació.

A més, també sóc president de l'Associació d'Alumnes de Benicàssim, I'associació d'estudiants de I'IES Violant de Casalduch des de la qual pretenem convertir a l'alumnat en el protagonista de l'educació implicant-lo en la presa de les diferents decisions que l'afecten.

La meua relació i implicació amb el món associatiu sempre ha sigut prou intensa i, tal com he explicat abans, a més de ser una eina transformadora, et permet viure experiències que completen la formació integral de qualsevol persona. Com diu Josep Anselm Clavé «Instruïu-vos i sereu lliures. Associeu-vos i sereu forts. Estimeu-vos i sereu feliços». 
Soy José Manuel Ordaz, tengo 54 años y mi relación con la Maranya se remonta

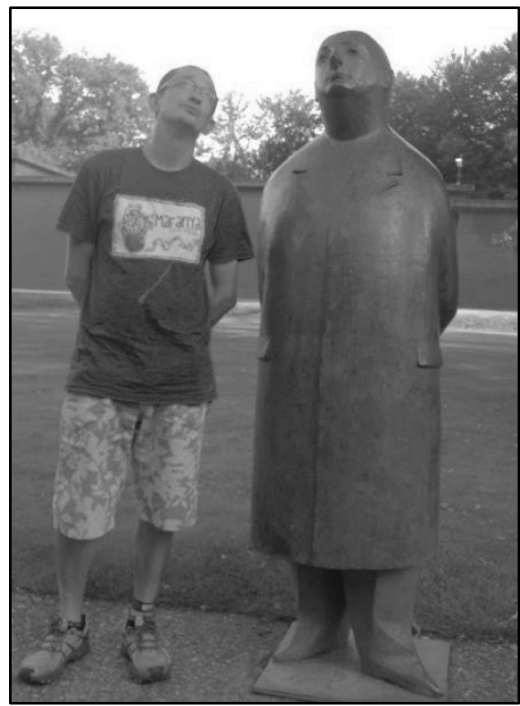
a sus orígenes. En el momento de tener que abandonar el espacio que se ocupaba en el Casal Jove del Ayuntamiento de Benicàssim, mis hijos pertenecían al grupo del Esplai. De esta forma me vi involucrado en su nacimiento.

Desde el principio he creído en este proyecto y no he dudado en formar parte de él. Formo parte del grupo de consumo y participo activamente en las labores de mantenimiento del local, también soy patrono desde su fundación. Estoy convencido de la necesidad de este tipo de espacios y espero que en el futuro sea una parte vital de la sociedad juvenil de la población.

El meu nom és Lydia Ferrando Ramos, tinc 19 anys, i porte en la Maranya des del primer moment que es va crear. Vaig entrar en aquest moviment quan vaig començar a ser una xiqueta de l'Esplai de Benicàssim, i l'any passat vaig estar com a monitora de l'Esplai de la Maranya. Sóc una resident en Benicàssim i pense que

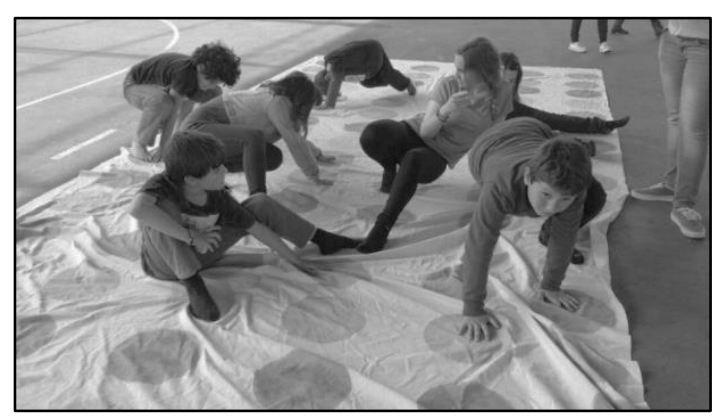
falten llocs com la Maranya pels pobles de tot arreu. La meua funció actualment és de jove responsable i ajude a fer activitats sempre i quan em necessiten. Una de les coses que més m'agradava de menuda era poder anarme'n d'acampada i conéixer gent nova. El problema de fer-se major i passar a ser monitora és que has de preparar tu l'acampada i a més estar sempre amb mil ulls per si a cap xiquet o xiqueta li passa qualsevol cosa. Però jo sempre he trobat alguna activitat que em torne a aquells records de quan anava a jugar com una xiqueta, per això he elegit aquesta fotografia, perquè una de les coses més boniques que vaig viure sent monitora va ser quan em vaig transformar jo també amb una xiqueta que anava a jugar. És veritat que encara així has d'anar 
amb compte i deixar que guanyen els xiquets i les xiquetes en algun moment, però encara així m'ho vaig passar molt bé. Mai es perd l'ànima de xiquet. Per això pense que han d'haver-hi moviments com aquest, perquè a més de jugar i conéixer gent nova, creixen també els teus pensaments i les teues idees. Et relaciones amb gent que pot ajudar-te a obrir els ulls i a lluitar per les teues idees, mai et sentiràs a soles i sempre respectaran les teues idees.

Me llamo Noel. Yo estoy en la Maranya desde su fundación y en ella he pasado

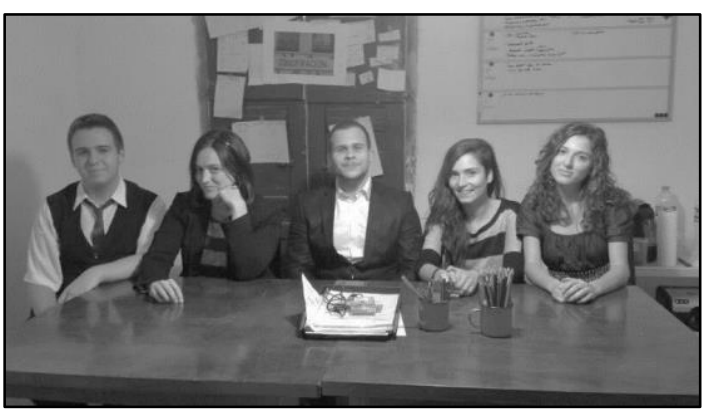
por diferentes etapas. Empecé coordinando un grupo estable y también fui secretario de la asociación. Luego estuve de integrante en otro grupo y animando una casa en Villareal para financiar el local de la Maranya.

Mi situación actual dentro de la casa es de animador y coordinador de los responsables, además de ocupar el cargo de presidente en la junta directiva y representar a la asociación en diferentes ámbitos, como en la Federació.

Yo estoy en la asociación porque creo en la necesidad de los espacios en los que los y las adolescentes y jóvenes puedan ser protagonistas de su propio tiempo libre y no solo consumidores de actividad, organizándose para hacer aquellas cosas que les generan inquietud. Así, a partir de fomentar estas inquietudes, conseguir la participación de estos y estas jóvenes y adolescentes y conseguir personas comprometidas que participen y se unan por aquello que consideren justo. $Y$, sobretodo, que sean críticas con la información que reciben de los medios y del entorno, que creen sus propio pensamiento y sepan defenderlo con argumentos propios y que ellos mismos entiendan. Ya que, en mi opinión, es la unión entre la conciencia crítica y la participación en la vida social la única forma de cambiar la realidad de hoy en día y mejorar así el contexto en el que estamos viviendo o al menos no ser cómplices de aquellos que se esfuerzan en mantener la situación actual. 
Hola sóc Ricky, Sóc un clown de les paraules i tot va començar per una Maranya...

La gent pot més del que pensa, sobre tot quan dus el nas de clown. No tothom ho sap però el nas de clown és la màscara més petita del món. Quan entra en contacte amb el nas, té la capacitat d'absorbir totes les pors i mals que habiten al cos. Per deixar la felicitat i les ganes de fer riure a la gent com a mètode de vida.

Sóc un dels integrants del grup d'animadors voluntaris de la Casa de Joventut La Maranya. Des dels 16 anys estic dins del moviment associatiu i de Cases, vàrem començar dins d'un grup estable en el centre juvenil del poble, el qual dinamitzaven Virginia i Víctor. Duc en el projecte

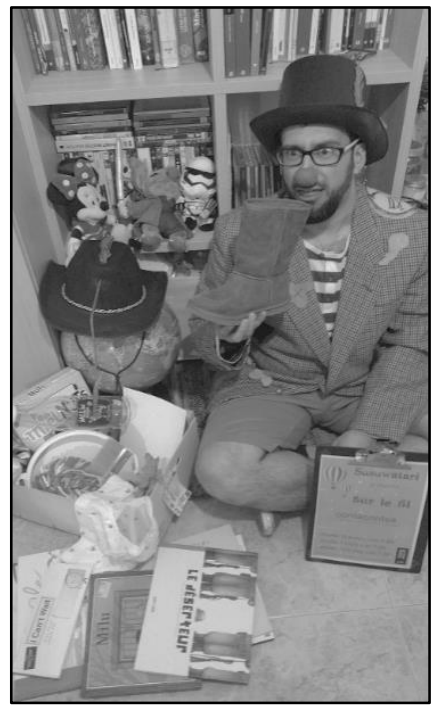
des del seu inici, quan decidirem tots marxar del centre juvenil i associar-nos. Alguns anys he estat menys actiu en el projecte, degut a no trobar-me en el municipi i no tindre tanta disponibilitat, i altres cursos amb més disponibilitat he pogut dur a terme tallers setmanalment. Sóc membre del grup estable Humanos y Casas, grup de jocs de taula i rol que duguem a terme activitats per al adolescents en el municipi.

Estic conscienciat en que paga la pena sensibilitzar als joves sobre la importància de la participació i la implicació directa en la presa de decisions en el seu dia a dia. Així com potenciar la creació d'activitats pròpies, recolzada en el treball en equip i en xarxa. 


\section{ANIMADORAS}

Sóc Virginia activista de Cases de Joventut i actualment participe del projecte La

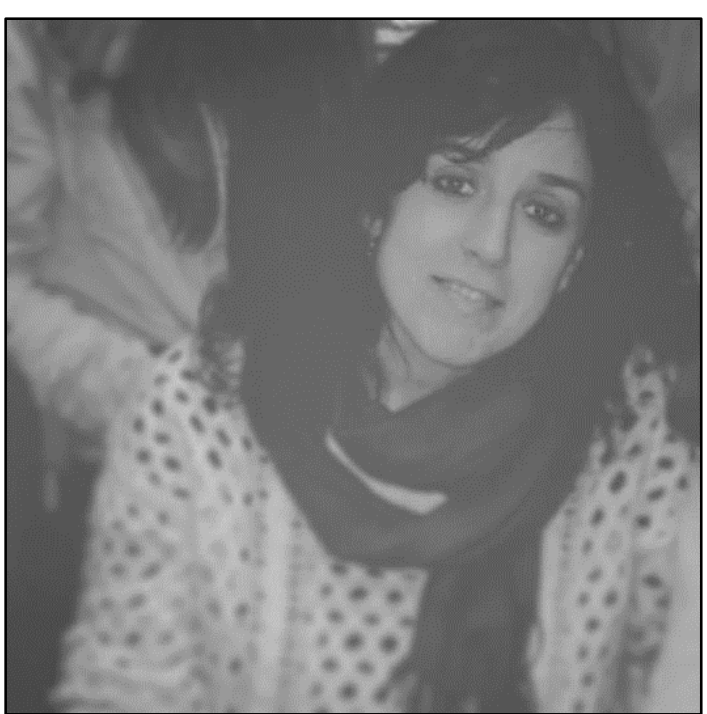

Maranya de Benicàssim com a voluntària en la part de gestió de l'entitat.

La meua relació és remonta als seus inicis. Abans de constituirnos com a entitat legal, fa ja al voltant de cinc anys, estava al costat dels joves promotors de l'entitat ja que des del treball professional en el departament municipal de joventut la meua funció era promoure la participació juvenil i la implicació del joves en el teixit

associatiu municipal.

Ha passat molt de temps, moltes persones i moltes implicacions diferents pel projecte, però continuem. Continue enganxada al projecte, un projecte necessari a Benicàssim, que està conectat amb altres pobles i territoris des de la Federació, que dona veu als joves i possibilita espais d'educació per en la participació, espais de desperta de la consciència i del pensament crític, autèntiques escoles de ciutadania. 
Sóc Mireia, animadora voluntària a la Maranya. La meva vinculació al projecte

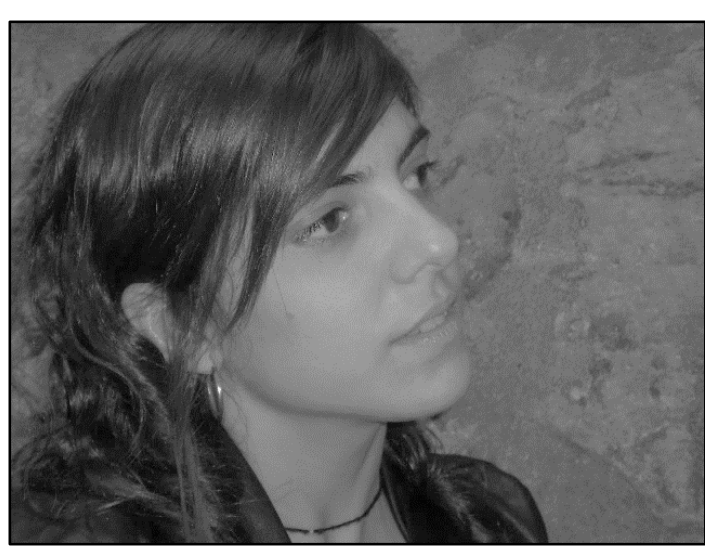
parteix quan realitze les pràctiques del curs de MTL, és així com comence a introduirme, primerament a I'Esplai, i finalment he acabat submergint-me al món de l'animació i la participació juvenil.

Sempre he estat vinculada a l'associacionisme, de menuda he sigut introduïda pels meus pares, després pels amics, i a poc a poc ho he anat entenent quasi com una forma de vida.

Pense que és molt important que les persones siguen les protagonistes de les seves vides, sent agents actius; i cal despertar consciències, educar en la participació, en valors democràtics, de respecte, tolerància, pensament crític,... Per això cal educar i tenir xarxes on treballar amb els/les joves $\mathrm{i}$ a tots els camps que calgue, però em centre als joves que és on estic. L'associacionisme i la metodologia de les Cases de Joventut, pense que és un model molt vàlid per a poder aconseguir canvis, empoderar a les persones i fer-les adultes responsables, formades, autònomes, participatives,...

En fi, que sóc animadora i ciutadana que participa en associacions, perquè pense que és la manera de canviar el món.

El meu nom és Víctor Escoín, i sóc un dels animadors voluntaris de la Maranya.

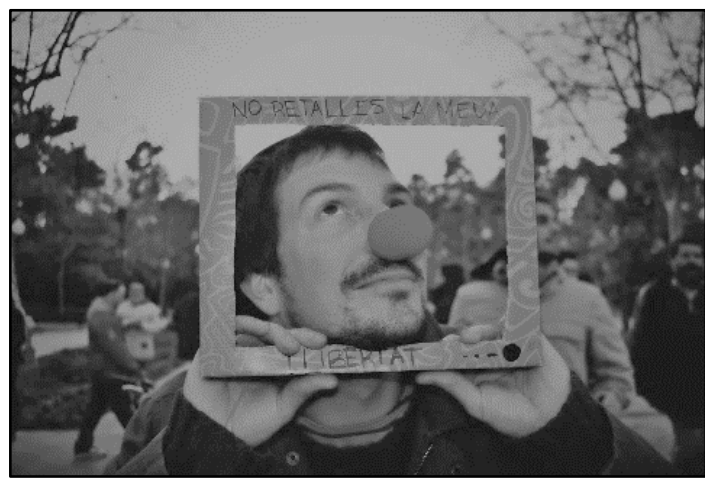

Tinc 35 anys i des dels 15 estic ficat en el món associatiu, especialment al tema juvenil. Vaig començar en grups estables de senderisme, però prompte vaig acabar fent el que més m'agradava d'adolescent: els mitjans d'expressió. Amb un grup reduït de joves vaig participar 
de la posada en marxa d'una revista juvenil al poble que immediatament acabà esdevenint un altaveu d'expressió políltica, literària i experimental on vaig crèixer ideològicament i en valors. Ocupar funcions directives de l'associació és conseqüència directa (almenys per a mi) d'aprendre que totes aquelles responsabilitats que un mateix no assumeix, acaben significant irresponsablement sobrecàrregues de feina per a altres. Així poc a poc, primer Casa de Joventut de Benicàssim, i després l'inici de nous projectes com la creació de l'Associació d'Esplais Valencians (AEV) (dedicada al lleure educatiu dels xiquets i xiquetes), i més tard la vinculació a la xarxa associativa que tant la Federació de Cases de Joventut com I'AEV fundaren per treballar conjuntament, o la meua implicació en l'equip de coordinació pedagògica de I'Escola d'Animadors de la FVCJ, on he treballat a fons la formació de qualitat dels i les monitores de temps lliure que després estaran als campaments, colònies i centres juvenils on s'associaran els i les nostres filles. En aquesta última he aprés que l'aprenentatge funciona quan és operatiu, i no repetitiu, memorístic o de discurs. Les coses s'aprenen quan es viuen directament, quan es el propi alumne qui les construeix, les crea.

La meva vida no s'enten si no gira sempre al voltant de les hores de treball voluntàries cada setmana a la millora de les projectes d'associacionisme transformador. Sempre he tirat més per la via de l'animador de sabatilla, és a dir, prioritzant el treball directe amb grups i empoderant les iniciatives dels joves amb qui treballava, donant l'espenteta que necessiten per despegar i ser imparables amb les seves idees de creació cultural o de crítica, solidaritat, ecologia. De vegades via ajuntament com a tècnic de joves, de vegades com a professor, i sempre en paralel, de forma voluntària. Però amb els anys hem construït una xarxa de treball i de fraternitat en la que allò que faig, allò al que em dedique, i que em mou interiorment, te sentit.

Des de jove he tingut la creença de que una societat millor havia ser laica, o no ser. Em sembla un principi fonamental aquell de deixar que cada persona crega el que considere i que ninguna creença no racional i empírica marque les normes de convivència social. He defensat sempre que pensar, sentir i creure en el que a mi em done la gana va lligat a acceptar a persones que ho fagen diferent a mi. Són dues coses indisolubles, que viatjen juntes.

L'experiència d'anys ens ha dut, i ja parle definitivament en plural, a detectar necessitats per al teixit associatiu que deuen ser resoltes. Necessitats com que 
les estructures associatives han d'enfortir-se a nivell econòmic i a nivell administratiu, o necessitats metodològiques que faciliten una forma de treballar a tots els voluntaris i activistes que intenten canviar el món educant el temps Iliure. És, al meu parèixer, una progressió natural en la meua vocació en el món de l'educació no formal i la transformació social i política des del temps lliure.

La Maranya és conseqüència d'un de tans d'estos processos de dinamització i empoderament de grups de joves, amb la diferència que per primera vegada en molt de temps, i supose que amb una barreja d'estratègia, experiència i inconsciència, aconsegueix quallar en un projecte estabilitzat més enllà de les esporàdiques i temporals reivindicacions juvenils. Per a mi la Maranya ha suposat un canvi de mirada envers allò que signifiquen les experiències úniques (i molt sovint marginals, tot i que positives) d'empoderament juvenil, i una altra cosa que últimament m'engresca molt més: les experiències significatives, capaços de fer-se un espai a l'imaginari de tota la població juvenil i que poden mobilitzar realment canvis d'època al cap de tothom. La Maranya ha sigut per a mi el començament d'una etapa de fer crèixer els projectes i de crear, un darrere altre, inèdits viables que tornen la capacitat de somiar el futur a una societat com la nostra que viu esperant que els canvis esdevinguen sols. Una societat de solidaritats administrades per Estats que no estan disposats a permetre que les persones s'autogestionen i deixen, poc a poc, de necessitarlo.

Crec que és molt fàcil d'explicar quina relació tinc amb el món associatiu i amb la Maranya: Reduisc al màxim les meves hores de treball, compromet moltíssimes hores voluntàries als projectes que hem comentat, no faig migdiada i intente dormir poc per aprofitar el temps que em queda després de les responsabilitats familiars. Hi ha temps per a tot. Una vegada em van preguntar «escolta, i tu per què no et poses en política, amb el que t'agrada?». La meva resposta: duc tota la vida fent política, encara no t'has adonat? 


\subsection{Contexto Maranya.}

La Casa de Joventut La Maranya nace en Benicàssim con la unificación de diferentes grupos estables de jóvenes que estaban trabajando para el municipio desde hacía tiempo. El colectivo afirma que son conscientes de que ellas solas no van a cambiar nada pero que nada cambiará sin ellas. Reciben a cualquier joven o grupo de jóvenes con ganas de hacer cosas, que entren en la dinámica de la casa, tomen decisiones y muestren su capacidad organizativa. Hacen actividades mediante la cultura y se organizan en grupos estables y con otras organizaciones. Piensan que hace falta defender los derechos de las jóvenes y también de la sociedad y por eso participan en la creación de una cultura alternativa y popular.

La Maranya es un Centro de Cultura y Juventud situado en el municipio de Benicàssim, Castellón. Desde hace alrededor de 5 años ofrecen un espacio en el cual trabajar actividades de ocio y tiempo libre con niñas y niños, adolescentes y jóvenes y también con personas adultas. Todo a partir de un modelo de educación en el tiempo libre basado en las estructuras y organización de las Casas de Juventud. Principalmente las personas que participan del local pueden reunirse a través de grupos estables y de esta forma, mediante sus propios gustos e intereses, van conformando una amplia gama de actividades propuestas desde abajo y en base a su propia participación montando su propio ocio desde el compromiso y la solidaridad.

El rango de edades en el que se trabaja es desde los 5 años hasta la edad adulta. Se insiste en el papel de las jóvenes en la Casa ya que La Maranya es considerada como un centro autogestionado por jóvenes debido al interés de dotar de un espacio de participación activa para este colectivo.

Actualmente Maranya cuenta con 124 socias que participan de un modo u otro en el mantenimiento de este espacio ya bien sea con aportación económica o también con su participación en la gestión del centro. El trabajo que se desempeña es totalmente voluntario a excepción de algún programa que se lleva de forma conjunta con el Instituto del municipio en el que la animadora del proyecto recibe una aportación por su trabajo. En su gran mayoría el centro se sustenta de las aportaciones económicas de las socias y de las donaciones de personas externas o también socias. 
Arecia Aguirre García-Carpintero

A continuación podemos leer el resumen de cuentas que ha tenido durante el ejercicio 2015 y que puede leerse en su web.

Imagen 10. Resumen de cuentas año 2015.

\section{RESUM COMPTES ASSOCIACIÓ DE CASES DE JOVENTUT DE CASTELLÓ 2015}

\begin{tabular}{|c|c|c|c|c|c|}
\hline \multicolumn{2}{|l|}{ GESTIÓ DEL LOCAL } & \multicolumn{2}{|c|}{ ACTIVITATS LA MARANYA } & \multicolumn{2}{|c|}{ PAGUEM DEUTES D'OBRA } \\
\hline$\overline{L L O G U E R}$ & $4.425,02 \mathrm{C}$ & EQUIPAMENTS VARIS & $1.733 .65 \mathrm{\epsilon}$ & OBRA & 464,816 \\
\hline LUM & 584,196 & IMPREMPTA & $202,66 \mathrm{\epsilon}$ & PORTA & 741,736 \\
\hline AIGUA & 201,606 & MENUAR I BEGUDES & 250,336 & & \\
\hline ADMINISTRATIUS & 177,006 & OFICINA & 13,306 & \multicolumn{2}{|c|}{ MANTENIMENT DEL LOCAL } \\
\hline BUTÀ-CALEFACIÓ & $70,00 €$ & $\begin{array}{l}\text { CURSOS } \\
\text { SERVEIS EXTERNS }\end{array}$ & $2.220,006$ & & \\
\hline FINANCERS & 44.606 & (despesa llicència) & $2.540 .88 \mathrm{C}$ & PETIES REPARACIONS & 834.846 \\
\hline WEB I XARXES SOCIALS & $91.18 \mathrm{6}$ & FUNGIBLES & $111,73 \mathrm{\epsilon}$ & NETEA & 4,906 \\
\hline WIFI & 394,736 & MERXANDATGE & 306.056 & DECORACIÓ & $75,87 €$ \\
\hline $\begin{array}{l}\text { COPIES CLAUS } \\
\text { ASSEGURANCA }\end{array}$ & $\begin{array}{l}19,056 \\
357,58 €\end{array}$ & BATUCADA & $1.850,00 €$ & CADIRESI MOBILIARI & $83,86 €$ \\
\hline \multirow[t]{2}{*}{ EXTINTORS } & 36,306 & \multicolumn{2}{|c|}{$\underline{\text { GESTIÓ DE L'ENTITAT }}$} & \multicolumn{2}{|c|}{ ADHESIONS/MECENATGES } \\
\hline & & PLA COMPTABLE & 508.206 & COOP. SANT ANTONI & 6.006 \\
\hline
\end{tabular}

\section{INGRESSOS}

\begin{tabular}{|c|c|c|c|c|c|}
\hline QUOTES & & $\begin{array}{l}\text { CURSOS } \\
\text { (Monitoría. Menjador) }\end{array}$ & $1.635,00 \mathrm{f}$ & $\underline{\text { SUBVENCIONS }}$ & \\
\hline QUOTES MARANYA & 5.145 .006 & Grup Batucada & $1.823 .00 \mathrm{f}$ & - Diputació de Castelló & $1.333 .33 \mathrm{f}$ \\
\hline QUOTES SOS ALQUERIES & 200,006 & $\begin{array}{l}\text { Prèstec grup batucada } \\
\text { DONATIU TREBALL }\end{array}$ & 450.006 & $\begin{array}{l}\text { - Aj. Benicàssim } \\
\text { - Fundació }\end{array}$ & $2.924 .52 \mathrm{G}$ \\
\hline QUOTES ESPURNA & $400,00 €$ & $\begin{array}{l}\text { VOLUNTARIS } \\
\text { INGRESSOS FINANCERS }\end{array}$ & $\begin{array}{l}3.885 .236 \\
0.286\end{array}$ & Novessendes a Espurna & $1.500,00$ \\
\hline DONATIUS & $651,56 \mathrm{E}$ & & & & \\
\hline
\end{tabular}

TOTAL $19.947 .92 €$

\section{BALANÇ 1.597,86€}

Aquest any hem fusionat les Cases de Joventutl'Espurna de Betxí, casal SOS les Alqueries i CJ La Maranya de Benicàssim. Des d'ara portarem junts la part fiscal $i$ legal de l'entitat.

Estem en positiu gràcies al treball voluntari de moltes persones implicades en l'entitat. 
La población de interés en Benicàssim está formada por 941 niños y niñas de entre 5 y 9 años; 970 adolescentes de entre 10 y 14 años, 936 de entre 15 y 19 años y 1823 jóvenes de entre 20 y 29 años. Desglosamos estas edades porque son las que forman el grueso del centro y las que conforman la parte de autogestión de la Casa. Es decir, hasta los 29 años de edad las socias del centro pueden asistir con voz y voto a las asambleas, mayores de esta edad únicamente pueden asistir con voz y no voto. De esta forma se quiere potenciar la autogestión de las jóvenes en el centro. Del mismo modo, podemos observar la población diana dividida en etapas educativas en los centros públicos de primaria y secundaria del municipio (tabla 41) que en su totalidad son 1.949 niños, niñas y jóvenes.

Tabla 41. Número de alumnado en Primaria y Secundaria en Benicàssim.

\begin{tabular}{|l|c|c|c|c|c|}
\hline \multicolumn{1}{|c|}{ Centros } & Infantil & Primaria & Secundaria & Bachillerato & $\begin{array}{c}\text { Ciclos } \\
\text { formativos }\end{array}$ \\
\hline $\begin{array}{l}\text { IES Violant } \\
\text { de Casalduch }\end{array}$ & 0 & 0 & 459 & 168 & 197 \\
\hline $\begin{array}{l}\text { CEIP } \\
\text { Palmerar }\end{array}$ & 150 & 300 & 0 & 0 & \\
\hline $\begin{array}{l}\text { CEIP Santa } \\
\text { Águeda }\end{array}$ & 225 & 450 & 0 & 0 & 197 \\
\hline \multicolumn{1}{c|}{ Total } & 375 & 750 & 459 & 168 & \\
\hline
\end{tabular}

Después de esta descripción quisiera referirme a la red de la que forma parte Maranya. Maranya es un espacio que trabaja codo con codo desde la Federació Valenciana de Cases de Joventut (FVCJ). La FVCJ nace hace más de 20 años a partir del trabajo que desempeñan un grupo de personas que se interesan por los modelos de Casas de Juventud europeos, catalanes y zaragozanos. Comienzan a trabajar a partir de estos en Manises y es allí cuando empiezan a sucederse CdJ alrededor de toda la provincia de Valencia. Coinciden en aquellos años 90 con la técnico del Ayuntamiento de Benicàssim y de ahí se inicia un contacto que continua hasta la actualidad. Aunque la relación se transforma, eso hace que años más tarde Maranya nazca desde este modelo concreto. Dentro de esta red forman parte también de la Asociación de Esplais Valencians y al hacerlo en esta y en FVCJ también se empapan del trabajo dentro del Movimiento Laico y Progresista valenciano (MLPV). 
De este movimiento surge la fuerza y el contacto con Zaragoza y también con Cataluña aunque es el primero el que acabará compartiendo espacios y proyectos con toda la red valenciana de manera más directa y cercana.

La Federació no pretende ser más que un instrumento al servicio de todos y todas las jóvenes que, de manera asociada y nunca solas, pretenden transformar la realidad que no les gusta. Hace más de veinte años que son parte de esta realidad y tienen la sensación de que el trabajo compartido no ha hecho más que empezar «los que tenían 20 años, ahora ya hace veinte años que los tenían, y los que ahora los hacen, dedican su tiempo con ilusión en cada pueblo. (...) Gente pequeña, en lugares pequeños, pueden cambiar el mundo. Seas quien seas, vengas de donde vengas, ven y haremos juntos» (revista Federacio).

La FVCJ es una organización con entidad jurídica de carácter laico y pluralista que se rige por principios estrictamente democráticos y participativos. Se crea en el año 1994 por cinco organizaciones juveniles: $\mathrm{La}$ Nau $i$ Al vent (Manises), NFR (Polinyà del Xúquer), La Cebollera i l'Amagatall (Quart de Poblet).

Se encuentran bajo un mismo paraguas de valores de gestión común, que facilita el día a día de grupos de jóvenes y de asociaciones de diferente tipo de la red de entidades desde la que trabajan a nivel local para mejorar la participación social de las jóvenes valencianas.

Creen en otra manera de hacer las políticas públicas. Una manera de hacer que tenga en cuenta que frente al lucro privado de las empresas, están las organizaciones ciudadanas que trabajan prioritariamente por el bien de las demás, por el bien común. Piensan que es el momento de reclamar que la ciudadanía se involucre en la gestión de lo público. Por eso se declaran maduras y capaces para dirigir todos aquellos servicios que les afecten. Así plasman que es hora de pasar del «yo te lo hago» al «hagámoslo juntas».

El funcionamiento de la FVCJ está basado en un secretariado formado por un equipo de voluntarias escogido en Asamblea general el cual asume la resolución provisional de imprevistos diarios, la representación y la administración de la Federació. Mantiene informado al Plenario de todos sus trabajos y sus funciones exactas están recogidas en los estatutos. 
El plenario está constituido por dos representantes de cada entidad y los miembros del Secretariado que tengan derecho a voto. Es el responsable de la dirección y la toma de decisiones entre asamblea y asamblea. Sus funciones también están recogidas en los estatutos.

La Asamblea general está formada por delegadas escogidas por todas las entidades. En ella se aprueban los informes de gestión, el Proyecto de Autonomía del Centro, la memoria, el balance económico y el presupuesto, entre otras cosas. La asamblea es abierta a todas las socias de las entidades miembro, a las profesionales que dinamizan las entidades, a las entidades de la red de MLPV y a la ciudadanía en general.

Para finalizar ver como la FVCJ está compuesta por diferentes asociaciones miembros, a día de hoy han pasado alrededor de $22 \mathrm{CdJ}$ y actualmente son 750 socias reunidas en 11 Casas de Juventud a lo largo de la provincia de Castellón y Valencia.

Por otro lado destacar que la FVCJ dio forma a una escuela de formación que en este 2016 ha cumplido 20 años de antigüedad, Escola de Cases. La escuela se dedica a la formación en el ámbito de la animación sociocultural. Forman monitoras de tiempo libre y animadoras juveniles, en las titulaciones básicas y en formación continua. Forman profesorado y hacen formación a medida para las entidades que así lo solicitan. Son una Entidad No Lucrativa (ENL). La Escola de Cases, o Escuela de formación de la FVCJ es la responsable del área de formación de la FVCJ, y fue reconocida y homologada como tal el 1 de febrero de 1996. Desde el año 2003 son socias fundadoras de la Coordinadora Valenciana de educación en el tiempo libre laico y progresista.

Comenzaron a caminar en la ciudad de Quart de Poblet (Valencia) y a fecha de hoy han formado a más de 4.706 monitoras y animadoras en más de 121 cursos. La escuela tiene su sede física en Manises pero el local no es sólo suyo, lo comparten con entidades como la Fundación Movimiento Ciudadano y la Asociación de Esplais y la Asociación Impuls. Piensan que el origen del local que ahora comparten explica también su origen. Este centro fue construido con el trabajo y el dinero de trabajadoras de un barrio olvidado que necesitaba una guardería y que el Ayuntamiento prometía de continuo pero nunca llegaba. 
Por otro lado, desde hace más de un año Maranya también participó en la creación de la primera Asociación de Casas de Juventud de la provincia de Castellón, integrando en ella a todas las CdJ que existían hasta ese momento en la zona: Alqueries, Betxí y Benicàssim. De esta forma se consolidaba el modelo de Casas en Castellón y se abría un espacio donde compartir proyectos, incertidumbres y celebraciones.

A continuación vemos el mapa (figura 15) que nos indica las relaciones entre las instituciones arriba nombradas y la Casa de Joventut La Maranya.

Figura 15. Relaciones institucionales en Maranya. 


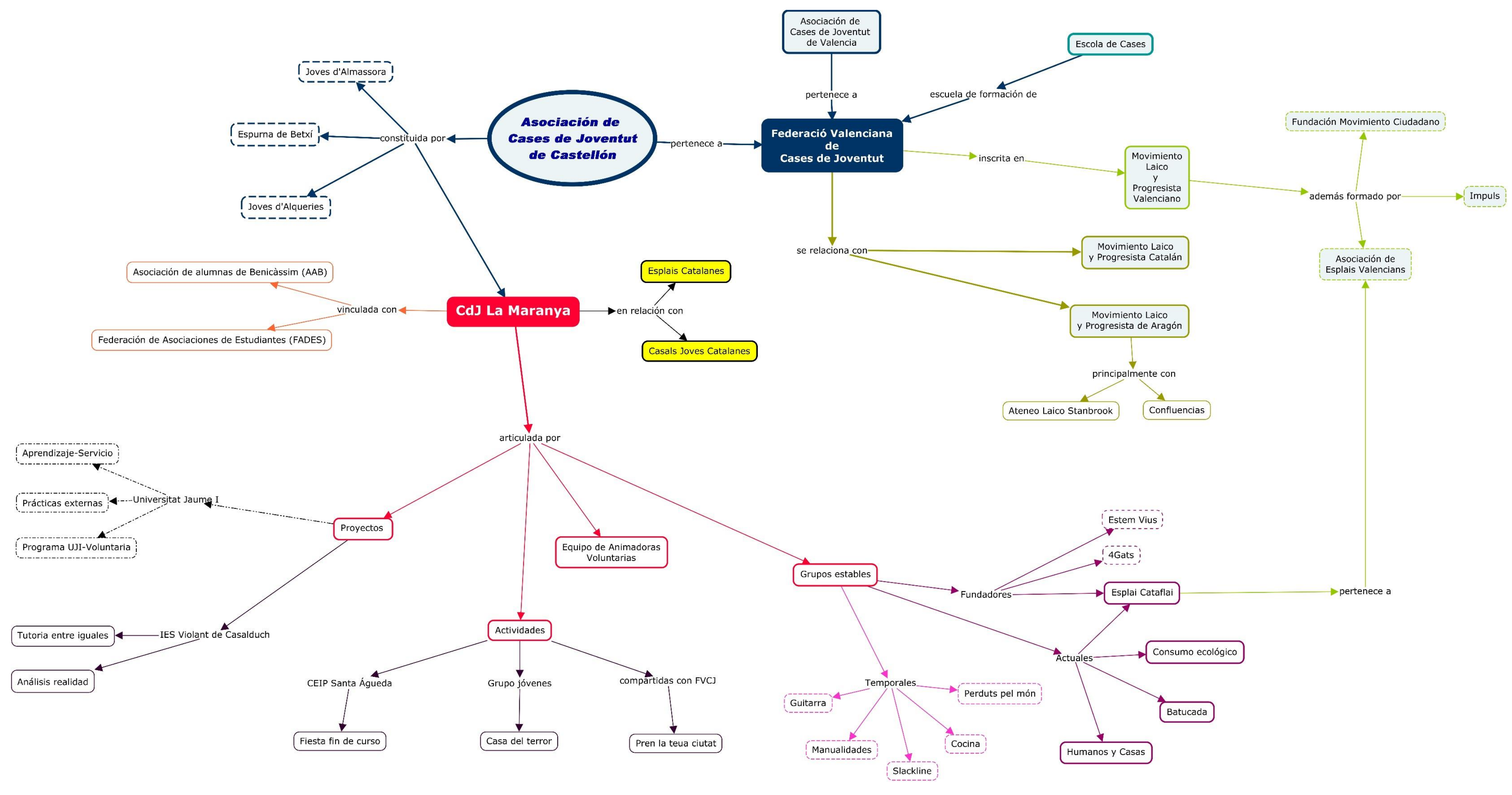


Para finalizar con este punto quisiera describir qué es Maranya a partir de las diferentes voces que he ido recogiendo a lo largo de esta tesis. Los datos parten del trabajo de campo, de las entrevistas o de los materiales que he ido recuperando a lo largo de todo este tiempo.

La Casa de Joventut La Maranya entiende que no es posible una joven despierta a cualquier precio. Son las personas adultas que no dejan participar a las jóvenes en los niveles que quieren y no las jóvenes las que no quieren implicarse. Es posible articular con una metodología concreta un tejido asociativo juvenil sencillo, alrededor de actividades de ocio, pero con un aire de trabajo de valores e ideales críticos. Hay que pensar que las jóvenes están preparadas para construir lo que necesitan con sus propias manos y no lo piden siempre a los padres, madres o instituciones. Hay una relación directa entre la actitud emancipada y madura y el aprendizaje progresivo de cosas básicas como hacer una reunión, escribir un acta, saber ceder un turno de palabra, asumir una responsabilidad dentro de un grupo y, sobretodo, organizar con otras personas (DC).

Por eso, «Maranya es un suma y sigue en el que un montón de personas, con sus necesidades, sus inquietudes, sus ilusiones, de una forma u otra convergen en un punto, unos porque son jóvenes, otros porque son monitores, otros porque son padres, otros porque necesitan participar de algo, otros porque necesitan sentir un paraguas de un grupo» (EI, Josevi). Algunas vecinas del pueblo hablan de ella como un conjunto de gente que hace cosas positivas y buenas para el municipio (EI, Miriam) asumiéndola como un punto de referencia que sirve de referente para sus hijas e hijos (EI, Guiomar). En ella tienen cabida muchas actividades, un montón de ellas, muy diversas que acaban enmarañándose (EI, Merche). Se organizan cosas alternativas al Ayuntamiento y es un buen lugar para hacer cosas nuevas para la gente (EI, vecina 2).

Algo que recuerda Miriam (EI) es que Maranya es como una telaraña que empieza siendo pequeña pero cada vez se hace más y más grande. Y no desde una connotación negativa sino desde un lugar en el que cada vez se ve la gente más atrapada y se engancha con el proyecto. Así cada vez se hace más y más grande, más y más fuerte centrándose en un proyecto social y educativo. Miriam define la finalidad de este espacio con el objetivo de construir cosas que a la gente le guste y que se acabe convirtiendo en un 
proyecto empoderador en sus vidas viendo a chavales menores de edad haciendo cosas muy grandes.

Ana María (EI) remarca en muchas ocasiones que a sus amigas siempre se lo dice, que Maranya para ella es su segunda casa. Allí puede hacer muchas actividades, conoces gente, se hacen amistades y ya considera a las personas con las que forma parte de Maranya como una familia. Además siente que esta Casa es distinta, nota como la gente la admira y eso le hace sentir orgullo de formar parte de este lugar.

Maranya es una alternativa a lo que tradicionalmente se propone en Benicàssim. Mari Carmen así lo cuenta «es una alternativa, es lo que no hay, asociaciones hay muchas en registro de asociaciones del Ayuntamiento pero que funcionen de verdad, verdad, verdad pues se pueden contar con los dedos de las manos. Entonces, Maranya es una alternativa más a las más tradicionales porque es la única que aglutina actividades para infantil y juventud, educativas además, o sea que van trabajando en una línea de la mano de la educación. Deberían estar ocupando un lugar importante en el municipio como referentes de un trabajo juvenil, de un trabajo en juventud, de hecho yo creo que están siéndolo ya pero estaría muy bien que tuviesen muchísima más visibilidad y más apoyo».

Desde Federació Valenciana de Cases de Joventut me cuentan que en este momento histórico es un modelo a seguir porque es la única Casa de Juventud que ha recuperado el espíritu de CdJ que nació en el año 94 y que por diversas circunstancias han ido desapareciendo o modificándose. Maranya, en cambio, es lo que queda del modelo llevado al estado puro de lo que es una Casa de Juventud, el funcionamiento de una CdJ, el modelo de participación, etc. (Julio, EG). Jesús afirma que para él es algo más poético, «es una ilusión, es casi un suicidio, es un planteamiento, es gente, es... más que la estructura de Casa de juventud, que lo es también se vive mucho desde fuera, es como esos ciertos detalles que hacen falta que existan para que todos los demás, nosotras, sepamos que es posible conseguirlo, que ahí hay un ejemplo concreto. Yo creo que otras Casas pasarán del tema bastante, pero que otras muchas nos identificamos, gracias a ella, más dentro de las Casas de Juventud. Para mí significa admiración» (Jesús, EG). 
Para otras personas como Armand (EG), es un espacio de participación en libertad y responsabilidad. Es un lugar donde la gente puede participar, implicarse y militar desde la responsabilidad y la absoluta libertad. Lydia (EG) contesta diciendo que para ella es gran parte de su vida, lleva muchos años aquí y aún está y no tiene intenciones de irse. Ella remarca que es un lugar que te impacta cuando entras ya que siempre ves a alguien trabajar, haciendo cosas que les gusta y quieras o no acabas contagiándote y haciendo tú también cosas que te gustan. Sabes que puedes salir pero no quieres, es parte tuya y siempre quieres estar ahí. Iván reafirma lo que dice Lydia pero además remarca que es un espacio donde aprender y sobretodo disfrutar.

Noel (EG) siente que Maranya es un espacio con muchísimas posibilidades, un lugar de mucho trabajo pero que aún tienen muchas cosas que ofrecer. En este sentido habla también Jose (EG) afirmando que es un espacio que se está construyendo continuamente, se reinventa siempre pase lo que pase y observa que cada vez tiene más peso en el municipio. Algo que echa de menos es que no se implique más gente, le gustaría que más personas participaran de esto porque siente que podrían aportar muchas cosas. En ello le apoya Armand diciendo que es un proyecto necesario. El asociacionismo en España se ha perdido y nos centramos en un discurso único individualista y competitivo, esa son las razones por las que Armand cree que Maranya es piedra angular para convertirse en espacio de referencia de que las cosas se pueden hacer de otro modo.

Maranya son muchas cosas, son sueños e ilusión. Iván dice que este lugar siempre se ha caracterizado por ello y eso le da fuerza. Maranya es un montón de cosas tal y como dice Virginia, es una Maranya enmaranyada, dice Mireia y Víctor afirma que es una bola de nieve con el reto de que cada vez se haga más grande. Las personas que va cogiendo la bola de nieve no marchan, se van, se mueven dentro de Maranya, se mueven en los espacios porque las personas necesitan estar militando, estar trabajando con otras, hacer solidaridad, sentirse parte de algo en el mundo y se puede hacer en muchos lugares y no sólo en Maranya. Maranya permite muchas formas de hacerlo y si marchas de los lugares se convierte en transformaciones dentro del mismo espacio y hacen que la bola de nieve se haga más grande. 
Por otro lado, Maranya sabe que tiene una imagen muy potente. Se ha conseguido consagrar como marca dentro de la cual hay mucho trabajo y contenido. Víctor dice que cuando nos encontramos con algo genuino, estamos tan acostumbradas a estar aisladas y solas que nos enganchamos enseguida. Por eso dice que son importantes estas marcas entendidas desde un lenguaje social y no desde un lenguaje de mercado. Maranya es ese ovillo rojo que desprende hilos entre las personas que pasan por allí, siempre está presente en cada proyecto y actividad que se monta, es esas camisetas cosidas de esa forma especial, es ese lenguaje de jo sóc Maranya. Es esa excusa que se ha conseguido construir para organizar a gente. Tanto Víctor como Virginia piensan que es maravilloso pero no tienen la sensación de que esto sea único e irrepetible, esto les genera una sensación de soledad que no entra dentro de la finalidad del proyecto.

Muchas de las entrevistadas sienten que Maranya es un proyecto de gente trabajadora, «es una media de sesenta horas a la semana de trabajo durante unos cuantos años, con la puerta abierta a todas aquellas que quieran aportar algo al mundo y sientan que este espacio significa algo para ellas. Podrán ser seis personas haciendo diez horas de esas sesenta o dividirse entre todas una hora y media, puede ser como sea pero es una suma de horas. Después es más cosas pero es una suma, es trabajo, es responsabilidad, es un ejercicio de renuncia a cosas personales por lo colectivo, es una persona que deja setecientos euros para pagar una puerta, aunque sabe que va a tardar en recuperarlos, otra que se va a comprar las juntas de insonorización porque hay que ponerlas ya y no pregunta como lo cobra, eso es Maranya», así lo explica Víctor (EG).

Además es política en el blog se declara como centro cívico político. Como un espacio de debate, de crítica donde hacer política tan necesaria estos días, para hacer de Benicàssim un lugar mejor para vivir. No se hace política de partidos, no es un centro partidista porque defienden la libertad de pensamiento, la conciencia crítica de las personas y el proceso de crecimiento personal de cada una. En un mundo gobernado por comerciantes y especuladores apuestan por la ciudadanía que lucha a golpe de sueño por ser antes persona que cosa. Por eso es política, porque también es confianza, confianza en las otras y en ti misma para construir algo que sea colectivo. 
Algunas ex activistas de la Casa afirman que se necesitan espacios como Maranya en el que trabajar la conciencia crítica de las personas. Para ellas es un referente y les gustaría que continuara durante muchos años y se pudiera incluso extender por más pueblos de la zona. Sienten que la gente debe relacionar Maranya con Benicàssim, «tendría que ser el centro de Benicàssim y tener ese reconocimiento» expone Isabel (EG). Creen que es un lugar idóneo para que las jóvenes puedan sentirse parte de algo importante y colectivo porque para ellas ha significado mucho: aprendizajes, momentos importantes, recuerdos inolvidables,... Por eso Maranya para ellas no es una sola cosa, son muchas, como la propia vida. Sienten que la vida es difícil de describir y les pasa lo mismo con Maranya porque esta es vida. Les gusta la diversidad del colectivo, las diferentes edades, los gustos, las actividades, ... creen que cada una puede hacer lo que quiera gracias a toda esta diversidad. «Tú vienes aquí y puede ser lo que tú quieras que sea, porque tienes esa libertad de hacer tu actividad y crear en ese momento lo que quiera el grupo. Eso es lo bueno. Sería difícil de explicarlo porque cada grupo lo ve desde una perspectiva. Desde el grupo de consumo se verá todo completamente diferente a como lo ven los niños o los adolescentes. Eso es lo bueno de Maranya» explica Joana (EG). 

«Els noms et trien a tu, tu poses nom a les coses però el nom et pren i arriba un moment en el que ja no te'l pots llevar de damunt» (Converses entre bastidors, revista Maranya 2016)
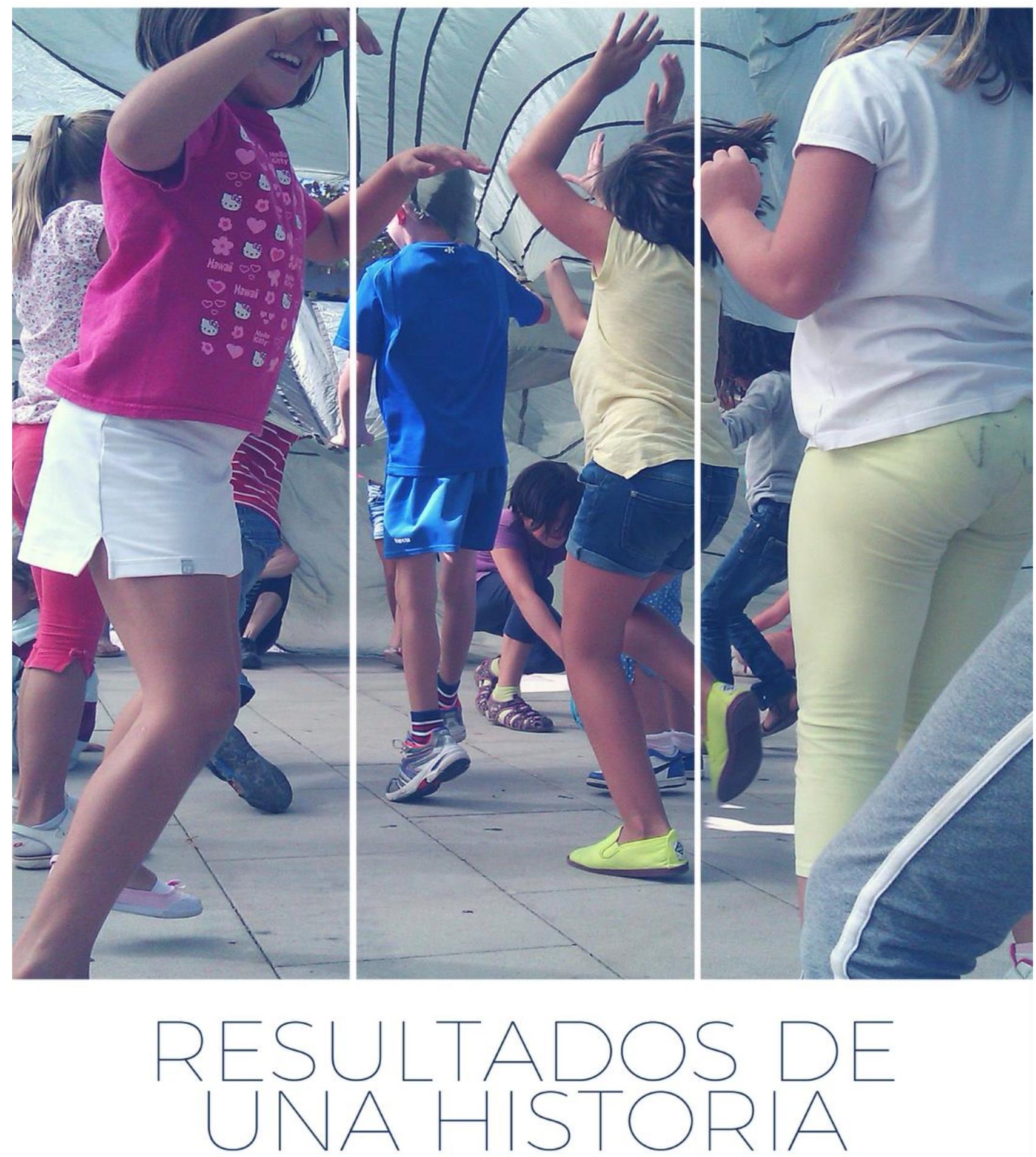

\section{CAPITULO 5}



En el siguiente capítulo abordaré los resultados de esta investigación a partir del relato sobre la Historia de vida de la Casa de Joventut La Maranya. El texto estará estructurado tal y como he descrito en el capítulo de Cartografía de la investigación. El relato parte de la primera vez que participo en una actividad global de la Casa en la que están invitadas todas las socias. A partir de las dinámicas que se suceden ese día voy contando la historia de la asociación hasta llegar al final de ese mismo día. De este modo, en la primera parte de la historia podemos encontrar todos aquellos acontecimientos que le van sucediendo a la Casa desde 1996 hasta 2014. A partir de ahí abordaré las partes más relevantes de la historia en relación a los cursos 2014/2015 y 2015/2016 en los que formo parte activa de la asociación.

Recordamos que encontraremos la siguiente estructura:

--Jo m'enmaranye,...

--Descobrint les nostres arrels.

- Explican's Quelcom que ens faci reviure (1996).

- En un tren va naìxer Cataflai (2006).

- El Casal torna a ser jove (2007).

- Una Maranya de joves, una Maranya de versos sense adulterar (2011).

- Qui no té ulls per a somniar no veu els somnis ni de dia ni de nit (2012).

- Maranya espai compartit, Maranya té ulls per a somniar col-lectivament (2013/2014).

-- Propera estació Maranya: viatges compartits.

--Una tesi per a Maranya.

- Maranya avui és moltes coses, encara que d'avui en endavant será moltes altres (2014/2015).

- Fem cami (2015/2016). 


\section{ELLS I ELLES S'ENMARANYEN}

Hoy tengo una cita importante. Estoy emocionada porque por fin voy a ver cómo es por dentro, estoy intrigada por cómo serán las personas que han construido toda esta historia, y tengo dolor de barriga, mucho dolor de barriga. Llevo días dándole vueltas, por mi mente van y vienen mil y una duda que no puedo dejar pasar: cómo hablar, cómo moverme, cómo interaccionar con ellas, no dejo de pensar cómo me verán o tan si quiera si me verán... Me pregunto quiénes y cómo serán, si habrá mucha gente o más bien será un momento familiar. Hoy es mi primer día y me siento como cuando entras por primera vez por la puerta del instituto con todas las inseguridades y toda la ilusión de empezar algo nuevo e importante en tu vida porque reconoces que vas a conocer a muchas personas que te la van a cambiar por completo. Hoy es domingo 13 de abril de 2014, empiezo mi relación con La Maranya y estoy nerviosa, muy nerviosa. Es un día especial porque vamos a hablar de la Historia de la Asociación, hoy vamos a trabajar el Fil històric, y será un día lleno de recuerdos, de cosas que nos recolocan y hacen que seamos lo que hoy somos: descubrir nuestras raíces y saber de dónde vienen las Casas de Juventud en el pueblo, descubrir qué es Quelcom y saber por qué Cataflai y también, encontrar el lugar para cuestionarnos si somos únicas o más bien «un entre tants...» ${ }^{39}$, así nos lo

39 "Un entre tants" es uno de los discos del cantautor valenciano Ovidi Montllor y también uno de los poemas de Vicent Andrés Estellés. 
presentaba Maranya en la noticia publicada en su $\operatorname{blog}^{40}$ y así lo descubrimos a lo largo del día.

Desde hace unos días Víctor y Virginia me insisten en que asista a este encuentro, lo han preparado todo con mucha ilusión y es un momento de convivencia de toda la asociación. Creen que es muy importante que conozcamos de dónde venimos y también hacia dónde nos dirigimos. Pero, ¿y quiénes son Víctor y Virginia? Ellas son las directoras de esta orquesta y me gustaría presentároslas. Las dos hacen una pareja muy peculiar, son como el director y la jefa de estudios de La Maranya, tal y como algunas personas en la Casa les llaman. Víctor es de Benicàssim de tota la vida y Virginia es de Madrid y ya adoptiva en la terreta. Ambas son Animadoras Voluntarias en La Maranya y son las dos personas que encabezan el Equipo de Animadoras Voluntarias (EAV), por ahora.

SVíctor lleva mucho tiempo vinculado al asociacionismo juvenil del pueblo. Desde muy joven formó parte de la primera Casa de Joventut en Benicàssim.

Quelcom, la primera Casa de Joventut del pueblo, se quedó grabado en su mente y es que

siendo un adolescente 'normalizado' buscas llegar y conocer gente. Aunque realmente busques reafirmación en ti mismo, el día que entras a un Casal Jove, tienes quince años y nadie de quince años, 'normalizado', piensa 'iesto es público o es privado?, ¿es político o qué es?’ pasas por la puerta y dices ‘jostras un pinpon!'. Entonces entras y conoces gente y como lo que mejor sabes hacer es escribir, piensas: 'Igual podríamos hacer una revista' y se lo comentas a otro amigo que está por allí sentado en la Casa comiendo pipas y al final, te dice 'Vale' porque es tu mejor amigo y siempre te decía que sí a todo, (Víctor, 003.02.02EG).

y aquí, comienza todo.

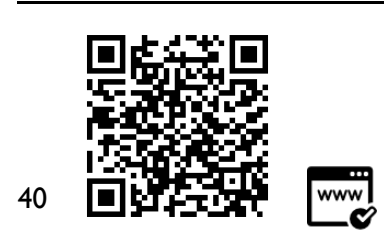


La revista Cami nou empieza haciéndose entre dos personas y acaban siendo catorce o quince en su mejor época. Camí nou empieza siendo una publicación sin ningún hilo editorial más allá de la reivindicación del espacio juvenil y al final, acaba encabezando un movimiento juvenil que hace sus 'pinitos' en política. Publican dos números al año dónde, básicamente, critican a los gobiernos que tienen. Se reafirman cada vez que sacan un nuevo número criticando la actuación del PP y otro nuevo criticando al

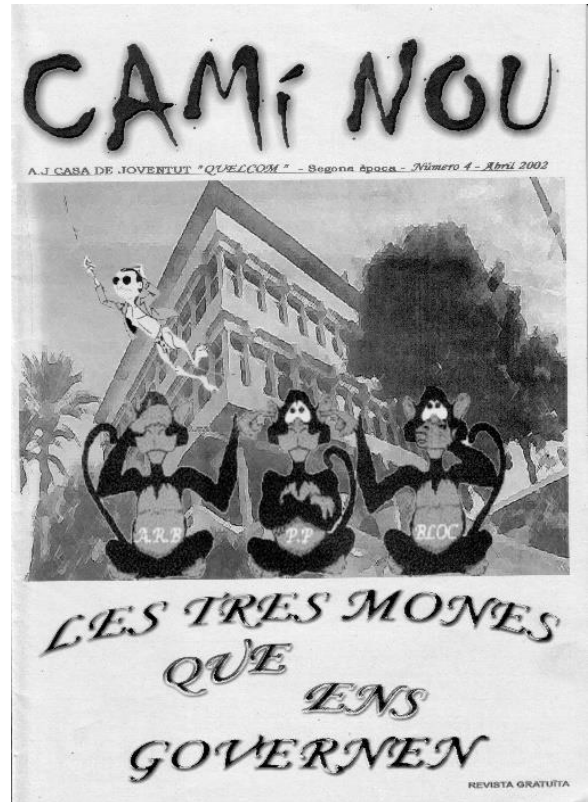
PSOE para que no les acusen de 'sociatas'. Llega el momento en el que desde fuera ven que no eran ni rojos, ni azules pero les acusan de nuevo: «Sois del BLOC!». Entonces sacan otro número criticando la situación y es una fantástica portada con tres monos diciendo "Les tres mones que ens governen".

Desorientan a los equipos de gobierno y el alcalde les llama a su despacho.

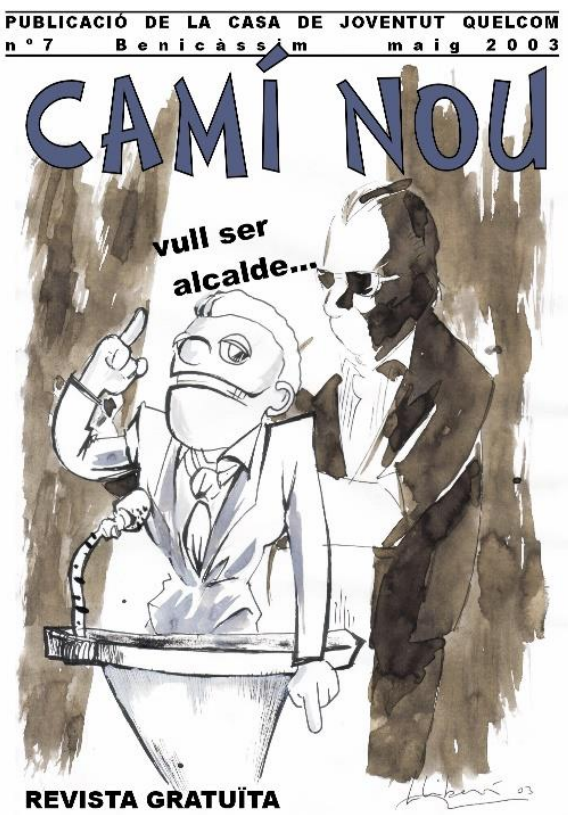

Recuerdo una reunión en su despacho, con diecisiete o dieciocho años, en la que nos sienta a los tres que hacíamos la revista $\mathrm{y}$ nos dice 'me encanta lo que hacéis, yo también escribía cuando era joven pero si seguís criticando

al Ayuntamiento como lo hacéis voy a hacer que os echen del Casal'. Entonces nos fuimos $y$ sacamos otra revista 
explicando lo que había pasado en esa reunión y parodiando en la primera página cómo se hacían fotos en todos los actos públicos. (Víctor, 003.02.02EG).

En ese mismo momento el carácter de Víctor se reafirma en pensar que en una sociedad normalizada si las jóvenes no tienen un apoyo, estas iniciativas juveniles no se hacen grandes. Si en ese momento la animadora del Casal no les llega a dejar la fotocopiadora no lo hubieran hecho y hubiera acabado siendo una cosa más de 'chiquillos' que pasa y pasa. La revista se acabó, llegó el momento, fueron sus estudios, fueron sus cosas y Víctor siguió con la idea de hacer algo, tenía que meterse en algún espacio de algún modo y empezó a apostar por ello. Volvió a Castellón sin nunca perder el contacto con su gente bonita de Quelcom, personas militantes que se han ido vinculado a diferentes movimientos: gestores de centros excursionistas, políticos en el PSOE, activistas en Greenpeace, militantes en Compromís, y forestales que en su estilo de vida se dedican a trabajar la educación medioambiental, entre muchas otras personas.

Siguió sin abandonar la idea de hacer algo en su pueblo y de repente salió una plaza en el Casal Jove de Benicàssim y dijo

esta es mi oportunidad de hacer lo que siempre he hecho voluntario pero con un sueldo, y por tanto más horas, y por tanto mejor. Yo estaba en Lleida estudiando, iba tres días a estudiar agrónomos y el miércoles me subía en el coche de mi padre. Al pobre lo hacía irse a trabajar con el coche de mi madre que no tenía trabajo. Él no quería, él quería su coche pero me lo dejaba porque era mejor para irme a Lleida y poder bajarme el miércoles por la tarde para entrar a trabajar a las seis. Llegaba corriendo, sin comer, con el bocadillo entre las piernas mientras conducía y empezaba a trabajar en el Casal, miércoles, jueves, viernes, descansar el sábado si no me había metido a organizar ninguna movida ese día y el domingo subir a Lleida otra vez, lunes, martes, miércoles. (Víctor, 003.02.02EG).

Allí coincidió con Virginia. Ella recuerda que estaba estudiando en Zaragoza y la contrataron en el Ayuntamiento de Benicàssim para hacer unos talleres de informática por las tardes (003.02.01 EG). Se monta un horario muy 'guay' y viene tres días a la semana, un ratito por las tardes. Va conociendo a las personas que andan por allí, va haciéndose con el espacio 
y ve que hay otra gente haciendo cosas mucho más elaboradas y más pensadas que lo que ella hacía, lo considera un nivel superior. Reconoce que está un tanto descolgada porque vive en Zaragoza la mitad de la semana y la otra mitad aquí, estudiaba allí y aquí se dedicaba a los talleres de informática, fue todo un poco extraño. Un día conecta con una persona del local y esta le dice ‘¿probamos a hacer un Esplai?' y ahí comienza todo. Empiezan a hacer reuniones eternas por las noches, ella siente que le gusta y se emociona al pensarlo.S

Pero volvamos, hoy, además de hacer la dinámica histórica que han preparado las animadoras, me han propuesto que presente la tesis a las jóvenes. No sé muy bien cómo va a funcionar el día, no sé cómo está organizado pero yo me he hecho un video presentación y me he organizado el discurso para que nada me coja desprevenida. '¡Está todo controlado! ahora a disfrutar y dejarse llevar' pienso antes de salir del coche. He aparcado en la calle de atrás de La Maranya, muy cerca del Nou Café, ese bar que se convertirá en el lugar de iniciativas, risas y muchas veces silencios pre, post o entre reuniones de equipo. Ese lugar dónde nunca pueden faltar las patatas fritas con queso, algún que otro pollo dos, medias ensaladas que son más grandes que las enteras y el ofrecimiento insistente de Jesús, el dueño del bar, en invitarnos a chupitos que siempre rechazamos. Paso caminando por delante de su puerta para dirigirme a la Plaza De los dolores, escucho el agua caer de la fuente, miro a un lado y a otro y continúo hacia la puerta de Maranya ${ }^{41}$. La persiana está levantada, las puertas abiertas y ya se escuchan voces en su interior. Eran las 10:15 horas de la mañana y en la puerta se podía leer Educar es estar amb el món y por el local ya había algunas jóvenes de Maranya. Las reconozco de los vídeos, de alguna vez que he coincidido con ellas en sesiones que he tenido con Víctor pero sobretodo las conozco de las miles y miles de palabras que él me ha contado sobre ellas. Creo que incluso podría decir quiénes son cada una sólo con escucharles hablar.

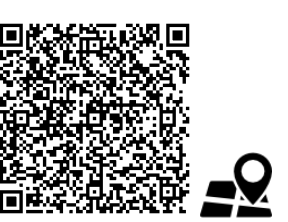


SVíctor y yo nos conocemos de antes, de antes de que yo supiera que quería hacer una tesis sobre Maranya. Eran tiempos en los que yo estaba estudiando en la Universidad y además colaboraba como becaria en el Seminari Garbell, ese seminario de aprendizaje en participación comunitaria que sentó mis raíces en el mundo académico y en el de la participación, aquel del que formaban parte mis codirectores de tesis, Lidón y Joan y en el que también conocí a Víctor. Recuerdo escuchar hablar a Joan de él. Joan siempre insistía en que era muy interesante que viniera a las reuniones porque en Benicàssim estaban pasando cosas increíbles respecto a la participación de las jóvenes y Víctor tenía relación directa con todo aquello. Estaba seguro que podría ser muy atractivo para el grupo escuchar su experiencia y podría servir para movilizar aquellas necesidades que los municipios tenían con respecto a la participación de sus jóvenes. Aquí empezó todo y me decanté por hacer mi trabajo final de Máster en la intervención con jóvenes desde valores educativos y participativos en la Comarca de Els Ports de Castellón. Víctor nos orientaba con algunas dudas, desaparecía siempre en el momento más oportuno y te lo volvías a encontrar de nuevo enredado en mil y una cosa. De su línea profesional y mi línea académica, hasta el momento, surgió la propuesta de encabezar juntos el Projecte Joves en el Programa de Extensión Universitaria de la UJI y aunque no consiguiéramos muchos frutos, sembramos y regamos un poquito sobre la importancia de la participación juvenil por muchos municipios de la provincia. 5

Además de las jóvenes maranyeras esta mañana también están en el local alumnas de la Universidad. Víctor está dando clases en el Máster de Psicopedagogía y ha invitado a sus alumnas a conocer La Maranya. Hay tres chicas, dos habían sido alumnas mías en el Máster, la otra compañera en algunas clases de Psicopedagogía. Entré en el local y di un tímido saludo a las que allí estaban. Enseguida vi a Virginia que iba de lado a lado con papeles en las manos y a Víctor que vino a saludar y se marchó a la otra sala. Me quedo hablando con las alumnas de la UJI mientras veo pasar a madres por allí, las jóvenes te miran, sonríen y alguna saluda mientras se van juntas a recorrer el local.

Diferentes mesas ocupan las dos salas de abajo, están repartidas por el espacio y en ellas puedes encontrar fotografías, recortes, revistas, pegatinas, 
carteles, hilo rojo, documentos oficiales, camisetas, sellos,... y un portafotos de 40x50 apoyado en una silla al lado de cada mesa dónde puedes leer: Quelcom (1996), Esplai Cataflai (2006...), Casal (2009...), Maranya (2011), Maranya (2012) y Maranya (2013). Estos carteles representan las diferentes etapas que dan forma a la historia del movimiento juvenil en el pueblo y de las que parece que hoy aprenderemos algo más.

Cada vez llegan más y más personas, van pasando por las mesas para ver y recordar. Entre ellas están Lydia, Iván, Ana María, Clara y Anna. Ellas cinco representan al grupo más sólido de jóvenes adolescentes que conviven en la Casa. También está Enric, que vino con sus padres y se trajo a su primo. Entre las más pequeñas pasean por allí Iris, Belén, Natalia y Jordi que con familia o sin ella se encontraban como en casa. En cuanto a las jóvenes veo al grupo que actualmente lleva el Esplai: Joana, Isabel, Guille y María además de Ricky, Noel y Mireia que también pasean por allí. Del grupo de adultos puedo ver a padres y madres de niños y niñas que están actualmente en el Esplai pero también muchas otras familias que se han quedado enganchadas al proyecto y que participan más que sus hijos e hijas en el local.

\section{DESCOBRINT LES NOSTRES ARRELS}

Ya son las 11:00 de la mañana, hay más gente que cuando he llegado y Noel, el presidente de la Casa de Joventut La Maranya, llama nuestra atención con un...

Anem a començar, ha arribat el moment de passejar per la ruta que tenim preparada per a vosaltres. Si veieu hi ha taules repartides per tot el local, anem a passar per cadascuna d'elles $i$ ens trobarem amb una persona que ens explicarà quins esdeveniments es van donar en aquell moment, ens contaran quines coses van ocórrer que son importants per al que som avui. Ja sabeu que conèixer la nostra historia ens permet saber qui som $i$ cap a on anem. Comencem el viatge! (001.01DC). 


\section{Explican's Quelcom que ens faci reviure (1996)}

No somos únicos, es algo que se repite de continuo en la Casa de Joventut La Maranya. Venimos de un Modelo de Casas muy consolidado que nos ha ayudado a ser lo que somos hoy.

Quelcom va canviar als anys 90, algo cambió en los años 90, bastó que alguien apostara por ese algo y así comenzó todo.

Francesc Colomer fue alcalde durante las legislaturas de 1991-1995, 20032004, 2007-2011 y en aquellos años era el Concejal de Juventud del Ayuntamiento de Benicàssim. En la Casa se le reconoce su labor para visibilizar el modelo de Casas de Juventud en la provincia. Fue él quien como representante en las Corts lleva la propuesta de Cases de Joventut apoyando a la Federació de Cases $^{42}$.

Mari Carmen Torres, nos cuenta como Francesc apostó fuerte por crear servicios y recursos para la juventud, por el establecimiento de un área específica que trabajase con las jóvenes del municipio y con personal profesional asignado al área. Durante los primeros años de andadura del Casal Jove, esta pareja de concejal y técnico del Casal, trabajaron muy estrechamente para implantar los servicios que Francesc tenía muy definidos en su hoja de ruta junto con las propuestas que Mari Carmen hacía. El Ayuntamiento destinó un presupuesto específico y se comenzó a 'montar' el espacio en el que empezarían a crear diferentes servicios: el Casal Jove y el CIDAJ (Centro de Información, Documentación y Asesoramiento Juvenil).

Entonces ella era lo que sería la animadora del Casal. Ella recuerda como su trabajo se centraba principalmente en la gestión y dinamización del centro a través de la programación y realización de actividades de ocio juvenil: acciones culturales, conciertos, talleres, acampadas, excursiones, organización de semanas de juventud... y en tareas de informadora juvenil

42

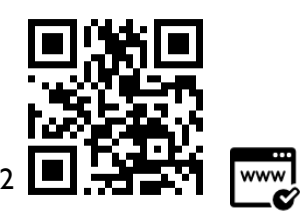


en el mismo Casal (002.09EI). Aquellos inicios los recuerda con gran ilusión

Cuando empecé a trabajar y comencé a analizar la realidad de los jóvenes del pueblo, me encontré con gratas sorpresas; los jóvenes estaban muy desorganizados pero con muchas ganas de 'hacer cosas', eran muy exigentes; trabajaba mucho porque te obligaban a buscar y encontrar recursos que pudieran satisfacer sus demandas y necesidades. El espíritu del nuevo concejal, su confianza y mis ganas de trabajar con los jóvenes del municipio, generó una enorme ilusión que fructificó en acciones políticas que sentaron unas bases bastante sólidas de las políticas juveniles en nuestra localidad. Existían diferentes niveles de participación. Detectarlos y diseñar una oferta distinta y adecuada a cada nivel, fue la clave del éxito en nuestras intervenciones en materia de juventud (Mari Carmen, 002.09EI).

Sería aproximadamente 1993 cuando hubo un grupo de jóvenes muy interesante de Benicàssim con el que se empezó a trabajar y a trabajar muy bien, cuenta Mari Carmen (002.09EI). Ella cuenta que esta experiencia, como técnico, le da pie a continuar viendo, moviéndose y proporcionando todas las herramientas que podía para que las jóvenes siguieran y al final, hacer que sea este movimiento asociativo y esta gente joven, que da igual que esté asociada o no, las que hagan las cosas.

Hagamos un inciso, cuando toda esta historia empezó Benicàssim tenía unos seis mil habitantes y las jóvenes se desplazaban cada día al Grao porque allí era donde estaba el Instituto en el que estudiaban. Todo cambió muchísimo en el ámbito juvenil cuando en el pueblo se inaugura el Instituto de Secundaria Violant de Casalduch $^{43}$, era el año 1995. Fue un cambio total y absoluto. En ese momento se acabaron los viajes Benicàssim-Grao, que hacían cada día para desarrollar acciones allí para después poder trabajarlas aquí en Benicàssim. El instituto fue, para la 
juventud y para el trabajo de Mari Carmen con jóvenes, un punto de inflexión (002.09EI).

A partir de entonces se pudieron desarrollar acciones y programas en las aulas teniendo al público objetivo aglutinado en el mismo centro. Además, los equipos directivos que han pasado por el IES siempre se han caracterizado por su buena voluntad y total colaboración afirma Mari Carmen (002.09EI). Esto impulsó que desde el Casal Jove se pudiera trabajar y cambiar no tanto la forma pero si el contenido del trabajo y la puesta en marcha de otro tipo de programas. Todo esto dio más visibilidad al Casal Jove y a todos los servicios que ofrecía, incrementó el número de usuarios, las demandas de servicios y la necesidad de nuevos programas.

Estos acontecimientos provocan que ese mismo año se ponga en marcha la primera Asociación Juvenil Ja Vorem. Sería entonces cuando, en el área de Información y Recursos, se trabajaría directamente con las jóvenes consiguiendo que fueran ellas las organizadoras y protagonistas de gran cantidad de las acciones que se realizaban.

Poco a poco, por la inquietud de la técnico y teniendo noción de otros modelos de trabajo que se implementaban en municipios similares a este además de por el convencimiento de que socialmente se pueden lograr resultados mucho más satisfactorios, se empiezan a trabajar y programar intervenciones a partir de la participación de las propias jóvenes. Se tienen en cuenta sus demandas y centros de interés, y se facilitan las herramientas necesarias para potenciar, organizar y consolidar grupos estables de trabajo autónomo, trabajando también en el asesoramiento, apoyo y promoción del asociacionismo. Todo esto se gestiona desde el Área de Animación y Participación.

En este camino laboral, Mari Carmen fue descubriendo, contactando y conociendo personas y nuevos modelos que cuadraban con su forma de ver nuevas maneras de trabajar. Consideraba que podían dar respuesta a la realidad de Benicàssim $\mathrm{y}$ a las necesidades juveniles y se fue a buscar respuestas a Huesca. Asistió a un seminario organizado por el Movimiento 
Laico y Progresista de Aragón ${ }^{44}$ para informarse sobre el modelo de Casas de Juventud que tenían en marcha en Aragón. Allí conoció a la gente de Valencia, que también estaba interesada en este modelo de participación. A partir de ahí no perdieron el contacto y comenzaron a surgir Casas de Juventud, sobre todo por municipios de Valencia. En la provincia de Castellón solamente se formaron en Benicàssim y hubo un amago de formación en Almazora. Mari Carmen recuerda que para Benicàssim fue algo difícil por la distancia, pero se empezó a trabajar estrechamente con Valencia, sobre todo al formarse la Federació Valenciana de Cases de Joventut (FVCJ) en 1994.

De forma paralela existía un Área de Formación en la que se empezaron a organizar cursos y otros servicios específicos (cursillos de radio, cómics, ajedrez...) dirigidos a la formación de jóvenes; regularmente cursos de Monitor de Tiempo Libre (MTL), Animadora Juvenil I (AJ-I) y promoción del asociacionismo. Esta formación se realizaba a través de la escuela de educación en animación de la FVCJ, la Escola de Cases ${ }^{45}$, anteriormente llamada Trajecte, y la finalidad era formar grupos estables entendidos como futuro y relevo. Como dicen en el lenguaje deportivo, había que hacer 'cantera', recuerda Mari Carmen (002.09EI).

Disponer de un grupo de jóvenes implicadísimas lo hizo todo más fácil, según me cuenta ella misma, fue un buen punto de partida. Era un grupo bastante asiduo al Casal, con ellas se empezó a poner en práctica un poco de todo esto, nuevas metodologías, modelos y proyectos. Fueron tomando las riendas de muchas cosas, se hicieron responsables de ellas, decidían y asumían y crecían, pensando y tomando decisiones. Mari Carmen me cuenta que iba dando responsabilidades y para que fueran trabajando, cuando veían que funcionaba y que les había salido muy bien era una satisfacción y el aprendizaje se amplificaba de unas maneras impresionantes.
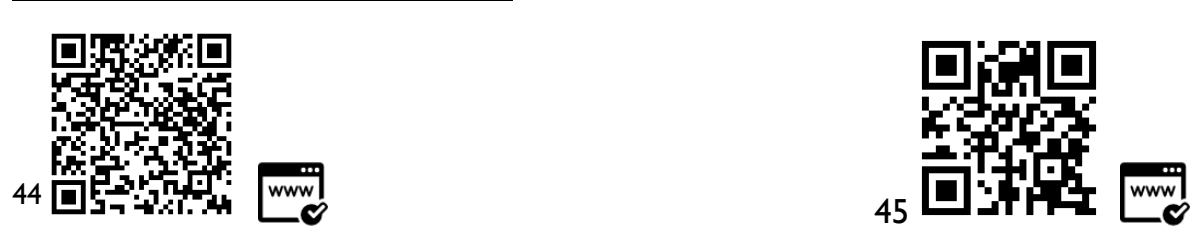
La animadora sólo ejercía el rol de facilitar y acompañar al grupo porque los proyectos eran principalmente de las jóvenes. El objetivo era que ellas tomasen sus propias iniciativas. Tenía grupos independientes que funcionaban y lo hacían bien y por eso cuando Mari Carmen les habló de reconvertirse en Casa de Juventud les gustó la idea de que en un mismo lugar se pudiera aglutinar a todos los grupos que allí participaban. Ya no serían una de rock, una de revista, una de radio, una de juegos de rol, una de juegos de mesa... sino una con muchos grupos estables dentro.

Esto dio pie a una mayor participación en el Casal, ellas cogieron el testigo y entonces la Asociación de jóvenes Ja Vorem cambió y se adaptó al modelo de Casas de Juventud, nace la Casa de Joventut Quelcom.

Visto desde la distancia todo lo que se consiguió vino de mano de ese grupo de jóvenes, exigente, con ganas de organizar y organizarse (Mari Carmen, 002.09EI).

Poco a poco se van poniendo semillas en el camino y las jóvenes que forman parte de esta Casa son todas aquellas que han pasado por los cursos de formación de la escuela de formación de la FVCJ, entre ellas, Víctor. Él pasa por un curso de monitores y después por uno de animadores que se hace en Manises.

Como proceso natural esta Casa se disuelve ya que cada uno de sus integrantes continuaron sus historias asociativas y estudios, se forjó un relevo generacional que ha hecho que esta estructura no decaiga y con el paso del tiempo haya ido evolucionando y adaptándose (Mari Carmen, 002.09EI; Víctor, 003.02.02EG).

\section{En un tren va náixer Cataflai (2006)}

En 2006 se amplió el equipo del Casal, se contrata a dos personas para trabajar en el Departamento de Juventud y es que Benicàssim ya contaba con alrededor de 18.000 habitantes. Durante todos estos años, desde que aparece y desaparece Quelcom, la cifra poblacional se había multiplicado por tres. Trabajar con otras personas y poder conformar un equipo fue enriquecedor para el espacio ya que se pudo rediseñar la estructura del departamento, implementándose nuevos proyectos y ampliando programas. 
Julio cuenta como las historias suceden de un modo u otro en función de las personas y sus acontecimientos. A veces sedimentan de una forma pero cambiando un mínimo detalle podría haber transcurrido de otro modo muy distinto. Tal vez si Escola de Cases no hubiera pasado por el Casal para hacer el curso de monitores, si no se hubiera apuntado Víctor, si no se hubiera contactado con Aragón y Valencia, si desde Federació no se hubiera copiado a Cataluña la idea de trabajar infancia desde estos movimientos asociativos... Si no se hubiera regado de este modo, tal vez la semilla no hubiera brotado. Pero brotó, convirtiéndose en un Esplai Cataflai que reunía a niños y niñas del pueblo todos los fines de semana a lo largo de todo el curso (003.04.02EG)

- Como se recoge en los informes escritos de los proyectos educativos (004.01PE y 004.09PE), Esplai es un proyecto educativo donde jóvenes, niños y niñas y sus familias se educan para poder ser ciudadanas activas. Lo hacen por medio del juego, del diálogo, del descubrimiento, de la aventura, de la imaginación y del riesgo intelectual, con la colaboración y aprendizaje compartido.

El grupo de monitoras saben que no somos iguales en todas las edades y por eso se dividen en grupos de edad para poder adaptarse a las diferentes etapas evolutivas. Forman tres grupos, el de las más pequeñas se compone de niños y niñas desde $1^{\circ}$ de primaria hasta $2^{\circ}$ de primaria. El segundo grupo es desde $3^{\circ}$ hasta $4^{\circ}$ de primaria. El tercero son los de $5^{\circ}$ y $6^{\circ}$.

Son un grupo educativo laico y progresista porque apuestan por el respeto a la libertad de creencias y por la igualdad de oportunidades de todas las personas para participar, y quieren transmitir una conciencia de la realidad social en la que vivimos para poder actuar sobre ella y cambiarla (004.01PE y 004.09PE).

Su lema como monitoras voluntarias es Sóc monitora, no faig de monitora, que no es lo mismo. Hacen Esplai porque saben que educar en el tiempo libre es una herramienta fuerte para el cambio social porque quieren fomentar las interrelaciones sin ánimo de lucro como manera de crear otras redes de intercambio y aprendizaje entre las ciudadanas, y también hacen Esplai por la satisfacción personal, porque lo pasan bien, se divierten y aprenden junto a niños y niñas. 
Un esplai és moltes coses: joves que dediquen el seu temps a ensenyar als infants valors de progrés $i$ participació social, xiquets $i$ xiquetes que volen passar-ho bé $i$ aprendre coses diferents durant el seu temps lliure, pares $i$ mares compromesos amb l'educació dels seus fills i filles. Formem part de la Casa Joventut la Maranya $i$ de l'Associació Esplais V alencians, això significa que posem èmfasi en la laücitat del nostre model pedagògic, treballem valors progressistes a les nostres activitats $i$ ensenyem participació social als infants (004.09PE).

En el proyecto (004.09PE) podemos leer como el rol que asumen las monitoras es el de acompañamiento en el proceso educativo. Piden al grupo que piense por si sólo y que les ayuden a decidir en todo momento, generando pensamientos abiertos y críticos. Favorecen la capacidad de expresión libre de las personas confiando siempre en sus capacidades. La toma de decisiones es consensuada por el grupo y se trabaja desde una perspectiva cooperativa. Animan en el reparto de tareas, iniciativas múltiples y responsabilidades respetando los ritmos e inquietudes de cada niño y niña. Durante el curso hay un reparto de roles entre las monitoras, cada una actuará bajo unos parámetros establecidos. Destacan que siempre una de ellas adopta un rol autoritario para tomar parte de las situaciones de conflicto desde un punto de vista de control y de autoridad.

Los niños y niñas pasan mucho tiempo en la escuela, dedican su tiempo libre mayoritariamente a actividades extraescolares. Por eso en Esplai piensan que no se valora la importancia del tiempo libre para el desarrollo personal infantil, alejándolo de ser parte activa de la gestión de su tiempo libre. Por eso quieren fomentar este espacio, el Esplai de Benicàssim es de los pocos lugares dónde niños y niñas participan de manera libre en la elección de aquello que quieren hacer durante la mañana del sábado intercambiándolo por su rutina televisiva anterior.

La forma de trabajo es a partir de talleres y fichas de trabajo. Además se trabajan las responsabilidades rotatorias de cada grupo y al final de la jornada, de manera asamblearia se tratan y reflexionan sobre los conflictos que se hayan podido dar a lo largo de la mañana, se evalúa la mañana y se proponen actividades para los días siguientes.

Las pautas básicas del grupo de monitoras para que el Esplai funcione son:

1) Comparte en todo momento con las compañeras. 
2) Participa en las actividades.

3) Respeta al resto.

4) Valora tu entorno.

5) Sé ordenado y cuida el material.

Por otro lado, Esplai también implica contactar con familias, niños y niñas y para eso hacen difusión de la actividad, en periódicos, en las aulas, en las puertas de los colegios,... e involucran a las familias en la actividad. Por eso invitan a las familias a participar en la programación de actividades dándose en esta acción una vinculación más seria de estas con este espacio.

SAlgunas de las jóvenes que hoy andan por el local lo recuerdan. Iván y Lydia son dos de ellas, no os he hablado de ellas y me gustaría hacerlo. Lydia e Iván son dos de las jóvenes que más tiempo llevan en la Casa. Ambos empezaron a formar parte del proyecto desde que nació Esplai Cataflai. Cuando esto sucedió creció una parte de ellas que hoy reconocen como esencial en su vida. Iván tiene ahora quince años y estudia en el IES Violant de Casalduch. Lydia tiene un año más que él va al mismo instituto y las dos forman parte del grupo Perduts pel món. Llevan juntas desde bien pequeñas, recuerdan que con siete años ya entraron a formar parte de Esplai y lo hicieron por el contagio de otras niñas que ya eran parte del grupo. A Iván se lo contó una amiga y entre madres se convencieron para que fueran ese mismo año. Era 2006 y Esplai Cataflai se consolidaba como grupo estable dentro del Casal Jove de Benicàssim. Lydia llegó un año más tarde, empezó a ir porque Iván la convenció. A ambos les gustó la experiencia y poco a poco la implicación iba siendo mayor y mayor hasta que se apuntaron al grupo de teatro porque ya no se sentían tan pequeñas como para seguir en Esplai. La historia de las dos es muy característica porque pasan de ser niñas del Esplai Cataflai a formar parte del equipo de monitoras del Esplai hoy. Lydia e Iván lo relatan como todo un ciclo que han conseguido, «és molt bonic! » dice Iván (003.01.03EG).S

Esplai Cataflai nace en un tren de camino a Manises, allí es donde se encontrarán con otras niñas y otros niños de diferentes Esplais de Valencia. Un vagón lleno de niñas y niños, monitores y monitoras que se sienten 
parte de algo y escriben en una hoja, la cual aún hoy rueda por La Maranya, una lluvia de nombres para su Esplai, un listado que acaba recogiendo más de 30 y del que sólo brota Cataflai.

Cataflai, un Esplai donde entre sus sueños, allá por el 2010, ya se encontraba el tener un local propio. Lo tenían claro y parafraseando a Freire sentían que ¡hacer Esplai es estar con el mundo!

\section{El Casal torna a ser Jove (2007)}

«Jo també ho vaig sentir. I durant tot el dia, em ronda.

I no es retira per molt que penses que no toca, que no és moment, que no és edat, ni cosa meva només. Cosa també d'altres, de majors. Ni de majoria, ni d'edat, ni de les dos coses.

Ahir vaig tornar a sentir trontollar-se unes cames que feia temps que no es tensaven, també, per les emocions de les abraçades del teatre, aquelles dels dos minuts abans del principi del final. Jo també $m$ 'he enamorat. Les abraçades més sinceres que he sentit i donat mai. Les vostres. I les del teatre.

Estic tot el dia en un núvol de fum de sofre, intentant desxifrar cada moment $i$ cada mirada que ningú m'explicava, $i$ que ningú gosaria preguntar en aquells instants tan emocionants.

Continue vigilant l'armari. Avui em posaré dins una estona, que fa temps que no entre.

Si. Sóc culpable. Jo vaig robar un rellotge en la foscor. I en eixa foscor seguiré robant-vos rellotges $i$ donant temps. El temps que faça falta per a vosaltres, $i$ per al que em ronda, que des d'abir, em té pendent del tic-tac dels rellotges més que mai.

Des d'abir (m'autoenganye, és d'abans...), busque un tic-tac sense vidre, on poder fotre dit com V anesa m'ensenyà, per fer el que realment sents sense imposicions socials. Amb la llibertat del cor i del que et ronda.

Des d'abir, visc als núvols, encara que crec que jo ja bo estava també! Extraordinari. Sense més.» (Victor Escoin, Aquell dia que vam perdre el cervell) ${ }^{46}$

46 Escrito después de la última obra de teatro que hizo Estem Vius (grupo de teatro). 
Pasan los meses, el equipo técnico del Casal está más organizado y tiene más capacidad para abordar las necesidades juveniles. Podríamos decir que pasa de trabajar principalmente con niños y niñas y su aclamado Esplai a renombrarse como Casal Jove. Las jóvenes vuelven al espacio mediante diferentes talleres y actividades que se ofrecen en el pueblo. Ricky, Noel y Guille, entre otras muchas jóvenes, recuerdan su entrada a través de las actividades que se hacían en el Instituto. Saben que el proyecto que montó Víctor y el resto de encargadas del centro juvenil del pueblo fue muy, muy grande. Comenzó a tener población joven, que en Benicàssim no es fácil de trabajar, sienten que la gente de su edad no están por la participación y menos si han de implicarse pero en este proyecto había gente implicada y eso lo hacía distinto (Ricky, 002.10 EI). En este sentido se considera una tarea difícil pero se consigue tener tres grupos muy potentes, estables y de adolescentes que hacen cosas por ellas mismas, proponen actividades y en cierta manera arrastran a gente del pueblo.

Ricky, Guille y Noel eran jóvenes de entre catorce y dieciséis años y de repente se toparon con actividades, talleres y grupos de cosas que les interesaban. Ricky entró en el Casal por el grupo de malabares. Recuerda que un día llegaron dos personas al instituto a proponer talleres oye, mira al Casal del poble estem fent aquestes coses (002.10EI). Él por aquel entonces estaba encantado con los malabares y le llamó mucho la atención. Lo hacía Victor, com, no? sempre a totes (002.10EI), y fue. Probó, le gustó y crearon un grupo de cuatro o cinco personas que hacían malabares.

Arràn d'entrar al grup de malabars vaig conèixer a la resta de gent, vaig conèixer a Judit, que es amb la que després vam formar el grup de teatre $i$ de sobte, estàvem implicats en algo. (Ricky, 002.10EI).

Los malabares llevaron al teatro y el teatro al clown, una de sus pasiones hoy. Cualquier persona se imagina a Ricky con una nariz de goma roja y treinta más en una bolsa para repartir.

Noel, en cambio, entró al Casal a través de los juegos de mesa, del taller que hacía Víctor de juegos de mesa. Hablar de Noel es pensar en fichas, 
tótems, tableros, dados, figuras,... o en diálogos de los Simpson o en Winter is coming ${ }^{47}$ pero sí o sí hablar de Noel es hablar de juegos de mesa.

Un día vaig entrar dins de la participació $i$ em vam veure tan implicat que em van dir 'eh tu et pots fer de coordinador del grup de jocs de taula? (Noel, 003.01.02EG).

Con quince años empezó con reuniones y con la coordinación del grupo hasta que llegó segundo de bachillerato y pensó que no podría con todo. Estaba encantado con el Casal pero era el último curso en el instituto, la selectividad y el inicio de un grado le daba mucho miedo pero de repente, se encontró con un amigo, Alberto le dijo 'vinga Noel vine't amb mi i fem un grup d'oci nocturn'. Todo esto acabó con viajes a Gijón, Barcelona, Zaragoza,... fue el año que más actividades hizo en el Casal y el año que se enganchó a esto para siempre.

Guille lo recuerda de un modo distinto, a él no le atrajo ninguna actividad en particular. Entró por primera vez en el Casal porque todos sus amigos estaban ahí. Venía, se reunía con sus amigos, hacían cosas diferentes al resto de jóvenes y se sentían parte de algo especial. Sentía que hacían cosas para el pueblo y estaban encantados. A él le gustaba este sitio y la amistad de la que disfrutaba dentro de él. Siente que si ningún amigo suyo hubiera estado por allí, él tampoco hubiera venido pero vino para quedarse durante algunos años.

De jóvenes como ellos surgen grupos, actividades, talleres que hacen que el Casal Jove esté más vivo que nunca. Entre todo ello se crean dos grupos potentes que serán la base de la participación de jóvenes en el Casal Jove. Ambos se han mencionado en las historias de Ricky y Noel. Ricky nos hablaba de cómo nace Estem Vius, el grupo de teatro, y Noel nos explicaba cómo le engancharon para ser parte de Quatre Gats, el grupo de ocio alternativo. Ambos, junto con el Esplai Cataflai, formaron los tres principales grupos estables del Casal.

Los grupos estables son el alma mater de una Casa de Juventud. Están formados por la persona que coordina el grupo. A esta se le llama Activista del grupo estable y es aquella que se compromete a dinamizar al colectivo. Por otro lado están los miembros del grupo estable, que son las personas

47 Frase de la serie Juego de Tronos: 'Se acerca el invierno'. 
que participan de la vida cotidiana del grupo. Entre todas dan forma a un colectivo interesado en una temática concreta (teatro, ocio nocturno, juegos de mesa, malabares, escalada, revista, música,...) que se reúnen para realizar una programación anual en la que aprenden a planificar, organizar y dirigir actividades, las cuales amplían el abanico de oportunidades que tiene el municipio.

'Estar vivos ${ }^{48}$ quiere decir tener ganas de cambiar el mundo, de participar

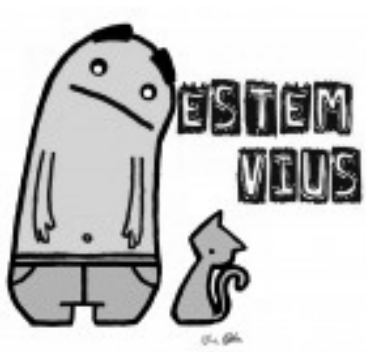
en una educación crítica de las mentes y sobretodo de tener inquietudes, así se presenta este grupo de artivistas juveniles (016.05DM). Estem Vius nació en 2007 como un proyecto de teatro, diversión, conciencia crítica y también amistad y juventud. Un grupo de jóvenes de Benicàssim, entre tres $\mathrm{y}$ ocho personas, con inquietudes y ganas de mejorar su entorno, ofreciendo una cultura alternativa, sin ánimo de lucro y con un fuerte empuje para hacer todo tipo de actividades para crear cultura en el pueblo. El teatro, la música y muchas más actividades eran su manera de llenar horas libres y de participar en el ocio del municipio y también de otros. Reivindican por qué es intrínseco a ellas. Trabajan a través del artivismo como método de hacer arte y cultura pero también de transmitir sus inquietudes sociales. El arte es la herramienta para cambiar aquello que no les gusta, para transformar todo lo que tienen alrededor.

El grupo de teatro nació en la base de un proyecto de tiempo libre en Benicàssim y las jóvenes que formaron parte de él asumieron su autonomía enseguida. Casi con quince años de media de edad las participantes organizaban sus actuaciones en la calle y poco después de tres años de andadura ya habían utilizado casi la totalidad de los espacios públicos existentes, incluyendo el mismo teatro municipal del pueblo.

Sus miembros recuerdan que se organizaban a través de Judit, la definen como la líder del grupo y la persona que establecía todo lo que se hacía en él mientras el resto ayudaban a organizar la actividad que ella montaba (Guille, 003.03.03EG). Dentro del Casal Jove tenían su espacio donde

\footnotetext{
${ }^{48}$ Traducción del nombre del grupo 'Estem Vius'
} 
podían dejar las cosas que utilizaban, eran un poco trasteros en el sentido que siempre recogían cualquier cosa que encontraban en la calle y les pudiera servir para hacer la obra, lo tenían como su almacén y el lugar dónde podían ensayar. No siempre resultaba fácil compaginarse con otras actividades pero al menos tenían el espacio para poder hacerlo.

Eran meses de movimiento en el Casal, las jóvenes solicitaban espacios, generaban actividades y demandaban las llaves del local para poder trabajar en horas que el Casal estaba cerrado. Un día una de las jóvenes propuso hacer un grupo alternativo al ocio al que estaban acostumbrados. Empezaron a hacer actividades por la noche, como por ejemplo, concursos de cortos y conciertos entre otras cosas. Pasado un tiempo, desde el Casal, se les ofrece la oportunidad de financiarles un curso de animadores de ocio nocturno en Gijón que realizaba la Asociación juvenil 'Abierto hasta el Amanecer'. Allí les enseñaron cómo funcionaba el ocio nocturno alternativo y les formaron bastante bien para poder seguir haciendo actividades, según cuenta Noel (003.01.02EG).

Por su parte, Quatre gats surge alrededor de actividades nocturnas entre

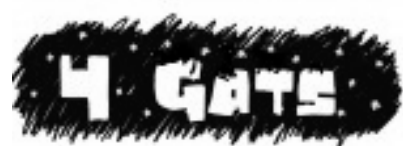
jóvenes. Pronto empieza a organizar actividades alternativas a las ofrecidas por las discotecas y los pubs del municipio para el público juvenil del pueblo.

Clar que anem de canyes. Però també volem lluitar contra un model que al poder li agrada massa, sospitosament. El consum de drogues $i$ alcohol especialment, entre els joves, ens manté dormits $i$ sense pensar en excés. Quan penses, $t^{\prime}$ adones de quant malament van les coses al nostre voltant, $i$ corres el risc de voler fer quelcom (Alberto, 005.04NP).

Es lo que explica Alberto en una de las revistas que publica el Casal. Poco tiempo hizo falta para que caminaran y lo hicieran con firmeza. Así se consagraron como otro de los grupos estables más potentes del Casal.

En cuanto a Esplai, algo cambia, se dan momentos de crisis, la animación sociocultural cambia el Esplai. Los significados del trabajo en el tiempo libre se transforman. Llegan momentos de cambios generacionales pero esas generaciones que han de estirar de Cataflai no existen. Las monitoras están quemadas, no tienen repuestos y sienten que su lugar es otro, quieren emprender nuevos proyectos pero también quieren que este espacio 
educativo de infancia en el tiempo libre no se acabe. Se produce una importante crisis en el grupo, entre las monitoras y las familias. Durante un tiempo se suceden reuniones entre niños y niñas, familias y monitoras para llegar a una solución favorable para todas las partes, una solución que continúe dando vida a Cataflai. Algunas familias se implican en ello y se llega a una propuesta colectiva. Esplai Cataflai necesita apoyos, las familias quieren arremangarse y colaborar y además hay que dinamizar el trabajo en red, hay que potenciar la unión con otros centros y fortalecer las relaciones en el municipio. Con este objetivo se realiza una cartografía social en el grupo para conseguir alianzas con el pueblo. Se produce una corresponsabilidad entre familias y monitoras y los padres y las madres se levantan y dicen 'yo también colaboro, si tengo que hacer sesiones las hago, fuera del papel de padre que ocupo ahora' (001.02DC). Al realizar la cartografía se dan cuenta que pueden contar con otras asociaciones y si ya hay un centro excursionista dinamizar sesiones con ellas y no duplicar, y si ya hay un centro de mayores que puede enseñar cualquier actividad también se puede trabajar de forma colaborativa con ellas.

En definitiva, se produce una corresponsabilidad entre todas las personas que conforman Esplai y se empiezan a trabajar elementos básicos del aprendizaje cooperativo. Hay un elemento que diferencia el momento y es el hecho de pagar la cuota asociativa que hasta ese instante sólo pagan las familias. Ahí las monitoras se levantan y dicen 'yo también quiero sentirme como tú, yo también quiero pagar la misma cuota que tú porque así me sentiré parte y me creeré con los mismos derechos que vosotras para poder hacer o deshacer'. Durante esos días de crisis, Esplai se fortalece y las relaciones entre familias, monitoras, niñas, niños y entorno se hacen más cómplices y cercanas. Esta crisis hizo que cambiara la filosofía del colectivo dando lugar a una más comunitaria (001.02DC).

En el Casal Jove se iba fraguando un potente movimiento. Hasta el momento actividades, talleres, salidas, formación y tres grupos estables: Esplai Cataflai dinamizando el tiempo libre de niños y niñas a través de la educación en valores con formas más comunitarias de trabajar; un grupo de teatro llamado Estem Vius que reivindicaba a través del arte y Quatre Gats que programaba actividades nocturnas alternativas y atractivas para las jóvenes del municipio. 


\section{Una Maranya de joves,}

\section{una Maranya de versos sense adulterar (2011)}

Dos mil once fue un año de cambios y reflexiones. El Casal Jove estaba en plena ebullición. Los grupos estables funcionaban y la participación había aumentado respecto a otros años. Se había conseguido dinamizar a un grupo de infancia y adolescencia benicense y también a las familias de las niñas y niños que formaban parte de él.

Las jóvenes continuaban con sus actividades, Quatre gats seguía con acciones durante las noches, a Estem Vius se les sucedían bolos por Benicàssim y alrededores, nació también la Revista Guirigall y el grupo de juegos de mesa se asentaba en el Casal. Durante los primeros meses del año se organizaron las I Jornadas de Reflexión. Se realizarían el fin de semana del 6, 7 y 8 de mayo y en ellas se propondrían talleres, actividades y charlas. Serían unas jornadas en las que se ofrecía alojamiento, comidas y cenas para todas las asistentes además de la disposición de espacios para proponer y diseñar futuras actividades en el municipio. Una de las que más impacto, de las propuestas que surgieron, fue la de realizar un Festival de música en valencià. Lo llamarían La Flama y sin saberlo sería el inicio de una historia co-construida entre muchas

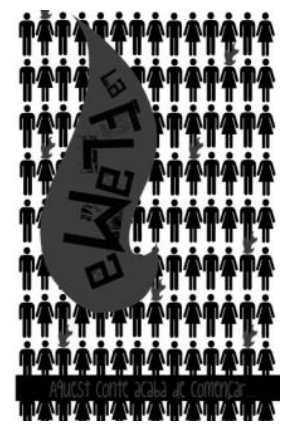
partes.

La Flama pretén ser una porta oberta a la normalització de la nostra llengua. Però no pretén ser només música, vol ser cultura, reivindicació, art, un punt de trobada per associacions $i$ gent amb ganes de fer coses, de moure's pel món... (005.05NP).

El 22 de mayo de ese mismo año se celebraron elecciones municipales. El partido más votado, con una mayoría absoluta, fue el Partido Popular encabezado por Susana Marqués, la cual fue nombrada Alcaldesa del municipio. Para ella ser alcaldesa es

un trabajo apasionante y aquellos momentos los viví con la pasión que supone llegar a poder tener la posibilidad de ser la 
alcaldesa del municipio que te ha visto nacer, que te ha visto crecer. Intentando poner tu granito de arena intentando que la gente pueda vivir mejor de lo que viviste tú y que encuentren un pueblo mejor, evolucionado y en movimiento (Susana, 002.11EI).

Para hacerlo tenía que convivir con estructuras que llevaban años activas en el municipio como era el Casal Jove. Un espacio que ofrecía un abanico de actividades programadas por jóvenes empoderados del propio municipio.

Una de las primeras decisiones que tendría que tomar la alcaldía fue en relación a la petición del grupo Estem Vius de celebrar un Festival de música en valencià en el pueblo ${ }^{49}$.

Després de 4 anys organitzant sense cap problema activitats a Benicàssim, fent ús dels espais públics de manera reiterada, com és normal en una societat democratitzada $i$ al servei dels ciutadans, demanàrem, un cop més, permis al Casal Jove per a fer uns concerts al carrer, amb alguns músics de renom. Quina fou la nostra sorpresa al rebre instruccions (mai per escrit) de que haviem de fer un fum de permisos, plànols, certificacions $i$ despeses, que evidentment, auguraven que la intenció real era no permetre l'activitat (005.05NP).

El Festival se tenía que celebrar el sábado 23 de julio de 2011. Ese día se decidió realizar una jornada de protesta sobre La Flama. A partir de ese incidente el resto de grupos que participaban en el Casal les apoyan, Víctor y Virginia como monitores les apoyan, el grupo de ocio nocturno les apoya y las familias y niños y niñas del Esplai también les apoyan. En ese momento se decidió que la actividad siguiera. Todos juntos, Esplai, Estem vius y Quatre Gats sacaron la actividad adelante, alquilaron un espacio privado, un bajo comercial, y en él se hicieron los conciertos (Andreu Valor), talleres (cocina, danza, clown, milotxes) y resto de actividades (flashmob 'fem xarxa, seguirem en marxa', charla del grupo Recerca Històrica de Castello). Al finalizar se realizó una publicación reivindicando el espacio juvenil apoyado por los diferentes colectivos que participaron en la jornada.

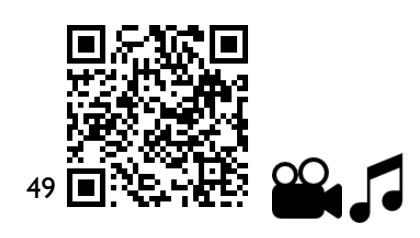


El día pasó y las jóvenes sentían que el Ayuntamiento les había puesto pals a la roda desde el principio (005.05NP). Les pidió documentación sobre la entidad y sobre el proyecto y al cumplimentarlo todo se les deniega el permiso debido a que, tal y como se les notifica en el e-mail recibido del Ayuntamiento, el programa de juventud de este Ayuntamiento no se ajusta a la memoria de actividades presentada en vuestro proyecto. Por ello las jóvenes del Casal decidieron visitar un plenario ${ }^{50}$ del Ayuntamiento para pedir explicaciones en el turno de palabra de la ciudadanía. Lo que ocurrió es que llegó el turno de ruegos y preguntas y la representante del PSOE solicitó que se aclarara la posición del Ayuntamiento respecto a las jóvenes del Casal remarcando su posicionamiento a favor de la autogestión juvenil. La alcaldesa entendió que estaba relatando un manifiesto a favor de ello y le recriminó que no era el lugar y que se ciñera a realizar preguntas. Cuando llegó el momento del turno de palabra de la ciudadanía, la alcaldesa leyó en voz alta las preguntas que el grupo Estem Vius había realizado por registro y se limitó a contestarlas. En el momento en el que se solicitó la palabra por parte del grupo de jóvenes que allí estaban la alcaldesa Susana Marqués contestó

Perdona un segon, carinyet, estem en el torn de propostes a on vosaltres ens doneu unes propostes $i$ nosaltres vos contestem $i$ si voleu que incidim en el tema teniu el despatx de l'alcaldia oberta (006.03, Vd).

Las jóvenes no entendían por qué no podían hablar en ese momento público para contrastar la información y en cambio, sí que se les remitía a hablarlo de forma privada. Sentían que no respetaban las voces disidentes (006.03Vd).

Todo esto provocó que el movimiento juvenil que se había generado en el Casal se fortaleciera. Noel cuenta como, al principio fue Estem Vius el que sufría un mayor ataque (003.01.02EG) pero Quatre gats continuó con sus actividades, incluso hicieron una después de volver de Gijón y asistieron concejales del PP que les felicitaron por lo que habían hecho. Él recuerda como una vez vieron que se unían a Estem Vius y crearon La Maranya, todo 
cambió (003.01.02EG). Les pedían más papeles, para algunas cosas no les concedían los permisos y siempre tenía que haber un monitor para poder hacerlas explican Noel, Iván y Lydia (01.02EG). 'Parecía que no pero nos estaban cortando las alas' afirmaba Noel (003.01.02EG). La entrada del nuevo equipo de gobierno no sólo les supuso censura sino que consiguió poner en una situación muy delicada a la técnico municipal (005.04NP), entre ellas y el equipo de gobierno 'Això no havia passat mai en el que portem d'ajuntament democrätic' expresaban las jóvenes (005.04NP).

Las cosas siempre se pueden hacer mejor y las cosas siempre tienen solución si existe realmente un problema. Para solucionar una cosa sólo hace falta hablarla. Si tú te sientes mal porque crees que yo he hecho algo mal o te sientes perjudicada por algo, lo normal es que vengas aquí y me digas 'Susana yo me siento perjudicada en esto, ¿me puedes explicar qué motivos, qué razón...?’ y yo te daré una visión. Hablando nos entendemos. Creo que ha sido nuestra seña de identidad, el tener el ayuntamiento de cristal, con la puerta del despacho abierta para que antes o después tú puedas venir y contar lo que sea, siendo nuestra bandera el atender diariamente a la gente, ¿por qué un joven tiene el reparo de decir 'oye yo quiero ir a hablar con la alcaldesa'? Si me reúno con gente de ochenta y noventa años por qué no con una persona joven, ¿por qué una persona de dieciséis, diecinueve años debería tener reparo en venir? Afortunadamente no es así, afortunadamente hay chavales que vienen y yo disfruto con ellos porque me cuentan cosas 'podrías hacer esto, para fiestas traer lo otro...' Y yo 'a ver, ojalá pudiera pero ¿sabéis cómo funciona el presupuesto de un ayuntamiento?' y se lo explicas y cuando se lo explicas un poco y razonas tu postura ellos comprenden y dicen 'ostras pues no sabíamos que esto era tan complicado' o sea que... (Susana, 002.11EI).

Jose es uno de los padres que participan con sus hijos en el Esplai Cataflai, y nos explica este choque de trenes entre jóvenes y administración (003.01.04EG).

En el momento en el que el Ayuntamiento cambia de equipo de gobierno, intenta imponer la burocracia por encima de muchas otras cosas En ese momento choca con la rebeldía normal, de 
sobre todo Estem Vius, personas que quieren hacer cosas, que quieren hacer unas dinámicas y que a esa institución no le gusta. Ahí entra el choque de trenes. Intentan burocratizar mucho el local y llega un momento que dicen mira 'rompemos la baraja, no jugamos con vuestras cartas' (003.01.04EG).

Las familias llegaron a intentar mediar en el conflicto, quisieron leer entre líneas en lo que planteaba el Ayuntamiento. Por su parte hubieran pedido permiso por escrito de todo lo que el Ayuntamiento les demandara: permisos para ocupar el espacio, para solicitar las llaves, para hacer actividades,... Querían conocer la normativa y entonces actuar en función de ella. Pero esa burocracia era incompatible con la vida de las jóvenes, así lo afirmaba Jose (003.01.04EG).

Durante unos meses se sucedieron las diferencias entre Ayuntamiento y jóvenes. Un grupo de activistas me cuenta (003.01EG) como se decide realizar una actividad que el Casal hacía todos los años, se pintaba el local, para decorarlo con murales, y se pinta, como una actividad más. Las jóvenes pidieron los permisos pero nunca se recibió la autorización y ese mismo día mientras jóvenes, niños, niñas y familias estaban reunidas en el Casal llegó la policía. Recuerdan el momento aún con incredulidad, reconocen que no estaba autorizada pero no pensaban que sería como para llamar a la policía.

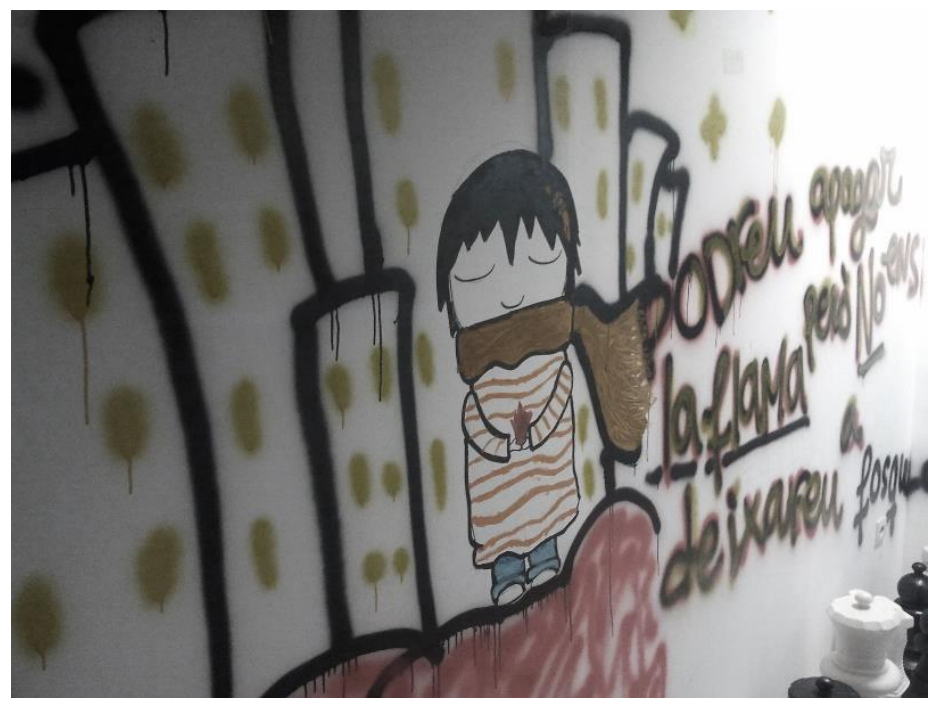


Los agentes que pasaron al local les dijeron que tenían que fotografiar una actividad y les preguntaron que si lo que estaban haciendo era pintar un mural, ellas contestaron que sí y las agentes se dispusieron a fotografiar. Dejaron a la policía hacer su trabajo, esta se despidió dando las gracias y tras este acontecimiento se creó una comisión, formada mayoritariamente por familias, que se reunió con técnicos para pedir explicaciones sobre lo que estaba ocurriendo con las jóvenes. Desde el Ayuntamiento les dijeron que no era nada personal, que únicamente se estaban ciñendo a lo establecido en las normativas que había del local y les aseguraron de que no era una cuestión de poder e ideología (001.02DC).

Explican que todo empezó a cambiar, incluso Noel afirma que la técnico que hasta el momento había trabajado junto a ellas, dejó de hacerlo y no quiso que pintaran, ni transformaran más el espacio.

Armand lo vivió desde fuera y lo vivió como una invasión

Volen un pensament unic, les coses s'ban de fer d'una forma $i$ si aquesta gent ho esta fent d'altra s'estan sortint de marc convenient $i$ per això bi ha que detindre-les. (003.01.05EG).

El Ayuntamiento argumentó que invadían el espacio sin entender que ese espacio era un lugar de la ciudadanía (001.01DC). Ojalá en mi juventud bubiésemos tenido un Casal Jove, contaba Susana (002.11EI).

Fueron meses de sorpresas, emociones encontradas y reflexiones diarias. Todo lo sucedido provocó la sensación de encontrarse sumergidos en tiempos complicados, la necesidad de agruparse, de pertenecer a algo más grande que fuera más fuerte a la hora de solicitar permisos al Ayuntamiento. Las personas que formaban los grupos en el Casal no pensaban que pasaría todo lo que después pasó, no pasaba por su cabeza ni la mitad de las cosas que ocurrieron pero estaban seguros del paso que tenían que dar. Para hacerse más fuertes tenían que co-construirse como colectivo y repensarse.

Instrü̈-vos i sereu lliures. Associeu-vos $i$ sereu forts. Estimen-vos $i$ sereu feliços (Josep Anselm Clavé).

Y La Maranya se constituye un verano de cambio de gobierno, se tejía desde hacía años y se hacía grande con cada paso. 
La creació i el inici de Maranya, vore nàixer Maranya ha estat com la representació màxima de que quan la gent s'agrupa per lluitar contra una causa realment les coses funcionen, perquè nosaltres inicialment érem tres grups dispers que feiem activitats dins del Casal Jove: estava l'esplai que treballa amb nanos, el grup d'oci nocturn que treballa activitats nocturnes fora del típic 'anar de botellon' i estava també el grup de teatre. V a ser fer front a una agressió contra els nostres drets de fer ús d'un lloc públic com es el Casal Jove. Maranya es com la finalitat d'eixa unió de dir 'no! Nosaltres tenim uns drets com a persones $i$ com a joves i pensem que hem de lluitar per ells' $i$ això va fer la unió que desprès va desenvolupar la Casa de Joventut La Maranya. Té un inici com a potència de que es de veres que la unió fa la força quan tots tenim un mateix ideari en quant a tema de formació, participació, associacionisme,...» (Ricky, 002.10EI).

Al crearse la Asociación, debían asignarse los perfiles de una junta directiva. Guille forma parte de la junta directiva, fue el primer presidente pero él no participaba en las responsabilidades del cargo exceptuando la firma de algunos papeles y ser la cara visible. La persona que tenía que ocupar dicho papel de presidenta aún no tenía la edad y entonces dice que se la 'endosaron a él. Así, él es el presidente de la Asociación juvenil La Maranya y describe la decisión tomada así

Abans de l'intent de censura antidemocràtica del nou ajuntament, erem 3 grups que s'allotjaven a l'espai associatiu municipal, que gairebé coincidiem $i$ que treballavem per lliure. Ara, ens hem solidaritzat amb l'atac als companys d'Estem Vius, $i$ ens hem unit en una sola veu per a fer-nos escoltar millor. No respecten les veus dissidents, i per això ens acusen de ser la maquinària juvenil del PSOE. Però amb això s'equivoquen, dins l'associació hi ha simpatitzants i fins $i$ tot algun militant tant del PSPV, com del BLOC $i$ EU. Ens agrada la política, però no el poder. I volem que qui governa, ho faça obeint. És la seva obligació. Eixa, i no perseguirnos, com estan fent (Guille, 005.04, NP) ${ }^{51}$

Nacía la Casa de Joventut La Maranya, después de 15 años desde Quelcom y siendo la segunda Casa de Juventud que se habrá fundado en Benicàssim.

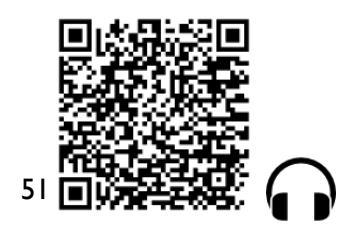


Para dar la bienvenida en las redes sociales y visibilizarse en el municipio grabaron un $L i p D u b^{52}$, lo hicieron al compás de Agraviats con su canción 'Les coses'. Era Septiembre y al ritmo de 'riure, pecar, crear' recorrían las instalaciones del Casal Jove para acabar en la Plaza de la Constitución con un repetido estribillo,

Qui no te ulls per a somniar no veu els somnis ni de dia ni de nit. (Els portadors de somnis, Gioconda Belli)

que se convertiría en más que un eslogan, se convertía en un verdadero símbolo de la Casa.

Continúan los cambios que conllevan la adaptación de un nuevo grupo de gobierno en el municipio. Se cambian normativas, se generan nuevos acuerdos, se modifica todo aquello que se hacía con anterioridad. Le tocó el turno al Casal Jove y se modificaron las normativas de acceso al local. Todo se burocratizó y las jóvenes para hacer cualquier actividad debían de pedir permisos y más permisos.

Claro, las jóvenes vivieron aquella situación fatal. Se sintieron, no es no queridas, pero sí sin importancia. No se les dio ninguna importancia a nada de lo que estaban haciendo, entonces lo vivieron mal, muy mal (Mari Carmen, 002.09EI).

Así lo recuerda Mari Carmen. En cambio para Susana el momento no fue distinto a otros, no cree que se diera ningún movimiento juvenil simplemente para ella fue

asumir una alcaldía con la responsabilidad de gestionar unos espacios públicos en la que llevas tu hoja de ruta para lo que tú quieres para tu municipio o para lo que tú pretendes para tú municipio. Dentro de esa hoja de ruta, evidentemente abarcas todas las áreas y cuando los ciudadanos te eligen y te eligen para que tú lleves adelante tu hoja de ruta pues tomas estas decisiones, por eso no lo viví de ninguna forma traumática. (Susana, 002.11EI). 
A su vez reconoce que el proceso de participación está demasiado burocratizado exponiendo que es la administración la que lo burocratiza todo mucho.

La administración es una máquina muy pesada y aunque se busquen planes de modernización tecnológica siempre va más aprisa el día a día que la administración. Los plazos son muy largos, las audiencias son eternas. Aquí es hoy para que dentro de diez días te presenten los papeles, para que dentro de quince días les des audiencia, para un mes de exposición pública, para que no sé cuántos... Cuando te das cuenta te han pasado cuatro años. Pide escrito, que no se solape con que ninguna actividad que se esté haciendo pero que si resulta que si quieren hacerlo en una dependencia municipal que esté libre ese día, porque si es en un teatro tienes que pagar las tasas de ocupación del teatro, si es en otro espacio...si es en la calle ocupación de vía pública, que si quieres montar un escenario tiene que pasar el ingeniero y autorizarte de que el escenario cumple la homologación de los metros de altura. Es que está todo tan, tan, tan, tan, tan jerarquizado y todo tan, tan, tan estipulado que al final dices mira si lo cumples todo a raja tabla y todo bien es que no das margen al error. (Susana, 002.11EI).

Susana afirma que la gente se cansa, que personas con iniciativa hay, pero que se cansan con todo este proceso.

Jaume lo vivió distinto. Jaume es un profesor del IES Violant de Casalduch. Conoce de primera mano las decisiones del Ayuntamiento en materia juvenil ya que algunas de ellas les han afectado directamente al centro. Sobre todo desde que una de las concejalas del nuevo equipo de gobierno hiciera público que ‘iAl Instituto ni agua!' (Jaume, 002.05EI). Para él todo está más claro si de toda esta situación haces un análisis político. En un principio puede parecer un acto de la política contrario a cualquier lógica porque « ¿cómo vas a interferir en la desaparición de un grupo de jóvenes que funciona y hace funcionar a la juventud del pueblo?», se pregunta Jaume y él mismo se contesta: «Ves que el estilo de participación o el estilo de provocar la reflexión de la juventud no cuadra con el estilo político del gobierno actual y ahí se queda todo»(002.05EI). Así expresa Jaume su 
visión de todo lo que ha ocurrido y las diferencias entre los modelos de participación del Ayuntamiento y del colectivo La Maranya.

Esta mirada se comparte con la que se tiene desde FVCJ.

La Casa de Juventud la Maranya tiene la particularidad en su origen, nace de la administración pública, de un germen que pone la administración pública. Este organismo no entiende el modelo de casas de juventud, no cree en un modelo de escuela democrática, en el trabajo en grupos y tampoco en los profesionales formados que hay detrás. El propio proceso de la Casa de Juventud no cuadra con la administración pública de ese momento, no se ajusta a la visión de determinados técnicos y determinados políticos y esa particularidad hace que Maranya crezca. (Julio, 003.04.02EG)

Ambos, al igual que muchas otras personas, piensan que el problema que existe entre Ayuntamiento y La Maranya es que no coinciden las formas de practicar la participación y eso ha hecho que el Ayuntamiento se posicione de tal forma ante el uso de los espacios públicos que él mismo gestiona.

Fueron momentos que sirvieron para repensarse ya que las jóvenes lo vivieron como un ataque. Nadie programa a tres meses, vamos ningún joven programa a tres meses dice Noel en más de una ocasión (003.01.02EG). Él reconoce que para activar la participación juvenil los tiempos son más cortos y no puedes estar pensando en realizar todos los trámites, dejarlo todo preparado para que después en el último momento no te den el visto bueno y no puedas sacar adelante la actividad. Del espacio de libertad que tenían pasaron a un espacio que les coartaba en acciones. Eso, Noel, lo tenía muy claro.

A finales de octubre llega una carta a nombre del representante legal de la Asociación Juvenil (anexo 13).

En el plazo de una semana debían vaciarlo todo ${ }^{53}$ para ponerlo a disposición de otras asociaciones que también lo solicitaban. Podían

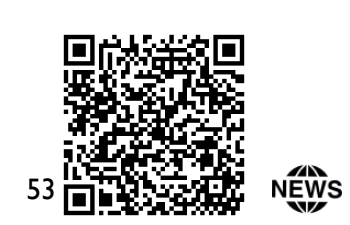


acceder a pedirlo de nuevo pero antes tenían que dejarlo todo conforme estaba. Después de solicitarlo de nuevo les dirían si lo cedían o no. Se decide que es imposible vaciar los trastos de seis años: materiales, ropa, libros, recuerdos... pero todo ocurre muy rápido.

Ya ha pasado unos meses desde que se crea La Maranya y se ha continuado trabajando en el Casal, de forma complicada, con permisos, quejas y choques entre el Ayuntamiento y el colectivo juvenil pero no han dejado de movilizar a los grupos que forman parte de esto. Reconocen que en ningún momento se les echó del local, que la carta no decía eso aunque invitaba a ello y fue el elemento que lo detonó todo.

La campaña \#Casaljovesensejoves enseguida sonó por muchos lugares, se recibieron multitud de apoyos con estas palabras se manifestaba $\mathrm{La}$ Maranya

La censura ens va unir, ens va unir l'abuis de poder sobre la voluntat ciutadana, la indignació, $i$ ens va unir en il.lusió, en germanor..., en somnis. Ara, en menys de cinc mesos, la història es repeteix, ens expulsen del local. Un local on vam nàixer, molts dels col-lectius, anys $i$ anys enrere, un local que ens hem estima't $i$ hem omplert de vida. Ara hem de marxar, sense més raó que un altre atac desmesurat als moviments juvenils, a les consciències critiques, un altre atac fruit de la seua räbia front a la nostra creixent il.lusió, un altre cop sobre la taula, per si algú dubta del seu poder.

Una setmana és el nostre termini per a abandonar part de les nostres vides, part del nostre creixement $i$ aprenentatge, els nostres records, la nostra vida des de fa més de cinc anys. Ataquen a la nostra dignitat sense miraments, a tots $i$ cada $u$ de nosaltres, ataquen directament a la nostra sensibilitat, a la nostra capacitat de creació. Volen esborrar-nos, suprimir la nostra història, part de la nostra vida, fer-nos invisibles.

Aixi que ens expulsen, sense miraments, del lloc públic que ens pertany a tots, que ens ha convertit en allò que som. 
Tot i així continuarem endavant com sempre hem fet, defensant allò que és just, creant $i$ educant, amb un somriure..., com els companys que som. No podran arrencar la il.lusió, no ho permetre'm. ${ }^{54}$

Con la campaña querían manifestar y denunciar que no están adscritos a ningún partido político, que tienen derecho a un espacio en condiciones para llevar a cabo su actividad cultural. Se comparan con otras asociaciones del municipio que sí que tienen un local pagado por el Ayuntamiento y pueden acceder a él siempre que lo deseen. Dicen que el Ayuntamiento se llena la boca diciendo que fomenta el asociacionismo pero cuando las jóvenes piensan por si solas intentan cargarse todo lo que han conseguido. Además se atrevían a decir lo que pasaría en un futuro en el Casal, se convertiría en un lugar de paso donde se realizarían talleres y cursos sin una base de educar en la participación. Acabarían programando de manera que el Casal se convertiría en un centro de servicios. Por último, las jóvenes manifiestan querer participar de las normativas que les afectan y no leerlas una vez publicadas. Quieren ser ciudadanas activas en su propia realidad.

A esto les siguió la amortización de las plazas de las dos animadoras que había en el Casal, Virginia y Victor. No se les renovó el contrato y el centro se quedó con una informadora juvenil y la técnico correspondiente.

Respecto a la situación Susana recuerda que

nadie vino a hablar conmigo y si alguien estaba ofendido debería de haberlo hecho. Se continuó con el Casal abierto con Mari Carmen de técnico como antes y simplemente ciertas personas se desvincularon. Después vino otro cambio, cuando Mari Carmen empezaba a compaginar temas de educación porque ella quería dar el salto a otro departamento. Entonces se optó por reestablecer una programación anual que se va siguiendo en función de las demandas, de las necesidades. Para el equipo de gobierno funciona, si no hubiera gente se podría replantear pero el modelo de gestión por el que se optó en su día, hoy por hoy es el que hay y se mantiene porque funciona.

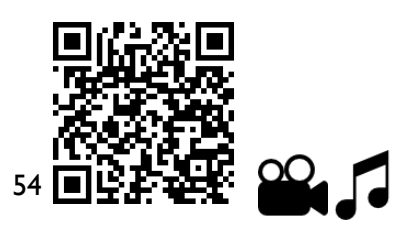


Mari Carmen también se reafirma en que el Casal está abierto pero con otros objetivos y otra línea de trabajo distinta a la anterior. Ella recuerda que cambió de departamento porque así se le ofreció cuando se jubiló la anterior directora del centro FPA municipal. Un día le ofrecieron el puesto y como también es una línea de trabajo que le gusta, aceptó.

Jóvenes y animadores se sintieron solos, necesitaban apoyos fuera de sus propias reafirmaciones y los encontraron en FVCJ. El caso les llega a Federació porque sus miembros conocían el proyecto de Casa de Juventud del Ayuntamiento de hace años. Estaban con él hasta cierto punto ya que no compartían todas las formas de hacer pero siempre les habían acompañado. En un momento dado hay un desentendimiento clave con el equipo de gobierno municipal que obliga a las jóvenes a crear, a seguir existiendo de alguna manera. La Maranya nació ayudado por la administración, ellas creen que sin quererlo (003.04EG).

«¿Qué vais a hacer? » les preguntó Julio un día a Victor y Virginia, y tras su encogida de hombros les dan una hoja con tres cosas fundamentales. Querer, saber y poder y como escucharían en múltiples ocasiones contar a Palas los tres presupuestos de William Morris lo que La Maranya necesitaba era inteligencia suficiente para concebir, coraje suficiente para querer y poder suficiente para forzar. Desde aquel momento, le encontraron el sentido a todo lo que había ocurrido y aprendieron a «enmarronar a la gente» (003.02EG) porque solos no podían con lo que estaba ocurriendo. Después ese contagio acaba siendo un «gracias por descubrirme estas historias» (003.02.02EG) y un día a las seis de la mañana se encuentran rodeados de gente metiendo papeles en los limpia-parabrisas que dicen «el PP nos manipula porque nos quiere echar del espacio público». Victor afirma que aquí empieza la reivindicación en conjunto, empezando por elaborar un discurso en el lenguaje político desde la ciudadanía y lo recuerda compartiendo las palabras del subcomandante Marcos: 'yo no quiero gobernar, quiero que los que gobiernan lo hagan obedeciendo' y de ahí viene La Maranya.

La Maranya empezó a pertenecer a esta red de personas que forman Federació. Muchas personas que aunque no compartan en cada momento todas sus problemáticas saben que cuentan y se apoyan mutuamente y que si una de ellas apuesta por un proyecto el resto respalda sin dudarlo. 
Enrique encuentra el sentido a este trabajo porque dice que cuando se rompe con la administración, cuando un proyecto como la Maranya comienza, lo hace frente a una realidad adversa, contra el Ayuntamiento, sin ningún tipo de recursos, y lo hace porque hay un grupo reducido de personas que lo echa hacia delante. Esas personas, que en este caso, era gente joven que había pasado por una formación, tuvieron una gran valentía para él. Además nos cuenta que hay un elemento psicológico en todo esto y es que «si yo echo para adelante todo esto, necesito no sentirme solo en esto. Necesito sentir cierta seguridad de que lo que voy a hacer va a salir bien». Ahí empiezan a formar parte las personas que años atrás arrancan el movimiento juvenil valenciano de Casas de Juventud. Todas y cada una de aquellas personas que tienen una trayectoria y una experiencia en Cases de Joventut que compartir. Todas a las que en un momento dado, las personas que deciden echar hacia adelante el proyecto de La Maranya, les preguntan, consultan, plantean dudas, hacen terapia, vuelcan sus ideas y sus expectativas, buscando que alguien les dé un poco de soporte o les dé un cierto empuje. Enrique cree que esa fue la labor que realizó en el proyecto de La Maranya

en un momento determinado pones tu experiencia o tu capacidad de análisis de la realidad para que este proyecto que ellos querían echar hacia adelante tuviese ese soporte psicológico o ese soporte inmaterial de decir bueno 'efectivamente no sois los primeros que lo hacéis, ha habido más gente que lo ha hecho, esto es un proceso que puede salir bien, será necesario....' La faena real la hicieron ellos pero no sentirte huérfano en el sentido de decir 'bueno pues, yo en concreto estoy echando adelante esto pero entra dentro de algo mucho más amplio y hay personas que físicamente las conozco, con las que tengo contacto, que ya han estado y han hecho esto y eso me da ánimos’ (003.04.01EG).

Fue un proceso complicado y se sucedieron las reuniones para tomar una decisión que implicara a todas las personas que formaban parte de la Asociación: familias, niños, niñas y adolescentes. Las familias tenían serias dudas sobre la decisión que tomar: abandonar el Casal o continuar en él. Pensaban que al menos allí tenían un techo donde se estaba bien o eso pensaba Iván al respecto. Los niños y niñas de aquel entonces hoy sienten 
que el Ayuntamiento no tenía diferencias con respecto al Esplai, piensan que desde el equipo de gobierno se valoraba a este grupo como el grupo bueno ya que sólo se dedicaban a hacer actividades y no protestaban nunca (003.01EG).

Algunos miembros de las familias que estuvieron en aquellas diarias conversaciones con el colectivo recuerdan que se plantearon dos opciones, una la de buscar local propio y continuar la historia en él, la otra, luchar por un espacio público al que legítimamente tenían derecho. Pero sobretodo esto estaba la decisión de que fuera la opción que fuera la que se tomase irían todos los colectivos a una ya que había sentimiento de La Maranya y eso hacía que quisieran ir todas juntas, que se escuchara una única voz pero colectiva (001.02DC).

Las jóvenes en cambio tenían claro que querían marcharse, tener un lugar de mayor libertad y no estar controlados en todo momento por el Ayuntamiento. Lydia tenía catorce años en aquel momento y le gustaba más la idea de irse porque el Casal sólo estaba abierto cuando trabajaba alguien y el resto del tiempo no podía estar por allí. Era distinto, estaba la sala con los ordenadores, que no se acercaban mucho a ellos por si rompían alguno. Para ella era un espacio frío, muy frío. Cambiando de lugar veían la oportunidad de poder hacerlo suyo, pintar las paredes, merendar si querían merendar y darle rienda suelta a su imaginación creando actividades. Era una opción distinta, querían algo más abierto, más libre.

Otras jóvenes tenían sentimientos encontrados, llevaban mucho tiempo allí, hacían talleres de lo que les gustaba y no podían pensar en nada más que en que les estaban quitando aquello que habían construido juntas (Ana María, 002.02EI). Por otro lado, les asaltaba la emoción de pensar que podrían conseguir un espacio propio, algo que desde hacía muchos años ya soñaban en Esplai.

El grupo de jóvenes lo vivió desde la alegría de empezar algo nuevo. La situación de conflicto con el Ayuntamiento les unió, fue motivante para esta quinta que sentía que si el Ayuntamiento estaba enfadado era porque estaban haciendo las cosas bien porque estaban avivando conciencias, o así lo vivió Noel (003.01.02EG). 
Las animadoras juveniles lo sabían, saben que el tener un enemigo une. Entonces debían aprovechar la cresta de la ola ya que ese momento era muy potente a nivel colectivo. Debían canalizar la energía destructiva que las jóvenes manifestaban en una energía más reflexionada, autónoma y crítica. Siguen convencidas de que lo hicieron bien a pesar de no respetar la decisión asamblearia. En las dos primeras asambleas que se convocan la vOz de la experiencia adulta, formada por la mayoría de familias, está diciendo claramente 'os estáis equivocando'. Recuerdan que fue muy difícil argumentarles su decisión a los padres y madres porque la consecuencia era que tenían que hacer el Esplai en la calle cuando allí disponían de un local con baños, calefacción y dos salas entre muchas otras cosas. Definitivamente, les dicen que se van, cuando ellas les habían dicho que no se fueran pero querían construir algo con jóvenes, querían que estuvieran las jóvenes y esa era su decisión y esta medida pasaba por marcharse del local. Victor explica que finalmente, las familias aceptan que no se respete esa mayoría y dejan espacio a que pudiera ser un error. Por eso, la asamblea decide marcharse y constituir La Maranya.

Sin el Esplai esto no hubiera salido. Virginia sabe que es así y sabe que no es por el Esplai en sí sino por todas las familias que se implicaron en el proyecto y que aún hoy continúan enganchadas a él. «Ellas son parte de la alegría de saber que se pueden seguir haciendo cosas»(003.02.01EG). Ella reconoce que el Esplai ha estado a la sombra pero ha jugado su función y esta ha sido tan relevante como la del resto de grupos.

En ese momento se gesta una cosa, se gesta lo que con el tiempo siempre hemos querido, generar identidad colectiva y que el poder de decisión del gobierno lo hagan las jóvenes (Victor, 003.02.02EG)

Las animadoras me explican que se gesta sin darse cuenta en esa decisión, porque ellas saben que el sector más enfadado, el que se está dejando llevar por las vísceras son las adolescentes y las jóvenes, en cambio las personas adultas están pensando con la cabeza. Las animadoras reconocen que pudo ser una decisión poco reflexionada pero con ella se obtuvo unidad colectiva, «nos tenemos que ir porque queremos que las jóvenes estén, y estarán si nos vamos aunque sean minoría» (003.02EG). Las personas adultas lo entienden, las familias lo entienden y dicen «tenéis razón y además no sólo os respetamos aunque no estemos de acuerdo sino que nos 
arremangamos y trabajamos» (003.02EG). Ese fue el comienzo de algo distinto, el poder de las minorías, el nacimiento de la identidad del grupo y eso les gusta, la sensación de que « una minoría fuera la que tuviera razón« les reconforta y les da seguridad, explica Victor.

Em fa una mica de llàstima que estem en una època en la que el 50\% dels joves estan desocupats, que els projectes de oci desapareguen, que els únics espais on pots anar $i$ estar fent coses de temps lliure desapareguen i que això siguen les prioritats en els retalls. Però per altra banda hi ha coses que m'agraden, m'agradat molt la manera de tota la nostra gent, de tota aquesta gent que al principi cadascun a la seua bola estava organitzant coses $i$ que s'bagen reunit $i$ que hage habut unió contra este tipus d'agressió per molt que siga l'administració pública perquè de vegades ens oblidem que l'administració ens ha de representar a tots per bé o per mal i que els espais públics son nostres, son de tots $i$ no només d'ells. Ells els gestionen però nosaltres tenim dret a estar. [...]M'ha agradat sentir que des del que té 14 anys fins al que té 50 no s'ban perdut res $i$ ens recolçem.

Pense que aquest tipus de situació, aquestes coses que li passen als colectius de joves, sembla que són del segle passat, però que no! que estan vigents $i$ que a partir d'ara anem a veure moltíssimes, pense que es un gran exemple a seguir, aconseguir que tota la gent s'unisca $i$ a partir d'ara tenim coses que fer. Hem de demostrar, no hem de demostrar res a ningú però a nosaltres sí, que el que feiem no era una tonteria, no ho sostenia l'administració sino la ciutadania $i$ que ens retiren el dret a fer teatre, ens retiren el dret a crear $i$ el dret a la critica buscarem altres espais on fer-ho i no passa res. No es van a carregar res, sino que han contribuit a construir una cosa molt, molt bonica que també cal dir que hauriem tardat molts anys en tirar endavant i gràcies a aquesta agressió, ens hem unit moltíssim. Inclus, m'arrisque a dir que d'aci uns mesos $i$ en perspectiva mirant enrere haurem de donar-los les gràcies a la gent amb la que ara mateix tirariem al mar (Victor, 006.01 Vd).

En dos meses pasaron de estar haciendo actividades, de continuar con el Esplai a vaciarlo todo e irse. Saben que si lo hubieran tenido que pensar durante mucho tiempo les hubiera desgastado pero no fue así. Decidieron vaciar un local, que a día de hoy aún sigue vacío informa Iván, y lo hicieron 
con una fiesta. Amb l'alegria a l'altra banda ${ }^{55}$, marcharon pero sonriendo porque todas ellas eran la alegría de ese espacio que ahora se queda triste. Celebraron la marcha del local y la construcción de algo nuevo y colectivo.

Si las cosas no funcionan se cambian pero ese es el modelo de gestión por el que se optó, que parece que se adecua y cumple las expectativas de muchos jóvenes, por un modelo de gestión, que quizás en un momento dado, no fue compartido por otras personas que decidieron montar su propio modelo de gestión y oye, a mí me parece fantástico que uno tenga la iniciativa de montarse cosas. Quisieron revelarse en un momento de arrebato juvenil y montarse su propia historia y eso es fantástico. O sea, que uno se crea lo que hace, lo que dice y en consecuencia actúe, eso es muy positivo. En ese momento hubo gente joven con inquietudes, que eso es muy bonito y muy loable, que dijeron 'mira, nosotras ha habido un cambio político y como no sabemos si esto de aquí nos va a gustar y encima me dicen que lo van a cerrar, vamos a montarnos nuestra asociación'. Ojalá hubiera cincuenta asociaciones, sabes qué bonito sería tener un tejido de jóvenes en Benicàssim asociados y que funcionaran a nivel organizativo por ellos mismos porque yo creo que lo bonito de una asociación ya no es sólo estar y pagar tu cuota, sino involucrarte en la programación... no sólo asistiendo, sino en la organización, en cada uno de los eventos...Aportar de forma altruista tu granito de arena para que otros se lo pasen bien, o sea, que de tu trabajo tu hagas el ocio y lo conviertas en el ocio de diversión de los demás, eso es fantástico. Es perfecto, y está funcionando y está funcionando muy bien, eso es digno de alabar. Ojalá mucha gente tuviera esa valentía. (Susana, 002.11EI)

Para muchas, entre ellas Jaume, el Casal se queda desamparado, muchas jóvenes iban al Casal porque van por La Maranya ya que este $\sin \mathrm{La}$ Maranya no tiene la misma «espenta» y sólo se centra en hacer actividades

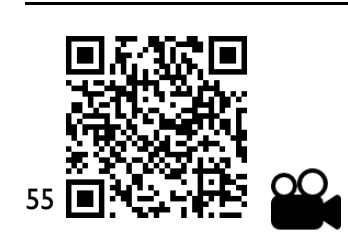


(002.05EI). El Casal, en ese mismo momento, se queda fuera de la vida juvenil de Benicàssim afirma el profesor.

Era el momento de pensar dónde íbamos, dónde asentaríamos los cimientos de la Casa. Lo que sí estaba claro es que sería con nuestra nevera (Virginia, 003.02.01EG).

Así empieza a contar Virginia el significado de este simbólico objeto. Una nevera se convirtió en el símbolo de transformación, de cambio sin perder la esencia. La nevera estaba en el antiguo espacio y sigue estando ahora en el nuevo. Fue la primera cosa que compraron las jóvenes del centro y ese dinero se quedó en el centro para hacer actividades.

De alguna manera es el paso de un espacio a otro y la implicación de los mayores que no estaban tan implicados y la apertura un poco a todo, y el saber que sin la gente esto no tenía sentido. El saber que hay cosas que siguen teniendo sentido, que estaban antes y las hacíamos y siguen ahora. Que gracias a lo viejo y a las tonterías que se hicieron salió todo y seguimos existiendo (003.02.01EG).

Les pones nombre a las cosas pero el nombre te atrapa a ti y llega un momento en el que no puedes quitártelo de encima. La Maranya te ha atrapado y ahora no hay vuelta a atrás.

\section{Qui no ré ulls per a somniar no veu els somnis}

\section{ni de dia ni de nit (2012) ${ }^{56}$}

Enrique quiere remarcarnos una cosa interesante para situarnos en el contexto actual en España. Nos explica que hay una cosa que es importante también en el caso de La Maranya. La Maranya es el ejemplo más claro de que España no se ha integrado en Europa, o de que realmente nosotras no

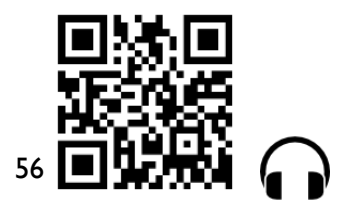


hemos hecho la transición social. Se hizo la transición política pero no se hizo la social que hubiese posibilitado la verdadera integración en Europa. Cuando una experiencia con la calidad de gente que hay detrás de $\mathrm{La}$ Maranya, con la garantía en cuanto a estructura de funcionamiento, metodología, etc. que tiene La Maranya se presenta, encualquier municipio europeo, a un Ayuntamiento para tirar adelante el trabajo en la localidad, el Ayuntamiento no pregunta nada, directamente firma un convenio y le da el apoyo. No se cuestiona si son o no son de mi ideología, si me harán o no me harán críticas. Él se lamenta pensando que no es el único ejemplo, pero de nuestro entorno, cree que es el ejemplo más cercano de que España aún está a años luz de haber hecho esa transición social y de estar integrada realmente en Europa. Se reafirma diciendo que un grupo de gente con capacidad profesional y con un equipo de voluntarias para hacer la labor que está haciendo La Maranya, en cualquier municipio europeo, el local sería del Ayuntamiento o si no, el Ayuntamiento lo hubiese pagado para que fueradirectamentepropiedad de esa entidad. Además de que el local tendría profesionales contratadas por el propio proyecto, con dinero público, que estarían haciendo su trabajo en el municipio. No es el primer ejemplo, y lamentablemente no va a ser el último. Independientemente de que en nuestro movimiento haya colectivos que cuentan con soporte de la administración y otros colectivos que no. En este caso en concreto, $\mathrm{La}$ Maranya, además, es útil para decir que, aquí, en este país nos hemos quedado en antes de los años 70 (Enrique, 003.04.01EG).

Julio le apoya y remarca que La Maranya tiene un valor añadido de que a pesar de no contar con el apoyo de la administración pública sigue más potente y fuerte que antes.

Desde la propia unidad se tenía claro como afrontar esta situación de conflicto

$M^{\prime}$ ha agradat molt la manera de respondre, $m^{\prime}$ ha agradat molt la traducció en alegria, $m^{\prime}$ ha agradat molt convertir-ho en activitats, en veure teatre, més treatre que mai, més rock que mai, més creativitat que mai. El llegir, el veure que la gent s'espressa $i$ sobretot sentir la unitat. (Victor, 006.01V d).

La independencia del espacio municipal les ha dado fuerza para seguir más unidas que antes. Tocaba asumir una decisión arriesgada, se necesita un local para poder continuar haciendo actividad. La primera opción para 
montar el local era alquilar un solar y poner contenedores marítimos, acondicionarlos y que La Maranya estuviera ahí. La otra opción fue alquilar un par de casas que fueron pubes hace 5 años y que por dentro estaban completamente destrozadas, en un estado verdaderamente lamentable.

Todo comienza en noviembre, es la primera vez que ven la casa y se enamoran, saben que es muy bonita (Animadoras, 003.02EG). La segunda etapa es en diciembre cuando entran y reconocen que hay mucho trabajo, están locos, no saben qué hacer y es a mitad del mes cuando empieza de verdad el trabajo en las casas. El hilo conductor de toda la obra es conseguir que dejara de tener apariencia de pub. Después se fueron arreglando los problemas de estructura que tenía, las goteras, ir descargando las casas de tabiques, ir recogiendo escombros y cosas que no les hacían falta. También lavarle la cara, pintar, lucir, renovar algunas partes,... Gracias a las jóvenes y su energía aquí se pudieron derribar tabiques, barras y más, lo canalizaban ahí y eso dio fuerza en el camino, es algo que afirman Jose y Armand entre emociones y risas cuando recuerdan entre las jóvenes lo que ocurrió en aquel momento.

Comenzaron a visibilizarse actitudes de grupo, colectivas y cooperativas. Los grupos estables, las familias y animadoras representaron de múltiples formas su objetivo común y para conseguirlo demostraron tener responsabilidades individuales y colectivas compartidas. Había responsabilidad, había compromiso y había trabajo conjunto. El local era una ruina y necesitaba organización, habría gente que se ocuparía de obra, animadores que seguirían con Esplai y otros que generarían actividades para recaudar dinero para la Casa.

Estem Vius quería continuar con la actividad, sabían que si no hacía algo el grupo acabaría muriendo porque en Benicàssim no podían hacer mucho, ese era su destino. Pero les salían proyectos en los municipios vecinos, en Vila-real uno de ellos y allí se fueron para subvencionar un poco la obra y al final, pasaron año y medio o así. Les contrató el Ayuntamiento del pueblo para dinamizar el espacio juvenil y sabían que era una fuente de ingresos importante para su Casa de Juventud. Consiguieron un grupo de más de veinte niños y niñas. Las jóvenes y adolescentes de allí también se implicaron y acabaron creando una Casa de Juventud, Serendípia. Mientras estaban en Vila-real, en Benicàssim también hacían obra, teatro, 
actividades,... todo con el objetivo de conseguir levantar la Casa con la mano de la ciudadanía. Querían abrir un espacio cultural alternativo en Benicàssim donde la gente más joven pudiera hacer actividades que no se ofrecen en otros lugares. Después de años trabajando en Benicàssim, como foco principal, las jóvenes habían adquirido destreza a la hora de organizar actividades y habían mejorado sus estrategias de comunicación con el entorno. Ahora que una nueva puerta se abría creían necesario dar apoyo a la creación de nuevas redes juveniles, de ahí que se movilizaran por Vilareal con el grupo Serendípia y también en Betxí con Espurna.

Las animadoras, por otro lado, estaban avergonzadas de tener que decirles a las familias que sus hijas estarían haciendo las actividades en la calle. Fueron días difíciles, algunos de lluvia y frío en los que se reducía la afluencia de niños y niñas y otros, en los que las actividades en el pueblo estaban en su máximo esplendor.

Con los días llegan caras nuevas, hay personas que van asomándose a la casa a ayudar. El grupo crece y se hace más fuerte. Se corre la voz entre las famílias y se crea un Verkami ${ }^{57}$ para recaudar dinero para parte de la obra. El Verkami \#unacasaperamaranya fue difundido por las redes sociales, con el boca a boca y a través de mailing a las redes personales de cada miembro de la Casa. Con él se querían conseguir 3.000€ para reparar el tejado y la instalación eléctrica. La campaña fue un éxito ${ }^{58}$ y se consiguieron $3.910 €$.

Aleshores a mi m' arriba a través de Joan que s'està organitzant un verkami per aconseguir diners per a poder acondicionar aquesta casa que encara estem acondicionant $i$ bó, com que jo coneixia les maneres de funcionament dels grups perquè el meu fill havia estat alguna vegada a l'Esplai $i$ sabia, a través dels comentaris, el que havia passat amb l'ajuntament, eixa espècie de cop, d'intentar acabar amb una manera d'entendre la realitat, tot plegat em va connectar, $i$ des de la mena rebel-lia vaig dir 'no no, aci hi ha que estar'. Vaig ser abans soci econòmic que participant; vaig estar mig any o nou mesos pagant qüotes i pràcticament no
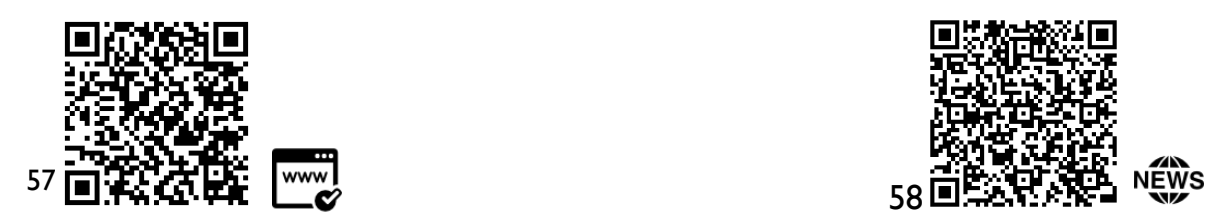
coneixia ningú a Maranya. Fins que m'incorpore al projecte adult, d'adults de la casa que s'estaven ocupant de la transformació de la casa $i$ del grup d'agroconsum ecologic, $i$ aixi es com comence. (Armand, 003.01.05EG).

Cada vez más personas iban escuchando sobre La Maranya, se extendía la marca y más de cien personas se unían a la Campaña\#josocmaranya ${ }^{59}$. La intención del grupo era invitar a todo el mundo a sentirse parte del proyecto. No se buscan socias sino que el colectivo intenta mostrar lo que es: educación, cultura, ilusión y trabajo, pero sobretodo se sienten conductores de futuro. Con ello querían explicar que cualquiera que quiera cosas similares a ellas o estuviera en otros proyectos ciudadanos también es La Maranya porque al final son muchas personas las que trabajan con las mismas finalidades y el nombre es sólo una anécdota.

Desde otros proyectos como los Casals Populars, otras Casas de Juventud y asociaciones varias se genera un apoyo mútuo y con él, aparecen nuevas personas dispuestas a aprender de esta experiencia que califican como potente. El caso de Mireia es uno de ellos. Mireia estaba haciendo el curso de monitores de tiempo libre que se hacía en el Casal Jove del Grao de Castelló cuando compañeras del Casal Popular le cuentan lo que está pasando en Benicàssim. Le enseñan el verkami y le informan del proyecto que ella desconocía por completo. A ella estas cosas de Casal Jove no le gustan porque lo considera locales sin fondo en donde las jóvenes van a hacer cosas sin más y el mundo 'animandi' no es lo suyo. Su referencia era el Casal Jove del Grao en donde se dejan las salas para hacer talleres. Entonces empezó a mirar un poco y por todo lo que le cuentan y ve, ella entiendeque son jóvenes organizadas, que hay algunas personas al frente de ellas que se organizan y que van depositando ideas pero no ideas politizadas aunque no niega que sí que se esté haciendo un buen trabajo de conciencia. Piensa que estas personas empiezan a tener diferencias con el Ayuntamiento por lo que están promoviendo con jóvenes. Indaga que el Ayuntamiento no está cediendo los espacios para hacer lo que quieren, por ejemplo, quieren hacer ocio nocturno y el Casal está cerrado por la noche.

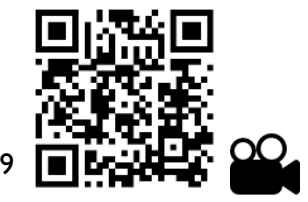


Ve que se promueve un tipo de ocio que choca con las ideas del Ayuntamiento y empiezan a chocar cada vez más entre ambos lados. Deciden, a partir de su propia organización y con el tejido social que tienen, plantarse y decir que ese Casal Jove no es un Casal Jove, no quieren pasar por las imposiciones del Ayuntamiento y deciden montarse su propia historia tal y como ellas la entienden. Aquí empieza una historia que a Mireia, desde fuera, le parece muy potente. Que un grupo organizado sin recursos decida de manera autogestionada y autónoma todo este proyecto es lo potente. Reconoce que habrá gente que se haya quedado por el camino pero cuando empieza a asomar la nariz por la Casa lo que ve es que las personas que vienen y que hacen ese traslado lo hacen de una manera muy consciente, están muy implicadas y lo generan desde formas muy coherentes con la acción que se ha decidido hacer. Ella percibe apoyo mútuo, cooperación y autogestión.

En esos momentos llega Mireia y llega para quedarse, para aprender al máximo de la experiencia y se vincula de manera directa haciendo las prácticas del MTL en La Maranya.

Fueron meses y meses de obra, la Casa de Joventut ha costado mucho, ha habido muchos esfuerzos personales e implicaciones varias de muchas personas, riñas y mucho trabajo (Animadoras, 003.02EG; Activistas 003.02EG). Ha habido esfuerzo económico, dinero para reformar y mantener el local, momentos de subida y de bajada pero al final la sensación era la misma, tenían que seguir porque necesitaban el espacio público.

Que l'objectiu és l'espai públic i que La Maranya té raó de ser quan torne a l'espai públic. Per què els espais públics entesos com a les places, o els locals de l'administració pública son de totes $i$ tots. (Animadoras, 003.02EG).

Y La Maranya volvió al espacio público, el 15 de julio de 2012 se inauguró el nuevo local en la Plaza de los Dolores de Benicàssim ${ }^{60}$. En pleno fin de

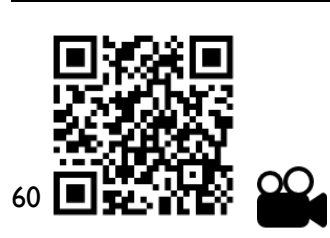


semana del conocido FIB (Festival Internacional de Benicàssim) esta Casa de Juventud se hizo un hueco. ${ }^{61}$

Maranya espai compartit,

\section{Maranya té ulls per a somniar col-lectivament}

\section{(Curso 2013/2014)}

Un hombre del pueblo de Neguá, en la costa de Colombia, pudo subir al alto cielo. A la vuelta, contó. Dijo que babía contemplado, desde allá arriba, la vida bumana. Y dijo que somos un mar de fueguitos.

-El mundo es eso-reveló-. Un montón de gente, un mar de fueguitos. Cada persona brilla con luzpropia entre todas las demás. No hay dos fuegos iguales. Hay fuegos grandes y fuegos chicos y fuegos de todos los colores. Hay gente de fuego sereno, que ni se entera del viento, y gente de fuego loco, que llena el aire de chispas. Algunos fuegos, fuegos bobos, no alumbran ni queman; pero otros arden la vida con tantas ganas que no se puede mirarlos sin parpadear, y quien se acerca, se enciende.

(GALEANO, Eduardo: El libro de los abrazos, Siglo XXI, Madrid, 2004).

A partir de ese momento había que volver a la metodología concreta: organización, fichas, estructuras, grupos estables, actividades extras, talleres,... Las animadoras creen firmemente que todo lo que les ha pasado se puede replicar y replicar como si fuera un vivero de plantas. Coger ramitas y empezar a sembrar y tener cuarenta mil. Es el sueño de cualquier revolucionario, ¿por qué no? La fórmula era fácil, el libro de Enrique
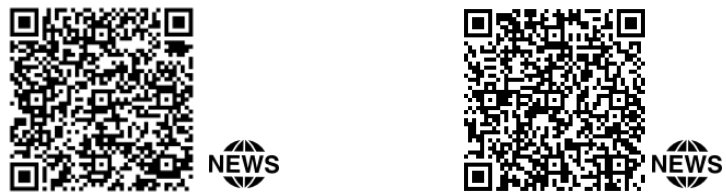
Deltoro $^{62}$. «En él lo encontrabas todo y de repente era la maldita biblia para la animación sociocultural y el trabajo con adolescentes» (Victor, 003.02.02EG). La gente con trayectoria de Casas de Juventud había escrito este libro y nadie lo leía, nadie les hacía caso y para ellas son sus referentes. Toda la gente que había formado a Víctor en el curso de monitore son referentes en La Maranya (Animadoras, 003.02EG).

Según este grupo de referencia, La Maranya tiene un modelo claro en cuanto a espacio físico y estructura al que imitar, el local de la Fundación Movimiento Ciudadano ${ }^{63}$. Este espacio acoge a múltiples asociaciones, entre ellas las vinculadas de forma directa con el Movimiento de Casas de Juventud Valenciano (Escola de Cases, FVCJ, Impulsy Esplais Valencians).

El lugar del que hablo es un espacio privado en el que confluyen distintos movimientos de trabajo con niñas y niños, con gente más mayor, con mujeres en particular y con vecinos y vecinas entre otros grupos. No tienen nada que ver con el Ayuntamiento y funciona de manera autogestionada. De forma resumida, cuenta su historia que este espacio se crea hace muchísimo tiempo y en su planta baja se da forma a una guardería social. La planta de arriba es el centro social de la Asociación de vecinos. Con el paso del tiempo, llega el momento en el que la guardería desaparece porque se municipaliza y se queda todo el edificio en propiedad de la Asociación de vecinos y es cuando se crea una Fundación (Fundación Movimiento Ciudadano) para garantizar que este espacio no cambie nunca de manos y no se especule con el terreno ya que se encuentra en Manises, el aeropuerto queda cerca y es bien conocida la especulación valenciana.

Esta experiencia de local en el que confluyen distintos proyectos y distintos grupos generacionales es un modelo que La Maranya tiene presente. Tal y como sucede en la historia de La Maranya, en la Fundación, se tuvo que hacer una transformación del espacio físico cuando se pasó de guardería a centro social. Se redefinió el local y se acondicionó a la nueva finalidad. Esa obra costó muchísimo dinero y hubo personas que lo aportaron, es más hubo personas que están vinculadas a La Maranya hoy que pusieron dinero

\footnotetext{
62 Deltoro, E. y Codina, J. (1993). Apuntes básicos para el animador juvenil. Barcelona: Certeza.
} 
en esa obra. Desde la lejanía colaboraron para que este espacio existiese físicamente. Se suceden las similitudes entre los dos lugares. En ambos hay un voluntariado que se ocupa de que el espacio físico tenga forma, que planifica el mantenimiento, y hace la reforma del local. En la Fundación hay una equipo de prejubilados que se reúne los lunes para hacer mantenimiento del local, igual que en La Maranya hay un equipo de adultos que se reúne para el mantenimiento.

Además, existen más semejanzas y es que La Maranya ha pasado de ser únicamente Casa de Juventud a convertirse en un Centro Cívico en el que se mezclan generaciones, actividades y grupos. Esa parte de abrir las puertas a otros sectores de la población es algo que en la Fundación también ocurre. A ella vienen desde niños de tres años con sus padres y madres para hacer actividades formativas o de educación en el tiempo libre hasta gente jubilada a hacer actividades de senderismo.

El mismo sentimiento de pertenencia a partir de la construcción de un espacio, sea donde sea y sea para quien sea, para tu hija, para la vecina, para ti, da igual, eso es lo que te hace sentir que es tu espacio. Más público que eso no hay nada describe Mireia

Ho vam fer junts amb les nostres mans. L'has fet tu, no te l'ha fet ningú, no l'han fet uns obrers amb els teus diners, no, no, l'has fet tu, abans que amb els teus diners amb les teues mans (Mireia, 003.02.03EG).

Lo estás construyendo tú y eso te ayuda a compartir el disfrute pero también el esfuerzo y el sacrificio tal y como nos cuenta Josevi.

Todo esto acaba siendo una demostración de que casi todo lo que hacemos en la vida no es por dinero (Jesús, 003.04.03EG). Hay gente que va a $L a$ Maranya a participar en actividades, en talleres, a organizar, a hacer obra,... Jesús está convencido de que es mucho más, que no únicamente son las personas voluntarias del proyecto sino toda la gente que hay detrás apoyando para que esto funcione, para que esto exista. Las que se apoyan de unos espacios a otros no lo hacen por dinero sino que hay cosas que mueven el mundo y no queremos reconocer que al final, son esas cosas las que mueven el mundo de verdad. Las que le dan vida.

Esas cosas convertidas en personas con nombres y apellidos que son la base de cualquier asociación. En esta línea uno de los adolescentes que pasa 
por allí, Iván G., remarca que lo importante en La Maranya es la gente «los que estamos aquí y los que hemos estado aquí y queremos seguir estando» (Iván G.002.03EI). Ellas son las que hacen esas cosas que pueden mover el mundo de verdad.

De ahí que los diferentes colectivos que forman La Maranya encuentren cada uno su espacio, «es fácil encontrarlo» (003.03.02EG) nos dice Joana afirmando que en este proyecto tiene cabida todo el mundo y seguro que cada una encuentra su potencial personal para ocupar un lugar que ponga en marcha los motores de la Casa. Es entonces cuando el colectivo de adultos continúa con su marcha de mantenimiento del local además de conformar el grupo de consumo de la Casa. A partir de ahora no sólo se reunirán por la obra sino que el mundo del agroconsumo les abre las puertas en La Maranya. Por otro lado, Esplai continúa con actividades coordinadas sobretodo por Víctor y Virginia. A estas animadoras maranyeras se les acumula el trabajo porque también activan talleres, fiestas, charlas con el objetivo de ir generando masa juvenil con la que poder trabajar a través del modelo de Casas de Juventud.

Son tiempos de convivencia en los que coexisten momentos de alegría y momentos de tensión, momentos de bienvenidas y momentos de pérdidas. Las pérdidas remueven estructura y sentimientos a la vez que aprendizajes. Muchos factores influyen en ellas: comienzo de estudios, traslados de ciudad, problemas personales, amor y desamor, incompatibilidad laboral,... Entre estas pérdidas está la de Estem Vius que como cualquier otro grupo nace, crece, se reproduce y muere (001.002DC).

El que ens va passar, o al menys com ho vaig viure jo, se'ns va ajuntar un poc tot. Érem joves, ens va agafar l'època d'entrar a la universitat $i$ cadascú estudiava en un lloc, era complicat quedar, també van influir temes personals dins del grup, gent que entra, gent que se'n va... V a aplegar un punt que, també com a grup pense que haviem adquirit, ja no a Maranya, sinó a nivell personal haviem adquirit molta més carrega, en general de coses de la que podiem assumir. Crec que el nostre error, per dir-lo d'alguna manera va ser no ser conscients que érem un grup de sis persones, que com a sis persones tenim unes limitacions mentals i fisiques $i$ voler avarcar tant va fer que ens cremarem de tal forma que quan va aplegar el punt ja no va ser 'bey intentem arreglar açò' sinó va ser un 'hey jo no tinc ganes de seguir' de fet jo vaig ser un dels primers que vaig eixir del grup perquè la situació de 
estar vivint en Valencia de tindre que treballar en Vila-real, de conciliar vida aci també a Benicàssim, me vaig vore prou agobiat $i$ sí, jo pense que açò va ser el que va acabar amb el grup, el no haver sigut conscients de les limitacions. (Ricky, 002.10EI)

De ahí surgen los aprendizajes y las nuevas estrategias de afrontamiento que tendrá el grupo. Ricky ha aprendido que para que no se dé esa carga se ha de ser consciente de las limitaciones personales, individuales y de grupo. Él explica que en temas de voluntariado es algo que debe entenderse, la implicación varía de unas personas a otras aunque es cierto que siempre hará falta una mínima para que funcione, dice que cada persona se implica hasta el punto que desea y este reconocimiento hará que no se fuercen situaciones cuando existen tensiones y según Joana, no acabe siendo una carga emocional para las personas. Para mejorarlo, Ricky dice que es imprescindible realizar un análisis de las limitaciones internas, externas y de las potencialidades que puedes aportar al grupo.

Jo $i$ un altre company, en aquest cas, Noel $i$ Judit també, de tant en tant ens veiem forçats a $X$ vegades a la setmana, ells des d'aci $i$ jo des de $V$ alència, quedar unes hores a la setmana per a fer uns tallers amb uns xiquets $i$ desprès tornar-te a casa. Clar, aleshores, possiblement no teniem eixa capacitat, també econòmica, perquè del grup d'Estem Vius tot era autogestionat, aleshores entre no tindre eixa capacitat econòmica i tampoc la disposició, feia que fora prou complicat conciliar el fer eixes coses amb el dia a dia. Sobretot a temporades, tu una temporada et sents que no pots pel tema $X$ que siga, no pots estar al cent per cent $i$ no pots aportar. En eixe moment simplement relegar-te a un segon pla $i$ ajudar en el que pugues, millor això que no forçar-te $i$ desaparèixer del grup.Lo important es això desconnecta, però torna. És un poc el missatge que crec que fa falta en els grups. (Ricky, 002.10EI)

Tal vez haya que remarcarla distribución de los niveles de participación de una Casa de Juventud a partir de su quíntuple estructura para que así todas las personas que pasan por allí conozcan qué se entiende por participación en la Casa y cuales son esos niveles. Muchas personas dicen saber que existe, otras muchas no tienen información al respecto pero lo que sí se tiene claro es que facilita el trabajo. No has de enfadarte porque unas $u$ otras se impliquen más o menos porque su grado de compromiso está 
teóricamente estipulado en función de este sistema de trabajo y organización. Por eso cada persona se sitúa en uno de estos cinco niveles:

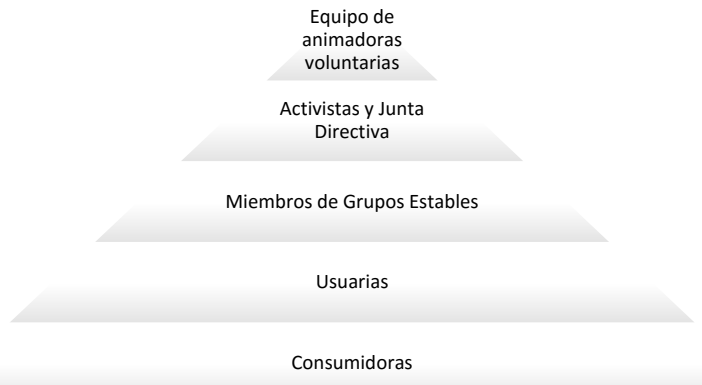

En función de ello se conocerá el nivel de implicación de la persona y se sabrá quienes son aquellas con las que se puede trabajar los cuadros medios que hagan que la Casa se autogestione a través de las participantes juveniles. En alguna ocasión, Virginia y Victor afirman que todo esto está basado en la construcción de confianza, es algo que no está escrito y que no se habla pero aparece. La persona se plantea hasta donde puede hacer y la gente confiará en ella para hacerlo y entonces lo hará. Virginia remarca que la gente no tiene que estar dando siempre explicaciones de todo, eso no significa convertirse en opacos, sino que todo es y será transparente pero sin tener que dar información en cada paso porque ahí es donde construyen la confianza. Tú confias en lo que yo estoy haciendo y yo en lo que tú estás haciendo porque ya sabemos que compartimos unos ideales y una línea de trabajo similar. Hay que construir confianza y esa construcción es algo que se trabaja en el día a día y cuando una joven aprende a hacerla a partir de las responsabilidades, las animadoras se dan cuenta que han conseguido uno de los objetivos más importantes de la educación y de la política ya que según ellas, el futuro de la política está en que volvamos a confiar en los políticos.

En julio de 2013, con 94 socias y diferentes grupos de actividad, de índole musical, periodístico, solidario, de consumo responsable, de educación en valores y de expresión artística, la Casa de Joventut La Maranya cumple dos años. Encarando el próximo curso con un nuevo plan de actividades entre las que destacan la organización de cursos de formación, la gestión de 
diferentes programas en el IES del pueblo, el Esplai, la Revista, los grupos de teatro, rol y guitarra y un campamento laico de verano.

Es hora de que las jóvenes emprendan sus propios proyectos en los que se fomentará su participación como ciudadanas a través de la organización de sus propias actividades en el tiempo libre, gestionando el espacio por ellas mismas bajo el paraguas del equipo de animadoras voluntarias de la Casa que coordinan toda la actividad del espacio.

\section{Propera estació MARANYA: VIATGES COMPARTITS}

SAcabamos entre risas de presentar cada uno de esos momentos que ha construído la historia de lo que es hoy La Maranya. Acabamos de recorrer las seis mesas que nos han mostrado fotografías y objetos que dan cuenta del recorrido, de las barreras y de las ayudas, que han facilitado que la Casa de Juventud a día 13 de abril de 2014 siga en pie. Ahora es momento para volver a pasar por las mesas de forma tranquila y que cada persona aporte lo que le gustaría que apareciera en esos cuadros que nos han dejado al lado de cada mesa. Así se completará un collage de la historia ${ }^{64}$, que se colgará en el local y que se complementará cada año con uno nuevo. No podemos olvidar la frase que resuena en la Casa, conocer nuestra historia nos permite saber quienes somos y hacia dónde nos dirigimos. Por eso, la historia maranyera siempre estará presente en el local para que no se nos olvide nunca todo lo que ha pasado para que hoy estemos aquí.

Las personas van pasando y seleccionando recuerdos y al acabar salimos al patio a almorzar todas juntas. Las telas rojas cuelgan de los amarres de la pared, el sol calienta y la gente seesparce por todo el patio. Al fondo, al lado del huerto, hay una mesa donde podemos encontrar algo para beber y alguna cosa para comer. Casi todas nos quedamos de pie y vamos hablando de recuerdos, percepciones, sensaciones y también de la vida del grupo. Las animadoras insisten en remarcar que no somos únicas, que formamos parte

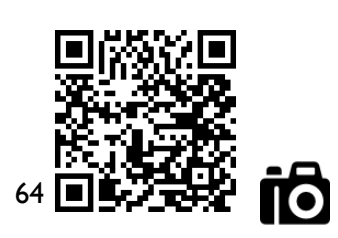


de un proceso y de un movimiento que hace que seamos quienes somos. Remarcan que todas hemos construido este espacio y quieren que nos llevemos un recuerdo como símbolo de esa construcción colectiva. Se rompen tejas, se ata cada trocito con lana roja y todas las personas que estamos allí nos llevamos un pedazo como parte del colectivo.

Nos dan tiempo para hablar y relajarnos mientras Virginia y Víctor ultiman el material para la segunda dinámica del día. Nos reunimos en el patio y aquí comienza L'Estació de tren. Cae en mis manos un pasaporte y Victor empieza a narrar:

Benvinguts a l'estació de ferrocarrils de Maranya a Benicàssim... ${ }^{65}$

Formar part de Maranya vol dir reconèixer que la vida és un viatge amb diferents parades a diferents estacions, $i$ aquesta és una d'elles. Com tota estació, Maranya té moments de repostatge, partides $i$ arrgemibades continues. Hi ha trens que s'aparquen aci anys, $i$ altres, els d'alta velocitat, fan parades instantànies. Alguns trens que passen per Maranya, fins $i$ tot passen sense aturar-se.

L'enigma de la nostra estació és que Maranya és una estació especial: també es mou amb el temps, no està sempre al mateix lloc. Som una estació moderna, transformadora. Per això posem a la vostra disposició un servei de «preparació del viatge de partida». Volem que partisques de viatge preparat per la recerca de la teva İtaca.

I recorda,

Més lluny, heu d'anar més lluny dels arbres caiguts que ara us empresonen, i quan els baureu guanyat tingueu ben present no aturar-vos.

Cada una de nosotras somos uno de esos trenes, cada una decidimos pasar un tiempo, un rato o bien hacer un transbordo en la estación de La Maranya por eso nos han repartido un billete para que en él podamos escribir dónde queremos viajar, cuáles son nuestros anhelos, nuestros sueños personales y colectivos para el futuro y el motivo que nos hizo pararnos en esta estación.

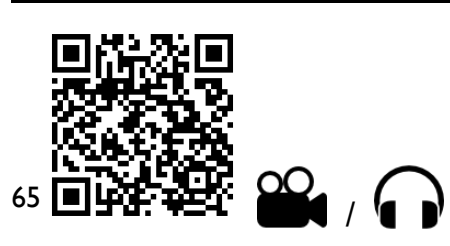


Se reparten bolígrafos, somos alrededor de 30 personas entre jóvenes, adolescentes, adultas, niñas y niños. Cada una se sienta y piensa qué escribir, algunas lo tienen muy claro, otras miran por encima del bolígrafo para ver que pone la de al lado y otras preguntan y comparten directamente qué escribir. Al salir del patio, justo en la pared ocre de la derecha hay colgados hilos rojos, lana llena de pinzas de madera donde cada persona va colgando su billete.

Virginia nos pide que subamos todas al piso de arriba. Ella nos explica que La Maranya tiene que darle la bienvenida a todas aquellas personas que pasan por su vida pero también que las que marchan puedan decir adiós. La gente cuando marcha y deja el colectivo lo hace con un malestar interno con las demás. Siempre dejas la puerta abierta para volver pero es difícil la vuelta si has marchado mal. En un colectivo es importante que todas las personas asuman que todo en la vida es temporal y que es posible que las personas marchen y por eso hay que cuidar esa marcha. De ahí el recrear esta dinámica para tomar conciencia de la temporalidad de las cosas y preparar el viaje de partida que comienza el dia que decides marchar.

En todo viaje hay que hacer una maleta en la cual cada persona decide qué tiene que llevar y qué tiene que dejar. En este caso cuando se acerque el día tendrás que decidir qué dejas y qué te llevas y tendrás que escribirlo en el libro-maleta de viaje que habrá en La Maranya. Además en la estación tendrás que pasar por consigna y después de seleccionar un objeto que te identifique con la casa, tendrás que depositarlo en la particular consigna. Ha de ser un objeto que hable de ti y de tu estancia en la estación. Para mostrarnos a todas cómo funciona es el turno de Bernat que hace unos días confirmó que dejaba el colectivo.

\Después de él, en estos 3 años, nadie que haya dejado el colectivo ha realizado el ritual. Tal vez haya que recordarlo, cuidar las pérdidas es algo importante. Las personas que entran en la Casa dejan un trocito de ellas, han dedicado muchas horas compartidas con el resto y ahora se merecen ver la puerta abierta para poder volver siempre que quieran.S

Una cosa más que hemos hecho hoy y que si que se ha continuado haciendo es el photopatchwork, la foto de grupo de cada año. 


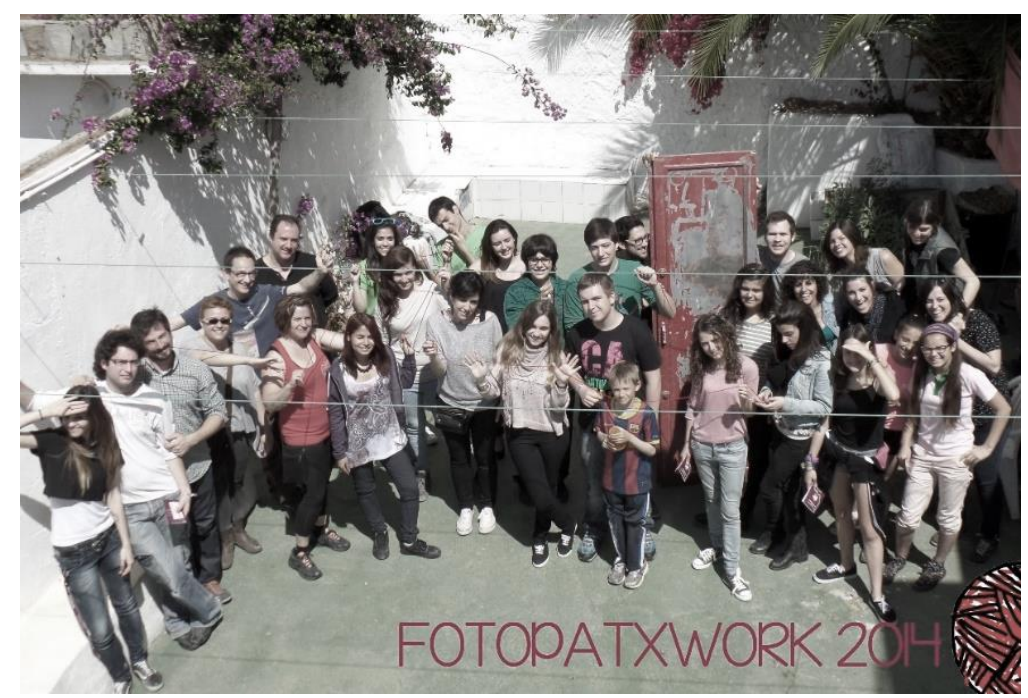

La idea es hacerse cada año una fotografía que tenga un significado especial para el colectivo. Este año las jóvenes deciden hacerla desde arriba y con la gente en el patio, una madeja de lana roja que una a las personas y la puerta del local, que se ha cambiado hace poquito, al fondo.

Se han acabado las dinámicas y llega el momento de ponernos a comer. Algunas familias se van dispersando, otras llegan de nuevo al local y todas han traído algo para compartir. Vamos organizando la mesa y preparando la comida para alrededor de 28 personas. En la mesa, en las dos puntas se sientan padres y madres y las jóvenes se sientan en la parte central. Yo lo hago al lado de Virginia y tres jóvenes de Mislata que también están montando su Casa de Juventud y me cuentan todo el proceso. Llegan Noel, Lydia e Iván y se oye un «¿es que hasta vuestro sitio para comer os lo tenemos que organizar?» Aunque el problema es que no quieren sentarse al lado de las familias porque les agobian, no les gusta estar todo el tiempo con ellas, prefieren algo más de libertad. Por eso nada más acabar de comer se salen fuera a tomar el café y allí hablan de muchas cosas: colaboraciones, adultos que dicen que hacen y no hacen, de cuotas, de reuniones con políticos y la junta directiva... Se acaba el día y me proponen que mañana vaya a la reunión plenaria con todos los grupos juveniles de La Maranya. Hoy se les ha olvidado por completo que yo presente la tesis, pero es normal, hoy el día era para otras cosas, era el momento de recorrer la historia y siento que no era el espacio para presentar investigaciones, ni 
estudios. Mañana en el plenario será distinto. A las 19 h30 nos veremos en la Casa y por fin presentaré y solicitaré al colectivo la posibilidad de hacer la investigación con ellas.

\section{UNA TESI PER A MARANYA}

La respuesta ya la sabéis, La Maranya tendrá su propia tesis, se escribirá su vida y durante estos tres años recogeremos todo aquello que pueda ayudarnos a contar juntas esta historia porque como dicen desde FVCJ, en este momento, La Maranya es un modelo a seguir. En este período histórico, es la única Casa de Juventud que ha recuperado el espíritu de Casa de Juventud que nació en el año 94 y que por diversas circunstancias han ido desapareciendo o modificándose. En cambio La Maranya es lo que queda de ese modelollevado al estado puro de lo que es una Casa de Juventud, en su funcionamiento, en su modelo de participación, en su organización, etc.

Los meses de mayo, junio y julio se suceden entre reuniones en las que me voy haciendo con el espacio. Mireia es la encargada de llaves y el día que me da la mía siento que algo ha cambiado, hay más confianza y siento un poquito más el cariño de la gente. Me dejo ver mucho por allí, las jóvenes y las animadoras ya se acostumbran a mi presencia aunque desde el primer momento me dicen que tengo que formar parte de ellas. Si quiero que la tesis salga bien, he de ser parte del grupo, participar de las reuniones y de las actividades, involucrarme en algún grupo estable, dejarme fluir, en definitiva, ser una militante más.

Es lo que hago, Perduts pel món, será mi puerta hacia el trabajo con jóvenes en la Casa, siempre desde una posición respetuosa y horizontal sin olvidar que desde EAV me dicen que me sitúe como animadora en el grupo. Es cierto que al principio, cuando entré por primera vez a una de sus reuniones, estaban muy definidos los roles de cada una. Había una que dirigía al grupo, era la que cubría el papel de activista aunque bien es cierto que el rol no estaba asentado en todas las cabezas por igual. Unas lo asumían y otras se negaban a que fuera esta persona la que coordinara el grupo. Pasan días y quedamos todas las semanas, nos marcamos objetivos pero el principal es realizar el video de La Maranya TV. Nos vamos 
conociendo, hablamos mucho, Iván convoca y lleva la agenda, Lydia escribe el acta en muchas ocasiones, en otras lo hace Ana María. Anna siempre llega tarde y Clara, hay veces que no llega, siempre hay alguna excusa para no poder bajar. Hay mayores afinidades entre unas y entre otras, algo natural en las relaciones y algo que influye en la dinámica de trabajo. Elegimos el tema para el video, queremos hablar de educación y nos ponemos a diseñar todo lo que en él queremos que aparezca. No es la primera vez que hacen un vídeo ya han hecho tres. Están hechos unos artistas y han grabado: Intolerancia, Laicidad y Democracia ${ }^{66}$. Vídeos con más de 300 visualizaciones en Youtube y que promueven el trabajo en valores con jóvenes. Pero este nuevo vídeo es diferente. Me dicen que no es igual, que los anteriores ya venían con el guión hecho y no tuvieron que hacer más que actuar. Victor y Virginia los diseñaron y ellas simplemente los implementaron, pero este es distinto. Este lo van a ver nacer ellas, lo van a diseñar ellas, lo van a gestionar ellas y eso cuesta mucho más. Pasan los días y cuesta arrancar, cada día falla una persona y las tareas no se llevan hechas. Se deja caer en alguna ocasión que el grupo está muriendo, que no continuarán. En esos momentos cojo las riendas y tiro del grupo para conseguir el objetivo.

Iván y Lydia están convencidos de hacer el curso MTL y les gustaría, el año que viene, ser las monitoras en el Esplai. El resto dicen que también quieren hacer el curso y que tampoco continuarán en el grupo. Iván decide convocar un día y hacer una sesión de evaluación, para valorar la situación, saber que implicación quiere tener cada una, describir los objetivos conseguidos y los nuevos que se plantean. Esto se plantea después de que el grupo de EAV hiciera su propia evaluación, ydecidiéramos hacer la misma evaluación de manera reducida en el grupo estable. La dirigió Iván, yo no pude asistir y en ella se decidió que el vídeo de Educación sería el último que harían como grupo. Perduts pel món quería recorrer otros mundos, se transformaba y se reconvertiría a partir de los intereses que tenía cada una para el próximo curso. Estos meses con ellas me sirvieron

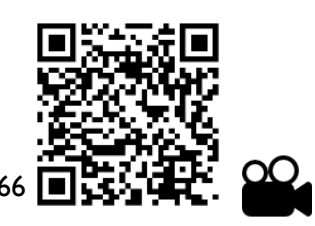


para conocer de forma más cercana el funcionamiento de los grupos, para saber hasta qué punto habían asumido la metodología de casas y pude evidenciar como algunas personas lo tenían muy claro pero otras no tanto (001.02DC). De manera general en La Maranya, tenía la sensación de que no existían intereses comunes que generasen actividad y los grupos estables cada vez eran menos. Se resentía en ello una época, se visibilizaban los ritmos por los que había pasado La Maranya.

Maranya ha tingut un colp molt fort en els últims dos, tres anys que ha tingut que fer obra si o si per a tindre els permisos $i$ tindre la casa adequada per a poder fer activitats. Això ha desgastat molt a la gent perquè no s'ban pogut fer activitats. Hi ban sigut dos, tres anys de fer activitats, però no tot el ventall d'activitats que ens haguera agradat, però a lo millor això en unes altres circumstàncies, amb un altre grup o inclús Maranya mateix, però amb altres circumstàncies haguera suposat la mort d'eixa entitat. Perquè clar, si no fas activitats $i$ no et dones a conèixer, tampoc tens ingressos vull dir $i$ el millor exemple es això que en aquestos tres anys ha aconseguit mantindre's. Uns anys millor $i$ uns altres amb cuetades, però sempre s'ha mantingut $i$ ara poc a poc des de que s'ba acabat l'obra, entre cometes, perquè falten cosetes, però el grup d'obra ba dit 'ja està tancat, he pogut presentar els permisos i ja està Maranya al seu 80\%', es a dir, que ja es viable continuar amb el projecte. Jo pense que ara poc a poc està agafant forces $i$ poc a poc van entrant en tallers, es van fent activitats $i$ macro activitats que es convida a tota la Federació de Cases de la Comunitat Valenciana $i$ jo pense que si no passa res aixina estrany pot arribar al punt de activitats que teniem abans en el Casal i inclús més. Sobretot la importancia d'aconseguir gent nova $i$ gent jove que tinga ganes de fer activitats. I projectes molt i molt potents com el que tenim ara al Institut, el de les tutories entre iguals $i$ jo pense que es una cosa molt potent $i$ molt bonica, implicar a gent per a donar-li eixa responsabilitat de que vullga assumir el poder ajudar a la gent. (Ricky, 002.10EI)

Toda esta carga se ve representada en la participación juvenil. No han existido espacios para el trabajo de grupos estables, se han facilitado otros espacios necesarios para que La Maranya sobreviviera. Julio nos explica otra variante más tratando el tema burocrático. La carga burocrática que supone abrir la persiana a la Casa de Juventud casi no la puede soportar ni una empresa, de hecho muchas empresas la cierran porque no pueden soportar esa carga burocrática y económica. Abrir la puerta a La Maranya les ha 
supuesto pagar a un arquitecto para cumplir las licencias, pagar los impuestos, cumplir la legislación, hacer una ley orgánica de protección de datos que también la tiene que pagar a una empresa, pagar para cumplir estrictamente con las obligaciones fiscales, pagar a un asesor fiscal, etc., etc. Pagos, pagos y más pagos, la militancia en la asociación se ha convertido en recaudar fondos y en obra, se ha descuidado un tanto la parte más potente de estructura de Casas pero todos estos incidentes críticos por los que ha tenido que pasar La Maranya, y las personas que la componen, ha posibilitado un sentimiento de pertenencia muy fuerte generado a partir del desarrollo de un discurso colectivo que promovía valores, intereses, relaciones y reconocimiento grupal. Esto ha provocado que el núcleo fuerte de la casa sea más fuerte y que el próximo curso escolar La Maranya pueda abrir la persiana y dedicarse a lo que realmente sabe hacer, educar en la participación.

\section{Maranya avui és moltes coses, encara que d'avui en endavant será moltes altres (2014/2015)}

A día de hoy La Maranya son muchas cosas pero seguro que a partir de hoy será muchas otras, afirma Virginia. Este mes de septiembre es el primero que abrimos la puerta y no tenemos escombros en ella. Es el primero que abrimos con una oferta de actividades para adolescentes. Hasta ahora La Maranya ha sido obra ${ }^{67}$ pero ahora ya no. «Hasta ahora no sabías que decirle a la gente para que no se fuera porque las condiciones eran de hacer cosas que no deberían hacer» (Virginia, 003.02.01EG). Virginia tiene claro que a partir de ahora sí que tenemos que empezar a exigir que las adolescentes se metan a ese nivel, que organicen sus actividades, que se impliquen, que hagan las tareas,...

Esplai pasa por momentos complicados, el curso pasado transcurre con altibajos, parece que se vaya a acabar. Hay muchas menos niñas y niños que

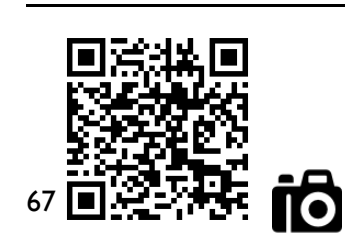


de costumbre pero en el nuevo curso de MTL se consolida que sean las personas del curso que han de hacer prácticas las que den forma al proyecto de Esplai cada año, siempre coordinadas por una persona del grupo EAV, concretamente Virginia. Así se realiza este año y serán Iván, Lydia, Enric y Andrea las encargadas de llevarlo adelante.

Cataflai sigue siendo referencia para muchas personas, para famílias como la de Guiomar y Aina que están encantadas. La madre alucina con lo que hacen las monitoras, con nada te pueden montar una actividad increíble, y su forma de organizarlo y ver como lo disfruta su hija la tiene enganchada. A Guiomar le gusta Esplai en particular y La Maranya en general para su hija, busca lo mejor para ella y quiere que siga siendo su punto de encuentro a partir de valores como el compañerismo, la amistad, la colaboración y el respeto, entre muchos otros. En la actualidad sabe que la infancia ya está absorvida por las nuevas tecnologías y cree que pertenecer a un Esplai es un modo de relacionarse con el mundo de una forma sana. Por eso le gusta para ella, para que pueda tener una transferencia cuando sea mayor. Esplai es un centro de referencia a nivel educativo. Le gusta la relación entre lo que se hace y lo que se dice, y siente que es una forma muy adecuada de utilizar el tiempo libre. Aina no deja de mover la cabeza reafirmando todo lo que su madre cuenta. Ella tiene ocho años y le encantan las acampadas y hacer nuevas amigas pero sobretodo cuando sea mayor quiere ser como Lydia, la nueva monitora del Esplai. El Esplai Cataflai lleva activo desde 2006, creciendo y aportando mucho a niños y niñas, monitoras y familias, siendo un pilar muy fuerte para la Casa de Joventut La Maranya y «es más que patente su importancia educativa en el pueblo», afirman las animadoras (001.02DC).

La Maranya no es solo jóvenes como otras Casas de Juventud. Todo el bagaje de aprendizaje que se tiene se recoge en infancia, adolescencia y juventud pero La Maranya da un paso más y lo hace con el trabajo con familias, con adultos (003.04EG). Jóvenes, personas adultas y niñas y niños que demuestran día a día una actitud activa hacia los aprendizajes. Jóvenes que forman grupos para reforzar a la asociación.

Formamos el grupo y lo hicimos para levantar otra vez todo porque estaba bastante parado. Quisimos que las jóvenes levantaran La Maranya que no fuera todo las personas adultas, 
que no se base todo en las personas adultas que nos lo dieran todo preparado y sólo tuviéramos que acudir sino hacerlo nosotras por nuestra propia cuenta con actividades y de hecho de ahí nació la Casa del terror, la hicimos las jóvenes y hoy es una actividad muy especial para todos (Ana María, 002.02EI). ${ }^{68}$

Reconocen que en la Casa han aprendido responsabilidades. Bueno «no son responsabilidades sino que es la forma más bien ética de enseñar a una persona lo que tú sabes» (Iván G., 002.03EI). Sentirse útiles, sentirse que pueden ayudar a las demás les anima a continuar en los proyectos de La Maranya. Muchas acaban describiendo su andadura por la Casa como un proceso vital de aprendizaje. Todas coinciden, ya sean adultas o jóvenes que es un aprendizaje constante, un aprendizaje de vivencias y un aprendizaje teórico que puedes poner en práctica a diario en tu vida. Trasladan todo lo aprendido a su vida fuera de la asociación porque la asociación es vida en sí misma y eso les empuja a analizar los beneficios de pertenecer al colectivo.

De una forma resumida han aprendido a organizarse, a realizar actividades y organizarlas además de responsabilizarse de ellas.

Jo, per exemple, en la part més tècnica de coordinació, organització $i$ de més jo pense que l'aprenentatge ha sigut brutal tant que fins al punt d'arrivar a la comparació acadèmica. Este tipus d'organització $i$ aprenentatge, per lo poc que sé en les carreres universitàries més de treball implicat en el tema social es treballa molt, el tema d'associacions $i$ jo si que he notat que tot lo que m'ha aportat la carrera a nivell social d'organització ja bo tenia per part de la Casa de Joventut de la Maranya per haver començat a treballar en el casal, per haver començat a fer les quatre reunions de adolescents, que jo no havia fet reunions en la vida $i$ per això, d'implicar-se, agafar responsabilitats, de si proposes coses que siguen coses coherents $i$ amb les teues limitacions (Ricky,002.10EI).

Jaume, el profesor del IES, coindice con esta afirmación. Él ha visto los cambios en su alumnado y reconoce que aquellas personas que pasan por

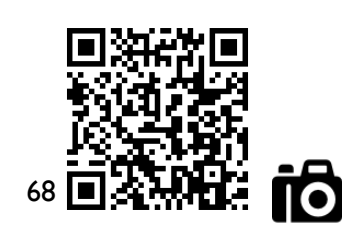


La Maranya tienen una actitud distinta al resto en cuanto a organización y compromiso con el centro. Muchas de ellas expresan que ahora sí que saben coger apuntes y planificarse a través de su agenda. Todo esto les ayuda a la hora de organizar sus estudios y eso les reconforta.

Pero no sólo se aprende a organizarse en una Casa de Juventud, también se aprende a relacionarse con el entorno con las personas que lo componen y con el medio ambiente en el que te mueves. Muchas de ellas han hecho amistades y la Casa les ha ayudado a abrirse y a empatizar con la otra y eso les ha llevado a no sentirse tan vergonzosas. Han aprendido a convivir, a disfrutar en equipo de todo aquello que realizan y a reconocer que nadie está por encima de nadie, que puedes aprender de la otra al igual que la otra puede aprender de ti. De ahí la importancia y el aprendizaje del trabajo cooperativo a la vez que se genera la interacción con grupos de diferentes edades. Las familias cuentan que han aprendido a ceder responsabilidades a las jóvenes y a resolver conflictos de una forma no violenta, siempre mediante el diálogo y la alegría. Por eso han aprendido a no enfadarse si no salen las cosas porque reconocen que se aprende a querer a las personas tal y como son. Es así como han aprendido a desvincularse de las cosas que no son responsabilidad de una única persona sino que son responsabilidades compartidas que salen adelante si todas participan.

Estoy aprendiendo a coordinarme mejor con más gente, estoy viendo como metodología de trabajo de coordinación de horarios y de diferentes grupos por parte de los monitores. Se me han abierto muchas ventanas a la problemática de trabajar con jóvenes, no desde la perspectiva de padre sino de tutor, de monitor, cómo lo están viendo los monitores. He aprendido también a trabajar con colectivos de gente más joven que tú en la que puedes participar con tu voz pero no con tus imposiciones, no tienes voto, tienes voz, pero la estrategia y los pasos a dar lo definen los más jóvenes. Es muy constructivo y enriquecedor, romper con esas estructuras piramidales que son las que están cristalizando el sistema (Josevi, 002.01EI).

Saben que en La Maranya creces como persona y descubres que tienes más cualidades de las que te pensabas tener y eso te ayuda a replantearte tu futuro profesional y ver hacia que camino puedes dirigirte (Lydia, 003.01.01EG). Es un aprendizaje de valores en la que descubres que no 
puedes ser víctima de la sociedad en la que vivimos y no puedes dejarte convencer por los demás (Iván G., 002.03EI). Tienes que respetar al resto pero has de conseguir expresar tu propio pensamiento desde la paciencia, la escucha a otras personas y la crítica. Esto lo viven en cada una de las campañas que promueve La Maranya, desde Benvinguts refugiats pasando por debates sobre la tauromaquia, la violencia de género, la homofobia, la inmigración ${ }^{69}$ y la guerra entre otras ${ }^{70}$.

Han aprendido a ser monitoras de tiempo libre y, familias y jóvenes, han asimilado recursos para trabajar con menores y adolescentes. Pero por otro lado más técnico no se olvidan de mencionar todos aquellos aprendizajes que han generado el trabajo con sus grupos: aprender a grabar vídeos, a hacer planos, guiones, a organizar materiales, a actuar, hacer slackline, manualidades e incluso hacer cemento e instalaciones eléctricas como explica Noel entre risas.

Así cosas concretas, a parte de la organización, optimizar el tiempo, coger una agenda y tomar apuntes, que hasta que no llegué aquí a Maranya no lo había utilizado para nada, pues a parte de eso aprendí también, por muy tonto que parezca, a hacer cemento y a hacer una instalación eléctrica. Aunque estudio ingeniería nunca nos habían enseñado a hacer una instalación eléctrica. He aprendido juegos de mesa un montón, como siempre. He aprendido burocracia de recepcionismo ya que fui secretario durante unos años, como montar una asociación, de arte no he aprendido nada por mucho que lo he intentado, y es que de donde no hay no se puede sacar (Noel, 003.01. 02EG).

Uno de los aprendizajes más referidos entre todas las personas de la Casa es esa convivencia intergeneracional. Una relación que ha tenido sus altos y bajos, sus acuerdos y desacuerdos pero que al final acaba reconstruyendo al grupo y haciéndolo más fuerte. La Maranya es una Casa de Juventud que lo
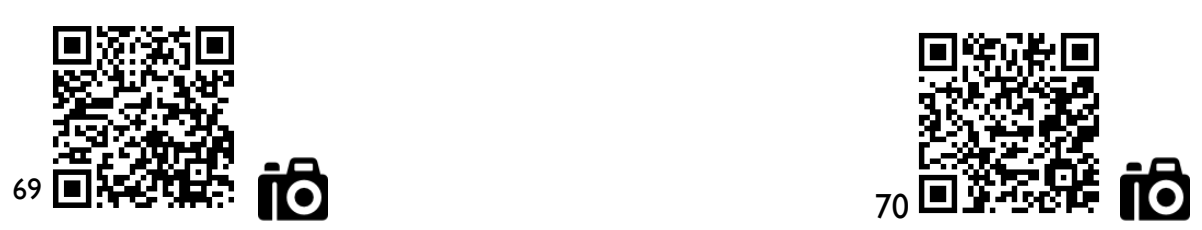
integra todo y esto se convierte en un cambio significativo en el modelo de Casas (Julio, 003.04.02EG). Todo ello lo favorece cuidando los ritmos de las personas pero también el de la entidad. Dando protagonismo a momentos clave para que las personas los sientan como propios. Así se cuidan los momentos como Amb l'alegria a l'altra banda, o Pengem el guants, acto en el que se quería celebrar que la obra, oficialmente, había acabado. Se quería dar un paso más allá para comenzar el nuevo curso con otro ritmo rodeadas de todas las personas que lo han hecho posible. O Fil bistorric, un momento más para compartir y generar esa convivencia intergeneracional. O también la Plaza Roja ${ }^{71}$, intervención en la plaza del pueblo en la que se celebro su visibilidad tiñiendo la Plaza de los Dolores de hilos rojos, fotografías de la obra y otras de protesta social.

A parte de todo esto, durante este curso, la estructura organizativa no varía a excepción de integrar en el grupo de EAV a algún miembro del grupo de adultos que anda por la Casa. A estos les resulta complicado entender las dinámicas de organización y han de hacerse con los espacios estipulados para cada función aunque pasa el año sin que acaben de adaptarse a ello. Actualmente, las personas adultas se vinculan a partir del Grupo de Consumo.

El grupo de consumo es una actividad muy concreta y concentrada en un día de la semana. Los miércoles vienen los que comparten cesta, vienen a por cesta y los agricultores que vienen a traer sus productos. Ese día generamos una dinámica, sobretodo no sólo de venir a recoger lo que se ha pedido sino también un intento de que sea un espacio donde la gente viene y comparte un rato, se charla, se habla,...Como hemos visto que ese espacio daba para que la gente viniera, se sentara, charlara,...pues ahora vamos a dar un salto y vamos a hacer que los miércoles sea el día de las meriendas y de las charlas. Hablando de temas que como consumidores, como gente que 
necesita alimentarse, que necesita gestionar su salud, tenemos temas que podemos compartir. (Josevi, 002.01EI).

Así lo explica Josevi, una de las personas que formó el grupo de consumo. Su participación consiste en reunirse para recoger la cesta quincenalmente, quieren realizar talleres y charlas pero nunca llega ese momento. Actualmente, no se implican en cuestiones organizativas de la Casa más allá de la del propio grupo de consumo. Yo misma me encargo de los turnos de limpieza y no ha habido manera en todo el año de encontrar a un responsable de grupo para que gestione la limpieza en Consumo. Hay un sector, que coincide con aquellas familias que participaron en la obra, que sí que quiere hacer reuniones, quiere participar y propone múltiples tareas pero una de las bases de la casa es «Tú propones, tú organizas» (001.02DC). Existe un nivel de confianza lo suficientemente elevado como para planificar actividades o acciones y proponerlas después al grupo siempre que seas tú el responsable. Derivar trabajo a otras personas se ha vivenciado como un no querer hacer y una sobrecarga de trabajo que también afecta a nivel emocional. El equipo EAV no está compuesto por muchas personas y estas ya tienen suficientes tareas con sus propuestas y gestiones como para cargarse con otras. En más de una ocasión surge la necesidad de realizar una sesión para que todo el mundo conozca cómo se organiza una Casa de Juventud, hace tiempo que no se hace y podría ser muy útil en muchos casos «ya que somos la única Casa con grupos estables que no somos capaz de coordinarnos, fallamos en el entramado interno y si no hay estructura no puede haber orden» tal y como explica Victor en alguna ocasión (001.02DC).

La Casa se estructura a partir del trabajo en diferentes espacios como son el plenario mensual, la asamblea general ${ }^{72}$, los grupos de tareas y coordinadora, la junta directiva y el EAV.

Los plenarios ${ }^{73}$ son mensuales, siempre al inicio del mes y es el lugar en el cual los grupos estables y las personas responsables de algún proyecto de la
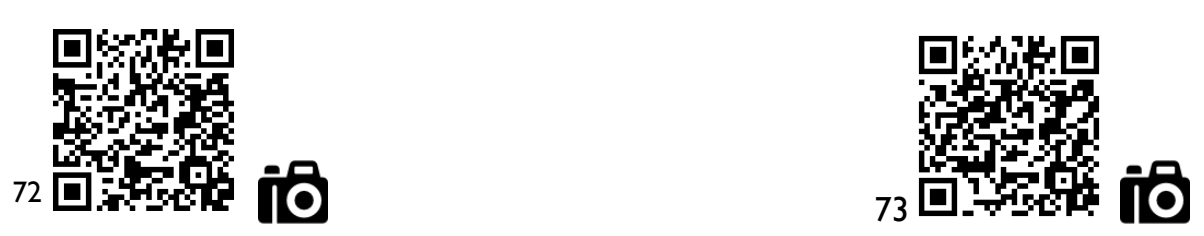
Casa nos reunimos para hacer una ronda de la situación de cada uno. Además después del punto informativo pasamos por un espacio de preguntas y otro de debate y discusión. A su vez, siempre existe un punto en el orden del día específico para tomar decisiones grupales ya bien sea del dinero que ha dado una actividad, de la campaña que se quiere realizar o de las actividades que se programan en la Casa. Este espacio empieza fuerte cada año pero va perdiendo fuelle conforme se acerca el final del curso.

Otro de los espacios que se realizan es la asamblea general. Se realiza dos veces al año. Una al inicio y otra al final. La Casa define esta herramienta como el órgano soberano de la asociación ya que en ella se toman las deciciones del curso. En ella participamos todas las socias del centro y aunque todas las personas que participamos tenemos derecho a realizar propuestas y acciones, siempre de forma argumentada, las únicas personas que tienen derecho a voto son las jóvenes entre 14 y 30 años. El resto tenemos voz pero no voto. Esto se debe a uno de los objetivos más fuertes de la Casa, el de darle protagonismo directo en la gestión de las iniciativas al colectivo juvenil. La función principal de la asamblea es la informativa además de la elección de los órganos de dirección y la aprobación de la gestión y los planes de trabajo. Aún explicándose esto en el papel, en la práctica no se lleva a cabo. Las propias animadoras querrían que fuera la asamblea la que diera el visto bueno al equipo de animadoras de ese año, que el propio colectivo decidiera los cargos, las funciones y las tareas de cada una. Victor explica que

seguimos empezando los septiembres sin tener un grupo que estire para que todo el mundo funcione, y si convocamos viene la gente sin saber a que viene, nuestro presidente aún no ha aprendido y tiene que aprenderlo ya, que tiene que ser él el que convoca a todo el mundo o alguien tiene que convocar a todo el mundo y decirle 'oye, ¿aceptáis a este equipo de animadores voluntarios este año? Se presenta 'pepito, fulanito y menganito' para mí esa es la metodología. (Victor, 003.02.02EG).

Pero no se hace así, las personas que forman parte del EAV no son seleccionadas por el colectivo sino que forman parte del grupo desde hace muchos años y se han asentado como figuras esenciales en la Casa. Esto 
genera una dependencia hacia ellas porque son las que tiran del proyecto, además de una posible sobrecarga en el EAV ya que provoca que no todas las personas que participan en la casa o incluso en el EAV de forma concreta conozcan los cargos, las funciones y las tareas de cada una (001.02DC).

Para facilitar la organización de las actividades y los grupos estables se promueven grupos de tareas y una coordinadora que apoya a las personas activistas de los grupos estables. La coordinadora es la animadora juvenil de la Casa y en este caso se representa en Virginia. Es cierto que dónde más explícita se hace esta figura es en la gestión del Esplai. En el resto de grupos estables como Humanos y Casas, el grupo de Guitarra, Slackline, Cocina o Manualidades no se ha evidenciado dicha figura de una manera constante. Virginia siempre está pendiente de esta labor pero no existen horas suficientes para poder abarcar todo el trabajo que supone y se deriva en la gestión directa a partir de las activistas de los grupos estables. Poco a poco, Mireia también va asumiendo este rol de coordinación y gestiona la organización de los grupos de jóvenes pero siempre con el apoyo de Virginia. Este papel se hace más patente cuando la responsable del proyecto de tutoria entre iguales en el Instituto de Benicàssim decide 'dejarse' La Maranya y lo asume Mireia.

Por otro lado, el órgano ejecutivo de las líneas generales que marca la asamblea es la junta directiva. En ella están representados los cargos de presidencia, secretaría, tesorería y los vocales que formen parte de la junta. En la práctica, la junta directiva, se reunía prácticamente de forma semanal. Los lunes eran días de reunión y la junta lo hacía antes de que empezara la sesión de EAV. Poco a poco se ha ido apagando la llama y la junta directiva se reúne de manera puntual para tratar temas concretos de firma de documentos y poco más. Desde que entré en La Maranya en 2014, Noel ha sido el presidente de la asociación pero las propias jóvenes han asumido que hay un 'presidente en la sombra'.

Asumen que Victor siempre está detrás de todo. Lo asumen y se resignan a la hora de proponer ya que explican que a la hora de planificar actividades siempre se acaban perfilando del modo que él quiere. Algunas se resignan, otras aprenden de él como modelo educativo, otras tiran la toalla y entre 
ellas se dan ánimos cuando han de planificar algo y después han de presentarlo ante Victor y Virginia.

Finalmente encontramos el Equipo de Animadoras Voluntarias (EAV). En él cada participante es responsable de una programación de intervención. En las reuniones se programaban actividades, planes de acción con las jóvenes, cuotas, se repasan responsabilidades a través de la quiniela y se hace una valoración de la semana anterior y sus actividades, entre otras cosas.

En la práctica es Victor y Virginia las que organizan al equipo, coordinan las reuniones y las acciones que se llevan a cabo dentro de él. En el equipo nunca ha habido menos de tres personas ni más de diez. La junta directiva debería de ser la encargada de seleccionar y proponer en asamblea al equipo de animadoras pero no es así. Al final en una Casa autogestionada, donde cada persona aporta desde el voluntariado, acaban formando parte del EAV aquellas que tienen ganas de trabajar y de tirar adelante La Maranya. Justo a estas personas se les otorga un rol de liderazgo dentro de la asociación. Entre ellas, Virginia y Victor se mantienen desde la formación de la Casa. Son dos personas que tienen clara su militancia, su deber con la casa y eso les hace trabajar por la continuidad del proyecto y por generar un relevo generacional para cuando ellas ya no estén aquí. «El resto de las personas son las que van variando, yendo y viniendo en función de sus posibilidades o voluntades» (Ricky, 002.10EI) aunque Noel y Mireia se mantienen en el equipo desde hace tiempo, se han construido su espacio y cada vez más se abren el camino como figuras esenciales en la Casa.

Virginia repite en muchas ocasiones que tenemos que emocionar y no comprometer porque la dinámica actual de la Casa se ha dirigido más al compromiso y a la asunción de responsabilidades que no a emocionar al colectivo juvenil. En algunas ocasiones se percibe la desesperación y tristeza de no saber como movilizar a las jóvenes y no hablamos de movilizar a gente nueva sino remover a ese colectivo de jóvenes que lleva años vinculado a la Casa pero no asume el activismo de grupo estable. Remover a todo ese grupo que pueden enganchar a otras y hacer que $\mathrm{La}$ Maranya crezca. El nivel de compromiso por parte del colectivo parece ser muy elevado pero cuando Virginia compara con otras Casas de Juventud ves como en ellas el colectivo está apuntado a actividades, talleres, se 
reúnen y programan más actividades. El grado de compromiso varía de unas personas a otras, el discurso de militancia no está asumido por todas las personas por igual.

En la Casa hay una sensación de desazón por no saber que va a pasar. $\mathrm{La}$ Maranya precisa de muchas horas de trabajo y sin apoyos de la administración pública es difícil. En alguna ocasión se habla de esperar hasta las elecciones de Mayo y si en ese momento el gobierno local no cambia y con él su percepción sobre la Casa de Juventud habrá que sentarse a hablar y a analizar implicaciones del grupo tanto de jóvenes como de adultos para saber y reconocer quien va a estar y qué hará mientras esté. Hasta el momento las personas que han estado en el EAV han jugado con la flexibilidad laboral que se buscaban para poder tirar adelante el proyecto. ¿Eso seguirá pasando cuando las personas del EAV cambien? o ¿La Maranya tendrá que cerrar sus puertas y deberá reconvertirse en otras cosas? Tú debes sentir la responsabilidad de estar aquí no debe ser otra persona la que te diga que debes asumir la responsabilidad (Ricky, 002.10EI). Ese cambio de percepción hace que unas y otras personas asuman trabajo de formas variadas.

Algunas personas que han sido parte activista de la Casa en otras ocasiones nos explican que debes tener muy claro que quieres estar, debes de estar dispuesto a invertir tu tiempo en ello porque se necesita mucho tiempo y trabajo para sacarlo adelante. La dificultad viene cuando esa responsabilidad se asume como obligación y no como algo voluntario que haces con otro objetivo distinto (Ricky, 002.10EI; Joana, Guille e Isabel, 03.01EG). Sentirte en la obligación y ya no sentirte agusto con lo que haces es el punto que te hace ver que ya no estás aquí porque quieres sino que algo ha cambiado y este hobbie ha pasado a ser una obligación.

Este es un punto de inflexión al que se refieren más de una persona que ya no forma parte de la Casa en la actualidad. Cuando algo lo haces porque quieres es muy distinto que cuando lo vives como una obligación, como si fuera tu trabajo. Ahí mezclas voluntariado con trabajo y la percepción de tu lugar en el grupo cambia. Debes coordinar muchas cosas, ingeniártelas para conseguir dinero y a nivel personal si te hace ilusión hacerlo es perfecto pero si te agobias comienzas a aflojar y piensas que reunirte una vez a la semana, si por ejemplo vas a hacer teatro con tus amigas pues mola, pero 
cuando empieza a ser algo obligado tu mirada cambia de «'oh que guai vaig a fer teatre' a 'bua, demà tinc teatre'» (Ricky, 002.01EI). Por otro lado está el momento de definirse como grupo estable, el hecho de convertirte en un grupo multidisciplinar y empezar a hacer diferentes actividades que nada tienen que ver con tu primer objetivo de hacer teatro. Es fantástico porque aprendes muchísimas cosas pero no beneficia al grupo en el sentido de centrarse en una cosa, hace que se pierda la finalidad o así lo ve Ricky

Jo vaig entrar a fer teatre, però no perquè m'agradara fer taller de reciclatge si no tal volta haguera format un grup de taller de reciclatge, però bueno, també la situació ho requeria. Si tu has de fer un taller de lo que siguera perquè et feia falta els diners, o ja no els diners simplement dir bey que nosaltres existim a la pròxima vegada que munteu algo conteu amb nosaltres', està bé, però la sensació d'obligació $i$ la perdua d'objectius va ser un poc el que va anar fent un poc de mina en el grup (Ricky, 002.10EI).

Las jóvenes en La Maranya deben aprender a militar, a mantener un espacio que es propio y que cuesta dinero a diferencia del resto de Casas apoyadas por la administración. Esas Casas pueden vivir y focalizar sus esfuerzos en otros temas pero aquí el principal quebradero de cabeza es cómo tener la solvencia económica como para poder sacar adelante actividades, pagar un local, agua, luz, gas, e incluso no quedarse sin papel del váter. Por eso la gestión puede llegar a ser distinta en comparación con otras Casas y el compromiso que se ha de asumir es mucho más fuerte y con mayor carga de responsabilidad.

La Maranya tiene un estructura muy clara de participación como vamos viendo pero aún así se asumen diferentes roles que no están estipulados como tal pero aparecen y hacen explícito que dentro de cada nivel de participación aún existen diferencias significativas entre las participantes.

Ricky también lo percibe y dice que todo proviene de un grupo de personas que siempre ha estado ahí y que gracias a ellas, a día de hoy La Maranya se mantiene. Otras han ido rodando por temas personales, unos años con mayor disposición y otros con no tanta pero hace patente que si el grupo de personas que forma el EAV no existiera, y si principalmente Virginia y Victor no estuvieran ahí, La Maranya hoy por hoy no se mantendría. Algo en lo que coinciden todas las participantes de la Casa a las que he entrevistado. Hay un grupo potente de personas que coordina y gestiona 
La Maranya que gracias a su trayectoria y a su asimilación del modelo de casas actúa de una forma muy estructurada y sistemática. Por otro lado, está la parte que tal vez no tenga tan asumido el modelo o lo haga desde otra perspectiva. Estas tensiones internas aparecen en mis primeros meses en La Maranya y disparan el valor que ocupan las animadoras en la Casa recordándome la importancia de analizar el liderazgo, cómo se da y cómo se acepta este ante las participantes.

Gran peso de la asociación recae en dos personas principalmente, Virginia y Victor. Ambos tienen experiencia, un método de trabajo asentado y una militancia muy fuerte con La Maranya. Existen jóvenes que sí que asumen liderazgos pero que según ellas dos no les corresponden por su edad, les correspondería estar haciendo otras cosas. El resto de animadoras del EAV comparan en múltiples ocasiones el voluntariado con el trabajo y esto les hace debilitarse. Al no asumirse del mismo modo, los compromisos varían y las implicaciones también. Si vienes a una sesión del EAV verás como siempre es similar, ellas dirigen y el resto suelen asumir lo que ellas proponen (001.01DC y 001.02DC). Algunas personas intervienen más en el trabajo pero es bastante habitual que se mantengan al margen. Hablamos de un grupo de seis personas en el que se asume que ambas son los pilares principales de activación de La Maranya por ahora, aunque ellas no pierden oportunidad para insistir en que son un equipo, cada vez más grande y todas somos clave. Ellas saben que han de estirar y así lo dicen

Maranya es estirar también, siempre hay alguien que estira. Entonces a veces tú tienes la sensación de que lo haces mal porque sólo estiras tú, y otras veces dices 'alguien tiene que hacerlo' y el imperativo moral está por encima de incluso del funcionamiento extremadamente asambleario y democrático. El imperativo moral de que hay que hacer algo, y sabemos que los demás necesitan ese estirón para ponerse (Victor, 003.02.02EG).

$\mathrm{Y}$ al igual que ellas lo saben, lo saben otros activistas que han pasado por la Casa los cuales reconocen que es un papel muy importante el que desempeñan.

Que perdonen si a vegades poden ser casinos en sentit de ja estan una altra vegada...' Però després quan ho mires fredament, des de fora dius 'bua si no haguera estat abí este 'pesao' gravant això, això no haguera eixit'. Te'n adones que es gent que envia emails de quatre pagines a les dotze i mitja de 
la nit $i$ tu dius 'no té res millor que fer?' doncs no, no tenia $i$ sort que l'ha enviat el correu perquè et fa vore la necessitat que hi ha d'activar-se $i$ de fer coses. Hi ha vegades que et relaxes $i$ et penses que està tot fet, però després quan arriba aquest tipus de persona $i$ et diu 'bey mira quina llista de coses hi ha per fer' $i$ tu dius 'pues no ho havia pensat' (Ricky, 002.10EI).

Algunos por actuar así los acusan de dirigir a las jóvenes, de provocar protestas, de pensarlos como manipuladores,... tal y como lo cuenta Jaume (002.05EI) que siente que ocurrió, otros los acusan de referentes educativos y de modelos para las consiguientes generaciones de jóvenes de Benicàssim (Guiomar, 002.04EI). Entre estos polos se encuentra el papel de las animadoras de la Casa y en función de cómo entienda cada uno su papel las actuaciones se asumen como una cosa o completamente la opuesta.

¿¿Quién es el número dos de Maranya?’ Me pregunta Jaume con total naturalidad. Yo asumo que el número uno es Víctor y mi respuesta es 'Virginia' y él asiente. (Jaume, 002.05EI)

Esta relación entre los niveles de participación y de liderazgo afecta al objetivo de generar un relevo generacional en la Casa. Victor y Virginia e incluso Julio y Enrique explican en alguna que otra ocasión (001.01DC y 001.02DC) que las CJ pasan por ciclos de cuatro o cinco años y en esos ciclos se debe de trabajar para conseguir un buen relevo generacional que soporte el trabajo de la Casa cuando el EAV cambie. Una persona bien podría empezar el ciclo en Esplai, continuar en actividades de un grupo estable, configurarse como activista del propio grupo y una vez tenga la edad adecuada realizar el curso de MTL para después empezar a formar parte del EAV como monitora, por ejemplo, del propio Esplai y más tarde ser animadora juvenil de la Casa. Siempre debe de haber alguien, tenemos que tener personas que puedan hacer ese relevo para que La Maranya no se acabe. Ahora esas cuatro o cinco personas son unas pero dentro de unos años deberían de ser otras. Por eso es importante que entre gente nueva, que la propia gente se mueva para que ese movimiento genere relevos adecuados.

Después está el hecho de cómo generar ese relevo y es con el trabajo diario. Es probable que se dé de manera automática pero también es cierto que es grande el trabajo de acompañamiento que hay que generar y este difiere entre unas personas y otras. En esos espacios se deberían de generar 
sentimientos de autonomía en lugar de dependencia. Anular los sentimientos de no saber hacer bien las cosas y aceptar por parte de las animadoras que si una persona hace algo de un modo distinto a como ella lo tiene asumido puede ser un espacio para el aprendizaje si después erra. En ocasiones las actitudes son duras porque las animadoras sienten que ese paso ya debería de haberse producido que «no tienen que verse desde el lugar de educador-monitor sino entre educadores iguales en responsabilidades» (001.01DC y 001.02DC), pero este paso no acaba de producirse. Habrá un momento en el que más adolescentes estarán asumiendo tareas y en algún momento «se sentirán lo suficientemente cualificados para dar ese paso» (Ricky, 002.10EI). Poco a poco las personas que han de conformar ese relevo tienen que ser conscientes y asumir de manera natural sus responsabilidades. Esas personas ahora mismo se personalizan en Noel y Mireia y este año se han visto con mayor autonomía a la hora de planificar y organizar el centro. Poco a poco, Virginia y Victor van soltando algunas de sus tareas y las van dejando caer sobre ellas. A veces no aparecen en las reuniones y Noel y Mireia se sienten entre ofendidos y nerviosos pero percibo que entienden que es su momento y esa responsabilidad y respeto por la Casa es la que hace que les entren los miedos.

Jo pense que la gent que està agafant o ha agafat eixe relleu es conscient $i$ pense que surt quasi, entre cometes, de manera automàtica perquè duu un treball darrere molt gran. Tu des del moment que entres a formar part del grup de no sé que, que no has fet reunions en la teua vida, comences a dir-li que han de fer reunions per a certes coses, poc a poc vas anant a les reunions, vas aprenent a organitzar-te, a planificar-te $i$ de més $i$ clar, aplega un punt que jo pense que ets conscient de que 'hostia tot això abans ho ha fet una persona per a que jo puguera estar dins d'este grup', ara es moment d'agafar responsabilitats o per exemple este grup, cau i es un moment en el que dones el pas, però perquè ha hagut un treball... no entre qualsevol del carrer $i$ et diu 'he això ho agafe jo $i$ jo ho faig' perquè porta un treball molt dur darrere. Clar, si inclús la forma de treballar, es torna mecànica $i$ quan vas a un altre lloc a on el tema de coordinació $i$ reunions no bo tenen tan assumit et xoca $i$ dius 'no entenc com no podeu fer aquestes coses' (Ricky, 002.10EI).

De forma paralela, llegan los cambios en las legislaciones asociativas, se escucha en mútiples foros el temor al impuesto de sociedades y La Maranya 
decide generar red, fortalecerla y afrontar la situación junto a otras Cases de Joventut. Desde hace un tiempo las Casas deben afrontar, como el resto de asociaciones, unas obligaciones legales que cada día son más severas y difíciles de costear. Por esta razón el pasado 2 de abril representantes juveniles de Betxí, Benicàssim, Castelló y Alqueries aprobaron oficialmente los estatutos de la nueva asociación provincial de Casas de Juventud. En ella se aglutinan diferentes asociaciones juveniles, grupos estables, Casas y Casales de la provincia que quieren formar parte. El presidente de la nueva Asociación es el representante de la delegación de La Maranya. Noel afirma que hay que agruparse para trabajar unidos y no en solitario. Es tiempo de fundir entidades y no de fundarlas. La financiación de las obligaciones legales resultan complicadas para una asociación juvenil: seguros, impuesto de sociedades, contabilidad, ley de voluntariado, contratos a monitores, ... Por eso se propone esta Associació de Cases de Joventut de la província de Castelló (ACJCS), una asociación para todas y con diferentes delegaciones en los pueblos que ayudará a las jóvenes a cubrir las obligaciones legales de manera mancomunada y por tanto, ahorrar dinero. Además facilitará que las actividades y las acciones conjuntas sean mejores. La nueva asociación tiene en su conjunto más de 300 socios y las representantes legales son miembros de las diferentes Cases de Joventut que convivían hasta el momento en la provincia de Castelló. Este acto se considera, entre parte del EAV, como un ejercicio de democracia. Otros no entienden porque sus esfuerzos tienen que ir a parar a otros lugares que no son su municipio. Algunos exteriorizan que quieren continuar la lucha en su pueblo y que abarcar tanto se les queda grande. Poco a poco se entiende que es un proceso estratégico y que las sedes van a seguir funcionando igual pero con un apoyo en red enriquecido y compartido.

Es un año de mucho trabajo, es un curso en el que a nivel municipal pueden pasar muchas cosas. El equipo EAV se sumerge en la organización del Recrea la tena ciutat. Ciclo de conferencias en el cual las participantes junto con alguna persona ponente debaten y acuerdan un nuevo proyecto para Benicàssim. Entre temas como la ocupación, el urbanismo, la educación, la participación, las necesidades básicas, el tiempo libre en el municipio y la mejora de las cuentas del Ayuntamiento nos reunimos alrededor de veinticinco personas de media a lo largo de siete sesiones. A los actos están invitados todos los partidos políticos del municipio aunque 
se hace evidente que desde el Partido Popular no se tiene una línea de trabajo conjunta después de los años que llevan gobernando en el pueblo ya que no asisten a ninguna sesión. Con este ciclo se da visibilidad al centro a nivel político y social y se marca como referente en la participación y la transformación social del municipio. Las asistentes disfrutan de los encuentros y al final de todo el ciclo se cuelga en la red un documento con todas las conclusiones acordadas en los debates. En él podemos encontrar acciones concretas que ayudarán a los partidos a mantener una línea de trabajo desde la ciudadanía y a generar planes estratégicos con dichas acciones que no surgirán de decisiones improvisadas.

Todo el proceso Recrea despertó una gran ilusión en el equipo, la emoción por poder generar un cambio de ciclo político en el municipio atrapaba a más de una persona en los debates. La Maranya también se emocionaba y todas pensamos que el cambio estaba cerca. En el país se había dado el efecto Podemos de manera muy fuerte. Los partidos, hasta ese momento minoritarios, parecían reflejar lo evidente, en España habría cambio y el Partido Popular dejaría su mayoría absoluta para convertirse en partido de la oposición. El mismo día de las elecciones todo el mundo «'se votaba encima'» (001.02DC), muchas personas de nuestro entorno deseaban que llegaran las ocho de la noche para que los colegios electorales cerraran y empezaran los recuentos. Yo voté en Castellón y me fui para Madrid, allí se contagiaban los gritos, la alegría, las sonrisas mientras en Benicàssim se reunía el EAV en La Maranya para seguir los recuentos y nos retransmitíamos por Whatsapp. En Madrid se pudo conseguir algo, Podemos ganó las elecciones en la capital pero no en la Comunidad en la que continúan las políticas de los populares. En Castellón y Valencia se llegaron a acuerdos gracias a tres partidos que imploraban el cambio en tierras valencianas: el PSOE, Compromís y Podemos pactaron acuerdo para gobernar. En Benicàssim ganó el Partido Popular, hoy continúan gobernando sin mayoría absoluta pero continúan sus políticas.

La campaña y los posteriores pactos se sucedieron con ofertas a algunas de las personas que forman La Maranya: asesorías, concejalías,...Quien sabe cuantas cosas más pero algo se tenía claro en el grupo, como sostienen Virginia, Victor, Julio o Palas (001.02DC) no se podía volver a dar el desmantelamiento asociativo que se dio en los años ochenta cuando el 
PSOE ganó sus primeras elecciones. En aquella época muchas personas cambiaron cargos asociativos por cargos políticos y en ese mismo momento, la potente red asociativa que se había generado en España desde los años de Dictadura Franquista se fue extinguiendo.

Los objetivos estaban claros fortalecer la red de Casas de Juventud en Castellón y 'capitalizar' el movimiento valenciano. Como ya he contado en algún momento el movimiento juvenil de Casas de Juventud valenciano y aragonés tienen una relación especial. Se muestran apoyos mútuos, palabras continuas y espacios compartidos. En estos espacios es nuestro querido Palas y su incansable compañero Jack los que nos advierten que tengamos ojo con estos momentos de euforía, que no nos quiten lo que ya tenemos, lo que hemos construido y es nuestro, lo que es del pueblo. Palas nos recomienda que si nos dan recursos no tenemos que perder las miras y debemos capitalizar el movimiento, es decir, conseguir dinero, personal o instalaciones. 'Siempre que hables con la administración piensa en ello' le dijo un día a Victor, 'esta situación política se acabará y si tú no te has fortalecido en estos tiempos de bonanza, después, todo será mucho más difícil' (001.02DC).

Como narraba más arriba, desde el EAV de La Maranya existen dos posicionamientos. Uno que entiende la necesidad de 'capitalizar' el movimiento. El otro que sigue pensando desde la Casa sin analizar los beneficios que puede tener para el movimiento global el tener convenios con otros ayuntamientos. Entre ellas se dicen que es momento de abrir la mirada y no pensar únicamente en lo local sino pensar en lo global y en los beneficios que puede conllevar a lo local.

Por estas razones, la estructura de trabajo de la Casa de Joventut La Maranya se transforma. Cada Casa de Joventut continúa con sus dinámicas y a su vez se crea un espacio semanal para coordinar las acciones conjuntas en ACJCS desde una misma metodología. Virginia coordina este espacio y es el enlace entre todas las Casas. Victor dedica mayores esfuerzos a Federació de Cases de Joventut y sigue asistiendo a las sesiones del EAV de ACJCS pero se aleja poco a poco del trabajo visible de La Maranya. Por otro lado, Noel será la persona que coordinará el EAV en La Maranya y Mireia continuará con los proyectos en Benicàssim como el del IES y acompañará a Noel en el equipo. Los foros se van activando desde la firma, comienzan las reuniones 
semanales, más bien se duplican las reuniones semanales: ACJCS, EAV Joves Maranya, antiguo EAV Maranya, plenarios,... Los espacios han de reorganizarse, tenemos que ir asumiendo una rutina marcada por el trabajo que ya se ha realizado anteriormente. En esos lugares, preguntar no nos hace más tontas sino más preparadas para emprender el nuevo trabajo y por ello se generan espacios para que las personas que hoy están al frente de las diferentes sedes de la ACJCS puedan compartir dudas, temores y propuestas.

A todo esto le sumamos que en julio acaban las visitas técnicas municipales a la Casa para conseguir la licencia de actividad y por fin en septiembre podremos empezar con normalidad el trabajo en La Maranya. Por fin, hemos conseguido la licencia ${ }^{74}$. Toda esta tramitación legal se ha conseguido gracias al dinero y las horas voluntarias de muchas personas. 


\section{Fem cami $(2 \oslash 15 / 2 \oslash 16)$}

El curso que empieza en septiembre es un año para tirarse a la piscina, se producen cambios estructurales y cada persona se sitúa en el espacio que más comodidad le aporta, otros en el que necesariamente tienen que ocupar por su trayectoria vital en La Maranya. Existe una extensa red de comunicación tanto interna como externa pretendiendo siempre una visibilidad en el municipio y ahora también en la provincia pero aún así hay personas que no conocen el local, que no saben si es algo público o privado, si las actividades son solo para socias o son para algo más (Vecina, 002.12EI).

Los relevos generacionales ya están en marcha entran nuevos jóvenes con ganas y con responsabilidades, Noel marca los tiempos en la Casa mientras Mireia se aleja y se embarca en el proyecto de Casas en Vila-real aunque sigue el proyecto de tutorización entre iguales en el IES $^{75}$. Victor y Virginia siguen con este proyecto pero con muchos otros que necesariamente restarán tiempo a La Maranya. Las familias siguen ahí, muchas desde consumo y estancadas en que quieren hacer algo más. Las jóvenes se marchan, empiezan a estudiar en la universidad, unas lejos, otras más cerca. Algunas encabezan movimientos de estudiantes y generan el nacimiento de la Asociación de Alumnos de Benicàssim que más tarde fundará la Federació d'associacions d'estudiants vinculada al MLPV (Movimiento Laico Progresista Valenciano). Siguen entrando usuarias a las actividades que se realizan, siguen apareciendo consumidoras sobretodo de cursos de formación. Las relaciones con FVCJ siguen siendo muy cercanas, con todo el MLP en general y con Aragón en particular. La red va creciendo, cada vez se va enmarañando a más y más personas en este movimiento ciudadano y juvenil. Incluso las relaciones con la administración pública van cambiando. El Ayuntamiento se ha diferenciado por su silencio administrativo ante las repetidas peticiones de La Maranya, se ha posicionado burocráticamente 
ante las peticiones de participación en los diferentes órganos que han ido apareciendo en el municipio pero se ha abierto una pequeña ventana al exterior. La Regidora de juventud y la informadora juvenil del Casal Jove de Benicàssim asisten a la presentación del estudio de participación que realiza el IVAJ (Instituto Valenciano de la Juventud) y que se presenta en La Maranya como sede juvenil de Benicàssim. Esto es el comienzo de una nueva relación. Un hito en Benicàssim. Una señal de que nos hemos limpiado las heridas y ya no hay más opciones que la de avanzar aproximándose. Entran al local y hoy nos dejan un cartel en el buzón. Algo insólito, algo que puede cambiar la trayectoria de La Maranya o al menos su invisibilización como ha pasado hasta ahora.

La Maranya deja de ser ciudad de papel para asentarse en todos los ámbitos del territorio. Se hace fuerte, se enmaraña y crece. Y es que «las huellas de aquellos que caminan juntos nunca se borran» (proverbio africano) ${ }^{76}$. 
«Més lluny, heu d'anar més lluny dels arbres caiguts que ara us empresonen, i quan els haureu guanyat tingueu ben present no aturar-vos».

(cita de Lluis Llach en el pasaporte de la

Casa de Joventut La Maranya )
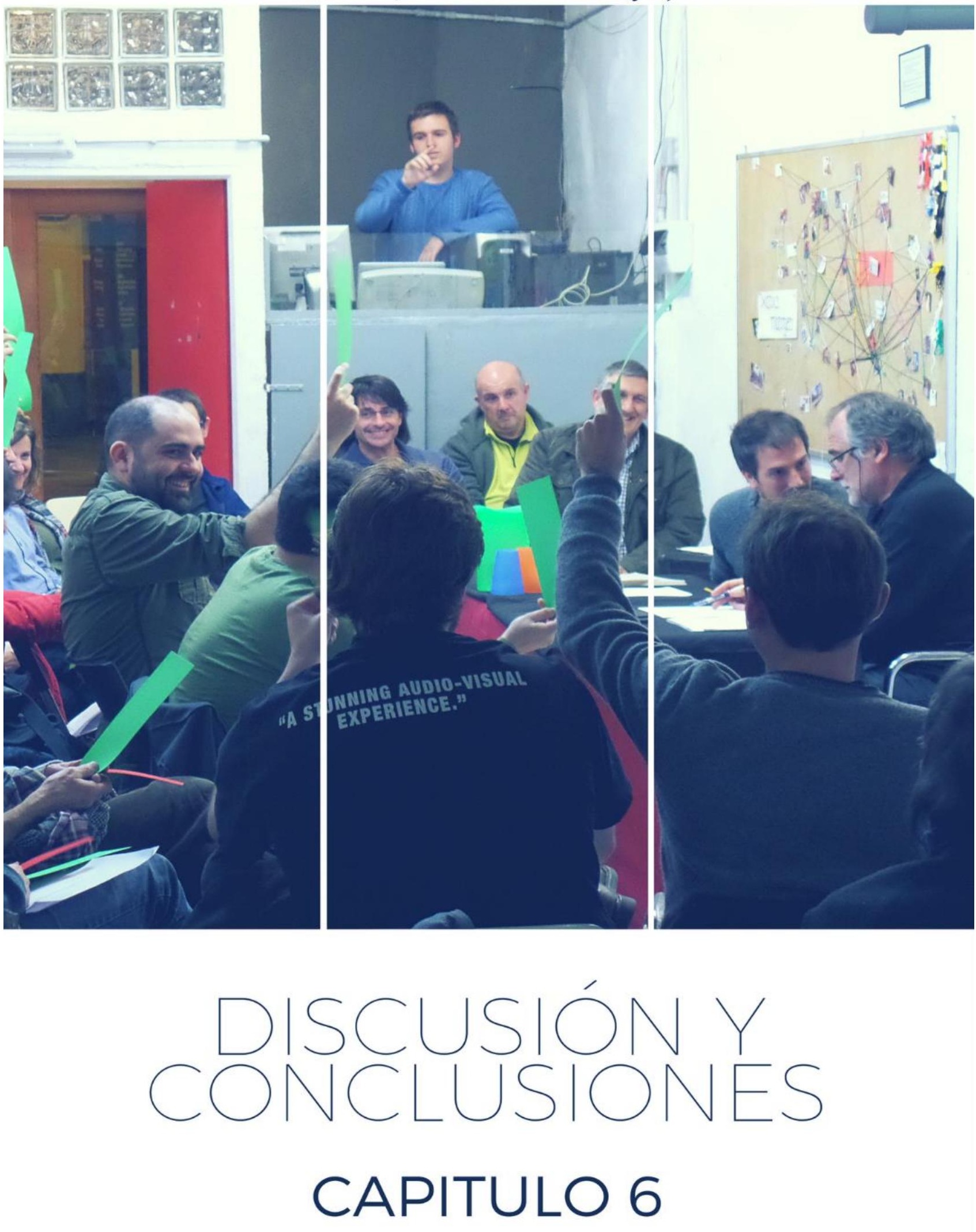

Después de presentar los resultados a través del relato de la Historia de Vida de La Maranya dedico el siguiente punto a conectar toda esta información haciendo una discusión conjunta con la teoría. Presentaré las conclusiones más relevantes a partir de las preguntas de investigación. Para ello recordamos cuales eran estas:

- ¿Qué papel juega la Casa de Joventut La Maranya en la cultura de participación social en las jóvenes de Benicàssim?

- ¿Por qué cubre este papel?

- ¿Es la Casa de Joventut La Maranya un agente educativo de cambio en el territorio?

- ¿Cómo se convierte la Casa de Joventut La Maranya en un agente educativo de cambio en el territorio?

La Casa de Joventut La Maranya de Benicàssim ha demostrado tener un papel importante en la construcción de la cultura de participación social en las jóvenes del municipio. Su proyecto reúne las condiciones oportunas para que las jóvenes puedan optar por un itinerario personal de aprendizaje sobre la participación y la justicia social a partir de elementos como las estrategias de afrontamiento, la gestión estructural de la participación, las relaciones, el discurso, el espacio de aprendizaje y la construcción colectiva. Vemos que si La Maranya cubre un relevante papel en la construcción de la cultura de participación de las jóvenes es porque se ha convertido en un agente educativo de cambio en el territorio. En este sentido he ido explorando los diferentes ingredientes que posibilitan este papel a la Casa de Joventut La Maranya.

Esta sería la premisa de la que partimos como conclusión genérica de este estudio. A continuación abordaré cuales son todos esos componentes que destacan en la Casa de Joventut La Maranya y que posibilitan que cubra dicho rol en el territorio.

Como hemos visto, la vinculación entre las dos principales preguntas de investigación hacen que abordemos este apartado desde su complementariedad. Debido a esta relación directa analizo las conclusiones 
a partir de diferentes ejes. Entre ellos se describen cuales son los principales factores para que la Casa de Joventut La Maranya cubra un papel como agente educativo de cambio en su territorio y se conforme como relevante en la cultura de participación juvenil.

Los elementos que analizaremos a continuación remarcan la importancia de trabajar desde el asociacionismo para así facilitar procesos de maduración, inserción social y desarrollo de un pensamiento crítico desde la acción (Palacios, 2005). Sabemos que la participación infantil y juvenil es predictora de una futura ciudadanía activa (Putman, 2002 y Collet y Sánchez, 2013) y además si esta participación se lleva a cabo en asociaciones de jóvenes voluntarias se fomenta la participación política futura en mayor medida (Mcfarland y Thomas, 2006). Si esta participación se trabaja de este modo podremos reforzar el componente democrático de nuestra sociedad a partir de modelos de participación que se consolidan como espacios de aprendizaje. En ellos encontraremos respuestas hacia modelos de gestión comunitaria que facilitan la democracia participativa a través del principio de subsidiariedad.

Para comprender mejor la estructura de los siguientes puntos vamos a ver que es lo que compone a una $\mathrm{CdJ}$ para convertirse en agente educativo de cambio y referente en la construcción de la cultura de participación juvenil. Se dan seis elementos que conforman la siguiente figura (figura 16). 
Figura 16. Elementos que convierten a Maranya en agente educativo de cambio.

Estructura

participativa

\section{Empoderamiento colectivo}

Estrategias de afrontamiento

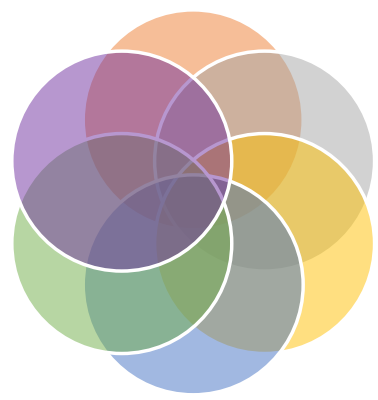

Organización del aprendizaje

Construcción del discurso

\section{Cuidado relacional}

La figura representa los seis ingredientes clave que permiten que $L a$ Maranya sea considerada como un agente educativo de cambio en el territorio y pueda influir de manera positiva en la cultura de participación juvenil. Estas seis partes se complementan entre ellas, a lo largo del texto de conclusiones se puede observar como se retroalimentan entre ellas por lo que una no puede subsistir sin la otra. Bien es cierto, que la figura se compone de un par de trinomios, uno de ellos da sentido a la parte más formal en una asociación. El otro se dedica a la parte más informal. Es así como la parte más formal dedicada a aquello más estructural se compone por 1) la estructura de participación, 2) la organización del aprendizaje y 3) la construcción del discurso. En cambio la parte informal, aquella que habla de la vida de la asociación, de la parte más humana está compuesta por 1) el cuidado relacional, 2) las estrategias de afrontamiento y 3) el empoderamiento colectivo.

Ambos lados deben complementarse y trabajarse para que el espacio sea potente en cuanto a la construcción de la cultura. Tanto la parte más organizativa, sistemática y formal como la más informal, de vida en el centro y de relaciones de convivencia que se dan en la Casa son esenciales para que una asociación como La Maranya se convierta en agente educativo 
de cambio en el territorio y pueda influir en la construcción de la cultura de participación juvenil.

Por la importancia de ambas partes debemos intentar que ninguna de ellas anule a la otra. El proceso de burocratización tiende a colonizar al «mundo de la vida» pero tampoco debemos descuidar como este último se pone en peligro si no existe una estructura donde apoyarse (Moliner, Traver, Ruiz y Segarra 2016). Así que hay que «crear mecanismos que facilitan los intercambios entre el mundo de la vida y el sistema, con el objetivo de crear instituciones educativas democráticas que fomentan la transformación social» (Elboj, Puigdellívol y Solery Valls, 2002:35). Que la Casa de Joventut La Maranya sea una escuela de democracia dependerá tanto de sus estructuras organizativas como de la agencia humana que forma parte de ella. 


\subsection{El lado formal de una asociación: el trinomio estructural.}

Partimos de la parte estructural, aquella que es más formal y pautada para saber cuales son las tres variables que le dan forma a la Casa. Estas son las siguientes: la gestión estructural de la participación, la gestión del espacio de aprendizaje y la construcción del discurso.

En el siguiente punto vamos a tratar estas tres cuestiones para abordar qué ingredientes las componen.

\subsubsection{La estructura de la participación.}

La estructura de una asociación es importante para saber la forma en la que organiza la participación para conseguir los objetivos que se ha marcado y entender así, cuales son las acciones que lleva a cabo para conseguirlos. La gestión estructural de la participación en La Maranya está basada en un modelo particular. A lo largo de toda la historia hemos visto que la participación se organiza de forma piramidal. El referente proviene de los modelos de participación de las Casas de Juventud en Zaragoza que elaboran un sistema propio que diferencia los grados de participación en función de la maduración participativa de las personas (Palacios, 2005).

Desde el grupo de animadoras que trabaja en el Casal Jove, y que más tarde forman parte del colectivo La Maranya, promueven la sistematización de este modelo de $\mathrm{CdJ}$ y sus prácticas. Es decir, organizan la participación en el Casal a partir de las ideas y estructuras que promueve el Modelo de CdJ valenciano y zaragozano. Esta sistematización va provocando cada vez más participación en el Centro a la vez que promueve liderazgos entre las jóvenes que poco a poco se transforman en activistas de grupos estables dando forma a la base social del centro: Estem Vius, Quatre Gats y Esplai Cataflai. En este hecho se observa como el grupo de jóvenes va asumiendo un grado de autonomía lo suficientemente elevado como para realizar y fortalecer sus propias iniciativas. Esto influye en la identidad juvenil haciendo que se conforme un movimiento estable y fuerte de jóvenes que promueven sus propias actividades. Willis (1998) también repara en esta idea describiendo la capacidad que tienen las jóvenes cuando se involucran en prácticas culturales que no han sido impuestas, sino que se han construido con su autonomía y a partir de sus propios intereses. También 
lo remarcan Kiilakoski y Kivijärvi (2015) que ven cómo cuando las jóvenes tienen la posibilidad de tomar decisiones y gestionar su espacio en centros juveniles (Youth clubs) se consiguen mejores resultados educativos. Esto hace que Estem Vius, Quatre Gats y Esplai Cataflai se fortalezcan y sean capaces de liderar el nacimiento de La Maranya.

Con este ejemplo vemos como se origina una trayectoria participativa personal que va de una menor a una mayor implicación. Esta estrategia de distribución participativa empodera a las jóvenes en la participación activa, el pensamiento reflexivo y crítico y la actuación responsable en torno a asuntos relevantes que les afectan (Díaz-Barriga, 2003). Así la convertimos en una participación efectiva, significativa y motivante para el aprendizaje de las jóvenes.

En este sentido una persona puede entrar como parte de un grupo de consumidoras puntuales, pasar por usuaria de algún taller que provoque la formación de un grupo estable, acabar dirigiéndolo como activista y finalizar formando parte activa del grupo de animadoras voluntarias. El análisis nos muestra como la misma joven va posicionándose en esta pirámide a partir de los aprendizajes que va realizando sobre su propia participación. El Esplai tiene una gran importancia en esta trayectoria ya que puede funcionar como primer escalón de participación cuando entras a la asociación como usuaria, y último cuando estás en él como animadora. Así vemos como este espacio infantil se convierte en el pilar que años más tarde sigue generando la base social para que haya jóvenes involucradas que gestionen la propia Casa de Juventud.

Por otro lado esta estrategia estructural provoca que las personas que forman parte del EAV sepan en cada momento cómo organizar las actividades y acciones que proponen, para así movilizar más a unos colectivos u a otros según las necesidades que haya en el momento dado. Además sirve de guía para enfocar las actividades hacia unos aprendizajes u otros en función de la participación que se da. Las responsabilidades van variando respecto de la fase participativa en la que se encuentran y así se van asumiendo compromisos en escala acompañados de los diferentes aprendizajes. Por ejemplo, una persona que es miembro de un grupo estable se preocupará de asistir a las sesiones del grupo y de participar de la vida cotidiana del grupo. En cambio, una activista se compromete a dar 
dinamismo al mismo grupo y por ello asume responsabilidades como la de convocar las reuniones y asegurarse de que se realizan las actas y se difunden entre el grupo, entre otras cosas.

Aunque parezca que esta estructura de participación piramidal hace alusión a una gradación del poder, realmente está estructurada de este modo para favorecer una trayectoria participativa personal como un proceso educativo y democrático. Por ello, es importante reparar en los componentes que sitúan a una persona en un grado u otro de maduración participativa. Principalmente existen cuatro variables que afectan a la maduración participativa: el compromiso, la responsabilidad, la disponibilidad y el liderazgo de las personas.

En el compromiso vemos como se puede medir la implicación de las personas, su esfuerzo por estar y formar parte del espacio y su capacidad para tomar conciencia de la importancia de su participación. De esta forma en función del grado en el que se sitúa la persona en la pirámide no estará igual de comprometida con los objetivos de la Casa una persona que asista para consumir un servicio concreto, como podría ser asistir a la fiesta de Halloween anual, como el activista de un grupo estable que forma parte del diseño y organización de la acción directa del grupo.

Observamos como las cuatro variables están muy relacionadas entre sí ya que la responsabilidad podría ser un factor clave dentro de la competencia del compromiso. Vemos como puedes situarte a la vez en un nivel u otro de responsabilidad y en función de ello asumirás un compromiso u otro con la asociación. En cuanto a esta variable es interesante indagar cómo dependiendo de la percepción que se tenga sobre ella la Casa gana o pierde fuerza. Algunas jóvenes hacen referencia a este factor antes de distanciarse de un modo u otro de la Casa. La razón se produce cuando estas responsabilidades se han sentido como una obligación, perdiendo el interés y dejando de sentirlas como algo propio. En estos casos o bien las personas han abandonado la Casa, se han distanciado del grupo o el grupo en sí se ha acabado. Cuando sienten la presión y empiezan a desilusionarse por tareas que antes les emocionaban, el desenlace siempre ha sido el distanciamiento de la persona respecto al grupo. «Lo debido descansa en el reconocimiento de un vínculo, de una ligatio, de la que sigue una ob-ligatio ob-ligación, y entonces la obligación puede ser o bien un deber, es decir, la ob-ligatio obl- 
ligación, respuesta a una exigencia, o bien un regalo que hace quien sabe y se siente ligado a otro. Sin ese reconocimiento del vínculo, el deber o el regalo carecen de sentido» (Cortina, 2007). Como vemos la obligación puede entenderse de formas distintas y dependerá de cómo se trabaje el reconocimiento de ese vínculo podrá situarse en un lugar o en otro. Esto puede tener relación con las diferencias de compromiso que cada persona decide ocupar y la falta de comprensión entre el resto. Como con todo en la vida las percepciones cambian de unas personas a otras y esto puede afectar en mayor o menor medida en función de los espacios que existan para compartir estos estados. Por esta razón, centrándonos en el aprendizaje que ello puede conllevar, debemos preocuparnos más por el proceso que se lleve a cabo para que una persona reconozca una tarea como deber o como regalo, y no tanto en el número de responsabilidades que asuma en el grupo, porque de ello dependerá su estabilidad en el tiempo. Así, lo interesante para conseguir, sea de la forma que sea, una participación auténtica es garantizar que las protagonistas encuentren aquellos modos de organizarse y funcionar que sean más acordes con su contexto y sus necesidades (Cornejo, González y Caldichoury, 2007) y trabajar desde la educación el compromiso y la responsabilidad. Por eso como se analiza desde el proyecto HEBE (Soler, 2016) necesitamos justamente de nuevas formas y estructuras de participación juvenil que surjan de las mismas jóvenes y se configuren a partir de sus principios y necesidades, que tengan una organización interna, definida y sostenida por las mismas jóvenes y que puedan convivir con las estructuras creadas para la democracia representativa política.

Otra variable que afecta al proceso de maduración participativa es la disponibilidad. El tiempo es un factor muy valorado en la actualidad, la ciudadanía está atrapada en el tiempo individual y se olvida de lo global interpelando de este modo al compromiso social que puede asumir en espacios colectivos (Traver, Aguirre y Moliner, en prensa). Por ello, en función de la esfera individual de cada persona y del compromiso que asuma con la sociedad se dispondrá de más o menos tiempo para dedicar a proyectos colectivos. Es así como se analiza a lo largo de la historia de $\mathrm{La}$ Maranya. Existen diferentes niveles de disponibilidad y de ello depende que la persona se sitúe en un nivel u otro de participación en la Casa. Muchas jóvenes están bloqueadas por las exigencias académicas y esto es uno de los 
factores que influyen en su percepción sobre el tiempo. Tal y como expone Melendro (2016) son jóvenes sin tiempo abocados a afrontar la vida cotidiana, sin tiempo para dejar de ser presente, sin tiempo para proyectar futuro, en un período evolutivo en que no es fácil hacerlo, sin tiempo cuando más lo necesitan, los que más lo necesitan. Aquí queremos poner un foco de atención para futuras propuestas de análisis de la realidad ya que considero que es un factor muy importante, el análisis del tiempo en la pedagogía del ocio y del tiempo libre.

Por otro lado, en relación a la maduración participativa encontramos la vinculación con el liderazgo que se ejerce en la Casa ya que este afecta a los roles que se asumen entre las participantes. Vemos que cuando una persona se ha caracterizado por su capacidad para dirigir, coordinar e influir en el grupo han pasado de ser usuarias a activistas de grupo estable e incluso a formar parte del EAV. De ahí que el liderazgo que se asuma afecte en la trayectoria participativa de la persona, a la estabilidad y al proyecto educativo de la Casa de un modo u otro (Agüera, 2004; Volante, 2008; Bolívar, 2010; Guibert, 2011).

Todo esto podemos ejemplificarlo con el papel que ejerce el EAV en todo este proceso. En primer lugar, el EAV se encuentra situado en la cúspide de la pirámide, es según el Modelo de CdJ el objeto de mayor maduración participativa. Por eso el tipo de liderazgo que asuman las personas que lo conforman influirá en las trayectorias participativas del resto de miembros de la Casa ya que la participación aumenta las habilidades de liderazgo (Walker y Saito, 2011) y por ello debemos de analizar y reflexionar sobre el tipo de liderazgo que mostramos ya que este influye en el trabajo de unos principios u otros (Cassels, Post y Nestor, 2015). Además se muestra en la historia como existen diferencias significativas en la participación de las personas que conforman el EAV. Hay unas que asumen claramente el rol de coordinadoras y otras que se instalan más en un rol de aprendizaje, y en medio están aquellas que se lanzan a dirigir proyectos pero con el acompañamiento de la coordinación. Me centro en el análisis concreto de esta participación porque el EAV es el encargado de llevar a cabo el proyecto educativo del centro además de ser un modelo hacia el resto de estructuras de la Casa. 
Digamos que al igual que la Casa se estructura a partir de la pirámide de participación de 5 fases, el EAV también se compone de diferentes fases en función de la maduración participativa de sus miembros:

- Animadoras coordinadoras de EAV.

- Monitoras voluntarias de proyectos.

- Aprendices de equipo.

Un factor que puede influir en esta distribución es la confianza mutua que se tiene en el grupo ya que este se identifica con sus líderes. Aunque en ocasiones esto provoca una dependencia del resto del equipo con las coordinadoras. No se sabe si funcionaría igual la CdJ sin esos liderazgos, si se cambiasen por otros o si no existieran pero lo que sí que aparece es que el acompañamiento, en múltiples ocasiones, se convierte en dirección y eso puede influir en la maduración de las personas para asumir responsabilidades en la CdJ. La coordinación tiene unas ideas muy consolidadas del Modelo de CdJ y del proyecto que quieren para $\mathrm{La}$ Maranya, esto junto con sus dotes de comunicación hacen que sea más sencillo dirigirse hacia un modelo concreto de acción. Creen saber cual es el camino que hay que seguir para que la participación aumente exponencialmente y esos son los pasos que quieren dar. Aunque hay que tener en cuenta que un elemento que dificulta la participación es no conseguir romper con esos estereotipos y roles que se asumen tradicionalmente y que ocupa cada actor social (Moliner, Traver, Ruiz y Segarra, 2006). Si en el proceso de aprendizaje no se consigue romper con ello nos encontraremos con dependencias entre las diferentes participantes que pueden llegar a influir en la consecución del relevo generacional que el grupo de coordinación espera.

Con todo esto las tareas se acaban repartiendo en función del compromiso, la disponibilidad y la responsabilidad de las personas aunque también influyen la iniciativa y las capacidades que tengan en la coordinación de grupos, es decir, el liderazgo. Vemos en función de estas variables como se establece un tipo de liderazgo u otro dependiendo del valor del contexto en el que se desarrolle tal y como Watkins (1989) afirmaba al hablar del comportamiento ideal de un líder. Del mismo modo, Hersey y Blanchard (1977) hablan que según la madurez, formada por la voluntad y la 
capacidad del grupo, el líder debe actuar de un modo u otro pasando por etapas de dirección, persuasión, participación o delegación. El EAV más que situarse en un estilo de líder u otro asume un cambio de papel en función de las características propias de la situación tal y como todas estas autoras describen. Esta elección cuestiona los valores que se arraigan en la Casa como son el diálogo, la horizontalidad, la toma de decisiones colectiva, el compartir objetivos, la confianza y reconocimiento mutuo y la planificación conjunta, entre otros aspectos.

Por ello debemos tener en cuenta que el tipo de liderazgo que se ejerza va a influir en el crecimiento individual y colectivo además de servir de modelo para el aprendizaje en la Casa. Así pues hay que replantearse la elección hacia un modelo de liderazgo distribuido (Gronn, 2002; Timperley, 2005; Spillane, 2006) que facilite el trabajo comunitario y que posibilite que todo el EAV se reconvierta en un agente de cambio dentro del colectivo. Conseguirlo no depende únicamente del cambio en la distribución de tareas sino que conlleva un cambio en la cultura del grupo (Murillo, 2006).

Así hay que plantear espacios desde el diálogo, la horizontalidad y la toma de decisiones conjunta. En el EAV son múltiples las ocasiones en las que esto no se produce de forma compartida y horizontal ya que sobresale la distribución arriba expuesta haciendo que la coordinación del grupo EAV asuma la toma de decisiones. Tampoco podemos obviar que en este tipo de elección hacia un estilo de liderazgo u otro influye en que el resto del equipo sea capaz de ver sus propias potencialidades en las aportaciones que realizan. Tal y como Moliner, Traver, Ruiz y Segarra (2016) afirman se conseguirá una participación plena cuando las personas que forman el colectivo sean capaces de adoptar protagonismo en este sentido. Comparándolo con las teorías de Hersey y Blanchard (1977) esto podría hacer referencia a aquella maduración del colectivo de la que hablaban y así a mayor adopción de protagonismo mayor madurez. En ello podemos ver una relación directa con el reconocimiento mutuo asumiendo la importancia de este para conseguir una madurez adecuada en las jóvenes. Recordamos que había jóvenes que no sentían un reconocimiento por el trabajo que realizaban, más bien percibían lo contrario, que si las cosas no se hacían de una cierta manera no estaban bien hechas. Esto abre una puerta de análisis a qué es lo que ocurriría si los proyectos y actividades no 
llevaran la forma que siempre se les ha dado, si no se siguieran exactamente los pasos dados antes por otras personas dentro del movimiento. Abrir paso a nuevas iniciativas y diferentes creatividades podría fortalecer el proyecto desde una mayor apertura sustentada por la diversidad. Eso, o realmente hacer explícito el reconocimiento, dar la oportunidad de contrastar con las diferentes opciones para construir algo nuevo de forma compartida.

Por esta razón « los motores de la acción no están en la obediencia sino en el significado; la gente hace aquello a lo que le encuentra sentido. El sentido es una producción colectiva, se construye con «otros significativos»» (Cohendoz, 2001). Así pues, para conseguir que la participación sea plena en este equipo se podría tener en cuenta el objetivo de pautar la participación con la finalidad de que todas las personas que forman parte tengan las mismas oportunidades de aportar en la construcción del conocimiento colectivo, encontrando el sentido en los espacios y los tiempos y adecuándolos a las características de cada una de las miembros. De este modo se favorecerá la consecución de un empoderamiento individual basado en una escala progresiva de participación que acabe dando lugar a algo más interesante, el empoderamiento del colectivo a partir de la participación democrática y el diálogo igualitario bajo un consenso argumentativo.

Aun existiendo un liderazgo tan claro, se comparten objetivos en el grupo y lo que más interesa dentro del equipo es el buen funcionamiento de la asociación y no asumir protagonismos ni dividir roles por estancias de poder. Lo remarcan en multitud de ocasiones insistiendo en la importancia de participar en las reuniones, los plenarios y las asambleas con el objetivo de planificar juntas el programa de La Maranya y así realizar el reparto de tareas correspondiente en función de las áreas de trabajo de una Casa de Juventud asumiendo que las personas jóvenes son interlocutores de pleno derecho (Úcar, 2008:6).

Vemos que estas acciones podrían ser facilitadores para conseguir un liderazgo distribuido en el colectivo. Además otra estrategia que sería útil es el objetivo de comunicar e informar de las acciones que se llevan a cabo en la Casa. Se cuidan los espacios en los que el grupo comparte proyectos, actividades, noticias y toda aquella información que puede resultar útil para 
perseguir objetivos comunes. Se exponen en los paneles informativos de la asociación y también se cuelgan en el blog de internet para favorecer la transparencia.

Un aspecto del que no hemos hablado casi es de la insistencia de generar un relevo generacional que permita que el EAV pueda ir cambiando. Es una de las máximas preocupaciones de la coordinación del EAV y es algo que se intenta trabajar a partir de la pirámide de participación. La coordinación está preocupada porque el resto de miembros no asumen responsabilidades del modo que ellas querrían y no existe una base social fuerte para ir generando activistas que acaben siendo ese relevo. Respecto a la primera cuestión podemos pararnos y pensar sobre si la asunción de responsabilidades surge de manera natural o impuesta. Si las jóvenes, a partir de su madurez participativa, deciden comprometerse de un modo u otro. Además de repensar sobre cómo se enfoca la asunción de estas responsabilidades. Por otro lado, replantear la situación con el colectivo podría ser una de las soluciones tal y como se hizo hace años. Recordemos que ocurre lo mismo en otro momento de la Historia de La Maranya, cuando se pide el relevo en Esplai. Si recordamos, en este caso, con la reflexión colectiva con las familias surgen una serie de opciones para dar respuesta a esta situación. La solución se vio en la posibilidad de generar vínculos con la comunidad fuera de las puertas del Esplai y por involucrar de forma más directa a familias, niños y niñas en la programación y gestión del grupo. Es así por lo que nos podríamos cuestionar si es necesario que el relevo sea únicamente generacional, ¿no podría producirse un relevo desde otros lugares?, ¿tal vez esos relevos se pudieran dar desde los grupos de adultos o desde nuevos animadores que entren en la Casa? El planteamiento de la coordinación del grupo EAV es conseguir desde la reflexión y con su propio liderazgo un relevo generacional que les sustituya cuando ya no estén por ese espacio. Habría que analizar qué opciones podrían darse y cuáles son las razones por las que no se da a nivel generacional.

En definitiva, tenemos que procurar que las asociaciones sean contextos donde poder desarrollar prácticas en función de unos intereses personales. Debemos configurar esos espacios, y además facilitar que las participantes tengan los recursos para aprender lo que precisan, con el objetivo de que 
actúen y tomen decisiones haciéndolo a partir de su propio conocimiento (Wenger, 2001:27). De este modo, en La Maranya, se fracciona la participación en niveles con la idea de generar esos espacios en los que cada persona, en función de su maduración participativa, pueda actuar en el proceso de aprendizaje correspondiente. Por ello, «funcionar desde criterios de eficiencia, priorizar objetivos y afrontar la necesidad de un reparto de tareas, debe entenderse desde la empatía, el respeto y sobre todo la búsqueda de coherencia entre los valores y la metodología» (Casado y Gómez, 2010:16) y nunca desde estamentos de poder, autoridad y/o personalismos. Es así por lo que tenemos que caminar hacia un liderazgo distribuido dentro de toda esta estructura piramidal de participación. 


\subsubsection{La construcción del discurso.}

Explorar la línea ideológica de la CdJ La Maranya y reconocer cómo se genera el discurso del movimiento nos remarca la importancia de la construcción colectiva en el discurso que asume la Casa y sus participantes.

Podríamos definir que el discurso de la $\mathrm{CdJ}$ nace de un modelo basado en el Movimiento Laico y Progresista (Palacios, 2005; Fundació Ferrer i Guàrdia, 2006). Las personas que forman parte de la Casa siguen una línea ideológica común centrada en el fomento de la democracia desde una ciudadanía crítica, activa y que lucha por una justicia social. No aparecen líneas ideológicas contrapuestas en este sentido aunque sí que se dé una diversidad de miradas sobretodo gracias a la intergeneracionalidad del centro. No existen contraposiciones dentro de unos valores que protegen los derechos humanos y se enmarcan en procesos de justicia social.

Aún así ponemos el foco de interés en cómo el discurso colectivo de la CdJ se empieza a fraguar en los incidentes críticos por los que pasa la Asociación. La Maranya se reconstruye en los momentos de crisis y estos son los que permiten que se vaya generando un discurso común entre todo el colectivo, ya no sólo entre las jóvenes sino también entre las familias y las animadoras. Se dan incidentes que producen cambios como el de pasar de ser Casal Jove a convertirse en Casa de Juventud dando mayor peso a la educación y la autogestión juvenil en el centro. Otros, que provocan transformaciones como el traslado de un local que depende de la gestión del Ayuntamiento, que genera multitud de burocracia y que paraliza la acción juvenil, a un espacio independiente de la administración con autonomía propia y con la expectativa de volver al espacio público. Existen otros momentos que generan sentimiento de pérdida, de desazón y la necesidad de reubicarse como son las marchas de algunas jóvenes del proyecto, unas aceptadas y otras desestabilizadoras. Otros que ocasionan conflictos como las decisiones que asume el Ayuntamiento y otros que inducen miedos como la falta de participación en grupos estables y la débil asunción de responsabilidades de las jóvenes. En todos estos momentos la Casa genera discurso, evoluciona y se transforma. Por eso deben ser momentos que tienen que estudiarse bien y reflexionar sobre ellos de manera individual y colectiva porque, entre otras cosas, provocan que $L a$ Maranya hoy sea quien es. 
Efectivamente es en los incidentes críticos donde el grupo debe posicionarse y en esa acción colectiva es donde nace la ideología que vertebra a la Casa. En esta ideología hay que destacar que La Maranya no es un centro partidista, no se posiciona con unos partidos u otros, lo podemos ver cuando a los actos se invita a todas las formaciones políticas aunque la parte más conservadora no aparezca nunca por allí. Aún así, sí que es un lugar político donde se genera debate y crítica a partir de la libertad de pensamiento, la conciencia crítica de las personas y su propio proceso de maduración participativa. Un ejemplo de ello son las sesiones del Recrea la tena ciutat donde diferentes agrupaciones políticas junto con ciudadanos y ciudadanas del municipio participan en la elaboración de un plan conjunto para mejorar Benicàssim. La Maranya, en esos casos, es el punto de inflexión, quiere consagrarse como un lugar en el cual defender unos derechos que favorezcan el bien común sin situarse a favor o en contra de unos u otros partidos. Vemos como con la elaboración del ciclo de charlas Recrea se genera un espacio para el debate colectivo y la construcción de un proyecto común. Este hecho evidencia la importancia de la mirada política en la CdJ y fortalece el discurso de la Casa en particular ya que favorece el análisis de la realidad de un modo colectivo y con ello la concientización (Freire, 1974) de las personas que allí participan, haciéndose protagonistas de su realidad y de su propio proyecto de vida.

En este sentido lo apolítico se entiende como una forma de irresponsabilidad encubierta, la despreocupación por la política es una manifestación de irresponsabilidad cívica (Ander Egg, 2004). Este argumento se trabaja como línea central en la Casa. En el proyecto de la CdJ hay una línea de acción que es el trabajo en valores en la que se analizan diferentes situaciones de actualidad para trabajar con las jóvenes. Alguna de las campañas son, por ejemplo, sobre la homofobia, la tauromaquia, las energías renovables o los refugiados. De este modo va trabajándose un discurso que se encamina hacia la construcción de ciudadanía crítica. Una ciudadanía crítica que apela al ejercicio de una ciudadanía que problematiza la realidad, reflexiona cooperativamente y propone acciones colectivas. Para ello es necesario un liderazgo compartido, un compromiso personal y social y una implicación activa en la planificación, toma de decisiones democrática y puesta en marcha de la acción (Sales, 2012 y Benjamin, 2002). 
Esto tiene relación directa con las formas de entender la acción en La Maranya si bien como algo voluntario, activista, militante o incluso como un espacio laboral. Analizar el significado de estos conceptos nos sigue enseñando sobre el significado de la participación que tiene la Casa además de remarcar hacia donde se dirige el discurso social.

Tres son las palabras que surgen en La Maranya para describir la acción sin ánimo de lucro que realizan muchos de sus participantes: voluntariado, activismo y militancia. La idea de voluntariado se empieza a transmitir desde bien adolescentes, la importancia de la palabra y de la actividad que supone, sin convertirlo en un voluntariado empresarial sino en uno que te moviliza por sus luchas y por el valor de la solidaridad. Sabemos que una de las mayores manifestaciones de solidaridad, además de ser una con una gran incidencia en la sociedad, es el voluntariado social (Traver, Aguirre, Moliner, en prensa). Siguiendo con esta idea y con las aportaciones de García Roca (1994) y García Roca y Comes (1995) encontramos los tres ingredientes básicos de la solidaridad mediante los cuales el voluntariado social ha ido construyendo su propia identidad. Uno de ellos es la compasión, el sentirse afectado y vivir como propio el mundo del otro; el segundo es el reconocimiento del otro y el tercero es la universalización como tendencia de nuestros actos. Esto ha generado tres modalidades de voluntariado en relación a estos tres ingredientes: el voluntariado asistencial, el voluntariado de la rehabilitación y el voluntariado de la promoción. Este último que atiende a dimensiones estructurales y de acción transformadora es el que equiparamos al trabajo en La Maranya. La persona voluntaria forma parte de la base social de la Asociación y se entiende que es aquella que participa en la Casa asumiendo responsabilidades y tareas concretas sin obtener una remuneración económica por ello, buscando unos beneficios sociales, la lucha contra la exclusión social y el cambio estructural. Su participación puede ser más bien puntual en un proyecto concreto o continua pero con la única pretensión de aprender de lo que en La Maranya se lleva a cabo. La persona voluntaria es la única figura que está reglada a nivel legislativo y por ello, todas las personas que asumen responsabilidades en la Casa se llamarán voluntarias si tienen responsabilidades y un compromiso firmado con ella. 
El enfoque desde el que se trabaja en La Maranya es conseguir que las jóvenes asuman que el protagonismo en la transformación recae en la propia comunidad de la que forma parte y su implicación compondrá una ayuda real a la comunidad (Marchioni, 2001). De ahí que se insista, desde que son pequeñas y a través de las estructuras participativas, en la asunción del compromiso con la comunidad. Con este enfoque se pasa a poner en el centro de la acción solidaria a la comunidad y al medio social posibilitando una nueva denominación, el voluntaridado del desarrollo (Ortega, Mínguez y Gil 1996), que promoverá una forma organizada de participación en la vida social. Desde este punto de vista, la solidaridad y su expresión en el voluntariado se convierten en objetivo clave de la educación del proyecto de La Maranya ya que busca formar personas y grupos sociales que sean eficaces y afectivamente solidarias (Traver, Aguirre y Moliner, en prensa).

El siguiente escalón podríamos llamarlo activista o militante, no existe una inclinación firme por una o por la otra en La Maranya. A algunas personas les gusta más definirse como activista por la implicación activa que la palabra comporta, a otras les anima más la idea de militancia por el compromiso hacia la causa que conlleva.

Entre estas dos palabras se define una persona que realiza tareas voluntarias en la Casa pero las asume desde un papel de lucha dentro del movimiento de Casas de Juventud. Es decir, son personas que tienen muy asumido su rol y creen fielmente en el proyecto juvenil en el que participan. Harán todo lo posible para que este no decaiga y se movilizarán de cualquier forma para conseguir que el movimiento llegue al mayor número de jóvenes posible. Realmente dedican sus horas y días a una línea de acción concreta en la vida pública, y en este caso se dedican en pleno esfuerzo a que la participación juvenil tenga espacios de representación en los municipios. Esta es su causa y la consideran imprescindible y necesaria socialmente.

$\mathrm{Si}$ recordamos las diferentes fases por las que pasaba una persona en el EAV podemos apreciar el cambio de mentalidad de aprendiz a voluntaria y de voluntaria a militante. El primer nivel aún mantiene las dudas y compara el trabajo que desarrolla como voluntaria con un trabajo remunerado y empresarial hasta que a partir de la experiencia y la asunción del discurso del movimiento se dan cuenta que si el voluntariado te lo tomas como un trabajo estás perdiendo la mirada activista y militante, y eso te hará 
quemarte con las responsabilidades y al final desistir en el intento de militar en el movimiento. Es lo que le ocurre de forma concreta a una de las integrantes del EAV, en un inicio pone al mismo nivel el trabajo en $\mathrm{La}$ Maranya con el que desarrolla de forma remunerada fuera de la Casa, poco a poco se va dando cuenta que es necesario cambiar de mirada, las coordinadoras del grupo así le aconsejan, si quiere hacer voluntariado bien tiene que diferenciarlo de la parcela remunerada o bien luchar para conseguir que lo que hoy hace como voluntaria pueda llegar el día que pueda hacerlo de forma remunerada. Se trata principalmente de crear futuros de vida viables, haciendo cosas que cambian la sociedad e influyendo en que este estilo de acción intensifique el valor del trabajo social y la necesidad de construir cultura desde la ciudadanía.

Por ello, desean mantener activo el modelo educativo en el tiempo libre a partir de sus acciones y entre ellas está la aportación económica como socias, de su trabajo voluntario y de los beneficios generados a partir de las actividades que realizan. Los beneficios económicos no se reparten entre las participantes sino que se reinvierte en actividades y otros gastos que la entidad educativa y cultural tiene. Esto es un valor militante que se transfiere de unas personas a otras en la Casa.

Otro aspecto que matiza la acción militante es la idea de capitalizar el movimiento. Aspecto que se ha considerado objetivo principal de la acción del EAV. Hemos visto en la historia como desde las experiencias compartidas con otros movimientos vecinos como el de Zaragoza se recomienda este tipo de medidas para conseguir fortalecer el movimiento. El modo de conseguirlo es a partir del aumento de los ingresos económicos, la ampliación de la base de voluntariado o la consecución de instalaciones. Este es el modo que tienen de fortalecer el movimiento de asociacionismo juvenil con el objetivo de conseguir espacios educativos y culturales con una misión pública promovida por la propia ciudadanía.

El trabajo a partir del voluntariado, activismo y militancia deja ver la importancia que se le da en la Casa a que sea la propia ciudadanía la encargada de gestionar sus propios espacios. Las asociaciones surgen como herramienta de apoyo social, como el mecanismo que hace posible que se cubran las necesidades entre la propia ciudadanía (Trilla, 1996; Alberich, 2007; Palacios, 2005). Hoy se parecen más a centros procuradores de 
servicios que a espacios de reflexión, acción y apoyo ciudadano y por esta razón, La Maranya continúa firme ante la idea de continuar utilizando las asociaciones como espacios donde ejercer la democracia, basándose en el principio de subsidiariedad (Artículo 5, Tratado Unión Europea), muy extendido en otros países democráticos y tan poco valorado en el nuestro. Cuando los gobiernos democráticos se basan en este principio saben que son los máximos responsables de los servicios ciudadanos pero que sólo lo gestionarán si la propia ciudadanía no es capaz de hacerlo a través de las asociaciones. Las experiencias llevadas a cabo, por ejemplo en Alemania o Francia, ya confirman que esta forma de funcionar de los servicios públicos tiene muchas ventajas y refuerza los mecanismos de participación y democracia ciudadana (Jacobson, 2014). En Cataluña se empieza a utilizar en este sentido el término de gestión comunitaria a partir del trabajo de la Plataforma de entidades de Gestión Ciudadana de Barcelona (Alcántara, 2016) dentro de un nuevo marco de acción como es la Economía social y solidaria (ESS) (Chavez y Monzón 2006; Guerra 2004, Coraggio 2015; Razetto, 2000) y desmarcándose de la terminología que utiliza la administración como es la de gestión cívica o colaborativa. En reflexiones como la de Font, Ojeda y Urbano (2015) se ve la importancia de definir los proyectos de una u otra forma ya que así se «hace visible la voluntad transformadora que ambiciona y el grado de autonomía que desea, y por lo tanto implica un posicionamiento ideológico y político en torno a la prestación de servicios y de rebote también, frente al modelo económico dominante y el rol que juega la administración en el mismo». Es por ello por lo que adoptamos la lucha sobre la gestión comunitaria por corresponderse con la idea de principio de subsidiariedad que recoge $\mathrm{La}$ Maranya. Tal y como expone el principio de subsidiariedad se parte de la idea de que los equipamientos no son propiedad de la administración sino que pertenecen a la ciudadanía por lo que «es derecho y responsabilidad de la sociedad el hecho de tomar parte de la gestión de aquellos recursos y servicios que le afectan en su cotidianidad» (Font, Ojeda y Urbano, 2015). De esta forma el binomio de gestión al que estamos acostumbradas se transforma y la administración asume el papel de acompañamiento y facilitadora de la gestión. Así es como nos lo explicaba Jacobson (2014) en algunas de sus visitas a La Maranya, al igual que lo referencia Alcántara (2016) en la charla que ofreció en la Casa, poniendo en el centro a las 
verdaderas protagonistas y partiendo de los siguientes valores que enumeran Font, Ojeda y Urbano (2015) y que la diferencian del resto de gestiones:

- Accesibilidad / universalidad.

- Democracia directa y autodeterminación.

- Transparencia.

- Autocontrol y autoevaluación.

- Vínculos territoriales.

- Capacidad de convertirse en una herramienta al servicio de la comunidad para transformar su entorno.

- Posibilidad de reversión en los propios proyectos y el retorno a la comunidad

Todo esto entronca con el interés de La Maranya por volver al espacio público, recuperarlo desde la ciudadanía. Esto lo observamos en uno de los videos que tiene la Casa colgados en youtube (Els portadors de somnis) en el que ya visibilizan su intención afirmando que La Maranya volverá a tener razón de ser cuando vuelva al espacio público porque es donde debe estar.

El hecho de que La Maranya reivindique el espacio público y la gestión desde la iniciativa ciudadana juvenil hace que se convierta en un lugar adecuado para trabajar a partir del marco de Gestión Comunitaria pero no sólo por ello sino por estar vinculada a todos los valores que enumeraba antes tal y como podemos leer a lo largo de estas conclusiones. No olvidemos como Subirats (2005) nos recuerda el interés por conocer y analizar otras formas de organización social que faciliten la reconstrucción colectiva, los vínculos entre las personas, el sentido de colectividad y el respeto hacia la autonomía individual. Aspectos que van analizándose a lo largo de esta investigación.

De este modo, las jóvenes serán las encargadas de diseñar esas actividades y servicios, lo que les reportará un itinerario de aprendizajes a partir de la participación real. Tenemos dos variables interesantes en este hecho, la primera la idea de que sea la propia ciudadanía la encargada de gestionar la cultura, y la segunda la posibilidad de que sea un colectivo como el juvenil, 
habitualmente marginado en la participación, el encargado de hacerlo y aprender mientras lo hace. «La democracia participativa e igualitaria por la que apostamos, debe recuperar la voz, la presencia y los saberes de los que han ido siendo apartados de los ámbitos decisionales. Reforzando las capacidades educativas de la participación»(Subirats, 2005:8). De este modo, se conseguirá ocupar un papel relevante como agente de cambio educativo en el territorio.

De ahí que necesitemos procesos de participación transformadores, prácticas y reflexiones desde la participación social que nos ayuden a afrontar y transformar la realidad social desde el espacio público, favoreciendo la construcción colectiva de ciudadanía activa y justa. Recuperar el espacio público para reconstruirlo de manera colectiva cediendo el protagonismo político a la ciudadanía viéndose capaz de construir su propia cultura a partir del bien común. Tal y como expone Aranguren (2010) no se trata de invisibilizar el papel del Estado pero si aceptar que existe una nueva sociedad civil organizada que apuesta por un espacio de gobernanza cooperativa y relacional.

Contraponiendo la realidad de los movimientos ciudadanos al de la administración vemos como el panorama generalizado es el uso de mecanismos ajenos a estas ideas, en su mayoría centradas en un marco de democracia participativa distorsionado y dentro de las instituciones públicas. Pero realmente nos preguntamos ¿existe calidad democrática en las actuales experiencias de democracia participativa? (Parés, 2009). Si la democracia participativa no se piensa desde las asociaciones y las actividades colectivas y ciudadanas, esta democracia se convertirá en un espacio institucionalizado, burocrático y restrictivo. Esta idea no se pone en duda ya que cada vez se encuentran más pruebas de incumplimiento democrático por parte de la administración pública (Subirats, 2005) y por ello la democracia participativa se convierte más en burocracia y desazón que en otra cosa (Serrano, 2008). Si se cree en otras formas de participación que no sean el voto y la consulta, se deben hacer extensivas al mayor número de ciudadanas posible (Alberich, 2004) fomentando los cauces participativos desde la gestión comunitaria.

Así pues, burocratizar la participación a partir de órganos y más órganos de participación ciudadana en lugar de potenciar los espacios y redes sociales 
ya existentes de participación popular únicamente nos llevará al agotamiento participativo y a la idea de que la participación no sirve para nada. «No hay que olvidar que el pensamiento neoliberal tiene un enorme poder y facilidad para penetrar, controlar, privatizar y vaciar de contenido las iniciativas y redes de educación no formal, con el consiguiente aumento de la desigualdad» (Carbonell, 2015:59). Por eso el problema está en la institucionalización del saber (Reimer, 1973 en Carbonell 2015:26) y en nuestro caso, la institucionalización de la participación en el ocio y el tiempo libre.

De forma resumida, vemos como la asunción de este discurso social, comunitario, de autogestión, concientización, responsabilidad cívica, trabajo en valores y fomento de la democracia favorece el hecho de que la Casa de Joventut La Maranya se defina como agente educativo de cambio y sea fundamental en la construcción de una cultura de participación democrática entre las jóvenes. 


\subsubsection{La organización delaprendizaje.}

Negar que la CdJ La Maranya es un espacio educativo sería un error. Se consolida como referente educativo entre familiares, profesorado, vecinas, técnicos y jóvenes como hemos visto a lo largo de la historia. Las familias dejan a sus hijos e hijas porque confían y creen en el proyecto educativo y piensan que las personas que coordinan el mismo pueden ser referentes para todas ellas. Por otro lado, desde el Ayuntamiento se reconoce su labor y se alaba su iniciativa pero no se apoya el proyecto de manera directa. Se amparan en la legislación y en las normativas vigentes de participación aunque la alcaldesa si que dice que si no existe un espacio participativo, promovido desde el Ayuntamiento, donde La Maranya tenga cabida tal vez haya que crearlo. Esto lo afirma al ver que no cumplen las características para entrar en ninguna de las plataformas creadas (mesa de la solidaridad, consejos escolares, consejos de la participación ciudadana y participación para presupuestos participativos entre otros) debido a los propios reglamentos de funcionamiento interno de estos espacios. Por lo que sería interesante el reconocimiento institucional como espacio educativo para que La Maranya pudiera ocupar un lugar en las plataformas adecuadas.

Analizando las potencialidades vemos que un espacio como La Maranya lo fortalece el situarse dentro de un proyecto educativo y así es como lo aluden diversas voces en la historia. Se valora como un espacio de aprendizaje en el que el trabajo se asume como tarea educativa y no como servicio para el entretenimiento de las participantes (Deltoro, 2006). La metodología utilizada es la que lo diferencia de otras experiencias en las que sobresale la finalidad de ofrecer un servicio a la ciudadanía sin un sentido educativo. Aquí tenemos que volver a la pirámide de participación ya que es importante para el diseño de las actividades. Ya he apuntado con anterioridad que la estructura piramidal permitía diseñar un proyecto educativo enfocado a cada uno de los niveles de participación. Por ejemplo, las consumidoras tendrán actividades masivas dedicadas a una temática de valores o algún acontecimiento musical o temático como puede ser la noche de Halloween con la Casa del terror; las usuarias asisten a cursos de formación o talleres; los grupos estables asisten a sus propias actividades y reuniones de preparación como puede ser teatro y grabación de videos entre otras; las activistas asisten a sus reuniones con el grupo estable y se reúnen con las coordinadoras en los plenarios; el grupo EAV tiene 
marcadas sus sesiones semanales de trabajo interno y asistirá a todas aquellas actividades que proponga. Todos estos ejemplos podrían ser estos espacios facilitadores del aprendizaje hacia la participación ya que se adaptan a las personas que los frecuentan generando un lugar en el cual la participante encuentra cubrir sus propias necesidades animándola a la participación plena. Esta adaptación lleva estudiándose desde hace años en la escuela y se ha visto que la adecuación del espacio a las necesidades de las personas favorece el aprendizaje (Laorden y Pérez, 2002; Arnáiz, 2004; Duke y Hinzen, 2009; Moriña, 2008; Martínez de Mandojana, 2014).

La CdJ es un espacio de aprendizaje donde se trabaja a partir de prácticas que se llevan a cabo en escenarios reales, es decir, se funciona a través del aprendizaje situado ya que el aprendizaje se considera una dimensión integral e inseparable de la práctica social (Lave y Wenger, 2001). Una de las premisas de La Maranya es que se aprende a participar participando. Esta idea cuaja a la perfección con el modelo de aprendizaje situado ya que se aprende a partir de la participación activa en la experiencia, centrándose en la importancia de esta además de concentrarse en el contexto social al cual se le requiere una pertenencia. Por otro lado, el aprendizaje situado entiende el aprendizaje como un continuo en la trayectoria de la persona, es un desarrollo continuado (Niemeyer, 2006) tal y como hace la Casa con la pirámide de participación y la trayectoria de aprendizaje que posibilita.

Wenger (1999) define cuatro dimensiones del aprendizaje situado en comunidades sociales: la pertenencia y participación, el llegar a ser y crecer, la experiencia y la vivencia, la práctica activa. Estas son imprescindibles para que se pueda conseguir un verdadero aprendizaje situado en la comunidad. Principalmente, en la Casa, se trabaja en un contexto social grupal que tiene una actividad común, la ocupación del tiempo libre y de ocio de las jóvenes de Benicàssim. En La Maranya se construye una identidad común entre las participantes, ellas hablan de la asociación como algo que es parte esencial de su vida en donde crecen y llegan a ser parte de esa realidad. Además se entiende la oportunidad de participar como un aspecto muy relevante ya que es el único modo de darle significado al aprendizaje. Como decía Dewey (1997) «toda auténtica educación se efectúa mediante la experiencia». 
Figura 17. El aprendizaje situado en comunidades sociales. Las cuatro dimensiones del aprendizaje situado. Fuente: Wenger, E. 1999. Traducción BN.

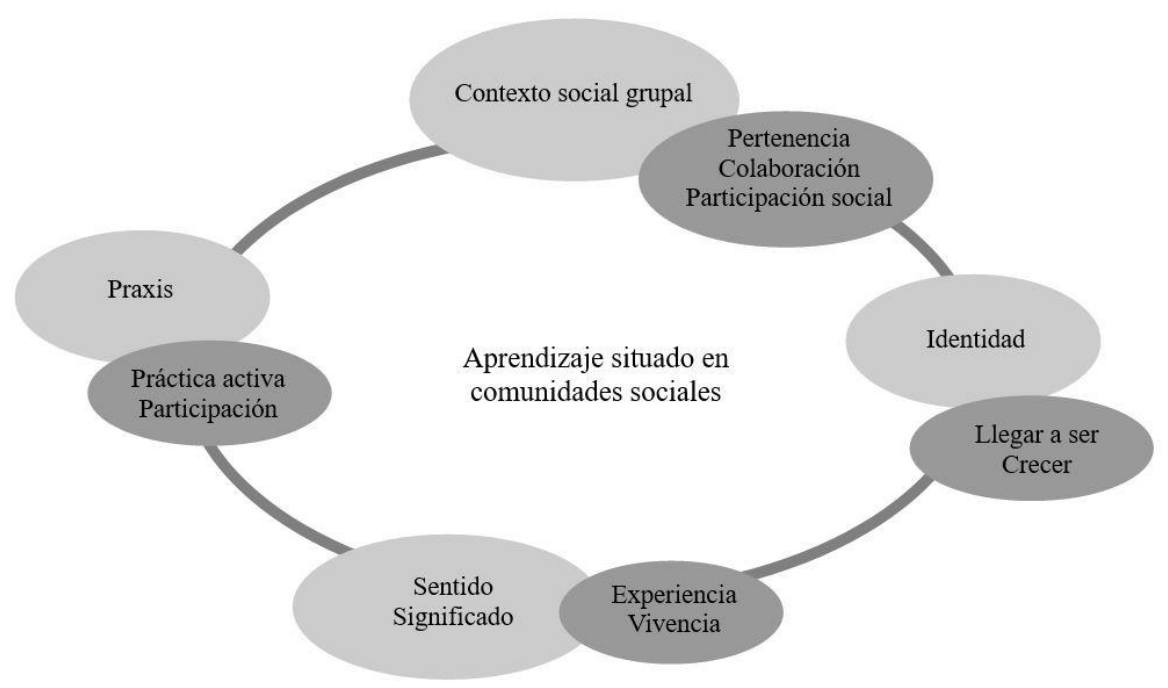

Este método posibilita una serie de aprendizajes en la Casa como los que McKeachie (1999) nombraba:

- Encarar diferentes fenómenos de la vida cotidiana. El trabajo en La Maranya es trabajo de la vida cotidiana tal y como se refieren a él algunas participantes. La posibilidad de convivir y compartir con otras personas facilita que los fenómenos de la vida se den también entre las cuatro paredes de la asociación. De esta forma el proceso de aprendizaje que se lleva a cabo en la toma de decisiones ayuda a encarar estos fenómenos cuando ocurren en un contexto distinto al de la Asociación.

Algo significativo que podría facilitar este tipo de aprendizaje es disponer de un espacio intergeneracional como es La Maranya. De este modo, la puesta en común de las estrategias de afrontamiento en función de las necesidades que presenta cada generación posibilitaría una mayor pluralidad en este aprendizaje. En 2005 el informe mundial sobre la juventud ya insistía en la necesidad de tomar medidas para desarrollar iniciativas intergeneracionales. En La Maranya la posibilidad de unificar algunos espacios para que las diferentes generaciones (infantil, juvenil y adulta) puedan compartir conocimientos la diferencia de otros espacios juveniles y la fortalece en sus aprendizajes. Es la diversidad intergeneracional la que 
refuerza el proyecto asociativo convirtiéndose en un lugar adecuado para la participación ciudadana de diferentes colectivos. La CdJ es un lugar donde cada una vive y realiza su cultura (Ander-Egg, 1989) en relación con el espacio generacional que ocupa y por ello, la animación sociocultural que se favorece en este lugar se convierte en un instrumento para la democracia cultural (Trilla, 1996) basada en la diversidad y la inclusión. En esta línea, La Maranya trabaja la cultura como un proceso dinámico y promueve que sea la propia ciudadanía la encargada de generarla. No es cuestión de acercar la cultura a las ciudadanas sino de que ellas mismas la construyan desde sus intereses. Se entiende la cultura como aquel modo en el que se construye el mundo (Mèlich, 1996) desde las representaciones de la vida que se amplían, enriquecen y modifican (Pérez Gómez, 1998) por aquellas personas que la viven. De ahí que la cultura se sitúe como elemento básico del desarrollo comunitario y la educación como motor fundamental del cambio (Aguirre García-Carpintero, 2012).

Conseguir aplicar y transferir el conocimiento de manera significativa. Un modo de conseguirlo es a través de la estructura de participación que tiene la Casa. Debido a los diferentes niveles de participación las jóvenes van aprendiendo habilidades que ponen en práctica y transfieren conforme van asimilando compromiso en la participación. Se percibe como las jóvenes que empiezan a participar en la CdJ, en estamentos de menor maduración participativa, poco a poco van asumiendo un mayor compromiso gracias a la aplicación y transferencia del conocimiento a partir de las experiencias que han vivenciado. Además consiguen aplicar las dinámicas y transferir el conocimiento a otros espacios como el escolar, si recordamos era una de los aspectos que remarcaba el profesorado del instituto.

Aprender y desplegar habilidades que faciliten la construcción de un sentido de competencia profesional. Es otro de los aspectos que mayor visibilidad tienen en los resultados. Las diferentes personas que forman parte de La Maranya se refieren a los aprendizajes que adquieren como adecuados para su futura práctica profesional. Habilidades como las cooperativas, de organización, sociales, de planificación e incluso actividades más técnicas como la de realizar la instalación eléctrica en la Casa, han posibilitado que las participantes adquieran competencias 
profesionales en diferentes áreas, desde el trabajo social, al periodismo, la comunicación audiovisual y las ingenierías, entre otras.

Saber como afrontar situaciones sociales y contribuir a la comunidad. La trayectoria en La Maranya se convierte en un proceso de concientización que consigue que las participantes sean capaces de analizar la realidad, hacer una crítica sobre la misma y actuar para mejorarla. Este acto en sí ya genera ciudadanía. Así se realiza en los diagnósticos sociales participativos (Aguirre García-Carpintero, 2012; Lobillo, 2002; Marchioni, 2001; Rebollo, 2001; Villasante, 1998; Expósito, 2003; HechavarríaLescaille, Salas-Delisle y Roldán-Ruenes, 2008; Martínez, 1995) y la Casa los ponen en marcha además de promover proyectos que interpelan, concientizan y transforman al propio colectivo o al municipio como podrían ser la elaboración de los videos sobre democracia, educación, ... o el ciclo de charlas Recrea la teua ciutat, que se realizó antes de elecciones. De este modo descubren y participan en su propia realidad.

Relacionar el pensamiento con la acción. No podemos dividir el elemento anterior del pensamiento para la acción. Ya lo exponía Schön en 1983 cuando describía que una de las características esenciales de la práctica es la reflexión para la acción. En la Casa se trabaja a través del pensamiento crítico, dando preferencia al diálogo y al consenso argumentativo antes que a la toma de decisiones a través de una participación indirecta como podría ser el voto. Por ejemplo en las asambleas se diseñan dinámicas para que las participantes puedan disponer de su espacio para el diálogo y la argumentación en la toma de decisiones del centro. Esta práctica genera que la propia acción se relacione con el pensamiento por la necesidad de reflexionar y argumentar los diferentes posicionamientos. También lo vemos en aquellos momentos en los que los miembros de La Maranya realizan sus propios diagnósticos sociales participativos donde se analiza la realidad de manera colectiva, se extraen conclusiones y se proponen acciones con el objetivo de concientizar al propio colectivo. Estos procesos se dan, principalmente, en los momentos de crisis, en los nuevos espacios que se generan a partir de ellos y también cuando se realizan las evaluaciones de final de curso.

- Trabajar acerca de valores y cuestiones éticas y reflexionar sobre ellas. La CdJ La Maranya trabaja a partir de una serie de valores 
contemplados en su propio manifiesto y que hacen explícitos en su práctica diaria. No se realiza ninguna actividad que pueda poner en peligro alguno de estos valores: solidaridad, igualdad, laicidad, contra el racismo y la xenofobia, libertad, democracia, ecología, defensa de la cultura, no a las drogas y a la violencia, y conciencia crítica. El compromiso con la educación en valores democráticos reclama que las experiencias de aprendizaje incidan en la construcción de esos valores (Moliner, Traver, Ruiz y Segarra 2016). Así se da forma a la Educación democrática en la Casa remarcándolo en su manifiesto, en las prácticas diarias y en la elaboración de campañas como la última que se elaboró sobre la situación de las refugiadas en Europa.

La Maranya se conforma como un espacio educativo juvenil que favorece la adquisición de diferentes aprendizajes tal y como hemos visto enfocados tanto a competencias técnicas, sociales como personales. La dinámica que se lleva a cabo dentro de la CdJ posibilita que las jóvenes adquieran competencias técnicas que les son útiles en sus estudios de secundaria y también en los universitarios. El hecho de saber coordinar una reunión, realizar un acta, respetar el turno de palabra, argumentar las posturas y tomar decisiones al respecto se evidencian en las sesiones de plenario con las jóvenes. Por otro lado, logran diferentes tipos de habilidades sociales que facilitan su integración en la sociedad y dinamizan la construcción de una ciudadanía crítica tal y como hemos visto: trabajo en valores, pensamiento crítico, contribución social,... Todo esto tiene una relación directa con aquellos aprendizajes que Warren (2001) remarca en cuanto a la participación en asociaciones. De forma concreta con los efectos del desarrollo individual como la eficacia, las habilidades de información política, cualidades cívicas y habilidades críticas que van apareciendo en $\mathrm{La}$ Maranya a lo largo de toda la trayectoria participativa. Esto se complementa a lo que Durlak y Weissberg (2007) analizaron a partir de la participación en actividades extraescolares con un trabajo explícito en el desarrollo social y personal observando que se consiguió que las participantes mejoraran en sentimientos y actitudes, comportamiento y rendimiento escolar.

Finalmente en La Maranya se produce un proceso de crecimiento personal que les permite empoderarse de forma individual. El empoderamiento hace que la persona se valore y se sienta capaz de afrontar su propia realidad, de 
actuar sobre ella y hacerlo mediante unos principios que convierten a la ciudadanía en democrática y crítica. De este modo, llega el turno del empoderamiento como proceso de crecimiento personal y grupal, como proceso de aprendizaje y de formación de ciudadanía crítica y transformadora. Son múltiples estudios los que han examinado y analizado el empoderamiento vinculándolo a factores de salud, bienestar individual, social y del entorno (Jennings, Parra-Medina, Kilfinger y Mcloughlin, 2008; Freire, 2002; Jones y Meleis, 1993; Pinderhughes, 1995; Rappaport, 1984; Rocha, 1997; Wallerstein, 1992; Zimmerman, 2000). Un fundamento del estudio de este concepto lo encontramos en el empoderamiento como proceso de transformación personal pero también colectivo por el cual las personas fortalecen sus capacidades, la confianza, la visión y el protagonismo para impulsar cambios positivos en las situaciones que viven (Rappaport, 1984). En esta variante, destacar los trabajos desde la educación no formal que entienden el empoderamiento desde esta transformación personal y social, entre ellos Villen (2008), y ya desde nuestro entorno más cercano los que hemos desarrollado desde el Seminari Garbell $^{77}$ (Aguirre, Traver y Moliner, 2011 y Gallego, Traver y Moliner, 2010). Además, se estudia este empoderamiento desde procesos de aprendizaje y a través de la transformación social con la cultura como pilar en Escudero (2004), Casacuberta (2011) y Checkoway (2008). Podría extenderme con este factor pero quisiera focalizar mi atención en que el empoderamiento que más nos interesa por todo lo que comporta (dentro de él el individual) es el empoderamiento colectivo. De él hablaremos en el apartado de construcción colectiva.

Siguiendo con la relación entre La Maranya y las propuestas de Etienne Wenger, vemos como al igual que el modelo de aprendizaje situado evoluciona hasta el de comunidades de práctica, La Maranya también le pasa algo en consonancia con esta idea. No sólo centra su aprendizaje en uno situado sino que convierte el espacio en una Comunidad de Práctica (Wenger, 2001). Dentro de la estrategia de participación piramidal es relevante el papel que cubre el EAV y los roles que se dan en él como ya hemos visto. El EAV es un espacio que se define como un lugar para el aprendizaje de la animación sociocultural desde un perfil de voluntariado,

\section{${ }^{77}$ http://www.peu-uji.es/ca/reflexio/seminari-garbell/seminari-garbell}


activismo y militancia, un lugar que bien podría definirse perfectamente como Comunidad de Práctica. Las razones se basan en que sus miembros buscan un objetivo común, tienen una identidad común, se reúnen para contrastar ideas y aprender en la gestión de la Casa desempeñando una misma actividad y compartiendo responsabilidades, se preocupan por un problema común y se movilizan por él, profundizando en su conocimiento y generando nuevas habilidades a partir de la interacción continua (Sanz Martos y Pérez-Montero, 2008). Además dinamizan una constelación de comunidades de práctica en pro de la participación juvenil con los espacios de trabajo junto a Escola de Cases, Federació de Cases de Joventut, Esplais Valencians y el Movimiento Laico y Progresista catalán y zaragozano que bien podrían definirse por asumir un compromiso mutuo, generar un emprendimiento común y compartir un carácter histórico en el movimiento juvenil. De esta forma esta constelación se define por ser una red de comunidades de práctica que se entreteje en torno a metas, reglas y creencias comunes (Cohendoz, 2001).

Los logros educativos que se dan debido al uso del aprendizaje situado y las comunidades de práctica se dan en todas las personas con las que me he entrevistado, observándose en ellas una actitud activa hacia el aprendizaje entendiéndose este como un reto y una oportunidad. La persona es la protagonista del aprendizaje y entra en procesos de valoración, crítica, cuestionamiento, comparación y reconstrucción de su propia información mostrando una apertura hacia el cambio personal y colectivo tal y como hemos ido viendo.

Si a estos aprendizajes les sumamos los que considera Trilla (1996), para que el trabajo en el tiempo libre sea potencialmente educativo, nos encontramos con una asociación que se construye bajo una base educativa en la que se promociona la sociabilidad al trabajar desde la colectividad. Además se focaliza el trabajo en elementos que desde la educación formal se han ido desatendiendo como podrían ser la expresividad, la sensibilidad y la creatividad, entre otras cuestiones, tal y como podemos ver en sus diferentes proyectos. Por otro lado posibilita que las participantes, sean de edad infantil o juvenil, den forma a proyectos de actividad de manera autónoma, para finalizar enfatizando el descubrimiento y la participación de ellas mismas en su propia realidad. Así las adolescentes se convierten en 
interlocutoras de pleno derecho (Úcar, 2008) tal y como ocurre en el estudio de Thomas y MacFarland (2010) en el que observa como la participación en asociaciones de voluntariado adolescente influye a lo largo de la vida en el fomento al voto y promueven que las jóvenes se conviertan en ciudadanas de pleno derecho.

Para finalizar, un aspecto importante en todo este proceso educativo es el rol de las educadoras del centro. Importante ya que en función de cómo se practique, podrá generar diferentes tipos de aprendizajes. Checkoway y Gutiérrez (2008) ponen en alerta que no es lo mismo que la animadora se instale en un rol de cuidadora que en el de educadora. Según estas autoras muchas animadoras se han formado más para cuidar de las jóvenes que para empoderarlas y eso, influirá en su proceso de aprendizaje personal. Si se sitúa en un rol educador se podrán facilitar esos espacios que posibilitan el empoderamiento, sino se generarán lugares para el entretenimiento y el cuidado juvenil. En La Maranya se trabaja desde roles educadores, si se generan actividades de entretenimiento son con una finalidad clara de enganchar a las jóvenes en una de las etapas concretas de la pirámide de participación como son las consumidoras y usuarias. El resto se diseña con el objetivo de generar procesos de aprendizaje participativos a partir de la acción directa. Vemos la vinculación de este tipo de proceso con el aprendizaje situado. Un ejemplo lo vemos en las jóvenes que participan en los grupos estables, ellas hacen sus propias reuniones, se organizan y planifican. Las animadoras son sus referentes y estas les acompañan durante el proceso. También existen diferencias entre el trabajo conseguido bajo un rol educativo cuando La Maranya aún pertenecía al Casal Jove de cuando se construye como espacio independiente. Me refiero al hecho de que las animadoras, en la primera etapa, consiguen arrancar tres diferentes grupos estables que consiguen trabajar de manera autónoma pero cuando La Maranya se independiza muchas tareas recaen sobre las mismas personas y el rol educativo queda apartado para centrarse en cuestiones de logística, mantenimiento y obra del local, esto provoca que los procesos educativos se construyan de un modo distinto. No se concentran en enseñar como se hace una reunión pero sí en cómo se pasan cables de luz o como se pinta pero sobretodo se concentran en procesos de pertenencia. En la creación del espacio de manera colectiva también se fraguan aprendizajes muy 
relacionados con la posibilidad de empoderarse colectivamente como veremos en los siguientes apartados.

De forma resumida vemos como aquellos procesos participativos, que permiten la construcción de espacios educativos y de empoderamiento juvenil, están basados en un aprendizaje situado y activo que se conforma a partir de experiencias significativas para las participantes, fomentando el pensamiento crítico y la concientización, entre otros aprendizajes. Además se centran en experiencias que se llevan a cabo a través del diálogo, la discusión grupal y la cooperación manteniendo un papel de la animadora como candidata a la problematización de la realidad, con la finalidad de posibilitar su propio cuestionamiento (Diaz-Barriga, 2003; Claus y Ogden, 1999).De este modo, hablamos que La Maranya se sitúa como espacio de aprendizaje dentro de una pedagogía de ocio democrática descrita desde la participación comunitaria, la inclusión, la cooperación y la búsqueda del bien común (Apple y Beane, 1999) asumiendo la construcción de la cultura desde estos mismos parámetros. 


\subsection{E1 lado informal de una asociación: el trinomio de vida.}

Nos adentramos en una parte más humana de la asociación, la Casa es estrategia participativa, espacio de aprendizaje y construcción de discurso al igual que es cuidado relacional, estrategias de afrontamiento y construcción colectiva.

Ahora vamos a abordar estas tres últimas que están íntimamente relacionadas con las diferentes acepciones de la participación social que comparten García Roca (2004) y Aranguren (2010): sentirse parte, tomar parte y partir con.

\subsubsection{El cuidado relacional.}

En numerosas ocasiones La Maranya se ha caracterizado por buscar esos espacios donde se cuidan las relaciones y se sueña colectivamente. Sobresalen en la primera etapa de la asociación cuando los momentos de crisis son más intensos y estos provocan que las relaciones se agiten y cada vez te sientas más cercano al de al lado y más lejano al de enfrente. Es decir, en estos momentos surgen espacios colectivos donde se comparten temores y alegrías, el discurso se convierte en colectivo y al enemigo se le ve más opuesto que nunca.

Estas diferencias con el Ayuntamiento van produciendo un sinfín de sentimientos en el colectivo y generan una red de apoyos mutuos entre las participantes. Las jóvenes, las monitoras, las familias y los niños y niñas hablan sobre la situación y se crean espacios para hacerlo. Comienzan un interesante proceso de «ser parte» (García Roca, 2004). Las participantes empiezan a sentirse parte de algo hasta que consiguen ser parte de ese algo, se apoyan, tienen objetivos y valores compartidos lo que hace que poco a poco se extienda la idea de pertenencia a un grupo. Con su participación sienten la pertenencia al colectivo (García Roca, 2004; Aranguren, 2010), sin participación, sin crear estos espacios distendidos para compartir, la pertenencia se convierte en efímera.

Observamos a lo largo de toda la historia como se compensa la parte más sistemática, su estructura, organización,... con la que trata sobre la vida de la CdJ. En ella podemos observar cómo se diseñan actividades para cuidar las relaciones del colectivo como son comidas, meriendas y cenas o jornadas como el Fil Històric, Pengem els Guants y Amb l'alegria a l'altra banda, 
entre otras. Por ejemplo con la jornada de Amb l'alegria a l'altra banda todo el colectivo se vuelca en ella, generando lazos de pertenencia cada vez más intensos. Es un aspecto relevante, el cuidar y mimar la parte no formal de una institución. Es algo que caracteriza al colectivo en sus inicios pero que en los últimos años se va perdiendo cada vez más. ¿Podría ser este el motivo por el cual cada vez cuesta más «enganchar» a la gente a la participación? La Maranya en su globalidad aprecia que tiene que cuidar los ritmos de vida de la asociación y su gente, el EAV en particular diseña estos espacios y los hace posibles haciendo un análisis de los tiempos por los que transcurre. En el último año estos espacios se han ido distanciando cada vez más y se ha descuidado los momentos de celebración colectiva. Los datos que tengo al respecto están enfocados al descenso debido al agotamiento y al exceso de trabajo que comportan para un núcleo concreto de la Casa, el EAV y principalmente su coordinación.

Aún así vemos que la parte humana es otro de los puntos fuertes de la Casa, ha posibilitado su construcción y la diversa participación que en ella se da. Se evidencia que el proyecto tendrá sentido siempre que el grupo sea capaz de ilusionarse de manera colectiva y de ahí que se tengan tan presentes los espacios de convivencia que en cuanto a organización piden un relevo que no se acaba de fraguar.

Me encuentro abordando uno de los factores que influyen de manera considerable en la participación social ya que cualquier actividad, en el tiempo libre, ha de ir vinculada al territorio y ha de trabajar el sentido de pertenencia para conseguir definirse como educativas (Muñoz, 2011). Además se encuentra directamente relacionado con uno de los elementos cooperativos que apuntan Traver y Rodríguez (2011) o Pujolàs (2008 a, 2008 b). Según estos autores hacen falta tres aspectos fundamentales que constituyen los ámbitos básicos del aprendizaje cooperativo. El que afecta a este punto es la creación y la cohesión del grupo para conseguir interaccionar de manera cooperativa. Pujolàs (2008 b) señala que se trata de generar una conciencia de grupo colectiva, la cual precisa de compartir sueños, amistad, alegría...pero también conceptos, saberes, experiencias, entre otras cosas, que hagan sentirnos un grupo. Todo ello puede perder un poco su sentido si no tenemos un proyecto común compartido que nos haga soñar juntas. La construcción de ese proyecto es La Maranya, el 
nacimiento de La Maranya no se produce cuando se le da nombre a un colectivo para transformarlo en $\mathrm{CdJ}$ sino cuando empiezan a sucederse acontecimientos que hacen que el grupo se cohesione cada vez más. Esto ocurre por ejemplo con los conflictos con el Ayuntamiento pero también con las pérdidas de personas que han formado parte del proyecto y lo han visto nacer.

Es así por lo que el sentido de pertenencia es fundamental para que se desarrollen procesos de cooperación social, para que las sociedades puedan resistir las tendencias a la fragmentación y para afianzar la inclusión y cohesión sociales (Turner, 1990). 


\subsubsection{Las estrategias de afrontamiento.}

La Maranya se describe en su metodología, sus valores, sus ideales y su gente. Se siente un espacio propio cuanto más se diferencia del contrario, conforme va asumiendo identidad propia. El Ayuntamiento no facilita la continuidad de los grupos juveniles, reconociendo que la burocracia agota y que las jóvenes son mucho más impulsivas a la hora de generar actividades pero para la administración es importante el cumplimiento de las normas y la ley. Existen dos posturas, una entender que el espacio es un lugar propio del Ayuntamiento y que se cede para las ciudadanas o bien entenderlo como un lugar propio de la ciudadanía. En estas acciones se evidencian cada vez más los dos modelos de participación seleccionados: uno ciudadano, autónomo, participativo, educativo y crítico mientras que el otro se decanta por estructuras empresariales, económicas y jurídicas conservadoras en las que el papel principal de gestión lo realiza el Ayuntamiento para cubrir necesidades de servicio y consumo de las ciudadanas. El primero más cercano al modelo de voluntarismo cívico que propone Putman (1993:90), que afirma como la participación en organizaciones cívicas genera habilidades cooperativas a la vez que responsabilidades compartidas sobre proyectos colectivos. El segundo dentro de un modelo asistencialista y autocrático de la participación centrado en crear una programación municipal sin contar con la opinión de las jóvenes. En consonancia con esto está la repetida frase «las jóvenes no participan» sin analizar que somos nosotras, las personas adultas alejadas de su realidad, las que les estamos diciendo cómo tienen que participar. Desde este punto de vista, se pierde el potencial educativo de transformar, de generar confianza y participar democráticamente centrándose en cambio en satisfacer a la potencial ciudadana/cliente a través de la actividad-servicio.

Pensemos que cuando nace La Maranya se reproduce lo que pasó hace 15 años cuando el alcalde citó en su despacho a aquellas jóvenes que un día decidieron criticar las actuaciones políticas mediante una revista. Se vuelve a reproducir el papel del Ayuntamiento de no apoyar las iniciativas que se llevaban a cabo en los grupos estables de jóvenes. En La Maranya vivieron la burocratización del espacio como un ataque y creen que lo que se esconde detrás de esto son mecanismos de control ideológico por parte del equipo de gobierno. Estas diferencias en el modelo de participación, entre la Asociación y el Ayuntamiento, provoca formas muy dispares de vivir la 
participación y la propia ciudadanía. Distintos significados en una misma palabra, participación. No sé si llegará el día en el que los lados se compensen, las burbujas existen y se está más cómodo y seguro dentro de ellas que si decidimos romperlas para respirar de nuevo aire libre. Citando a Max Hub a partir de Serrano (2008): «Aquí no es que no haya libertad. Es peor: no se nota su falta». Pero el día que se nota nacen iniciativas que ponen en duda las formas democrático participativas que se utilizan desde el poder visibilizando otros modos de hacer participación.

La defensa del modelo contra otras personas, la lucha contra un enemigo común todo lo magnifica. Se ganan complicidades, se generan espacios de discusión y se promueve un proceso de concientización en el que niñas, niños, jóvenes, familias y animadoras realizan su propio análisis de la realidad (Freire, 1974). Este provoca la necesidad de actuar para cambiar las cosas que asumen como injustas. Se dan cuenta de cómo están las cosas y tienen la voluntad e iniciativa para proponer soluciones. En ello observamos una actitud activa hacia el aprendizaje pero también hacia la acción, asumiéndose el tomar parte en la realidad que les rodea con el objetivo de conseguir justicia social. Según Aranguren (2010:30) la implicación viene al sentir que algo nos afecta, por eso «es la participación guiada por el principio de voluntad según el cual, tomar parte es incorporarse activamente a algo que se siente como propio». Además la implicación afecta de forma directa a la mejora de la experiencia y al grado de compromiso (Doistua, Pose y Ahedo, 2016).

El colectivo empieza a tomar parte, ya no solo son parte sino que quieren implicarse porque hay algo que les afecta de manera directa, se sienten atacadas y vivencian cada vez más incidentes críticos: visitas policiales, cartas del Ayuntamiento, advertencias de las técnico e incluso reafirman que existe un silencio administrativo hacia la asociación. Lo destacado es que ven las tensiones como algo dinámico y constructivo. Todos estos incidentes generan que la Casa sea capaz de diseñar estrategias de afrontamiento que les hacen sentirse más parte del proyecto. Me arriesgaría a decir que puede incluso que estos incidentes sean más potentes, educativamente hablando desde la colectividad, que el día a día en la Casa. En el día a día se reconocen modelos educativos a nivel individual, el trabajo parece elaborarse más desde el modelo que ejercen las animadoras 
sobre las jóvenes que desde el conjunto. En cambio en los momentos de crisis los espacios se extienden y se construyen modelos de manera colectiva ya que se amplía la pluralidad de voces. Los momentos de crisis se afrontan desde espacios comunitarios y dialógicos ampliando los momentos de discusión colectiva y la toma de decisiones conjunta. Lo vemos por ejemplo cuando empiezan a crearse reuniones y asambleas en el momento de tomar una decisión sobre marcharse o no del espacio institucional. En ellas participan todos los colectivos que forman parte de un modo u otro del espacio (familiares, niños y niñas, animadoras y jóvenes).

Cousée-Ghent (2016) afirma que es un mecanismo de aprendizaje el vivenciar las tensiones, los incidentes, las crisis como algo positivo, como un momento de reconstrucción. Tal y como Edgar Morin expone hay que «aprender a navegar en un océano de incertidumbres, a través de archipiélagos de certeza» (2011:117). Esos archipiélagos de certeza son todas esas experiencias críticas que consiguen provocar la acción socieducativa.

En este estudio esta navegación se hace de manera colectiva lo que aumenta el valor de los incidentes críticos ya que, a partir de ellos, se generan estrategias de afrontamiento colectivas y no individualistas. La participación desde este lugar es plural y diversa y propone espacios desde la inclusión ya que se crean lugares en los que se tienen en cuenta a todos los colectivos que dan forma a la asociación. De este modo, desde la construcción colectiva, se consiguen diseñar estrategias de afrontamiento a las crisis que se definen por su creatividad e impacto social (Lip dub, documental Els portadors de somnis, La flama,...) y que consiguen que el colectivo consiga tener una mayor pertenencia al proyecto ya que con la elaboración de estrategias de manera colectiva se sienten representadas, son parte y toman parte.

Esto contrasta con lo que propone Cornwall (2008) sobre los obstaculizadores de la participación ya que según él, siempre que existan facilitadores y se encuentren por encima de los obstáculos se sabe que la propia comunidad desarrollará y vivenciará contextos, situaciones o procesos de empoderamiento que llevarán al empoderamiento comunitario. En este caso se suceden los obstáculos como las visitas policiales, la 
burocratización de los procesos y la carta para vaciar el espacio entre otras cosas, pero eso no evita que se reconstruyan facilitadores que promueven el empoderamiento comunitario como podrían ser la creación de espacios de discusión, la transformación a una asociación cada vez más intergeneracional y los actos y campañas de visibilización. Vemos como en este caso, lo interesante no es encontrar facilitadores sino construirlos desde la comunidad para de este modo generar procesos de aprendizaje colectivo.

En resumen, tanto el nacimiento de la Casa como otros incidentes críticos por los que pasa el colectivo ayudan a construir estrategias de afrontamiento reconvirtiendo las crisis en momentos de crecimiento colectivo. 


\subsubsection{El empoderamiento colectivo.}

Como vemos a lo largo de toda la historia y de estas conclusiones, los momentos de crisis hacen que La Maranya se transforme y tome nuevos caminos. Así es como a partir de distintos acontecimientos en la Casa se empieza a trabajar desde una metodología comunitaria que parte de elementos cooperativos como los que apuntan Traver y Rodríguez (2011) o Pujolàs (2008 a, 2008 b). Según estos autores hacen falta tres aspectos fundamentales que constituyen los ámbitos básicos del aprendizaje cooperativo y estos aspectos influyen en la construcción de la metodología comunitaria que se extiende en la CdJ. Uno ya lo hemos visto con anterioridad cuando hemos tratado la cohesión del grupo y el ser parte de este.

A continuación vemos el segundo de estos tres aspectos, que las personas que formen parte del colectivo aprendan a cooperar. Como Traver y Rodríguez (2011) apuntan, para trabajar de manera cooperativa hemos de ser más hábiles en las relaciones con las otras, aprender a construir en compañía, comprometerse y exigir a las demás. Decir las cosas bien, escuchar, pedir y ayudar son, entre otros, los aprendizajes que constituyen la riqueza de la cooperación. Aprender a cooperar es aprender a compartir, a convivir y a darle una dimensión socialmente justa a nuestra existencia (Aguirre García-Carpintero, 2012). En este sentido se empiezan a construir los espacios comunitarios y se diseñan con la idea de que el colectivo aprenda a cooperar compartiendo opiniones, reflexiones y tareas entre ellas. Así lo recuerdan las familias cuando todo el colectivo, niños y niñas, jóvenes, adultas y animadoras se sientan a tomar decisiones sobre el futuro de la asociación. En esos momentos se aprende a trabajar en equipo y a ser solidarias con las percepciones del resto.

Además nos topamos con el tercer aspecto, donde se precisa que se organicen esos mismos espacios para propiciar la construcción compartida de conocimiento, es decir, que se coopere para aprender entre todas las participantes del colectivo. De este modo no solo se aprende a cooperar sino que se coopera para aprender.

Reconocemos en todo ello la idea de partir conque nos propone Aranguren (2010). Con esta idea complementa el trio de aspectos esenciales para una participación social real, el «ser parte», el «tomar parte» y el «partir 
con». Emprender el camino junto a las demás, construir de manera colectiva dejando atrás la participación exclusivamente de aquellas que se sienten con el poder de hacerlo porque han sido las elegidas para ello. En el estudio vemos como se pretende crear lugares para la toma de decisiones colectiva y por ejemplo, en la decisión de independizarse del Casal Jove, podemos ver como se pone en práctica la idea de partir con las demás y trabajar a partir de elementos cooperativos que fortalecen la construcción de una cultura colaborativa.

Si hay algo que favorece la crítica de este proceso es que llega un día, después del trabajo de obra, cuando la organización de La Maranya tiene que volver a establecerse como Casa de Juventud, en el que todo se emprende mayoritariamente desde el EAV, como ejemplo, las actividades para jóvenes provienen del EAV y la planificación del ciclo de charlas para adultas también. Se percibe que la falta de grupos estables juveniles o adultos carga el trabajo de las animadoras y su voz resuena sobre el resto. Observamos como, por ejemplo, las jóvenes se hacen eco del discurso colectivo conforme van participando más de las actividades y de la elaboración de propuestas. Lo comprobamos en los momentos de evaluación de curso en el que las aportaciones de las jóvenes se encuentran en consonancia con el discurso de justicia social que se difunde en la Casa. De esta forma vemos la importancia de construir discurso de manera colectiva y en red en el día a día. Esto permitirá que se escuche la pluralidad de voces y la participación no se convierta en un monólogo o monopolio de una sola voz (Aranguren, 2010). Aquí retomo e insisto en la idea anterior de que La Maranya se define colectivamente en los momentos de crisis pero en el día a día se aísla, en gran parte, en el trabajo que elabora el EAV. Por este motivo, el discurso se va asumiendo a lo largo de toda la trayectoria participativa de la persona pero sobretodo se afianza cuando la persona forma parte de incidentes críticos que sumergen a la entidad en un proceso de análisis, reflexión y toma de decisiones colectiva ya que es en esos momentos cuando se cuida el trabajo a partir de los siguientes elementos cooperativos que proponen diferentes autoras Johnson, Johnson y Holubec, 1999; García, Traver y Candela., 2001; Traver y Rodríguez, 2011; Aguirre, Traver y Moliner, 2011): 
- Interdependencia positiva: tanto jóvenes, familias, monitoras y niños y niñas han de entender que están ligadas las unas con las otras, que sólo de este modo cada una de ellas tendrá éxito si tiene éxito el resto del colectivo. Se ha de perseguir un objetivo común aunque en este caso existen diferencias entre los grupos. Jóvenes y monitoras tienen claro que quieren marcharse, por encima de la decisión democrática y asamblearia está el querer formar su propio espacio juvenil. En cambio, las familias aunque tienen una perspectiva no tan impulsiva creen que la decisión, sea la decisión que sea se tomará de manera democrática. Aquí el grupo de familias está demostrando una mayor vinculación hacia la interdependencia positiva que los grupos de jóvenes y monitoras lo que puede dibujar las diferencias que se tienen entre colectivo juvenil y adulto a lo largo de la Historia de La Maranya.

- Interacción cara a cara: la dinámica que se pone en práctica es la de la interacción continua y directa entre las personas del colectivo. Una interacción que estimula y que convierte el intercambio en ánimos, elogios, implicaciones y voluntades de querer hacer las cosas mejor. Por esto se crean espacios en donde discutir, reflexionar y tomar decisiones de manera conjunta. Lugares en los que animarse de forma colectiva, las unas con las otras. Todo esto empieza a aparecer cuando se inicia el conflicto entre el Ayuntamiento y el colectivo juvenil. En el grupo florece la necesidad de compartir momentos para hablar y trabajar la situación y vemos como se continúan dando siempre que existe una crisis en la asociación.

- Responsabilidad individual y exigencia grupal: como individuo cada persona debe asumir sus propias responsabilidades, aquellas que se le hayan asignado a partir de la dinámica colectiva y debe asumirlas como una exigencia del grupo. La construcción del grupo nace de los aportes individuales que realiza cada miembro del colectivo. Esta responsabilidad se estructura de forma escalonada ya que no todas las personas del colectivo se responsabilizan o asumen el compromiso con el grupo del mismo modo. Cada uno lo hace desde su propio proceso de maduración participativa dependiente de la estructura participativa que hemos visto con anterioridad.

- Liderazgo compartido o democrático: se promueve un liderazgo democrático procedente de la discusión en los espacios colectivos aunque 
la coordinación y moderación del grupo se realiza desde el grupo de animadoras en la gran mayoría de las ocasiones.

- Evaluación grupal: como venimos hablando desde el inicio de estos elementos cooperativos se llevan a cabo actividades de reflexión y evaluación crítica a partir de diagnósticos de la realidad en los que se hace un análisis crítico del entorno y se promueve la toma de decisiones colectiva. La evaluación es un momento importante en la casa y siempre se realiza al finalizar cada curso.

Todo esto son cuestiones que hay que retomar, reflexionar y trabajar para no acabar con los espacios colectivos y poder poner la mirada en el empoderamiento colectivo y no sólo en el individual, hay que volver a la colectividad. Sabemos que son los momentos de crisis los que guían el proceso de pertenencia al grupo a través de sus acciones, convivencia, intereses y valores compartidos, relaciones y reconocimiento pero eso no quita que podamos recoger para el día a día asociativo todos aquellos beneficios que comportan las crisis y que hacen crecer y fortalecer al grupo.

En definitiva, el nacimiento de La Maranya y todos los incidentes críticos que le suceden consiguen que se pase de una cultura individualista a una colaborativa a partir de diferentes elementos. Una cultura de participación colectiva en la que sobresale el valor de lo cooperativo y la reconstrucción conjunta a partir de las tres acepciones de la participación social: ser parte, tomar parte y partir con. En este sentido, Traver, Sales y Moliner (2010) nos presentan tres elementos clave observados en sus experiencias de escuelas en transformación los cuales favorecen la construcción de una cultura colaborativa. El primero es asumir el proyecto como propio, el segundo es fomentar la pluralidad de voces y el tercero es la transparencia informativa y el avance desde el disenso. En el caso que nos ocupa podríamos decir que estos elementos se amplían en tres elementos más como es trabajar desde elementos cooperativos, conseguir el empoderamiento colectivo y diseñar estrategias de afrontamiento colectivas. 


\subsection{El cambio social y político también depende de las asociaciones juveniles.}

La Animación cultural aboga por una serie de valores como son la participación activa, la cultura en constante evolución, el contacto con la población, la no directividad, la facultad de expresión para todas, el progresismo y la liberación, la libre expresión y la comunicación abierta, la acción allí donde vive la gente, la apertura hacia todas, la valoración del grupo y la creatividad (Grosjean e Ingberg, 1980). Todos estos valores se han ido integrando a lo largo de todas estas conclusiones con lo cual podríamos decir que La Maranya produce las condiciones adecuadas para la transformación cultural (Ander-Egg, 1989) potenciando la creación de la cultura desde la misma ciudadanía, es decir, consiguiendo establecer una democracia cultural (Trilla, 1996). La Animación Sociocultural impulsa el cambio social y político de nuestro país a través de iniciativas asociativas como la analizada en esta tesis. Collet y Sánchez (2013) se plantean qué modelo de asociación debería ser el ideal partiendo del supuesto de que no todas las formas de articularse de manera colectiva son igualmente positivas en sí mismas. Las Casas de Juventud son una herramienta de cambio social y para ser consideradas Asociación juvenil de « excelencia social« deben reunir los siguientes ingredientes descritos por Collet y Sánchez (2013) y que se cumplen del siguiente modo en el caso de la Casa de Joventut La Maranya:

Ser un espacio de participación democrática, una escuela de participación y democracia a la par que de construcción ciudadana que favorezca el desarrollo de personas autónomas y críticas. Uno de los aspectos fundamentales de La Maranya es trabajar a partir de un proyecto educativo que empodere a las jóvenes mediante su propia participación democrática. Es notorio encontrarlo en el modo de organizar y gestionar las estructuras de participación en la Casa mediante las cuales se desarrolla una trayectoria personal de participación en la que la persona se empapa de la participación a partir de un aprendizaje situado (Lave y Wenger, 1991).

Configurarse como un espacio de aprendizaje social donde se trabajen actitudes, valores, habilidades, conocimientos y relaciones, entre otras cosas. Como hemos visto a lo largo de las conclusiones La Maranya se enmarca en una teoría social del aprendizaje que se concreta en la 
propuesta por Wenger (2001) sobre Aprendizaje situado y Comunidades de Práctica. Además, como hemos recorrido en los puntos anteriores, las participantes de la Casa adquieren una serie de actitudes, valores, habilidades, conocimientos y relaciones que configuran su identidad a partir de un trabajo de formación ideológica que bien podría semejarse al que propone Deltoro (2006). En él sobresalen el desarrollo personal, los hábitos de comunicación y relación con las demás, la cooperación y la conciencia en valores.

Saber promover el compromiso social y cívico, en el presente y para un futuro. Uno de los ejes evaluados a lo largo de las conclusiones es la elaboración de un discurso directamente relacionado con el compromiso social y cívico. Además a través de la pirámide de participación y las actividades diseñadas en cada una de las fases se promueve el compromiso de las participantes siempre mediante elementos que luchan por la justicia social.

Convertirse en un espacio de politización, entendiendo esto como el interés y la actuación en temas, ámbitos, espacios y conflictos colectivos. Es decir, se construye a partir de una articulación colectiva de intereses y problemáticas individuales siempre que se busque la transformación social. Dentro del mismo discurso social al que me refiero arriba se encuentra el hecho de que La Maranya se considera lugar político de actuación y que la apolítica se considera una irresponsabilidad ciudadana. De este modo se promueven espacios de concientización en los que se reflexiona sobre la propia realidad con el fin de actuar en temas, ámbitos, espacios y conflictos que les preocupan y les afectan de manera directa como el ciclo de debates que se abre con Recrea la tena ciutat o las conferencias y debates que se realizan en actos como el Pren la teua ciutat con adolescentes en las que se habla sobre la situación saharaui o se exponen roll-ups sobre la LGTBifobia.

Fomentar el bienestar, la calidad de vida y la vertebración de las personas y el territorio donde sean insertadas. El mismo proyecto de Casas de Juventud surge de la necesidad de tener en cuenta a las jóvenes, alejarlas de espacios de ocio y tiempo libre tóxicos (drogas, alcohol, abandono escolar,...) y promover ciudadanas críticas que puedan mirar hacia un futuro desarrollando una serie de habilidades que les permitan destacar e 
insertarse académica, social y laboralmente en su territorio. Como eje fundamental en el Modelo de Casas de Juventud, La Maranya lo asume dentro de sus objetivos y lo hace explícito en el trabajo diario y en sus dinámicas. En este sentido algunas de las jóvenes ven reflejado este trabajo en su día a día por ejemplo montando la Asociación de estudiantes de Benicàssim o participando en los consejos escolares. En estos dos ejemplos se ve como se promueve una ciudadanía crítica vinculada a su territorio. El profesorado del IES da fe de ello evidenciando el trabajo y las diferencias que existen entre el alumnado que asiste a La Maranya y el que no afirmando el desarrollo de habilidades y capacidades en la asociación juvenil.

Impulsar el encuentro y la interacción de personas de diferentes perfiles sociales. En este punto vemos otros de los apartados que aparecen en el manifiesto de la Casa y que ponen en práctica en el diseño de sus prácticas, la diversidad. Realmente cada persona que participa en La Maranya representa ya de por sí un perfil social diverso y único por todo lo que su experiencia le ha comportado. Por ello el encuentro se favorece entre una diversidad de gentes, un ejemplo nos lo pone una de las entrevistadas cuando se refiere a que La Maranya recoge perfiles religiosos muy diversos en las niñas y niños que participan en el Esplai a la vez que reconocen a familias con perfiles políticos más conservadores y otros más progresistas.

Trabajar por la cohesión social y la inclusión de todas, respetando la diversidad y afrontando y aprovechando el conflicto. Ya hemos visto en alguno de los puntos anteriores la importancia de la diversidad y también el valor que se le da en la Casa a la cohesión del grupo a nivel interno y también externo. La inclusión se trabaja en la asociación de manera directa en su metodología y en el trabajo en valores que se asumen y promueven entre las jóvenes: el trabajo contra la intolerancia y el racismo, las campañas en contra de la discriminación en cuanto a género y diversidad sexual, el proyecto de tutorías entre iguales en el IES,... todos estos podrían ser ejemplos del trabajo diario de inclusión. Por otro lado está el hecho de afrontar y aprovechar el conflicto y como hemos visto en las conclusiones, La Maranya se reconstruye en los momentos de crisis y transforma los conflictos en un facilitador para el aprendizaje. 
A estos siete puntos me gustaría añadir alguno más que para mi, a partir del trabajo de esta tesis, me parecen fundamentales para que una Asociación juvenil pueda considerarse de «excelencia social». Algunos aspectos complementan ciertos puntos de los expuestos por Collet y Sánchez (2013) y otros amplían las características que debe tener un centro para considerarse de este tipo.

* Reconocerse como referente educativo de su propia realidad. Para ello, por un lado, ha de ser un espacio reconocido por el vecindario, las familias, las niñas y niños y las jóvenes y adultas que participan en él para que así pueda sentirse como propio y relevante en la trayectoria educativa infantil y adolescente. Por otro lado, se ha de establecer que las coordinadoras, animadoras, monitoras,... asuman un rol educador dentro de la asociación. Esta idea conecta de forma directa con la anterior ya que vemos que es esencial que para que una asociación sea de excelencia social debe ser educativa y para ser educativa el rol del educador debe estar presente por encima de todos aquellos roles asumidos en muchos espacios que se convierten en lugares de cuidado o de simple entretenimiento. Finalmente deberá articularse para ser un espacio de aprendizaje que aumente la autonomia de las jóvenes, la sociabilidad, la expresividad, sensibilidady creatividad. De este modo, como hemos visto a lo largo de las conclusiones, la asociación podrá convertirse en lugar donde el trabajo con jóvenes, y en especial, el trabajo con jóvenes en el tiempo libre sea totalmente educativo y referente.

* Ser espacio de concientización y responsabilidad cívica. En este sentido tenemos varias aspectos a tener en cuenta para conseguir que el espacio se instaure como lugar para la concientización en donde las participantes puedan analizar la realidad, reflexionar sobre la misma, responsabilizarse de ella y actuar para mejorarla promoviendo ciudadanas críticas y justas. Para ello se ha de facilitar la participación y dinamizar la maduración participativa de las jóvenes a través de compromiso, la responsabilidad y el liderazgo distribuido. Que la participación nombrada en alguno de los puntos de Collet y Sánchez (2013) sea trabajada como proceso educativo en el cual las jóvenes aprenden a comprometerse, responsabilizarse y liderar desde elementos democráticos y de justicia social. Conseguirlo dependerá en parte de si se trabaja desdeespacios de diálogo, horizontalidad y toma de decisiones colectiva. Para conseguir muchos de los puntos ya expuestos debemos trabajar desde 
el diálogo, remarcando la importancia de la pluralidad de voces y que estas sean promovidas desde la horizontalidad para así ser capaces de tomar decisiones de manera colectiva. De forma colectiva porque uno de los objetivos de una asociación de excelencia social debería ser el generar empoderamiento colectivo. Hemos visto la importancia de la construcción colectiva a lo largo de toda la Historia de La Maranya por lo que es algo que ha de remarcarse. El empoderamiento individual no es el fin último, si este no llega a convertirse en colectivo estaremos perdiendo el sentido comunitario.

*Estructurar la gestión interna para que posibilite la gestión comunitaria en el municipio. La importancia de cambiar el marco de referencia en cuanto a la práctica social y su organización dentro de unos valores que fortalecen la solidaridad y el sentido comunitario es fundamental si se tiene una voluntad transformadora. Para ello la gestión interna de la asociación ha de ser transparente, horizontal, democrática,.. poniendo en el centro a la persona y no el máximo beneficio para así conseguir una herramienta de transformación social y empoderamiento de la comunidad.

Estos ingredientes son los que nos dirán si una $\mathrm{CdJ}$ se convierte en un agente de cambio educativo en el territorio como es el caso de la Casa de Joventut La Maranya. Todos ellos junto con los descritos más arriba configuran una completa representación de cómo puede convertirse una CdJ en un agente de cambio educativo en el territorio influyendo y configurando de manera positiva en la cultura de participación de las jóvenes. 

«Més lluny, heu d'anar més lluny dels arbres caiguts que ara us empresonen, i quan els haureu guanyat tingueu ben present no aturar-vos».

(quote of Lluis Llach in

La Maranya Youth Club passport)
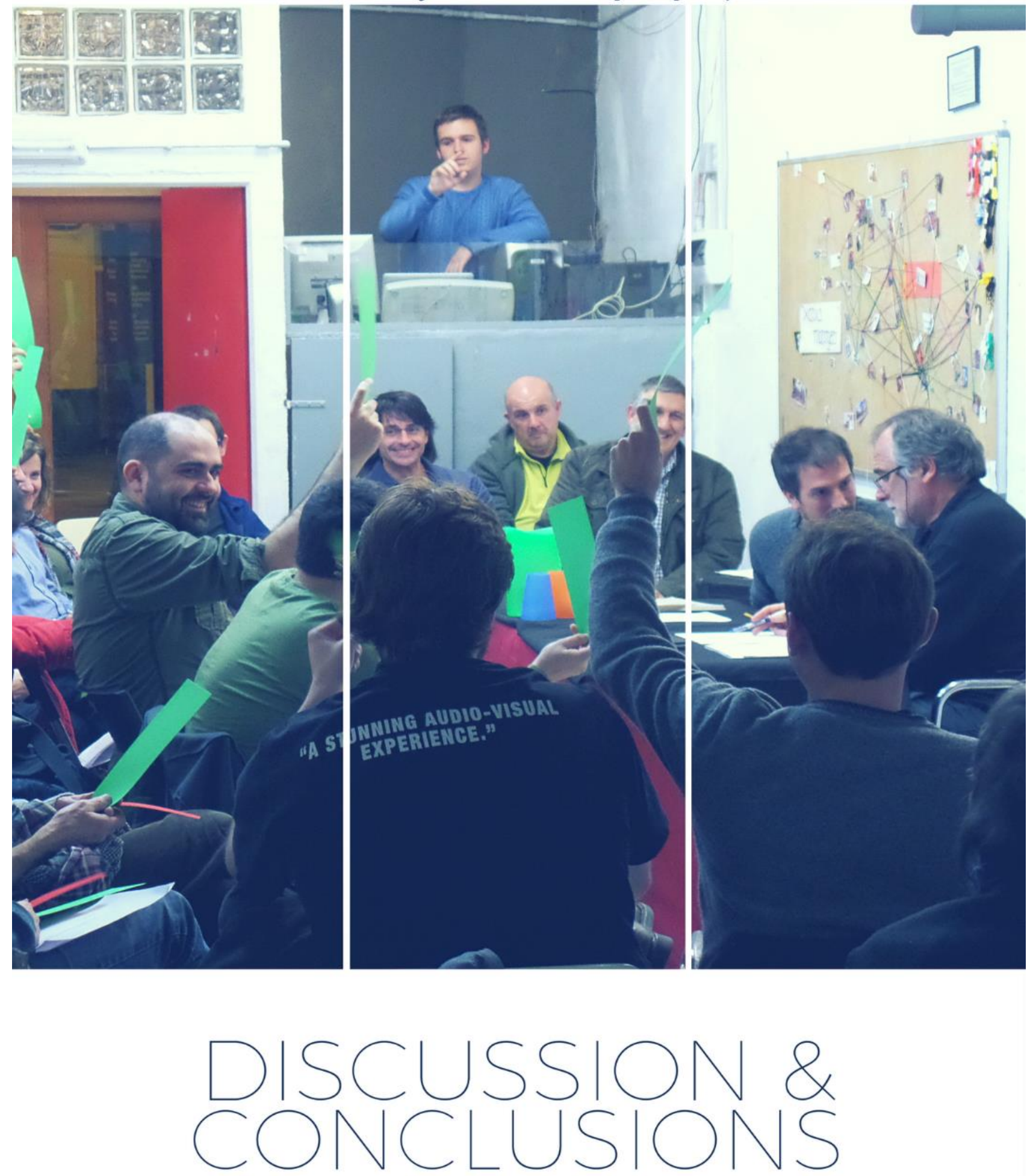

After presenting the results through the account of the Life History of $L a$ Maranya, the following section will have the purpose of connecting all the information by making a discussion that is joined with the theory. I'll present the most relevant conclusion from the research question. In order to do that we'll recall them:

-What role does La Maranya Youth Club play in the culture of youth social participation in Benicàssim?

-Why does it take over this role?

-Is La Maranya Youth Club an educational agent of change in the territory? -How does La Maranya Youth Club become an educational agent of change in the territory?

La Maranya Youth Club from Benicassim has proved to have an important role in building the culture of social participation among the youth population of the town. Its project meets the appropriate conditions for the young people to be able to choose their own learning path about participation and social justice from elements like coping strategies, structural management of participation, relations, discourse, learning space and collective construction. We see that Maranya plays a relevant role when building the culture of social participation among youngsters because it has become an educational agent of change in the territory. In this sense I've been exploring the different ingredients that make this role possible for $\mathrm{La}$ Maranya Youth Club.

This would be the premise from which we start as a generic conclusion of this study. Following, I'll address which ones are all these ingredients that stand out in La Maranya Youth Club and make it possible for the club to play this role in the territory.

As we have seen, the connection between the two main research questions is what makes us address this section from its complementarity. Due to the direct relation, I analyze the conclusions from different strands. Among them there's the description of which are the main ingredients for $\mathrm{La}$ Maranya Youth Club to be able to play the role of educational agent of 
change in the territory and become relevant in the culture of youth participation.

The ingredients we'll analyze next focus on the importance of working in associations to facilitate processes of maturation, social inclusion and development of critical thinking from action (Palacios, 2005). We know child and youth participation predicts a future active citizenship (Putman, 2002 plus Collet and Sánchez, 2013) and if this involvement is achieved in volunteer youth associations, it promotes future political participation to a greater extent (McFarland and Thomas, 2006). If involvement is worked this way, we can strengthen the democratic component of our society from participation models that are consolidated as learning places. In them we find answers to community management models that facilitate participatory democracy through the principle of subsidiarity.

For a better understanding of the structure of the following points we'll see what constitutes a YC (Youth Club) to become an educational agent of change and a model for the construction of the culture of youth participation. Six elements constitute the following figure (figure 16).

Figure 16. Elements that make La Maranya become an educational agent of change.

\section{Participation structure}

\section{Collective empowerment}

Coping strategies

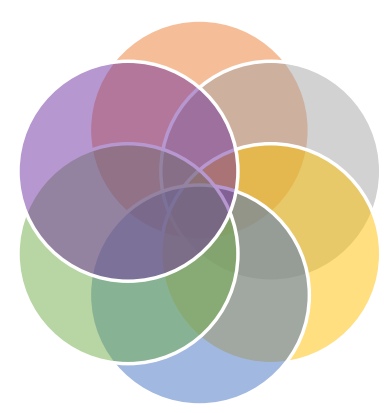

Construction of discourse

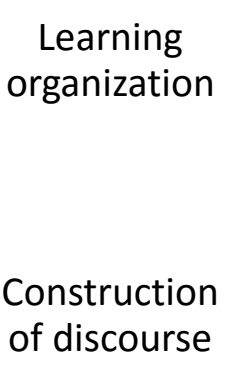

Relational care

The figure represents the six key ingredients that make La Maranya Youth Club be considered an educational agent of change in the territory and it 
can influence positively the culture of youth participation. The six ingredients complement each other, as it can be seen in the conclusion section. They feed off each other, so one cannot exist without the other. It is true that the figure is constituted by two trinomials: one of them makes the most formal part of an association more meaningful and the other is associated to the most informal part. So the most formal part is dedicated to what's structural and it's constituted by 1) participation structure, 2) learning organization and 3) construction of discourse. However, the informal part, the one that speaks about the association's life, its human dimension is constituted by 1) relational care, 2) coping strategies and 3) collective empowerment.

Both sides should complement each other and be worked on so the area for culture construction is powerful. Both the most organizational, systematic and formal side and the most informal, of life in the Club and its community relations are essential for an association like La Maranya to become an educational agent of change in the territory and is able to influence the construction of the culture of youth participation.

As both sides are important we have to avoid one of them canceling out the other. The process of bureaucratization tends to colonize the "life world" but we should pay attention that the last one is put into danger if there's not a structure to lean on (Moliner, Traver, Ruiz and Segarra 2016). So there's the need 'to create mechanisms that facilitate exchanges between the world and the system, with the objective of creating democratic educational institutions that promote social transformation" (Elboj, Puigdellívol and Solery Valls, 2002:35). La Maranya Youth Club being a democracy school will depend on both organizational structures and the human agency that is a part of it.

\subsection{The formal side of an association: the structural trinomial.}

We start from the structural aspect, which is more formal and determined. The Club is shaped thanks to three main variables: the structural management of participation, the management of the learning area and the construction of discourse.

The following section will deal with these three aspects to explain what elements constitute them. 


\subsubsection{Participation structure.}

The structure of an association is important to know how they organize participation to attain the established objectives and thus understand what actions will be performed to achieve them. The structural management of participation in La Maranya is based on a specific model. Over the course of history we've seen participation is organized hierarchically. The reference comes from the participation models of Youth Clubs in Zaragoza that elaborate a unique system that differentiates the degree of participation according to participative maturation of people (Palacios, 2005).

The group of youth workers that are in the Youth Club, that later will become the association Maranya, promote the systematization of this model of $\mathrm{YH}$ and its practice. That is, they organize the participation in the Club from ideas and structures that the YH model from Valencia and Zaragoza promotes. This systematization causes an increasing participation in the Centre and at the same time promotes leadership among the youngsters that gradually turn into active members of stable groups and give shape to the social basis of the centre: Estem Vius, Quatre Gats and Esplai Cataflai. In this fact one can see how the group of youngsters assumes a degree of autonomy that is high enough to carry out and strengthen their own initiatives. This influences youth identity consolidating the stable and strong movement of young people that promote their own activities. Willis (1998) also notices this idea when he describes the capacity that young people have when they get involved in cultural practices that haven't been imposed, but have been built thanks to their autonomy and based on their own interests. Kiilakoski and Kivijärvi (2015) also emphasize it because they see that when youngsters have the possibility of taking decisions and managing their function in youth clubs, they obtain better educational outcomes. This makes Estem Vius, Quatre Gats and Esplai Cataflai get stronger and be able to lead the birth of Maranya.

With this example we see how a personal participatory trajectory goes from a lower to a higher degree of involvement. This strategy of pacticipatory distribution empowers youngsters to active participation, reflective and critical thinking and responsible action around relevant matters that affect them (Díaz-Barriga, 2003). This way we turn it into an 
effective, meaningful and motivating participation for the learning of young people.

In this sense a person can start as a member of a group of eventual users, move to being the user of a workshop that constitutes a stable group, then managing it as an activist and end up being an active part of the group of volunteer active members. The analysis shows how one person positions in the hierarchy from the learning derived from his/her own participation. Esplai is very important in this trajectory as it can work as the first step of participation when you become a member of the association as a user, and as the last step when you become a youth worker. So we see how this child area turns into the cornerstone that years later keeps generating the social basis for youngsters to be involved and manage the Youth Club.

On the other hand, this structural strategy makes the volunteer youth worker team (VYT) to know at all times how to organize activities and actions that they propose, to mobilize more some groups or others depending on the needs at that time. It also works as a guide to address activities to some learnings or others depending on its participation. Responsibilities vary depending on the participatory stage where they are so commitments are assumed gradually together with the different learnings. For example, one person who is a member of a stable group will ensure his/her attendance to group sessions and the participation in the group's everyday life. However, a youth worker commits to giving a dynamic edge to the group and for this reason they take on responsibilities like convene meetings and make sure the minutes are written down and are disseminated in the group, among others.

Although it may seem this hierarchic participation structure refers to a gradation of authority, it is really structured like this to facilitate a personal participatory trajectory as an educational and democratic process. For this reason, it is important to notice the components that place a person in one degree of participatory maturity or other. There are mainly four variables that affect participatory maturity: compromise, responsibility, availability and leadership of people.

In compromise we see how the involvement of people can be measured, their effort for being there and be a part of the place and their capacity to 
become aware of the importance of their participation. In this way, depending on the level where one person is in the hierarchy, they will not be as committed to the objectives of the Club. For example, one person that goes to the club for a specific service, like attending the annual Halloween party, will not be as committed as a youth worker of a stable group that takes part in the design and organization of the group's direct action.

We see that the four variables are interrelated as responsibility could be a key factor within compromise. We see how you can find yourself at the same time in one level of responsibility or other and depending on that aspect, you will assume a type of commitment with the association. Concerning this variable it is interesting to investigate how depending on the perception people have about the Club, it gains or loses strength. Some youngsters refer to this factor before they distance themselves from the Club. The reason for it originates when responsibilities are perceived as an obligation, they lose interest and stop feeling the responsibilities as their own. In these cases they have either abandoned the Club, they have distanced themselves from the group or the group ceased to exist. When they feel the pressure and start being disenchanted by tasks that were exciting before, the outcome has always been the person's detachment from the group. "What is owed lies in the recognition of a bond, of a ligatio. , from which an ob-ligatio (ob-ligation) arises, and this obligation can be either a duty, that is the ob-ligatio, as a response to a demand or a gift given by whoever knows and feels bonded to someone else. Without the bond being recognized, the duty or gift are meaningless" (Cortina, 2007). The way we see the duty can be understood in different ways and depending on how the bond recognition is worked, duty can be perceived in a different way. This can be related to the different levels of compromise that each person decides to have and the lack of understanding among the rest. Like all things in life, perceptions change depending on the person and that may affect to a greater or lesser extent depending on the existing spaces to share those perceptions. For this reason, focusing on the learning associated to it, we have to worry more about the process that is carried out so a person recognises a task as a duty or as a gift and worry less about the number of responsibilities they have in a group, because its stability through time will depend on that. So, the interesting aspect is to obtain, no matter how, 
authentic participation and that is a guarantee that the protagonists will find the organization methods that work most effectively in their context and needs (Cornejo, González and Caldichoury, 2007) and work the concepts of compromise and responsibility in the educational context. That's why, as they analyze in HEBE project (Soler, 2016) we precisely need new forms and structures of youth participation that emerge from youngsters themselves and are created from their own principles and needs. These structures have an internal defined and sustained organization that can coexist with the structures created for the political representative democracy.

Another variable that affects the process of participative maturation is availability. Time is a highly valued factor nowadays, citizens are trapped in their individual time and forget about the global aspect and that has repercussions in the social commitment that could be assumed in collective spaces (Traver, Aguirre y Moliner, in the press). For this reason, depending on the individual sphere of each person and the commitment they assume to society, they'll have more or less time available to dedicate to collective projects. This is the way it's analyzed in Maranya's history. There are different levels of availability and they depend on the level of participation of people in the Club. Many youths are blocked by academic requirements and this is one of the factors that influence their perception of time. As Melendro (2016) states, they are young people without time, compelled to confront daily life, with no time to stop being in the present, with no time to shape a future, in an evolutionary period when it's not easy to do it, with no time when they most need it, the ones who need it the most. We'd like to focus on that for future proposals of reality analysis as I consider it is a very important factor, the analysis of time in leisure and free time pedagogy.

Furthermore, relating to participatory maturity we find its connection with leadership that is exercised in the Club as it affects the roles that participants take on. We see that when youths that have been characterized by their capacity to lead, coordinate and influence the group, they have gone from users to active members of a stable group and even join the VYT. For this reason the leadership exercised affects the participatory trajectory of the person somehow or other. Besides, depending on the type 
of leadership exercised, it will affect the stability and the educational project of the Club differently (Agüera, 2004; Volante, 2008; Bolívar, 2010; Guibert, 2011).

All this can be exemplified with the role of the VYT in all this process. First of all, we find the VYT on top of the pyramid, and they are, according to the YH Model, the object of higher participatory maturity. That's why the type of leadership exercised by the ones that constitute it will influence the participatory trajectory of the rest of members of the Club as participation increases leadership abilities (Walker and Saito, 2011) and for this reason we have to analyze and reflect on the type of leadership we show because it influences the work of some principles or others (Cassels, Post y Nestor, 2015). Besides, history shows there are significant differences in the participation of people that constitute the VYT. Some take on the role of coordinators and others prefer to take on an learning role. Half way we find the ones who manage projects with the help of coordinators. I'm going to focus on the specific analysis of this participation because the VYT is in charge or carrying out the educational project of the centre apart from being a model for the rest of structures of the Club.

Let's say the same way the Club is structured into a pyramid that is divided into 5 stages, the VYT is also constituted by different stages according to the participatory maturity of its members:

-Youth worker coordinators of VYT.

-Volunteer monitors of projects.

-Team apprentices.

A factor that can influence this distribution is mutual trust that exists in the group as the group identifies with their leaders even though sometimes it creates a dependency of the rest of the team on coordinators. It is unknown if the YC would work the same without leadership, with different leaders or if they didn't exist. What we know is that guidance, in many occasions, turns into management and that can influence the maturation of people to assume responsibilities in the YC. Coordinators have very consolidated ideas of the YC Model and of the project they want for $\mathrm{La}$ Maranya. If we add to that their communication skills, it makes it simpler to 
work towards a specific model of action. They think they know what path to follow to exponentially increase participation and those are the steps they want to take. However, it has to be taken into account that an element that poses a difficulty in participation is the difficulty to break these stereotypes and roles assumed traditionally and that each social actor takes on (Moliner, Traver, Ruiz and Segarra, 2006). If we can't break them in the learning process we will find dependence between the different participants that can influence the achievement of generational replacement that the coordinating team expects.

With all this, tasks are distributed according to commitment, availability and the responsibility of the people although initiative and their abilities coordinating groups, that is, leadership are also important. We see that these variables will influence the type of leadership depending on the value of the context where it originates like Watkins (1989) stated when he talked about the ideal behaviour of a leader. Likewise, Hersey and Blanchard (1977) say that depending on the maturity, shaped by the will and capability of the group, the leader has to behave in a different way going through stages of management, persuasion, participation or delegation. The VYT, rather than being a type of leader, takes on a different role depending on the situation like all these authors say. This choice questions the values that are embedded in the Club like dialogue, horizontality, collective decisionmaking, sharing objectives, trust and mutual recognition and joint planning, among other aspects.

For this reason we have to take into account that the type of leadership that is exercised is going to influence the individual and collective growth apart from working as a model for learning in the Club. Therefore we need to rethink the choice towards a model of distributed leadership (Gronn, 2002; Timperley, 2005; Spillane, 2006) that facilitates community work and makes it possible that all the VYT turns into a change agent inside the organization. Achieving it doesn't only depend on the change in task distribution but needs a change in the culture of the group (Murillo, 2006).

So there's the need to present space for dialogue, horizontality and collective decision-making. This doesn't happen collectively and horizontally in the VYT when because the distribution explained before stands out making the coordinators of the VYT group take the decisions. 
We cannot neglect that in this type of choice towards a specific leadership style, it is important that the rest of the team is able to value their own potential in their contributions. As Moliner, Traver, Ruiz and Segarra (2016) state full participation will be achieved when whoever constitutes the group are able to play a leading role in this sense. Comparing it with the theories from Hersey and Blanchard (1977) this could make a reference to the maturity of the group they were talking about in a way that the more prominent they get, the more mature they are. There we can see a direct connection with mutual recognition assuming its importance to reach adequate maturity in young people. Let's remember there were youths that didn't feel their work was recognized, but the contrary. If things were not done a certain way they weren't well done. This opens a door of analysis to what would happen if projects and activities were not done the way they've always been done, if they didn't follow the exact same steps people had taken before within the movement. Opening the door to new initiatives and different creativity could strengthen the project with an increased openness sustained by diversity. That, or really making recognition explicit, gives the opportunity to contrast with the different options to share the construction of something new.

For this reason "the engine of action is not found in obedience but in meaning; people do what they find meaningful. Meaning is a collective product, it is built with significant others" (Cohendoz, 2001). So, in order to obtain full participation in the team, they could consider the objective of guiding participation with the aim that everybody involved has the same opportunity to contribute when building collective knowledge finding meaning in spaces and moments and adapting them to the characteristics of each member. This way they will favour the achievement of individual empowerment based on a progressive scale of participation that eventually leads to something more interesting, the group empowerment from democratic participation and fair dialogue under an argumentative agreement.

Even if there is a clear leadership, objectives are shared in the group and what's most interesting part for the team is the good performance of the association and no one being the protagonist or dividing roles into power degrees. This idea is emphasized frequently and they insist it is important to 
participate in meetings, plenaries and assemblies with the objective of planning together the program of Maranya and so distribute tasks according to the work areas of a Youth Club assuming youngsters are fullright partners (Úcar, 2008:6).

We see these actions could make work easier to achieve a leadership that is distributed in the group. Apart from that, another useful strategy is the objective of communicating and informing about the actions carried out in the Club. They pay special attention to the spaces where the group shares projects, activities, news and all the information that may be useful to pursue common goals. They are displayed in the association's boards and they are also posted on the Internet's blog to favour transparency.

One aspect we haven't dealt with yet is the need to create a generational replacement that permits a change in the VYT. It is one of the main concerns of the VYT coordination and it is something that tries to be worked on from the participation pyramid. Coordinators are concerned because the rest of members don't take charge the way coordinators would like to and there isn't a strong social basis to generate active members that end up being that replacement. With respect to the first question we can stop to think if taking responsibilities comes up naturally or it is imposed, if youths decide to commit from their participatory maturity. Also, we have to rethink about how the responsibility taking is addressed. On the other hand, reassess the situation with the group could be one of the solutions as it was done some years ago. Let's remember the same happened in another moment of the history of La Maranya, when they ask for a replacement in Esplai. If we remember, in this case, collective reflection with the families brought a series of options to give an answer to this situation. They found the solution in the possibility of generating connections with the community outside Esplai and involve families, boys and girls more directly in the program and management of the group. This is why we could wonder if it's necessary that the replacement is only generational. Couldn't there be a replacement coming from other places? Maybe those replacements could come from adult groups or from new youth workers that become members of the Club? The approach of the VYT group coordination is to obtain a generational replacement that substitutes them from reflection and with their own leadership, when they 
are not in this space anymore. We should analyze what options could be possible and what are the reasons why it doesn't happen at a generational level.

In conclusion, we have to try associations to be the context where we are able to develop practices according to personal interests. We have to set those spaces and also facilitate participants the resources to learn what they need with the objective of taking action and taking decisions doing it from their own knowledge (Wenger, 2001:27). In this way, participation in Maranya is divided into levels with the idea of generating these spaces in which each person, according to their participatory maturity, can take action in the corresponding learning process. For this reason," operate on efficiency criteria, prioritize objectives and face the need of a distribution of tasks, must be understood from empathy, respect and above all the search for coherence among the values and methodology (Casado and Gómez, 2010:16) but never from tiers of power, authority and/or personalities. That's why we have to walk towards a leadership distributed within all this pyramid structure of participation.

\subsubsection{Construction of discourse.}

Exploring the ideological approach of the YC La Maranya and recognize how the discourse of the movement is generated emphasizes the importance of collective construction of discourse that the Club and its participants assume.

We could say that the discourse of the YC arises from a model based on the Secular and Progressive Movement (Palacios, 2005; Ferrer i Guàrdia Foundation, 2006). Those who belong to the Club share an ideological approach focused on the promotion of democracy with citizens that have a critical thought, they are active and fight for social justice. We don't find opposing ideological positions on that sense although there is a diversity of viewpoints above all thanks to the cross-generational variety of members in the centre. There are no oppositions of values that protect human rights and take place in processes of social justice.

Nevertheless we focus our attention in how collective discourse of the YC started forging in the critical incidents the Association goes through. Maranya rebuilds itself in times of crisis and these allow the generation of a 
common discourse together, not only among youngsters but also among families and youth workers. Incidents happen that produce changes like changing from a Casal Jove into a Youth Club and giving more importance to education and youth self-management in the centre. Others bring changes like going from premises that depended on the town council's management, which generates an enormous amount of bureaucracy and stops youth action, to premises that are independent of government, with autonomous power and with the expectation to becoming a community association that is independent from the administration. There are other moments that generate a feeling of loss, discomfort and the need to relocate like some youths leaving the project: some are accepted and others are disruptive. Other moments cause conflict like the decisions taken by the council and others provoke fears like lack of participation in stable groups and the weak responsibility taking of youngsters. In all these moments the Club generates a discourse, it evolves and transforms. That's why these moments have to be studied thoroughly and reflect on them individually and in group because, among other things, this is what makes Maranya what it is.

Indeed it is in critical incidents where the group should take a stand and in this collective action is where the ideology that articulates the Club is born. Concerning ideology we should highlight that Maranya is not a partisan centre, with no political affiliations. We can see that when all political groups are invited to the events although the most conservative never attend them. Still, it is a political site where debate and criticism are generated from freedom of thought, critical awareness of people and their own process of participatory maturation. An example of it is the sessions of "Recreate your city" where different political groups together with citizens of the town participate in the drafting of a joint plan to improve Benicàssim. Maranya is the turning point in these cases; they want to emerge as a place to defend rights that promote common good without positioning themselves for or against a political party. We see that with the development of the series of talks "Recreate" they generate an opportunity for collective debate and the construction of a common project. This fact reveals the importance of the political perspective in the $\mathrm{YC}$ and strengthens the discourse of the Club in particular as it favours the analysis of reality in a collective manner (Freire, 1974) and awareness of the 
individuals that participate in it, becoming protagonists of their own reality and of their own life plan.

With that in mind the non-partisan position is understood as a sort of covert irresponsibility, unconcern for politics is a display of civic irresponsibility (Ander Egg, 2004). This argument is worked as a central line of the Club. In the YC's project there's a line of action that is the work on values in which several situations of current events are analyzed with youths. Some of the campaigns are, for example, about homophobia, bullfighting, renewable energies or refugees. In this way a discourse is being worked on that walks towards the construction of critical citizenship. Critical citizenship that appeals to the exercise of a citizenship that problematises reality reflects cooperatively and proposes collective action. In order to do that we need a shared leadership, a personal and social commitment and active involvement in planning, democratic decision taking and implementation of the action (Sales, 2012 and Benjamin, 2002).

This has a direct relation with the way of viewing the action in Maranya, like something that is volunteer, activist, militant or even like a working space. The analysis of the meaning of these concepts keeps teaching us about the meaning of participation in the Club, apart from emphasizing the direction of the social discourse.

Three words come up in Maranya to describe the non-profit action that many of its participants perform: volunteering, activism and militancy. The idea of volunteering starts being conveyed when they are early teens, the importance of the word and the activity involved, without turning it into corporate volunteering but into one that mobilizes for their struggles and for the value of solidarity. We know one of the greater expressions of solidarity, apart from having a severe impact in society, is social volunteering (Traver, Aguirre, Moliner, in the press). Further developing this concept and the contribution of García Roca (1994) and García Roca y Comes (1995) we find the three basic ingredients of solidarity through which social volunteering has been building their own identity. One of them is sympathy, feeling moved and experiencing the other's world as their own; the second is recognition of others and the third is universalization as a tendency of our actions. This has generated three types of volunteering with regard to these three ingredients: assistance 
volunteering, rehabilitation volunteering and promotion volunteering. The last one addresses structural dimensions and transforming action and it is the one we equate with the work in Maranya. The volunteer constitutes the social basis of the Association and participates in the Club assuming responsibilities and specific tasks without getting paid for it, but looking for social benefits, the fight against social exclusion and structural change. Their participation can be occasional in a specific project or continued but their only objective is learning what is carried out in La Maranya. The volunteer is the only regulated figure in legislative terms and for this reason, all the people who assume responsibilities in the Club will be called volunteers if they have responsibilities and a signed commitment with it.

The approach used to work in Maranya is getting youths to assume that the limelight in transformation stays with the community to which they belong and their commitment will imply a real help to their community (Marchioni, 2001). That's why they insist, from an early age and through participatory structures, on taking responsibilities with the community. With this approach, the community and the social environment become the centre of solidarity action, creating a new denomination: volunteerism of development (Ortega, Mínguez and Gil 1996), which will promote an organized form of participation in social life. From this point of view, solidarity and its expression in volunteerism turn into key goals of the education of Maranya project as they want to train people and social groups that are effective and emotionally charitable (Traver, Aguirre and Moliner, in the press).

The following step we could call activist or militant. There's not a definite preference for either of them in Maranya. Some people prefer to be called activist because of the active implication of the word, and others opt for the idea of militancy because of the commitment to the cause it implies.

These are the two concepts that define a person that works voluntarily in the Club but the tasks are assumed from a fight role within the movement of Youth Clubs. That is, they are very committed to their role and they firmly believe in the youth project where they participate. They'll do everything they can so the project is kept alive and they'll mobilize in any way to make the movement known to as many young people as they can. They really dedicate their time to a specific line of action in public life, and 
in this case, they are totally committed to youth participation having representation spaces in towns. This is their cause and they consider it essential and socially necessary.

If we remember the different stages through which one person moves in the VYT, we can see the change of mentality from apprentice to volunteer and from volunteer to militant. The first level still has doubts and compares the work they develop as volunteers to paid or business work until experience and the discourse assumption of the movement makes them realize if they consider volunteerism like a job they're losing the activist and militant view, and they will get burnt out with responsibilities and will end up giving up on trying to militate in the movement. This is what happens specifically with one of the members of the VYT. At the beginning, this person started to place the work in Maranya at the same level as the one for which this person got paid outside the Club. Little by little this person realized that it is necessary to change views, and this is the advice they get from group coordinators. If they want to do volunteer work, they should differentiate it from the paid one or fight so that what they do today as volunteers, they can do getting paid in the future. It is mainly about creating viable living futures, doing things that change society and influence that this style of action increases the value of social work and the need to build culture from citizenship.

For this reason, they want to keep the educative model in free time alive with their actions and among them we find financial contribution as partners, their volunteer work and the benefits obtained from their activities. Economic benefits are not shared among participants but are reinvested in activities and other expenses the educative and cultural entity has. This is a militant value that is transferred from person to person in the Club.

Another aspect that qualifies militant action is the idea of capitalizing on the movement: an aspect than has been considered the main objective of the VYT's action. History has shown that experiences shared with other neighbour movements like Zaragoza recommend this type of measures to strengthen the movement. The way to achieve it is by increasing economic income; expand the number of volunteers or obtaining premises. This is the way they make the youth association movement stronger with the aim 
to get educational and cultural spaces with a public mission promoted by citizenship itself.

Volunteer work, activist and militancy show the importance that the Club gives to citizenship being in charge of managing their own spaces. Associations emerge as a tool for social support, like the device that makes it possible that citizens needs are met (Trilla, 1996; Alberich, 2007; Palacios, 2005).Today they look more like service provider centres than reflection, action and citizen support spaces and for this reason, Maranya still has the firm conviction of using the associations like spaces where to exercise democracy, based on the subsidiarity principle (Article 5, Treaty on European Union), which is very popular in other democratic countries but not valued in ours. When democratic governments are based on this principle they know they have the greatest responsibility of citizen's services but they will only manage them if citizens can't do it themselves through associations. The experience in Germany or France, for example, confirms this way to work in public services has many advantages and strengthens participation mechanisms and civil democracy (Jacobson, 2014). In Catalonia they are starting to use this concept of community management from the work of the Platform of Civil Management Organizations in Barcelona (Alcántara, 2016) in a new framework of action like Social and Solidarity-based Economy (SSE) (Chavez and Monzón 2006; Guerra 2004, Coraggio 2015; Razetto, 2000) detaching itself from the terminology the government uses: civic or collaborative management. In insights like the ones coming from Font, Ojeda and Urbano (2015) we see the importance of defining projects in order to "make visible the transforming determination and the degree of autonomy desired, and therefore, it implies an ideological and political stance around the provision of services and by extension also to the dominant economic model and the government's role in it". For this reason we fight for community management, because it fits the picture of subsidiarity principle that Maranya backs up. As the principle of subsidiarity explains, facilities don't belong to the government but to citizenship, so "it is a right and a responsibility of society to take active part in the management of resources and services that affect their everyday life" (Font, Ojeda and Urbano, 2015). This way, the usual management binomial is transformed and the government takes a backing and facilitating role. This is the way Jacobson 
(2014) explained it in some of his visits to Maranya, just as Alcántara (2016) did in the talk he gave in the Club, giving prominence to the real protagonists and on the basis of the values that Font, Ojeda and Urbano (2015) list and make it different from the rest of managements:

-Accessibility/universality.

-Direct democracy and self-determination.

-Transparency.

-Self-control and self-assessment.

-Territorial bonds.

-Capacity to become a tool at the service of the community to transform its surroundings.

-Possibility of reversal of their own project and payback to the community.

All this connects with the interest of Maranya to go back to the public sphere, recuperate it with citizenship. We can see that in one of the videos the Club posted on youtube (Els portadors de somnis) where they show their intention stating that Maranya will regain its fundamental purpose when they go back to the public sphere because there is where it should be.

The fact that Maranya demands the public sphere and management done by youth citizen initiative makes it become an appropriate place to work from the framework of Community Management but not only for it but for being connected to all the values listed before as we can read throughout these conclusions. Let's not forget that Subirats (2005) reminds us of the interest in knowing and analyzing other forms of social organization that facilitate collective reconstruction, bonds among people, the sense of community and the respect for individual autonomy. Aspect analyzed through this investigation.

Doing so, young people will be in charge of designing these activities and services, and it will provide learning pathways from real participation. We have two interesting variables in this fact, the first is the idea that citizenship will be in charge of managing culture, and the second is the possibility that a youth organization, typically deprived form participation, will be the one in charge of doing it and learn while they do it. "The equal 
and participatory democracy we support, must recuperate: its voice, the presence and the knowledge of those who have been deprived of their right to decide and strengthen educational skills of participation" (Subirats, 2005:8). Doing so, we will play a very important role as an agent of educational change in the territory.

That's why we need transforming processes of participation, practices and reflections coming from social participation that help us face and transform social reality from the public sphere, promoting collective construction of active and fair citizenship. We need to recuperate the public sphere to rebuild it collectively by transferring the political prominence to citizenship that is able to build its own culture from common good. As Aranguren (2010) presents, this is not about making the role of the government invisible but to accept that there is a new and organized civil society that bets on a governance body that is cooperative and relational.

Opposing the reality of citizen movements to the government's we see the general situation is the use of procedures that are foreign to these ideas, most of them focused on a participatory democracy framework that is distorted and inside public institutions. But we really wonder if there is really a democratic quality in current experiences of participatory democracy (Parés, 2009). If participatory democracy is not considered from associations and civic and collective activities, democracy will become a space that is institutionalized, bureaucratic and restrictive. This idea is not questioned as there's an increasing evidence of the government's democratic failure (Subirats, 2005) and that's why participatory democracy turns into bureaucracy and discomfort (Serrano, 2008). If one believes in other forms of participation other than vote and consultation, they should be extended to as many citizens as possible (Alberich, 2004) promoting participatory channels from community management.

Thus, bureaucratize participation by adding more and more citizen participation organizations instead of promoting existing channels and social networks of popular participation will only lead us to participatory exhaustion and to the idea that participation is useless. "We can't forget that neo-liberal thinking has an enormous power and facility to enter, control, privatize and undermine initiative and non-formal teaching networks, with the subsequent increase of inequality" (Carbonell, 2015:59). 
That's why the problem lies in the institutionalization of knowledge (Reimer, 1973 in Carbonell 2015:26) and in our case, the institutionalization of participation in leisure and free time.

In brief, we see the assumption of this discourse that is social, communal, of self-management, promoting awareness, civic responsibility, work on values and promotion of democracy encourages the definition of $\mathrm{La}$ Maranya Youth Club like an educative agent of change and it is fundamental in the construction of a culture of democratic participation among youths.

\subsubsection{Learning organization.}

Saying La Maranya YC is not an educational area would be a mistake. It is consolidated as an educational referent among family members, teachers, neighbours, technicians and youngsters as we've seen through history. Families trust them with their sons and daughters because they believe in the educational project and they think that those who coordinate the project can set an example for them. On the other hand, the Town Council recognizes their work and praises their initiative but doesn't back up the project directly. They take refuge in legislation and current regulations of participation although the mayoress says if there is not a participative space, promoted from the council, where Maranya is included, they may have to create it. This is what she says when they see they don't meet the criteria to become members of any of the created platforms (table of solidarity, school boards, citizen participation board and participation for participatory budgets, among others) due to their own internal functioning regulations for these spaces. For this reason it would be interesting the institutional recognition as an educational space so Maranya could have a place in the right platform.

If we analyze potential we see that an institution like Maranya gets strengthened if it's placed in an educational project and this is the way voices mention it in history. It is valued like a learning space in which work is assumed as an educational task and not like a service for the entertainment of its participants (Deltoro, 2006). The methodology used is what differentiates it from other experiences in which they highlight the objective of offering a service for citizens without an educational sense. Here we have to go back to the participation pyramid as it is important for 
the design of activities. As I pointed out before, the pyramidal structure allows the design of an educational project focused on each one of the levels of participation. For example, consumers will have massive activities dedicated to a topic of values or any musical or thematic events like Halloween with the Haunted house; users attend training courses or workshops; stable groups attend their own activities and preparation meetings like drama and video recording among others; active members attend meetings with the stable group and meet coordinators in plenaries; the VYT group has their weekly sessions of internal work arranged and will attend all the activities they present. All these examples could be those facilitator spaces of learning towards participation as they adapt to those who attend them generating a place in which the participant seeks to cover their own needs and encourages full participation. This adaptation has been studied for years at school and it showed that adapting space to the needs of people favours learning (Laorden and Pérez, 2002; Arnáiz, 2004; Duke and Hinzen, 2009; Moriña, 2008; Martínez de Mandojana, 2014).

The YC is a learning space where they work from practice carried out in real scenarios, that is, they work through situated learning as learning is considered an integral and inseparable dimension of social practice (Lave and Wenger, 2001). One of the Maranya premises is that you learn to participate by participating. This idea fits perfectly with the situated learning model as you learn from active participation in experience, focusing on its importance apart from concentrating on the social context to which a bond is required. On the other hand, situated learning considers learning as a continuum in a person's trajectory; it is a continued development (Niemeyer, 2006) as the Club does with the participation pyramid and the learning trajectory it enables.

Wenger (1999) defines four dimensions of situated learning in social communities: bonding and participation, becoming and growing, expertise and experience, active practice. These are essential to achieve true learning located in the community. In the Club, they mainly work in a group social context that has a common activity: the use of leisure and free time of young people in Benicàssim. In Maranya they build a common identity among participants, they talk about the association like something that is essential in their lives and it is a place where they grow and become a part 
of that reality. They also understand that the opportunity to participate is a very relevant aspect as it's the only way to give meaning to learning. As Dewey (1997) said "all true learning is achieved by means of experience".

Figure 17. Situated learning in social communities. The fourth dimensions of situated learning. Source: Wenger, E. 1999. Translation BN.

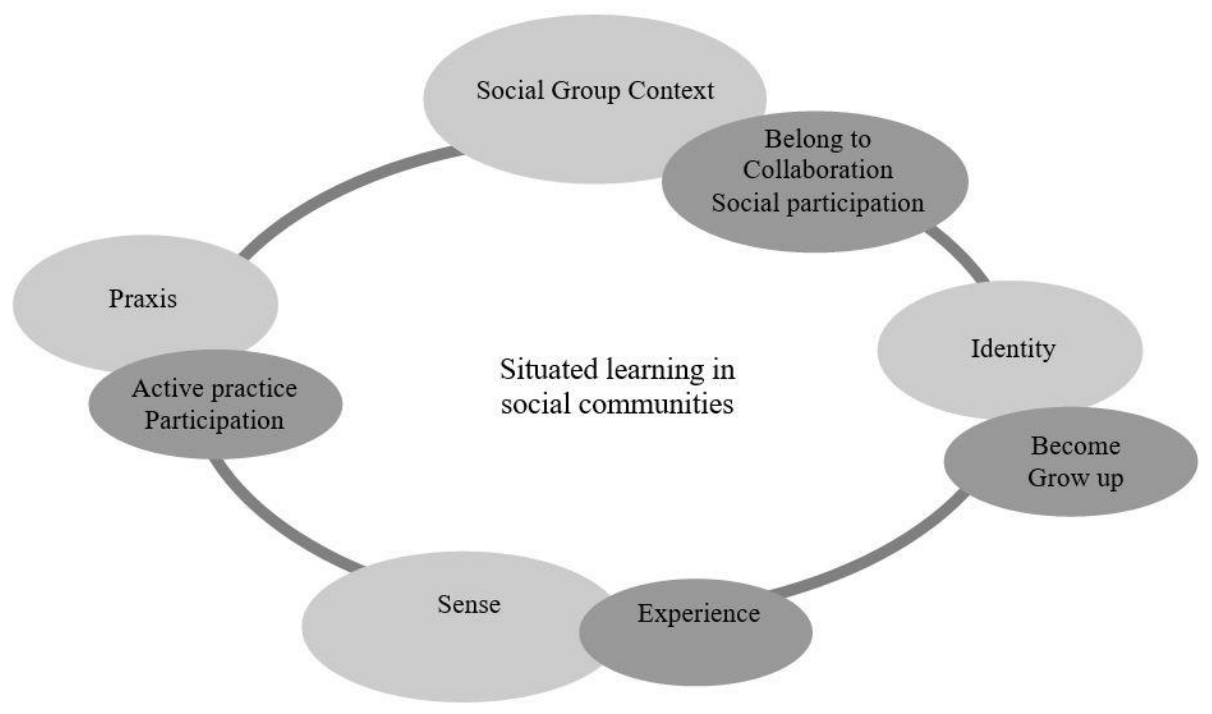

This method enables a series of learning in the Club like McKeachie (1999) said:

Address events of daily life. The work in Maranya is daily life work as some participants call it. The possibility to live together and share with other people facilitates that life events also happen within the four walls of the association. In this way, sharing coping strategies according to the needs of each generation would enable greater plurality of learning. In 2005 the World Youth Report insisted on the need to take action to develop intergenerational initiatives. In Maranya the possibility of unifying some spaces for the different generations (children, teenagers and adults) to be able to share knowledge, makes it different from other youth spaces and strengthens their learning. Intergenerational diversity reinforces the partnership project becoming an adequate place for citizen participation of different groups. The YC is a place where each one lives and develops their culture (Ander-Egg, 1989) in relation with the generational space it has and 
for this reason, the socio-cultural animation this place promotes becomes an instrument for cultural democracy (Trilla, 1996) based on diversity and inclusion. In this line, Maranya works culture like a dynamic process and promotes citizenship as the one in charge of generating it. It is not a matter of bringing culture closer to citizens but let them be the ones who build it according to their interest. Culture is understood as the way the world is built (Mèlich, 1996) from the representations of life that are expanded, enriched and modified (Pérez Gómez, 1998) by those who experience it. Hence culture is considered a basic element for community development and education as the key driver of change (Aguirre García-Carpintero, 2012).

Implementing and sharing knowledge in a meaningful way. A way to do it is through the structure of participation the Club has. Due to the different levels of participation, youths learn abilities that put into practice and share as they assimilate a participation commitment. It is perceived that youngsters that start to participate in the $\mathrm{YC}$ in stages of less participatory maturity, little by little assume a greater commitment thanks to the application and sharing of knowledge from the experiences they've had. Besides they get to apply the dynamics and transfer the knowledge to other spaces like school. If we remember, it was one of the aspects that teachers from high school highlighted.

Learn and deploy abilities that facilitate the construction of a sense of professional expertise. This is another of the aspects with greater visibility in results. The people that constitute Maranya refer to the learning they acquire as adequate for their future professional activity. Abilities that are cooperative, organizational, social, planning and even more technical activities like carrying out the electrical installation of the Club, have made it possible that participants learn professional skills in different areas: from social work, to journalism, audiovisual communication and engineering, among others.

Knowing how to handle social situations and contributing to community. The trajectory in Maranya turns into an awareness process that gives participants the ability to analyze truth, make a criticism about it and move towards improving it. This act in itself already generates citizenship. This is the way it's done in participatory social diagnoses (Aguirre García- 
Carpintero, 2012; Lobillo, 2002; Marchioni, 2001; Rebollo, 2001; Villasante, 1998; Expósito, 2003; Hechavarría-Lescaille, Salas-Delisle and RoldánRuenes, 2008; Martínez, 1995) and the Club initiates them apart from promoting projects that question, raise awareness and transform the group or the town like the preparation of videos about democracy, education,... or the series of talks "Recreate your city", that were done before the elections. Doing so, they discover and participate in their own reality.

Relating thought to action. We can't divide the previous element from thought for action. Schön already stated it in 1983 when he described that one of the essential features of practice is reflective practice. In the Club they work through critical thinking, giving preference to dialogue and argumentative agreement rather than decision taking through indirect participation like voting. For example, in meetings they design dynamics so participants can have their space for dialogue and argumentation when taking the decisions of the centre. This practice generates a relation of the action to thought due to the need of reflection and argumentation of the different positions. We also see it in those moments when the members from Maranya make their own participatory social diagnoses where reality is analyzed collectively, conclusions are drawn and actions are suggested with the objective of raising awareness in the group itself. These processes are carried out, mainly, in moments of crisis, in the new spaces that are generated because of it and also in evaluations at the end of the course.

- Working on values and ethical issues and reflect on them. La Maranya YC works from a series of values included in their own manifesto and they make specific reference of them in their daily practice. They do not perform any activity that could endanger any of those values: solidarity, equality, secularism, being against racism and xenophobia, freedom, democracy, ecology, culture defense, no to drugs and violence and critical awareness. Commitment to education in democratic values asks for learning experiences to insist on the construction of those values (Moliner, Traver, Ruiz and Segarra 2016). This is the way democratic Education is shaped in the Club and they highlight it in their manifesto, in daily practice and planning campaigns like the last one they developed about the refugees' situation in Europe. 
Maranya becomes a youth educational space that promotes the acquisition of learning, as we've seen before, that is focused towards technical, social and personal skills. The dynamics that are carried out in the YC make it possible that youngsters acquire technical skills that are useful for their secondary school studies and also for their university ones. Being able to coordinate a meeting, record minutes, keeping to their speaking time, argue opinions and take decision accordingly are evidences in plenary sessions with youths. On the other hand, they also achieve different types of social skills that make their integration in society easier and boost the construction of critical citizenship as we've seen previously: work on values, critical thinking, social contribution,...All this has a direct relation with the learning that Warren (2001) emphasizes concerning participation in associations. Specifically with the effect of individual development like effectiveness, political information abilities, civic qualities and critical abilities that emerge in Maranya all through the participatory trajectory. This complements what Durlak and Weissberg (2007) analyzed from the participation in after-school activities with explicit work in social and personal development and they noted that participants improved their feelings and attitudes, behaviour and school performance.

Finally, in Maranya there's a process of personal growth that lets them empower individually. Empowerment makes people value themselves and feel able to face their own reality, act on it and do it by means of principles that make citizenship become democratic and critical. In this way, empowerment arrives as a process of personal and group growth, as a learning process and formation of critical and transforming citizenship. There are many studies that have examined and analyzed empowerment and connect it to health factors, individual, social and the environment well-being (Jennings, Parra-Medina, Kilfinger and Mcloughlin, 2008; Freire, 2002; Jones and Meleis, 1993; Pinderhughes, 1995; Rappaport, 1984; Rocha, 1997; Wallerstein, 1992; Zimmerman, 2000). A foundation of the study of this concept is found in empowerment as a process of personal as well as collective transformation, thanks to which people strengthen their capacities, trust, vision and prominence to promote positive changes to the situations they encounter(Rappaport, 1984). In this variation, we should highlight the studies of non-formal education that understand empowerment from this personal and social transformation, among them 
Villen (2008), and from our immediate surroundings the studies we have developed from Seminar Garbell ${ }^{78}$ (Aguirre, Traver and Moliner, 2011 and Gallego, Traver and Moliner, 2010). Furthermore, this empowerment is studied from learning processes and through social transformation with culture as a focus in Escudero (2004), Casacuberta (2011) and Checkoway (2008). I could go on with this factor but I would like to focus my attention in that the empowerment that is most interesting for us with all that it entails (inside one, the individual) is collective empowerment. We will speak about it in the section of collective construction.

Following with the relation between Maranya and Etienne Wenger's proposals, we see that the same way the model of situated learning evolves to the communities of practice one, there is a similar situation in Maranya. It does not only focus its learning on a situated one but it turns the space into a Community of Practice (Wenger, 2001). Inside the strategy of pyramid participation, the role of VYT is relevant and the roles they take on, as we have already seen. The VYT is a space that is defined like a place to learn socio-cultural animation from a volunteering, activism and militancy profile, a place that could be perfectly defined as Community of Practice. The reasons for it are based on that its members have a common objective, they have a common identity, they meet to contrast ideas and learn while managing the Club, engaging in the same activity and sharing responsibilities, they are concerned for a common problem and they mobilize for it, extending their knowledge on it and generating new abilities from continuous interaction (Sanz Martos and Pérez-Montero, 2008). They also invigorate a constellation of communities of practice for youth participation in work spaces together with Escola de Cases, Federació de Cases de Joventut, Esplais V alencians and the Secular and Progressive Movement of Catalonia and Zaragoza that share the objective of assuming a mutual commitment, generate a common venture and share a historic character in the youth movement. So this constellation is a network of communities of practice that weaves around goals, rules and common beliefs (Cohendoz, 2001).

78

http://www.peu-uji.es/ca/reflexio/seminari-garbell/seminari-garbell 
Educational achievements happen because of the use of situated learning and the learning communities exist in all the people I have interviewed, and I observed an active attitude towards learning in them understood as a challenge and an opportunity. The person is the protagonist of learning and participates in processes of assessment, criticism, questioning, comparison and reconstruction of their own information showing openness to personal and collective change as we have seen.

If to this learning we add the one that Trilla (1996) suggests, so the work during free time is potentially educational, we find an association that is built on an educational base in which sociability is worked when working collectively. Besides, the work focuses on elements that have been neglected in formal education like expressiveness, sensibility, creativity, among others, as we can see in his projects. What is more, it enables that participants, either children or teenagers, give shape to activity projects independently, to end up emphasizing discovery and the participation in their own life. So teenagers become full-right partners (Úcar, 2008) as it happens in the study of Thomas and MacFarland (2010) in which they observe how the participation in teenage volunteer associations influences their encouragement of vote through life and promotes youths to become full citizens.

Finally, an important aspect in all this educational process is the role of the centre's educators. It is important because depending on how it is done, it can generate different types of learning. Checkoway and Gutiérrez (2008) alert that it is not the same if the youth worker takes the role of a caregiver or that of an educator. According to these authors many youth workers have been trained more towards taking care of youngsters than to empower them and that will influence their process of personal learning. If they take an educator role those places that facilitate empowerment will be generated, otherwise they will be places for entertainment and youth care. In Maranya they work from educator roles and if they generate entertainment activities they have a clear objective of hooking youths to one of the specific sections of the participation pyramid as consumers and users. The rest is designed with the objective of generating processes of participative learning on the basis of direct action. We see the connection of this type of process with situated learning. One example can be seen in 
youths that participate in stable groups; they hold meetings, organize and plan themselves. Youth workers are their referent and they help them through the process. There are also differences between the works achieved under an educational role when Maranya still belonged to the Casal Jove and when they become an independent space. I'm referring to the fact that youth workers, at first, get to join three different stable groups that work independently but when Maranya becomes independent many tasks fall to the same people and the educational role is set aside to focus on logistics matters, maintenance and construction of the premises, and that makes educational processes to be built in a different way. They don't concentrate on teaching on how to organize a meeting but on how to accommodate power cables or how to paint, but above all they concentrate on bonding processes. The creation of space in a collective way forges learning associated with the possibility of collective empowerment as we'll see in the following sections.

In a summarized form we see participatory processes that allow the construction of educational and youth empowerment spaces are based on an active and situated learning that is formed by significant experiences for participants, promoting critical thinking and awareness, among other lessons. Furthermore, they focus on experiences that are carried out through dialogue, group discussion and cooperation keeping a role of the youth workers as a candidate for problematization of reality, with the objective of making their own questioning possible (Diaz-Barriga, 2003; Claus and Ogden, 1999). So, Maranya becomes a learning space within democratic leisure pedagogy that is described from community participation, inclusion, cooperation and the search for common good (Apple and Beane, 1999) assuming the construction of culture from these parameters. 


\subsection{The informal side of an association: the trinomial of life.}

Now we move on to a more human side of the association. The Club is participatory strategy, learning space and construction of discourse as much as it is relational care, coping strategies and collective construction.

Next we're going to address the last three aspects that are closely related to the different meanings of social participation that García Rosa (2004) and Aranguren (2010) share: feeling a part of, take part in and leave with.

\subsubsection{Relational care.}

In many occasions Maranya has been characterized by looking for those spaces where relations are taken care of and dreams are collective. They stand out in the first moments of the associations when times of crisis are more serious and those relations are agitated and you feel closer to the one on your side and more distant from the one in front of you. That is, in these moments collective spaces come up and it is there where people share fears and joys, the discourse becomes collective and your enemy is bitter than ever. These differences with the council produce endless feelings in the group and generate a network of mutual support among participants. Youths, instructors, families and boys and girls talk about the situation and spaces are created to do it. They start an interesting process of "Being part" (García Roca, 2004). Participants start to feel part of something until they actually achieve it, they support each other, and they share objectives and values which creates a gradual spread of the idea of bonding to a group. With their participation they feel the bond to the group (García Roca, 2004; Aranguren, 2010). Without participation, without creating those relaxing spaces to share, bonding becomes ephemeral.

We see all through history the most systematic part is compensated: its structure, organization... with the one that's about the life of the YC. In it, we can see how activities are designed to take care of the group's relationships like meals, afternoon snacks and dinners or conferences like Fil Historic, Pengem els Guants and Amb l'alegria a l'altra banda, among others. For example, with the conference Amb l'alegria a l'altra banda all the group is overtaken with it, generating bond ties that are increasingly intense. Taking care of and pampering the non-formal part of an institution is a relevant 
aspect. It is something that characterizes the group in its beginnings but in the last times it is gradually getting lost. Could this be the reason why it's more and more difficult to "hook" people to participation? Maranya as a whole understands they have to care for the life patterns of the association and its people, the VYT in particular designs these spaces and makes them possible making an analysis of times they go through. In the last year those spaces have been increasingly growing apart and they've neglected the moments of collective celebration. The data I have related to it tends to reduction due to exhaustion and excess of work that burderns a specific nucleus of the Club, the VYT and mainly its coordination.

However we see the human side is another of the strong points of the Club. It has enabled its construction and the varied participation it gets. It is clear that the project will always make sense as long as the group can get excited collectively and that's why the spaces where people meet are so borne in mind. These spaces are asking for a change of organization and it has not quite been forged yet.

I'm now approaching one of the factors that influence social participation considerably ,because any activity, during leisure time, has to be linked to the territory and has to work the sense of bonding to be defined as educational (Muñoz, 2011). It is also directly related to one of the cooperative elements that Traver and Rodríguez (2011) or Pujolàs (2008 a, $2008 \mathrm{~b}$ ) talk about. According to these authors three fundamental aspects are needed and constitute the basic environment of cooperative learning. The one that affects this aspect is the creation and cohesion of the group to interact in a cooperative way. Pujolàs (2008 b) points out that the aim is to create a collective group conscience, which needs to share dreams, friendship, happiness...but also concepts, knowledge, experiences, among other things, that make people feel like a group. All of it can lose its purpose if a common project that makes them dream together is not shared. The construction of this project is Maranya. The birth of Maranya doesn't occur when the group is given a name to turn it into a YC but when events start happening and make the group more united. This happens for example in the conflicts with the council but also when they lose people that have been part of the project and saw its birth. 
For this reason the sense of bonding is fundamental for processes of social cooperation to develop, so communities can resist the tendency to fragmentation and to reinforce social inclusion and cohesion (Turner, 1990).

\subsubsection{Coping strategies.}

Maranya is described in its methodology, its values, ideals and its people. It is felt like a space of their own and it gets more differentiated from the contrary, as they get their own identity. The council doesn't make the continuity of young groups easy, and they admit bureaucracy is exhausting and youths are much more impulsive when generating activities but for the government the compliance of regulations and law are important. There are two sides, one has to understand the space belongs to the council and is loaned to citizens or it is a place that belongs to citizens. In these actions the two models of participation selected are more evident: for citizens, independent, participative, educational and critical while the other side opts for business, economic and legal structures that are conservative whose primary role in management is done by the council to meet service and consumption needs of citizens. The first is close to the model of civic voluntarism that Putman (1993:90) suggests, that states the participation in civic organizations generates cooperative abilities as well as shared responsibilities about collective projects. We find the second in an assistance-driven autocratic model of participation focused on creating a municipal programming without taking into account the opinion of young people. Related to that, we find the repeated refrain "youngsters don't participate" without analyzing its use, adult people who are far from their reality, the ones telling them how they have to participate. From this point of view, the educational potential of transforming, generating trust and participating democratically is lost and they focus on satisfying the potential citizen/client with the activity-service instead.

Let's think when Maranya is born it happens the same that occurred 15 years ago when the mayor summoned in his office a group of young people who decided to criticize political actions in a magazine. The role of the council replicates when they don't back up the initiatives that were carried out in stable groups of young people. In Maranya they experienced the bureaucratization of the space like an attack and they believe there were 
mechanisms of ideological control behind that coming from the governing team. These differences in the model of participation, between the Association and the Council, create very different ways of living participation and citizenship itself. Different meanings for one work: participation. I don't know if there will be a day when both sides are compensated. Bubbles exist and one is safer and more comfortable inside them than if you decide to burst them to breathe fresh air again. Citing Max Hub from Serrano (2008): "It is not the fact there isn't freedom. It's worse: its absence is not noticed". But the day it's noticed, initiatives that challenge democratic participative ways that power uses start and new forms of participation are visualized.

The defense of the model against other people, the fight against a common enemy magnifies everything. Complicity is increased, discussion spaces are generated and they promote a process of awareness in which girls, boys, youngsters, families and youth workers carry out their own analysis of reality (Freire, 1974). This calls for the need of taking action to change things that are considered unfair. According to Aranguren (2010:30) commitment comes when we feel affected by something, that's why 'it is participation guided by the principle of willingness according to which, taking part is incorporating actively to something that is felt as one's own". Besides, implication affects directly to improving experience and the degree of commitment (Doistua, Pose and Ahedo, 2016).

The group starts to take action, they aren't just part of but they want to commit because they are affected directly by something, they feel attacked and they experience more and more critical incidents: police visits, letters from the council, warnings from managers and they even claim that there's an administrative silence towards the association. Remarkably, they see tensions like something dynamic and constructive. All these incidents make the Club be capable of designing coping strategies that make them feel more part of the project. I would risk stating that these incidents may be more powerful, educationally speaking, for the group, than the day by day in the Club. In normal circumstances educational models are recognized individually, work seems to be carried out more from the model that youth workers exercise over youngsters than over the whole group. However, in moments of crisis spaces are extended and models are built collectively as 
the plurality of voices increases. Moments of crisis are confronted from community and dialogic spaces and they extend the times of collective discussion and joint decision taking. We see it for example when meetings and assemblies are convened in the moment of taking a decision about leaving or not the institutional space. All the groups that belong in some way or another to the group participate (relatives, boys and girls, youth workers and youngsters).

Cousée-Ghent (2016) says that it is a learning mechanism to live tensions, incidents, crisis like something positive, like a moment of reconstruction. As Edgar Morin presents you have to "learn how to navigate a sea of uncertainties, through archipelagos of certainties" (2011:117). Those archipelagos of certainties are all those critical experiences that lead to social educative action.

In this study the navigation is done collectively, which increases the value of critical incidents as, out of them people generate collective but not individual coping strategies. Participation here is plural and diverse and proposes spaces of inclusion because they create spaces in which all the groups that form the association are taken into account. So, from collective construction, they design strategies for crises coping that are defined for its creativity and social impact (Lip dub, documentary Els portadors de somnis, La flama,...)and the group gets a higher feeling of bonding with the Project because with the creation of strategies in a collective way they feel represented, are part of and take part in.

This contrasts what Cornwall(2008) suggests about participation that hinders because according to him, if facilitators are higher than the number of obstacles, they know the community itself will develop and experience context, situations and empowerment processes that will lead to community empowerment. In this case, obstacles emerge like police visits, bureaucratization of processes and the letter to empty the premises among other things, but that does not stop facilitators being reconstructed to promote community empowerment: for example the creation of discussion spaces, the transformation towards an association that is more and more cross-generational and events and diffusion campaigns. We see how in this case, the most interesting aspect is not the idea of finding 
facilitators but to find them in the community in order to generate collective learning processes.

In short, both the birth of the Club and the critical incidents of the group help build coping strategies turning crises into moments of collective growth.

\subsubsection{Collective empowerment.}

As we see all through history and these conclusions, moments of crisis make Maranya transform and take new paths. This is how from different events in the Club, they start to work with a community methodology that begins by cooperative elements like the ones Traver and Rodríguez (2011) or Pujolàs (2008 a, 2008 b) note. According to these authors three fundamental aspects are needed and they constitute the basic areas of cooperative learning as these aspects influence the construction of the community methodology that extends in the YC. We've seen one of them before when we've spoken about the group's cohesion and being part of it.

Following, we see the second of these three aspects: belonging to the group people learn to cooperate like Traver and Rodríguez (2011) point. To work in a cooperative way we have to be more skillful in our relationships with others, learn to build together, commit and demand from others. Saying things politely, listening, asking and helping are, among others, the learning that makes cooperation rich. Learning to cooperate is learning to share, live together and provide a fair social dimension to our existence (Aguirre García-Carpintero, 2012). In this sense, community spaces start to be built and they are designed with the idea that the group learns to cooperate, exchange opinions, reflections and share tasks. This is the way families remember it when all the group, boys and girls, youngsters, adults and youth workers gather to take decisions about the future of the association. In these moments they learn to work in teams and feel solidarity for the other person's perceptions.

Apart from that we find the third aspect, where those spaces need to be organized to promote joint construction of knowledge, that is, all the participants of the group cooperate to learn. This way they don't only learn to cooperate but they also cooperate to learn. 
In all this we recognize the idea of "leaving with" that Aranguren (2010) suggests. This idea complements the three essential aspects for real social participation, "be part of", "take part in "and "leave with". Embark on the path with the others; build collectively leaving behind the exclusive participation of those who feel with the power to do it because they've been chosen to do it. In the study we see they want to create spaces for collective decision taking and for example in the decision of becoming independent form Casal Jove, we can see how they put into practice the idea of leaving with the others and working from cooperative elements that strengthen the construction of collaborative culture.

If there's something that favours criticism on this process is that after the refurbishment work, when Maranya's organization has to establish itself again as Youth Club, everything is undertaken mainly by the VYT, for example activities for youths come from the VYT and the planning of the series of talks for adults too. It is perceived that the lack of youth or adults stable groups burdens the work of youth workers and they have to take the lead. We see that, for example, youths reflect the collective discourse as they participate in activities and in the elaboration of proposals. We see it in moments of course evaluation when the youth's contribution is in line with the discourse of social justice that the club communicates. This way we see the importance of building collective and networked discourse collectively in the day to day. This will allow that the plurality of voices is heard and participation doesn't become a monologue or the monopoly of one voice (Aranguren, 2010). Here I take up and insist on the previous idea that Maranya is defined collectively in moments of crisis but the day to day is isolated, mostly in the VYT's work. For this reason, discourse is assumed all through the participatory trajectory of the person but it is above all consolidated when this person becomes involved in critical incidents that immerse the entity in a process of analysis, reflection and collective decisions taking as in these moments work is cared for from the following cooperative elements that different authors suggest (Johnson, Johnson and Holubec, 1999; García, Traver and Candela., 2001; Traver and Rodríguez, 2011; Aguirre, Traver and Moliner, 2011):

- Positive interdependence: youngsters, families, instructors and boys and girls have to understand they're linked one to the other, because only then 
each one of them will be successful if the rest of the group is successful. They have to pursue a common objective although in this case there are differences among the groups. Youngsters and instructors are sure they want to leave, more important than the democratic decision is the wish to create their own youth space. However, even though families have a perspective that is not as impulsive, they believe that whatever decision is taken, will be taken in a democratic way. Here the group of families is showing a stronger bond towards positive interdependence than youth groups and instructors and that shows the differences between the youth group and the adult group in Maranya's History.

- Face to face interaction: the dynamics that is put into practice is direct and continuous interaction among the people in the group. This interaction stimulates and turns the exchange into encouragement, compliments, commitment and willingness to do things better. That is why they create spaces where to discuss, reflect on and take decisions in a collective way. They want places where to encourage collectively, one to the other. All this starts to appear when the conflict between the council and the youth group starts. The need to share moments to talk and work the situation flourished in the group and we see this keeps happening every time there is a crisis in the association.

- Individual responsibility and group demand: as an individual, each person has to assume their own responsibilities, those that have been assigned from collective dynamics and they have to assume them like a group demand. The construction of the group arises from individual contributions of each member of the group. This responsibility is structured in a staggered way because not everybody in the group takes responsibility or assumes a commitment with the group the same way. Each one does it depending on their own process of participatory maturity that is dependent on the participatory structure we have previously seen.

- Shared or democratic leadership: democratic leadership coming from discussion in collective spaces is promoted although coordination and moderation of the group is done by the group of youth workers in most cases. 
- Group evaluation: as we've been talking since we started enumerating these cooperative elements, activities of critical reflection and evaluation are carried out from reality diagnoses in which a critical analysis of the environment is made and they promote collective decision taking. The evaluation is an important moment in the Club and it's always conducted at the end of each course.

All these are questions that need to be taken up, reflected on and worked on to try not to shut collective spaces down and be able to look at collective and not only individual empowerment: we have to go back to the community. We know that moments of crisis guide the process of bonding to the group through their actions, coexistence, interests and shared values, relationships and recognition. But that doesn't prevent us from getting all the benefits that crises bring that make the group grow and get stronger.

In the end, the birth of Maranya and all the critical incidents that occur make it go from an individualist to a collaborative culture. A collective participatory culture where the value of cooperation and joint reconstruction sticks out from the three meanings of social participation: be part of, take part in and leave with. In this sense Traver, Sales and Moliner (2010) present three key elements they observed in their experiences of schools in transformation which favour the construction of collaborative culture. The first is assuming the project as one's own, the second is to encourage the plurality of voices and the third is information transparency and advance from dissension. In this case we could say these elements include three more elements like working from cooperative elements, obtaining collective empowerment and designing collective coping strategies.

\subsection{Social and political change also depends on youth associations.}

Cultural development advocates for a series of values like active participation, culture in constant evolution, contact with citizens, being non-directive, the capacity for expression for all, progressivism and liberation, free expression and open communication, action carried out where people live, openness to everyone, group valuation and creativity (Grosjean and Ingberg, 1980). All these values have been integrated along 
the conclusion so we could say that Maranya has the adequate conditions for cultural transformation (Ander-Egg, 1989) promoting the creation of culture from citizenship itself, that is, getting to establish a cultural democracy (Trilla, 1996). Socio-cultural animation boosts the social and political change of our country through associative initiatives like the one analyzed in this thesis. Collet and Sánchez (2013) consider what association model would be the ideal one under the assumption that not all the collective forms of organization are equally positive. Youth Clubs are a tool for social change and in order to be considered youth Association of "social excellence" they have to include the following ingredients described by Collect and Sánchez (2013) that are met by the Youth Club La Maranya:

- Being a space of democratic participation, a school of participation and democracy as well as of citizen construction that encourages the development of autonomous and critical individuals. One of the fundamental aspects of Maranya is working on an educational project that empowers young people through their own democratic participation. It is noteworthy that we find it in the way of organizing and managing participation structures in the Club thanks to which they develop a personal trajectory of participation where the person is steeped in participation from situated learning (Lave and Wenger, 1991).

- Conceive as a space of social learning where attitudes, values, abilities, knowledge and relations, among other things, are worked on. As we've seen in the conclusions Maranya uses a social theory of learning, specifically the one proposed by Wenger (2001) about Situated Learning and Communities of Practice. Furthermore, as we've seen in previous sections, the participants of the Club acquire a series of attitudes, values, abilities, knowledge and relationships that create their identity from a work of ideological training that could be compared to the one Deltoro (2006) proposes. In it we see personal development, communication and relationship habits with the others, cooperation and awareness of values.

- Knowing how to promote social and civic commitment, in the present and for the future. One of the themes evaluated through the conclusions is drawing up a discourse that is directly related to civic and social commitment. Also, through the participation pyramid and the 
activities designed in each stage they promote the commitment of participants through elements that fight for social justice.

- Become a space of politicization, understood as the interest and action in collective issues, areas, spaces and conflict. That is, it is built from a collective articulation of interests and individual problems provided social transformation is intended. In the same social discourse I mentioned before we find the fact that Maranya is considered a political place of action and a non-political position is considered irresponsible for citizens. This way they promote spaces of awareness in which they reflect on their own reality with the aim of taking action in issues, areas, spaces and conflicts they care about and affect them directly like the series of talks that they start with "Recreate your city" or conferences and debates that are carried out in events like Pren la tena ciutat with teenagers where they talk about the Saharan situation or they display roll-ups about LGTB phobia.

- Foster well-being, quality of life and structuring of people and the territory where they are integrated. The project of Youth Clubs stems from the need of taking into account young people, keep them away from toxic spaces of leisure and free time (drugs, alcohol, school drop-out,...) and promote critical citizens that can look toward the future developing a series of abilities that make them stand out and integrate academically, socially and working in their territory. As a key focus in the Model of Youth Clubs, Maranya does it within their objectives and makes it explicit in daily work and their dynamics. In this sense some of the youngsters see this work reflected on their daily basis for example starting the Association of students from Benicàssim or participating in school boards. In these two examples we see how a critical citizenship that is connected to their territory is promoted. The teachers in the secondary school of that town bear witness to that highlighting the work and the differences that exist between the students that attend Maranya and those who don't, which confirms the abilities and capacities development in the youth association.

- Boost gathering and interaction of people from different social profiles. In this aspect we see other sections that are included in the Club's manifesto that they put into practice in the design of their practices: diversity. Actually, each person that participates in Maranya represents a diverse and unique social profile because of his/her experience. For this 
reason gathering is done between a diverse people. One of the interviewees tells us that Maranya includes different religious profiles of girls and boys that participate in Esplai and they recognize families with political profiles that are more conservative and others more progressive.

- Working for social cohesion and the inclusion of all, respecting diversity and dealing with and taking advantage of conflict. We've seen in previous sections the importance of diversity and also the value the Club gives to group cohesion internally as well as externally. Inclusion is worked in the association directly in their methodology and in the work on values that are assumed and promoted among youths: work against intolerance and racism, campaigns against gender and sexual diversity discrimination, a peer tutoring project in the high school....all these could be examples of daily work for inclusion. On the other hand there is the fact of coping with and taking advantage of the conflict as we've seen in the conclusions, Maranya is reconstructed in moments of crisis and transforms conflicts in a facilitator of learning.

To those seven aspects I'd like to add some more that for me, with the work of this thesis, have become fundamental so a youth Association can be considered "social excellence". Some aspects complement the ones explained by Collect and Sánchez (2013) and others extend the features that a centre has to have to be considered under this category.

* See themselves as an educational referent of their own reality. To do that, on one hand, it has to be a space that is recognized by the community, families, girls and boys and youths and adults that participate in it so that it is felt as their own and relevant in the child and youth educational trajectory. On the other hand it has to be established that coordinators, youth workers, organizers...assume an educator role in the association. This idea connects directly with the previous one as we see it's essential that an association of "social excellence" is educational and to be educational, the role of the educator must be prominent over all the roles assumed in many spaces that become care or entertainment spaces. Finally it has to articulate to be a learning space that will increase the youth's autonomy, sociability, expressivity, sensibility and creativity. Doing so, as we've seen in the conclusions, the 
association will become a place where the work with young people, especially in their free time, is totally educational and a reference.

*To be a space of awareness and civic responsibility. In this sense we have several aspects to take into account so the space is established as a place for awareness where participants can analyze reality, reflect on it, be responsible for it and do something to improve it promoting critical and fair citizens. To do that, we need to facilitate participation and boost "participation maturity" of youths through commitment, responsibility and distributed leadership. The above-named participation in some of the sections of Collect and Sánchez (2013) has to be worked as an educational process where young people learn to commit, take responsibility and lead from democratic and social justice elements. Achieving it will depend partially on work from "spaces for dialogue, horizontality and collective decision taking". To achieve many of the ideas already explained, we have to work with dialogue, focusing on the importance of voice plurality and that voice being promoted from horizontality to be able to take decisions collectively. We say collectively because one of the objectives of an association of social excellence should be generating "collective empowerment". We've seen the importance of collective construction through all the history of Maranya so it is something that has to be emphasized. Individual empowerment is not the ultimate goal, if it doesn't become collective we're losing the community purpose.

*Structuring internal management to enable community management in the town. The importance of changing the reference framework with regard to social practice and its organization within values that strengthen solidarity and community purpose is fundamental if one has a transforming will. To do that the internal management of the association has to be transparent, horizontal, democratic...focusing on the person and not the maximum profit to obtain a tool of social transformation and community empowerment.

These ingredients will tell us if a YC becomes an agent of educational change in the territory like in the case of La Maranya Youth Club. All these 
ingredients, together with the ones mentioned before shape a full representation of how a YC can become an agent of educational change in the territory by positively influencing and configuring the culture of participation of youths. 
«Transformem la realitat a cop d'art, alegría i acció» (enganxina Maranya)
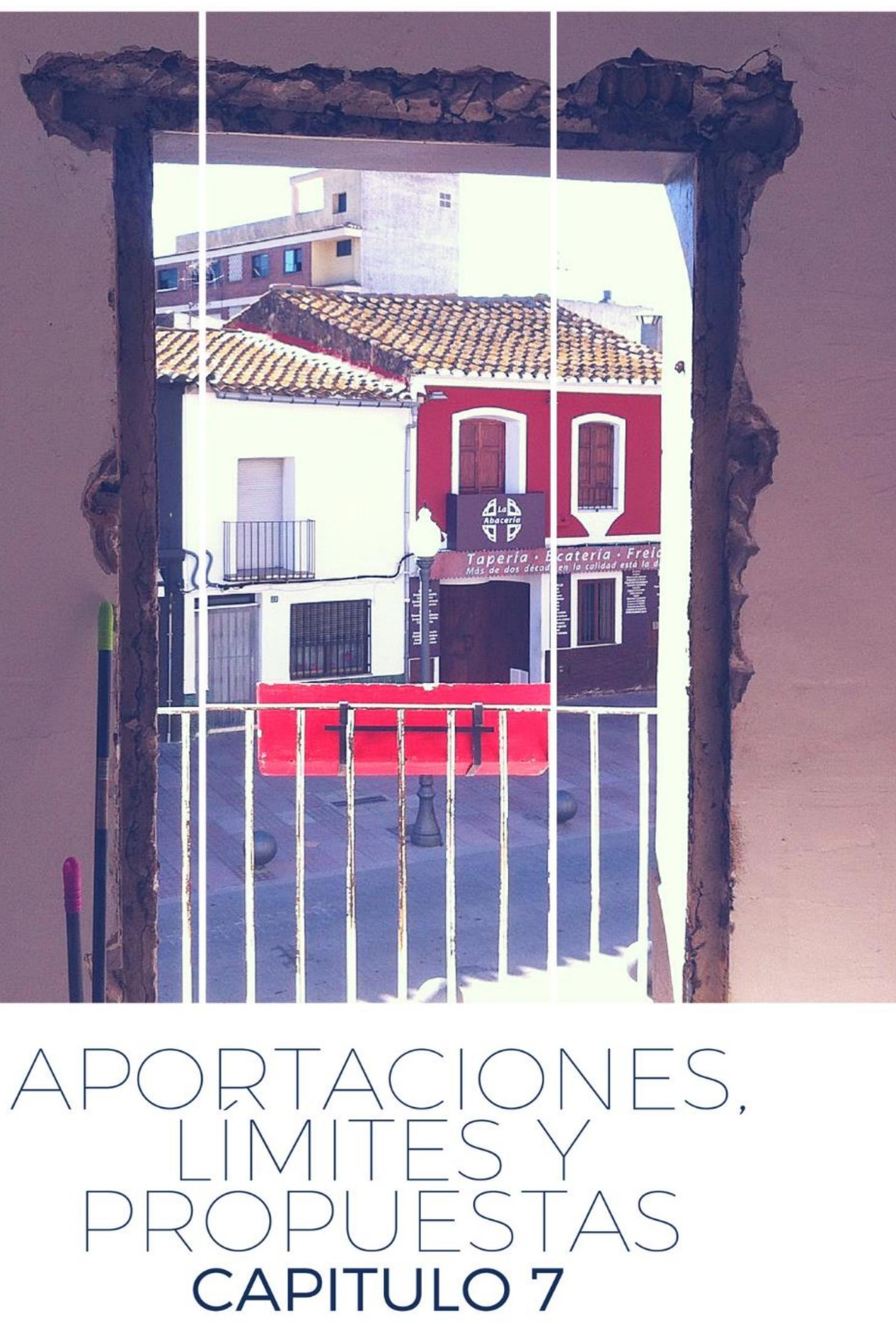



\subsection{Aportaciones a la investigación.}

Las aportaciones que hace esta tesis se centran en el desarrollo de metodologías y prácticas que mejoran la Educación no Formal en espacios juveniles, las políticas juveniles, la pedagogía del ocio y la investigación posibilitando el desarrollo de conocimiento desde la ciudadanía a través de las prácticas que ella misma desarrolla.

El no haber encontrado investigaciones similares sobre Casas de Juventud y espacios de ocio y tiempo libre que se valoren como agentes educativos de cambio fortalece las aportaciones que esta investigación puede conllevar.

Por un lado encontramos aportaciones metodológicas para la Educación no formal en el área de la participación con jóvenes. En primer lugar, el hecho de que las Casas de Juventud se conviertan en una herramienta educativa que promueve la participación, convive en democracia y hace extensivo el trabajo a partir de valores que generan justicia social y ciudadanía crítica y activa es un aporte interesante que ahonda en las posibilidades existentes para confeccionar espacios educativos de plena participación juvenil. La historia en la Casa de Joventut La Maranya se puede definir como referente para otras experiencias y así conseguir que este modelo se extienda en múltiples municipios.

En segundo lugar encontramos el valor de educar a través de una metodología comunitaria que favorece el diálogo, el pensamiento crítico, la concientización y el empoderamiento de las personas y los colectivos. En esta contribución remarcamos la importancia de conseguir mediante procesos participativos el empoderamiento colectivo para así llegar a conformar una ciudadanía concientizada, crítica y dialógica.

Además reforzamos la idea sobre la importancia de la educación no formal en la trayectoria educativa y profesional de las jóvenes. Su influencia en la adquisición de aprendizajes técnicos, sociales y personales permite que las jóvenes posean un mayor abanico de habilidades en muchos ámbitos. Insistir en la idea de que la escuela, como institución educativa formal, no es el único espacio de aprendizaje y en la necesidad de indagar en nuevos lugares en los que las jóvenes puedan seguir formándose desde un espacio que también interpone la educación en la construcción de la cultura. Además el interés por conectar espacios educativos y que la educación 
formal, no formal e informal caminen juntas en el proceso educativo de las jóvenes.

A continuación, otra de las contribuciones en este ámbito es el uso del Aprendizaje situado como metodología para conseguir un aprendizaje sobre la participación real de las jóvenes. Construir escuelas democráticas de participación beneficia la adquisición de aprendizajes en las jóvenes que participan en ellas alcanzando una serie de habilidades óptimas para su crecimiento educativo gracias al trabajo llevado a cabo mediante el aprendizaje situado.

Finalmente remarcar la estrategia de participación estructurada (pirámide de participación) para el desarrollo de una trayectoria personal en el desarrollo del compromiso ciudadano y la participación democrática. El disponer de una estructura que tenga en cuenta las capacidades, habilidades y madurez de las personas que participan y utilizarla para generar una trayectoria personal individualizada puede conllevar un empoderamiento individual que fortalezca el trabajo comunitario.

El segundo bloque de aportaciones es de interés para el desarrollo de políticas públicas juveniles democráticas y ciudadanas. Entre ellas encontramos el valorar el asociacionismo como el principal fenómeno para conseguir una sociedad civil organizada. Además de la necesidad de ejercer la democracia cultural y posibilitar que la cultura se construya desde la ciudadanía y no de manera autocrática. La ciudadanía demanda nuevos roles que asumir y ya son en muchos lugares en los que el asociacionismo ha vuelto a resurgir poniendo en el centro el protagonismo ciudadano y dejando a un lado la mera dotación de servicios a consumir. Se sostiene la necesidad de practicar la democracia cultural y el asociacionismo a través de CdJ puede ser un buen mecanismo para la práctica juvenil.

Asimismo acentuamos el interés por crear espacios educativos en todos los ámbitos de vida que posibiliten la creación de una ciudad educadora pero sin perder la mirada en que la creación de estos se haga desde la gestión comunitaria. Tal y como exponía arriba, la ciudadanía precisa de nuevos protagonismo construidos desde su propia participación y no únicamente desde la creación de espacios institucionales. Por ello, puntualizar que esta ciudad educadora se haga desde la gestión comunitaria, ejercida desde la ciudadanía y a través de modelos asociativos que funcionen estructural y 
organizativamente. En este mismo sentido, destaca la importancia de trabajar a partir del principio de subsidiariedad tal y como pretende la CdJ La Maranya, con el objetivo de conseguir una ciudadanía implicada y una verdadera democracia participativa que posibilite el cambio hacia un marco diferente como es la Economía Social y Solidaria y la Gestión Comunitaria.

Otra aportación en este grupo es la de posibilitar la equiparación de las políticas juveniles con el resto de Europa a partir de herramientas como la estudiada aquí. Además de abrirse al cambio, a los espacios dialógicos y ciudadanos con el interés de mejorar las políticas desde la opinión crítica de la ciudadanía favoreciendo así espacios de expresión política, que no partidista. Este será el modo para construir políticas de manera horizontal y desde la participación ciudadana.

Para finalizar con el reconocimiento de la acción del voluntariado como práctica social y educativa de mejora ciudadana. El voluntariado ha recontruirse y acabar siendo parte importante en el curriculum vital de las jóvenes. En múltiples países ya ocupa un papel fundamental como formación y experiencia laboral indispensable. Aquí aún debemos trabajar para conseguir este reconocimiento de experiencias como la trabajada en esta tesis en la que las jóvenes adquieren habilidades que les permitirán diferenciarse de otras cuando tengan que buscar un empleo.

El tercer grupo de aportaciones están dirigidas a una pedagogía del ocio que posibilite la transformación social. Una de ellas es el hecho de trabajar a partir de la pedagogía comunitaria posibilitando la acción colectiva. Así también como utilizar estrategias de afrontamiento que generen discurso común a través del empoderamiento colectivo. Esto podrá conseguirse creando espacios dialógicos de toma de decisiones colectiva como las asambleas, plenarios y reuniones siempre y cuando se estructuren para que todas las partes sean partícipes de ellos.

Por otro lado, el interés por la potencialidad y el aprovechamiento de los incidentes críticos como lugares de aprendizaje colectivo y posibilidades de mejora. Hemos visto en este estudio como la gestión de las crisis ha posibilitado el desarrollo de habilidades de afrontamiento creativas, positivas y sinceras que han permitido que los incidentes se configuren como espacios para el aprendizaje. 
Otro punto es el de dotar de importancia al trabajo a partir de la pluralidad de voces y la diversidad intergeneracional. Precisamos de lugares plurales en los que educar a través de la diversidad de voces, si además esta se favorece de la intergeneracionalidad se consigue conformar una ciudadanía capaz de compartir espacios, modelos y experiencias de forma inclusiva.

Asimismo, reconocer que la pedagogía social no únicamente se trabaja en espacios de marginación social sino que es una ciencia práctica que posibilita la mejora educativa de toda la población sea quien sea y esté donde esté.

El último bloque de aportaciones hace referencia al propio proceso de investigación. En él se se remarca el hecho de visibilizar las prácticas ciudadanas como espacios de construcción de conocimiento. Por otro lado, se encuentra el hecho de acercar la investigación a la ciudadanía a través del compromiso social como investigadoras. Con esta tesis se muestran formas de conseguirlo a través de investigaciones comprometidas con la ciudadanía y rigurosas con la ciencia.De este modo contamos con abrir el camino hacia una investigación comprometida con la ciudadanía en sentido práctico.

Una contribución más hace referencia a la posibilidad de convertir la investigación en un dispositivo de acción social y construir conocimiento de manera colectiva. Subirats (2005) nos recuerda el interés por conocer y analizar otras formas de organización social que faciliten la reconstrucción colectiva, los vínculos entre las personas, el sentido de colectividad y el respeto hacia la autonomía individual. Aspectos que también van analizándose a lo largo de esta investigación y que posibilitan que la investigación también se reconstruya desde la realidad y su ciudadanía. En este sentido colaboramos en remarcar la importancia de la investigación colaborativa a través de grupos asesores como un primer nivel de acercamiento.

Del mismo modo, entrando en cuestiones más técnicas aportamos un proceso de investigación detallado que puede facilitar el trabajo de otras o simplemente ayudarlas con sus miedos y dudas. Así colaboramos en el diseño de herramientas que visibilizan los criterios de rigor científicos llevados a cabo y aportan luz a los procesos de investigación participativos. La importancia en la elaboración de protocolos, consentimientos y materiales que ofrecen rigurosidad al proceso así como el mecanismo de 
análisis de datos detallado para facilitar la comprensión y visibilizar las acciones de este.

Finalmente apuntar contribuimos en el ejercicio de un posicionamiento investigador crítico y militante que devuelve la construcción del conocimiento a la ciudadanía

Todas estas son las aportaciones más relevantes de la investigación las cuales posibilitan comprometernos socialmente como investigadoras, comprender la realidad, reconocer la dimensión pública de la ciencia y reconstruir políticas y metodologías educativas desde la realidad.

\section{2. Retos del estudio.}

Soy consciente de que el conocimiento se construye en un momento dado, a partir de unos acontecimientos concretos, unas participaciones delimitadas y una investigadora particular. Seguro que este listado de retos puede ampliarse a algunas más si la mirada de análisis procediera de otro lugar pero expongo aquellos más significativos que han podido llegar a limitar esta investigación a la par que la han convertido en particular entre muchas otras. Por esta razón las nombro como retos del estudio y no como limitaciones ya que estas cuestiones no han impedido la investigación simplemente la han transformado adaptándola a los mismos.

\section{- En el tiempo y el espacio.}

Es un aspecto que se refleja, prácticamente, en todas las investigaciones sociales que se llevan a cabo. Los tiempos para actuar y planificar el proceso de investigación se limitan a las participantes al igual que al resto de responsabilidades que la investigadora y la dirección de tesis tiene. Eso comporta que la investigación tenga que estar en continua adaptación pero también posibilita la interesante tarea de reconstruirla en función de las necesidades reales.

Sabemos que una investigación conlleva la condición del tiempo y el espacio y tenemos que tener presente que el estudio se produce en procesos dinámicos que continúan hasta el presente que no acaban con la última construcción de información sino que al componerse de procesos personales estos están en continuo cambio y transformación. Por ello nos 
toca abandonar ciertos elementos de contraste para no entrar en una espiral infinita de investigación.

De manera concreta las limitaciones en el tiempo que he sufrido ha sido, principalmente, el hecho de retrasar sesiones de entrevistas porque o bien no consigues contactar o bien no cuadras agenda con la persona en cuestión. Por ejemplo la entrevista que más tiempo me llevo conseguir fue la de Susana Marqués, alcaldesa de Benicàssim. Fueron alrededor de 9 meses lo que tardaron en aceptar que le hiciera dicha entrevista. Con el resto de entrevistadas los retrasos han podido ser como máximo de un par de semanas desde lo programado lo que no ha supuesto una reestructuración tan grande como la primera. Del mismo modo, una barrera a superar consiste en la devolución de la información al grupo asesor. Debido a los contratiempos personales de diferentes miembros del equipo hemos tenido que retrasar la devolución aunque gracias a la voluntad de cada una se pacta dicho objetivo para llevarlo a cabo en las próximas semanas.

En cuanto al espacio otra de las mayores limitaciones ha sido compaginar docencia, gestión e investigación con la tesis doctoral ya que reducía los espacios en los que podía trabajar en la Casa. Pero el que afectaba de un modo más intenso eran las dos estancias de investigación que hice a lo largo de toda la tesis doctoral en las que tenía que desplazarme fuera de Castellón y no podía continuar con el trabajo directo en el campo.

\section{- En el rol de las participantes.}

Otro de los aspectos a tener en cuenta es el rol que ocupan las participantes en la investigación. Su curiosidad, sus creencias e incluso sus prejuicios sobre la ciencia influyen en el proceso de investigación. En este caso, la insistencia de las participantes en conocer resultados en momentos diferentes a los que se planificaban en el proceso de investigación provocaba un distanciamiento entre sus intereses y los tiempos de la investigación. Además la reticencia de algunas participantes al interés que puede comportar una investigación sobre la asociación también influye en la relación con la investigadora y en el propio proceso de investigación al generar una barrera hacia la construcción colectiva. Esto genera una dificultad añadida que es que las participantes me vean más como investigadora que no como militante del colectivo. Mi objetivo era 
conseguir que todas me vieran como militante pero también como investigadora ya que gran parte de mi trabajo de militancia en la Casa provenía de las acciones que comportaba la tesis. Esto ha comportado un gran reto en la investigación que será analizado en profundidad con la asociación cuando finalice todo el proceso que comporta la elaboración de una tesis doctoral.

En este apartado y en relación con la limitación de los tiempos está la dificultad de crear, coordinar y planificar los tiempos con las participantes que han formado el grupo asesor por sus diferentes responsabilidades y compromisos. Además de esta limitación está la concreta sobre el rol participante de cada una de las integrantes del Grupo Asesor. En este sentido hemos conseguido formar un grupo de asesoramiento hacia la investigación pero puede que lo que hubiera fortalecido a la investigación hubiera sido conseguir una investigación colaborativa o incluso un verdadero órgano de investigación propia en la asociación. Con ello hemos conseguido abordar el segundo nivel, de cuatro, de participación en la pirámide de la investigación inclusiva propuesta por Pallisera et al. (2016).

Un aspecto que también ha influido en el rol que asumen las participantes es respecto al silencio detectado en la información proporcionada por las participantes. Hablamos de silencios cuando las participantes han omitido información ya sea de manera voluntaria o involuntaria. Es decir, el ser parte del colectivo, conocer por mi propia vivencia la Historia de $\mathrm{La}$ Maranya ha posibilitado la detección de lagunas en la información que las participantes me han proporcionado. Un ejemplo lo vemos en un aspecto muy particular como es el hablar sobre los liderazgos ejercidos por ciertas jóvenes en la etapa en la que nace y se independiza la asociación. Su papel es fundamental en la Historia de La Maranya pero se observa un silencio, generalizado entre prácticamente todas las entrevistadas, y no se habla mucho sobre quienes en particular ejercieron ese papel, cómo lo ejercieron y qué fue de ellas en la asociación. La mayor parte de las personas entrevistadas hablan del colectivo en general sin personalizar.

\section{- En cuestiones formales de una investigación.}

En este punto observamos algunos retos relacionados con cuestiones formales en una investigación como las que atañen a las revisiones bibliográficas y la construcción de información entre otras. 
En cuanto a la revisión bibliográfica el límite que hemos tenido es la escasa bibliografía de investigación sobre Casas de Juventud, Asociacionismo Juvenil y Participación Juvenil desde opciones de construcción de la cultura y la transformación social. Además podemos añadir la dificultad en encontrar bibliografía sobre investigación militante, su proceso y sobre etnografía con jóvenes en espacios de educación no formal. Por otro lado y en relación también con la revisión bibliográfica hemos encontrado múltiples temáticas relacionadas con la tesis doctoral con la dificultad de acotar la bibliografía a una que dotara de sentido a toda la investigación teniendo que decantarnos por una línea de trabajo que consideramos la más adecuada para el estudio.

Respecto a la bibliografía específica de elaboración de historias o relatos de vida hemos vivenciado diferentes dificultades debido a su escasez. Ha sido complicado encontrar escritos en los cuales se desarrollara el proceso para elaborar una narración de una comunidad en el que el relato se escribiera de manera cruzada entre las diferentes participantes sin diferenciar las historias personales por capítulos para dar forma a una historia global del colectivo.

Pasar por un proceso de duelo documental para seleccionar información y conseguir sistematizar sus resultados ha sido otra de las limitaciones en este estudio al encontrarnos con la dificultad de condensar toda la información en una coherente pero también completa.

La dificultad de analizar toda la información que en un principio te planteas y planificas hace que tengas que limitar las herramientas de construcción de información guiándote siempre por la saturación de los datos y objetivos del estudio. Además limitar el número de participantes a la investigación ha hecho que no todas las voces estén recogidas en la narrativa aunque sí hemos conseguido que estén representadas a través de otras.

\section{- En la cercanía con la realidad y la investigación.}

En este caso, los retos se relacionan con el interés por realizar una investigación cercana a la realidad social a la vez que a las necesidades científicas. Producir una tesis interesante en cuanto a su narrativa y correcta en su valor metodológico a la par que cercana a las participantes compensando la variable científica con la ciudadana ha sido una de los retos que hemos encontrado en este sentido. 
Por otro lado, la dificultad a la hora de poner fin a la recogida de información cerrando una historia que aún está construyéndose es otro de los aspectos destacados. La Maranya es un fenómeno social y como tal su historia siempre está en constante cambio, transformación y evolución y eso hace que una investigación realizada en prácticas de este tiempo nunca sea definitiva.

El conectar la investigación con un contexto concreto imposibilita la generalización pero matiza el valor de dicho caso con la posibilidad de contrastar experiencias y visibilizar prácticas. Por esta razón consideramos una limitación a medias ya que la no generalización de la experiencia no conlleva que esta no sea rica para el interés científico.

\section{- En el rol como investigadora.}

Los diferentes roles que has de asumir en una investigación militante (investigadora profesional, formadora, facilitadora de la participación, agente de cambio y militante, entre otras muchas) te hacen vivir incertidumbres en algunos momentos del proceso (Moliner y St-Vicent, 2014). Continuos ajustes y desajustes que te hacen recuperar espacios para la reflexión sobre el proceso. Entre otras cuestiones podría plantearme los siguientes retos que han ido apareciendo por el hecho de sumergirme en una investigación que es militante y mis relaciones con las diferentes agentes que han participado de ella.

- El colectivo y la militancia.

Una de las primeras cuestiones con las que me tuve que enfrentar en esta investigación fue con la comprensión colectiva de la necesidad de investigar en la asociación. Las personas que conforman el movimiento están acostumbradas a un objetivo instrumentalista de la investigación y se ha necesitado la convivencia entre iguales para hacer ver que no existe un beneficio propio de la investigadora sin que se de un beneficio para el colectivo. Esta convivencia también me ha hecho toparme con momentos en los que, en unos casos unas personas y en otros casos otras, me solicitaban complicidad para posicionarme a favor o en contra de ciertas acciones. Principalmente estas acciones se basaban en las diferencias que unas y otras tenían sobre el significado de la militancia, de los niveles de compromiso y de responsabilidad que se asumían en el trabajo diario de la 
Casa. Estos momentos también han sido espacios para la reflexión y para posicionarme a instancias de igualdad con el colectivo pero sin perder la ética de la investigación. Al fin y al cabo una investigación militante es militancia pero siempre será investigación.

- Las agentes externas.

Como militante, el mantener las distancias con las agentes externas ha sido todo un trabajo personal. Como investigadora el convencimiento de que la investigación debe servir como dispositivo de crítica social también ha intervenido en esta bipolaridad. Mantener la igualdad de voces sin ejercer mecanismos de poder ni en la dirección asociativa ni en la dirección institucional ha conformado un verdadero reto. Como parte de la asociación y una pequeña parte de su historia conservar la igualdad en la crítica hacia el Ayuntamiento y hacia la asociación se ha visto afectada por el enamoramiento hacia La Maranya y ha supuesto un verdadero reto personal y profesional. Al militante lo engulle la asociación, sus ritmos y sensibilidades pero no debe perder su voz crítica hacia ambos lados y por ello debe construir estrategias de afrontamiento que den voz a todas las partes y mantengan la calidad investigadora.

\section{- La relación académica.}

Como vamos viendo la relación militancia-investigación comporta un interesante reto y la necesidad de llevar a cabo mecanismos que nos ayuden con esta bipolaridad. Por un lado, ser consciente que una investigación militante debe evaluarse como investigación y no solo como militancia comporta la necesidad de distanciarse para conseguir un trabajo riguroso científicamente, sin perder la mirada crítica, transformadora y emancipadora de la investigación.

Por otro lado, investigar sobre participación y militancia no puede conllevar una investigación que se resienta de la participación y la militantcia en el contexto. Tanto investigadora como participantes pueden sentirse desestabilizados respecto a sus valores y principios profesionales (StVicent, 2012) ya que tienen que compartir un espacio común que se encuentra entre la militancia y la investigación.

Esto ha sido un esfuerzo a desempeñar en esta particular investigación en la que mis directores han sabido jugar el papel adecuado para facilitarme el 
distanciamiento necesario. Los espacios de encuentro y las reflexiones conjuntas han proporcionado la detección de los aspectos que carecían de mirada investigadora o de aquellos que se distanciaban de la militancia en el propio diseño de investigación, en la elaboración de los resultados y en las conclusiones realizadas.

De este modo se han conseguido no ejercer estamentos de poder como investigadora en el colectivo ni abandonar la rigurosidad científica como militante.

\section{○ La información}

En otro sentido aunque también vinculado con las relaciones próximas con el colectivo se encuentra: el malestar por no compartir los datos en bruto con el grupo, la confidencialidad y el respeto del anonimato y la correcta devolución de la información.

El primer punto proporcionó la posibilidad de que el colectivo aprendiera más sobre investigación ya que produjo momentos en los que tuvimos que pararnos y pensar sobre la ética de investigación y nuestro papel como constructores de información. En relación con esto se aborda la confidencialidad y el respeto por el anonimato con el colectivo ya que en más de una ocasión se solicita la información de entrevistas. Quieren saber más sobre lo que me cuentan, quieren tener datos en bruto de lo que voy construyendo aunque la convivencia conmigo como militante produce aumento del nivel de confianza para con la investigación.

\section{○ La soledad}

Por otro está la soledad que viven muchas doctorandas y que comporta la investigación de una tesis doctoral. La constante necesidad de compartir visiones y la toma de conciencia de que ha de ser un proceso individual y no colectivo con las limitaciones en la pluralidad de miradas que ello comporta ha aparecido también en esta tesis. Aún así hemos configurado una nueva aproximación y es la de reconvertir la investigación social en participativa y la misión del grupo asesor ha cubierto el papel de acompañamiento que tanto precisábamos en algunos momentos posibilitando los necesarios espacios de soledad con la proximidad de la realidad social. 
Por un primer momento, todas estas particularidades se me presentaron como limitaciones, tenía miedos y la incertidumbre me nublaba hasta que entendí que la investigación militante es un reto en sí misma y todo lo que acontece a su alrededor posibilita que debatamos nuestro papel profesional como investigadoras sociales. Esta bipolaridad ha hecho que, en múltiples ocasiones, me cuestionara la finalidad de la investigación científica aunque también ha posibilitado espacios de autoreflexión y crecimiento personal. En momentos así recordaba muchas de las frases de Freire que te hacen replantearte el papel investigador y es que «El mundo no es. El mundo está siendo. Mi papel en el mundo no es sólo el de quien constata lo que ocurre, sino también el que interviene como sujeto de ocurrencias» (Freire, 1997). Investigadoras como Smith (2016) remarcan la necesidad de apostar por investigaciones que estén conectadas a la realidad y para que esto sea posible tenemos que replantearnos el papel como investigadoras desde un estado más social y no simplemente científico. Yo, puedo ocupar el lugar que Freire nos cuenta, puedo constatar lo que ocurre en un lugar pero siempre desde la humildad que ello comporta. Es decir, por mucho que me ubique en un papel de investigadora eso no quiere decir que mis constataciones sean la única verdad. Construyo las constataciones a partir de un momento dado, con unos sentimientos concretos, con unas personas a mi alrededor que caminan por un momento u otro de vida. Por ello, el distanciarme de la investigadora y acercarme a la militante me ha permitido situarme en un lugar en el que mirar con ojos humanos la investigación científica. Si recordamos los cuatro elementos clave por los que para mi debe caminar la investigación encontramos esa conexión entre el que constata pero también el que interviene. Asumir compromiso social, comprender la realidad, reconocer la dimensión pública de la ciencia y reconstruir los modelos de conocimiento y las políticas públicas desde la realidad son aquellos aspectos que recuperaba cada vez que asomaba mi bipolaridad. Conseguir diferenciar mis juicios como investigadora y como militante me ha sumergido en un proceso de aprendizaje personal y no sólo académico. Pero conseguir combinar la investigación con la militancia ha posibilitado cubrir esos cuatro elementos que debería tener en cuenta la investigación para existir. 
Esta idea militante en la construcción del conocimiento ha hecho que el mundo académico y la vida no caminen en paralelo sino que se fundan en un mismo recorrido.

\subsection{Prospectiva: posibles líneas de trabajo o investigación y propuestas de mejora.}

Plantear unas posibles líneas de trabajo e investigación futura así como unas posibles propuestas de mejora nos da muestra de la prospectiva que podríamos alcanzar en los próximos años y que ayudaría a ampliar el estudio sobre las materias que aquí se trabajan para conseguir un abordaje de la realidad.

- Líneas relativas a la investigación.

Por un lado, reconocemos la necesidad de indagar en nuevos modelos de educación no formal con jóvenes, analizando a su vez, el papel de las jóvenes en la investigación. Debido a estas razones, y al compromiso ético de la investigadora para con la realidad, se proponen analizar las claves que pueden hacer que la investigación con jóvenes se convierta en una berramienta de transformación social.

En este sentido, sería interesante evaluar el proceso de investigación militante junto con las participantes. Analizar sus perspectivas, observaciones y propuestas de mejora nos ayudaría a mejorar el proceso metodológico de investigación militante. En este sentido sería ideal realizar una meta investigación de la propia investigación para ver donde se sitúa y así evaluar el modelo de investigación seleccionado (Folgueiras, 2016).

Otro aspecto relevante sería el de construir y diseñar, en su totalidad, una investigación militante con las participantes. Esto precisaría de mayores tiempos y espacios de reunión pero podría conseguir un impacto positivo del papel que juega la ciencia en el activismo y en la realidad social, redescubriendo la investigación como una herramienta de acción social.

En este mismo sentido sería interesante fortalecer la parte participativa en la investigación siguiendo los parámetros de una investigación inclusiva y colaborativa como la propuesta por (en Pallisera encontraré el nombre). Para conseguir una investigación colaborativa en lugar de un grupo de asesoramiento se puede proponer un curso de formación en investigación 
educativa para que las participantes partan de unos conocimientos básicos sobre la investigación. Continuar con la investigación colaborativa y conseguir un órgano de investigación propia en la asociación o en el movimiento juvenil sería el objetivo final de esta propuesta.

Por último, precisamos indagar en la influencia que ha podido ejercer esta etnografía militante en la visibilización del colectivo así como en otros aspectos que puedan ser relevantes para reflexionar sobre el papel de la investigación. Esta línea está programada para llevarla a cabo una vez se consiga defender públicamente este trabajo para así abordar el proceso de investigación en su totalidad con el colectivo La Maranya.

- Mejoras relacionadas con esta investigación.

Debido a la gran cantidad de información que se ha conseguido construir en este estudio proponemos aumentar los elementos de análisis aprovechando toda esta información. Por ejemplo, ver el papel que cubre toda la información virtual que existe en la red en la cultura de participación juvenil, cómo influye en esta y de qué modo puede mejorar su visibilización.

Por otro lado, considero interesante el indagar en las trayectorias vitales de las participantes de manera individual para construir sus propias historias de vida y no la de la Asociación. Generar estas historias de vida nos permitirá, más tarde, realizar un cruce de perspectivas y experiencias dispares y nos facilitará el estudio de los aprendizajes particulares que han obtenido debido a la participación social que han realizado.

Finalizar con el análisis de los silencios en la información como aspecto relevante en la construcción de la bistoria. Es decir, averiguar porqué se producen silencios en la historia, qué es lo que hace que las participantes omitan información de su historia y se prescinda de cierta información para construir su historia.

Difusión y visibilidad.

Este punto, en gran parte, también tiene relación directa con la investigación pero me ha parecido interesante remarcarlo de manera independiente para darle el valor que se merece. La difusión y visibilidad de un trabajo de investigación es fundamental a la hora de reflexionar y poder mejorarlo. Por esta razón, propongo como futura línea de trabajo el generar una campaña de difusión de la tesis que tenga relación directa con diferentes agentes 
comunitarios y no únicamente el sector académico y cientifico. Comprender que la ciencia es un deber hacia la ciudadanía nos ayuda a comprender la importancia de hacer esa conexión entre investigación y ciudadanía y no abandonar la difusión a meros retos académicos y científicos.

En relación a este apartado se expresa el interés de editar en formato libro el modelo de Casas de Juventud contado por diferentes agentes para continuar con la singularidad del estudio en relación a su pluralidad de voces, así como concretado en la Casa de Joventut La Maranya como ejemplo del espacio a construir.

Todo ello ayuda a transferir la investigación a otras realidades sociocomunitarias, aspecto que no debemos abandonar en el futuro de este trabajo.

Nuevos abordajes complementarios.

Finalizar con nuevas propuestas temáticas de investigación refuerza la idea de hacer extensivo que el asociacionismo siga siendo un ámbito de estudio y de intervención a la vez que de investigación y acción de la Pedagogía Social.

En el ámbito de la política, sería interesante indagar en los efectos que conlleva y promueve que existan equipos de gobierno que apoyen iniciativas como la abordada en esta tesis. Conocer qué es lo que ocurre cuando existe una política que facilita este tipo de movimientos y asociaciones nos ayudará a conocer aquellos aspectos en los que mejorar y analizar qué beneficios o perjuicios conlleva.

Por otro lado, profundizar en diferentes propuestas de intervención comunitaria con las jóvenes como protagonistas nos abrirá un amplio abanico de posibilidades para conocer e indagar en la cultura de participación juvenil. Evidenciar el interés por visibilizar la voz de las jóvenes manifestando la necesidad de convertirse en interlocutores de pleno derecho.

Continuar con una línea de investigación militante en la que se pueda visibilizar procesos de activismo social basados en espacios de aprendiraje para conocer en mayor profundidad las prácticas que llevan al empoderamiento de la ciudadanía. Además evaluar diferentes experiencias para detectar buenas prácticas en 
animación sociocultural puede hacer extensivo el interés por la educación no formal y los procesos de aprendizaje que se dan en ella.

Finalmente, trabajar en esta línea de investigación con el objetivo de poder contrastar espacios de participación juvenil en ocio y tiempo libre a nivel internacional. Para desarrollar esta línea ya hemos realizado los contactos para conocer experiencias en EEUU para poder comparar a partir de la investigación y así conseguir mejorar nuestros métodos de investigación y nuestras prácticas asociativas. 


\section{Una entre tants...}

Castill de Montornès of ing

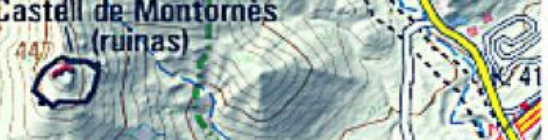

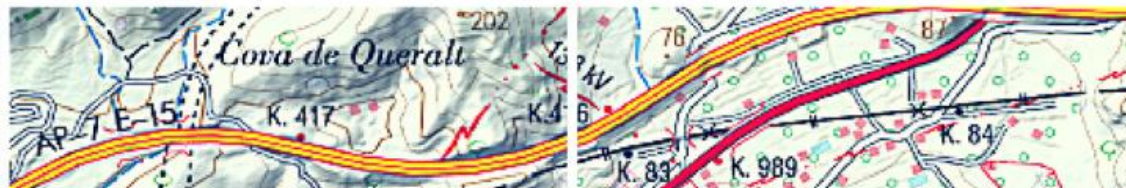

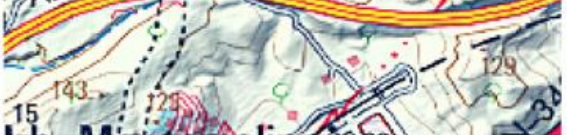

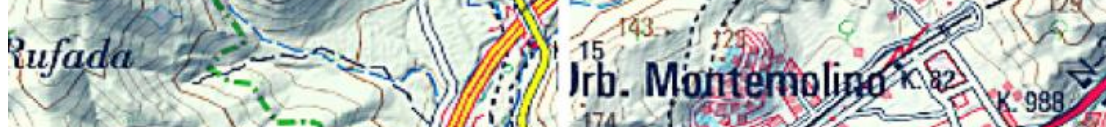

1. I Paldatet

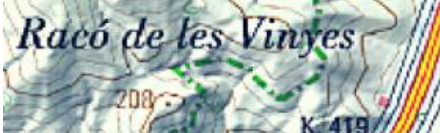

Juan XXIII

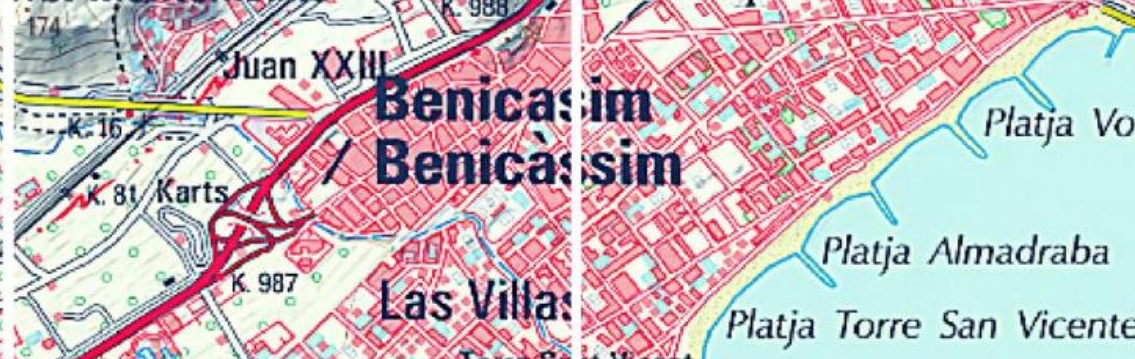

\section{$213-189-21$ \\ Las Palmas}

in. 20

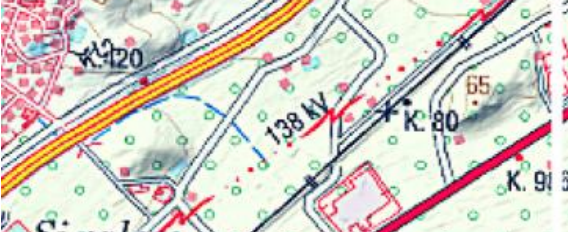

Sigalefo

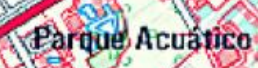

Parque Acuatico 3 : Torcos S it Vicent

Platja Torre San Vicente

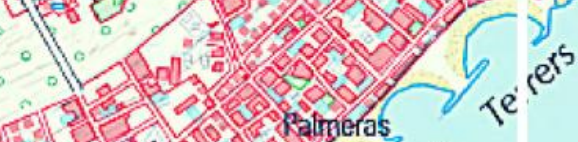

in 5 .

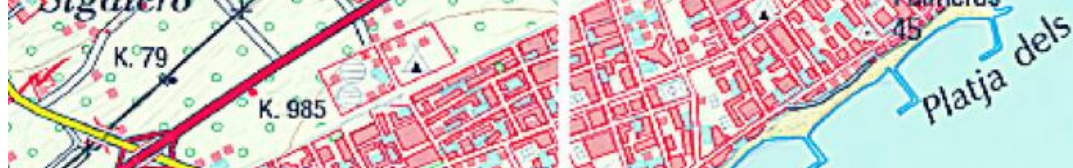

La Mastandes ares

$984.0 \% \frac{1}{0}$
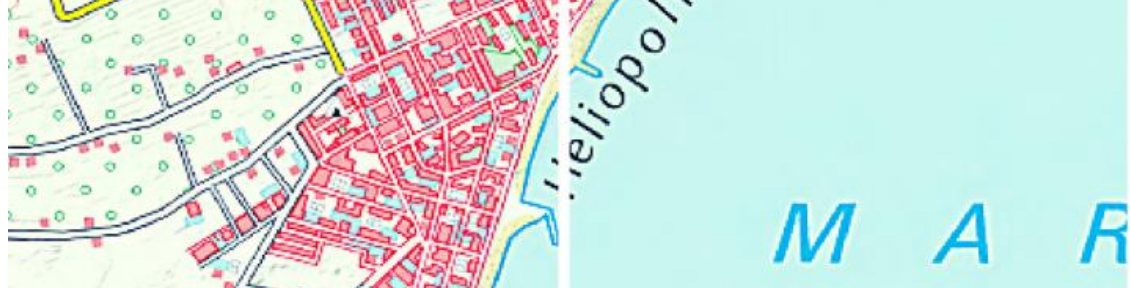

iuadro Santiago
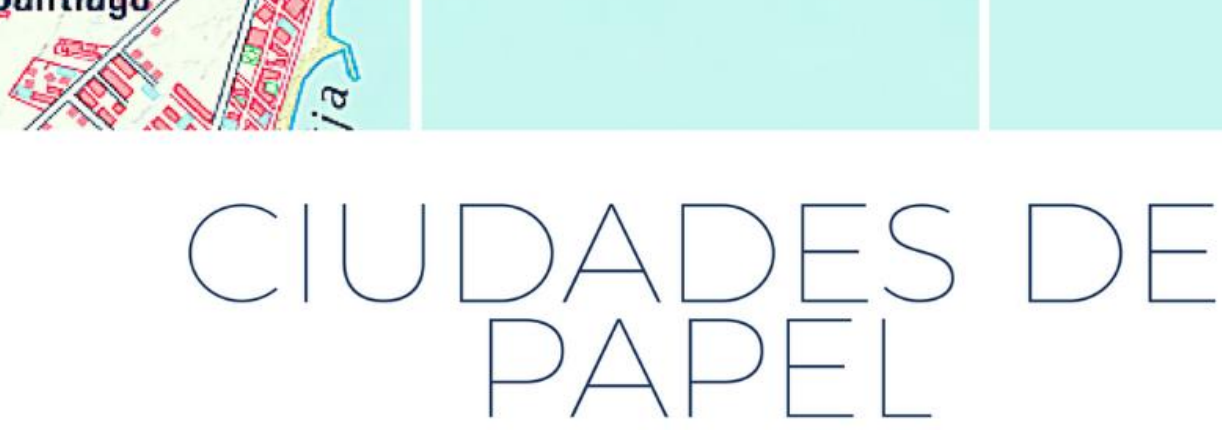

Las cartógrafas dibujan ciudades de papel inventadas, espacios que no existen en la realidad pero sí en sus obras, en sus sueños, en su ambición de ser únicas o simplemente en su inquietud porque su mapa se diferencie del resto. Son frágiles porque ellas mismas las pueden hacer desaparecer pero muy fuertes a la vez porque se pueden extender alrededor del mundo. Las unen con otras ciudades, con otros pueblos, con otros lugares, las cruzan en el destino de mucha gente, en los caminos de muchos mundos. Las ciudades de papel se vuelven reales cuando se reconocen y pasan a formar parte de nuestra identidad.

Maranya es nuestra ciudad de papel, surgió de pensarla, de dibujarla en una hoja, de la inquietud de las jóvenes por diferenciarse del resto y de compartirla con el mundo. Surgió de la utopía, de aquello que siempre piensas que nunca se podrá hacer realidad hasta que al final se acaba impregnando en el mapa imborrable de mucha gente.

Podrán borrarla de algunos mapas sobrantes pero ya nos ha atrapado tan fuerte a tantas personas que será imposible hacerla desaparecer. Se podrá transformar, crecerá, se hará más pequeña, se reproducirá, se convertirá en camino, en pueblo, en ciudad, en destinos de muchas personas aquí o allá, pero desearemos que no sea única y sí una entre muchas más.

Una entre tants...
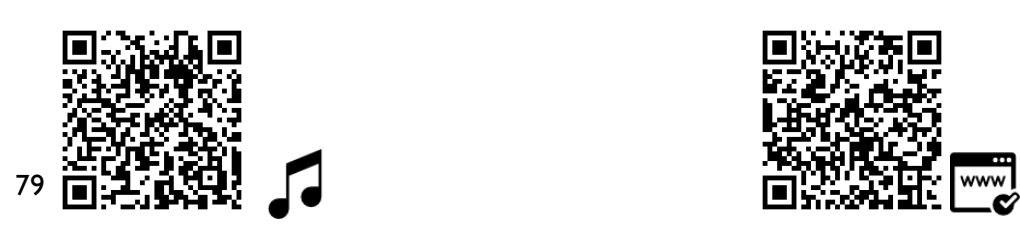



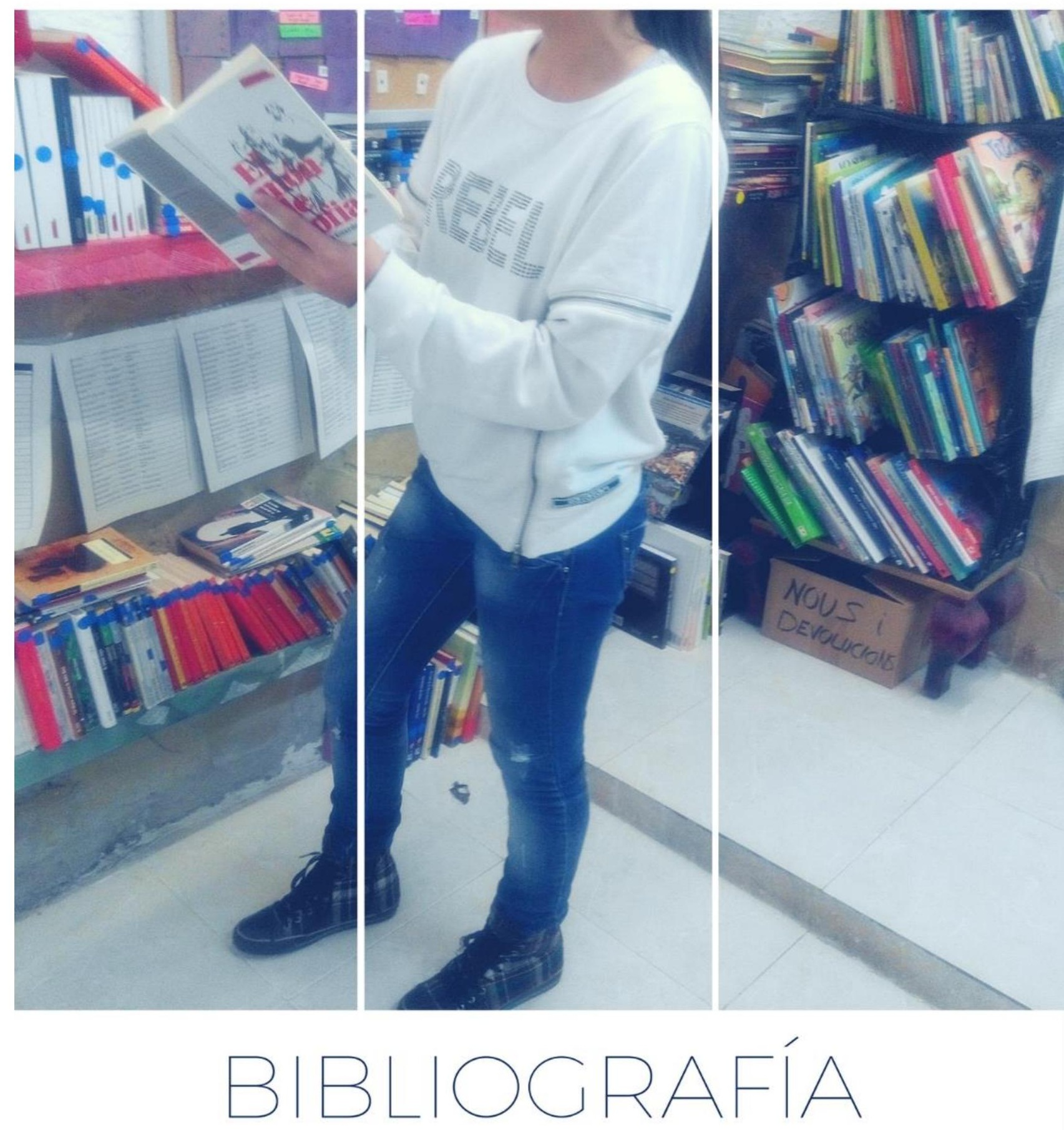





\section{A}

Academy for Educational Development (2012). Young Adult Capacity Initiative Cross-Site Analysis.

Adams, P., \& Horton, M. (1975). Unearthing seeds of fire: The idea of Highlander. North Carolina, USA: John F. Blair Publisher.

Agar, M. (1980). The Professional Stranger: An informal introduction to Ethnography. Orlando: Academic Press.

Aguirre Baztán, A. (1995). Etnografía: Metodología cualitativa en la investigación sociocultural. Barcelona, España: Boixareu Universitaria-Marcombo.

Aguirre García-Carpintero, A. (2012). Diagnóstico social participativo, desarrollo local y transformación social. Un estudio de caso sobre participación juvenil en la Comarca Els Ports. (Trabajo Final de Máster inédito). Universitat Jaume I, Castellón, España.

Aguirre García-Carpintero A., Traver, J.A. y Moliner, L. (2011). Ingredientes educativos en la Agenda 21 de la cultura. Revista Quaderns Digitals (69), Actas del Congreso Mejora Educativa y Ciudadanía Crítica.

Aguirre García-Carpintero, Beltrán, M., Checa, I., Escoín, V., Morales, V. y Tomás, N. (2015), Relato de una experiencia: La Maranya, una escuela de democracia ciudadana con jóvenes. Kult-ur, 2(3), 171-184.

Agüera, E. (2004). Liderazgo y compromiso social. México: Universidad Autónoma de San Luis Potosí.

Armengol, C. (1997). Profesionalización y voluntariado en la animación sociocultral. En J. Trilla (Ed.), Animación Sociocultural (pp. 285-295). Barcelona, España: Ariel.

Alarcón, J. (1997). No tengo un duro ni jóvenes organizados: ¿qué hago? Selección de experiencias significativas en materia de juventud, en Progresar con las jóvenes, 
Actas jornadas de concejales y responsables políticos de juventud. Federación Valenciana de Casas de juventud.

Alanís, A. (2000). Una versión comparativa entre los paradigmas cualitativo y cuantitativo. Revista Digital de Educación y Nuevas Tecnologías Contexto Educativo, Año III (20), 1-8.

Alberich, T. (1994). Aspectos cuantitativos del asociacionismo en España. Documentación Social, 94, 110-114.

Alberich, T. (2003). Asociaciones y ONG. Dimensiones y características del mundo asociativo en España. En E. Liikanen (Ed.), La Economía Social y El Tercer Sector. España y el Entorno Europeo. Madrid, España: Escuela Libre Editorial y Fundación ONCE.

Alberich, T. (2004). Guía fácil de la participación ciudadana: Manual de gestión. Para el fomento de la participación ciudadana en ayuntamientos y asociaciones. Madrid, España: Dykinson.

Alberich, T. (2007). Asociaciones y movimientos sociales en España: cuatro décadas de cambio. Revista de estudios de juventud, 76, 71-89.

Alberich, T. y Espadas, M. A. (2011). Asociacionismo, participación ciudadana, y políticas locales: planteamiento teórico y una experiencia práctica en Jaén. Revista Alternativas, 18, 119-146.

Alberich, N., Bretones, E. y Ros, P. (2013). Biografías al descubierto: Historias de vida y educación social. Barcelona, España: UOC.

Alberich, T. (2015). Desde las asociaciones de vecinos al 15M y las mareas ciudadanas: Breve historia de los movimientos sociales. Madrid, España: Dykinson.

Albom, M. (s.f.). Martes con mi viejo profesor. Editorial Maeva. 
Alcántara, A. (2016). El temps lliura com a espai de participación ciutadana. Conferencia inaugural del curso 2016/2017 de la Casa de Joventut La Maranya. Septiembre, 2016.

Aldridge, J. (2007). Picture this: the use of participatory photographic research methods with people with learning disabilities. Disability \& Society, 22(1), 1-17.

Álvarez, C. (2011). El interés de la etnografía escolar en la investigación educativa. Estudios Pedagógicos XXXVII, (2). 267-279.

Ander-Egg, E. (1989). Características de la animación sociocultural. En AA.VV. (Ed.), La comunitat (pp. 69-75). Palma, España: Ajuntament de Palma.

Anderson, G. (1989). Critical Ethnography in education: origins, current status and new directions. Review of Educational Research, 59(3), 249-270.

Anduiza, E., Bonet, E. y Morales, L. (2006). La participación en las asociaciones: niveles, perfiles y efectos. En J. R. Montero, J. Font \& M. Torcal (Eds.). Ciudadanos, asociaciones y participación en España. Madrid, España: CIS.

Anfara, V. A., Jr., Brown, K. M. \& Mangione, T. L. (2002). Qualitative Analysis on Stage: Making the Research Process More Public. Educational Researcher, 31(7). 28-38.

Angrosino, M. (2012). Etnografia y observación participante en investigación cualitativa. Madrid, España: Morata

Apple, M. W. y Beane, J. A. (Comps.). (1999). Escuelas democráticas. Madrid, España: Morata

Aracil, R., Mayayo, A. y Segura, A. (Eds.). (2003). Memòria de la Transició a Espanya i a Catalunya: Els joves de la Transició. Barcelona, España: Edicions Universitat de Barcelona. 
Aragon, S. (2015). Youth voting: state and city approaches to early civic engagement. Education trends. Education Comission of the States.

Aranguren, L. (2000). Cartografía del voluntariado. Madrid, España: PPC.

Aranguren, L. (2010). La nueva órbita de la participación social. Madrid, España: Plataforma 2015.

Ariño, A. (2004). Asociacionismo, ciudadanía y bienestar social. Papers, revista de sociología, $74,85-110$.

Ariño, A. (Dir.). (2007). Asociacionismo y voluntariado en España: Una perspectiva general. Valencia, España: Tirant lo Blanch.

Arnaiz, P. (2004). La educación inclusiva: dilemas y desafíos. Educación, desarrollo y diversidad, 7(2), 25-40.

Aznar, M. (1993). Las asociaciones. En El sector no lucrativo en España. Madrid, España: Escuela Libre Editorial Fundación ONCE.

\section{B}

Baquero, R. (2002). Del experimento escolar a la experiencia educativa. La transmisión educativa desde una perspectiva psicológica situacional. Perfiles Educativos, 24(97-98), 57-75.

Barham, A. y Fals Borda, O. (1992). La situación actual y las perspectivas de la IAP en el mundo. En M. C. Salazar (Ed.), La investigación Acción Participativa. Inicios y desarrollos (pp. 205-230). Madrid, España: Popular.

Bassi Follari, J. E. (2014). Hacer una historia de vida: decisiones clave durante el proceso de investigación. Athenea Digital, 14(3), 129-170.

Bateson, G. (1972). Steps to an ecology of mind. New York: Ballantine.

Bhatti, Y., Dahlgaard, J. O., Hansen, J. H. \& Hansen, K. M. (2015). Getting out 
the vote with evaluative thinkng. American Journal of Evaluation, 36(3), 389400 .

Bauman, Z. (2005). Vidas desperdiciadas. La modernidad y sus parias. Barcelona, España: Paidós Estado y Sociedad.

Bauman, R. \& Scherzer, J. (1977) (Eds.). Explorations in the Ethnography of Speaking. Londres, U.K.: Cambridge University Press.

Bazeley, P. (2009). Analysing Qualitative Data: More Than Identifying Themes. Malaysian Journal of Qualitative Research, 2(2), 6-22.

Bereiter, C., (1997). Situated cognition and how to overcome it. En D. Kirshner y J. A. Whitson (Eds.), Situated cognition. Social, semiotic and psychological perspectives (pp. 281-300). Mahwah, NJ: Lawrence Erlbaum.

Bernard, H. R. (2000). Social Research Methods: Qualitative and Quantitative Approaches. Thousand Oaks, California: Sage.

Bernard, H. R. \& Ryan, G. W. (2010). Analyzing Qualitative Data: Systematic Approaches. Thousand Oaks, California: Sage.

Berson, M. J., Rodríguez-Campos, L., Walker-Egea, C., Owens, C. \& Bellara, A. (2014). Youth engagement in electoral activities: a collaborative evaluation of a civic education project. Journal of education and training studies, 2(1), 8187.

Bertaux, D. (2005). Los relatos de vida: perspectiva etnosociológica. Barcelona, España: Bellaterra.

Bisquerra, R. (2004). Metodología de la investigación cualitativa. Madrid, España: La Muralla.

Blaikie, N.W.H. (2010). Designing social research (2nd. ed.). Cambridge, U.K.: Polity Press. 
Blommaert, J. \& Jie, D. (2011). Ethnographic Fieldwork: A Beginner's Guide. Bristol, U.K.: Multilingual Matters.

Bogdan, R. \& Taylor, S. (1975). Introduction to Qualitative Research Methods: A Phenomenological Approach to the Social Sciences. Nueva York: John Wiley.

Boix, C. y Posner, D. N. (2000). Capital Social y Democracia. Revista Española de Ciencia Politica 1(2), 159-185.

Bolívar, A. (2002). “¿De nobis ipsis silemus?”: Epistemología de la investigación biográfico-narrativa en educación. Revista Electrónica de Investigación Educativa, 4(1), 1-26.

Bolívar, A. (2010). El liderazgo educativo y su papel en la mejora: una revisión actual de sus posibilidades y limitaciones. Psicoperspectivas. Individuo $y$ Sociedad, 9(2).

Bolívar, A. y Domingo, J. (2006). La investigación biográfica y narrativa en Iberoamérica: Campos de desarrollo y estado actual. Forum Qualitative Sozialforschung / Forum: Qualitative Social Research, 7(4), Art. 12.

Bolívar, A., Domingo, J. y Fernández, M. (2001). La investigación biográfico-narrativa en educación. Madrid, España: La Muralla.

Botero, P. (2012). Investigación y acción colectiva -IAC-. Una experiencia de investigación militante. Utopia y práxis latinoamericana, Revista internacional de filosofía iberoamericana y teoría social, año 17(57), 31 - 47.

Botey, Jaume (1981). Cinquanta-quatre relats d'immigració. Barcelona, España: Serveis de cultura popular.

Boyatzis, R. E. (1998). Transforming Qualitative Information: Thematic Analysis and Code Development. Thousand Oaks, California: Sage.

Braun, V. \& Clarke, V. (2006). Using thematic analysis in psychology. Qualitative Research in Psychology, 3(2), 77-101. 
Brown, J., Collins, A. \& Duguid, P. (1989). Situated cognition and the culture of learning. Educational Researcher, 18(1), 32-42.

Bruner, J. (1986). Actual minds, possible worlds. Cambridge, MA: Harvard Universtiy Press.

Bueno, J. R. (1991). Hacia un modelo de servicios sociales de acción comunitaria. Madrid, España: Educación Popular.

\section{C}

Cabello, M. J. (2002). Educación permanente y educación social. Controversias y Compromisos. Málaga, España: Aljibe.

Calvo, A. (2002). La animación sociocultural. Una estrategia educativa para la participación. Madrid, España: Alianza Editorial.

Calle, A. (2007). Democracia Radical. La construcción de un ciclo de movilización global. Jóvenes, globalización y movimientos altermundistas. Revista de Estudios de Juventud, (76).

Campbell, E. \& Lassiter, L. E. (2015). Doing ethnography today: Theories, methods, exercises. Oxford, UK: Wiley Blackwell.

Carbonell, J. (2008). Una educación para mañana. Barcelona, España: Octaedro.

Carbonell, J. (2015). Pedagogías del siglo XXI. Alternativas para la innovación educativa. Barcelona, España: Octaedro.

Caride, J. A. (1986). Educación y animación sociocultural: la pedagogía social como modelo de intervención. En J.M Quintana (Ed.), Fundamentos de animación sociocultural, Madrid, España: Narcea (pp. 94-127).

Casacuberta, D., Rubio, N. y Serra, L. (Coords.). (2011). Acción cultural y desarrollo comunitario. Barcelona, España: GRAÓ. 
Casado, F. y Gómez, L. (2010). Liderazgo asociativo. Cádiz: Crac/Acudex.

Casas, M. I. (2008). Etnografías made in USA: rastreando metodologías disidentes. En A. Leizola, J. Hernández (Eds.), Miradas, Encuentros y Críticas Antropológicas. Actas del XI Congreso de Antropología de la FAAEE. (pp. 165171). Donostia, España: Ankulegi Antropologia Elkartea.

Cassels, A., Post, L. \& Nestor, P. I. (2015). The 4-H club meeting: An essential youth development strategy. Journal of extension, 53(1), 1-7.

Centeno, C. (2005). Pedagogía social: Marco metodológico y profesional del educador. Jaén, España: Formación Alcalá.

Chapman, D. E. (2010). Examining social theory: Crossing borders/reflecting back. New York: Peter Lang.

Chase, S. (2013). Narrative inquiry: Still a field in the making. En N. K. Lincoln \& Y. S. Denzin (Eds.), Collecting and interpreting qualitative materials (4th ed.). Thousand Oaks, California: Sage.

Chaves, R. y Monzón, J. L. (2006). La Economía Social en la Unión Europea. Comité Económico y Social Europeo: CIRIEC.

Checkoway, B. N. y Gutiérrez, L. M. (2008). Teoría y práctica de la participación juvenil y el cambio comunitario. Barcelona, España: GRAÓ.

Cheek, J. (2011). The Politics and Practices of Funding Qualitative Inquiry: Messages about messages about messages... En N. K. Denzin \& Y. S. Lincoln (Eds.), The Sage Handbook of Qualitative Research (pp. 251-268). Thousand Oaks, CA: Sage

-- (2013). La práctica y la política de la investigación cualitativa financiada. En N. K. Denzin \& Y. S. Lincoln (Eds.), Manual de investigación cualitativa, vol III, (pp. 52-93). Barcelona, España: Gedisa. 
Claus, J. y Ogden, C. (1999). An empowering, transformative approach to service. En J. Claus y C. Ogden (Eds.), Service learning for youth empowerment and social change (pp. 69-94). Nueva York: Peter Lang.

Cohendoz, M. (2001). Reseña de Wenger, E. (2001). Comunidades de práctica: Aprendizaje, significado e identidad. Madrid, España: Paidós.

Collado, M. y Álvarez, V. (1986). La animación sociocultural como educación no formal. En VV. AA., Fundamentos de animación sociocultural (pp. 73-93). Madrid, España: Narcea.

Collet, J. y Sánchez, E. (2013). Taula 1 Els reptes del moviment associatiu juvenil pel segle XXI. En M. A. Lozano y M. Andreu. Els reptes del moviment associatiu juvenil pel segle XXI. Una reflexió sobre el jovent associat avni. (pp. 817). Barcelona, España: CNJC.

Constas, M. A. (1999). Qualitative Analysis as a Public Event: The Documentation of Category Development Procedures. American Educational Research Journal, 29(2), 253-266.

Coombs, P. H. (1968). The World Educational Crisis. NuevaYork: Oxford University Press.

—(1985) La crisis mundial de la educación. Madrid: Santillana.

Coraggio, J. L. (2015). Economía social y economía popular en América Latina, en I Congreso de Pensamiento Económico Latinoamericano, Asociación del Pensamiento Latinoamericano, Buenos Aires, 25 de septiembre de 2015.

Cornejo, R., González, J. y Caldichoury, J. P., (2007). Participación e incidencia de la sociedad civil en las politicas educativas: el caso chileno. Buenos Aires, Argentina: Fundación Laboratorio de Políticas Públicas.

Cornudella, M. (2004). III Carta de la joventut catalana. El programa polític del moviment associatiu català, Barcelona, Xarxa Jove núm 4. Consell Nacional de la Joventut de Catalunya. 
Cornwall, A. (2008). Democratising engagement. What the UK can learn from International experience. London, U.K.: Institute Development Studies. Demos.

Cortés, P. (2010). El sentido de las historias de vida en las investigaciones socio-educativas. Una revisión crítica, en I Jornadas de Historias de Vida en Educación, Barcelona, 10 y 11 de junio de 2010.

--(2013). El guiño del poder, la sonrisa del cambio. Estudio pedagógico sobre identidad resiliente en situaciones de desventaja social, cultural y jurídica. Universidad de Málaga. (Tesis doctoral). Recuparada del Repositorio Institucional de la Universidad de Málaga.

Cortina, A. (2007). Ética de la razón cordial. Oviedo: Nóbel.

Cottino, P. (2005). La ciudad imprevista. Barcelona, España: Edicions Bellaterra.

Counsell, S. L., \& Boody, R. M. (2013). Social Pedagogy and Liberal Egalitarian Compensatory Programs: The Case of Head Start. Education Policy Analysis Archives, 21(39).

Cousée-Ghent, F. (2016). Una perspectiva pedagógica social sobre la juventud y la sociedad. La resocialización del interrogante de la juventud. Conferencia de apertura en el Congreso internacional y XXIX Seminario interuniversitario de Pedagogía Social, juventud y transformaciones sociales. Septiembre, 2016, Girona, España.

Creswell, J. W. (1994). Research design: Qualitative \& quantitative approaches. Thousand Oaks, CA: Sage.

--(2002). Educational research: Plan- ning, conducting, and evaluating quantitative and qualitative research. Upper Saddle River, NJ: Merrill Prentice Hall.

--(2003). Research Design Qualitative, Quantitative and Mixed Methods Approaches (2nd. ed.). Thousand Oaks: Sage.

--(2007). Qualitative Inquiry and Research Design: Choosing Among Five Approaches. 
Thousand Oaks, California: Sage.

Crossouard, B. \& Dunne, M. (2015). Politics, gender and youth citizenship in senegal: youth policing of dissent and diversity. International review of education, 61(1), 43-60.

Crouch M, \& McKenzie H. (2006). The logic of small samples in interview-based qualitative research. Social Science Information 2006; 45(4), 483-499.

Cruz, J. (1996). Cómo romper paradigmas y provocar el cambio. México: Orión, Col. Siglo XXI.

Cuenca, M. (2004). Pedagogía del ocio: Modelos y propuestas. Bilbao, España: Universidad de Deusto.

\section{D}

Daniels, H. (2003). Vigotsky y la pedagogía. Madrid, España: Paidós.

Davis, J. E. (Ed.). (2002). Stories of Change: Narrative and Social Movements. Albany: State University of New York Press.

De Jesús, A., Oviedo, S. \& Feliz, S. (2015). Global kids organizing in the global city: generation of social capital in a youth organizing program. Afterschool Matters, 21, 20-28.

De la Rosa, L. (2008). La historia de vida de Angel: Parálisis cerebral, normalidad y comunicación. Madrid, España: La Muralla.

- (2010). ¿Investigamos juntos? Personas con discapacidad, historias de vida y emancipación. Revista de Educación Inclusiva, 3(3), 11-22.

Delgado, J. M. \& Gutiérrez, J. (Coords.). (1994). Métodos y técnicas cualitativas de investigación en ciencias sociales. Madrid, España: Síntesis.

Del Rincón, D. (1997). La metodología cualitativa orientada a la comprensión. Barcelona, 


\section{España: EDIOUC.}

Deltoro, E. (1995). Cómo hacer proyectos de animación: Para trabajar con niños y jóvenes. Zaragoza, España: Certeza.

--(2006). Cómo trabajar con adolescentes en el tiempo libre. España: Certeza.

De Miguel, S. (1995). Perfil del Animador Sociocultural. Madrid, España: Nárcea.

Denzin, N. K. (1970). Sociological Methods: a Source Book. Chicago: Aldine Publishing Company.

Denzin, N. K. \& Lincoln, Y. S. (Eds.). (2011). The Sage Handbook of Qualitative Research. Thousand Oaks, California: Sage.

-- (2013). Introducción al Volumen III: Estrategias de investigación. En N. K. Denzin \& Y. S. Lincoln (Eds.), Manual de investigación cualitativa, vol III (pp. 33-51). Barcelona, España: Gedisa.

-- (Coords.). (2013). Manual de investigación cualitativa. Volumen I: El campo de la investigación cualitativa. Barcelona, España: Gedisa.

-- (2013). Manual de investigación cualitativa. Volumen II: Paradigmas y perspectivas en disputa. Barcelona, España: Gedisa.

-- (2013). Manual de investigación cualitativa. Volumen III: Las estrategias de investigación cualitativa. Barcelona, España: Gedisa.

-- (2013). Manual de investigación cualitativa. Volumen IV: Métodos de recolección y análisis de datos. Barcelona, España: Gedisa.

Dewey, J. (1995). Democracia y educación. Madrid, España: Morata.

-- (1938/1997). Experiencia y educación. Madrid, España: Biblioteca Nueva. 
Dey, I. (1993). Qualitative Data Analysis: A User-Friendly Guide for Social Scientists. London, U.K.: Routledge.

Díaz-Barriga, F. (2003). Cognición situada y estrategias para el aprendizaje significativo. Revista electrónica de investigación educativa, 5(2).

Díaz de Rada, A. (2003). Etnografía y técnicas de investigación antropológica. Madrid, España: UNED.

Doistua, J., Pose, H. y Ahedo, R. (2016). Espacios, experiencia de ocio y participación de la juventud: contribución a los modelos de gestión e intervención a partir del análisis de buenas prácticas. Contextos educativos, 19, 2016, 133-145.

Duarte, A. (1987). El Republicanisme català a la fi del segle XIX. Vic, España: Eumo.

Duke, C., y Hinzen, H. (2009). Documento de antecedentes: Un nuevo esfuerzo para los nuevos tiempos avanzando en la larga marcha hacia Belem. Educación de adultos y desarrollo, 73. DVV Internacional.

Dumazedier, J. (1968) Hacia una civilización del ocio. Barcelona, España: Estela.

Durlak, J. A., \& Weissberg, R. P. (2007). The impact of after-school programs that promote personal and social skills. Chicago, IL: Collaborative for Academic, Social, and Emotional Learning.

\section{$\mathbf{E}$}

Eisner, E. (1998). El ojo ilustrado. Indagación cualitativa y mejora de la práctica educativa. Barcelona, España: Paidós.

Elboj, C. Puigdellívol, I., Soler, M. y Valls, R. (2002). Comunidades de aprendizaje: transformar la educación. Barcelona: Graó.

Ellingson, L. L. (2011). Analysis and representation across the continuum. En N. K Denzin \& Y. S. Lincoln (Eds.), The Sage Handbook of Qualitative Research 
(pp. 595-610). Thousand Oaks, CA: Sage.

Engeström, Y. \& Cole, M., (1997). Situated cognition in search o fan agenda. En D. Kirshner \& J. A. Whitson (Eds.). Situated cognition. Social, semiotic and psychological perspectives (pp. 301-309). Mahwah, NJ: Lawrence Erlbaum.

Erazo, M. S. (2011). Rigor científico en las prácticas de investigación cualitativa. Ciencia, docencia y tecnología, (42), 107-136.

Escudero, J. (1987). La investigación-acción en el panorama actual de la investigación educativa: algunas tendencias, Revista de Innovación $e$ Investigación Educativa. 3, 14-25.

--(2004). Análisis de la realidad local: Técnicas y métodos de investigación desde la animación sociocultural. Madrid, España: Narcea.

Espadas, M. A. y Alberich, T. (2010). Ser parte y tomar parte: Análisis y propuestas sobre asociacionismo y participación ciudadana en la ciudad de Jaén. Jaén, España: Universidad de Jaén.

Estalella, A. (2015). Etnografía: observación participantes y diario de campo. Charlas auditorio Medialab Prado: Madrid. Recuperado de http://cccd.es/wp/etnografia-observacion-participante-y-diario-decampo/

Expósito, M. (2003). Diagnóstico Rural Participativo. Una guía práctica. Centro Cultural Poveda: República Dominicana.

European Comission (2015). Focus on: Empowering young people to participate in society. 


\section{$\mathbf{F}$}

Fenstermacher, G. D. (1989). Tres aspectos de la filosofía de la investigación sobre la enseñanza. En M.C. Wittrock (Eds.), La investigación de la enseñanza I. Enfoques, teorías y métodos. Barcelona, España: Paidós Educador.

Fermoso, P. y Pont, J. (Eds.). (2000). Sociología de la educación. Valencia, España: NAU llibres.

Fielding, M. (2011). La voz del alumnado y la inclusión educativa: una aproximación democrática radical para el aprendizaje intergeneracional. Revista Interuniversitaria de Formación del Profesorado, 70, 31-62.

Flick, U. (2002). An introduction to Qualitative Research. Londres, UK: Sage.

Foley, D. (2002). Critical ethnography: the reflexive turn. International Journal of Qualitative Studies in Education, 15(4), 469-491.

Foley, D. y Valenzuela, A. (2013). Etnografía crítica. La política de la colaboración. En Denzin \& Lincoln (coords.), Manual de investigación cualitativa, Volumen II. (pp. 79-110). Barcelona, España: Gedisa.

Font, J., Ojeda, H. y Urbano, X. (6 de marzo de 2015). La gestión comunitaria en la economía social y solidaria. Periódico Diagonal. Recuperado de https:/ /www.diagonalperiodico.net/movimientos/25987-la-gestioncomunitaria-la-economia-social-y-solidaria.html

Franscisco, A. (2013). El banquete de safo. Una tertulia dialógica sobre los discursos mediaticos del amor y los modelos de atracción con mijeres lesbianas y bisexuales. Universitat Jaume I, Castellon. (Tesis doctoral). Recuperada del Repositorio de la Universitat Jaume I, Castellón.

Freilich, M. (1970). Marginal natives: Anthropologist at work. New York: Harper \& Row.

Freire, P. (1970). Pedagogy of the Oppressed. New York: Continuum. 
--(1974). Concientización: teoría y práctica de la liberación. 3. ed. Bogotá, Colombia: Asociación de Publicaciones Educativas.

--(1978). Education for critical consciousness. New York: Seabury.

--(1985). The politics of education: Culture, power and liberation. South Hadley, MA: Bergin \& Garvey.

--(1997). A la sombra de este árbol. Esplugues de Llobregat, España: El Roure.

--(2002). La pedagogía del oprimido. Madrid, España: Siglo XXI.

Froufé, S. (1998). Técnicas de grupo en animación comunitaria. Salamanca, España: Amaru ediciones.

Froufé, S. y Sánchez, M.A. (1990). Animación sociocultural. Nuevos enfoques. Salamanca, España: Amarú.

Fullan, M. (2002). El significado del cambio educativo. Un cuarto de siglo de aprendizaje. Profesorado, revista de currículum y formación del profesorado, 6(1-2), $1-15$.

Funes Artiaga, J. (2010). Adolescentes con autonomía. La Vanguardia 25.07.2010.

--(2010). Educar en la adolescencia. 9 Ideas clave. Barcelona, España: Graó.

Funes Rivas, M. J. y Robles, J. M. (2016). Civic Participation as Means of Empowerment. Preventing Social Exclusion of Youth in Precarious Life Conditions in Spain. Papers, revista de sociologia, 101(3), 315-337.

Fung, A. (2003). Associations and democracy: between theories, hopes and realities. Annual Review of Sociology, 29, 515-539.

\section{G}

Gadotti, M. (2003). Historia de las ideas pedagógicas. México: siglo XXI. 
Gallego, M., Traver, J.A y Moliner, L. (2010). La Agenda 21 de la Cultura como herramienta de potenciación de los aprendizajes a lo largo de la vida. Actas del I Congreso Internacional de Aprendizajes a lo largo de la vida. Universitat Jaume I: Castelló.

García, E. (2013). Flashback 15M: las raíces culturales de la política callejera en España. Congreso 15MP2P: encuentro transdisciplinar Redes, Movimientos y Tecnopolítica. Universitat Oberta de Catalunya.

García, E. (2014). Entre la participación y la reflexividad: Desbordes epistemológicos para una antropología de los movimientos sociales emergentes. Periferias, fronteras y diálogos. Actas del XIII Congreso de Antropología de la Federación de Asociaciones de Antropología del Estado Español (pp. 3213-3234). Tarragona, 2-5 de septiembre, 2014.

García, M., Ibáñez, J. y Alvira, F. (2000). El análisis de la realidad social: Métodos y técnicas de investigación. Madrid, España: Alianza Editorial.

García Jorba, J.M. (2000). Diarios de campo. Cuadernos metodológicos, 31. Madrid, España: Centros de Investigaciones Sociológicas.

García Roca, J. (1994). Solidaridad y voluntariado. Bilbao: Sal Terrae.

--. (2004). Politicas y programas de participación social. Madrid: Síntesis.

García Roca, J. y Comes, J. A. (1995). El voluntariado como recurso social. En AA.VV. El voluntariado. València: Bancaixa.

García, R., Traver, J. A. y Candela, I. (2001). Aprendizaje cooperativo. Fundamentos, caracteristicas y técnicas. Madrid: CCS. ICCE

Germeten, S. (2013). Personal Narratives in Life History Research. Scandinavian Journal of Educational Research, 57 (6), 612-624.

Gibbs, G. R. (2007). Analyzing Qualitative Data. EEUU: Sage. 
Bibliografía

Gibbs, G. R. (2012). El análisis de datos cualitativos en investigación cualitativa. Madrid: Morata.

Gimeno Sacristán, J. (1982). La pedagogía por objetivos. Obsesión por la eficiencia. Madrid: Morata.

Giner, H, López, M., Maín, B. y Murgui, C. (2013). Aixequem la persiana. Barcelona: Casals de Joves de Catalunya.

Girardi, G. (1977). Por una pedagogía revolucionaria. Barcelona, España: Laia.

Giroux, H. A. (1996). Placeres inquietantes. Barcelona, España: Paidós.

Given, L. (2008) (ed.) The SAGE Encyclopedia of Qualitative Research Methods. California: Sage.

Glaser, B. (1992). Basics of grounded theory analysis. Mill Valley: Sociology Press.

Glickman, C. (2009). Educating for citizenship: a system wide responsability for preparing studens to became wise citizenzs. Education Digest: Essential Readings Condensed for Quick Review, 74 (8), 50-56.

Goetz, J. P. \& LeCompte, M. D. (1988). Etnografia y diseño cualitativo en investigación educativa. Madrid, España: Morata.

Goetz, J. y Lecompte, M. (1984). Ethnography and qualitative design in education research. Orlando: Academic Press.

Goig, J.M. y Nuñez, M.A. (2011). El fomento de la juventud participativa: tratamiento constitucional, desarrollo legislativo y políticas públicas. Revista de Estudios de Juventud, (94), 29-48.

González, A. (2014). Nuevas formas de ciudadanía: las entidades del tercer sector social. Revista Qurriculum, 27, 129-148. 
Goodenough, W. (1979). Description and comparison in Cultural Anthropology. Chicago: Aldine.

Gould, S. J. (1998). The sharp-eyed lynx, outfoxed by nature (Part 2), Natural History, 107, 23-27,69-73.

Graeber, D. (2011). Fragmentos de antropología anarquista. Barcelona: Virus Editorial.

Grinberg, J. (2003). Only the facts? En D. Weil \& J. L. Kincheloe (Eds.) Critical thinking: An encyclopedia. New York: Greenwood.

Guba, E. G., \& Lincoln, Y. S. (1981). Effective evaluation: Improving the usefulness of evaluation results through responsive and naturalistic approaches. San Francisco: Jossey-Bass.

Guba, E. G., \& Lincoln, Y. S. (1982). The epistemological and methodological bases of naturalistic inquiry. Educational Communications and Technology Journal, 31, 233-252.

Guba, E. G. (1983). Criterios de credibilidad en la investigación naturalista. En J. Gimeno Sacristán, y Á. Pérez Gómez (Eds.), La enseñanza: Su teoría y su práctica (pp. 148-165). Madrid: Akal.

Guba, E. G. (1990). The Paradigm Dialog. Newbury Park and London: Sage.

Guest, G., MacQueen, K. M. \& Namey, E. E. (2012). Applied Thematic Analysis. Thousand Oaks: Sage.

Guia para la promoción de la participación juvenil en el ámbito local. (2002). Madrid, España: INJUVE, Ministerio de trabajo y asuntos sociales.

Gumperz, J. y Hymes, D. (1972). Directions in sociolinguistics. The Etnography of Communication. Nueva York: Basil Blackwell.

Guttman, A. (2001). La educación democrática: Una teoría politica de la educación. Barcelona, España: Paidós. 
Gronn, P. (2002). Distributed leadership as a unit of analysis. The Leadership Quarterly, 13, 423-451.

Guerra, P. (2004). Economía de la Solidaridad. Una introducción a sus diversas manifestaciones teóricas. Recuperado de http://docplayer.es/12557788Economia-de-la-solidaridad-una-introduccion-a-sus-diversasmanifestaciones-teoricas.html

Guibert, J.M. (2011). Gestión socialmente responsable. Serie Humanidades, 24. Bilbao: Universidad de Deusto.

\section{$\mathbf{H}$}

Habermas, J. (1987/1989). Teoría de la acción comunicativa. Vol I: Racionalidad de la acción y racionalización social. Vol II: Crítica de la razón funcionalista. Madrid: Taurus.

Hammersley, M. \& Atkinson, P. (2001/1994). Etnografia: Métodos de investigación. Barcelona, España: Paidós.

Hammersley, M. y Atkinson, P. (1983). Ethnography: Principles in practice. Londres: Tavistock Publications.

Harper, D. (1987). Working knowledge: Skill and community in a small shop. Chicago: University of Chicago Press.

Hart, J. K. (1926). Light from the north: The Danish folk high schools: their meanings for America. New York: Henry Holt.

Hart, P. (2015). Young people negotiating and maintaining boundaries in youth work relationships: findings from an ethnographic study of youth clubs. Journal of Youth Studies, 19 (7), 869-884.

Heath, S. y B. Street (2008). On Ethnography: Approaches to language and literacy research. New York and London, Teachers College. 
Hechavarría-Lescaille, M. J., Salas-Delisle, D. y Roldán-Ruenes, A. (2008).

Diagnóstico Rural Participativo. Sus potencialidades en situaciones de montaña. Ciencia en su PC (2), 24-32.

Hersey, P. \& Blanchard, K.H. (1988). Management of organizational behavior. Englewood: Prentice Hall.

Horn, R. (2004). Standards. New York: Peter Lang.

\section{I}

INJUVE (2007). Sondeo de opinión y situación de la gente joven

INJUVE (2014). Sondeo Jóvenes, Satisfacción Personal, Participación Asociativa y Voluntariado.

Innerarity, D. (2016). Las ciudades en un mundo globalizado: hacia una nueva forma de ciudadanía. Conferencia inaugural XII Encuentro Ibérico de Directores de Planes Estratégicos Urbanos y Territoriales.

Innerarity, D. (2006). El nuevo espacio público. Madrid, España: Espasa.

Izquieta J.L y Callejo, J.J. (2013). Asociacionismo y participación voluntaria de las jóvenes españoles. Cambios y tendencias actuales. Cuadernos de Trabajo Social, 26 (1), 159-170.

J

Jacobson, A. (2014). Una visita repleta d'experiències interessants. Papers Associatius de L'Horta Sud (55).

Janesick, V. J. (2000). The choreography of qualitative research design. Minuets, improvisations, and crystallization. En N. K. Denzin \& Y. S. Lincoln (Eds.), Handbook of Qualitative Research (pp. 379-399). Thousand Oaks, CA: Sage. 
Jennings, L., Parra-Medina, D.M., Kilfinger, D.K. y Mcloughlin, K. (2008). Hacia una teoría social crítica del empoderamiento de la juventud. En Checkoway y Gutiérrez (2008), Teoría y práctica de la participación juvenily el cambio comunitario (pp.43-90). Barcelona: Graó.

Johnson, D.W., Johnson, R. T. y Holubec, E.J. (1999). El aprendiraje cooperativo en el aula. Barcelona: Paidós.

Jones, P.S. \& Meleis, A. I. (1993). Heatlh is empowerment. Advances in nursing science, $75(3), 1-4$.

Juris, J. S. \& Khasnabish, A. (Eds.) (2013). Insurgent encounters. Transnational Activism, Ethnography \&o the Poplitical. Durham, London, U.K.: Duke University Press.

\section{$\mathbf{K}$}

Kiilakoski, T. \& Kivijärvi, A. (2015). Youth clubs as spaces of non-formal learning: professional idealism meets the spatiality experienced by young people in Finland. Studies in Continuing Education, 37(1), 47-61.

Kincheloe, J. (2001). Getting beyond the facts: Teaching social studies/social sciences in the twenty-first century. (2nd ed.). New York: Peter Lang.

--(2008). Knowledge and critical pedagogy. Dordrecht, the Netherlands: Springer.

Kincheloe, J., MacLaren, P. \& Steinberg, S. (2011). Critical pedagogy and qualitative research. Moving to the bricolage. En N. K. Denzin \& Y. S. Lincoln (Eds.), Handbook of Qualitative Research (pp. 163-177). Thousand Oaks, CA: Sage.

Kirshner, B. (2008). Guided participation in three youth activism organizations: facilitation, apprenticeship and joint work. Journal of the learning Sciences, 17(1), 60-101. 
Kuhar, K. \& Sablji, J. (2016). The Work and Role of Extracurricular Clubs in Fostering Student Creativity. Journal of Education and Training Studies, 4(4), 93-104.

\section{$\mathbf{L}$}

Laorden, C. y Pérez, C. (2002). El espacio como elemento facilitador del aprendizaje. Una experiencia en la formación inicial del profesorado. Pulso 2002, 25, 133-146.

Lassiter, L. E. (2005). The Chicago guide to collaborative ethnography. Chicago: The University of Chicago Press.

Lave y Wenger (1991) Situated Learning. Legitimate peripheral participation. New York: Cambridge University Press.

Lebrero, M. P., Montoya, J. M. y Quintana, J. M. (2002/2008). Pedagogía social. Madrid, España: UNED.

LeCompte, M. (2000). Analyzing Qualitative Data. Theory into Practice, 39(3. Getting Good Qualitative Data to Improve Educational Practice), 146-154.

Leontiev, A. (1978). Actividad, conciencia y personalidad. Buenos Aires: Ciencias del Hombre.

Levin, M. \& Greenwood, D.J. (1998). Action Research, science and co-optation of social research. Studies in cultures, organizations and societies, 4(2), 237-261.

Lewis, O. (1961/2012) Los bijos de Sánchez: Una muerte en la familia Sánchez. México DF, México: Fondo de Cultura Económica.

Ley Orgánica 1/2002, de 22 de marzo, reguladora del Derecho de Asociación.

Ley 39/2006, de 14 de diciembre, de Promoción de la Autonomía Personal y Atención a las personas en situación de dependencia. 
Bibliografía

Lincoln, Y. S. \& Denzin, N. K. (Eds.). (2013). Collecting and interpreting qualitative materials. Thousand Oaks, CA: Sage.

Lincoln, Y. S. \& Guba, E. (1985). Naturalistic inquiry. Beverly Hills, CA: Sage.

Lincoln, Y. S., Lynham, S. \& Guba, e. (2011). Paradigmatic Controversies, Contradictions and Emerging Confluences, Revisited. En N. K. Denzin \& Y. S. Lincoln (Eds.), Handbook of Qualitative Research (pp. 97-128). Thousand Oaks, CA: Sage.

Linz, J. (1970). La realidad asociativa de los españoles. Sociología española de los años 70. Madrid: Confederación Española de Cajas de Ahorros.

Llena, A., Parcerisa, A. \& Úcar, X. (2009). 10 ideas clave: La acción comunitaria. Barcelona, España: GRAÓ.

Lobillo, J. (coord.) (2002). Experiencias de diagnóstico rural participativo. Dossiers d'extensió universitària, $\mathrm{n}^{\circ} 2$. Universitat Jaume I.

López De Aguileta, I. (1986). Ponencia Base del Encuentro de Animación Sociocultural. Bilbao.

López, F. y León, L. (2009). La animación sociocultural como contribución a la construcción de la identidad comunitaria. Cuestiones pedagógicas: Revista de ciencias de la educación, 16, 2002, 139-150.

Ludhra G. y Chappel, A. (2011). You were quiet -I did all the marching: research processes involved in hearing the voices of South Asian girls. En International Journal of Adolescence and Youth, 16, 101-118.

Luque, S. y Serrano, J. (2007). L'estat de la joventut a Catalunya. Barcelona, España: Fundació Ferrer i Guàrdia.

Luria. A. R. (1987). Desarrollo histórico de los procesos cognitivos. Madrid, España: Akal. 


\section{$\mathbf{M}$}

MacCall, G. \& Simmnes, J. L. (1969). Issues in participant observations: A text and reader. Reading, U.K.: Addison Wesley.

Macedo, E. (2009). Cidadania em confronto: Educação de jovens elites em tempo de globalização. Porto, Portugal: Livpsic.

Madison, S. (2012). Critical Ethnography: Method, ethics, and performance. Thousand Oaks, California: Sage.

Mahmud, A. \& Manda, D. (2016). The Implementation of Character Education through Scout Activities. Internacional Education Studies, 9(6), 130-138.

Malo, M. (2004). Nociones comunes. Experiencias y ensayos entre investigación y militancia. Madrid, España: Traficantes de sueños.

Marcelo, C. (1994). Formación de profesorado para el cambio educativo. Barcelona.PPU.

Marchioni, M. (2001). Comunidad, Participación y desarrollo. Teoría y metodología de la intervención comunitaria. Editorial Popular: Madrid.

Marshall, C. \& Rossman, G. B. (1999/2006). Designing Qualitative Research. Thousand Oaks, California: Sage.

Marshall, M. N. (1996). Sampling for qualitative research. Family Practice, (6), $522-$ 525.

Martínez, A. (1995). El diagnóstico participativo: una herramienta de trabajo para las comunidades. Costa Rica: Catie.

Martínez J.C. (1999): Els camps d'intervenció de l'educador/a social. Els àmbits i els subjectes d'intervenció. Aportacions des de l'Escola d'Educadors/es de Navarra. En Fullana, J. (Coord.), Els àmbits de treball de l'educador social (pp. 29-53). Málaga, España: Aljibe. 
Martínez de Mandojana, I. (2014). Trabajando desde las fortalezas, una apuesta por las personas. Revista Edetania (45), 211-218.

Martínez-Salgado, Carolina. (2012). El muestreo en investigación cualitativa: principios básicos y algunas controversias. Ciência \& Saúde Coletiva, 17(3), 613-619.

Massot, I. (2003). Jóvenes entre culturas: La construcción de la identidad en contextos multiculturales. Bilbao, España: Desclée de Brouwer.

Matos, M. (2009). Entre a vida e a escola: Um tempo para pensar a tensão da relação. Porto, Portugal: Livpsic.

McDonough, P., Barnes, S. H. \& López, A. (1984). Authority and associations in Spain. Journal of Politics 60, 919-953.

Mcfarland, D. \& Thomas, R. J. (2006). Bowling Young: How Youth Voluntary Associations Influence Adult Political Participation. American Sociological Review 71(3), 401-425.

McKeachie, W. J. (1999). Teaching tips. Strategies, research and theory for college and university teachers. Boston, MA: Houghton Mifflin.

McLaren, P. y Kincheloe, J. L. (2008). Pedagogía crítica: De qué hablamos, dónde estamos. Barcelona, España: GRAÓ.

McMahan, E. M. y Rogers, K. L. (1994). Interactive Oral History Interviewing. Thousand Oaks, California: Sage.

Mejía Navarrete, J. (2002). Problemas metodológicos de las ciencias sociales en el Perú. Fondo Editorial de la Facultad de Ciencias Sociales: Universidad Nacional Mayor de San Marcos.

Melendro, M (2016). De la vulnerabilidad al compromiso a través de la acción socioeducativa: claves para transformar las políticas de juventud. Conferencia Congreso Internacional y XXIX Seminario interuniversitario 
de Pedagogía Social, juventud y tranforamción social.

Mèlich, J.C. (1996). Antropología simbólica y acción educativa. Barcelona: Paidós.

Méndez y Mota (2006). Las características organizativas de las asociaciones en España. En J. R. Montero, J. Font, y M. Torcal (Eds.), Ciudadanos, asociaciones y participación en España. (pp. 203-222). Madrid, España: CIS.

Mendia, R. (1991). Principios pedagógicos del tiempo libre. Corrientes de Pensamiento. Infancia y Sociedad, 8, 33-50.

Meneses, M. T. y Cano, A. (2008). Técnicas conversacionales para la recogida de datos en investigación cualitativa: La historia de vida (I). Nure Investigación, 37, Noviembre - Diciembre 08.

Merino, J. V. (1997). Programas de animación sociocultural. Tres instrumentos para su diseño y evaluación. Madrid, España: Narcea.

Miles, M. B. \& Huberman, A. M. (1994). Qualitative Data Analysis: An expanded sourcebook. Thousand Oaks, California: Sage.

Moliner, O., Traver, J. A., Ruiz, M. A. y Segarra, T. (2016). Estrategias que inciden en los procesos de democratización de la escuela. Una aproximación teórica. Revista Electrónica de Investigación Educativa, 18(2), 116-129. Recuperado de http://redie.uabc.mx/redie/article/view/1110

Montero, J. R., Font, J. y Torcal, M. (2006). Ciudadanos, asociaciones y participación en España. Madrid, España: CIS.

Moral, C. (2016). Estrategias para resistir a la crisis de confianza en la investigación cualitativa actual. Educación XX1, 19(1), 159-177.

Morales, L. y Mota, F. (2006). El asociacionismo en España. En J. R. Montero, J. Font, y M. Torcal (Eds.), Ciudadanos, asociaciones y participación en España (pp. 77-104). Madrid, España: CIS. 
Morata, T. (1997). Animación sociocultural y desarrollo comunitario. En J. Trilla (coord.), Animación sociocultural. Teorías, programas y ámbitos. (pp. 297-305). Barcelona, España: Ariel.

--. (2009). De la animación sociocultural al desarrollo comunitario. Universidad de Barcelona (tesis doctoral). Recuperada del respositorio de la Universitat de Barcelona.

Morin, E. (2011). Los siete saberes necesarios para la educación del futuro. Barcelona, España: Paidós.

Moriña, A. (2008). La escuela de la diversidad. Madrid, España: Síntesis.

--(2010). Vulnerables al silencio. Historias escolares de jóvenes con discapacidad. Revista de Educación, 353. Septiembre-Diciembre 2010, 667-690.

Moriña, A. (en prensa). Investigar con historias de vida.

Morrow, R. A. \& Torres, C. A. (2002). Reading Freire and Habermas: Critical pedagogy and transformative social change. New York: Teachers College Press.

Morse, J. M. (Ed.). (2005). Asuntos críticos en los métodos de investigación cualitativa. Alicante, España: Publicaciones de la Universidad de Alicante.

Moura, P. (2008). Associações e democracia. Faz o associativismo alguma diferença na cultura cívica dos jovens portugueses? Sociologia, problemas e práticas, 57, 2008, 109-130.

Muñoz, J. M. (Ed.). (2011). Adolescencia y tiempo libre. Análisis y propuestas educativas en Salamanca. Salamanca, España: Universidad de Salamanca.

Murillo, F.J. (2006). Una Dirección Escolar para el Cambio: del Liderazgo Transformacional al Liderazgo Distribuido. Revista Electrónica Iberoamericana sobre Calidad, Eficacia y Cambio en Educación, 4(4e), 11-24. 


\section{$\mathbf{N}$}

Neely, J.C. (2015). Pluggin in: possibilities for connecting teens and communities through scholastic and nonscholastic youth media websites. Youth and society, 47(4), 565-585.

Nelson, C., Treichler, P.A. y Grossberg, L. (1992). Cultural studies: An introduction. En L. Grossberg, C. Nelson y P.A. Treichler (coord), Cultural Studies (pp. 1-16). Nueva York: Routledge.

Niemeyer, B. (2006). El aprendizaje situado: una oportunidad para escapar del enfoque del déficit. Revista de Educación (341), 99-121.

Noreña, A., Alcaraz-Moreno, N., Rojas, J., Rebolledo, D. (2012). Aplicabilidad de los criterios de rigor y éticos en la investigación cualitativa. Aquichan, Norteamérica, 12, 263-274.

Núñez, V. (1999). Pedagogía social: cartas para navegar en el nuevo milenio. Argentina: Santillana.

Núñez, H. y Úcar, X. (2010). Los ámbitos de intervención de la Pedagogía Social. Contenidos teoricos asignatura on-line: Pedagogia Social y Comunitaria. Facultat d'Educació: Universitat de les Illes Balears.

\section{$\mathbf{O}$}

Ortega, P., Mínguez, R. y Gil, R. (1996). Valores y educación. Barcelona: Ariel

O’Brien, P., McConkey, R., \& García-Iriarte, E. (2014). Co-researching with people who have intellectual disabilities: Insights from a National Survey. Journal of Applied Research in Intellectual Disabilities, 27, 65-75.

O’Donnell, J. \& Kirkner, S. L. (2016). Helping low-income urban youth make the transition to early adulthood: a retrospective study of the MYCA Youth Institute. Afterschool Matters, 23, 18-27. 


\section{$\mathbf{P}$}

Palacios, J. L. (2005). Tiempos libres, ciudadanos libres en ponencia marco El reto de una nueva política municipal de juventud en I Jornadas de Buenas prácticas en la organización de políticas municipales de juventud. La Farga l'hospitalet: FEMP y Hospitalet de Lobregat, España.

Palacios, J. L (2016). Ponencia inauguración en Jornada Aniversario Escola de Cases, Manises, España.

Pallisera, M., Fullana, Martín, R.; J.; Puyaltó, C. y Vilà, M. (2013) La transición a la edad adulta y vida activa de jóvenes con discapacidad intelectual: análisis y propuestas a partir de una investigación inclusiva. $2 n$ Congrés Internacional Multidisciplinar de Recerca Educativa (CIMIE). Associació Multidisciplinar d’Investigació Educativa (AMIE). Julio, 2013. Tarragona, España.

Pallisera, M., Fullana, J., Vilà, M., Puyalto, C. y Díaz, G. (2016). Dónde vivir y con quién? El desarrollo de procesos colaborativos con jóvenes con discapacidad intelectual en una investigación sobre vida independiente. Congreso Internacional XXIX Seminario Interuniversitario de Pedagogía Social Pedagogía social, juventud y transformaciones sociales. Septiembre, 2016. Girona, España.

Pantoja, A. (2010). La fotografía como recurso para la didáctica de la Historia. Tejuelo, No9, 179-194.

Paré, M. H. (2015). Seminario Fundamentos del análisis de datos cualitativos. SAIC, Febrero, 2015. Barcelona, España.

Parés, M. (Coord.). (2009). Participación y calidad democrática: Evaluando las nuevas formas de democracia participativa. Barcelona, España: Ariel.

Parrilla, A. (2000) (Dir.). Análisis de Innovaciones Educativas derivadas de la Atención a la Diversidad. Memoria de Investigación. Inédito. Universidad de Sevilla.

Patton, M. (1990/2002). Qualitative research and evaluation methods. Thousand 
Oaks, California: Sage.

Paz, H. (2009). El aprendizaje situado como una alternativa en la formación de competencias en ingeniería. En Memorias I Congreso Nacional de investigación en educación en ciencias y tecnología. Junio, 2009. Colombia.

Percy-Smith, B. \& Thomas, N. (Ed.). (2010). A handbook of children and young people's participation: Perspectives from theory and practice. Abingdon, UK: Routledge.

Pérez, G. (1998). Contexto culturaly socioeducativo de la educación social. Sevilla, España: Universidad de Sevilla.

Pérez Serrano, G. y Pérez de Guzmán, M.V. (2006). Qué es la animación sociocultural. Epistemología y valores. Madrid, España: Narcea.

Perks, R. \& Thomson, A. (Ed.). (1998). The oral bistory reader. London, UK: Routledge.

Petrie, P. (2013). Social Pedagogy in the UK: Gaining a firm foothold? Education Policy Analysis Archives, 21 (37).

Petrus, A. (1989). Animación sociocultural. En F. Etxebarría (Dir.), Pedagogía social y educación no escolar (pp. 241-254). San Sebastián, España: Universidad País Vasco.

--(1997). Pedagogía social. Barcelona, España: Ariel.

Pinderhughes, E. (1995). Empowering diverse populations: Family practice in the 21st century. Families in Society, 76(3).

Placer, F. (1989). Animación sociocultural: criterios y opciones para una intervención transformadora. Intervención transformadora en una sociedad en crisis. VitoriaGasteiz: Gobierno del País Vasco.

Plummer, K. (1995). Telling Sexual Stories: Modernists Stories of Desires, Danger and Recovery. New York: Routledge. 
Bibliografía

Potter, W. J. (1996). An Analysis of Thinking and Research about Qualitative Methods. New Jersey: Routledge.

Poveda, D. (2013). Presentación seminario Etnografia en educación. Universitat Jaume I.

Print, M. (2007). Citizenship education and youth participation in democracy. British Journal of Educational studies, 55(3), 325-345.

Progresar con las jóvenes: Guía para la reflexión de un concejal de juventud. (1999). Actas Jornadas de concejales y responsables políticos de juventud. Valencia, España.

Pujadas, J. J. (1992/2002). El método biográfico: El uso de las historias de vida en ciencias sociales. Cuadernos metodológicos, 5. Madrid, España: Centro de investigaciones sociológicas.

Pujadas, J. J., Comas, D. y Roca, J. (2010). Etnografía. Barcelona, España: Editorial UOC.

Pujolàs, P. (2008a). El aprendizaje cooperativo como recurso y como contenido. Aula de Innovación Educativa (170), 37-41.

Pujolàs, P. (2008b). El aprendizaje cooperativo. 9 ideas clave. Barcelona: Graó.

Putnam, R. (1993). Per a fer que la democràcia funcioni. Barcelona, España: Proa.

--(2002). Solo en la bolera. Colapso y resurgimiento de la comunidad norteamericana. Barcelona, España: Galaxia Gutenberg.

Q

Quintana, J. M (1993). Los ámbitos profesionales de la animación. Madrid, España: Narcea. 
Quintana, J. M. (2002). Aproximación conceptual. En M. L. Sarrate (coord.) Programas de animación sociocultural. Madrid, España: Universidad Nacional de Educación a Distancia.

\section{$\mathbf{R}$}

Rappaport, J. (1984). Studies in empowerment: Introduction to the issue. Prevention in Human Services.

Rappaport, J. (2007). Más allá de la escritura: la epistemología de la etnografía en colaboración, Revista Colombiana de Antropología, 43, 197-229.

Ratcliffe, J. W. (1983). Notions of validity in qualitative research methodology. Knowledge, Creation, Diffusion, Utilization, 5(2), 147-167.

Richardson, L. (1997). Fields of play: Constructing an academic life. NJ: Rutgers University Press.

Rivas, J. I. y Leite, A. (2010). La devolución en los procesos de construcción interactiva de los relatos. Actas I jornadas de Historias de Vida en Educación. Junio, 2010. Barcelona, España.

Rocha, E. M. (1997). A ladder of empowerment. Journal of the American Planning Association (77), 31-44.

Rockwell, E. (2009). La experiencia etnográfica. Historia y cultura en los procesos educativos. Buenos Aires, Argentina: Paidós.

Rodrigues Ramalho, R. (2013). Contribución a la propuesta de una etnografía militante. En X Jornadas de Sociología de la Universidad de Buenos Aires. Mesa 67: Sociología del compromiso militante y del activismo político.

Rodríguez, J. R. (2013). Las políticas de lucha contra la exclusión social y su relación con la Pedagogía Social: Los programas de Rentas Mínimas de Inserción y la propuesta de las Rentas Básicas. Archivos Analíticos de Políticas Educativas, 21(40). 
Rodríguez Gómez, G.; Gil Flores, J. y García Jimenez, E. (1996): Metodología de la investigación cualitativa. Archidona, España: Aljibe.

Rogoff, B. (1993). Aprendices del pensamiento. Barcelona, España: Paidós.

Rojas, R. (1989). Teoría e investigación militante. México: Plaza y Valdes.

Romagnano, L. S. (1991). Managing the dilemmas of change: A case study of two ninth grade general mathematics teachers. (Tesis doctoral). University of Colorado, Boulder.

Romaní, O. (Coord.). (2010). Jóvenes y riesgos: ¿Unas relaciones ineludibles?. Barcelona, España: Edicions Bellaterra.

Romans, M., Petrus, A. y Trilla, J. (2000). De profesión: educador(a) social. Barcelona, España: Paidós.

Russell, C. A., Mielke, M. B. \& Reisner, E. R. (2009). Evidence of program quality and youth outcomes in the DYCD Out-of-school time initiative: report on the initiative's first three years. Executive summary. New York: Department of youth and community development and The Wallace Foundation.

Razeto, L. (2000). Economía de la Solidaridad y Mercado Democrático. Santiago, Chile: Ediciones PET.

Rebollo, O. (2001). El Plan Comunitario de Trinitat Nova: una experiencia de participación ciudadana. Mientrastanto, 79.

Ruiz Olabuénaga, J. I. (1999). Metodología de la investigación cualitativa. Bilbao, España: Universidad de Deusto.

--(2001). El voluntariado en España. Documentación Socia 122, 67-84.

Ruiz-Olivares, R, Pino, M. J y Herruzo, J. (2013). Assessment of prosocial-altruistic behavior of members and non-members of the scout movement. European Journal of Psychology of Education, 28(2), 189-199. 


\section{S}

Sáez, J. (1997). La construcción de la pedagogía social: algunas vías de aproximación. En A. Petrus (Coord.), Pedagogía social. (pp. 40-66). Barcelona, España: Ariel.

Sánchez, T. \& Estalella, A. (Eds.) (2016). Experimental collaborations: Ethnography through Fieldwork Devices. London, U.K.: Berghahn.

Sandín, M. P. (2003). Investigación Cualitativa en Educación. Fundamentos y Tradiciones. Madrid, España: Mc Graw and Hill Interamericana.

San Román, T. (2009). Sobre la investigación etnográfica. Revista de Antropología Social, 18, 235-260.

Sanz, J. y Luque, S. (2002). Polítiques de joventut local a les Illes Balears. Barcelona, España: Fundació Ferrer i Guàrdia.

-- (2006). Els locals de les entitats juvenils $i$ els equipaments municipals per a joves a la ciutat de Barcelona. Informe de resultats. Col·lecció Polítiques de jovenut, $\mathrm{n}^{\mathrm{o}} 2$. Barcelona: Fundació Francesc Ferrer i Guàrdia.

Sanz Martos, S. y Pérez-Montoro, M. (2009). Conocimiento colaborativo: Las comunidades de práctica y otras estrategias organizacionales. Actas del IX Congreso Isko-España, Nuevas perspectivas para la difusión y organización del conocimiento.

Schön, D. A. (1983). The reflective practitioner. How professionals think in action. EEUU: Basic Books.

Schugurensky, D. (2011). Paulo Freire. NY: Continuum.

Schugurensky, D. \& Silver, M. (2013) Social pedagogy: Historical traditions and transnational connections. Education Policy Analysis Archives, 21(35). 
Serido, J., Borden, L. M. \& Wiggs, C. B. (2014). Breaking down potential barriers to continued program participation. Youth and Society, 46(1), 51-69.

Serra, C. (2004). Etnografía escolar, etnografía de la educación. Revista de Educació, $334,165-176$.

Serrano, J. (2003). Memòria i desmemòria de la Transició entre els joves. En R. Aracil, A. Mayayo y A. Segura, (Eds.). Memòria de la Transició a Espanya i a Catalunya: Els joves de la Transició. (pp. 45-88). Barcelona, España: Edicions Universitat de Barcelona.

--(2008). Contra la democracia participativa. Los tramposos atajos hacia la participación Democracia participativa. Barcelona, España: Fundació Ferrer i Guàrdia.

Shulman, L. S. (1981). Disciplines of inquiry in education: an overview. Educational researcher, 10(6), 5-12.

-- (1989). Paradigmas y programas de investigación en el estudio de la enseñanza: una perspectiva contemporanea. En M. C. Wittrock, La investigación de la enseñanza I. Enfoques, teorías y métodos. Barcelona, España: Paidós Educador.

Simpson, J.A. (1989). Animación sociocultural. En T. Husen y N. Postlethwaite (Ed.), Enciclopedia Internacional de la Educación, vol. 1. (pp. 282-285). Madrid, España: MEC-Vicencs Vives.

Smith, L. T. (1999). Decolonizing methodologies: Research and indigenous peoples. Dunedin, NZ: University of Otago Press.

Solà, P. (1987). Associacionisme i condició juvenil. En La Joventut a Catalunya al segle XX. Barcelona, España: Diputació de Barcelona.

Soler, P. (2015). Proyecto HEBE. El empoderamiento de las jóvenes: análisis de los momentos, espacios y procesos que contribuyen al empoderamiento juvenil. Programa Estatal de R+D+I «Retos de la Sociedad 2013», MINECO (EDU201342979-R). 
Soler, P, Novella, A. M. y Planas, A. (2014). Les estructures de participació juvenil a Catalunya d'ençà de la transició democràtica. Educació i Història. Revista d'Història de l'Educació, 25 (gener-juny, 2015), 211-237.

Speed, S. (2006). Entre la antropología y los derechos humanos. Hacia una investigación activista y comprometida críticamente. Alteridades, 16(31), 73-85.

Spillane, J.P. (2006). Distributed Leadership. London, U.K.: Jossey-Bass.

Spindler G. \& Spindler, L. (1987). Interpretative Ethnography of Education: At home and abroad. Hillsdale, NJ: Lawrence Erlbaum.

Spradley, J. \& McCurdy, W. (1972). The cultural experience: ethnography in complex society. Chicago: Sciences Research Associates.

Stocking, G. W. (1993). La magia del etnógrafo. El trabajo de campo en la Antropología británica desde Tylor a Malinowski. En H. M Velasco, F. J. García, F.J. y A. Díaz de Rada (eds.). Lecturas de antropología para educadores: el ámbito de la antropología de la educación y de la etnografía escolar. Madrid: Trotta, pp. 248-258.

Subirats, J. (2005). Democracia, participación y transformación social. Polis, 12.

Susinos, T. (2012). Presentación. Las posibilidades de la voz del alumnado para el cambio y la mejora educativa. Revista de Educación, 359, 16-23.

Susinos, T. y Ceballos, N. (2012). Voz del alumnado y presencia participativa en la vida escolar. Apuntes para una cartografía de la voz del alumnado en la mejora educativa. Revista de Educación, 359, 24-44.

\section{$\mathbf{T}$}

Taylor, S. J. y Bogdan, R. (1987). Introducción a los métodos cualitativos de investigación. Buenos Aires, Argentina: Paidós. 
Bibliografía

Terriquez, V. (2015). Training Young Activists. Grassroots Organizing and Youths' Civic and Political Trajectories. Sociological perpectives, 58 (2), 223242.

Tesch, R. (1990). Qualitative Research: Analysis Types and Software tools. New york: Falmer Press.

Thomas, J. (1993). Doing critical ethnography. Newbury Park, California: Sage.

Thomas, R. J. \& McFarland, D. A. (2010). Joining young, voting young the effects of youth voluntary associations on early adult voting. Circle working paper. Tufts University, USA.

Thompson, P. (1978). The voice of the past: Oral History (2nd ed.). Oxford, U.K.: University Press.

Timperley, H. (2005). Distributed leadership: developing theory from practice. Journal of Curriculum Studies, 37(4), 395-420.

Tocqueville, A. (1984). La democracia en América, I y II. Madrid, España: Sarpe.

Tönnies, F. (1979). Comunidad y asociación. Barcelona, España: Península.

Tonucci, F. (1997). La ciudad de los niños. Madrid, España: Fundación Germán Sánchez Ruipérez.

Torrente, D. (1997). La sociedad policial: Poder, trabajo y cultura en una organización local de Policía. Madrid, España: Centro de Investigaciones Sociológicas.

Torres, J. (1988). La investigación etnográfica y la reconstrucción crítica en educación. En J. Goetz y M. D. Lecompte, Etnografía y diseño cualitativo en investigación educativa. (pp. 11-23). Madrid, España: Morata.

Traver, J. A. (2007). Una estrella dansaire. (Proyecto docente inédito). Universitat Jaume I, Castellón, España. 
-- (2009). Igualtat i diferència en educació. El difícil equilibri de la inclusió. AAVV. Escola inclusiva. Una escola per a saber $i$ viure sense exclusions. Valencia: Ajuntament de Cullera, pp. 77-93.

Traver, J.A.; Aguirre, A. y Moliner, L. (en prensa). Fent grup. Solidaritat i cooperació com a base. En J.A. Traver, T. Segarra, M. Lozano y E. Trilles (Eds), Missions Interculturals. Participació comunitària $i$ nomadisme cultural a Vilanova d'Alcolea i Sant Mateu. Castelló: Publicacions de la Universitat Jaume I, pp.67-92.

Traver, J. y Rodríguez, M. (2011): Los cuadernos de aprendizaje en grupo. Una herramienta para favorecer el aprendizaje cooperativo. Valencia: Novadors, LaXara Edicions.

Traver, J. A, Sales, A. y Moliner, O. (2010). Ampliando el territorio: algunas claves sobre la participación de la comunidad educativa. Revista iberoamericana sobre Calidad, Eficacia y Cambio en Educación, 8 (3), 97-119.

Trilla, J. (1988). Animación sociocultural, educación y educación no formal. Educar (13), pp.17-42. Barcelona: Universitat Autònoma de Barcelona.

-- (1992). La educación no formal: definición, conceptos básicos y ámbitos de aplicación. En J. Sarramona (ed.). La educación no formal. Barcelona, España: CEAC.

-- (1993/1996a). La educación fuera de la escuela: Ámbitos no formales y educación social. Barcelona, España: Ariel.

-- (1996b). L' Aire de Familia de la pedagagogia social. Temps d'educació, 15, 39-57.

-- (Coord.). (1997). Animación Sociocultural: Teorías, programas y ámbitos. Barcelona, España: Ariel.

Turner, J. C. (1990). Redescubrir el grupo social. Una teoría de la categorización del Yo. Madrid: Morata. 


\section{$\mathbf{U}$}

Úcar, X. (1992). La animación sociocultural. Barcelona, España: CEAC.

-- (1996). Los estudios de educación social y la animación sociocultural. Claves de Educación Social, 2, 18-29.

-- (2001). Actualidad de la profesión de educador social. Letras de Deusto, 31(91), 69-80.

-- (2008). Factores clave de la participación en los espacios públicos. Animador Sociocultural, Revista iberoamericana, 2(1).

-- (2013). Exploring different perspectives of Social Pedagogy: towards a complex and integrated approach. Education Policy Analysis Archives, 21(36).

Úcar, X. y Llena, A. (Coords.). (2006). Miradas y diálogos en torno a la acción comunitaria. Barcelona, España: GRAÓ.

\section{V}

Van Maanen, J. (Ed.). (1998). Qualitative studies of organizations. Thousand Oaks, California: Sage

Vázquez, C. (2011). La participación ciudadana juvenil como un recurso externo al Gobierno. Revista latinoamericana de Ciencias Sociales, Niñez y Juventud, 9(1), 45-59.

Vega-Centeno, I. (1994). Amor y sexualidad en tiempos del SID A. Las jóvenes de Lima metropolitana. Urna, Perú: Ministerio de salud.

Velasco, H. y Díaz de Rada, A. (2009). La lógica de la investigación etnográfica: Un modelo de trabajo para etnógrafos de la escuela. Madrid, España: Editorial Trotta.

Viejo, R., Martí-Costa, M., Parés, M., Resende, P. y Vilaregut, R. (2009). La participación ciudadana en la esfera pública: enfoques teórico-noramtivos 
y modelos de democracia. En Parés (Eds.). Participación y calidad democrática: evaluando las nuevas formas de democracia participativa. (pp. 29-54). Barcelona, España: Ariel.

Villasante, T. R. (1988). Movimientos populares y conciencia social. En R. Reyes (Eds.) Terminología científico-social. Aproximación crítica. Barcelona, España: Anthropos.

-- (1998). Cuatro redes para mejor vivir, vols. I y II. Buenos Aires: Lumen.

Villen, C. (2008). Historias de vida: una herramienta para el empoderamiento. Documentos de Trabajo Social. No 43-44. pp. 87-97.

Volante, P. (2008). Influencia del liderazgo instruccional en resultados de aprendizaje. En O. Maureira, (Ed.), Perspectivas de gestión para la innovación y el cambio educativo (185-214). Santiago, Chile: Ediciones Universidad Católica Silva Henríquez.

Vygotsky, L. (1986). Pensamiento y lenguaje. Buenos Aires, Argentina: La Pléyade.

-- (1988). El desarrollo de los procesos psicológicos superiores. México: Grijalbo.

\section{W}

Wacquant, L. (2005). Pointers on Bourdieu and Democratic Politics. En L. Wacquant (ed.). Pierre Bourdieu and Democratic Politics, Polity Press, pp.1028.

Walker \& Saito (2011). Youth Are Here: Promoting Youth Spaces through Community Mapping. Afterschool Matters (14), 30-39.

Wallerstein, N. (1992). Powerlessness, empowerment and health: Implications for health promotion programs. American Journal of Health Promotion, 6(3), 197205. 
Bibliografía

Walmsley, J. (2004). Involving users with learning difficulties in Health improvement: lessons from inclusive learning disability research. Nursing Inquiry. 11, 54-64.

Warren, M. E. (2001). Democracy and association. Princeton, New Jersey: Princeton University Press.

Watkins, P. (1989). Leadership, power and symbols in Educational Administration. En J. Smith (Ed.), Critical perspectives on educational leadership. London, U.K.: The Falmer Press.

Wax, R.H. (1971). Doing Fieldwork: warnings and advice. Chicago: University of Chicago Press.

Weaver, A. \& Atkinson, P. (1994). Microcomputing and Qualitative Data Analysis. Aldershot, Hants: Avebury.

Weber, E. (1969). Elproblema del tiempo libre. Madrid, España: Editora Nacional.

Wenger, E. (1999). Communities of Practice: Learning, Meaning, and Identity. Cambridge, U.K.: Cambridge University Press.

- (2001). Comunidades de práctica: Aprendizaje, significado e identidad. Madrid, España: Paidós.

Willis, P. (1998). Cultura viva: Una recerca sobre les activitats culturals dels joves. Barcelona, España: Diputació de Barcelona.

Wolcott, H. (2000). The art of fieldwork. Walnut Creek: AltaMira Press.

Woods, P. (1987). La Escuela por Dentro: La Etnografía en la Investigación Educativa. Buenos Aires, Argentina: Editorial Paidós.

\section{Z}

Zapata, O. (2005). La aventura del pensamiento crítico. Herramientas para hacer una tesis e 
Bibliografía

investigaciones socioeducativas. México: Pax México.

Zimmerman, B.J. (2000). Self-efficacy: An essential motive to learn. Contemporary Educational Psychology (25), 82-91. 

ANEXOS 

Anexo 1. Cronograma de la investigación

\begin{tabular}{|c|c|c|c|c|}
\hline AÑO & MESES & FASES & ACCIONES & ACTIVIDAD/OBJETIVOS \\
\hline 2011 & & $\begin{array}{l}\text { Acercamiento } \\
\text { al caso }\end{array}$ & $\begin{array}{l}\text { Inicio en la } \\
\text { temática } \\
\text { juvenil }\end{array}$ & $\begin{array}{l}\text { Trabajo en proyectos juveniles } \\
\text { SASC } \\
\text { Primeras noticias: 1er contacto } \\
\text { Víctor } \\
\text { (Miembro de FVCJ, Escola de } \\
\text { Cases, EAV Maranya) }\end{array}$ \\
\hline 2012 & & & $\begin{array}{l}\text { Acercamiento } \\
\text { al caso }\end{array}$ & $\begin{array}{l}\text { Presentación TFM } \\
\text { Acercamiento al caso: } \\
\text { Formación y claustro Escola de } \\
\text { Cases } \\
\text { Verkami: Una casa per a Maranya }\end{array}$ \\
\hline 2013 & & Planificación & $\begin{array}{l}\text { Revisión } \\
\text { bibliográfica }\end{array}$ & $\begin{array}{l}\text { Revisión bibliográfica } \\
\text { Estancia de investigación } \\
\text { Universidad de Valencia } \rightarrow \text { abordar } \\
\text { la Pedagogía social. } \\
\text { Diseño de la investigación } \\
\text { Formación Escola de Cases } \\
\text { (claustro) } \\
\text { 1er contacto Virginia (Miembro de } \\
\text { FVCJ, Escola de Cases, EAV } \\
\text { Maranya) }\end{array}$ \\
\hline 2014 & $\begin{array}{l}\text { Enero } \\
\text { Febrero } \\
\text { Marzo }\end{array}$ & & $\begin{array}{l}\text { Revisión } \\
\text { diseño }\end{array}$ & $\begin{array}{l}\text { Etnografía: } \\
\text {-Fuentes externas personales } \\
\text {-Formación } \\
\text {-Congresos } \\
\text {-Bibliografía }\end{array}$ \\
\hline 2014 & Abril & $\begin{array}{l}\text { Trabajo de } \\
\text { campo }\end{array}$ & $\begin{array}{l}\text { Entrada } \\
\text { campo }\end{array}$ & $\begin{array}{l}\text { Negociar entrada al campo: } \\
1^{\circ} \text { Víctor y Virginia } \\
2^{\text {o }} \text { Plenario CJ } \\
3^{\text {o }} \text { Video público en blog Maranya }\end{array}$ \\
\hline 2014 & $\begin{array}{l}\text { Mayo } \\
\text { Junio } \\
\text { Julio }\end{array}$ & & $\begin{array}{l}\text { Participación } \\
\text { activa }\end{array}$ & $\begin{array}{l}\text { Sesiones EAV } \\
\text { Entrada en primeros grupos de } \\
\text { Whats App } \\
\text { Cenas } \\
\text { Fil historic } \\
\text { Perdutspel món } \\
\text { Formación } \\
\text { Limpieza y obra local }\end{array}$ \\
\hline
\end{tabular}




\begin{tabular}{|c|c|c|c|}
\hline 2014 & Agosto & $\begin{array}{l}\text { Trabajo } \\
\text { protocolario }\end{array}$ & $\begin{array}{l}\text { Elaboración de protocolos: grupo } \\
\text { asesor y entrevistas } \\
\text { Planificación : } \\
\text { - Componentes del grupo y primer } \\
\text { contacto } \\
\text { - Envío primera convocatoria } \\
\text { Grupo Asesor } \\
\text { - Preparación de la primera sesión } \\
\text { Grupo Asesor }\end{array}$ \\
\hline 2014 & Septiembre & Activismo & $\begin{array}{l}\text { Primera reunión grupo asesor: } \\
\text { - presentación investigación } \\
\text { - repaso protocolos } \\
\text { - modificación protocolos } \\
\text { - planificación próximas actuaciones } \\
\text { Formación Escola de Cases } \\
\text { Entrevistas y mapa de relaciones }\end{array}$ \\
\hline 2014 & $\begin{array}{l}\text { Octubre } \\
\text { Noviembre }\end{array}$ & $\begin{array}{l}\text { Activismo } \\
\text { virtual }\end{array}$ & $\begin{array}{l}\text { Transcripciones y primer análisis } \\
\text { Devoluciones } \\
\text { Revisiones bibliográficas } \\
\text { Estancia CES-Coimbra } \rightarrow \\
\text { Metodología: etnografía, historias de } \\
\text { vida y participación social. }\end{array}$ \\
\hline 2014 & Diciembre & Activismo & $\begin{array}{l}\text { Entrevistas y mapa de relaciones } \\
\text { Transcripciones y primer análisis } \\
\text { Devoluciones } \\
\text { Estancia CES-Coimbra } \rightarrow \\
\text { Metodología: etnografía, historias de } \\
\text { vida y participación social. }\end{array}$ \\
\hline 2015 & Enero & $\begin{array}{l}\text { Activismo } \\
\text { virtual }\end{array}$ & $\begin{array}{l}\text { Transcripciones y primer análisis } \\
\text { Devoluciones } \\
\text { Revisiones bibliográficas } \\
\text { Estancia CES-Coimbra } \rightarrow \\
\text { Metodología: etnografía, historias de } \\
\text { vida y participación social. }\end{array}$ \\
\hline 2015 & $\begin{array}{l}\text { Febrero } \\
\text { Marzo } \\
\text { Abril }\end{array}$ & Activismo & $\begin{array}{l}\text { Revisión del diseño de investigación } \\
\text { Actividades CdJ } \\
\text { Entrevistas y mapa de relaciones } \\
\text { Transcripciones y primer análisis } \\
\text { Devoluciones }\end{array}$ \\
\hline
\end{tabular}




\begin{tabular}{|c|c|c|c|c|}
\hline 2015 & $\begin{array}{l}\text { Mayo } \\
\text { Junio } \\
\text { Julio }\end{array}$ & & Activismo & $\begin{array}{l}\text { Actividades Casa } \\
\text { Revisión y organización datos } \\
\text { Planificación del análisis } \\
\text { Presentación y valoración/discusión } \\
\text { proyecto Maranya + TDR: } \\
\text { seminario, grupo UAM, Congreso } \\
\text { Etnografía. } \\
\text { Estancia en UAM } \rightarrow \text { metodología } \\
\text { etnográfica, jóvenes e infancia } \\
\text { contemporánea. }\end{array}$ \\
\hline 2015 & Agosto & & $\begin{array}{l}\text { Trabajo } \\
\text { protocolario }\end{array}$ & $\begin{array}{l}\text { Organizar información } \\
\text { Análisis de la información } \\
\text { construida } \\
\text { Planificación sesiones Grupo Asesor } \\
\text { Enviar convocatoria } \\
\text { Preparación de la segunda reunión } \\
\text { del Grupo Asesor }\end{array}$ \\
\hline 2015 & Septiembre & & Activismo & $\begin{array}{l}\text { Reunión Grupo Asesor } \\
\text { Contrastar información } \\
\text { Actividades en la Casa }\end{array}$ \\
\hline 2015 & $\begin{array}{l}\text { Octubre } \\
\text { Noviembre } \\
\text { Diciembre }\end{array}$ & & Activismo & $\begin{array}{l}\text { Contrastar información } \\
\text { Actividades en la Casa }\end{array}$ \\
\hline 2016 & $\begin{array}{l}\text { Enero } \\
\text { Febrero } \\
\text { Marzo } \\
\text { Abril } \\
\text { Mayo } \\
\text { Junio }\end{array}$ & & $\begin{array}{l}\text { Activismo } \\
\text { Trabajo de } \\
\text { investigación }\end{array}$ & $\begin{array}{l}\text { Análisis de datos } \\
\text { Recuperación de información y } \\
\text { contraste } \\
\text { Actividades en la Casa } \\
\text { Redacción de la historia }\end{array}$ \\
\hline 2016 & $\begin{array}{l}\text { Julio } \\
\text { Agosto } \\
\text { Septiembre }\end{array}$ & $\begin{array}{l}\text { Reflexión } \\
\text { Devolución } \\
\text { Final }\end{array}$ & $\begin{array}{l}\text { Trabajo de } \\
\text { investigación } \\
\text { Redacción } \\
\text { informe final }\end{array}$ & $\begin{array}{l}\text { Resultados } \\
\text { Conclusiones } \\
\text { Discusión } \\
\text { Devolución de la historia }\end{array}$ \\
\hline 2016 & $\begin{array}{l}\text { Octubre } \\
\text { Noviembre } \\
\text { Diciembre }\end{array}$ & $\begin{array}{l}\text { Protocolo } \\
\text { programa de } \\
\text { doctorado }\end{array}$ & $\begin{array}{lr}\text { Depósito, } & \\
\text { evaluación } & \text { y } \\
\text { envío } & \text { al } \\
\text { tribunal } & \end{array}$ & Evaluación y defensa de tesis \\
\hline
\end{tabular}


Anexo 2. Email presentación.

\section{Estudi investigació a La Maranya}

Hola maranyers i maranyeres ;)

Hem presente per a tota persona amb la que no haja coincidit encara. Sóc Arecia treballe a la Universitat Jaume I al Departament d'Educació i tinc el plaer de poder fer la meua tesi doctoral amb totes vosaltres tal com vam concretar fa un parell de setmanes al plenari de la Casa. Estic preparada per a començar a fer carmi, però sobretot estic molt illusionada amb la possibilitat que m'esteu oferint per aprendre tant junt a vosaltres.

Per a començar necessite arreplegar informació de cada grup i comissió. Concretament la planificació de treball que teniu, reunions, activitats,... Les generals de Maranya les tinc del blog. Per això us escric grup per grup actiu en Maranya.

Per un altra banda, necessitem fer una sessioneta per a parlar de l'estudi i que hem feu totes les preguntes que necessiteu. Podem parlar-ho dilluns al plenari. A més us adjunte un link amb la presentació de l'estudi, ja me dieu que us pareix ;) Açí està presentació estudi Maranya

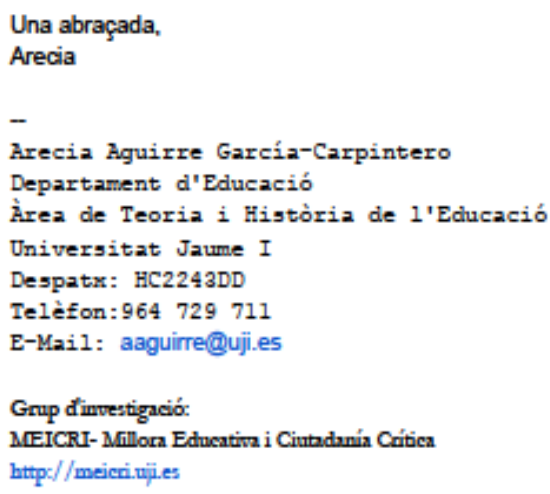


Anexo 3. Email del grupo asesor.

\section{Presentació i primera reunió grup assessor Estudi CJ Maranya}

Arecia Aguirre García Carpintero <aaguirre@edu.uji.es>

28 d'agost de 2014, 11:51

Bon dia companys i companyes,

Ja estem de tornada, pareix que la rutina comença a aparéixer després de dies de vacances en què espere que hàgeu pogut disfrutar i descansar. D'aquesta forma anem a retomar tot el procés d'investigació que estem portant a terme a la nostra Maranya. Abans de vacances vaig parlar-vos del grup assessor que voliem formar i després de posar-lo en comú amb vosaltres i tindre el vostre vist-i-plau anem a ficar-nos en marxa.

En aquest missatge vos envie tota la documentació relacionada amb el grup i la investigació que necessitem en aquesta etapa. Tenim:

- Enllaç al video presentació del estudi (en otro email independiente)

- Carta đinvitació al grup

- Consentiment informat

- Protocol del grup assessor

- Protocol de entrevistes

Com podreu llegir al protocol del grup assessor, hem de fer una reunió conjunta molt prompte (setmana que ve) per a treballar el següent pas de la investigació, les entrevistes que ens donaran els relats de vida maranyers. Vaig a proposar-vos tres dades i heu de dir-me quin dia i hora teniu disponibilitat. Vos demane flexibilitat perque hem de estar tots i totes. Aquest enllaç vos envia a doodle a on heu de clicar quins dies i hores teniu disponibilitat. http://doodle.com/y2c2evmtym28rirm El diumenge vos envie la opció guanyadora.

Recordeu, a la reunió hem d'anar amb els protocols llegits i el consentiment informat signat.

Ens veiem prompte!! Salut i molta força,

Arecia

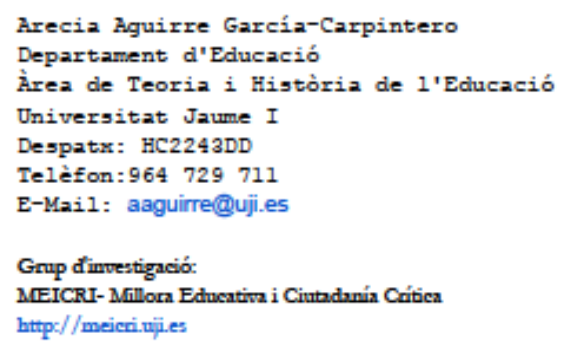

4 fitxers adjunts

7 Consentimientoinformado.pdf

$166 \mathrm{~K}$

Protocoloentrevistas-2.pdf

$202 \mathrm{~K}$

Protocologrupoasesor.pdf

$250 \mathrm{~K}$ 
Anexo 4. Carta participación.

Castelló de la Plana, 25 de Agost, 2014

Benvolgut/da company/a,

La doctoranda i professora de la Universitat Jaume I de Castelló, Arecia Aguirre Garcia-Carpintero, té el grat de proposar-li a participar a la investigació corresponent a la seua tesi doctoral-Voces juveniles en tiempos de participación y transformación social. Un estudio etnográfico sobre la cultura de participación juvenil- que es du a terme en la Casa de Joventut La Maranya de Benicàssim.

L'objectiu d'aquesta carta es fer-li partícep de la construcció i posada en marxa d'un grup assessor integrat per persones relacionades directament amb la participació juvenil i les Cases de Joventut, que tindràn la funció d'assessorar al grup d'investigació en les diferents etapes de l'estudi.

L'establiment del grup assessor condiciona la temporalització i organització de l'estudi ja que les decisions relatives al disseny, aplicació d'instruments, anàlisi de dades, interpretació i formulació de conclusions es realitza de forma colaborativa amb totes les persones participants en el grup assessor. L'única condició es que vosté puga assistir a les reunions (màxim de tres reunions entre setembre de 2014 i setembre de 2016) de manera presencial o en cas que siga impossible, de forma virtual, i que la investigadora puga contactar amb vosté, si fóra necessari, al llarg de la investigació.

Des de ja moltíssimes gràcies pel seu interès i esperem que aquesta participació siga un punt de partida per a l'enriquement de coneixement en participació juvenil en pràctiques reals.

\section{Atentament,}

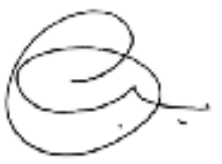


Anexo 5. Consentimiento informado

\section{CONSENTIMENT INFORMAT}

(Sol-licitud de consentiment segons capítol II del REIAL DECRET 1720/2007, de 21 de desembre, pel qual s'aprova el Reglament de desplegament de la Llei Orgànica $15 / 1999$, de 13 de desembre, de protecció de dades de caràcter personal)

Arecia Aguirre García-Carpintero, com doctoranda de la tesi doctoral Voces juveniles en tiempos de participación y transformación social. Un estudio etnográfico sobre la cultura de participación juvenil, redacte aquest document de Consentiment Informat amb l'intenció de deixar constancia per escrit de les característiques del projecte d'investigació que estem realitzant. D'aquesta forma, estem convidant-la a participar d'aquest estudi. Abans de decidir-se, és important que comprenga per què estem fent aquest i què implica. Per favor, agafe's el temps que necessite per a llegir la informació acuradament i comente-la amb persones de la seua confiança o amb qui vosté desitge. Demane'ns més informació si considera que alguna cosa encara no queda clara o, simplement si vol preguntar-nos alguna cosa més. Agafe's temps en decidir si desitja participar o no. Gràcies per llegir açò.

Mitjantçant aquest document solicite la seua col-laboració i consentiment en aquest estudi així com la seua autorització per a recollir i analitzar les dades que es donaràn durant el procès. Amb aquest fi li expose la següent informació:

$>$ Aquest estudi forma part d'un projecte d'investigació autofinanciat per la doctoranda i relacionat amb les seues tasques d'ajudant dins de l'àrea de Teoria i Història de l'Educació del Departament d'Educació de la Universitat Jaume I. Està previst que la duració de la recogida de dades en l'estudi siga aproximadament d'un parell d'anys, fins l'any 2016.

> Aquest document es sitúa dins de la nostra ètica d'investigació com a indispensable ferramenta d'informació als participants de la investigació. El nostre estudi parla d'inclusió de la població, de fer partíceps a la ciutadania en la construcció de coneixement i d'escoltar la veu de tots els grups socials per a trencar amb la marginació de colectius, com el joves. Per això:

- El posicionament ètic de la investigació ha sigut clau en la decisió de seleccionar un métode d'investigació com la etnografia per a portar a terme aquest estudi. En la seua necessitat de fer-lo mitjançant les veus amb els relats de vida per a construir discurs grupal, de possibilitar que les 
participants es feren ames de la seua informació en el consentiment informat $i$ en tota acció de devolució d'informació i, en la decisió de que la investigadora forme part del grup de referència, de la Casa de Joventut La Maranya.

- De forma concreta, la devolució de la informació i aquest document de consentiment informat es una estratègia clau d'empoderament de la informació que es treballa i fonamentalment atend a valors de justícia social. Per això, en tot moment la informació es de la persona que la dóna i d'aquesta forma ella es l'única persona que pot decidir que es prescindisca de la informació ja que li pertany.

- En relació amb això, encara que la llei ampara que nomès els menors de 14 anys hauràn de signar conjuntament amb el seu tutor legal i no els majors de aquesta edat, en aquesta investigació i debut al seu posicionament ètic, serà necessari que tots els menors de 18 anys donen el consentiment amb el vist i plau dels seus tutors legals.

$>$ El projecte es portarà a terme en un context particular dins de la Casa de Joventut La Maranya, elegida pel caliu del seu projecte educatiu, per ser un espai de referència i adoptar la participació com a eix fonamental de treball. En ell formaràn part: l'equip de tesi doctoral (directors: Joan Traver Martí i Lidón Moliner Miravet; investigadora: Arecia Aguirre García-Carpintero), joves que formen part i/o han format part de La Maranya, animadors voluntaris de la Casa de Joventut i tota aquella persona de la Xarxa Local amb relació directa o indirecta amb La Maranya que puga ajudar-nos en la construcció de l'estudi.

És vosté qui ha de decidir si participa o no. Rebutjar prendre part no li suposarà la pèrdua de qualsevol benefici relacionat amb l'estudi que puga tindre la Casa de Joventut La Maranya. Si vosté decideix participar-hi, vosté conservarà una cópia d' aquest full de consentiment informat. Encara que vosté signe el prendre part, en qualsevol moment pot decidir deixar de participar-hi, sense que se li puguen exigir explicacions i sense cap penalització ni pèrdua de beneficis.

> L'objectiu general de l'estudi es conèixer y analitzar cóm es conforma y quin significat se li dóna a la cultura de participació juvenil dins de la Casa de Joventut La Maranya i cóm aquest procès cultural genera espais educatius en el grup de joves. 
> La participació que se li sol-licita per a la investigació no es més que dur a terme el dia a dia a La Maranya. Per altra part i de forma puntual, es faràn sessions de treball amb dinàmiques de participació tambè hi haurà entrevistes, grups de discussió, sessions de grup assessor,... L'informació s'arreplegarà mitjantçant entrevistes, diari de camp, observacions, videos, fotografies, documents de treball,...

$>$ Vostè serà informat de qualsevol canvi en l'estudi que puga afectar-li directament, siga avantatge o desavantatge, benefici o incomoditat previsible. En aquest sentit, tot i que no s'esperen beneficis inmediats derivats d'aquesta investigació, pensem que aquest treball afavoreix a llarg termini processos de concientització, construcció de coneixement, impuls cap a una societat més participativa, crítica i lliure.

- Si es donés el cas, i la investigació haguera de aturar-se, es donaran i explicaran les raons a totes les persones participants.

- Si es donés el cas, i tinguera alguna queixa en referència a la investigació no dubte en posar-se en contacte amb la investigadora o amb els seus directors en les següents direccions electróniques (aaguirre@uji.es; jtraver@uji.es; mmoliner@uji.es)

> Tota la informació que s'arreplegue sobre vosté durant el curs d'aquesta investigació serà mantinguda estrictament confidencial. Qualsevol informació sobre vosté que es diponga no portarà ni el seu nom ni la seua adreça, i es presentarà de manera que ningú puga reconèixer'l a partir d'ella. Per a fer públics els informes i publicacions corresponents a la difusió de la investigació es demana el consentiment previ a la persona participant. Les seues dades son personals i estàn protegides per la vigent Llei Orgànica de Protecció de Dades 15/1999. Aquestes podràn ser rectificades i/o cancelades quan vosté ho desitge. L'informe final es farà pùblic en la defensa de la tesi doctoral aproximadament en 2016.

Per a finalitzar, l'equip d'investigació vol agraïr la seua col·laboració en aquest projecte, no no més per la seua importància com a testimoni sino tambè per la confiança que ens deposita.

Amb la firma d'aquest document, la persona col·laboradora es compromet a participar activa i voluntariament en aquesta investigació. D'aquesta forma es 
procedeix al signament del consentiment informat:

Jo,

declare estar informat $\mathrm{i}$ autoritze als membres de l'equip d'investigació del projecte, a la recopilació, custodia i tractament de les dades necesaries per al desemvolupament de l'estudi. D'aquesta forma:

- Acepte participar en aquesta investigació.

- Desitge que, en aquest treball acadèmic i en la seua posterior publicació, s'utilitze un pseudónim per a referir-se a la meua persona amb el nom . (S'entendrà que si no escrius cap pseudónim, vols aparèixer amb el teu nom).
A
a ...... de de $20 \ldots$.

Participant a l'investigació Tutor/a legal del participal Investigador Principal (en cas necessari)

Fdo: Fdo. Fdo:

DNI $n^{\circ}$ DNI $n^{\circ}$ DNI $n^{\circ}$ : 
Anexo 6. Protocolo grupo asesor.

\title{
Tesis Doctoral:
}

\author{
Voces juveniles en tiempos de participación $y$ \\ transformación social. Un estudio etnográfico \\ sobre la cultura de participación juvenil
}

Doctoranda:

Arecia Aguirre García-Carpintero

Directores:

Joan Traver Martí y Lidón Moliner Miravet

En el siguiente documento puede encontrar un pequeño resumen de la investigación, con objetivos, preguntas, fases de la investigación, actividades de la primera fase y el papel del grupo asesor en el estudio.

A lo largo de esta investigación queremos recabar información sobre los valores educativos que tiene la participación juvenil en una casa de juventud, cómo se conforma su propia cultura de participación y qué factores educativos influyen en la misma. Nos interesa conocer las experiencias de jóvenes que han vivido estos procesos, por lo que nos centramos en jóvenes de la CJ Maranya y planteamos el diseño de instrumentos que nos permitan recoger sus voces, opiniones y valoraciones desde un enfoque de investigación basado en la inclusión, la participación ciudadana, la construcción conjunta de conocimiento, la pluralidad de voces,....

Para conseguirlo nos centramos en el método de Estudio etnográfico que según Tamayo (2001) " constituye la descripción y análisis de un campo social específico, una escena cultural determinada (una localidad, un barrio, una fábrica, una práctica social, una institución u otro tipo de campo, sin perjuicio de la aplicación de otros métodos y técnicas de recolección,síntesis y análisis. La meta principal del método etnográfico consiste en captar el punto de vista, el sentido, las motivaciones, intenciones y expectativas que los actores otorgan a sus propias acciones sociales, proyectos personales o colectivos, y al entorno sociocultural que los rodea « . Nosotras concretamente nos centramos en: 
"Conocer y analizar, siendo parte de la vida de Maranya, cómo se conforma y qué significado se le da a la cultura de participación juvenil en la Casa de Joventut (CJ) La Maranya y cómo ese proceso cultural genera espacios de aprendizaje en el grupo de jóvenes" .

A continuación podemos ver un listado de objetivos más específicos que estructuran el estudio y que han hecho que nos planteemos diferentes cuestiones en él:

- Indagar en la identidad del grupo, en las percepciones y, en su incidencia en el contexto.

- Conocer cómo se definen los espacios, las relaciones, las posiciones del grupo.

- Analizar el papel de la educación en el tiempo libre y la animación sociocultural en el proceso de aprendizaje de la persona.

- Indagar sobre las nuevas formas de asociacionismo juvenil y cómo se fomenta este en función de la participación.

- Analizar cuáles son los valores sociales, elementos educativos y actitudes democráticas que aparecen en el proceso y conforman el tipo de participación. etnográfica.

- Estudiar el rol del investigador en una investigación

Dentro del estudio etnográfico nosotras dividimos la investigación principalmente en dos etapas diferenciadas:

1. Acercamiento y reflexión sobre la historia de vida de la Maranya

2. Análisis de los significados sobre participación (se construye a partir de la primera etapa)

Actualmente estamos llevando a cabo la primera fase del estudio por ello, exponemos a continuación cuales son las principales actividades que se realizarán a lo largo de esta etapa:

$\star$ Contacto e inmersión en la Casa de Juventud por parte de la investigadora

$\star$ Integración de la investigadora en grupos estables 
$\star$ Configuración del grupo asesor

$\star$ Elaboración de entrevistas: ¿Quién es Maranya?

$\star$ Análisis / configuración de los relatos

$\star$ Reconstrucción grupal de los relatos

$\star$ Análisis de los datos

$\star$ Diseño de la segunda fase de investigación: Etnografía participativa y visual.

\section{EL GRUPO ASESOR EN EL ESTUDIO ETNOGRÁFICO $\mathrm{DE}$ \\ LA CASA DE JOVENTUT LA MARANYA}

Usted va a formar parte de esta investigación como participante de un grupo asesor. Lea a continuación para saber por qué es imprescindible este grupo, qué es, cómo participa y cómo vamos a organizar las sesiones:

\section{- ¿Por qué la participación de un grupo asesor?}

De forma directa nuestra ética como investigadores hace que el enfoque desde el cual partimos para realizar investigación hable de inclusión, participación ciudadana, construcción conjunta de conocimiento, pluralidad de voces,.... Por ello, debemos buscar herramientas que favorezcan dicho enfoque con la finalidad de enriquecer y construir discurso grupal convirtiéndolas en estrategias clave de empoderamiento de la información que se trabaja, atendiendo a valores de justicia social.

\section{- ¿Qué es un grupo asesor?}

Está formado por un equipo de personas relacionadas con la temática o el caso a abordar en una investigación. En nuestro estudio, personas vinculadas con la participación juvenil, concretamente dentro de la Red de Casas de Juventud de la Comunidad Valenciana.

El grupo asesor nos tiene que brindar la oportunidad de contrastar la información que allí se exponga y así acercarla a la muestra. Queremos saber desde el punto de vista de la institución cómo ven todo lo que se 
aborda en la investigación y que en función de sus propios intereses se debatan las propuestas.

\section{- ¿Cómo participa en una investigación el grupo asesor?}

Tiene la función de asesorar de forma colaborativa al equipo de investigación en las diferentes fases del estudio tomando decisiones en lo relacionado con el diseño y la aplicación de instrumentos, análisis de datos, interpretación de los mismos y formulación de conclusiones a lo largo del estudio (Pasillera, 2013).

Debemos evitar que el grupo asesor se convierta en una réplica de los argumentos que la investigadora da, queremos debate, reflexión y nuevas propuestas procedentes de las propias participantes.

\section{- ¿Quienes forman parte del grupo en nuestra investigación?}

Principalmente existen seis núcleos formados por las siguientes personas:

1. Persona externa a Maranya, vinculada con Federació y Escola de Cases: Julio Huerta

2. Directores de tesis doctoral: Joan Traver, Lidón Moliner

3. Promotores del grupo de animadores voluntarios de la Casa de Juventud: Victor Escoín, Virginia Morales

4. Animadores voluntarios y miembros de la junta directiva: Mireia Beltrán, Noel Tomás, Lledó Ballester

5. Socio y participante activo del grupo de adultos de Maranya: Armand Congost

6. Doctoranda: Arecia Aguirre

\section{- ¿Cómo organizamos las sesiones con el grupo?}

Serán tres las sesiones en la primera fase de la investigación. Cada una tendrá una duración aproximada de una hora, se realizarán en horario de mañana o de tarde en función de la disponibilidad de las participantes y será necesario haberse leído la documentación que la investigadora envíe con anterioridad vía correo electrónico a todos los componentes del grupo:

Primera sesión (primera semana de septiembre): Presentación del grupo, puesta en común de las tareas a realizar, preparación de las entrevistas para abordar los relatos de vida. En concreto cada 
integrante del grupo asesor expondremos nuestro punto de vista sobre la investigación y sobre las preguntas de las entrevistas a realizar, a partir de ello modificaremos y reestructuraremos las entrevistas con lo aportado en el grupo. Además, se seleccionaremos a los informantes clave y trabajaremos todos aquellos aspectos que consideremos necesarios en el momento.

Segunda sesión (diciembre/enero): La investigadora aportará la información recogida por cada una de las informantes clave. Realizaremos la discusión correspondiente a los relatos además de analizar conjuntamente la información y el proceso para poder diseñar el grupo de discusión con los informantes de cada uno de los relatos.

Tercera sesión (febrero): Se pondrá en común la siguiente fase de investigación y se tratarán futuras acciones e implicación de las personas del grupo asesor. 
Anexo 7. Protocolo entrevistas.

\title{
Tesis Doctoral:
}

\author{
Voces juveniles en tiempos de participación $y$ \\ transformación social. Un estudio etnográfico \\ sobre la cultura de participación juvenil \\ Doctoranda: \\ Arecia Aguirre García-Carpintero \\ Directores: \\ Joan Traver Martí y Lidón Moliner Miravet \\ PROTOCOLO DE ENTREVISTAS
}

\section{Introducción:}

¿Por qué dentro de una investigación etnográfica? La investigación etnográfica intenta describir el estilo de vida de una sociedad o de un grupo de personas que viven en sociedad. Conocer su estructura, sus razonamientos, sus creencias,... en definitiva, conocer su cultura, su forma de vida con la participación del grupo a investigar. Por ello, las entrevistas son una de las herramientas más utilizadas, junto con la observación participante, en este tipo de investigación cualitativa. La entrevista ofrece al estudio la oportunidad de enriquecerse del diálogo y del intercambio de conocimiento gracias a la pluralidad de voces que participan en el proceso.

¿Cuál es el objetivo principal de la entrevista?: Conseguir información para poder construir relatos de vida de las personas que integran Maranya y así contextualizar y analizar la Casa de Joventut (CJ) a partir de la información aportada por ellas. Esta etapa dentro de la primera fase no es el fin último de la investigación sino que forma parte del proceso.

¿Y por qué un relato de vida? Porque la persona nos ofrece el 
testimonio subjetivo de lo social de su propia experiencia humana dentro del grupo y el análisis se realiza en primera persona. Además nos ayudará en la construcción de discurso grupal.

¿Qué queremos conocer? Cómo y por qué nace Maranya (M.), qué valores educativos tiene, cómo se participa, por qué están los informantes seleccionados en el proyecto, cómo se enreda $\mathrm{M}$. en el territorio.

¿Cómo lo queremos hacer? Para obtener los relatos de vida sobre Maranya tenemos que realizar una serie de entrevistas individuales a informantes que de forma interna o externa tienen una vinculación con la Casa de Juventud La Maranya. Tras el análisis realizado durante los primeros meses de observación participante en las actividades de M. y tal y como propone la Federació de Cases de Joventut, la estructura de participación principal que rige a este grupo y que fomenta la integración de los diferentes jóvenes en función de su proceso de maduración es la pirámide de participación siguiente:

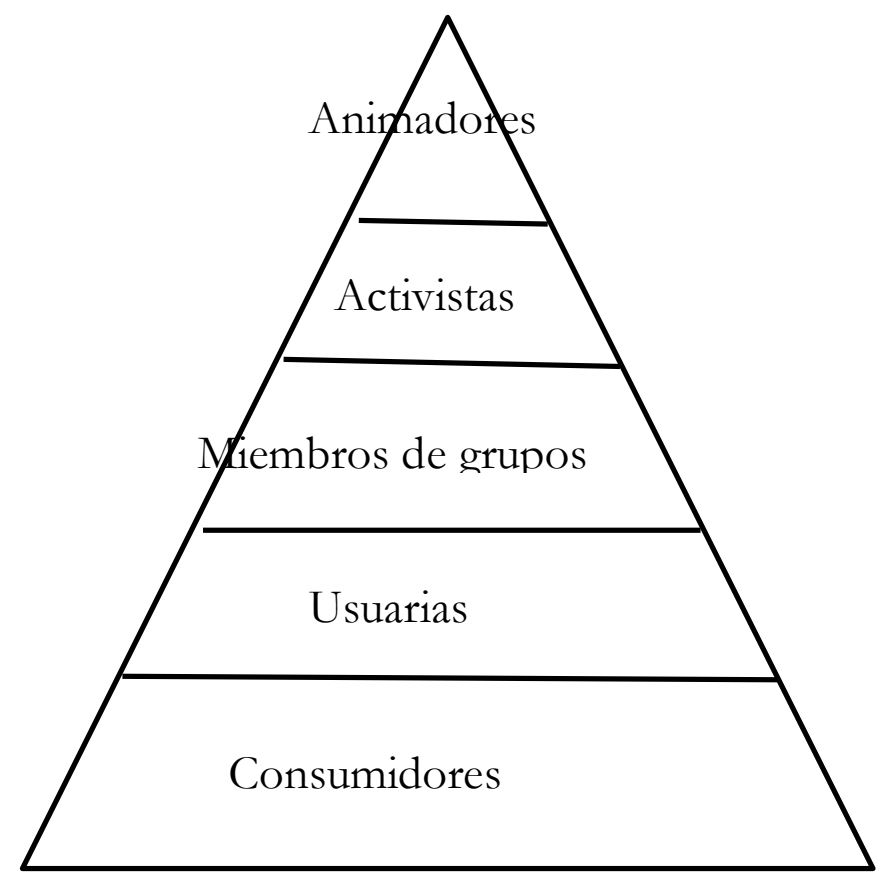

Maranya se estructura de este modo y por ello debemos de basar 
nuestro estudio y la construcción de los relatos de vida en distintas personas que formen parte de cada uno de estos niveles. Justificándonos en ella se seleccionan los cinco grupos que conforman la estructura y además añadiremos dos que nos ofrecerán la visión externa. En total serán 7 los grupos entrevistados, en cada uno habrá un máximo de dos personas a entrevistar. A continuación podemos observar cuáles serán los grupos, por qué se seleccionan y quienes son las personas propuestas como informantes clave.

1. Animadores son los implicados en la dirección y en el proyecto de manera global. Posibles informantes clave: 2

2. Activistas de grupo estable / Junta directiva: comprometidos a dinamizar su grupo y a participar como miembros de la Junta directiva. Posibles informantes clave: 2

3. Miembros de grupos estables: jóvenes y adultos participantes de actividad cotidiana de su colectivo. Posibles informantes clave: 2

4. Usuarios de servicios y cursos que ofrece la Casa de Juventud. Posibles informantes clave: 2

5. Consumidores de actividades masivas organizadas por la casa. Posibles informantes clave: 2

6. Territorio: barrio, administración. Posibles informantes clave: 2

7. Federació de Cases de Joventut: aporta su visión externa y de trabajo en red. Posibles informantes clave: 2

\section{Ex-activistas.}

\section{Grupos políticos de la oposición.}

Todo ello justifica el contexto de participación de Maranya y sólo de este modo podremos obtener la imagen de lo que es la Casa de Juventud para analizar Maranya desde diferentes miradas.

\section{El proceso de entrevista}

Realizaremos entrevistas semiestructuradas/ abiertas que posibilite el conocimiento del territorio y de la CJ a analizar. Es decir, tendremos una pequeña estructura basada en preguntas abiertas de nuestro interés que podrán variar y complementarse con otras a lo largo de la 
entrevista.

El tema principal a tratar es la historia de Maranya y su papel dentro de la CJ y esto se realizará entrevistando a un mínimo de 7 personas y un máximo de 10. El espacio que se utilizará para la entrevista será dentro de la CJ o algún otro lugar cercano al entorno social de la persona entrevistada.

Se consensuará el día y hora de entrevista, al igual que la duración, como mínimo con una semana de antelación.

En ella pasaremos de preguntas más generales y poco a poco se encauzan hacia las específicas.

.De lo general a lo concreto

.De lo impersonal a lo personal

.De lo informativo a lo interpretativo

Finalmente se realizarán entrevistas grupales e individuales.

- Pasos a seguir en el momento de la entrevista:

A lo largo de la entrevista observar si la grabación coarta o influye la respuesta de la persona.

a. Explicar a las entrevistadas el trabajo que se está llevando a cabo. Definir el uso de herramientas para digitalizar la información: grabadora de voz, video.

b. Leer y firmar el consentimiento informado.

c. Describir cómo lo vamos a hacer. Abordaje: entrevista y audiovisual.. Cada informante tendrá que traer una fotografía, lectura, canción $u$ objeto que relacione con Maranya. Esta estrategia se utiliza para romper el hielo y emprender la entrevista.

d. Duración no más de una hora. Mejor hacer dos de una hora que una larga ya que puede repercutir en la cantidad y la calidad de la información aportada. Esto variará en función de la persona 
entrevistada.

e. Hacer resúmenes en el proceso de la entrevista.

f. Abordar las preguntas dentro de un eje:

¿Qué aspectos comunes queremos que tengan los relatos? (cómo nace $M$, cómo identifican a $M$, qué imagen le dan, objetivos de $M$, necesidades de $M$, para qué sirve $M$, cómo se relaciona $M$ )

01.¿Qué objeto, fotografía, canción, lectura,... has traído?, ¿por qué lo relacionas con Maranya? y ¿por qué lo relacionas contigo?

02.¿Qué imagen quieres mostrarme de Maranya?

03.¿Qué es Maranya?, ¿qué significado tiene para tí?, ¿qué te une a Maranya?

04.¿Cómo empezaste a formar parte de la CJ?, ¿Cual es tú papel en Maranya?, ¿Para qué vienes a M?

05. ¿A qué grupo de participación perteneces dentro de Maranya?, ¿identificas a tu grupo dentro de Maranya?, ¿qué haces en M.?, ¿qué responsabilidades tienes?

06. ¿Qué aprendes en Maranya?, ¿Cómo lo has aprendido? Formas concretas

07. ¿Cómo esos aprendizajes los trasladas a la vida?

08.Cuéntame tu historia en Maranya. ¿Cómo nace Maranya y cual es tu experiencia en esa historia? Muy interesante para conocer el proceso de participación.

09.Si tuvieras que mantener a Maranya en tu memoria, ¿con qué recuerdo la mantendrías? ¿Qué recordarás de Maranya dentro de cinco/diez años?, ¿cómo ves a Maranya dentro de 5-10 años?

10. ¿Qué opinas del espacio dónde está ubicado? (privado con ganas de hacerlo público, plaza, interior). Provocar qué pensamos sobre el espacio físico (propio y autogestionado).

11. ¿Qué tipo de comunicación tiene Maranya con el exterior? A nivel virtual, presencial,...

12.¿Qué relación tiene con el Casal Jove, el ayuntamiento, los IES, los coles,...?

13. ¿Dónde ubicas a Maranya en el territorio? y ¿Dónde te 
ubicas tú dentro de Maranya? Actividad_Mural de relaciones: cada persona tendrá que ubicarse y ubicar a $\mathrm{M}$ con el objetivo de crear un mapa de relaciones de la Casa de Juventud.

\section{4. ¿Qué te gustaría contar que no te he preguntado?}

g. Agradecer la colaboración y remarcar la importancia de sus aportaciones, de su relato.

h. Los siguientes pasos tras la elaboración de las entrevistas serán:

- Registro, transcripción, elaboración del relato.

- Puesta en común y lectura crítica de los relatos: grupo de discusión / dinámica participativa

- Análisis, interpretación y presentación. 
Anexo 8. Guía para entrevistadas.

\author{
Tesis Doctoral: \\ Voces juveniles en tiempos de participación $y$ \\ transformación social. Un estudio etnográfico \\ sobre la cultura de participación juvenil \\ Doctoranda: \\ Arecia Aguirre García-Carpintero \\ Directores: \\ Joan Traver Martí y Lidón Moliner Miravet \\ PROTOCOLO DE ENTREVISTAS
}

Introducción:

A lo largo de esta investigación queremos recabar información sobre los valores educativos que tiene la participación juvenil en una casa de juventud, cómo se conforma su propia cultura de participación y qué factores educativos influyen en la misma. Para conseguirlo nos centramos en el método de Estudio etnográfico que según Tamayo (2001) " constituye la descripción y análisis de un campo social específico, una escena cultural determinada (una localidad, un barrio, una fábrica, una práctica social, una institución u otro tipo de campo, sin perjuicio de la aplicación de otros métodos y técnicas de recolección,síntesis y análisis. La meta principal del método etnográfico consiste en captar el punto de vista, el sentido, las motivaciones, intenciones y expectativas que los actores otorgan a sus propias acciones sociales, proyectos personales o colectivos, y al entorno sociocultural que los rodea «.

Nosotras concretamente nos centramos en:

"Conocer y analizar, siendo parte de la vida de Maranya, cómo se conforma y qué significado se le da a la cultura de participación juvenil en la Casa de Joventut (CJ) La Maranya y cómo ese proceso cultural genera espacios de aprendizaje en el grupo de jóvenes“ .

¿Por qué dentro de una investigación etnográfica? La investigación etnográfica intenta describir el estilo de vida de una sociedad o de un 
grupo de personas que viven en sociedad. Conocer su estructura, sus razonamientos, sus creencias,... en definitiva, conocer su cultura, su forma de vida con la participación del grupo a investigar. Por ello, las entrevistas son una de las herramientas más utilizadas, junto con la observación participante, en este tipo de investigación cualitativa. La entrevista ofrece al estudio la oportunidad de enriquecerse del diálogo y del intercambio de conocimiento gracias a la pluralidad de voces que participan en el proceso.

¿Cuál es el objetivo principal de la entrevista?: Conseguir información para poder construir relatos de vida de las personas que integran Maranya y así contextualizar y analizar la Casa de Joventut (CJ) a partir de la información aportada por ellas. Esta etapa dentro de la primera fase no es el fin último de la investigación sino que forma parte del proceso.

¿Y por qué un relato de vida? Porque la persona nos ofrece el testimonio subjetivo de lo social de su propia experiencia humana dentro del grupo y el análisis se realiza en primera persona. Además nos ayudará en la construcción de discurso grupal.

¿Qué queremos conocer? Cómo y por qué nace Maranya (M.), qué valores educativos tiene, cómo se participa, por qué están los informantes seleccionados en el proyecto, cómo se enreda $M$. en el territorio.

¿Cómo lo queremos hacer? Para obtener los relatos de vida sobre Maranya tenemos que realizar una serie de entrevistas individuales y grupales a informantes que de forma interna o externa tienen una vinculación con la Casa de Juventud La Maranya y su territorio.

\section{El proceso de entrevista}

Realizaremos entrevistas abiertas que posibilite el conocimiento del territorio y de la CJ a analizar. El tema principal a tratar es la historia de Maranya y la relación de los informantes con la CJ y esto se realizará entrevistando a un mínimo de 25 personas y un máximo de 30 . El 
espacio que se utilizará para la entrevista será elegido por la persona informante y la investigadora pero siempre cercano al entorno social de la persona entrevistada.

Se consensuará el día y hora de entrevista, al igual que la duración, con anterioridad a la cita.

\section{- Pasos a seguir en el momento de la entrevista:}

a. Explicar a las personas entrevistadas el trabajo que se está llevando a cabo.

Definir el uso de herramientas para digitalizar la información : grabadora de voz, video.

b. Leer y firmar el consentimiento informado.

c. Describir cómo lo vamos a hacer. Abordaje: entrevista y audiovisual. Cada persona tendrá que traer una fotografía, lectura, canción u objeto que relacione con Maranya.

d. Duración no más de una hora. Esto variará en función de la persona entrevistada y de si la entrevista es grupal o individual.

e. Estructura de entrevista:

01.Relación con la fotografía, lectura, canción u objeto que la persona trae.

02.Definición y significado de Maranya.

03. Experiencia personal.

04.Participación.

05.Aprendizajes.

06.Espacio físico.

07.Comunicación externa e interna y relaciones.

08. Otras cuestiones. 
09.Mural de relaciones (actividad): cada persona tendrá que ubicarse y ubicar a Maranya con el objetivo de crear un mapa de relaciones de la Casa de Juventud.

g. Explicación de los siguientes pasos tras la elaboración de las entrevistas:

- Registro, transcripción, elaboración del relato.

- Puesta en común y lectura crítica de los relatos: grupo de discusión / dinámica participativa

- Análisis, interpretación y presentación. 
Anexo 9. Proceso entrevista alcaldesa.

\section{El contacto con alcaldía se sucede de la siguiente forma:}

1. Día, Febrero de 2015: presento la solicitud formal por registro de entrada en el ayuntamiento para poder realizarle la entrevista a la Alcaldesa.

2. 30, Marzo de 2015: me escriben un email desde el gabinete de comunicación del Ayuntamiento para contestar a mi petición «En respuesta a la carta que hemos recibido en alcaldía respecto a la solicitud de la participación de la alcaldesa a través de la entrevista en la Tesis doctoral que estás realizando sobre el municipio. Dadas las fechas en las que estamos, debido a las elecciones locales del próximo 24 de mayo, la alcaldesa no considera ético participar antes que se constituya el nuevo gobierno municipal en el mes de junios.

3. 4, Mayo de 2015: escribo un email al gabinete de comunicación exponiendo mi voluntad de continuar con el proceso para poder realizar la entrevista después de elecciones.

4. 19, Junio de 2015: envío un email recordatorio a gabinete de comunicación y a alcaldía solicitando la entrevista.

5. Día, Julio de 2015: presento la solicitud de entrevista por registro de entrada del ayuntamiento adjuntado emails y la primera solicitud por registro de entrada efectuada.

6. 13, Octubre de 2015: contacto por email del gabinete de comunicación solicitando mis necesidades concretas sobre la entrevista y ofreciendo alternativas en función de estas. Las opciones que se barajan es realizar la entrevista a la alcaldesa tal y como se solicita o hacerlo a la concejalía de juventud o a la concejalía de participación ciudadana. Por otro lado preguntan si la entrevista ha de ser presencial o se pueden contestar las preguntas por escrito para agilizar las cosas.

7. 13, Octubre de 2015: insisto en mi voluntad por realizar la entrevista a la alcaldesa antes de que acabe el mes de octubre.

8. 14, Octubre de 2015: desde el gabinete de comunicación me envían la cita para realizar la entrevista epróximo martes 20 de octubre a las 13:30 en el despacho de la alcaldesa».

9. 15, Octubre de 2015: confirmo mi asistencia. 
Anexo 10. Tabla final de participantes.

\begin{tabular}{|c|c|c|c|c|c|c|}
\hline 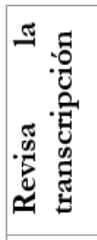 & 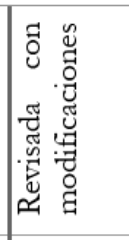 & 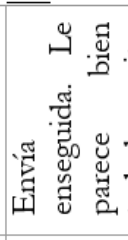 & 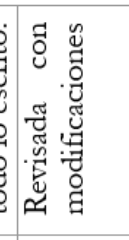 & 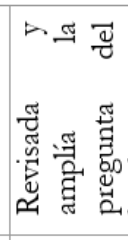 & 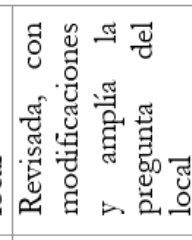 & 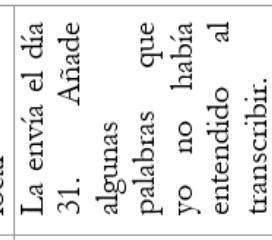 \\
\hline 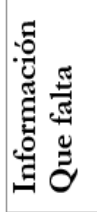 & $\begin{array}{l}0 \\
0 \\
\frac{0}{2} \\
0 \\
0 \\
0 \\
0 \\
0 \\
1\end{array}$ & $\begin{array}{l}0 \\
.00 \\
\frac{0}{0} \\
0 \\
0 \\
0 \\
0 \\
4\end{array}$ & 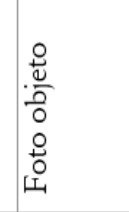 & $\begin{array}{l}\frac{1}{4} \\
\frac{0}{0} \\
\frac{0}{0} \\
0 \\
0 \\
0\end{array}$ & $\begin{array}{l}8 \\
\frac{0}{2} \\
\frac{0}{2} \\
0 \\
0 \\
0 \\
0 \\
1\end{array}$ & $\begin{array}{l}0 \\
.0 \\
0 \\
0 \\
0 \\
0 \\
0 \\
0 \\
0\end{array}$ \\
\hline 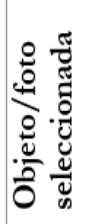 & 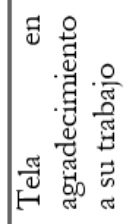 & 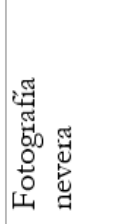 & 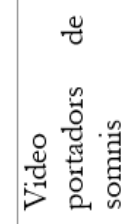 & 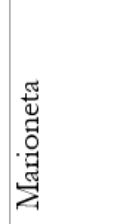 & 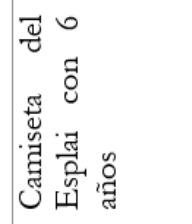 & 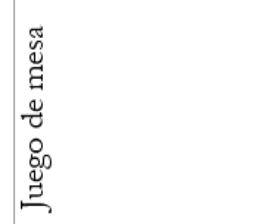 \\
\hline 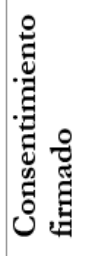 & $\vec{n}$ & $\vec{r}$ & $\vec{v}$ & $\vec{n}$ & $\vec{n}$ & $\vec{n}$ \\
\hline 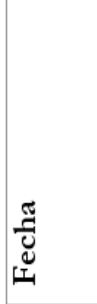 & 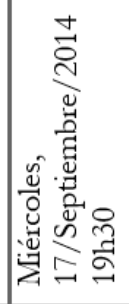 & 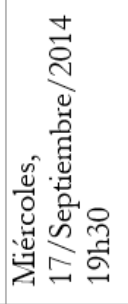 & 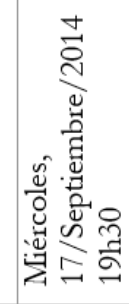 & 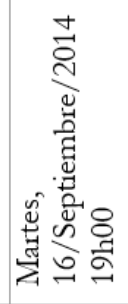 & 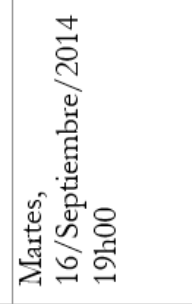 & 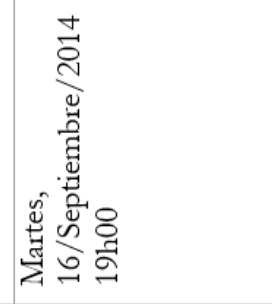 \\
\hline 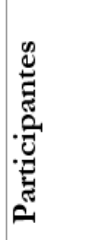 & 菢 & 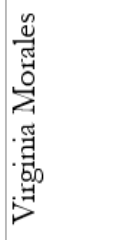 & 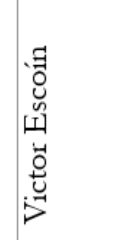 & 急 & 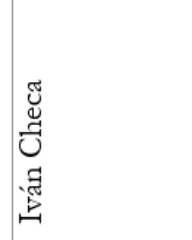 & $\overrightarrow{\mathrm{d}}$ \\
\hline 㤎 & 总 & & & 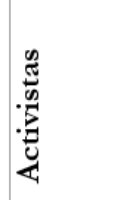 & & \\
\hline
\end{tabular}




\begin{tabular}{|c|c|c|c|c|c|}
\hline 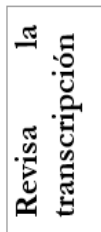 & \multicolumn{2}{|c|}{ 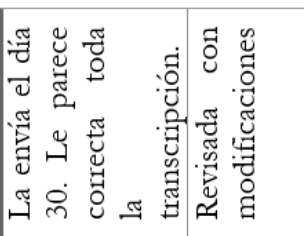 } & 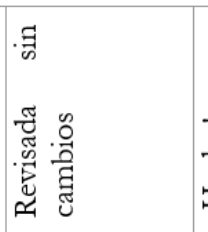 & 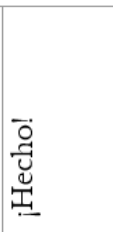 & 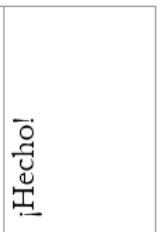 \\
\hline 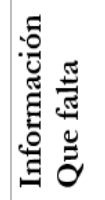 & $\begin{array}{l}0 \\
.0 \\
\frac{0}{0} \\
0 \\
0 \\
0 \\
0 \\
1\end{array}$ & $\begin{array}{l}.0 \\
.0 \\
0 \\
0 \\
0 \\
0 \\
0 \\
1\end{array}$ & $\begin{array}{l}\frac{8}{0} \\
\frac{0}{2} \\
\frac{0}{0} \\
0 \\
0 \\
0 \\
1\end{array}$ & $\begin{array}{l}0 \\
.00 \\
\frac{0}{2} \\
0 \\
0 \\
0 \\
0 \\
\text { i }\end{array}$ & $\begin{array}{l}0 \\
.0 \\
\frac{0}{0} \\
0 \\
0 \\
0 \\
0 \\
1\end{array}$ \\
\hline 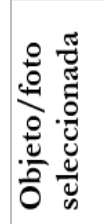 & 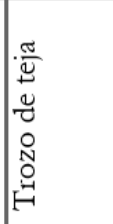 & 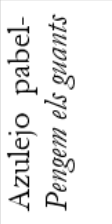 & 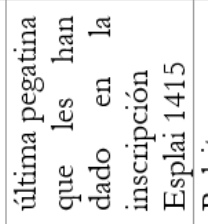 & 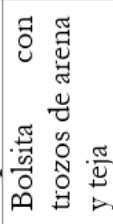 & 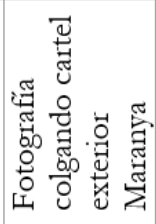 \\
\hline 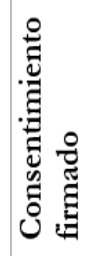 & $\vec{\omega}$ & $\vec{\omega}$ & $\vec{\omega}$ & $\vec{\omega}$ & $\vec{\omega}$ \\
\hline 䍃 & 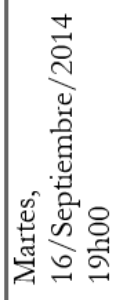 & 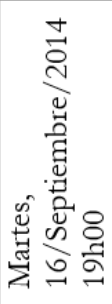 & 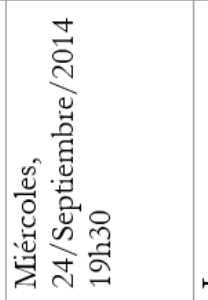 & 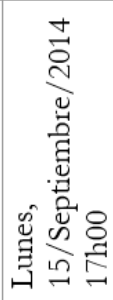 & 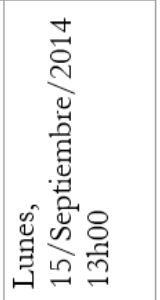 \\
\hline 选 & 总 & 芩 & 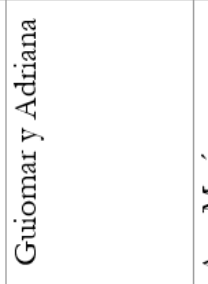 & 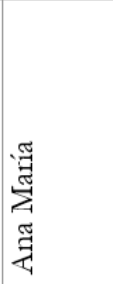 & 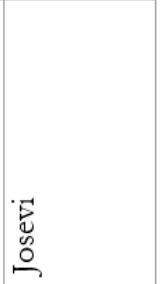 \\
\hline 咢 & & & 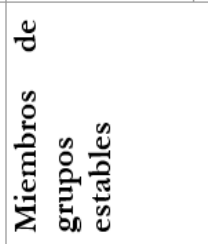 & & \\
\hline
\end{tabular}




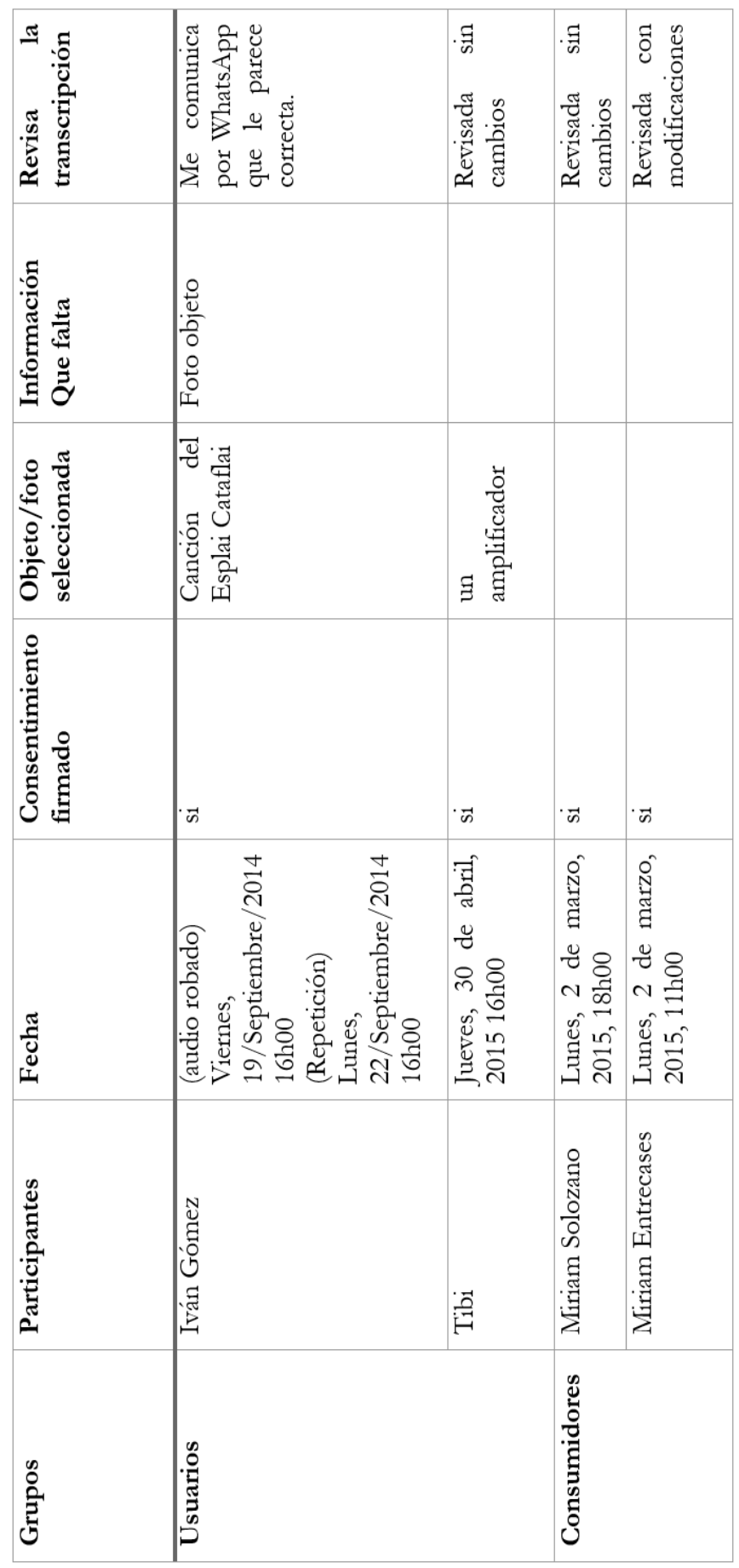




\begin{tabular}{|c|c|c|c|c|c|}
\hline 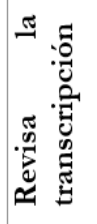 & 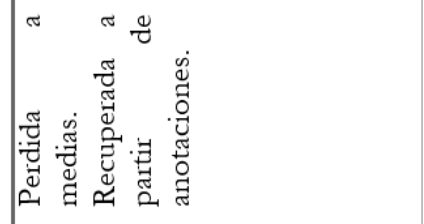 & 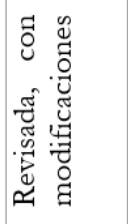 & 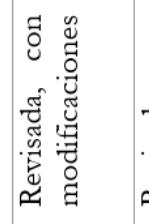 & 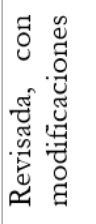 & 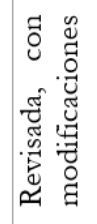 \\
\hline 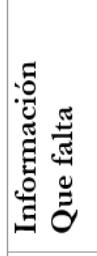 & 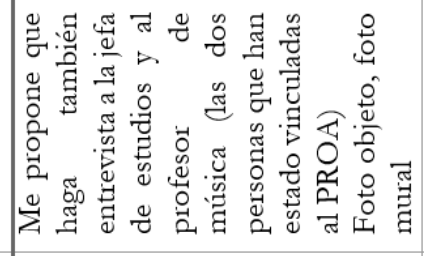 & 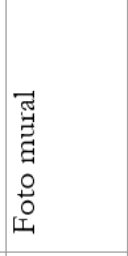 & $\begin{array}{l}\text { 폄 } \\
\vdots \\
0 \\
0 \\
0 \\
0\end{array}$ & $\begin{array}{l}\overrightarrow{\widetilde{G}} \\
\vec{\Xi} \\
0 \\
0 \\
0 \\
\text { I }\end{array}$ & 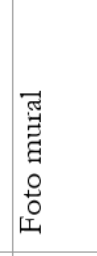 \\
\hline 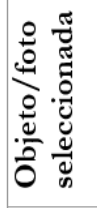 & ' & ' & ' & ' & , \\
\hline 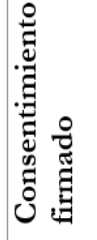 & $\vec{\omega}$ & $\vec{\omega}$ & $\vec{\omega}$ & $\vec{\phi}$ & $\vec{\omega}$ \\
\hline 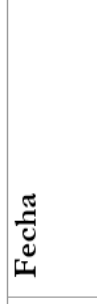 & 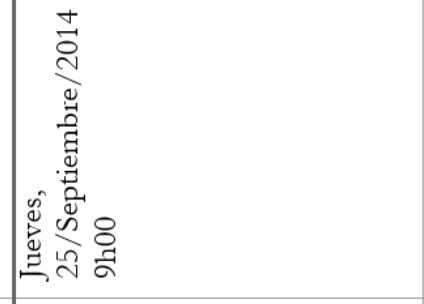 & 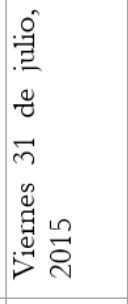 & 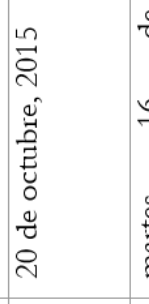 & 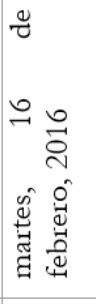 & 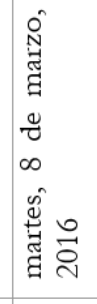 \\
\hline . & 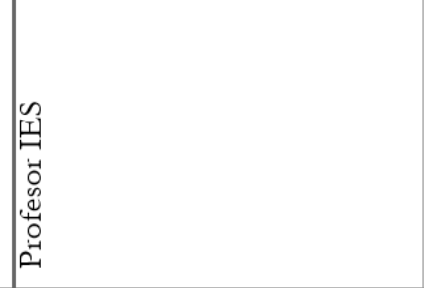 & 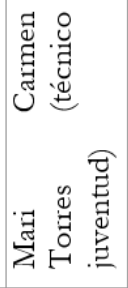 & 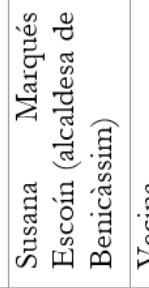 & : & 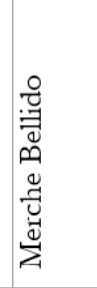 \\
\hline 莣 & | & & & & \\
\hline
\end{tabular}




\begin{tabular}{|c|c|c|c|c|c|c|c|}
\hline 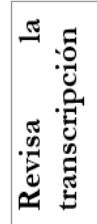 & 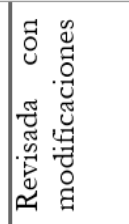 & 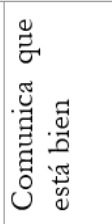 & 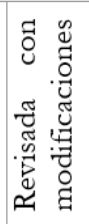 & 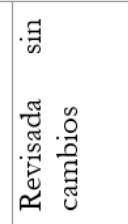 & 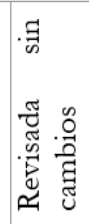 & 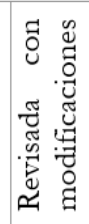 & 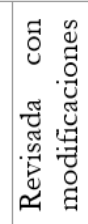 \\
\hline 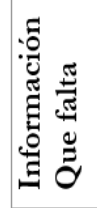 & 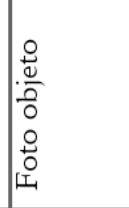 & $\begin{array}{l}0 \\
.0 \\
: 0 \\
0 \\
0 \\
0 \\
0 \\
1\end{array}$ & $\begin{array}{l}0 \\
.00 \\
\frac{0}{2} \\
0 \\
0 \\
0 \\
0 \\
1 \\
4\end{array}$ & 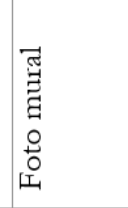 & & & \\
\hline 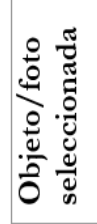 & 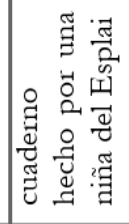 & 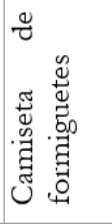 & 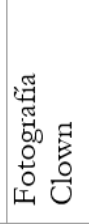 & 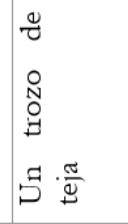 & ' & ' & ' \\
\hline 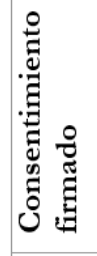 & $\vec{n}$ & $\vec{\omega}$ & $\vec{\omega}$ & $\vec{\omega}$ & $\vec{n}$ & $\vec{w}$ & $\vec{\omega}$ \\
\hline 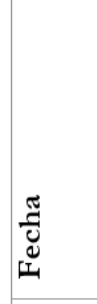 & 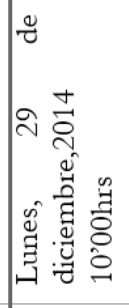 & 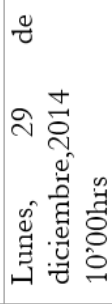 & 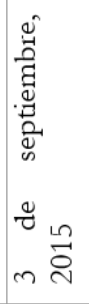 & 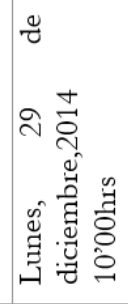 & 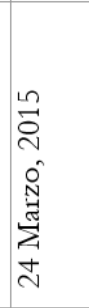 & 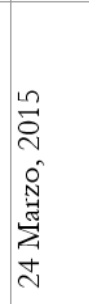 & 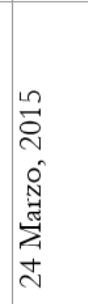 \\
\hline 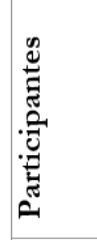 & 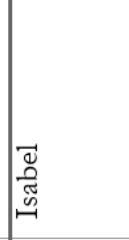 & 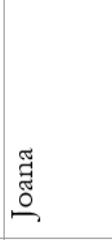 & $\frac{5}{2}$ & 莺 & 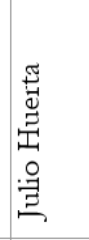 & 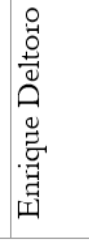 & 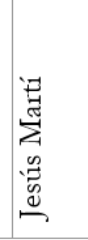 \\
\hline 离 & & 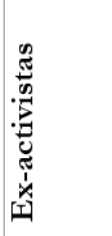 & & & 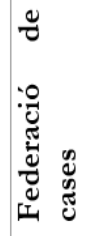 & & \\
\hline
\end{tabular}


Anexo 11. Email de devolución de la entrevista.

\section{Revisión entrevista Maranya}

Arecia Aguirre García Carpintero <aaguirre@edu.uji.es>

Hola equipo de activistas,

Aprovecho el email, ya que a algunos de vosotros no os he visto en Navidades para desearos un feliz año 2015. Espero que marche muy bien. En unos 20 días ya estoy de vuelta por Castellón, así que nos vemos de nuevo en breve.

Me pongo en contacto con vosotros para comunicaros que la transcripción de la entrevista que hicimos hace unos meses ya está lista para que podáis revisarla. El objetivo de esta tarea es que podáis leerla tranquilamente y modifiquéis o añadáis lo que creáis conveniente sobre vuestras intervenciones. Recordad que es vuestra experiencia personal y nadie mejor que vosotros puede redactar lo que queréis expresar. Para ello, en el documento que os envío podéis borrar aquello que no queráis que aparezca y añadir, en el color correspondiente, lo que necesitéis. Cada uno de su propia intervención y no de las intervenciones del resto. La asignación del color es simplemente para facilitarme la tarea cuando tenga que juntar todas vuestras versiones en un solo documento. Para reenviarme el documento personal de cada uno de vosotros, con las modificaciones pertinentes, dejaremos un plazo de unos 15 dias, con lo que como fecha tope la espero de vuelta el viemes 30 de enero.

Si tenéis cualquier duda al respecto no dudéis en poneros en contacto œonmigo.

Un abrazo,

Arecia

-

Arecia Aguirre Garcia-Carpintero

Departament d'Educació

Àrea de Teoria i Història de l'Educació

Universitat Jaume I

Despatix: HC2243DD

Telèfon: 964729711

E-Mail: aaguirre@uji.es

Grup dimvestigació:

MEICRI- Millora Edueativa i Cintadanía Cática

http://meicri.upi.es

3. RevisiónTranscripción Activistas Grupos Estables 24p.doc $120 \mathrm{~K}$ 
Anexo 12. Listado de categorías y códigos con definición y ejemplos.

\begin{tabular}{|c|c|c|c|}
\hline 竞 & 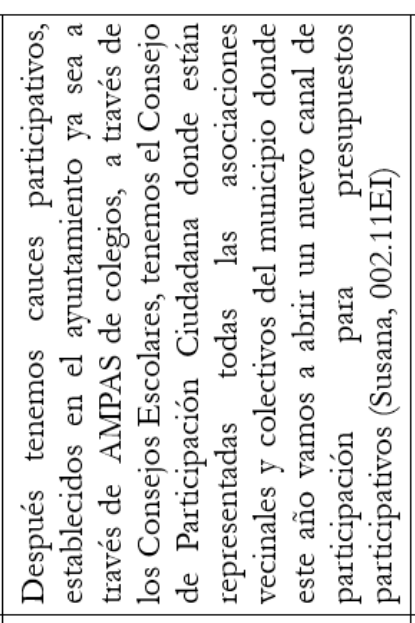 & 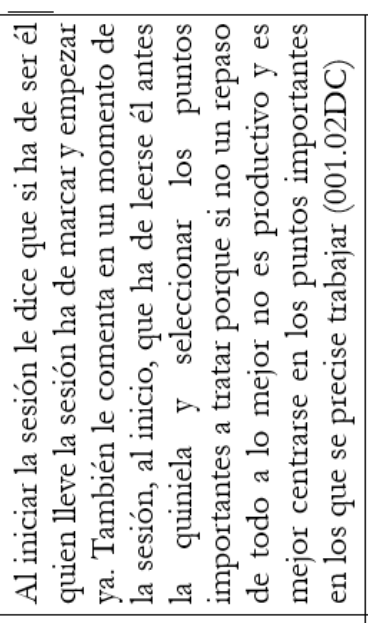 & 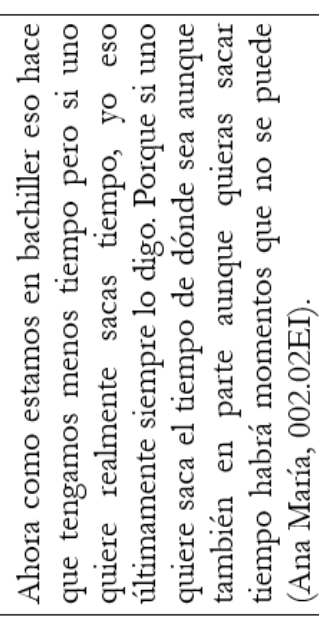 \\
\hline 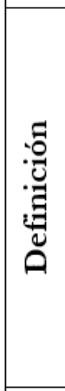 & 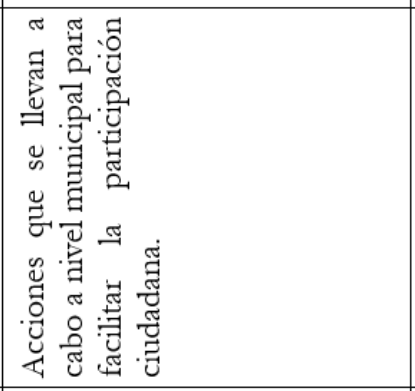 & 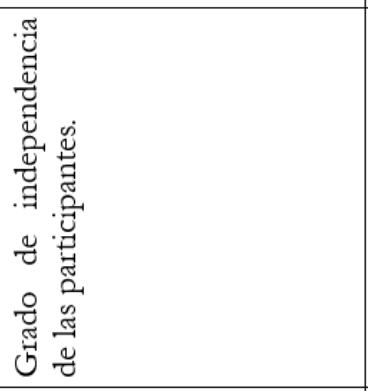 & 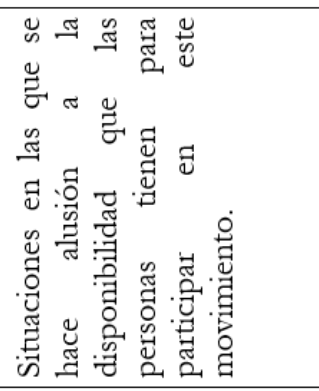 \\
\hline \multirow[t]{2}{*}{ ن } & \multirow{2}{*}{ 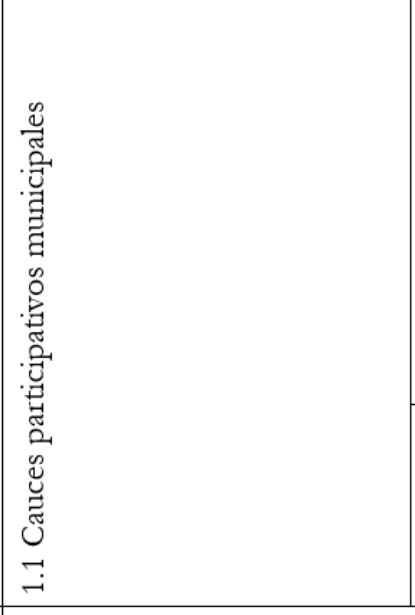 } & 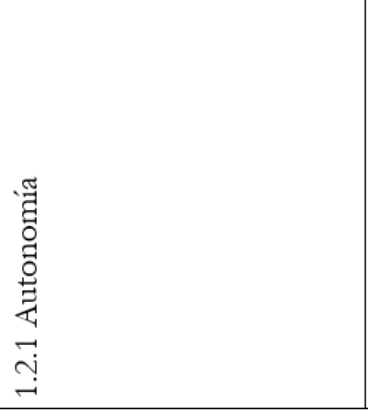 & 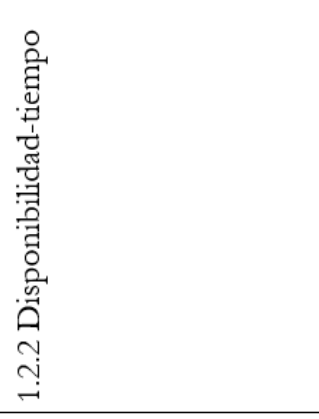 \\
\hline & & \multicolumn{2}{|l|}{ 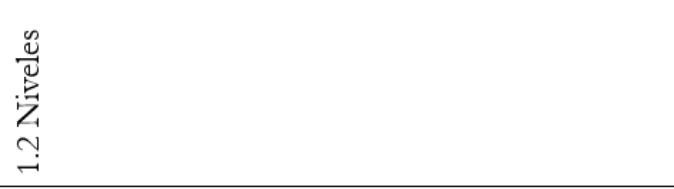 } \\
\hline 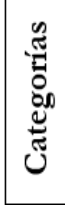 & 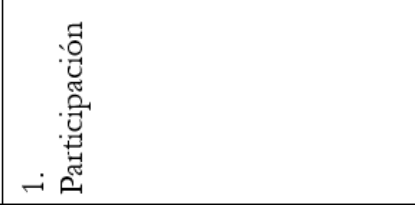 & & \\
\hline
\end{tabular}




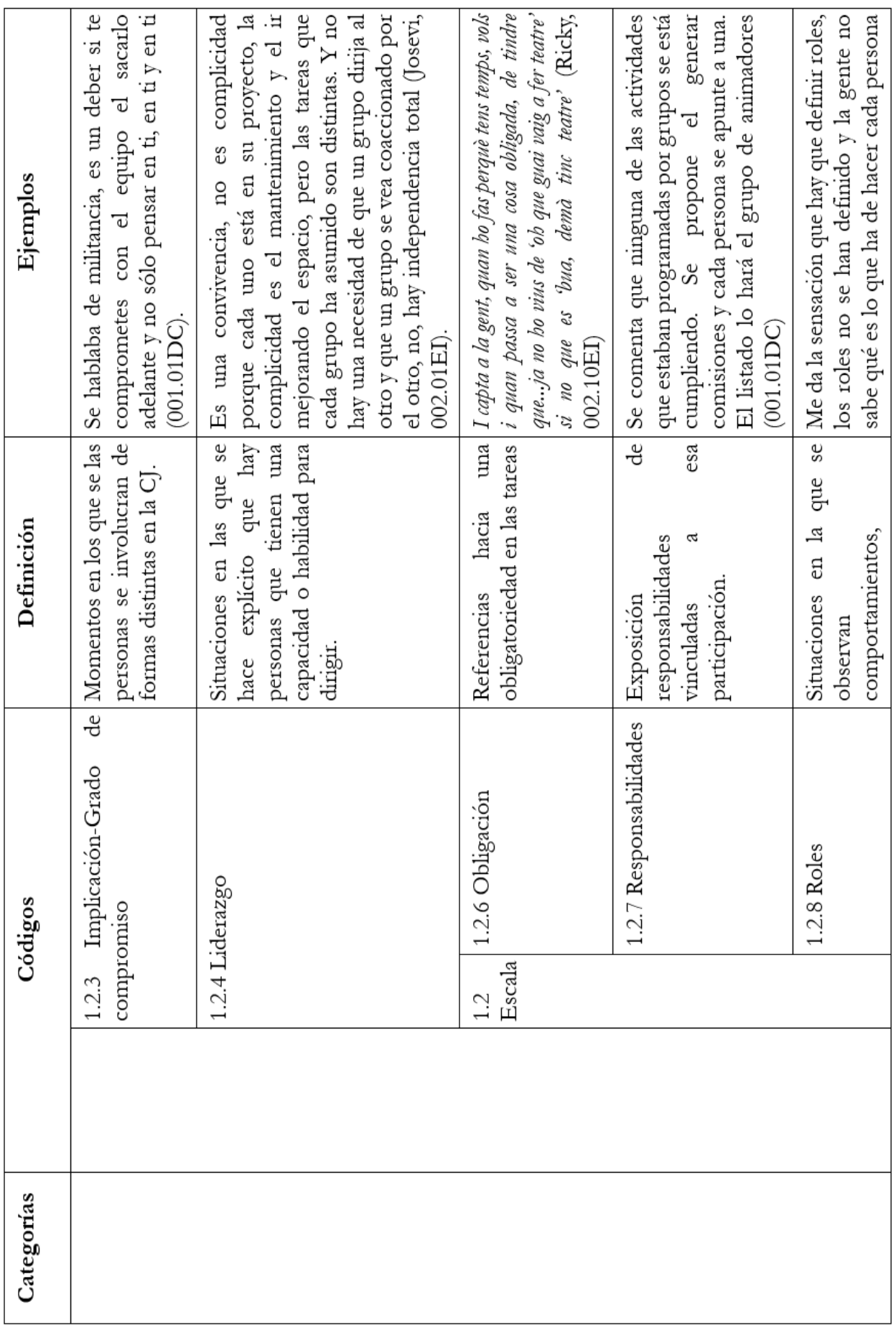




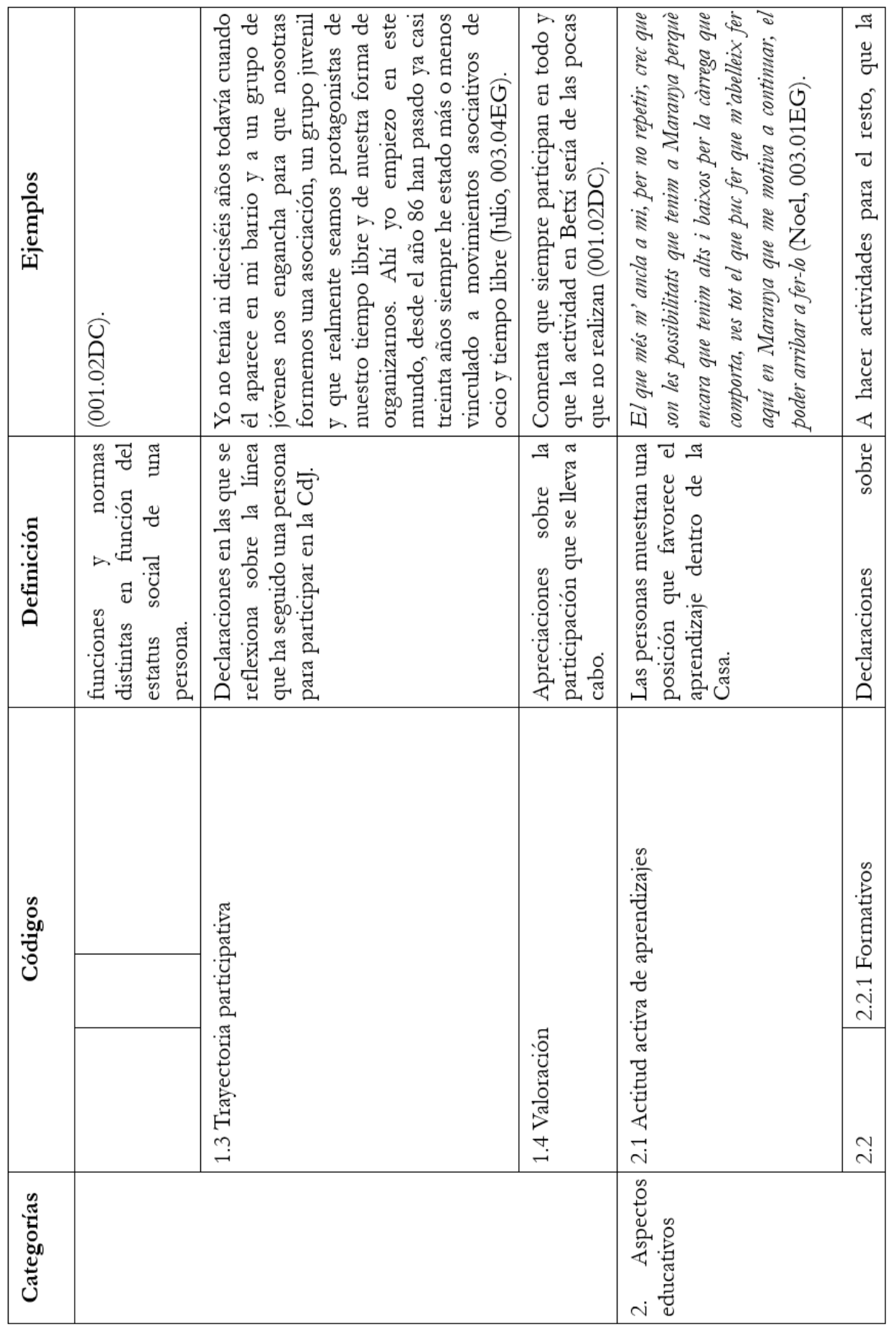




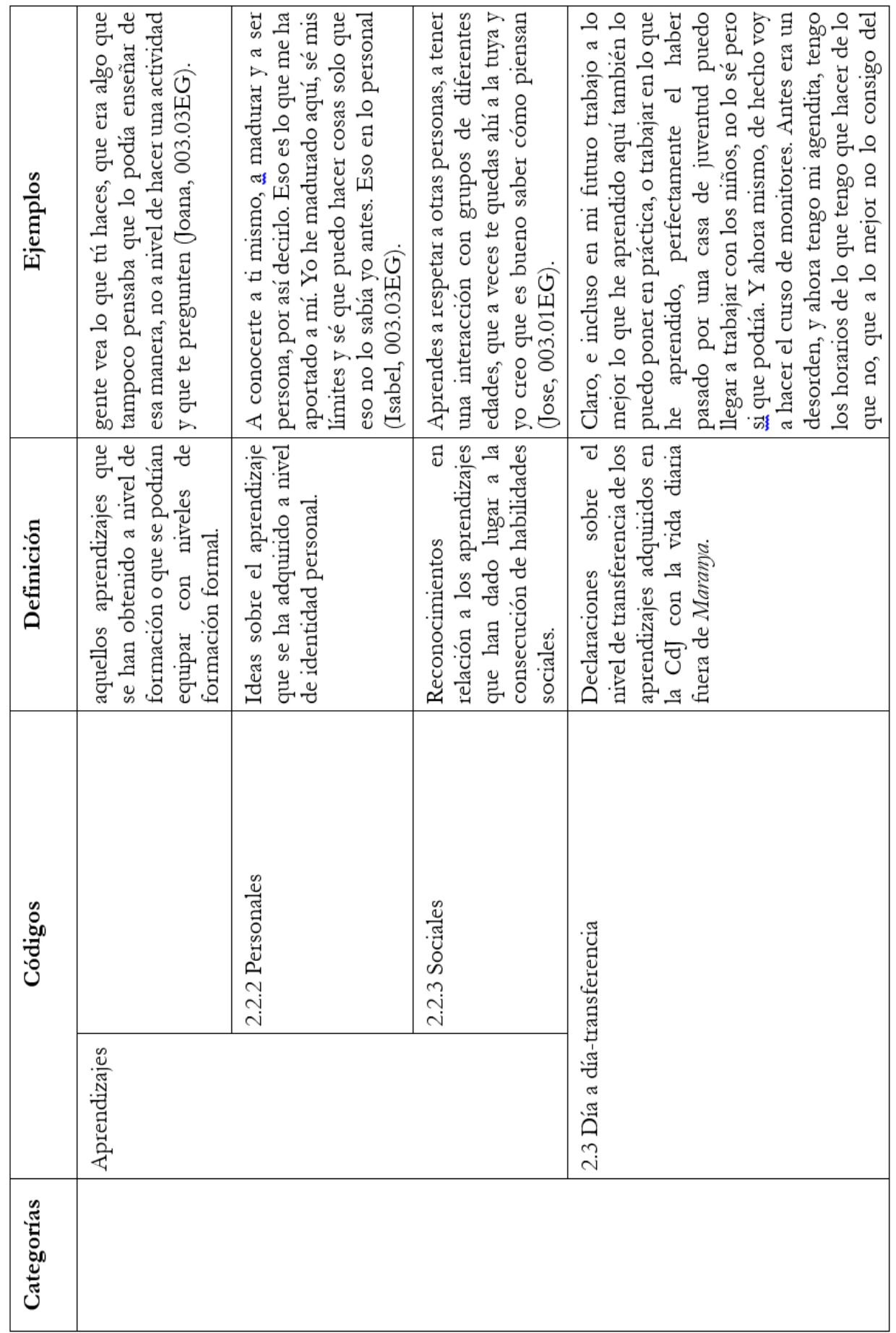




\begin{tabular}{|c|c|c|c|c|}
\hline 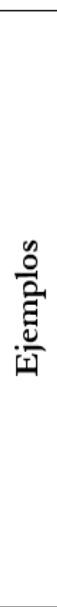 & 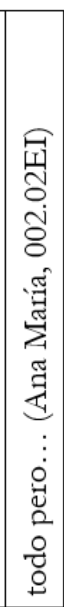 & 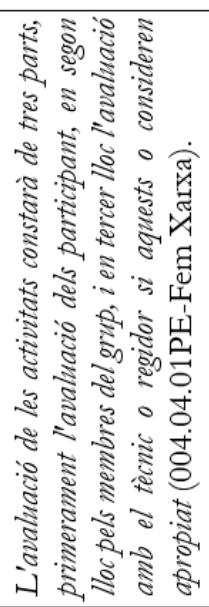 & 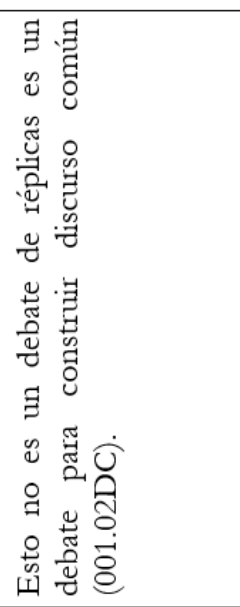 & 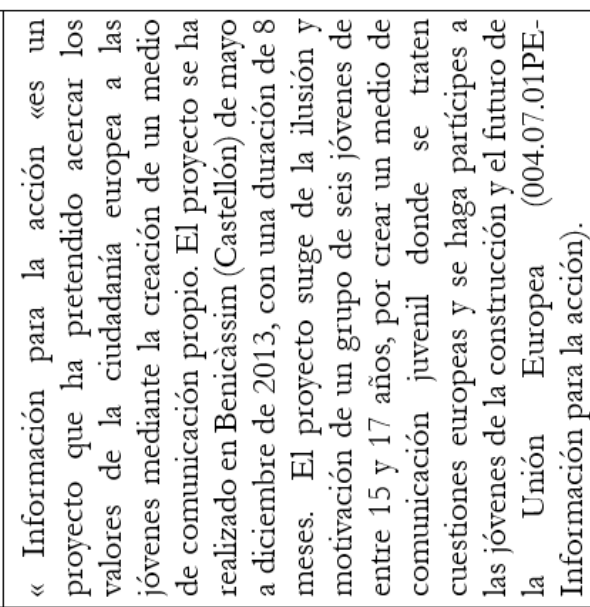 \\
\hline 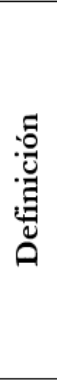 & & 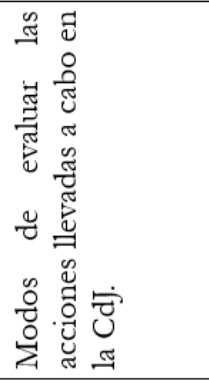 & 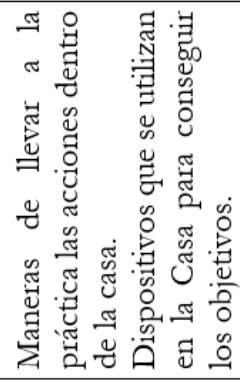 & 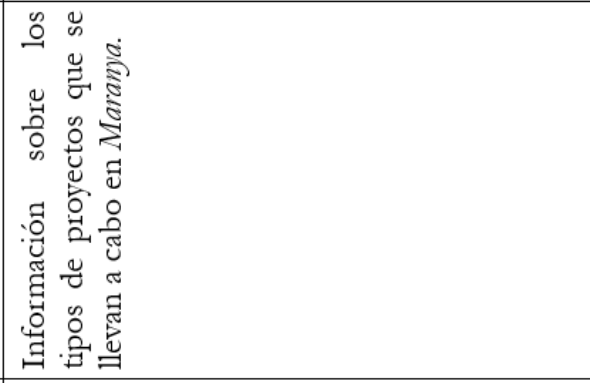 \\
\hline \multirow[t]{2}{*}{ نُ } & & 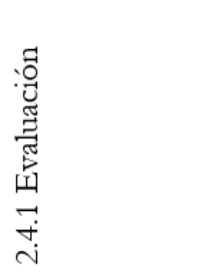 & 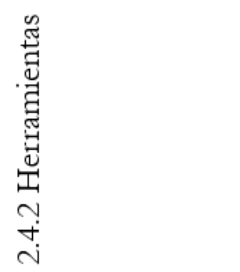 & 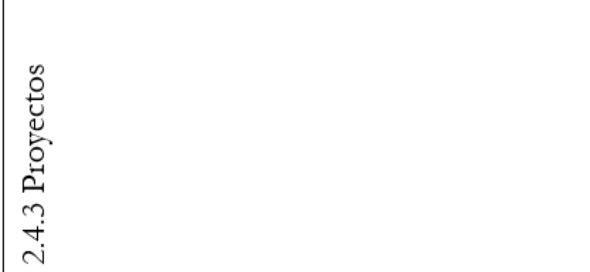 \\
\hline & & 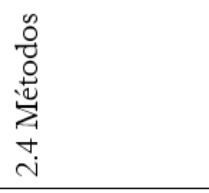 & & \\
\hline & & & & \\
\hline
\end{tabular}




\begin{tabular}{|c|c|c|c|c|}
\hline 总 & 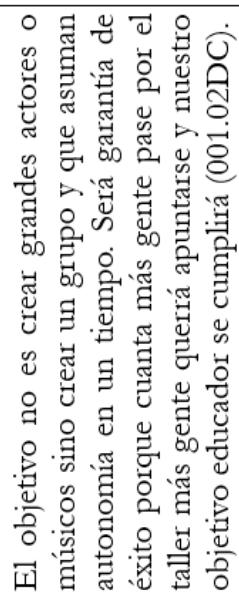 & 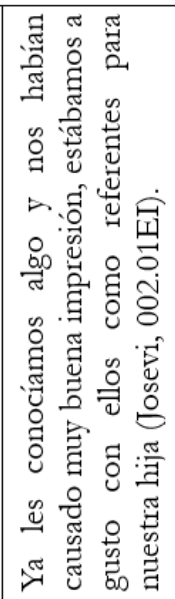 & 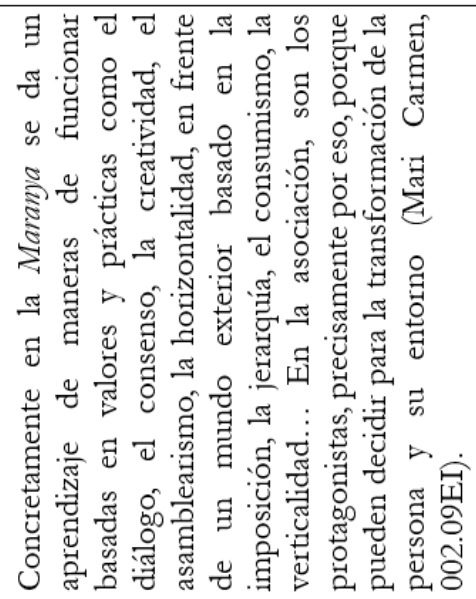 & 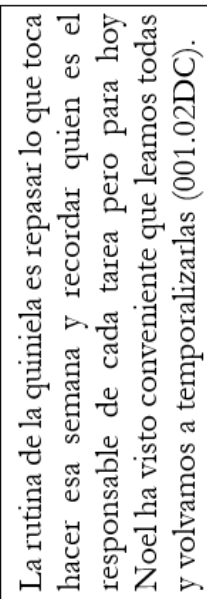 \\
\hline 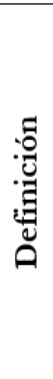 & 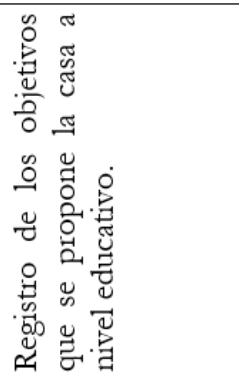 & 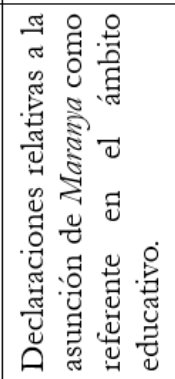 & 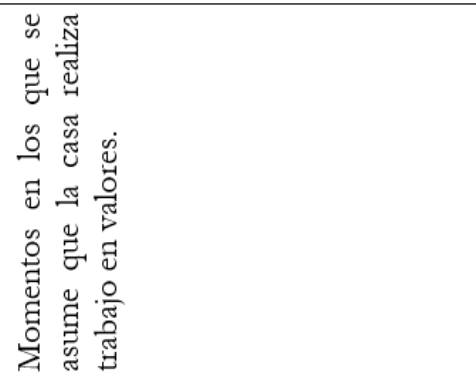 & 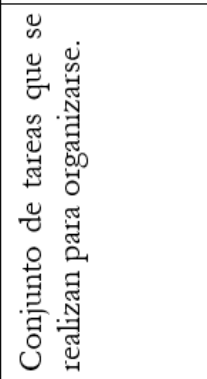 \\
\hline 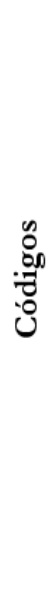 & 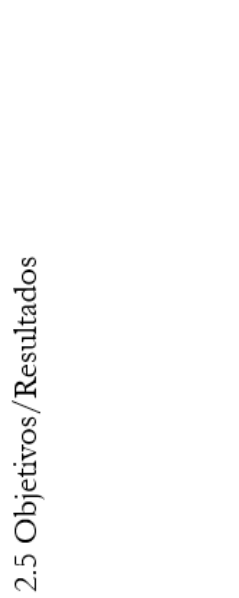 & 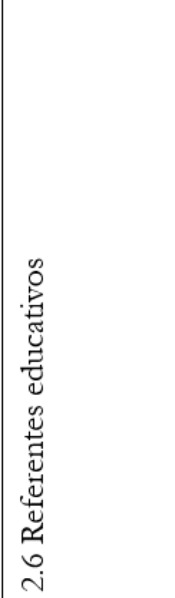 & 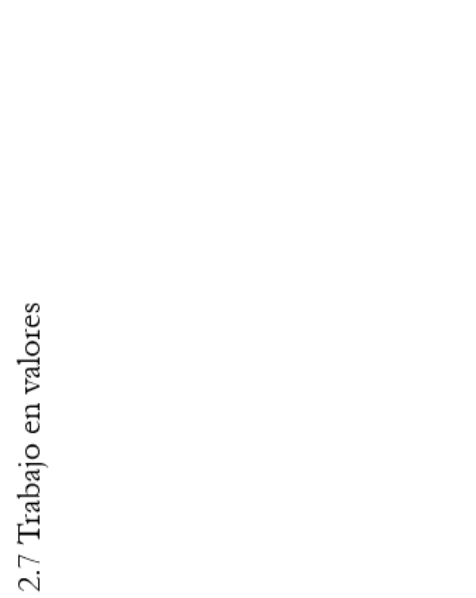 & 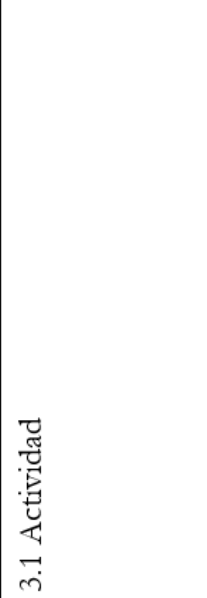 \\
\hline 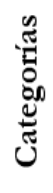 & & & & 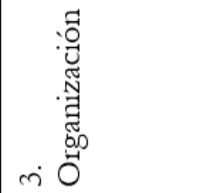 \\
\hline
\end{tabular}




\begin{tabular}{|c|c|c|c|c|}
\hline 总 & 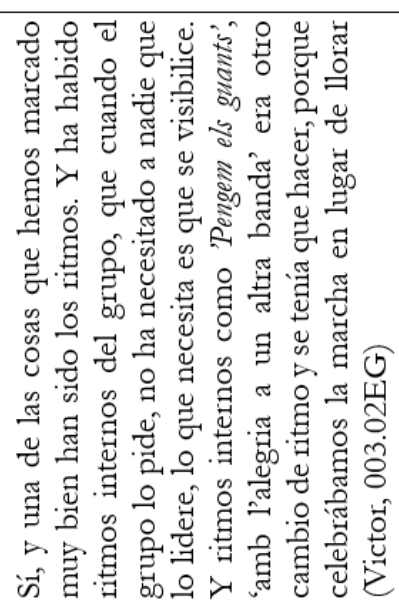 & 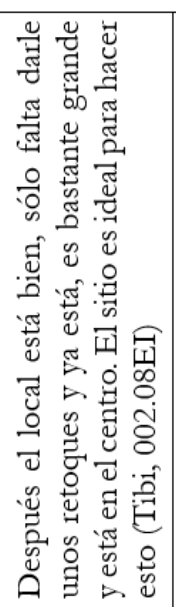 & 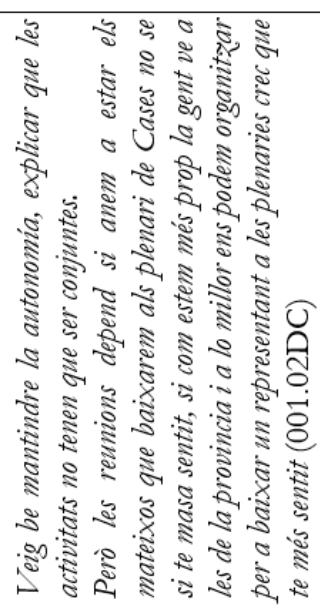 & 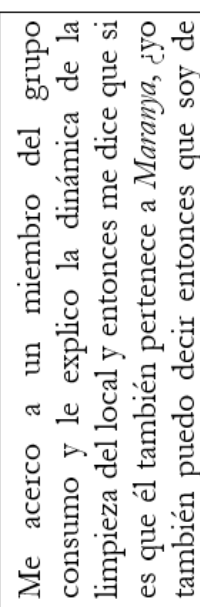 \\
\hline 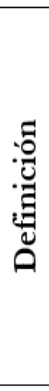 & 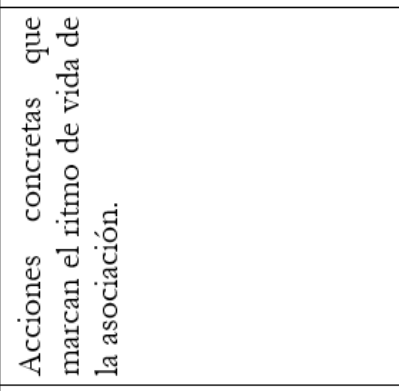 & 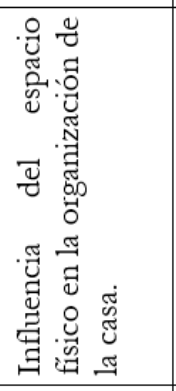 & 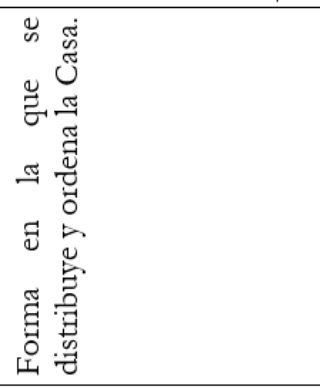 & 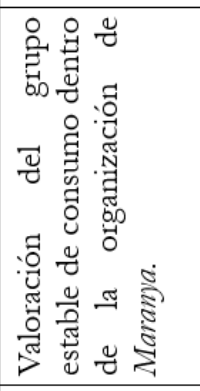 \\
\hline $\begin{array}{l}0 \\
0 \\
0 \\
0 \\
0 \\
0\end{array}$ & 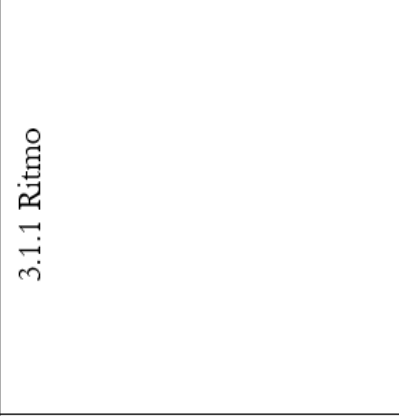 & 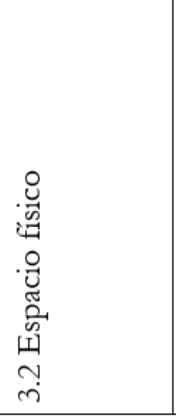 & 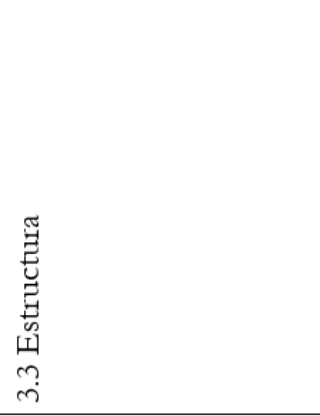 & 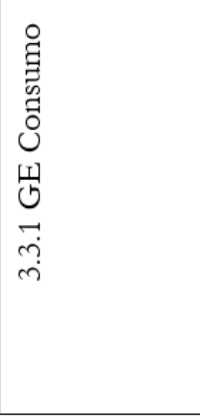 \\
\hline 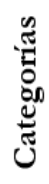 & & & & \\
\hline
\end{tabular}




\begin{tabular}{|c|c|c|c|c|c|c|}
\hline 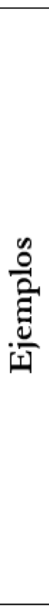 & 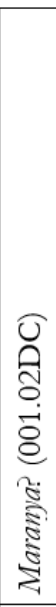 & 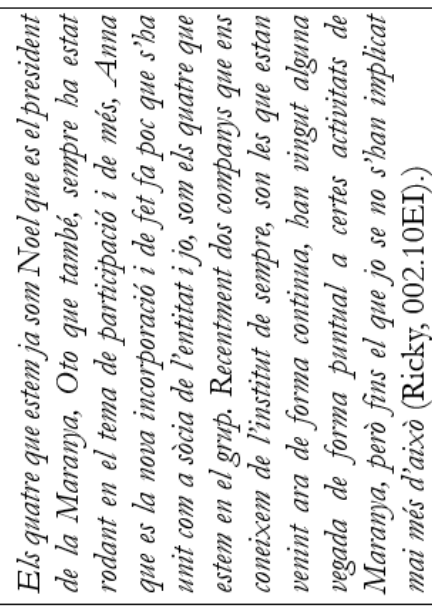 & 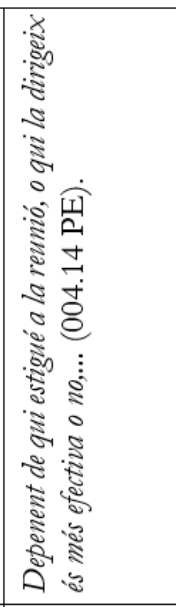 & 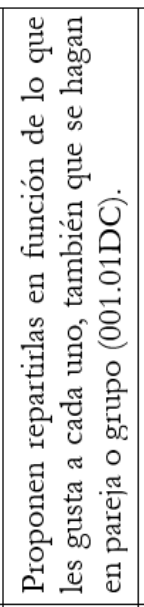 & 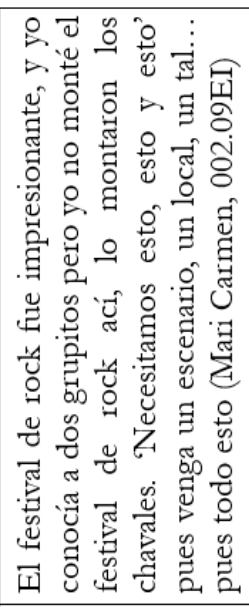 & 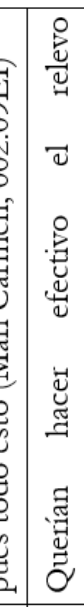 \\
\hline 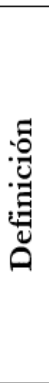 & & 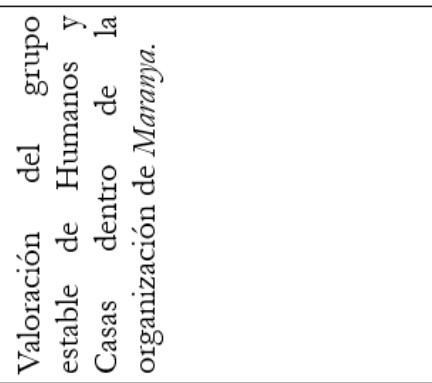 & 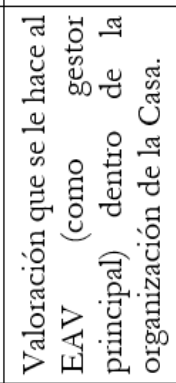 & 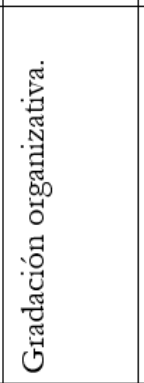 & 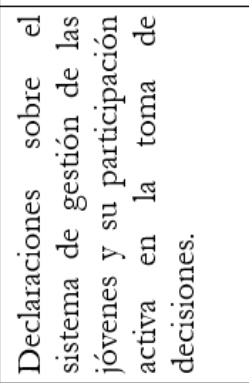 & ध \\
\hline 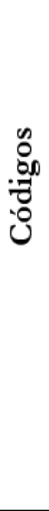 & & 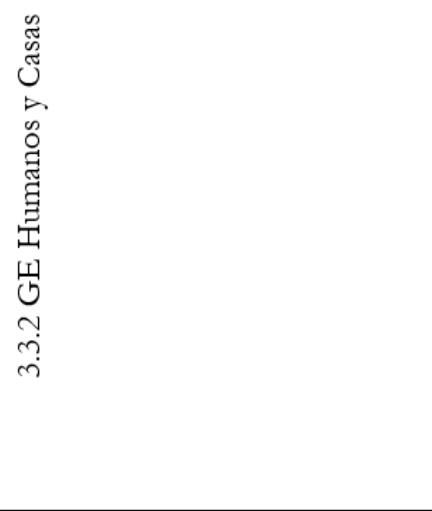 & 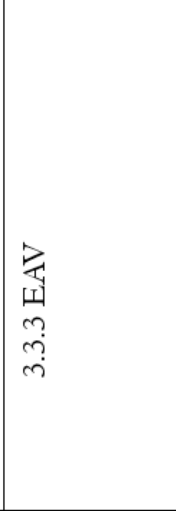 & $\begin{array}{l}\stackrel{8}{\mathbb{J}} \\
\tilde{G} \\
+ \\
\dot{c}\end{array}$ & 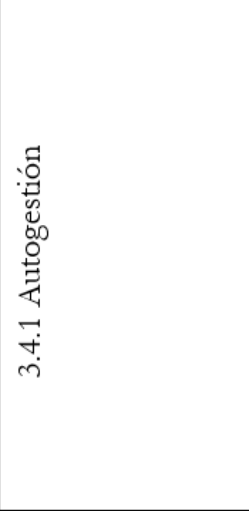 & 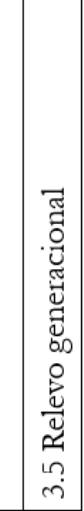 \\
\hline & & & & & & \\
\hline
\end{tabular}




\begin{tabular}{|c|c|c|c|c|c|}
\hline 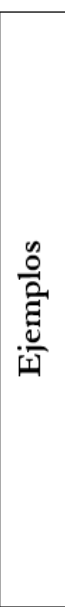 & 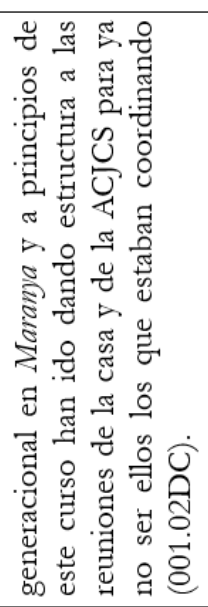 & 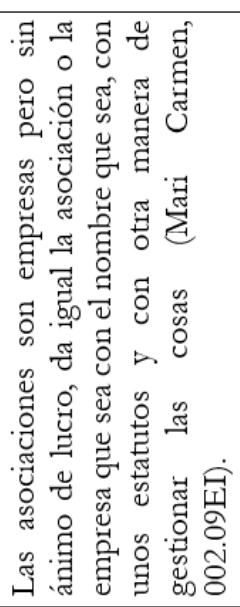 & 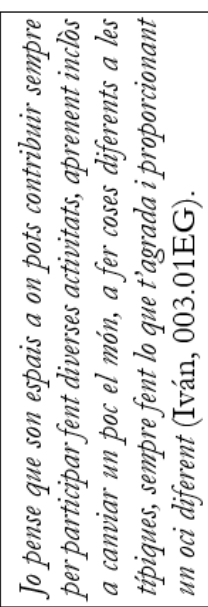 & 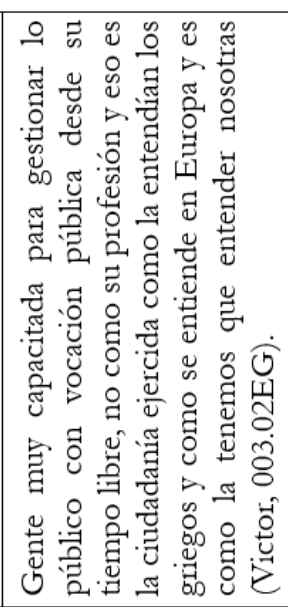 & 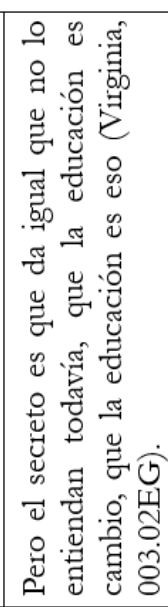 \\
\hline 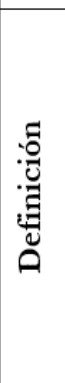 & 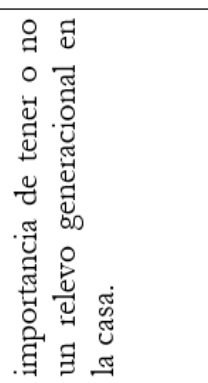 & 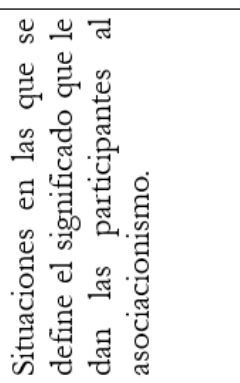 & 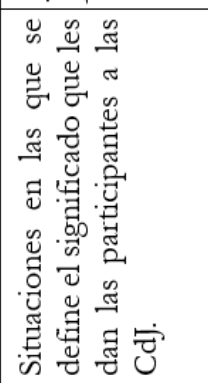 & 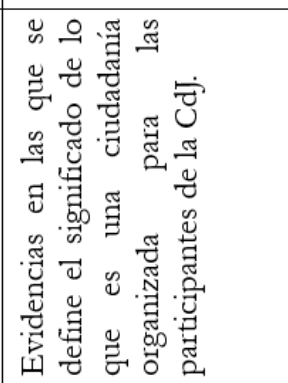 & 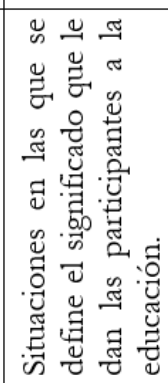 \\
\hline نه & & 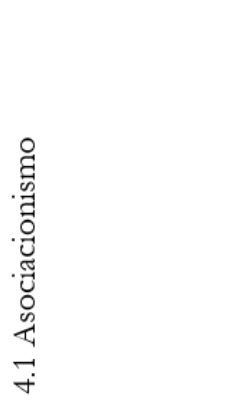 & 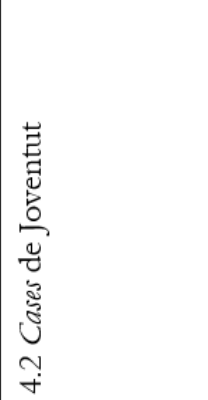 & 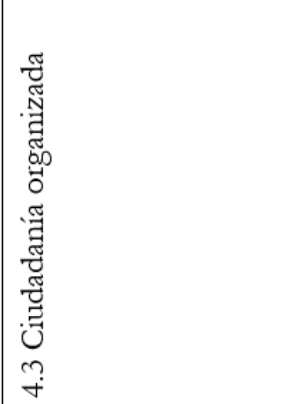 & 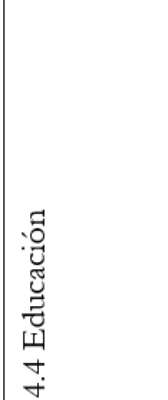 \\
\hline 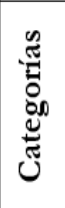 & & \multicolumn{4}{|l|}{ 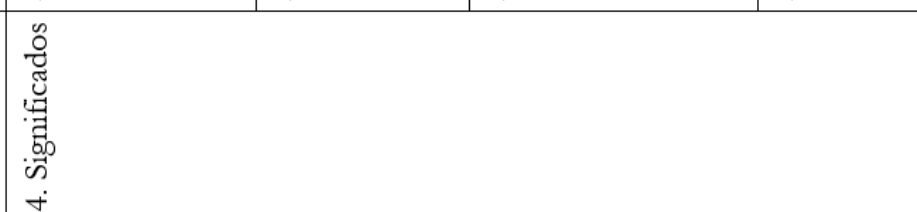 } \\
\hline
\end{tabular}




\begin{tabular}{|c|c|c|c|c|c|}
\hline 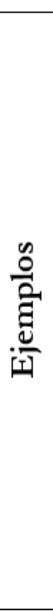 & 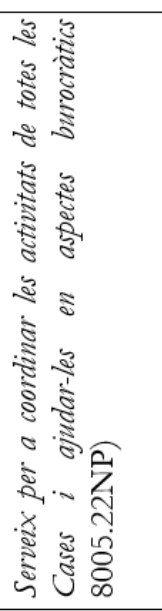 & 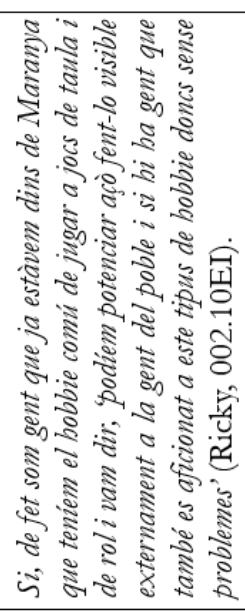 & 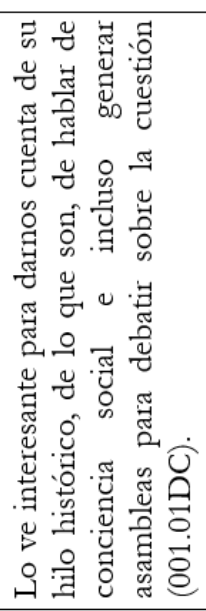 & 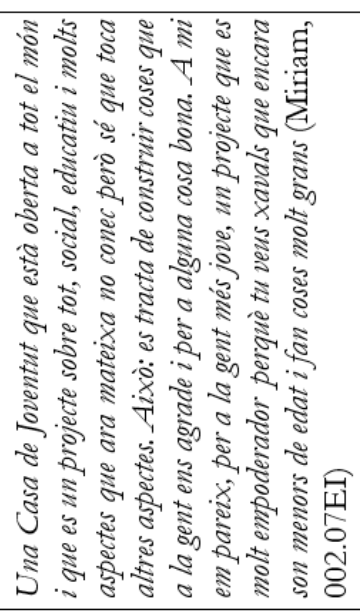 & 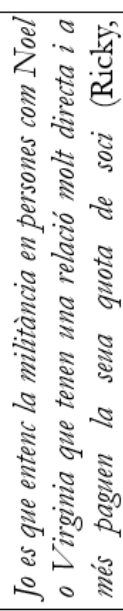 \\
\hline 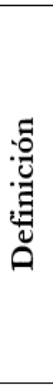 & 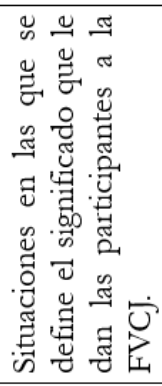 & 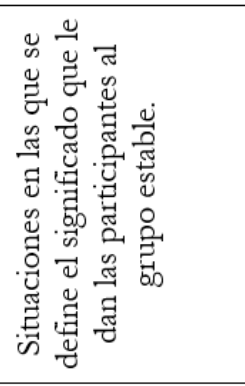 & 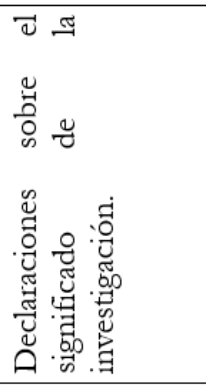 & 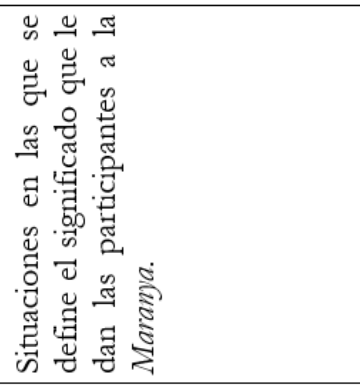 & 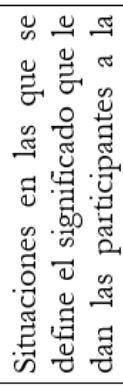 \\
\hline نْ & 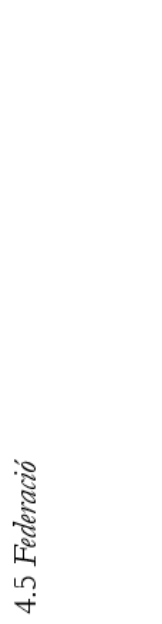 & 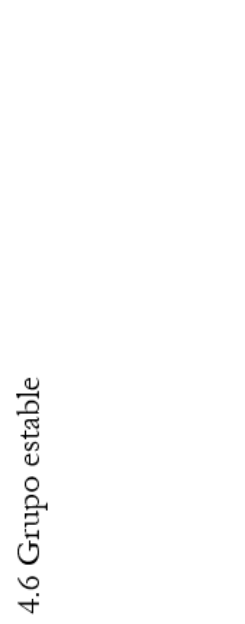 & 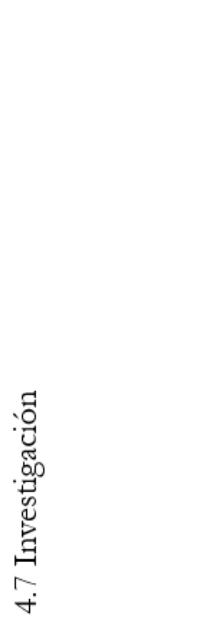 & 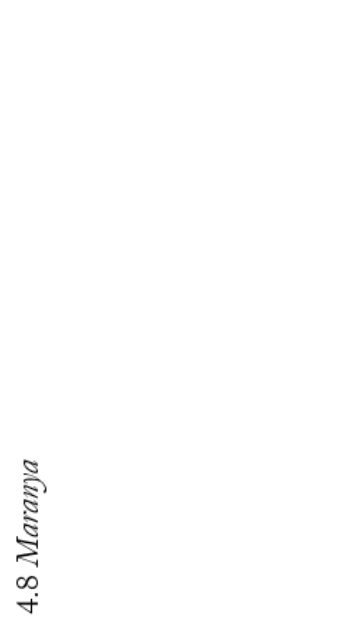 & 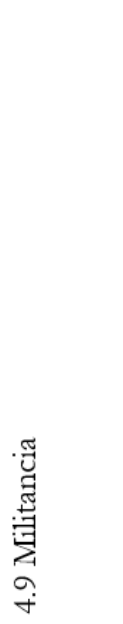 \\
\hline 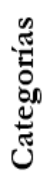 & & & & & \\
\hline
\end{tabular}




\begin{tabular}{|c|c|c|c|c|c|}
\hline 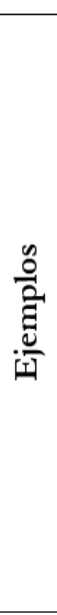 & $\begin{array}{l}\text { 空 } \\
\text { ते } \\
\text { ه }\end{array}$ & 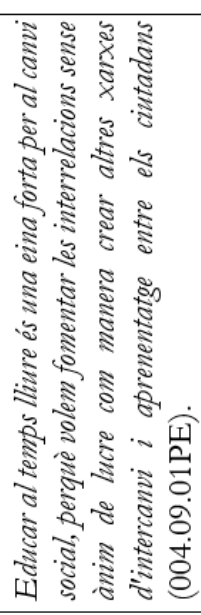 & 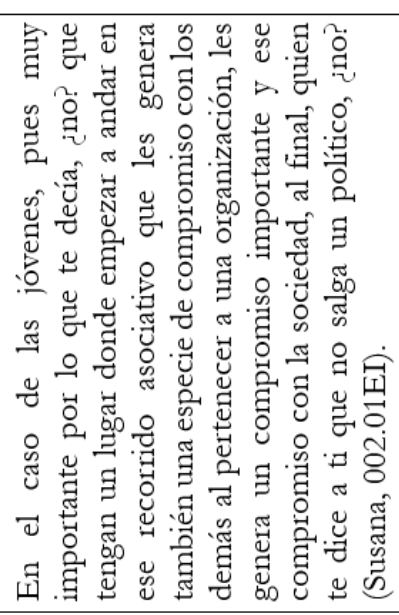 & 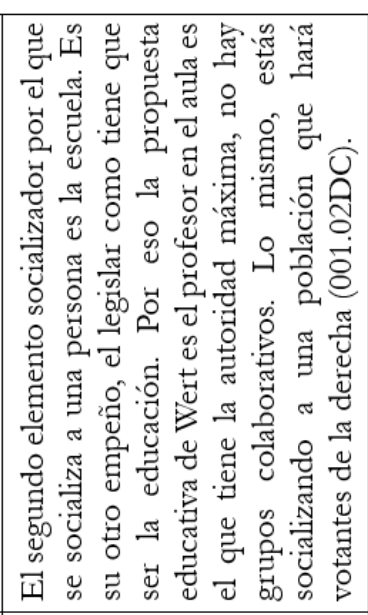 & 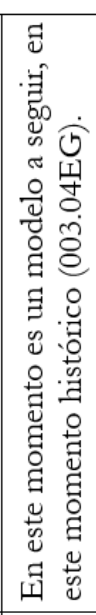 \\
\hline 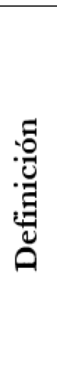 & 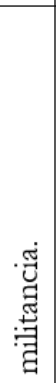 & 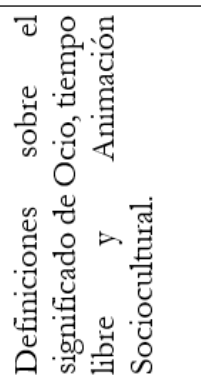 & 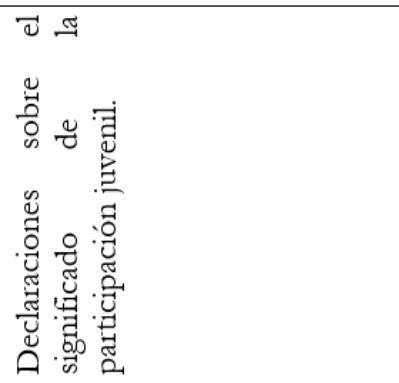 & 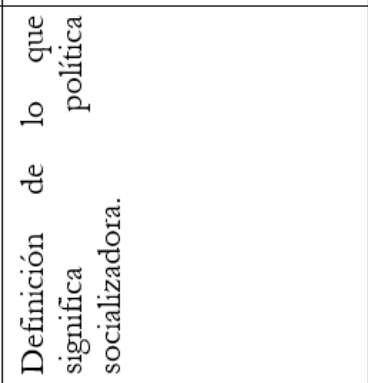 & 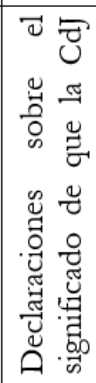 \\
\hline ن' & & 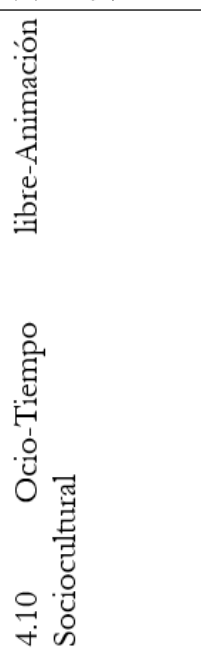 & 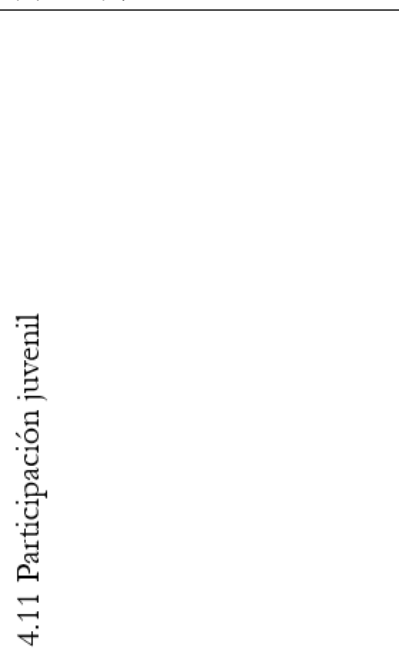 & 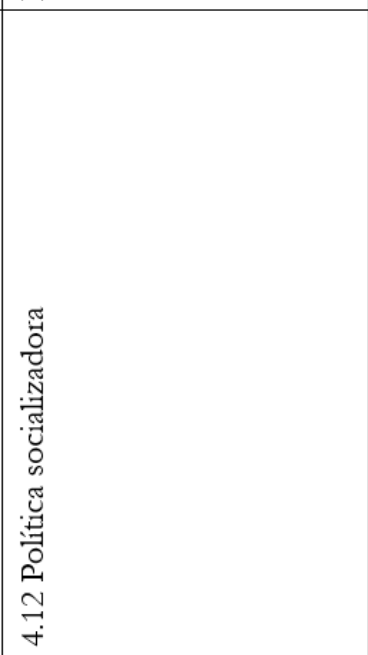 & 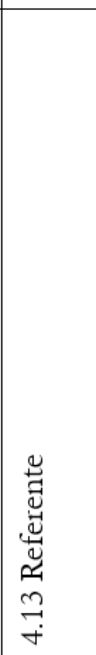 \\
\hline 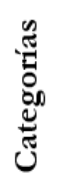 & & & & & \\
\hline
\end{tabular}




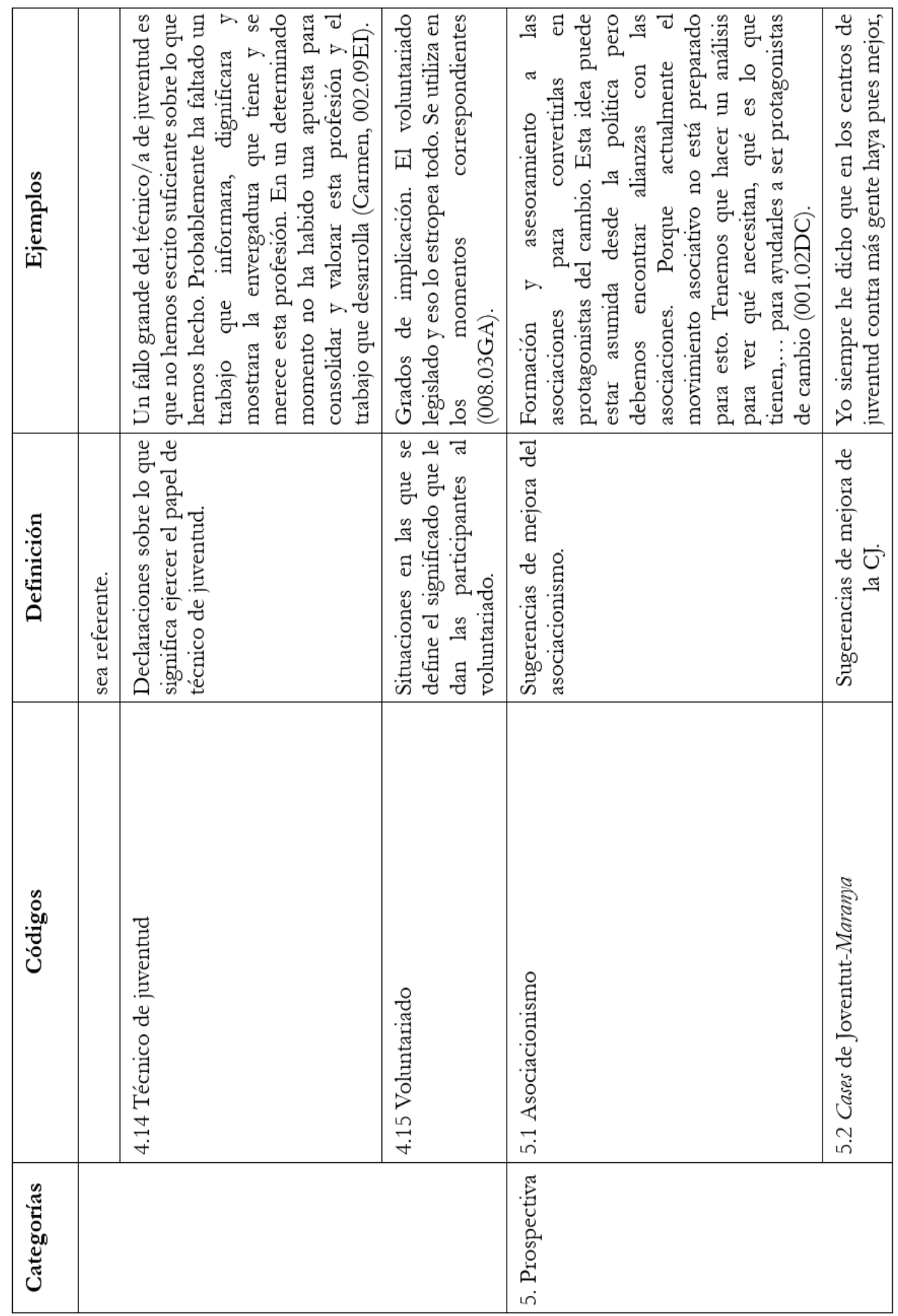




\begin{tabular}{|c|c|c|c|c|}
\hline 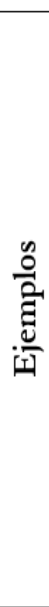 & 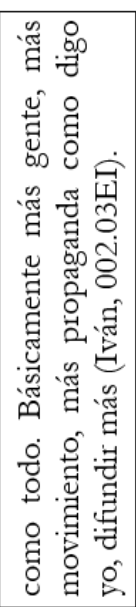 & 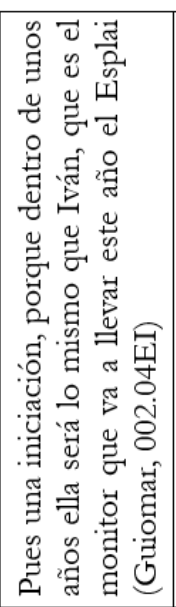 & 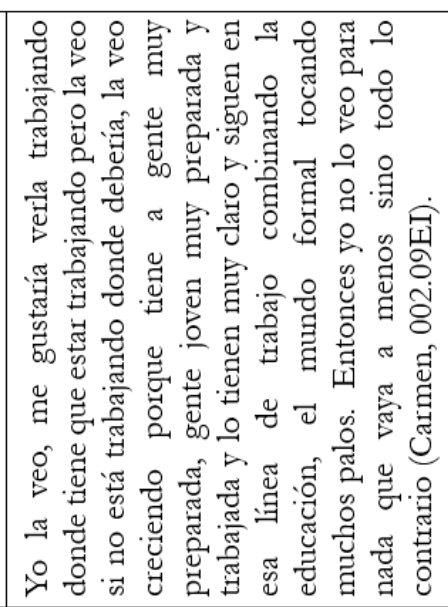 & 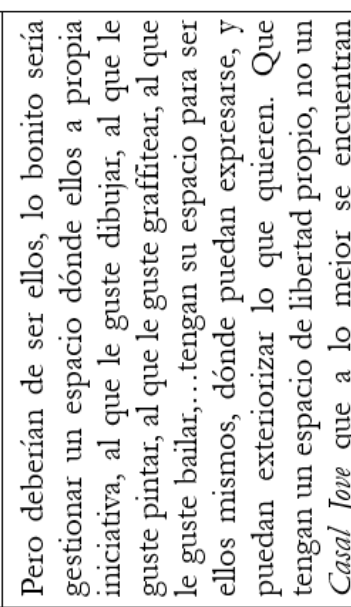 \\
\hline 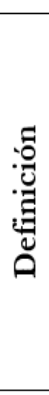 & & 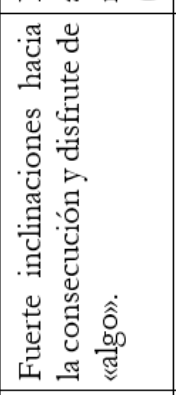 & 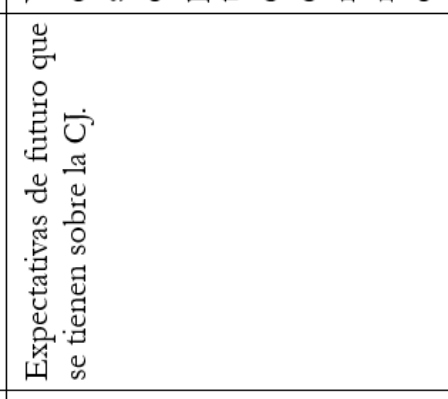 & 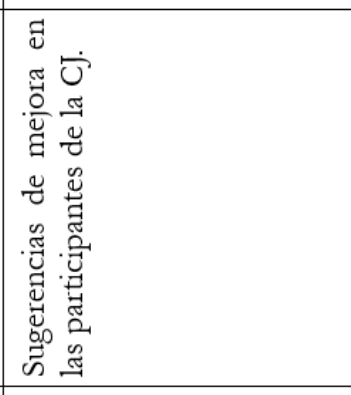 \\
\hline نे & & $\begin{array}{l}0 \\
0 \\
0 \\
\infty \\
0 \\
\text { ñ } \\
\text { in }\end{array}$ & 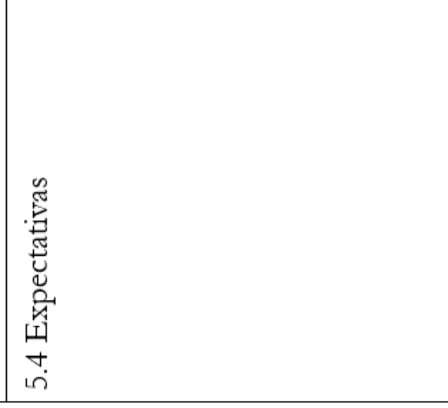 & 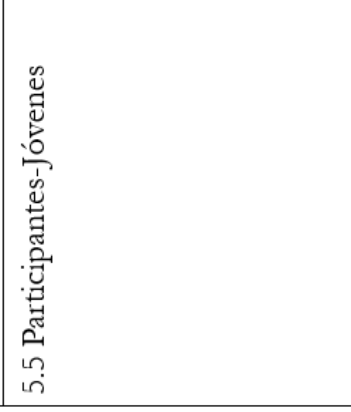 \\
\hline & & & & \\
\hline
\end{tabular}




\begin{tabular}{|c|c|c|c|c|}
\hline 造 & 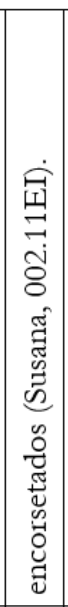 & 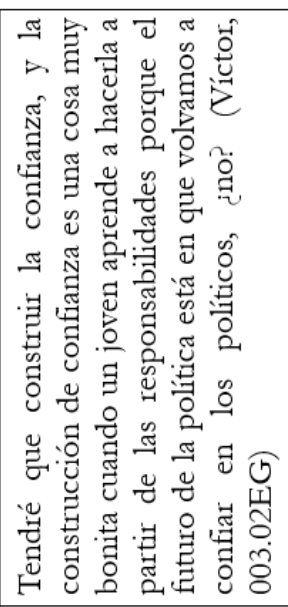 & 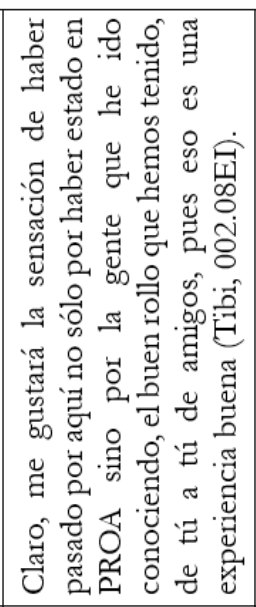 & 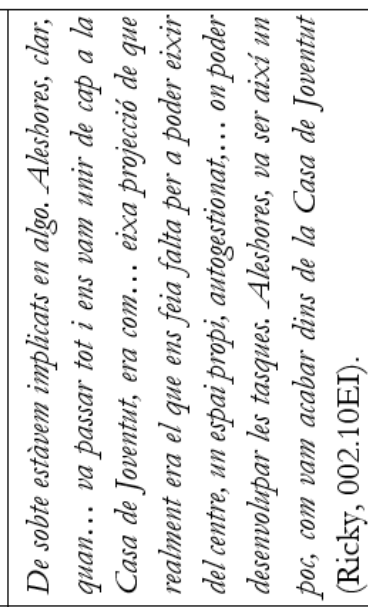 \\
\hline 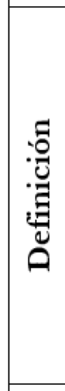 & & 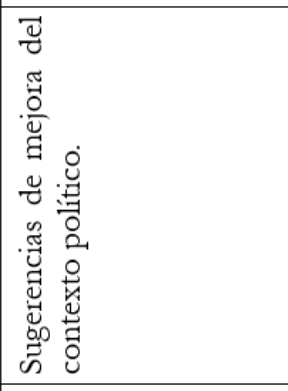 & 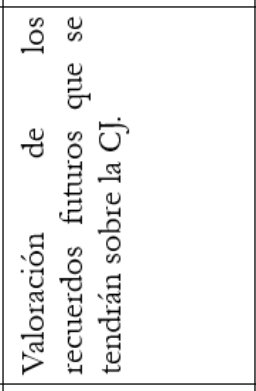 & 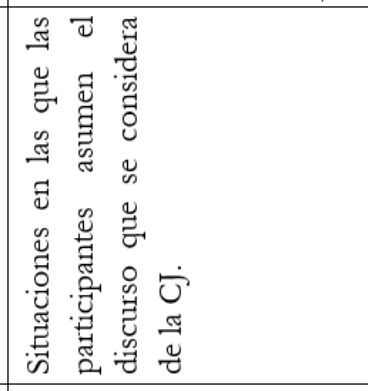 \\
\hline \multirow[t]{2}{*}{ نهّ } & \multirow{2}{*}{\multicolumn{2}{|c|}{ 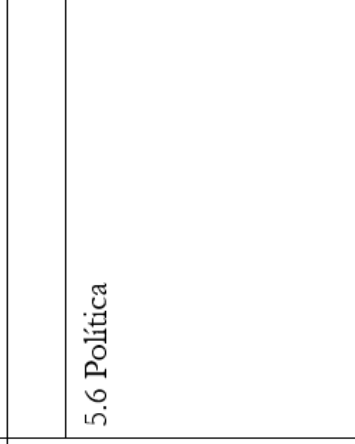 }} & \multirow[b]{2}{*}{ 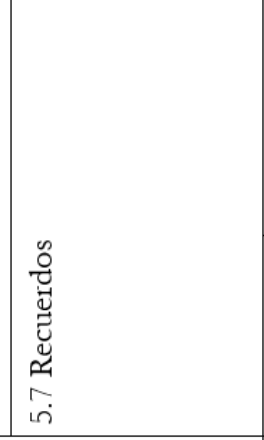 } & 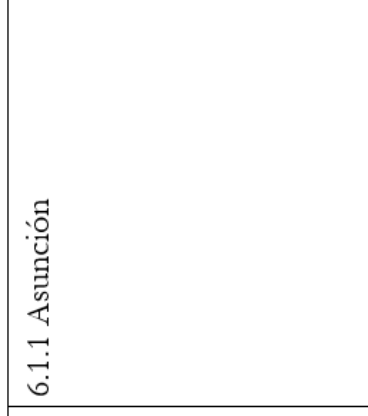 \\
\hline & & & & 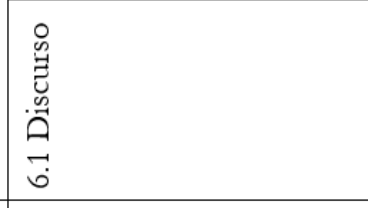 \\
\hline 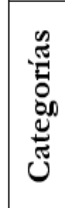 & & & & 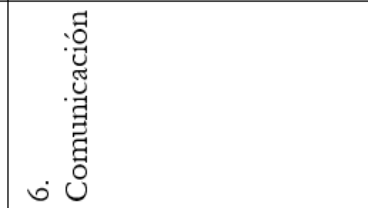 \\
\hline
\end{tabular}




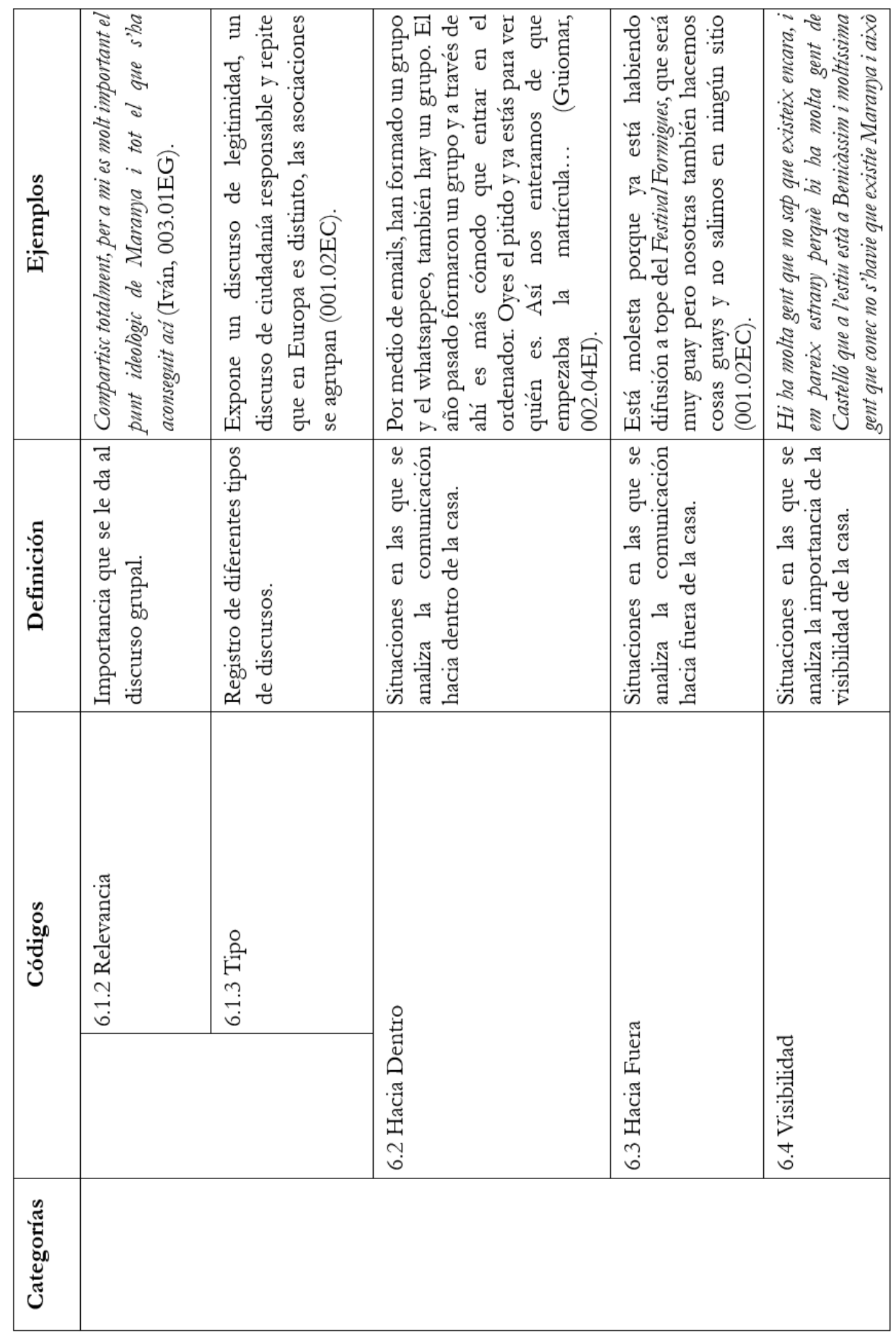




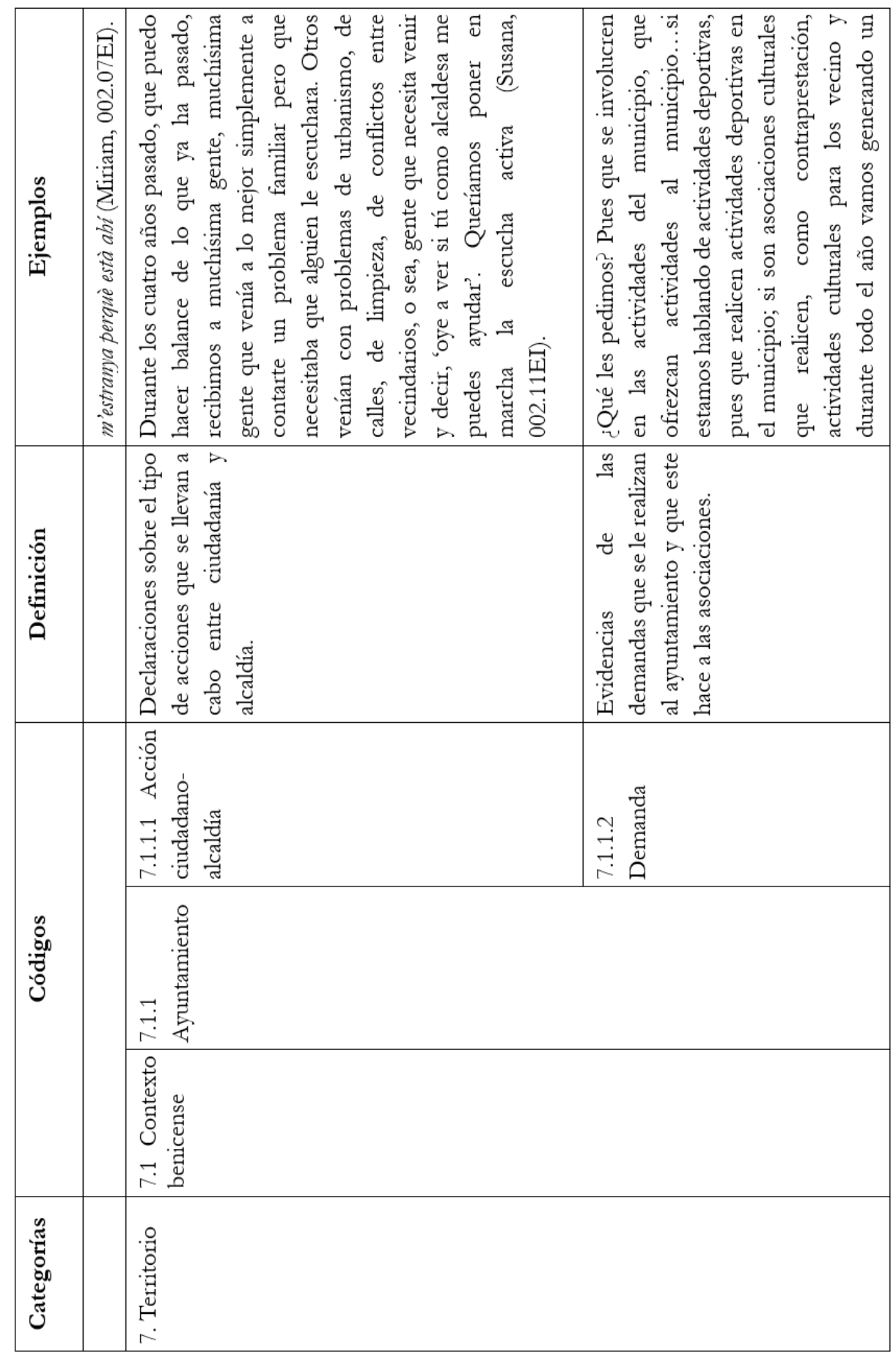




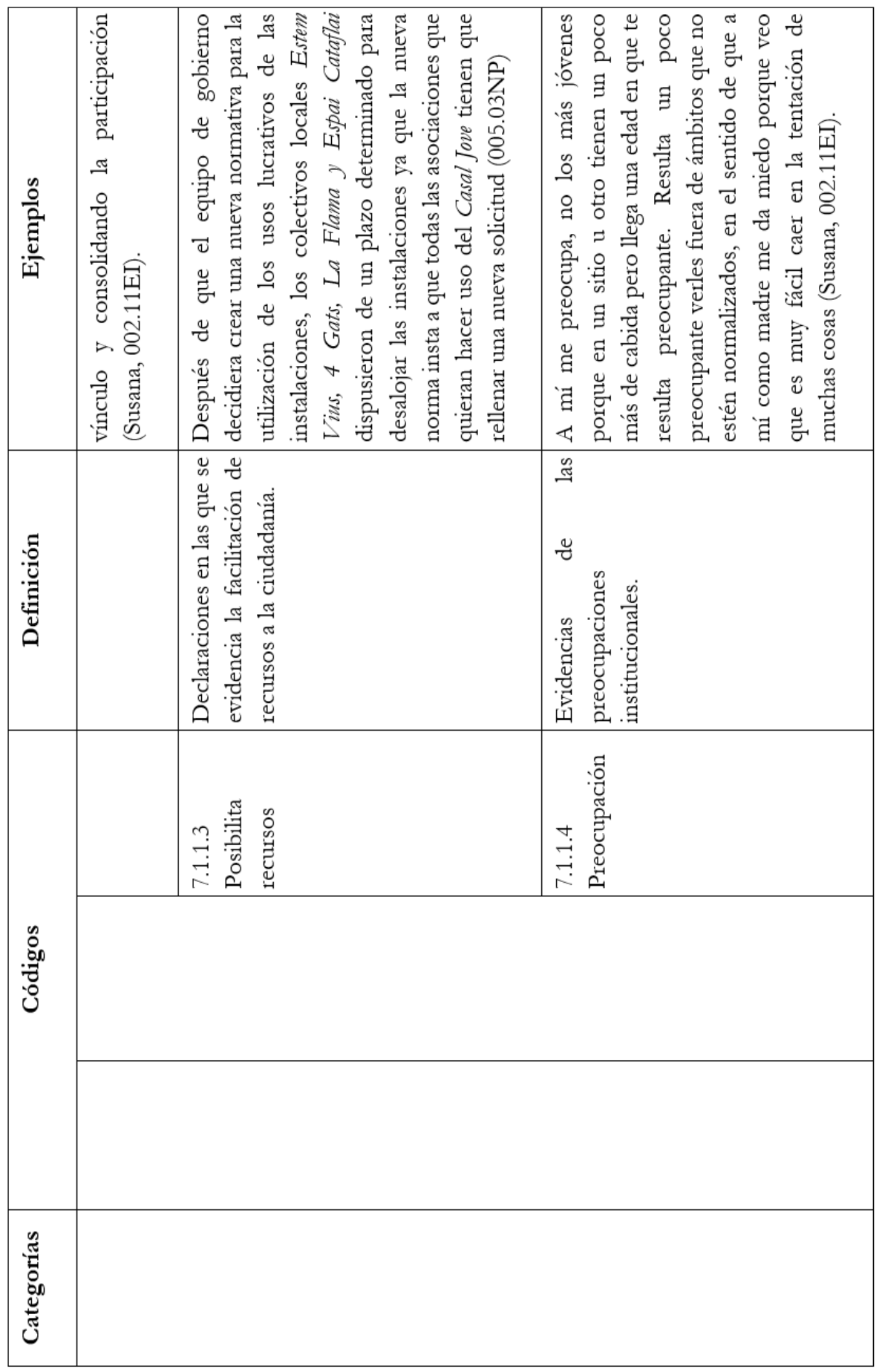




\begin{tabular}{|c|c|c|c|}
\hline & 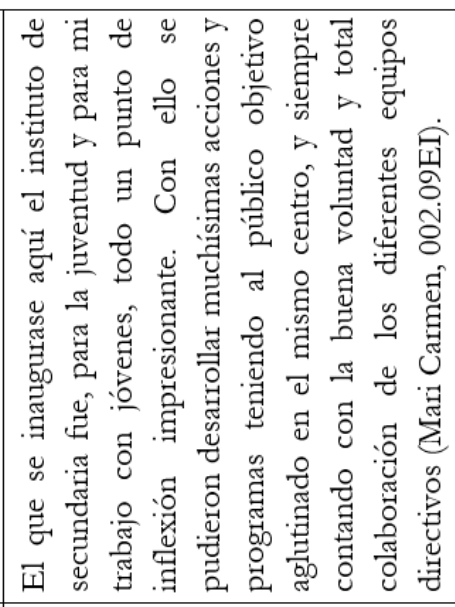 & 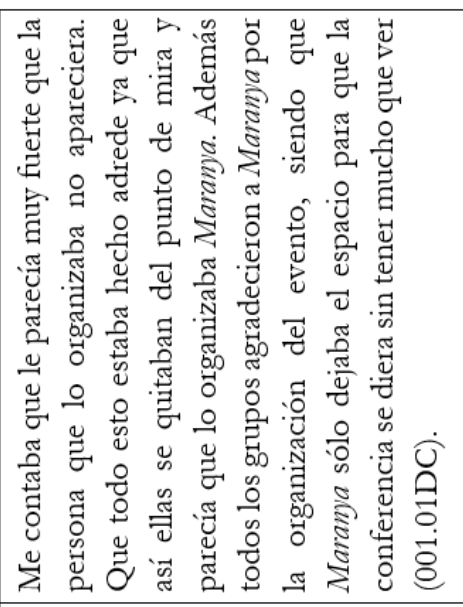 & 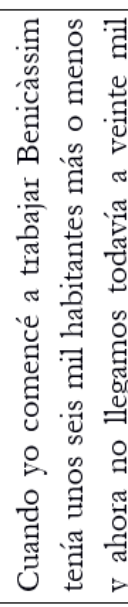 \\
\hline 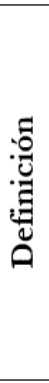 & 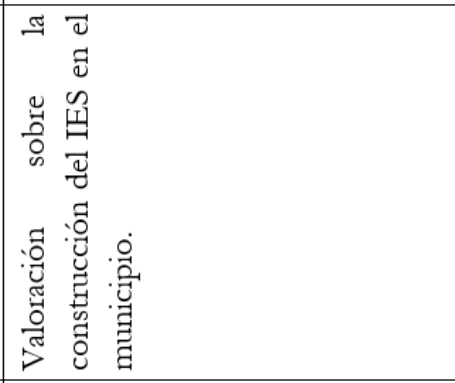 & 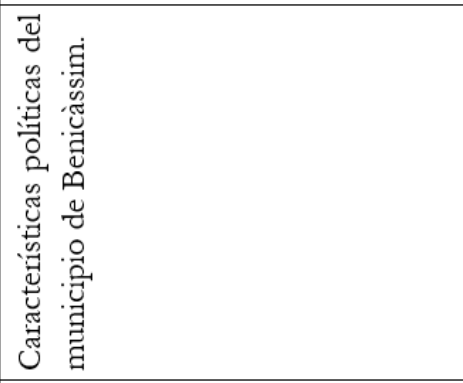 & 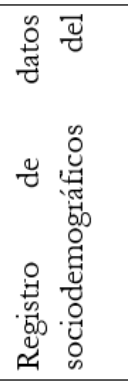 \\
\hline نْ & 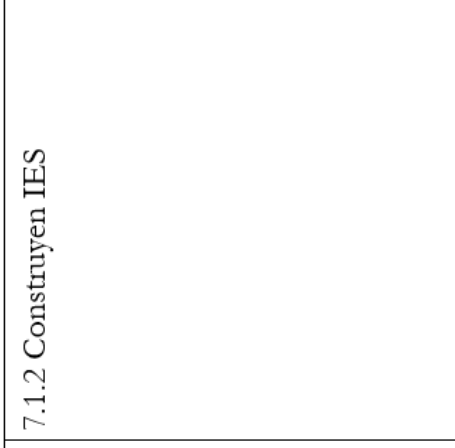 & 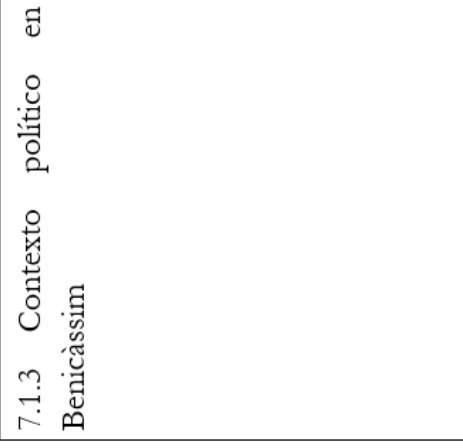 & 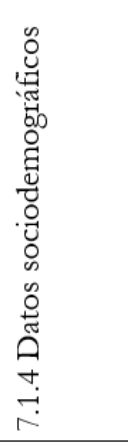 \\
\hline & & & \\
\hline
\end{tabular}




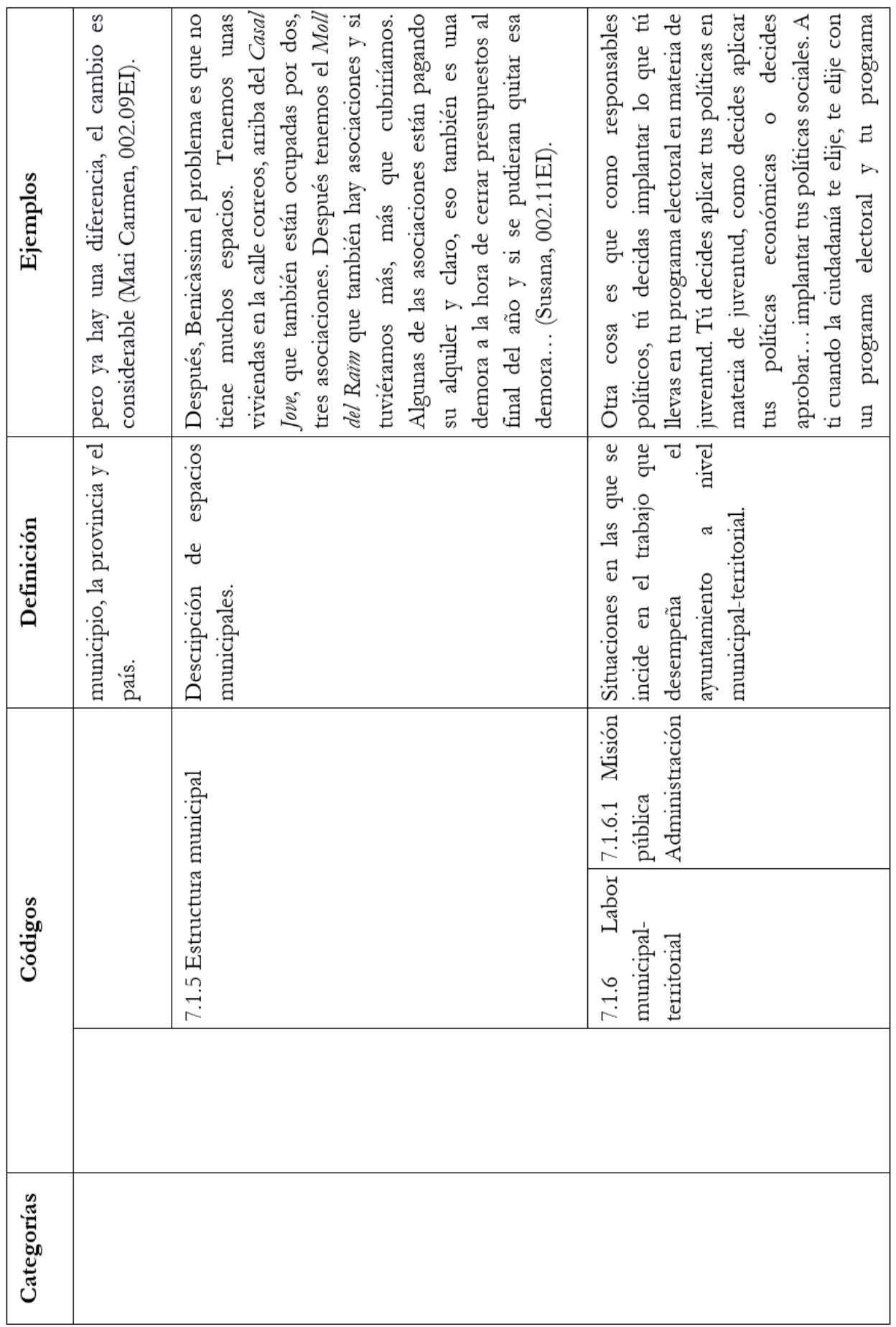




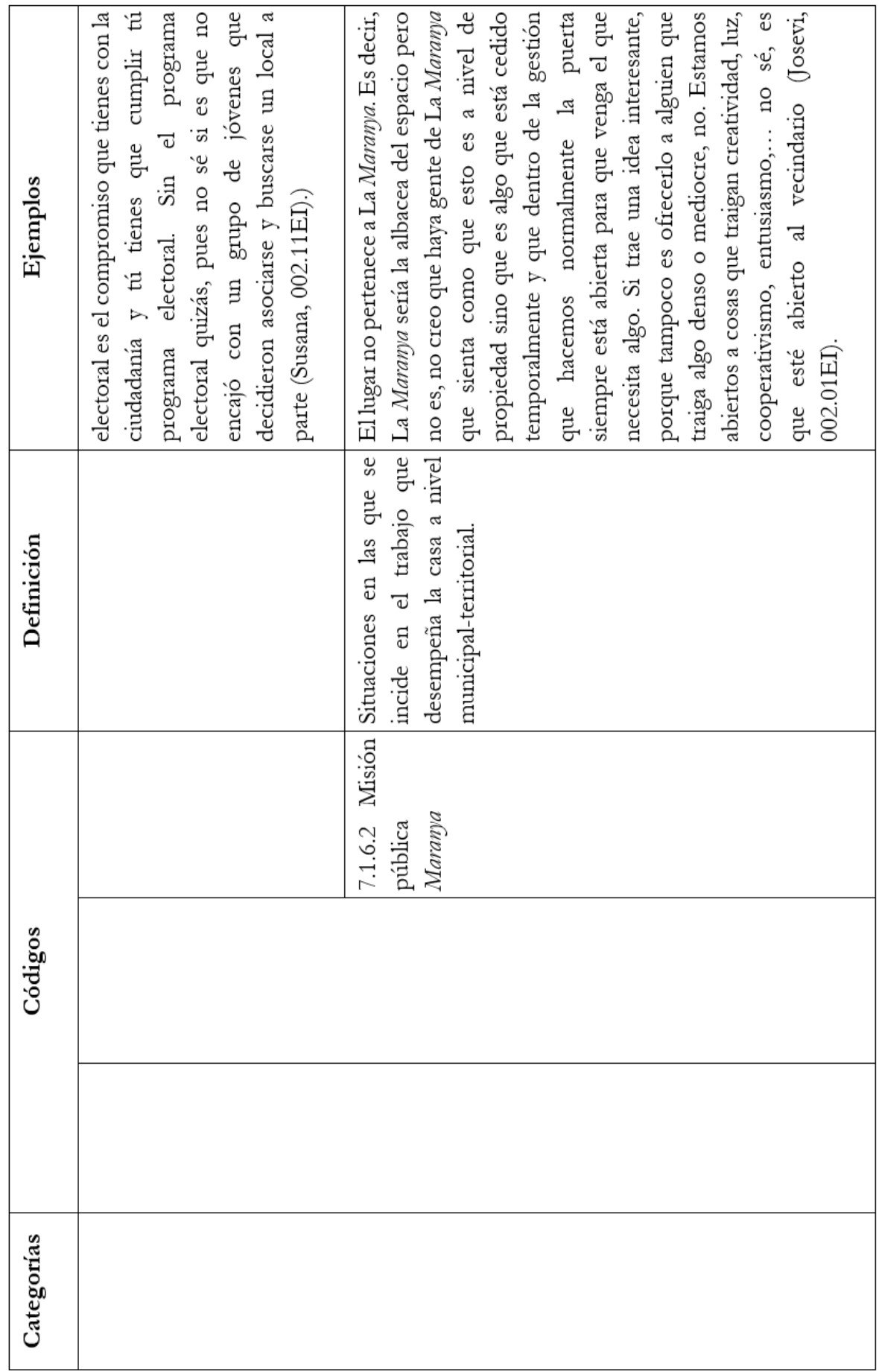




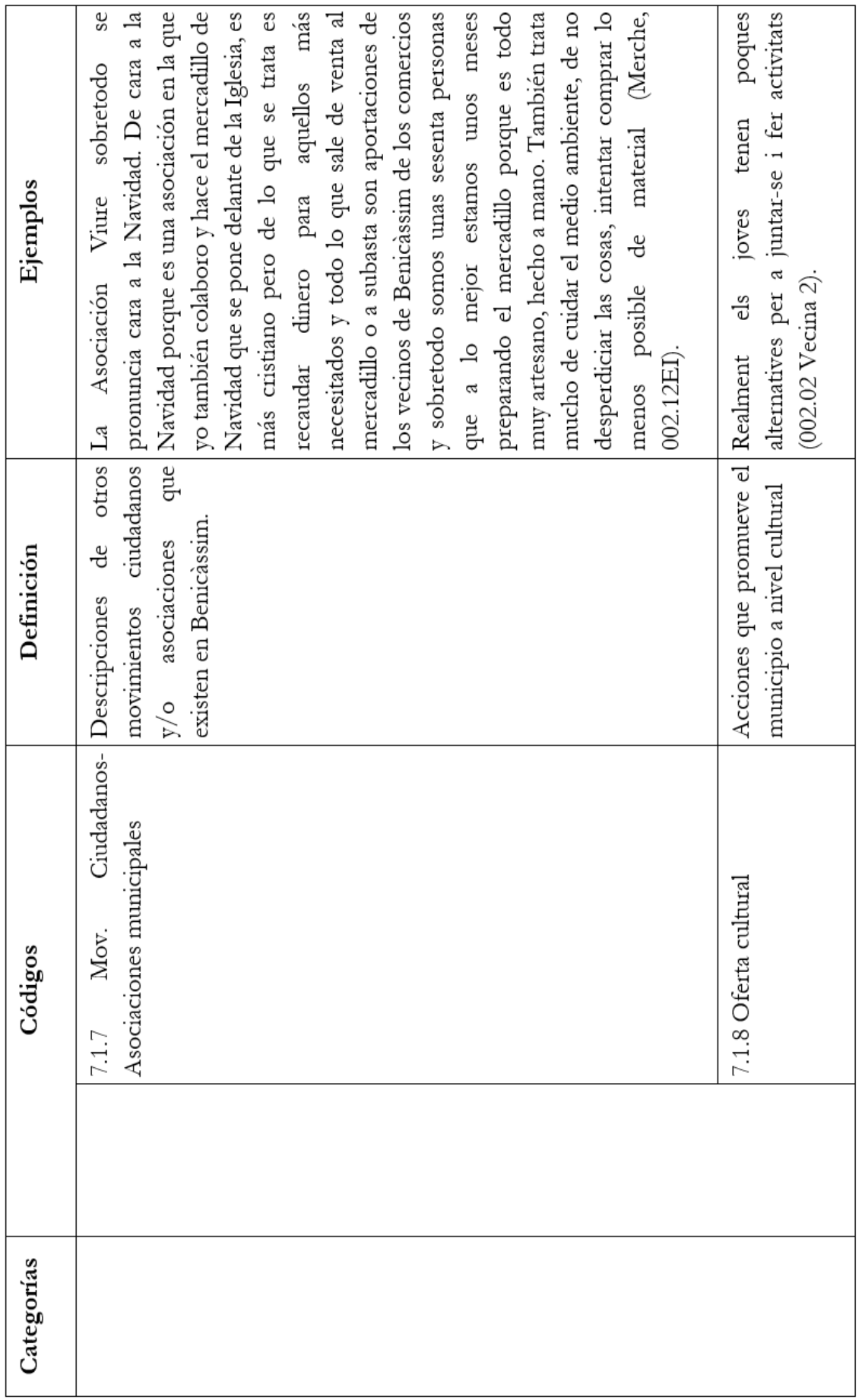




\begin{tabular}{|c|c|c|c|}
\hline$\frac{n}{0}$ & 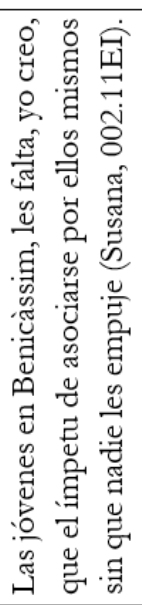 & 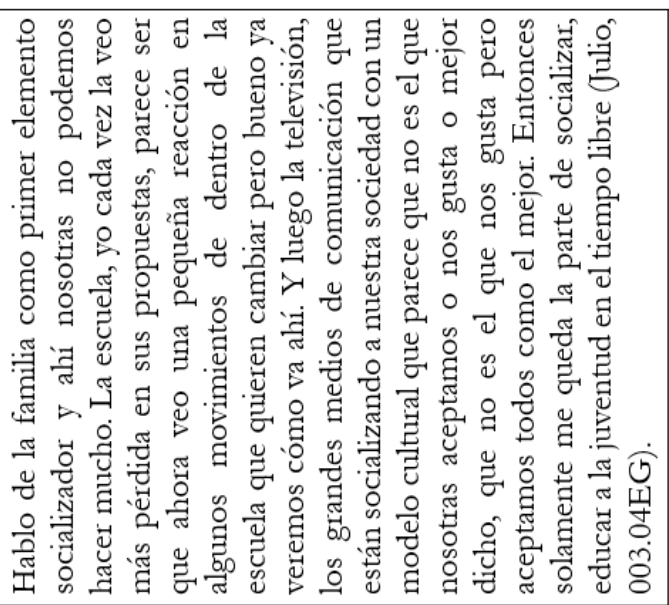 & 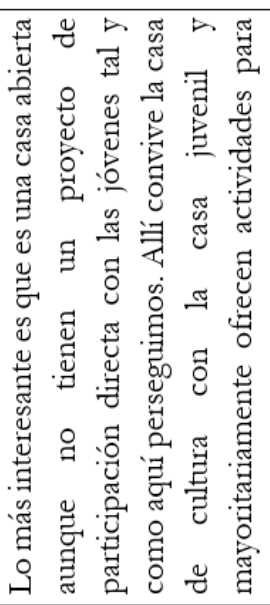 \\
\hline 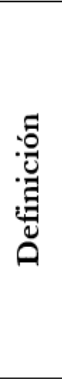 & 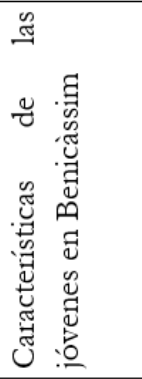 & 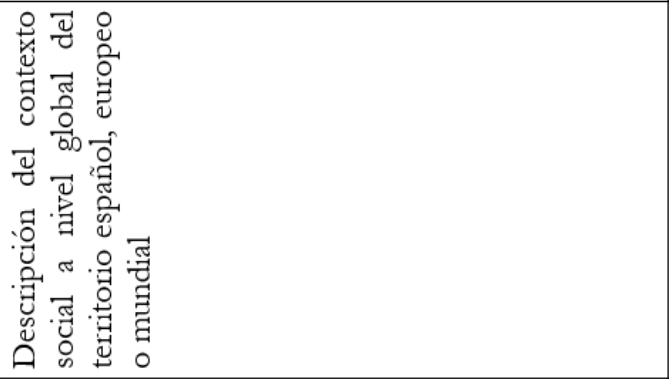 & 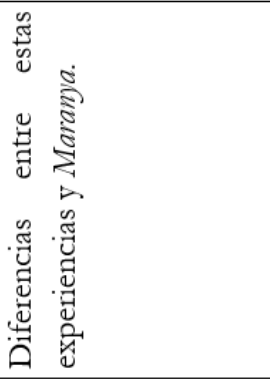 \\
\hline \multirow[t]{2}{*}{ : } & 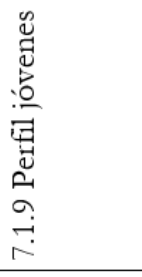 & \multirow{2}{*}{ 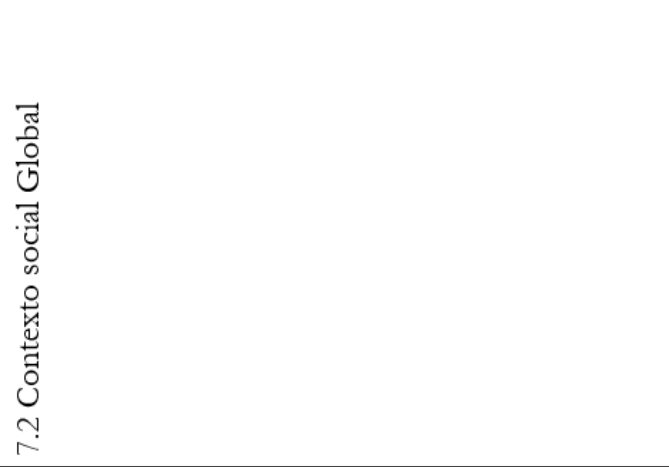 } & 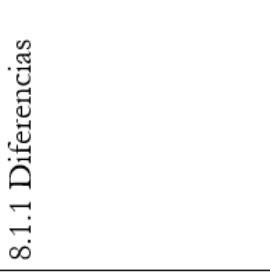 \\
\hline & & & 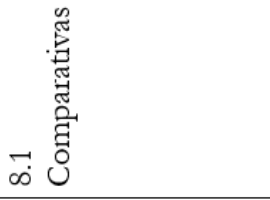 \\
\hline 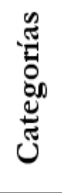 & & & 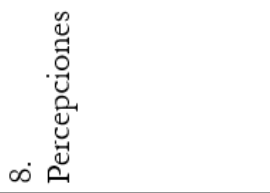 \\
\hline
\end{tabular}




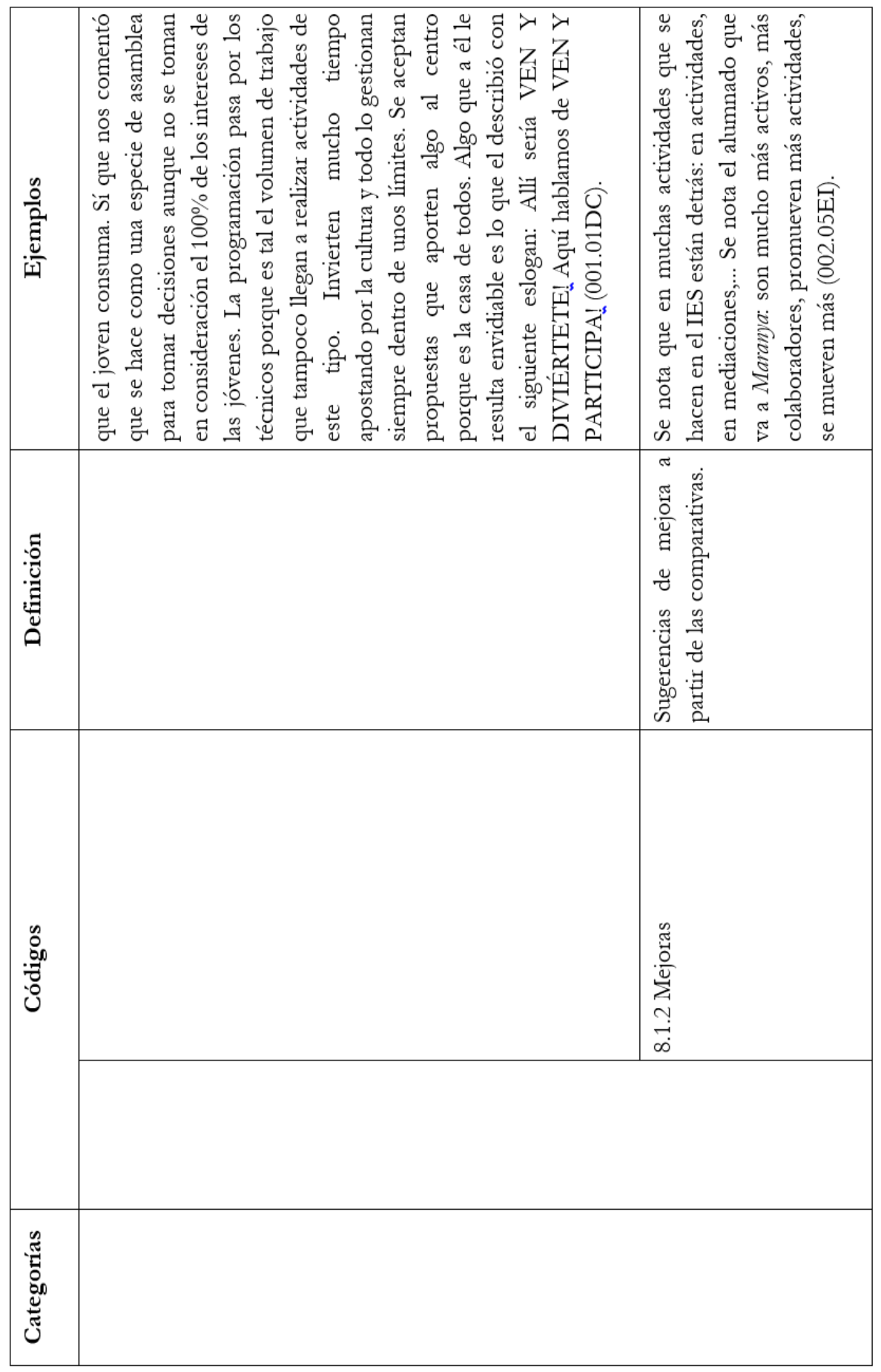




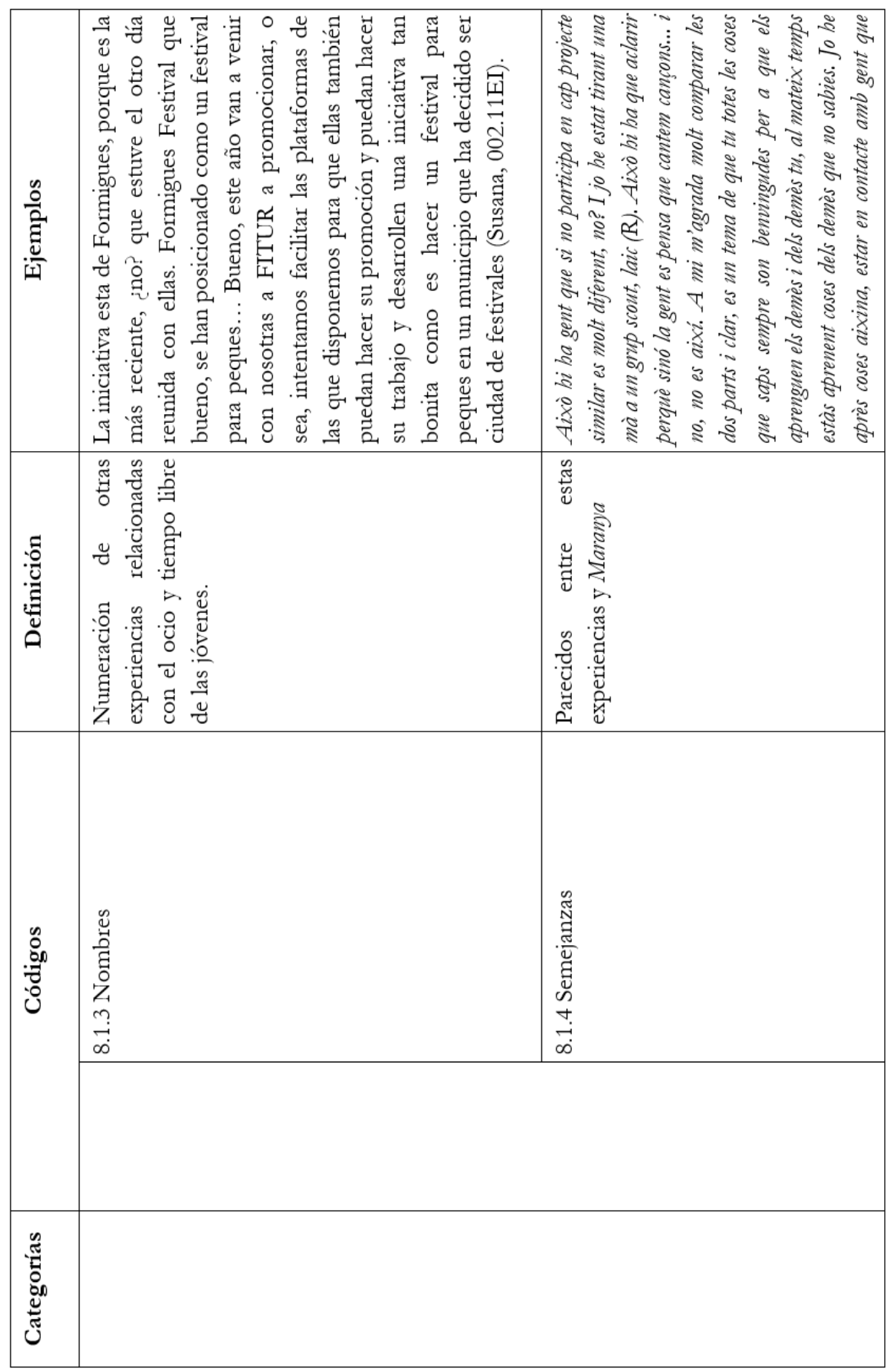




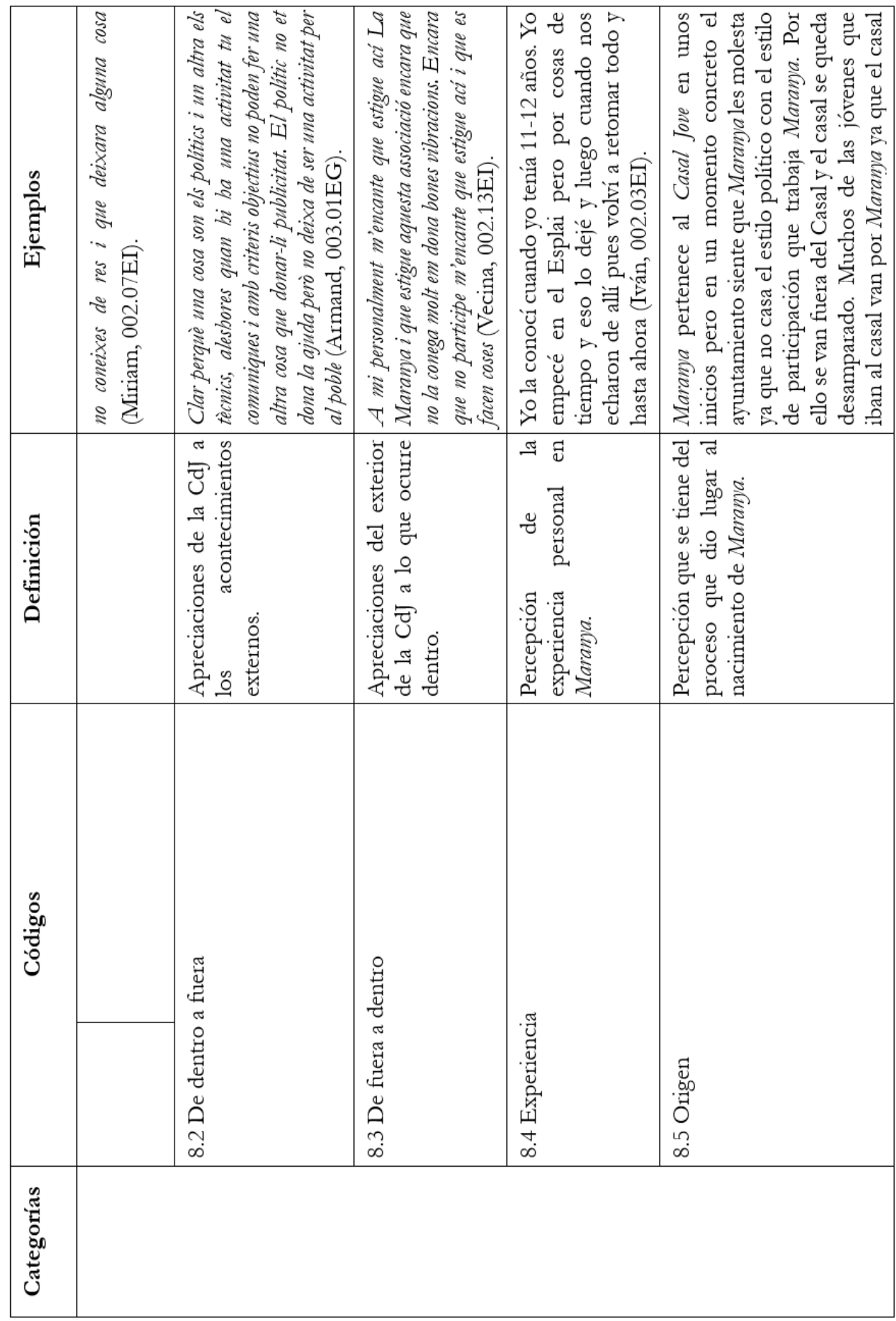




\begin{tabular}{|c|c|c|c|}
\hline 离 & 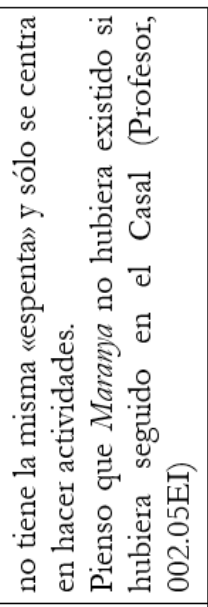 & 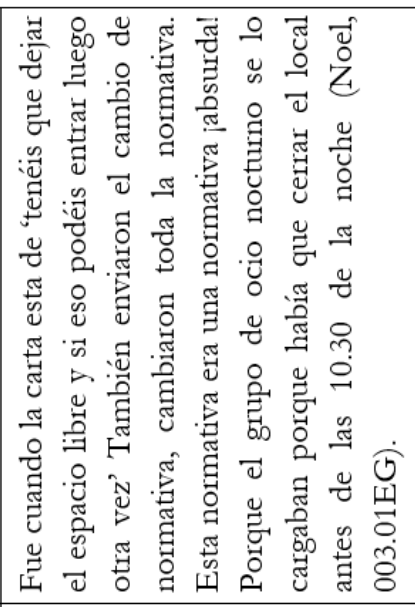 & 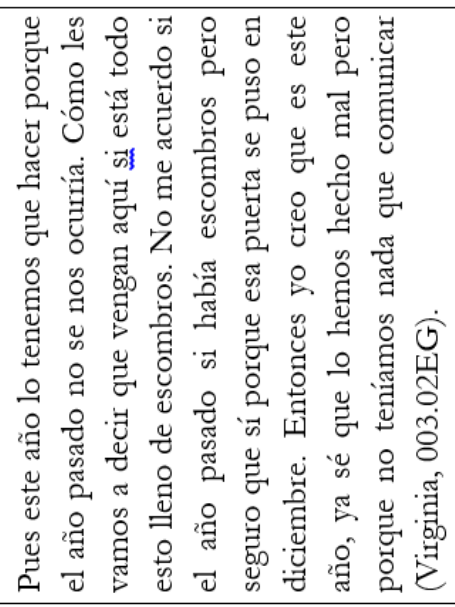 \\
\hline & & 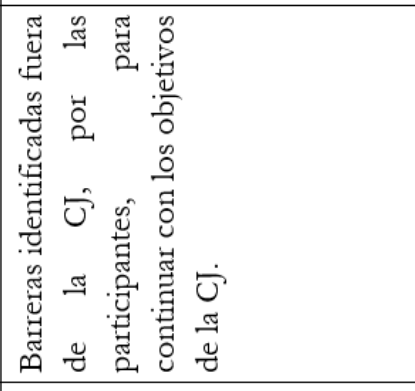 & 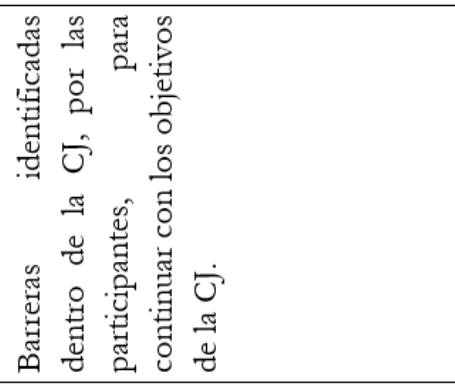 \\
\hline \multirow[t]{2}{*}{ ن } & & 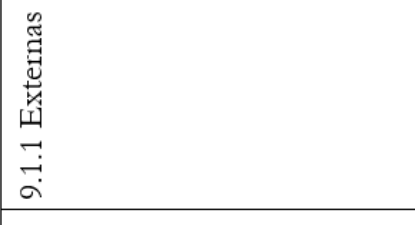 & 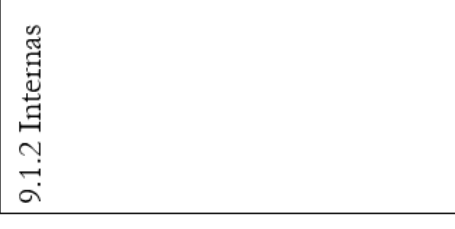 \\
\hline & & 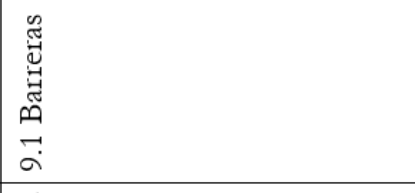 & \\
\hline 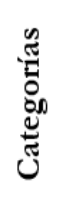 & & 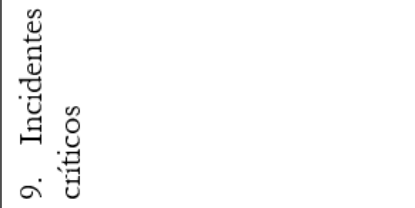 & \\
\hline
\end{tabular}




\begin{tabular}{|c|c|c|c|c|}
\hline 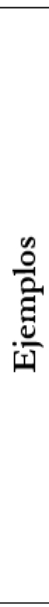 & 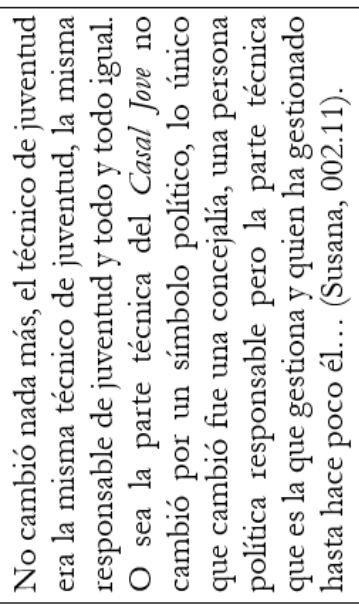 & 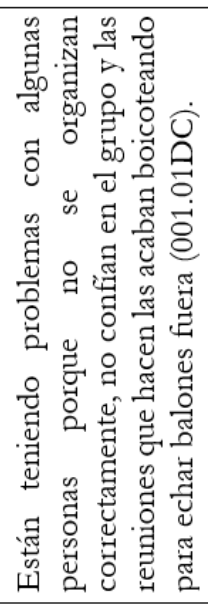 & 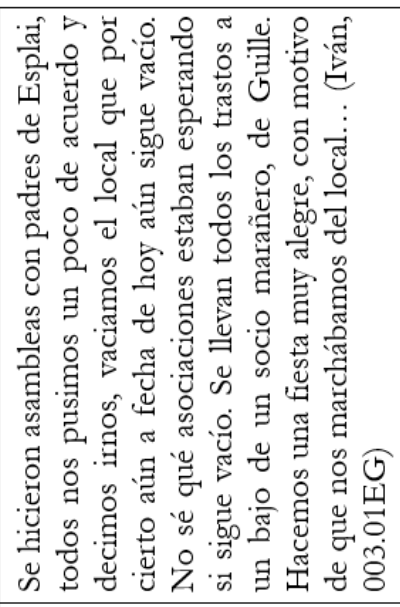 & 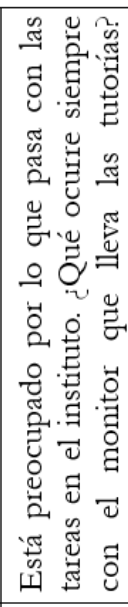 \\
\hline 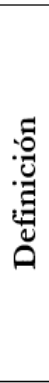 & 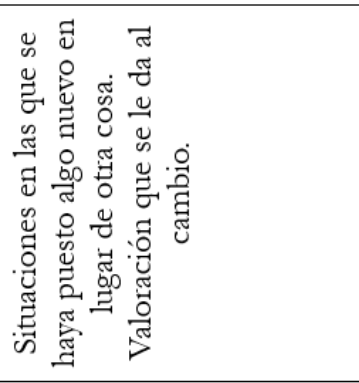 & 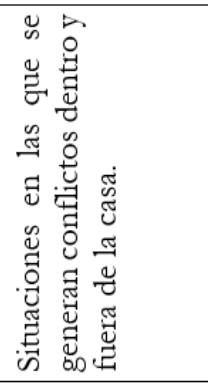 & 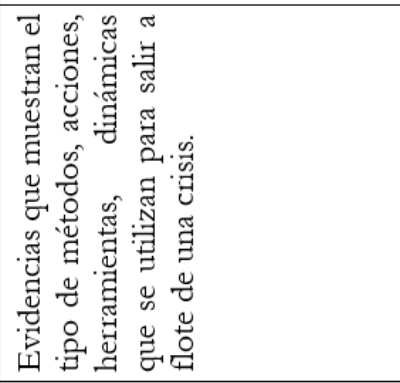 & 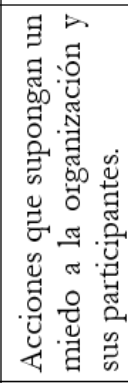 \\
\hline ن' & 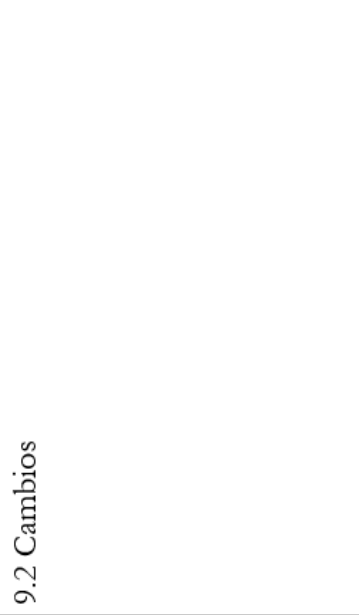 & 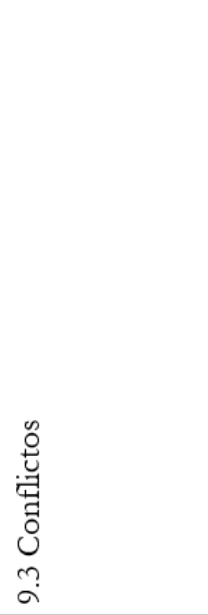 & 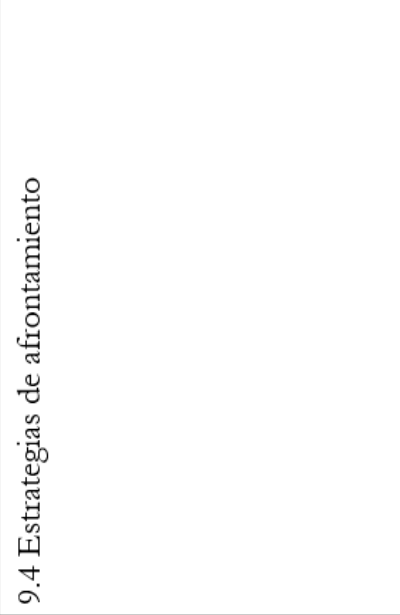 & 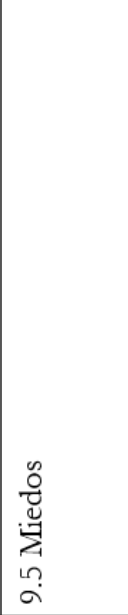 \\
\hline & & & & \\
\hline
\end{tabular}




\begin{tabular}{|c|c|c|c|c|c|}
\hline$\frac{\varrho}{\stackrel{0}{a}}$ & $\begin{array}{l}\text { ठิ } \\
\text { बे } \\
\dot{8} \\
\dot{8}\end{array}$ & 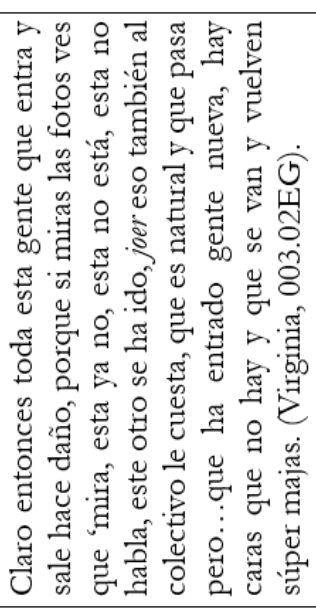 & 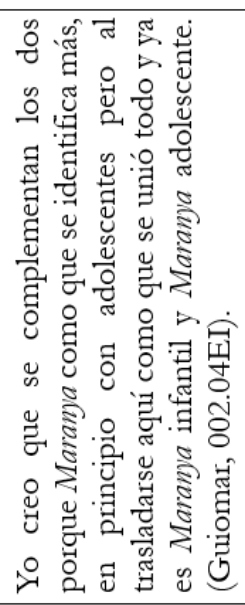 & 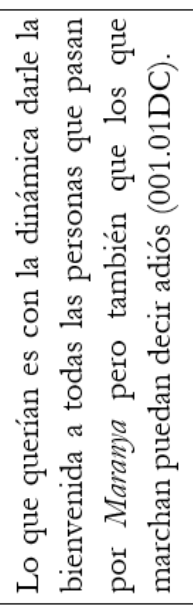 & 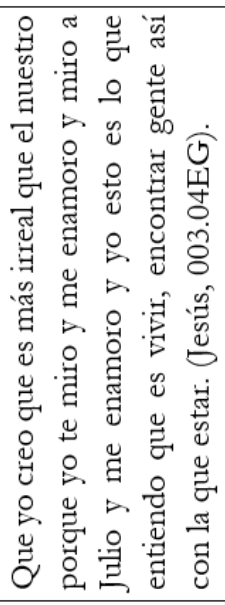 \\
\hline 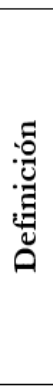 & & 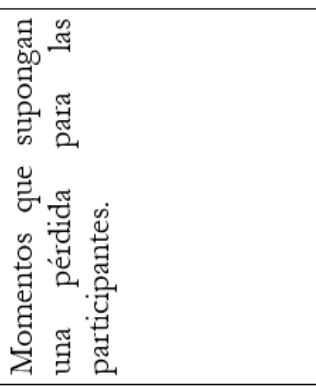 & 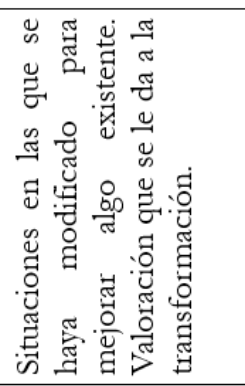 & 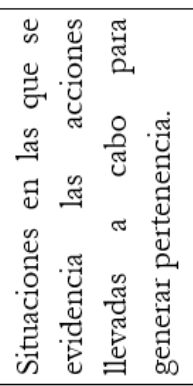 & 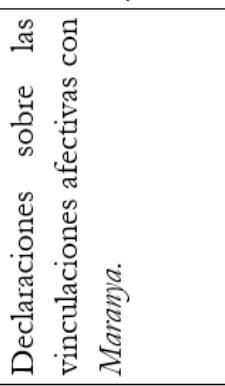 \\
\hline ن & & 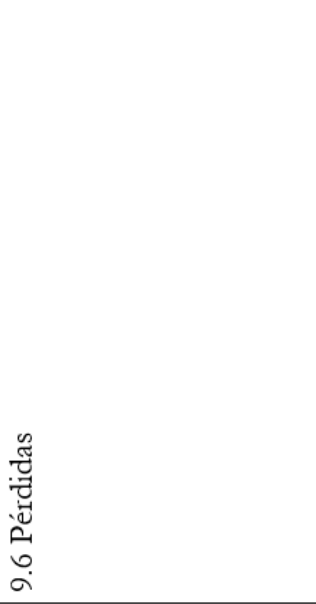 & 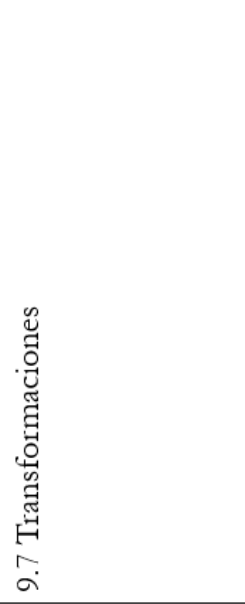 & 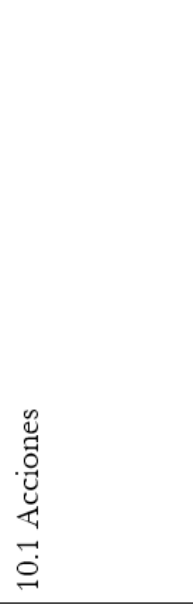 & 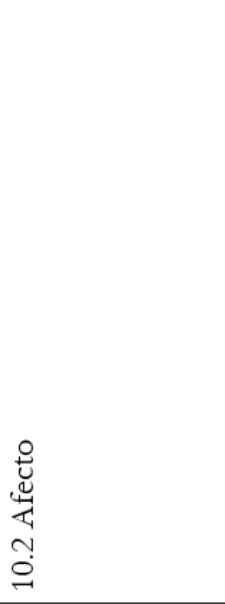 \\
\hline 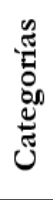 & & & & ○. & \\
\hline
\end{tabular}




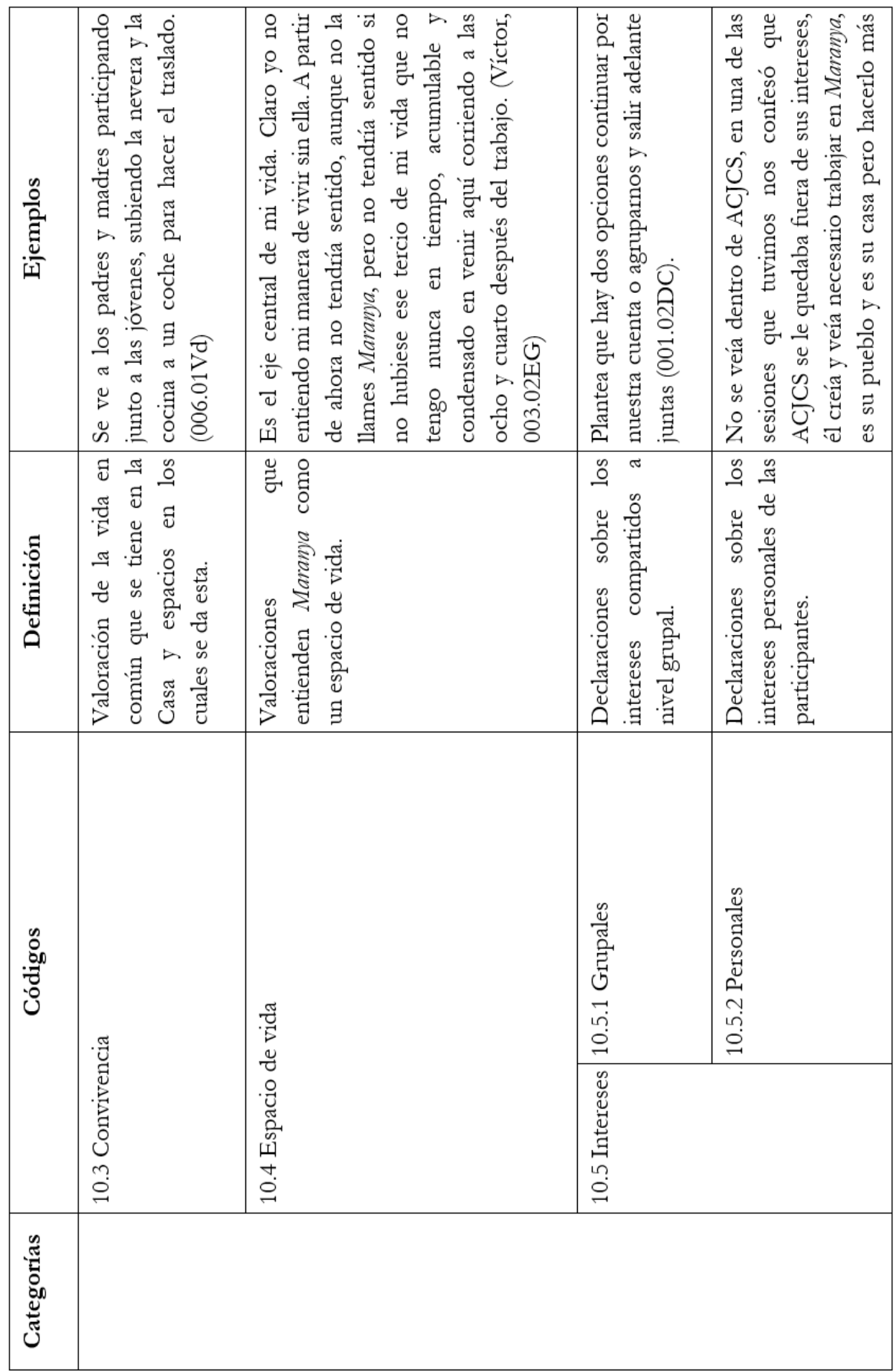




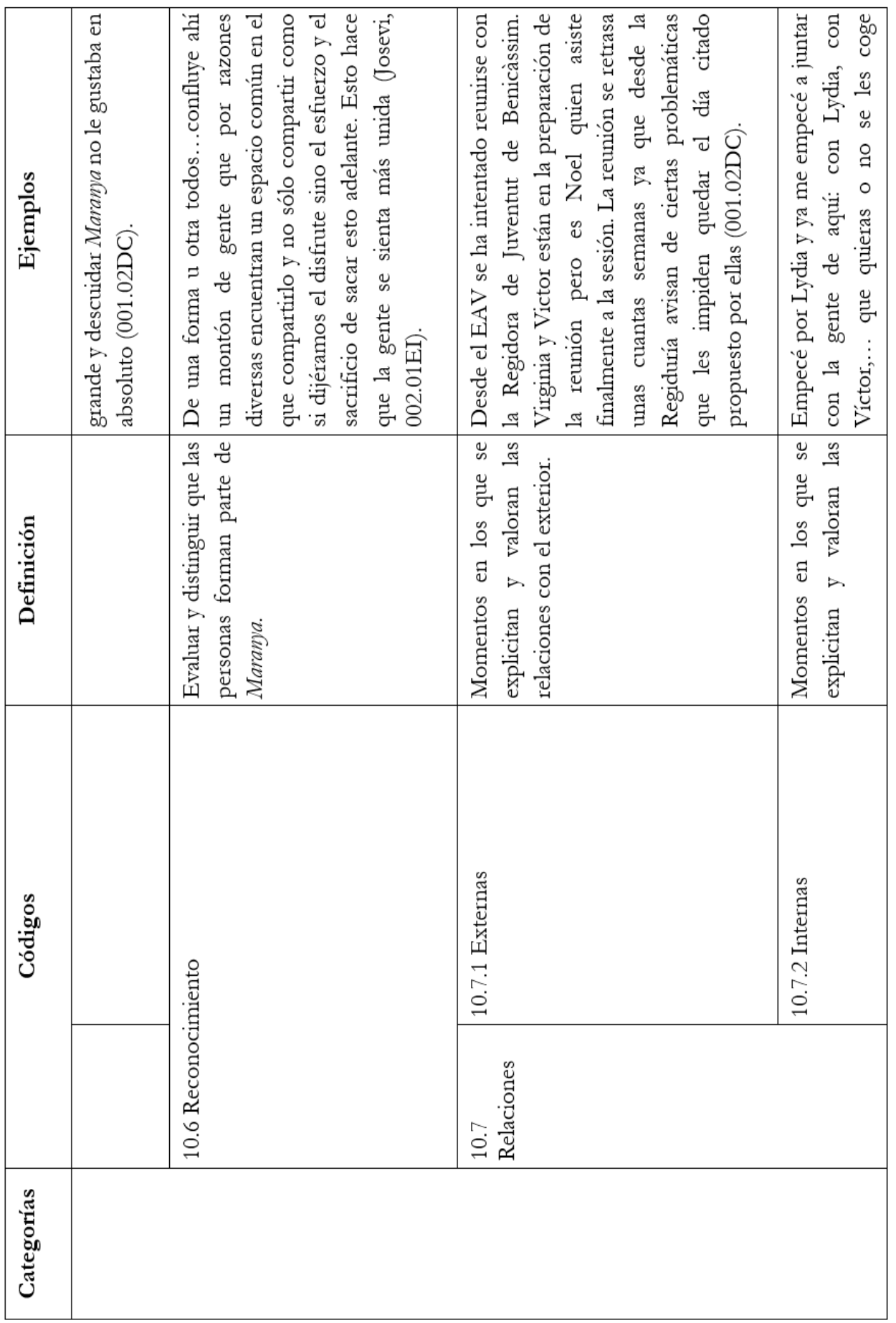




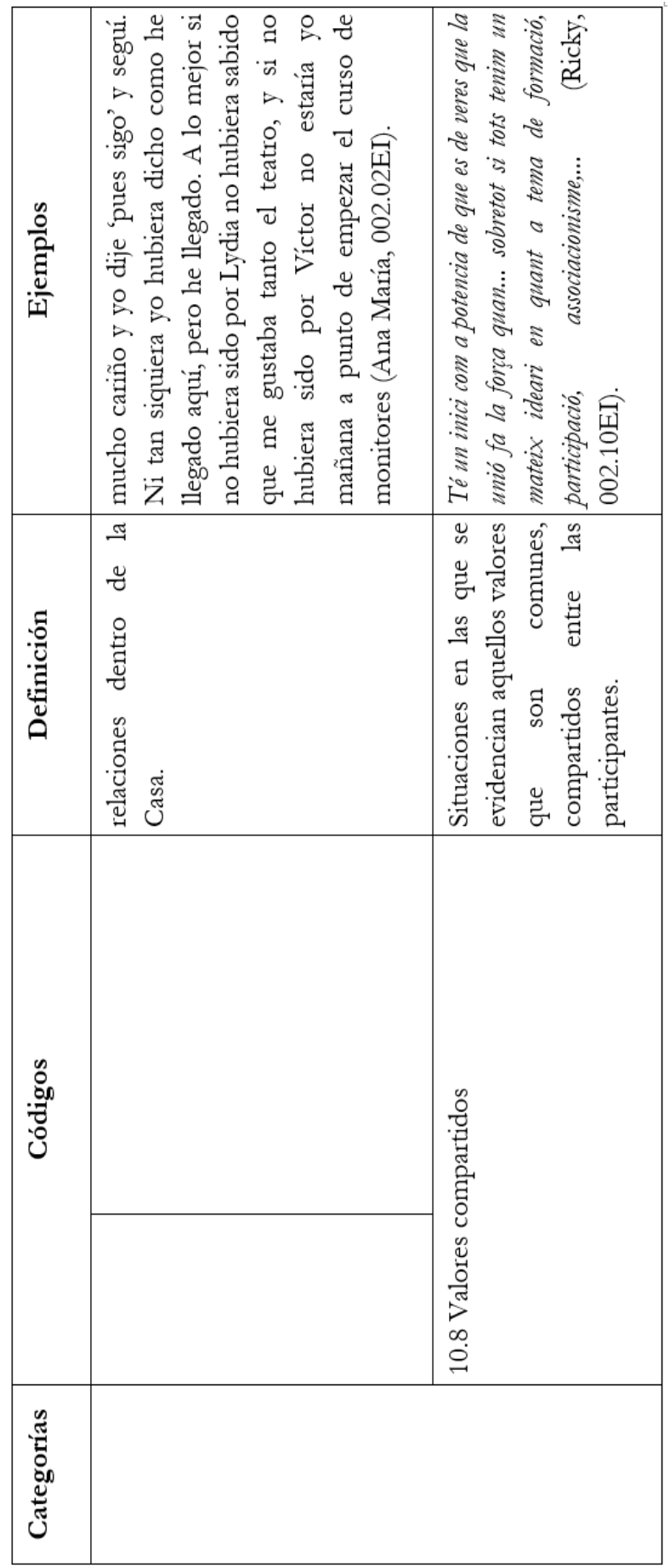




\section{AJUNTAMENT DE BENICÀSIM \\ Concejalia de Juventud}

ATT:

Estimados/as jóvenes:

Para dinamizar eficazmente el Espacio Asociativo del Casal Jove de nuestra localidad, como sabrás, anualmente se revisa cada solicitud, para detectar los posibles cambios en los grupos o asociaciones que ocupan cada uno de los espacios susceptibles de cesión. Por esto y atendiendo a la antigua normativa interna para el uso y cesión de los Espacios Asociativos (artículo 9), rogamos que lo más pronto posible nos comuniquéis por escrito cualquier cambio producido en el grupo del que eres responsable.

Se adjunta la nueva Instrucción de Alcaldía (16/2011) con las nuevas "Normas de utilización de los espacios asociativos del Casal Jove"con algunas novedades para que las tengáis en consideración y, si continuáis interesados, podáis renovar la solicitud del uso del Espacio informando de los cambios pertinentes, si los hubiera.

Como veréis, uno de los cambios más significativos está en el sistema de disposición de las llaves y la adecuación del espacio para poderlo compartir con otros grupos y/o asociaciones de diversa índole; por ello a partir del 31 de octubre se retirarán las llaves del lugar habitual. Hasta esa fecha tenéis tiempo suficiente para ir renovando las solicitudes y poder adecuar y acondicionar de nuevo los espacios dejándolos tal y como estaban en un principio cuando se cedieron.

$\mathrm{Y}$ para que conste y surtan los efectos oportunos, firma el presente en Benicàssim a veinte de octubre de dos mil doce.

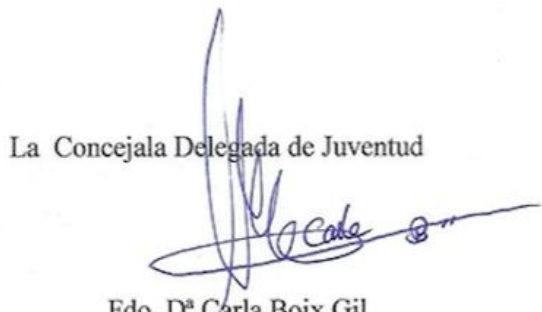

Fdo. D Carla Boix Gil 
Anexo 14. Listados de códigos y acrónimos de las herramientas utilizadas.

\begin{tabular}{|c|c|c|c|}
\hline CÓDIGO & ACRÓNIMO & NOMBRE & DESCRIPCIÓN \\
\hline 001 & $\mathrm{DC}$ & $\begin{array}{l}\text { Diario de } \\
\text { Campo }\end{array}$ & $\begin{array}{l}\text { Cuaderno mediante el cual, la } \\
\text { investigadora, recoge todas aquellas } \\
\text { vivencias, experiencias, percepciones, } \\
\text { actividades del día a día en Maranya. }\end{array}$ \\
\hline 002 & EI & $\begin{array}{l}\text { Entrevistas } \\
\text { individuales }\end{array}$ & $\begin{array}{l}\text { Entrevistas individuales con el objetivo } \\
\text { de recoger información sobre el origen e } \\
\text { historia de Maranya. }\end{array}$ \\
\hline 003 & $\overline{E G}$ & $\begin{array}{l}\text { Entrevistas } \\
\text { grupales }\end{array}$ & $\begin{array}{l}\text { Entrevista grupal con el objetivo de } \\
\text { recoger información sobre el origen e } \\
\text { historia de Maranya. }\end{array}$ \\
\hline 004 & $\mathrm{PE}$ & $\begin{array}{l}\text { Proyectos } \\
\text { Educativos }\end{array}$ & $\begin{array}{l}\text { Proyectos educativos de la Casa de } \\
\text { Joventut La Maranya que han sido } \\
\text { redactados por el EAV para marcar la } \\
\text { línea de trabajo en la asociación. }\end{array}$ \\
\hline 005 & NP & $\begin{array}{ll}\text { Notas } & \text { de } \\
\text { prensa }\end{array}$ & $\begin{array}{l}\text { Noticias que salen en prensa en relación } \\
\text { directa con la Casa. }\end{array}$ \\
\hline 006 & $\mathrm{Vd}$ & Vídeos & $\begin{array}{l}\text { Videos elaborados por alguno de los } \\
\text { grupos estables de Maranya. }\end{array}$ \\
\hline 007 & $\mathrm{Ft}$ & Fotografías & $\begin{array}{l}\text { Fotografías elaboradas y seleccionadas } \\
\text { por miembros de Maranya para } \\
\text { completar el hilo histórico de la Casa. }\end{array}$ \\
\hline 008 & GA & $\begin{array}{l}\text { Grupo } \\
\text { Asesor }\end{array}$ & $\begin{array}{l}\text { Grupo asesor de la investigación que } \\
\text { participa en el diseño y revisión del } \\
\text { estudio. }\end{array}$ \\
\hline $009-016$ & $\mathrm{Dm}$ & $\begin{array}{l}\text { Documentaci } \\
\text { ón Maranya }\end{array}$ & $\begin{array}{l}\text { Actuaciones de reivindicación, protesta o } \\
\text { visibilización; actas de reuniones; } \\
\text { evaluaciones, otros. }\end{array}$ \\
\hline 010 & $\mathrm{DF}$ & $\begin{array}{l}\text { Documentos } \\
\text { Federación }\end{array}$ & $\begin{array}{l}\text { Documentos de la FVCJ que } \\
\text { contextualizan y enmarcan el movimiento } \\
\text { juvenil valenciano. }\end{array}$ \\
\hline
\end{tabular}

\begin{tabular}{|l|l|l|l|l|}
\hline \multicolumn{2}{|l|}{ DIARIO DE CAMPO } \\
\hline CÓDIGO & ACRÓNIMO & NOMBRE & FECHA Inicio & FECHA Fin \\
\hline 001.01 & DC & Diario de campo & $24 / 07 / 2013$ & $26 / 09 / 2014$ \\
\hline 001.02 & DC & Diario de campo & $01 / 10 / 2014$ & $21 / 08 / 2016$ \\
\hline
\end{tabular}




\begin{tabular}{|c|c|c|c|c|}
\hline \multicolumn{5}{|c|}{ ENTREVISTAS INDIVIDUALES } \\
\hline $\begin{array}{l}\text { CÓDI } \\
\text { GO }\end{array}$ & $\begin{array}{l}\text { ACRÓN } \\
\text { IMO }\end{array}$ & NOMBRE & PARTICIPANTES & $\begin{array}{l}\text { FECHA } \\
\text { RECOGIDA }\end{array}$ \\
\hline 002.01 & EI & $\begin{array}{l}\text { Entrevista } \\
\text { individual }\end{array}$ & Josevi (Miembro Grupo Estable) & $15 / 09 / 2014$ \\
\hline 002.02 & EI & $\begin{array}{l}\text { Entrevista } \\
\text { individual }\end{array}$ & $\begin{array}{l}\text { Ana María ( Miembro Grupo } \\
\text { Estable) }\end{array}$ & $15 / 09 / 2014$ \\
\hline 002.03 & EI & $\begin{array}{l}\text { Entrevista } \\
\text { individual }\end{array}$ & Iván Gómez (Grupo Usuarios) & $22 / 09 / 2014$ \\
\hline 002.04 & EI & $\begin{array}{l}\text { Entrevista } \\
\text { individual }\end{array}$ & $\begin{array}{l}\text { Guiomar y Adriana (Miembro } \\
\text { Grupo Estable) }\end{array}$ & $24 / 09 / 2014$ \\
\hline 002.05 & EI & $\begin{array}{l}\text { Entrevista } \\
\text { individual }\end{array}$ & Profesor IES (Territorio) & $25 / 09 / 2014$ \\
\hline 002.06 & EI & $\begin{array}{l}\text { Entrevista } \\
\text { individual }\end{array}$ & Miriam Solozano (consumidoras) & $25 / 09 / 2014$ \\
\hline 002.07 & EI & $\begin{array}{l}\text { Entrevista } \\
\text { individual }\end{array}$ & Miriam Tijiani (Consumidoras) & $25 / 02 / 2015$ \\
\hline 002.08 & EI & $\begin{array}{l}\text { Entrevista } \\
\text { individual }\end{array}$ & Tibi (Usuarias) & $30 / 04 / 2015$ \\
\hline 002.09 & EI & $\begin{array}{l}\text { Entrevista } \\
\text { individual }\end{array}$ & $\begin{array}{l}\text { Carmen } \quad \text { Torres-Técnico } \\
\text { Ayuntamiento (Territorio) }\end{array}$ & $31 / 07 / 2015$ \\
\hline 002.10 & EI & $\begin{array}{l}\text { Entrevista } \\
\text { individual }\end{array}$ & Ricky (activistas) & $03 / 09 / 2015$ \\
\hline 002.11 & EI & $\begin{array}{l}\text { Entrevista } \\
\text { individual }\end{array}$ & $\begin{array}{ll}\text { Susana } & \text { Marqués-Alcaldesa } \\
\text { Ayuntamiento (Territorio) }\end{array}$ & $20 / 10 / 2015$ \\
\hline 002.12 & EI & $\begin{array}{l}\text { Entrevista } \\
\text { individual }\end{array}$ & Vecina 2 (Territorio) & $16 / 02 / 2016$ \\
\hline 002.13 & EI & $\begin{array}{l}\text { Entrevista } \\
\text { individual }\end{array}$ & Merche (Territorio) & $08 / 03 / 2016$ \\
\hline
\end{tabular}




\begin{tabular}{|c|c|c|c|c|c|}
\hline \multicolumn{6}{|c|}{ ENTREVISTAS GRUPALES } \\
\hline $\begin{array}{l}\text { CÓD } \\
\text { IGO }\end{array}$ & $\begin{array}{l}\text { ACRÓ } \\
\text { NIMO }\end{array}$ & NOMBRE & $\begin{array}{l}\text { PARTICIP } \\
\text { ANTES }\end{array}$ & $\begin{array}{l}\text { GRUPO AL } \\
\text { QUE } \\
\text { PERTENECEN }\end{array}$ & $\begin{array}{l}\text { FECHA } \\
\text { RECOGIDA }\end{array}$ \\
\hline $\begin{array}{l}003.0 \\
1.01\end{array}$ & EG & \multirow[t]{5}{*}{$\begin{array}{l}\text { Entrevista } \\
\text { grupal }\end{array}$} & Lydia & \multirow[t]{5}{*}{ Activistas } & \multirow[t]{5}{*}{$16 / 09 / 2014$} \\
\hline $\begin{array}{l}003.0 \\
1.02\end{array}$ & EG & & Noel & & \\
\hline $\begin{array}{l}003.0 \\
1.03\end{array}$ & EG & & Iván Checa & & \\
\hline $\begin{array}{l}003.0 \\
1.04\end{array}$ & EG & & Jose Ordaz & & \\
\hline $\begin{array}{l}003.0 \\
1.05\end{array}$ & EG & & Armand & & \\
\hline $\begin{array}{l}003.0 \\
2.01\end{array}$ & EG & \multirow[t]{3}{*}{$\begin{array}{l}\text { Entrevista } \\
\text { grupal }\end{array}$} & $\begin{array}{l}\text { Virginia } \\
\text { Morales }\end{array}$ & \multirow[t]{3}{*}{ Animadoras } & \multirow[t]{3}{*}{$17 / 09 / 2014$} \\
\hline $\begin{array}{l}003.0 \\
2.02\end{array}$ & EG & & $\begin{array}{l}\text { Victor } \\
\text { Escoín }\end{array}$ & & \\
\hline $\begin{array}{l}003.0 \\
2.03\end{array}$ & EG & & $\begin{array}{l}\text { Mireia } \\
\text { Beltrán }\end{array}$ & & \\
\hline $\begin{array}{l}003.0 \\
3.01\end{array}$ & EG & \multirow[t]{3}{*}{$\begin{array}{l}\text { Entrevista } \\
\text { grupal }\end{array}$} & Isabel & \multirow[t]{3}{*}{ Ex-activistas } & \multirow[t]{3}{*}{$29 / 12 / 2014$} \\
\hline $\begin{array}{l}003.0 \\
3.02\end{array}$ & $\overline{E G}$ & & Joana & & \\
\hline $\begin{array}{l}003.0 \\
3.03\end{array}$ & EG & & Guillermo & & \\
\hline $\begin{array}{l}003.0 \\
4.01\end{array}$ & EG & \multirow[t]{3}{*}{$\begin{array}{l}\text { Entrevista } \\
\text { grupal }\end{array}$} & $\begin{array}{l}\text { Enrique } \\
\text { Deltoro }\end{array}$ & \multirow[t]{3}{*}{ FVCJ } & \multirow[t]{3}{*}{$24 / 03 / 2015$} \\
\hline $\begin{array}{l}003.0 \\
4.02\end{array}$ & EG & & Julio Huerta & & \\
\hline $\begin{array}{l}003.0 \\
4.03\end{array}$ & EG & & Jesús Martí & & \\
\hline
\end{tabular}




\begin{tabular}{|l|l|l|l|l|}
\hline \multicolumn{2}{|l|}{ PROYECTOS EDUCATIVOS } \\
\hline CÓDIGO & ACRÓNIMO & NOMBRE & DESCRIPCIÓN & $\begin{array}{l}\text { FECHA } \\
\text { RECOGIDA }\end{array}$ \\
\hline 004.01 & PE & Proyecto educativo & Esplai Cataflai & 2010 \\
\hline 004.02 & PE & Proyecto educativo & $\begin{array}{l}\text { Tutoria entre } \\
\text { Iguals }\end{array}$ & 2012 \\
\hline 004.03 & PE & Proyecto educativo & Puc tocar la lluna & 2012 \\
\hline 004.04 & PE & Proyecto educativo & Fem Xarxa & 2012 \\
\hline 004.05 & PE & Proyecto educativo & Art a l'abast & 2012 \\
\hline 004.06 & PE & Proyecto educativo & Arrela Vila-real & 2012 \\
\hline 004.07 & PE & Proyecto educativo & $\begin{array}{l}\text { Información para } \\
\text { la acción-Europeo }\end{array}$ & 2013 \\
\hline 004.08 & PE & Proyecto educativo & Activisme al IES & 2013 \\
\hline 004.09 & PE & Proyecto educativo & Esplai Cataflai & 2014 \\
\hline 004.10 & PE & Proyecto educativo & Teatro-Europeo & 2014 \\
\hline 004.11 & PE & Proyecto educativo & Recrea la teua ciutat & 2015 \\
\hline 004.12 & PE & Proyecto educativo & La plaça roja & 2015 \\
\hline
\end{tabular}

\begin{tabular}{|l|l|l|}
\hline \multicolumn{2}{|l|}{ NOTAS DE PRENSA } & FECHA RECOGIDA \\
\hline CÓDIGO & DESCRIPCIÓN & \\
\hline 005.01 & Casal jove sense joves & \\
\hline 005.02 & Nuevo local & \\
\hline 005.03 & Actividades & \\
\hline 005.04 & Permisos y licencias & \\
\hline 005.05 & Investigación & \\
\hline
\end{tabular}

\begin{tabular}{|c|c|c|c|c|}
\hline \multicolumn{5}{|l|}{ VIDEOS } \\
\hline CÓDIGO & ACRÓNIMO & NOMBRE & DESCRIPCIÓN & $\begin{array}{l}\text { FECHA } \\
\text { RECOGIDA }\end{array}$ \\
\hline 006.01 & $\mathrm{Vd}$ & Video & $\begin{array}{l}\text { El portador de } \\
\text { somnis }\end{array}$ & $30 / 12 / 2011$ \\
\hline 006.02 & $\mathrm{Vd}$ & Video & $\begin{array}{l}\text { La Maranya } \\
\text { estrena casa }\end{array}$ & $15 / 10 / 2012$ \\
\hline 006.03 & $\mathrm{Vd}$ & Video & Contra la censura & $29 / 07 / 2011$ \\
\hline
\end{tabular}




\begin{tabular}{|c|c|c|c|c|}
\hline \multicolumn{5}{|c|}{ FOTOGRAFÍAS } \\
\hline CÓDIGO & ACRÓNIMO & NOMBRE & DESCRIPCIÓN & $\begin{array}{l}\text { FECHA } \\
\text { RECOGIDA }\end{array}$ \\
\hline 007.01 & $\mathrm{Ft}$ & Fotografias & $\begin{array}{l}\text { Fil històric- } \\
\text { Quelcom }\end{array}$ & 2014 \\
\hline 007.02 & $\mathrm{Ft}$ & Fotografias & Fil històric- Casal & 2014 \\
\hline 007.03 & $\mathrm{Ft}$ & Fotografias & Fil històric- Esplai & 2014 \\
\hline 007.04 & $\mathrm{Ft}$ & Fotografias & Fil històric- 2012 & 2014 \\
\hline 007.05 & $\mathrm{Ft}$ & Fotografias & Fil històric- 2013 & 2014 \\
\hline 007.06 & $\mathrm{Ft}$ & Fotografias & Fil històric- 2014 & 2014 \\
\hline 007.07 & $\mathrm{Ft}$ & Fotografias & Fil històric- 2015 & 2015 \\
\hline
\end{tabular}

\begin{tabular}{|l|l|l|l|l|}
\hline \multicolumn{4}{|l|}{ GRUPO ASESOR } \\
\hline CÓDIGO & ACRÓNIMO & NOMBRE & DESCRIPCIÓN & $\begin{array}{l}\text { FECHA } \\
\text { RECOGIDA }\end{array}$ \\
\hline 008.01 & GA & Grupo Asesor & Reunión I & 2014 \\
\hline 008.02 & GA & Grupo Asesor & Reunión II & 2015 \\
\hline
\end{tabular}

\begin{tabular}{|l|l|l|l|l|}
\hline DOCUMENTACIÓN MARANYA \\
\hline CÓDIGO & ACRÓNIMO & NOMBRE & DESCRIPCIÓN & $\begin{array}{l}\text { FECHA } \\
\text { RECOGIDA }\end{array}$ \\
\hline 009.01 & DM & Campaña & $\begin{array}{l}\text { Casal Jove sense } \\
\text { Jove }\end{array}$ & 2011 \\
\hline 009.02 & DM & Campaña & $\begin{array}{l}\text { Amb l'alegria a un } \\
\text { altra banda }\end{array}$ & 2011 \\
\hline 009.03 & DM & Campaña & Jo soc maranya & 2012 \\
\hline 009.04 & DM & Campaña & Verkami & 2012 \\
\hline 016.01 & DM & Documentos & Definen & 2015 \\
\hline 016.02 & DM & Documentos & Organizamos & 2015 \\
\hline 016.03 & DM & Documentos & Carta amortización & 2011 \\
\hline 016.04 & DM & Documentos & Presupuestos & 2016 \\
\hline 016.05 & DM & Documentos & Revista Flama1 & 2011 \\
\hline 016.06 & DM & Documentos & Revista Flama2 & 2011 \\
\hline 016.07 & DM & Documentos & Revista Flama3 & 2011 \\
\hline
\end{tabular}




\begin{tabular}{|l|l|l|l|l|}
\hline \multicolumn{2}{|l|}{ DOCUMENTACIÓN FVCJ } \\
\hline CÓDIGO & ACRÓNIMO & NOMBRE & DESCRIPCIÓN & $\begin{array}{l}\text { FECHA } \\
\text { RECOGIDA }\end{array}$ \\
\hline 010.01 & DF & $\begin{array}{l}\text { Documentación } \\
\text { Federación }\end{array}$ & Revista antigüa & 1996 \\
\hline 010.02 & DF & $\begin{array}{l}\text { Documentación } \\
\text { Federación }\end{array}$ & Revista actual & 2014 \\
\hline 010.03 & DF & $\begin{array}{l}\text { Documentación } \\
\text { Federación }\end{array}$ & Instrucciones CJ & 1996 \\
\hline 010.04 & DF & $\begin{array}{l}\text { Documentación } \\
\text { Federación }\end{array}$ & Propuestas MLPV & 2015 \\
\hline 010.05 & DF & $\begin{array}{l}\text { Documentación } \\
\text { Federación }\end{array}$ & $\begin{array}{l}\text { Funciones } \\
\text { asociaciones }\end{array}$ & 2014 \\
\hline 010.06 & DF & $\begin{array}{l}\text { Documentación } \\
\text { Federación }\end{array}$ & Presupuestos & 2014 \\
\hline 010.07 & DF & $\begin{array}{l}\text { Documentación } \\
\text { Federación }\end{array}$ & Retos asociativos & 2015 \\
\hline
\end{tabular}




\section{TABLA DE CONTENIDOS}

\section{Tablas}

Tabla 1. Raíces latinas de la palabra animación. ............................... 23

Tabla 2. Características de la Animación Sociocultural. .................... 25

Tabla 3. Diferencias entre animadoras profesionales o voluntarias. . 29

Tabla 4. Diferencias entre animación y difusión. ............................... 41

Tabla 5. Acontecimientos y crisis. ..................................................... 54

Tabla 6. La participación en asociaciones en Europa, 1999-2002. ... 60

Tabla 7. Formas de implicación asociativa en España, 2002 ............. 61

Tabla 8. Implicación en diversas asociaciones en España, 2002........ 62

Tabla 9. Forma de implicación que predomina para cada categoría asociativa en España y en las comunidades autónomas de Cataluña,

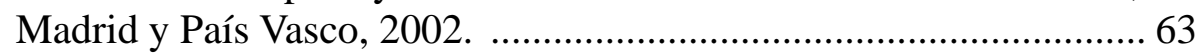

Tabla 10. Evolución del asociacionismo. ........................................... 66

Tabla 11. Diferencias entre Extensión cultural e Intervención cultural.

Tabla 12. Estadios de la historia de la investigación cualitativa.

Tabla 13. Denominaciones a un modo de entender la investigación social. 120

Tabla 14. Diferencias entre etnografía convencional y etnografía crítica. 124

Tabla 15. Objetivos y preguntas cruzadas. ..................................... 142

Tabla 16. Conjunto de técnicas, dispositivos y instrumentos. .......... 161

Tabla 17. Leyenda de codificaciones de dispositivos. ...................... 161

Tabla 18. Tiempos de registro de los dispositivos utilizados. .......... 162

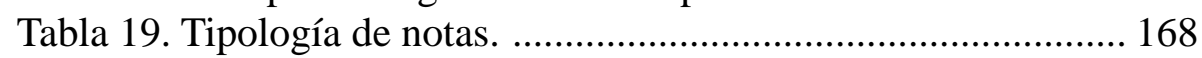

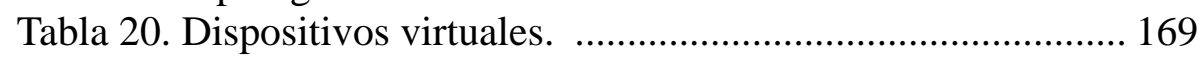

Tabla 21. Documentos de interés. ................................................. 170

Tabla 22. Participantes del grupo asesor. ........................................ 175

Tabla 23. Cronograma del grupo asesor. ....................................... 176

Tabla 24. Ventajas e inconvenientes de las narrativas biográficas según Pujadas (1992) y propuesta en nuestro estudio. .................... 181

Tabla 25. Proceso del trabajo narrativo. ........................................ 185

Tabla 26. Perfiles de las entrevistadas. ............................................ 193 
Tabla 27. Niveles de participación. ...................................................197

Tabla 28. Relaciones entre entrevistadas e investigadora. ................201

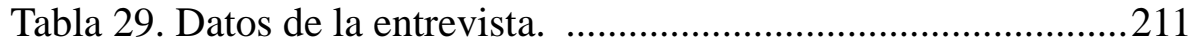

Tabla 30. Leyenda entrevista. .......................................................211

Tabla 31. Diferencias entre análisis paradigmático y narrativo. .......216

Tabla 32. Los tres niveles de concreción de nuestro estudio. ...........219

Tabla 33. Tipo de datos utilizados en el análisis. ............................220

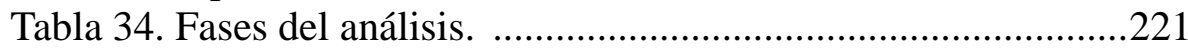

Tabla 35. Listado de categorías y códigos. ....................................226

Tabla 36. Tabla de categorías cronológicas. .....................................230

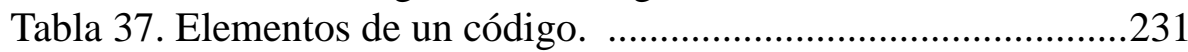

Tabla 38. Ejemplo de tipos de código. .............................................232

Tabla 39. Tabla criterios de rigor. ......................................................251

Tabla 40. Cruce de catergorías con fuentes de datos. .......................254

Tabla 41. Número de alumnado en Primaria y Secundaria en

Benicàssim. .291

\section{Figuras}

Figura 1. El activismo asociativo: Una escala. .................................64

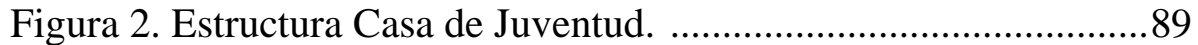

Figura 3. Aproximación al proceso cíclico.

Figura 4. Ciclo de investigación etnográfica. ....................................146

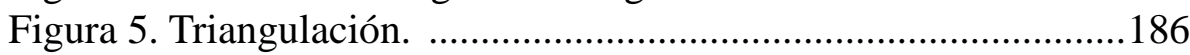

Figura 6. Mapa de criterios de selección de las entrevistadas. ..........191

Figura 7. Pirámide de participación. ..............................................196

Figura 8. Pirámide de los niveles de participación en las entrevistas.

Figura 9. Proceso líneal de entrevistas. ..........................................200

Figura 10. Temáticas que aparecen en las entrevistas......................209

Figura 11. Ciclo y fases del Análisis de Datos Cualitativos. ............218

Figura 12. Fase del proceso de análisis. .........................................221

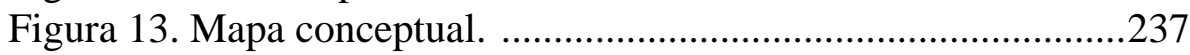

Figura 14. Leyenda de iconos de códigos QR. ...............................248

Figura 15. Relaciones institucionales en Maranya. ..........................295

Figura 16. Elementos que convierten a Maranya en agente educativo de

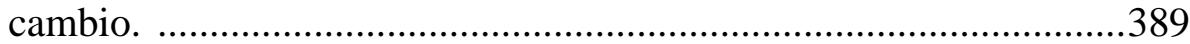

Figura 17. El aprendizaje situado en comunidades sociales. ...........412 


\section{Imágenes}

Imagen 1. Registro temático final. ............................................. 214

Imagen 2. Registro de entrevistadas: autocodificación. .................. 214

Imagen 3. Registro cronológico. ................................................. 215

Imagen 4. Herramientas de recogida de información. ..................... 222

Imagen 5. Códigos de entrevistas grupales. .................................. 223

Imagen 6. Memos registradas. ...................................................... 224

Imagen 7. Ejemplo de extracto en la unidad de significado. ........... 225

Imagen 8. Mapa NVivo® de relaciones entre códigos de la

categoría Aspectos Educativos. .................................................... 233

Imagen 9. Ampliación de grupos temáticos. ................................... 233

Imagen 10. Resumen de cuentas año 2015. ................................... 290

\section{Códigos QR}

QR 1. Mapa Europeo de Casas de Juventud federadas en

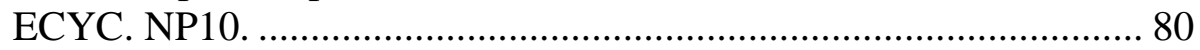

QR 2. Línea del tiempo. NP12. .................................................... 81

QR 3. Video presentación tesis. NP26. ............................................ 152

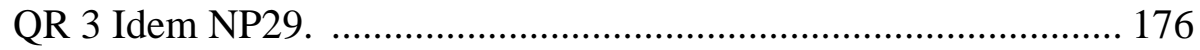

QR 4. Invitación al Fil Històric en la web de Maranya. NP40. ...... 307

QR 5. Localización de CdJ Maranya. NP41. .................................. 310

QR 6. Web FVCJ. NP42. ......................................................... 313

QR 7. Localización del IES Violant de Casalduch de

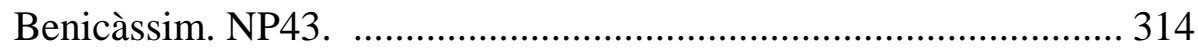

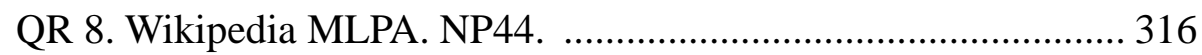

QR 9. Web Escola de Cases. NP45. ................................................ 316

QR 10. Video de Estem Vius con música de Andreu Valor. NP49. .. 328

QR 11. Video plenario Ayuntamiento de Benicàssim. NP50. ......... 329

QR 12. Canción L'estaca de Lluis Llach. NP51. ........................... 333

QR 13. Lip Dub Maranya. NP52. ................................................ 334

QR 14. Nota de prensa: Desalojo. NP53. ....................................... 336

QR 15. Video Fils trencats en la campaña de \#casaljovesensejoves.

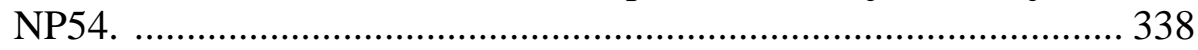

QR 16. Documental Els portadors de somnis grabado en

Amb l'alegria a l'altra banda. NP55. ............................................. 344

QR 17. Poema recitado: Portadores de sueños de

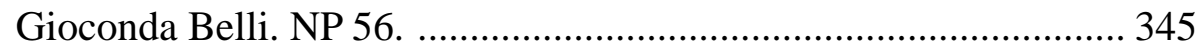

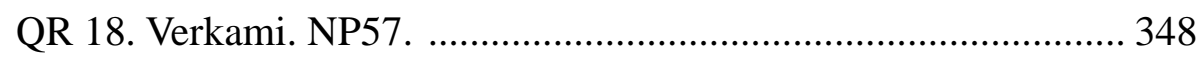

QR 19. Nota de prensa «La Maranya arregla su nuevo local gracias a la colaboración vecinal ». NP58. 
QR 20. Video campaña \#josocmaranya. NP59.

QR 21. Video inauguración local. NP60.

QR 22 y 23. Nota de prensa «El colectivo La Maranya celebra la inauguración de su nueva sede en Benicàssim». NP61.

QR 24. Fotografías Fil Històric. NP64. ..........................................357

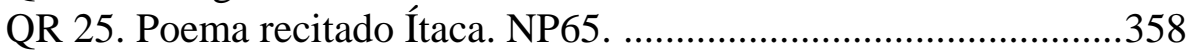

QR 26. Canal de videos Maranya Tv. NP66 ……............................362

QR 27. Fotografías Flickr: Tres años de obra. NP67. .......................364

QR 28. Fotografía Instagram: Casa del Terror. NP68. ......................366

QR 29. Fotogafía Instagram: Campaña \#cappersonaesil·legal.

NP69.

QR 30. Fotografía Instagram: Xocolatada pel Sahara Lliure.

NP70. 368

QR 31. Fotografías Flickr: Intervención La Plaza Roja. NP71. .......369

QR 32. Forografía Instagram: Asamblea. NP72. .............................370

QR 33. Fotografía Instagram: Plenario. NP73. ................................370

QR 34. Noticia web Maranya: Ja tenim Llicència! NP74. ...............382

QR 35. Video Tutoría entre iguales IES. NP75. ...............................383

QR 36. Fotografías Flickr. Imágenes de nuestra historia. NP76. .....384

QR 37 y 38. Canción Un entre tants de Soul Atac y letra de Vicent Andrés Estellés. NP79.

\section{Anexos}

Anexo 1. Cronograma de la investigación. .........................................551

Anexo 2. Email presentación. ........................................................554

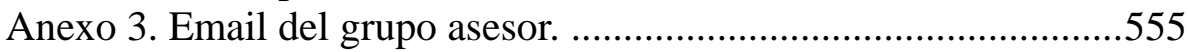

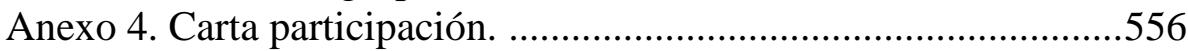

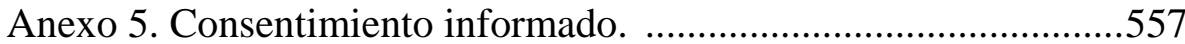

Anexo 6. Protocolo grupo asesor. ...................................................561

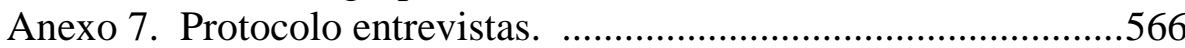

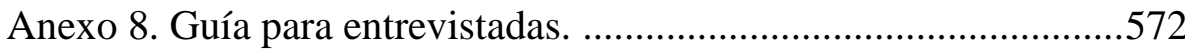

Anexo 9. Proceso entrevista alcaldesa. ............................................576

Anexo 10. Tabla de participantes entrevistadas. ……………….......577

Anexo 11. Correo de devolución de la entrevista. ...........................582

Anexo 12. Listado de categorías, códigos, definiciones y

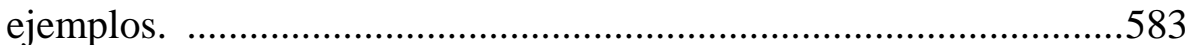

Anexo 13. Carta de abandono del local. ...........................................614

Anexo 14. Listados de códigos y acrónimos de las herramientas utilizadas. 
